UNIVERSITY OF PITTSBURGH

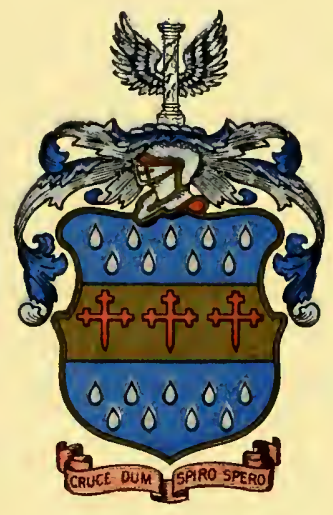

Darlington Memorial Library 



Mritian Macinfion 
$\div \quad$.

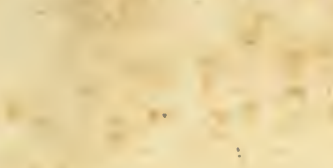

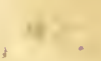




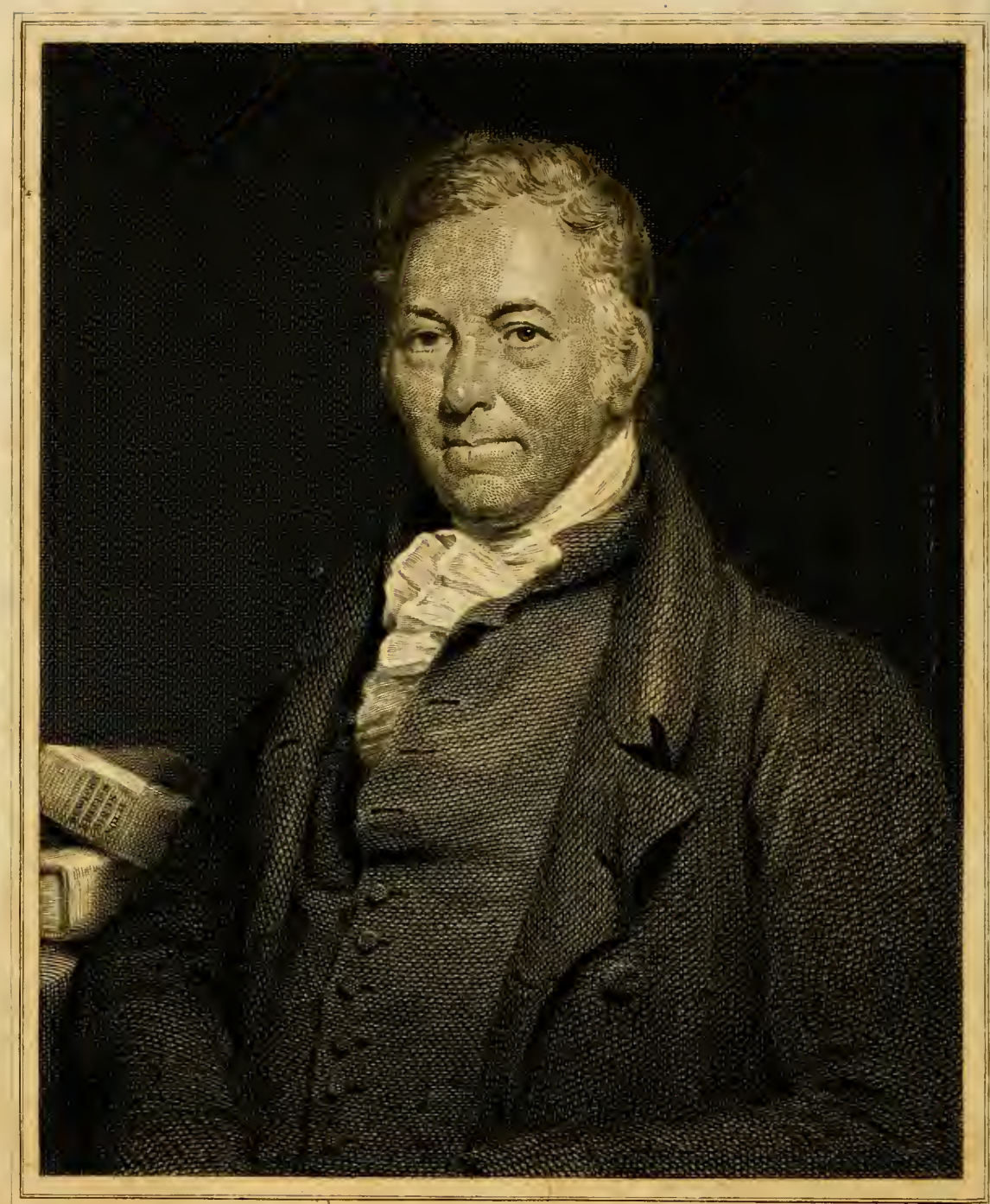

Painaid by TiRP.amizy

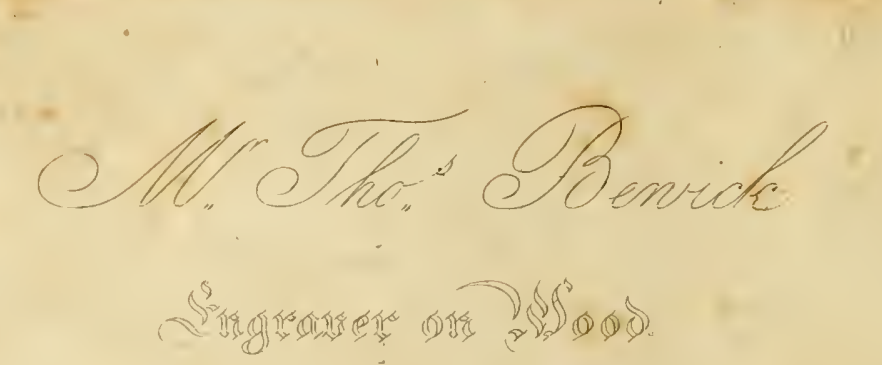




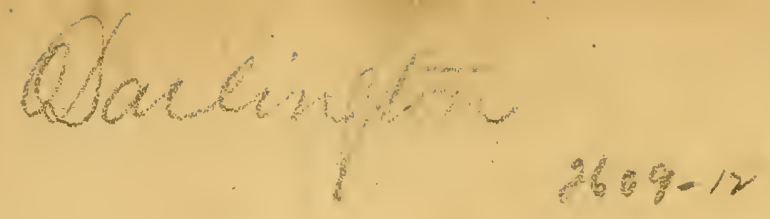

\author{
$\AA$ GENERAL \\ H I S T O R Y
}

\title{
OF \\ QUADRUPEDS.
}

THE FIGURES ENGRAVED ON WOOD BY T.

THE FOURTH EDITION.

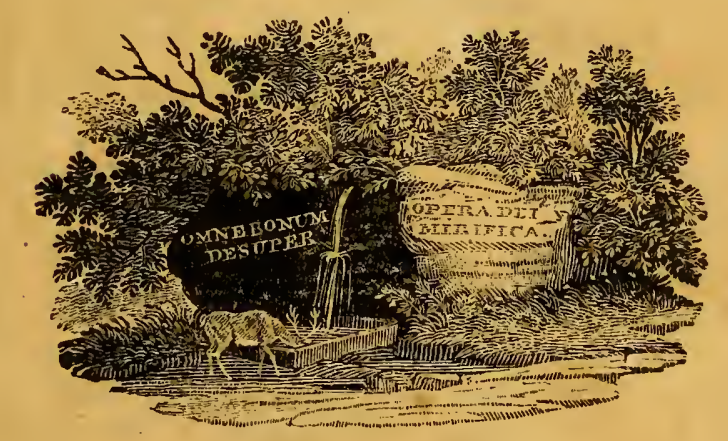

NEWCASTLE UPON TRNE:

PRINTED BY AND FOR S. HODGSON, R. BEILBY, AND T. BEWICK:

SOLD BY THEM, AND J.'BELL, NEWCASTLE; BY G. G. \& J.

ROBINSON, J. MAWMAN, (SUCCESSOR TO MR DIL-

LY) AND F. \& C. RIVINGTON, LONDON.

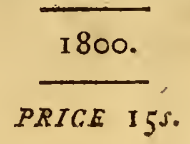




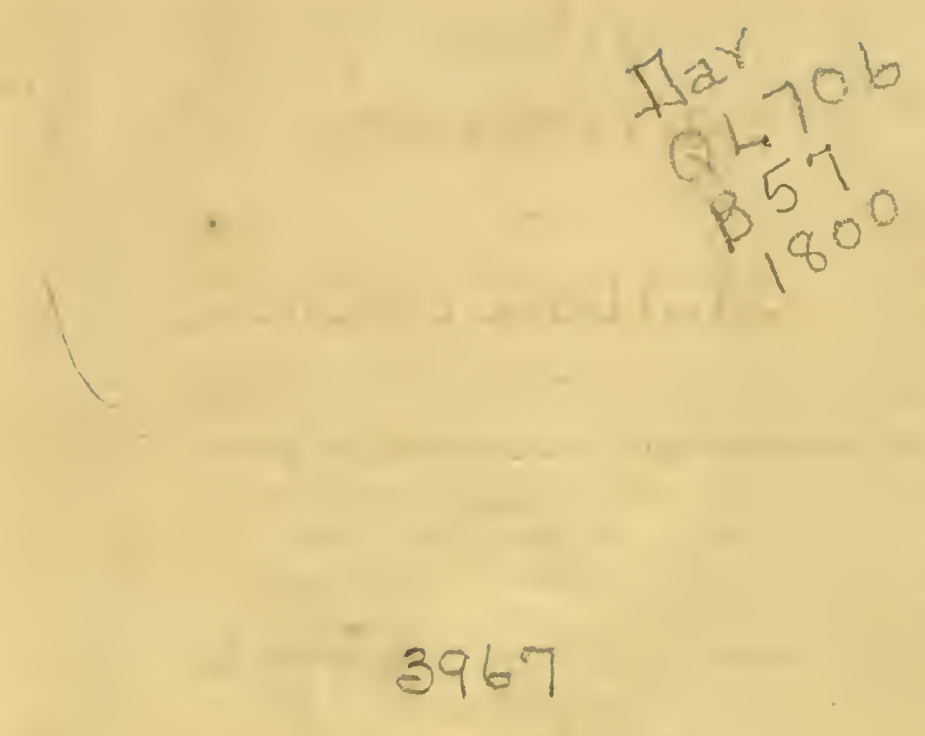

$2, y$
$3 \mid 12) \geqslant 0$ 


\section{ADVERTISEMENT.}

IN difpofing the order of the following work, we have not thought it neceffary to confine ourfelves ftrictly within the rules prefcribed by fyftematic writers on this part of Natural Hiftory; as it was not fo much the object of our plan to lay down a methodical arrangement of the various tribes of fourfooted animals, as to give a clear and concife account of the nature, habits, and difpofition of each, accompanied with more accurate reprefentations than have hitherto appeared in any work of this kind. Our difregard of fyftem, however, has not prevented us from attending to the great divifions of Quadrupeds, fo obvioufly marked out by the hand of Nature, and fo clearly diftinguifhed, that the moft carelefs obferver cannot avoid being forcibly ftruck with an agreement of parts in the outward appearance of the different individuals of which it confifts.

The intermediate ftations, however, have not been always fo clearly defined; thefe are frequently occupied by characters fo dubious, that naturalitts have not always agreed in afcribing to each its proper place: Of this kind are the Elephant, the Hippopotamus, the Rhinoceros, the Cameleopard, the Beaver, the Hedge-hog, the Sloth, the Jerboa, \&c. which bear in themfelves characteriftics fo peculiar, that they might feem to conititute diftinct genera.

We have endeavoured to lay before our readers a particular account of the animals with which our own country is abundantly ftored, efpecially of thofe which fo materially contribute to the ftrength, the wealth, and the happinefs of this kingdom; of thefe the Horfe, the Cow, and the Sheep, claim the firft pláce; and in treating of thefe, we have noticed the improvements which an enlarged fyftem of agriculture, fupported by a 


\section{ADVERTISEMENT.}

noble fpirit of emulation, has introduced into all parts of the country. To thefe we may add that moft ufeful animal the Dog, the account of which forms a confpicuous part of our hiftory, and we truft will afford fome entertainment to thofe who are pleafed with contemplating the various talents of that trufty fervant and humble companion of man: We have felected the moft remarkable of the different kinds, and have given faithful portraits of them, drawn from the life; there are ftill others, not unworthy of attention, which might have been added; but to have noticed all the variations and thades of difference obfervable in the canine race, would have fwelled our account, already large, to an immoderate length, and have left us too little room for others of equal importance, in a comprehenfive view of this part of the animal creation.

Our attention has been directed in a particular manner to the various inftinctive powers of animals - that hidden principle, which actuates and impels every living creature to procure its fubfiftence, provide for its fafety, and propagate its kind. To difcover more and more of this unerring guide, directing the brute creation to their higheft good by the fimpleft and moft certain methods, is a purfuit worthy of the moft refined underftanding, and leads us to contemplate the wifdom and goodnefs of the adorable Author of Nature, who "openeth his hand, and all things are filled with good."

It may perhaps be thought neceffary to offer fome apology for the evident want of proportion obfervable in the fize of the different animals; a defect to which every work of this kind muft, in fome meafure, be liable. In adverting to this, we found, that at whatever point, between the Elephant and the Moufe, the fcale were to be fixed, a great and unavoidable deficiency would be the confequence; we were therefore obliged to relinquifh a plan, which, fo far from being practicable, would have been the means of throwing the whole into irregularity and confufion. 


\section{$I N D E X$.}

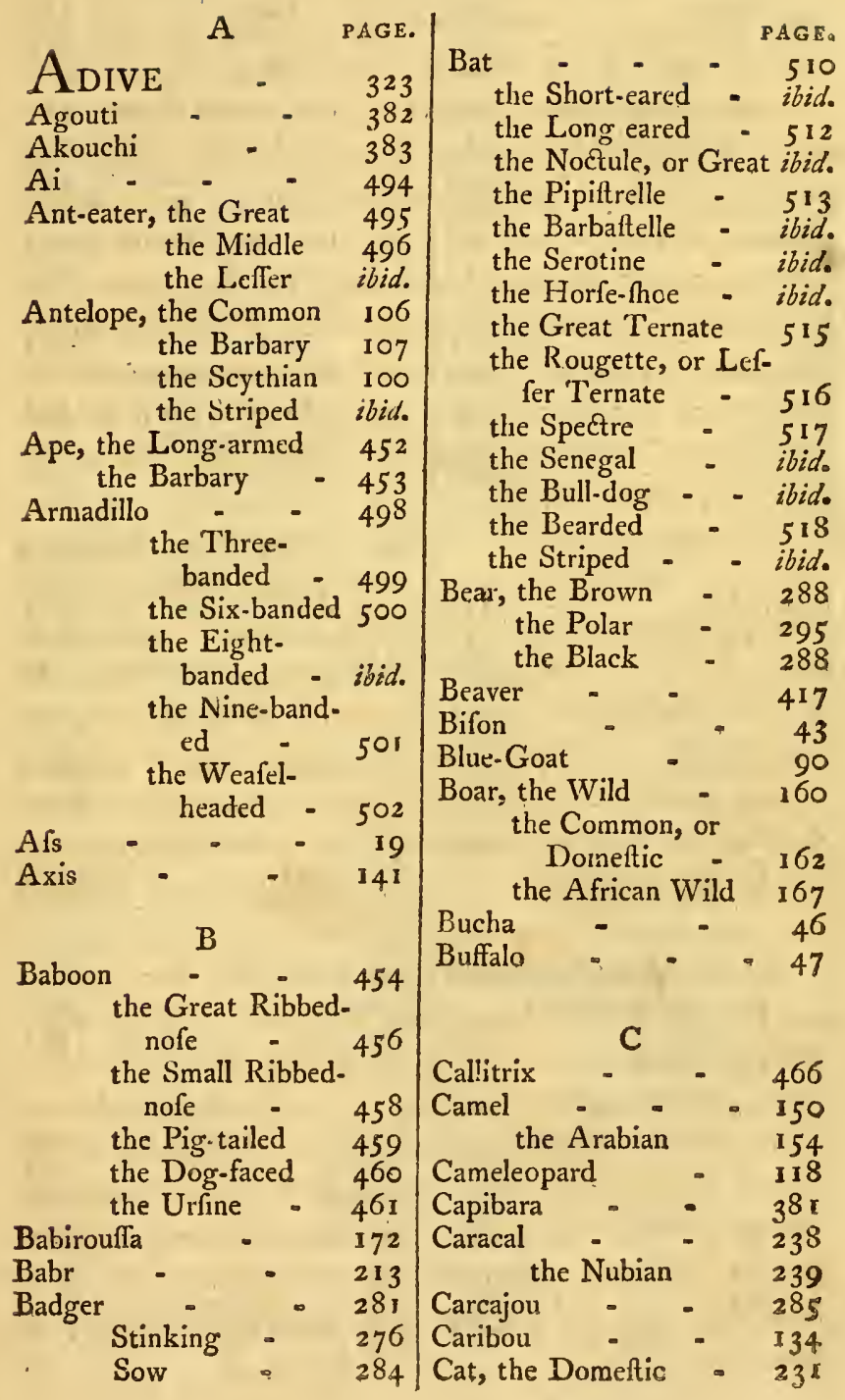




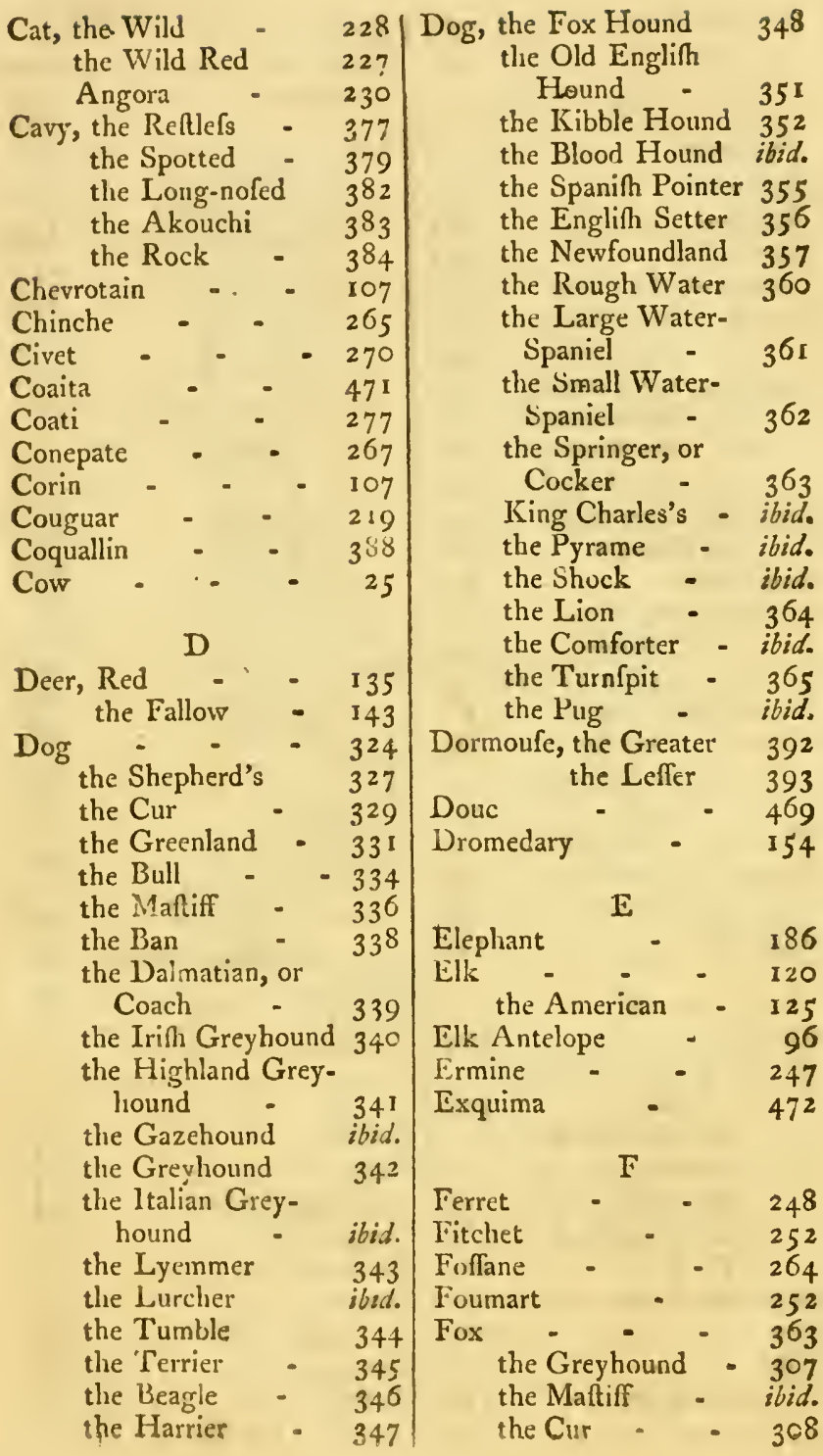


INDEX.

vii

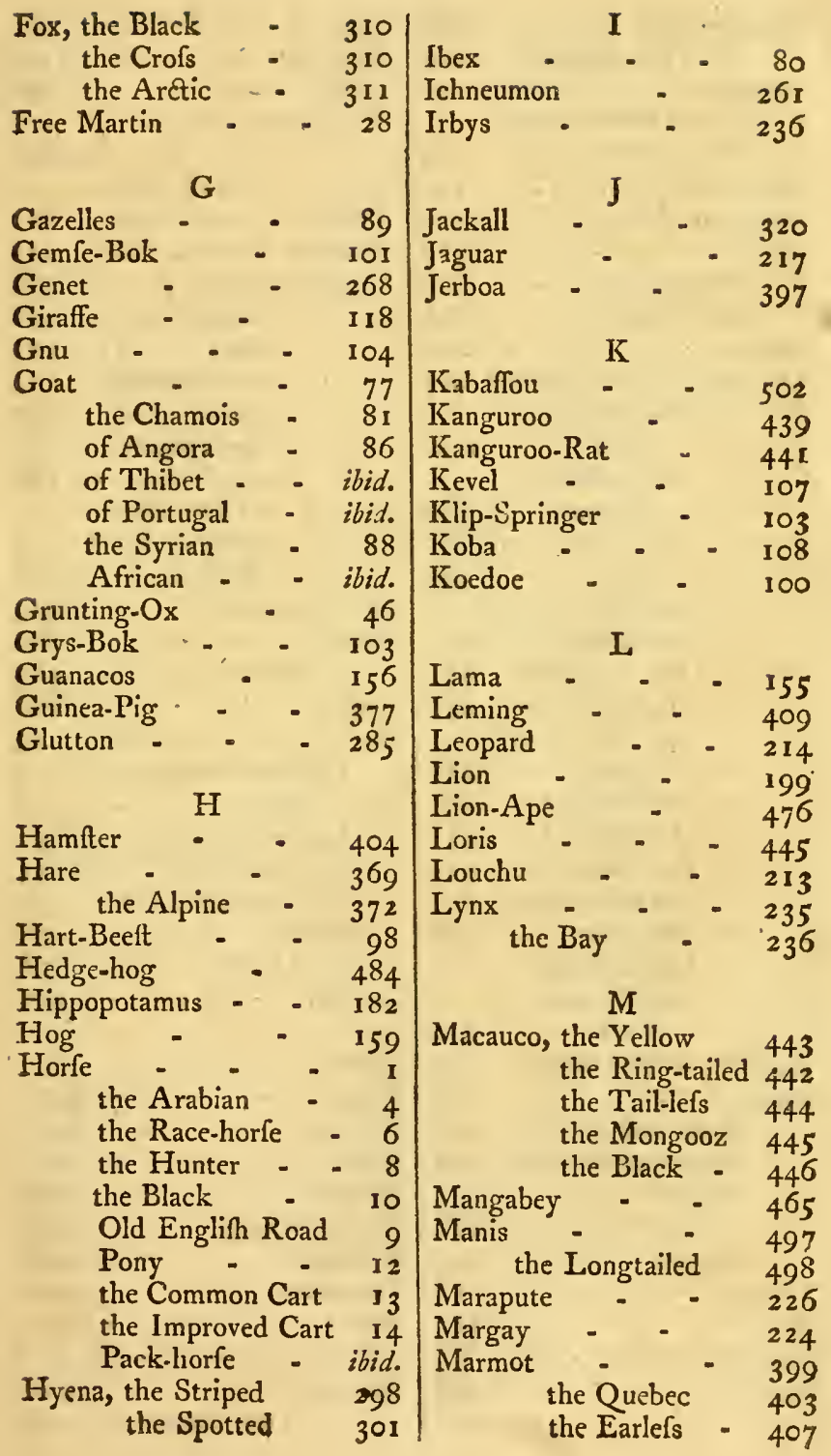


INDEX.

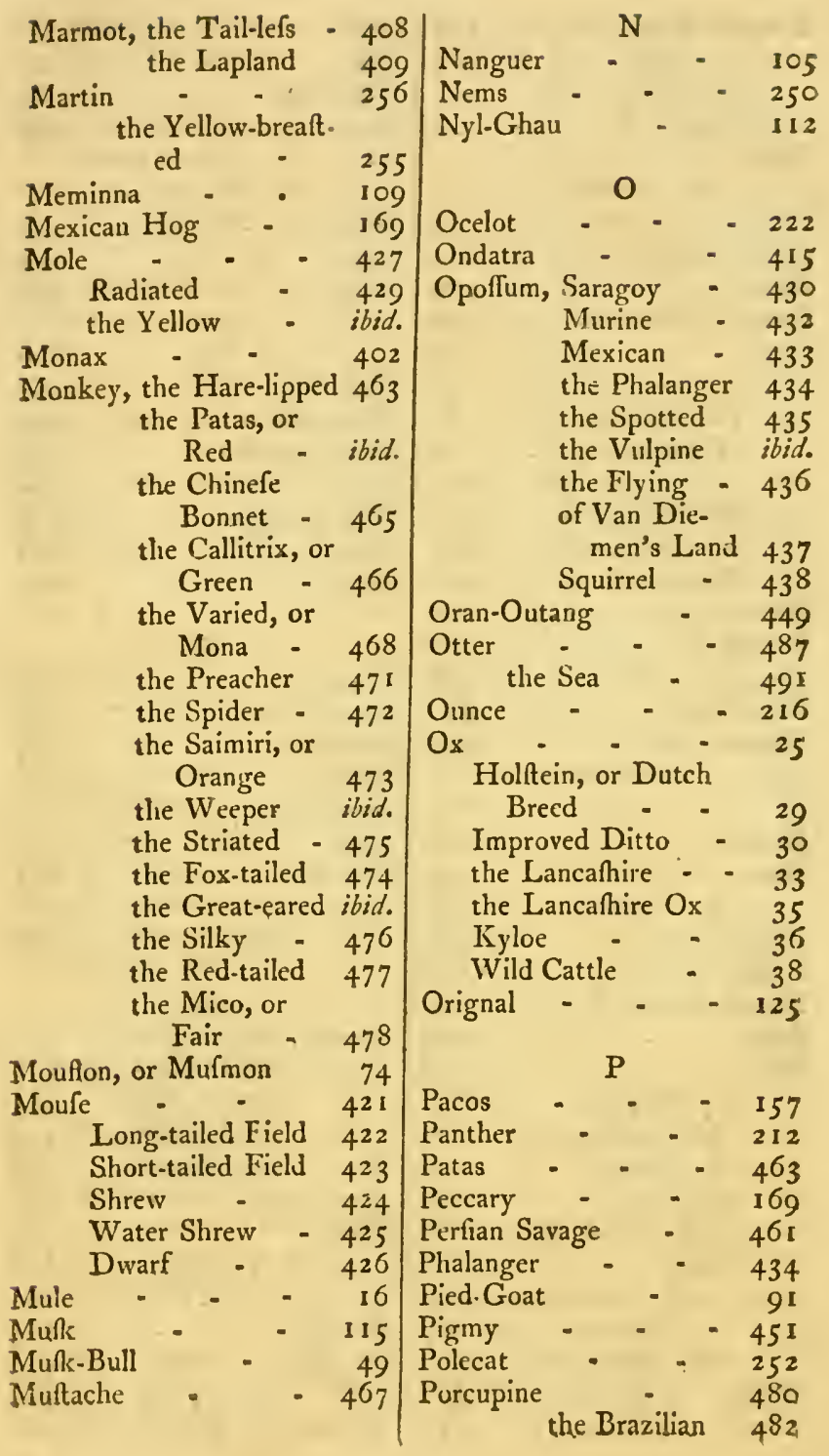


INDEX.

xis

Porcupine, the Canada

Potto - - . 443

' R

Rabbit

the Dumeftic - $\begin{array}{r}374 \\ 376\end{array}$

of Angora - ibid.

the Hooded - ibid.

Racoon

279

Ram, Black-faced - $\quad 56$ Heath - 57

Cheviot - 58

Tees-Water - 60

Ditto Improved 61

Rat - - - 4 II

Water - 4I4

Munk of Canada 4I5

Mufcovy Mufk - 416

Ratel

- - 275

Ree-Bok - 102

Riet - ibid.

Rein-Deer - - 127

Rhinoceros - 175

the Two-horn-

ed $\quad 179$

Roe-Buck - - 146

Ruminating Animals - 24

Sifac

Sheep, Lincolnfhire Breed 54

Dorfetfhire Ditto ibid. the Short - 56

Leicefterhire Ditto 63 Mr Culley's breed 66 the Shetland ' - 68 the Dunky, or

Dwarf - 70 the Tartarian - 7I the African, or

Guinea - ibid. the Many-horned 72 the Broad-tailed ibid. of Thibet - 73 the Wallachian ibid.

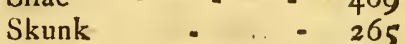

Sloth - - 493

Soulik - - 407

Sow, of the Improved

breed - 164

Chinefe - . 166

Springer - - 94

Squirrel - - 385

the Hudfon's

Bay - 390

the Gray - 387

the Black - 388

the Ground $\quad 389$

the Barbary - 39 I

the Palm - ibido

the Fat - 392

the Garden - ibid.

the Flying - 394

the Great Flying 395

the Hooded ibid.

the Long-tailed 396

Stag, or Red Deer - 135

the Corfican - 140

the Axis, or Ganges 141

Steen-Bok

Stifling, or Squalh - 266

Serval - . $\quad 226$

Stoat - - 246

Sheep - 50 Suricate . . 274 
INDEX.

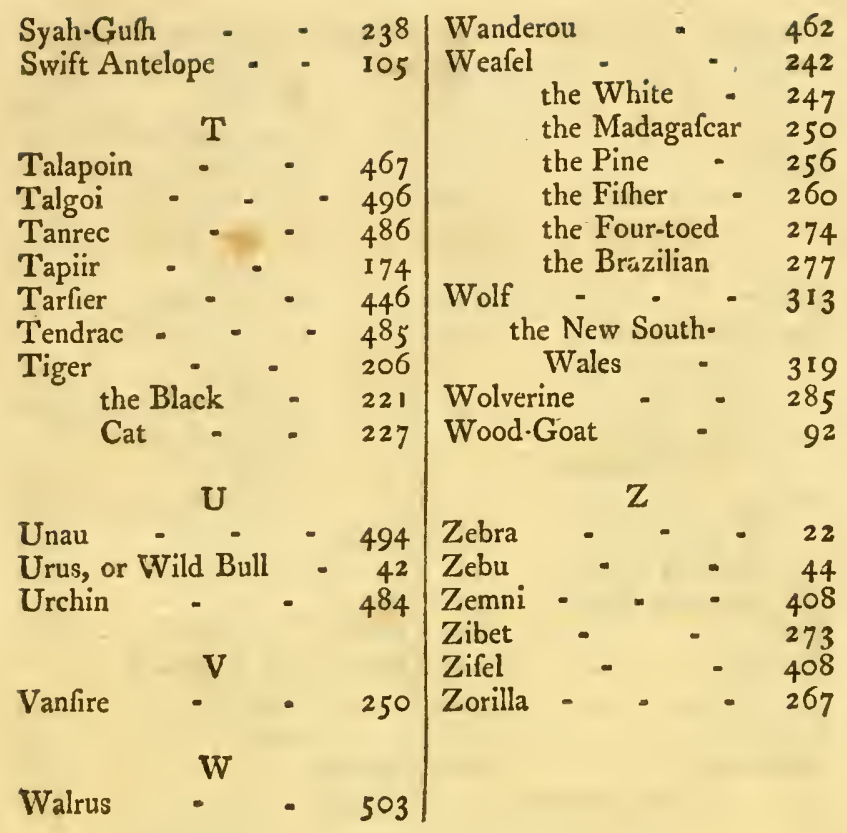

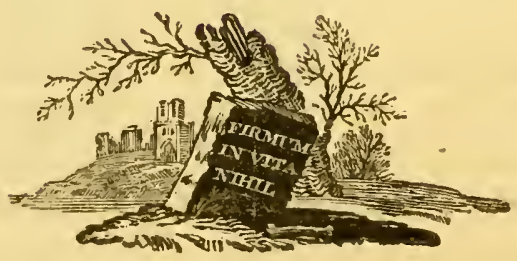




\section{HISTORY}

OF

\section{QUADRUPEDS.}

\section{(Equus Caballus, Linnæus.-Le Cheval, Buffon.)}

\section{THE HORSE.}

THE various excellencies of this noble animal, the grandeur of his ftature, the elegance and proportion of his parts, the beautiful fmoothnefs of his fkin, the variety and gracefulnefs of his motions, and, above all, his utility, entitle him to a precedence in the hiftory of the brute creation.

The Horfe, in his domeftic ftate, is generous, docile, fpirited, and yet obedient; adapted to the various purpofes of pleafure and convenience, he is equally ferviceable in the draught, the field, or the race.

There are few parts of the known world where the Horfe is not produced; but, if we would fee him in the enjoyment of his native freedom, (unfubdued by the reftraints man has impofed upon him) we muft look for him in the wild and extenfive plains of Africa and Arabia, where he ranges without controul, in a ftate of entire independency. In thofe immenfe tracts, the wild Horfes may be feen feeding together, in droves of four or five 
hundred; one of them always acting as centinel, to give notice of approaching danger: This he does by a kind of fnorting noife, upon which they all fly off with aftonifhing rapidity. The wild Horfes of Arabia are efteemed the moft beautiful in the world: They are of a brown colour, their mane and tail of black tufted, hair, very thort; they are fmaller than the tame ones, are very active, and of great fwiftners. The moft ufual method of taking them is by fnares or pits formed in the fand.It is probable there were once wild Horfes in Europe, which have long fince been brought under fubjection.Thofe found in America were originally of the Spanifh breed, fent thither upon its firft difcovery, which have fince become wild, and fpread themfelves over various parts of that vaft continent. They are generally fmall, not exceeding fourteen hands high; with thick heads, and clumfy joints: Their ears and necks are longer than thofe of the Englifh Horfes. They are eafily tamed; and if by accident they fhould regain their liberty, they feldom become wild again, but know their mafter, and may be eafily caught by him.

At the age of two years, * the Horfe is in a condition to propagate. - The mare is generally in feafon from the

* There are various ways of judging of the age of a Horfe. The fullowing are the mon general :-The eye-pits of old Horfes are commonly hollow; but that mark is equivocal, young Horfes, begot by old fallions, having them alfo hollow. - The teeth afford the beft criterion of the age of Horfes. The Horfe has, in all, forty teeth; viz. twenty-four grinders, four canine teeth or tufks, and twelve fore-teeth: Mares have either no tufks, or very fhort ones. Fiye days after birth, the four teeth in front begin to fhoot: Thefe art called nippers, and are cant at the age of two years and a half: They are foon renewed: And the next year, he again cafts two above, and two below,- one on each fide of the nippers. At four years and a half, other four fall out, next thofe laft placed: Thefe laft four foal teeth are fucceeded by other four, which 
latter end of March till the beginning of June; but her chief ardour for the Horfe continues only fifteen or twenty days. She goes with young eleven months and fome days; continues to breed till the age of fixteen or eighteen years; and lives, on an average, between twenty and thirty years.

Although the Horfe is endowed with vaft ftrength and powers, he feldom exerts either to the prejudice of his mafter: On the contrary, he fhares with him in his labours, and feems to participate in his pleafures; generous and perfevering, he gives up his whole powers to the fervice of his mafter; though bold and intrepid, he repreffes the natural vivacity and fire of his temper, and not only yields to the hand, but feems to confult the inclination, of his rider.

But it muft continue to be matter of regret to every feeling mind, that thefe excellent qualities fhould be often fhamefully abufed in the moft unneceffary exertions; and the honeft labours of this noble animal thrown away in the ungrateful tafk of accomplining the purpofes of unfeeling folly, or lavifhed in gratifying the expectations of an intemperate moment.

grow much more flowly than the firf eight: And it is from thefe late four corner teeth, that the age of a horfe is diflinguifhed: They are fomewhat hollow in the middle, and have a black mark in the cavitiss. At five years, thefe teeth icarcely rife above the gums; at $f \mathrm{x}$, their cavities begin to fill up, and turn to a brownith fpot, like the eye of a garden bean; and before eight years, the mark generally difappears. - The tufks aifo indicate the age of a Horfe. Thofe in the under jaw generally thoot at the age of three years and a half; and the two in the upper jaw at four: Till fix, they continue fharp at the points; but at ten, they appear long and blunted.-Thefe are the general rules for afcertaining the age of a Horfe; but there are frequent exceptions, as fome Hortes retain the mark two or three years longer.

A 2 


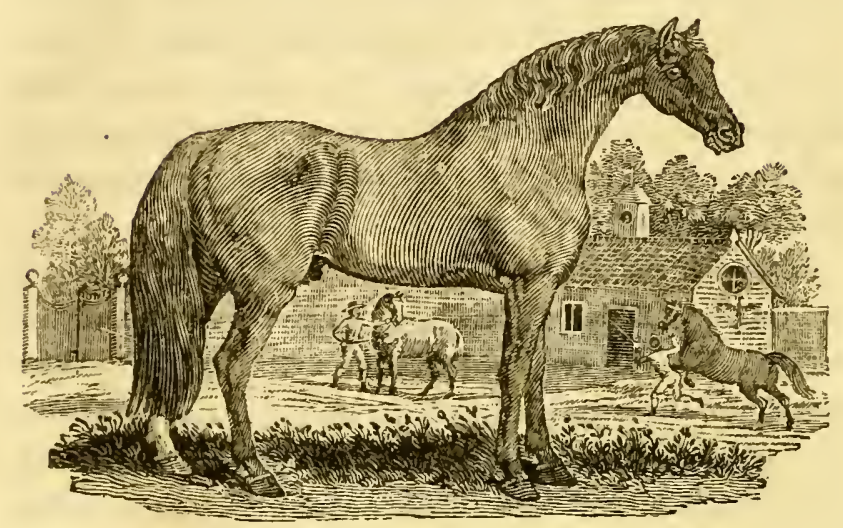

THE ARABIAN HORSE.

There is fcarcely an Arabian, how poor foever in: other refpects, but is poffeffed of his Horfe, which he confiders as an invaluable treafure. Having no other dwelling but a tent, the Arabian and his Horfe live upon the moft equal terms: His wife and family, his mare and her foal, generally lie indifcriminately together; whilft the little children frequently climb without fear upon the body of the inoffenfive animal, which permits them to play with and carefs it without injury. The Arabs never beat their Horfes; they fpeak to, and feem to hold friendly intercourfe with them; they never whip them; and feldom, but in cafes of neceffity, make ufe of the fpur. Their agility in leaping is wonderful; and if the rider happen to fall, they are fo tractable as to ftand fill in the midft of the moft rapid career. - The Arabian Horfes, in general lefs than the Race-Horfes of this country, are eafy and graceful in their motions, and rather inclined to leamnefs.-It is worthy of remark, that, inftead of. 
croffing the breed, the Arabs take every precaution to keep it pure and unmixed: They preferve, with the greateft care and for an amazing length of time, the genealogies of their Horfes; thofe of the firf kind are called Nobles, being " of a pure and ancient race, purer than milk." They have likewife two other kinds, which, having been degraded by common alliances, fell at inferior prices.

From Arabia, the race of Horfes has probably extended into Barbary and other parts of Africa; thofe being confidered as next to the Arabian Horfes in fwiftnefs and beauty, though they are fomewhat fmaller.

The Spanifh Genette is held in great eftimation: Like the former, it is fmall, but beautiful, and extremely fwift.

The Horfes of India and many parts of China are extremely fmall and vicious. One of thefe was fome years ago brought into this country as a prefent to the queen, which was very little larger than fome maftiffs, meafuring only nine hands in height.

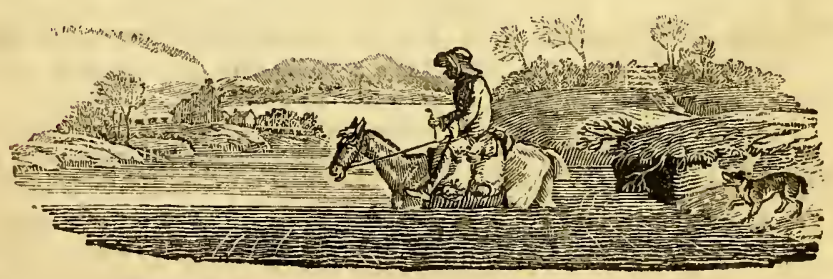




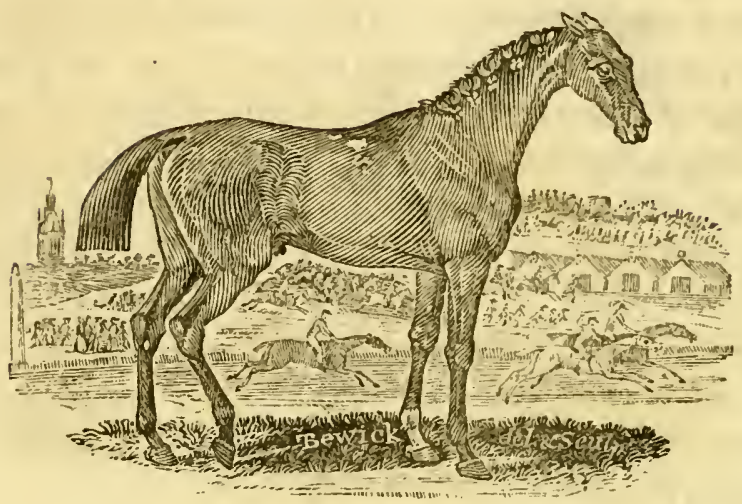

THE RACE-HORSE.

IN Great-Britain the breed of Horfes feems to be as mixed as that of its inhabitants.-By great attention to the improvement of this noble animal, by a judicious mixture of feveral kinds, and by fuperior tkill in management, the Englifh Race-Horfe* is allowed to excel thofe

* The following account of the prizes won by fome of our capita! Race-Horfes, will flew the importance of that breed in England, where fuch vaft fums frequently depend on the iffue of their contefts :-

BAY MALTON, (by Sampfon) the property of the late Marquis of Rnckingham, in feven prizes won the amazing fum of 5,900 . At York, he ran four miles in feven minutes and forty-three and an half feconds, which was feven and an half feconds lefs time than it was ever done before over the fame courfe.

CHILDERS, (well known by the name of llying Childers) the property of the Duke of Devonflire, was allowed by iportfmen to be the fleetef Horfe that ever was bred in the world: He farted repeatediy at Newmarket againft the beft IIorfes of his time, and was never beaten: He won, in different prizes, to the anount of nearly 200ol.; and was afterwards referved as a flallion.-The fire of Childers was an Arabian, fent by a gentleman as a prefent to his brother in England.

DoRIMANT, a famous Horfe belonging to Lord Offory, won prizes to the great amount of $I_{3}, 3,6_{3} 1$. 
of the reft of Europe, or perhaps the whole world. For fupporting a continuance of violent exertion, (or what is called, in the language of the turf, bottom) they are fuperior to the Arabian, the Barb, or the Perfian; and for fwiftnefs, they will yield the palm to none. An ordinary Racer is known to go at the rate of a mile in lefs than two minutes; but there have been inftances of much greater rapidity: The famous Horfe Childers has been known to move eighty-two feet and an half in a fecond, or nearly a mile in a minute; he has run round the courie at Newmarket, which is little lefs than four miles, in fix minutes and forty feconds.

ECLIPSE was allowed to be the fleeteft Horfe that ever ran in England lince the time of Childers. After winning king's plates and other prizes to a great anount, he covered, by fubfeription, forty mares, at thirty guineas each,-befides thofe of his owner.

HighFLyer was accounted the beft Horle of his time in England. The fums he won and received amounled to near 9,000 . though he never ftarted after five years old. He was never beaten, nor eyer paid a forfeit.

MatcheM, a Horfe belonging to the late W. Fenwick, Efq. befides being a capital racer, was patticularly remarkable as a ftallion; and may be truly faid to have earned more money than any other Horfe in the world. He was engaged, during nine years of his life, to cover twenty-five mares, at fifty guineas a mare, and was uncommonly fuccefsful in the celebrity of his progeny, having been fire to many of our moft famous running Horfes. He was remarkable for being the quieteft ftallion that ever was known; to which, perhaps, may be attributed his great age, being in his thirty-third year when he died.

SHARK won, befides a cup value I20 gs. and eleven hogfheads of claret, the aftonihing fum of $15,507 \mathrm{gs}$. in plates, matches, and forfeits.

On tlie $2 s^{\text {th }}$ of March, I799, a match for $3000 \mathrm{gs}$. was run at Newmarket, by Sir H. Vane Tempelt's HAMBLETONIAN, and Mr Cookfon's DiAmond, and won by the former. It was fuppufed that wagers to the amount of nearly truo burdred thoufand paunds were betted on the event of this fevere race. 


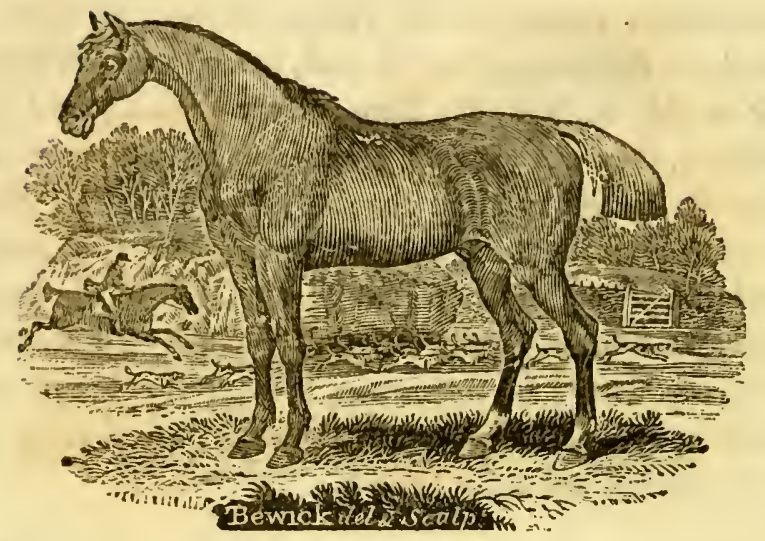

\section{THE HUNTER}

Is a happy combination of the Race-Horfe with others of fuperior ftrength, but inferior in fwiftnefs; and may be confidered as the moft ufeful breed of Horfes in Europe. Their fpirit and activity in the field are well known, and can only be equalled by the perfeverance with which they endure the much more fevere labour of pofting on the road, which is now carried on by this active and hardy race, with a celerity unknown at any former period.

Geldings of this kind are fent over to the continent in great numbers: Their fuperior worth is univerfally adknowledged abroad; and they are fold at very high prices to foreigners of the firft diftinction.

The mixture of this with others of inferior rank forms an endlefs variety, the different gradations becoming too minute to be difcriminated. 


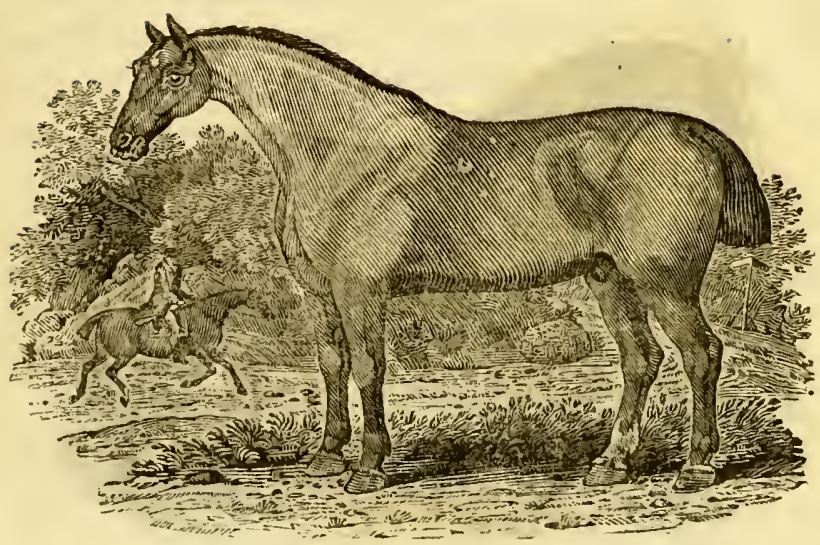

THE OLD ENGLISH ROAD-HORSE

Is a ftrong, vigorous, and active kind, capable of enduring great hardhip ; its ftature rather low, feldom exceeding fifteen hands; the body round and compact, its limbs ftrong, and its head thick.

Although this breed has of late years been neglected, and almoft totally fuperfeded by Horfes of another kind, more nearly related to the Race-Horfe, where the falhion of figure feems to have been preferred to utility, we cannot help congratulating our aflociated countrymen* $^{*}$ on their fpirited exertions towards public improvement, in which nothing of excellency in the various kinds of domeftic animals is fuffered to efcape their vigilance, and this kind is again likely to be brought into notice. A mare of this breed, in the poffeffion of Arthur Mowbray, Efq. of Sherburn, appears to us to poffefs all the valuable properties attributed to the old Road-Horfe.

* Agricultural Socicties. 


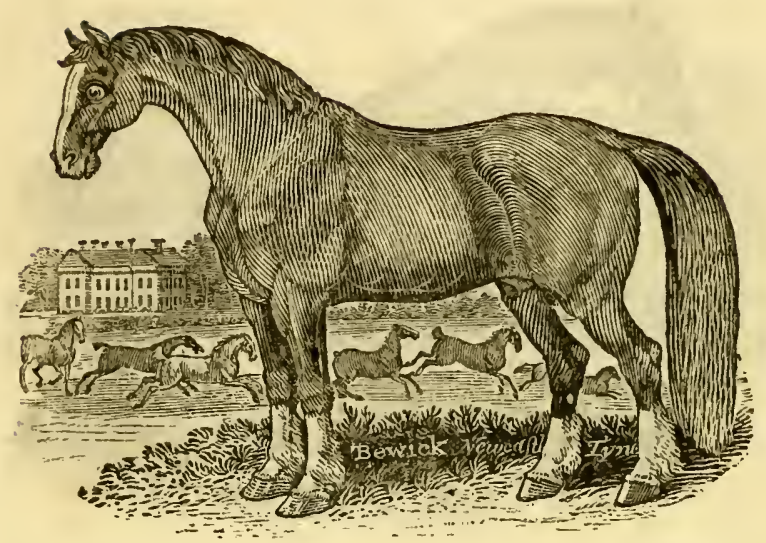

THE BLACK HORSE.

No other country has produced a breed of Horfes equal in fize and ftrength to the larger kind of our draught Horfes. The cavalry of England formerly confifted of this clafs of Horfes; but their inutility being experienced in moft fituations, others of a lighter and more active kind have been generally fubftituted, except in a few regiments. The fens of Lincolnfhire produce a larger breed than any other part of the kingdom. In London, there have been inftances where a fingle Horfe of that kind has drawn, for a fmall fpace, the enormous weight of three tons, half of which is known to be their ordinary draught.

Confiderable improvements have of late years been made in this kind of Horfes, by Mr Bakewell of Difhley, and others; who, by great ingenuity and attention, have acquired fuch celebrity, that they frequently fell ftallions of their refpective breeds for two hundred guineas; or, what is a more general practice, let them to hire by the 
feafon, for forty, eighty, or perhaps an hundred guineas; and fome of them cover at five guineas a mare. The form of the black Lincolnhire Horfe has, by their management, been materially altered: The long fore-end, long back, and long thick hairy legs, have gradually contracted into a fhort thick carcafe, a fhort but upright foreend, and thort clean legs; experience having at length proved, that ftrength and activity, rather than height and weight, are the more effential properties of farm Horfes.

Another advantage poffeffed by this improved breed, is its hardinefs, or thriving quality; its being able to carry flefh, or ftand hard work, with comparatively little provender. This hardinefs of confitution, or natural propenfity to thriving, the Leicefterfhire breeders affert is hereditary in particular individual breeds or lines of Horfes. If this obfervation be juft, and that the feeding quality can be obtained with any degree of certainty by management in breeding, in this as well as other kinds of live ftock, it is a moft interefting circumftance in the nature of domeftic animals.

A ftrong, bony, and active kind of Horfes is now ufed in our carriages, inftead of the old black Coach-Horfe, which is almoft univerfally laid afide. The docked tail, offenfive both to humanity and decency, is rarely to be feen: Propriety and good fenfe have at length prevailed over a cuftom replete with abfurdity; and our Horfes are permitted to retain a member both ufeful and orna'mental. But we have ftill to regret, that the cruel practice of forming the tail, by cutting and nicking it on the under fide, is yet continued.

Although it would be impoffible to trace out the kind of Horfes with which our Britilh anceftors oppofed them- 


\section{HISTORY OF QUADRUPEDS.}

felves to the legions of Julius Cxfar, on his landing in this country; yet that celebrated warrior himfelf bears teftimony to their activity and difcipline.

The Ponies of Wales, and thofe brought out of the Highlands of Scotland, feem to he original and unmixed. 'They are both much efteemed for the neatnefs and beauty of their forms, for the nimblenefs of their motions, and, above all, for being remarkably fure-footed in the moft difficult roads, which renders them extremely valuable in the mountainous tracts to which they originally belong. -Thofe brought from Shetland are the fmalleft of the genus, being in general much lefs than the Afs.

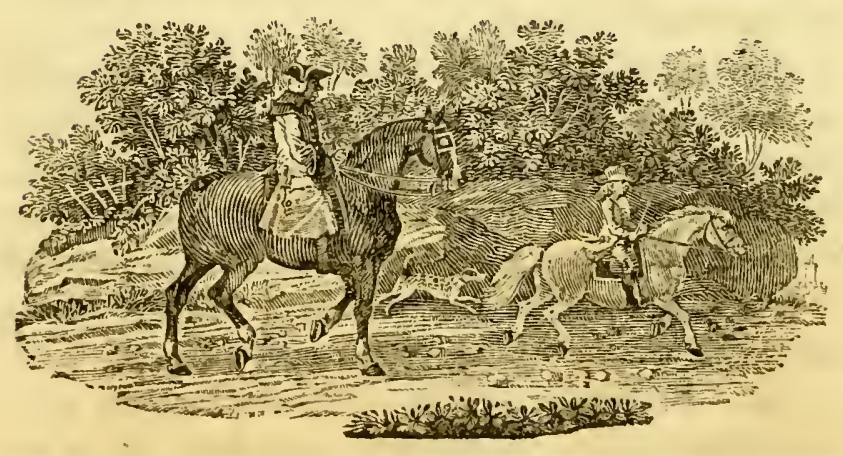




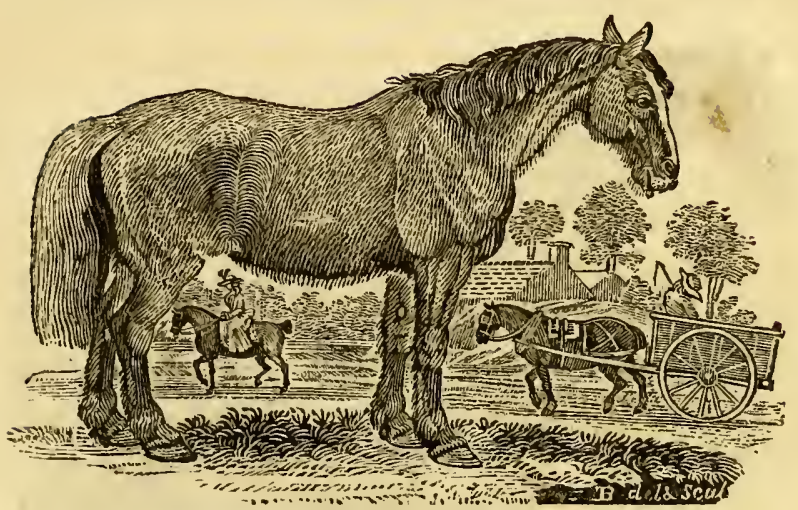

THE COMMON CART-HORSE

Is inferior to the Black Horfe both in fize and ftrength: His form is heavy, his motions flow, and his afpect without fprightlinefs : He is neverthelefs extremely ufeful, and is employed in the bufinefs of agriculture and other domeftic concerns.

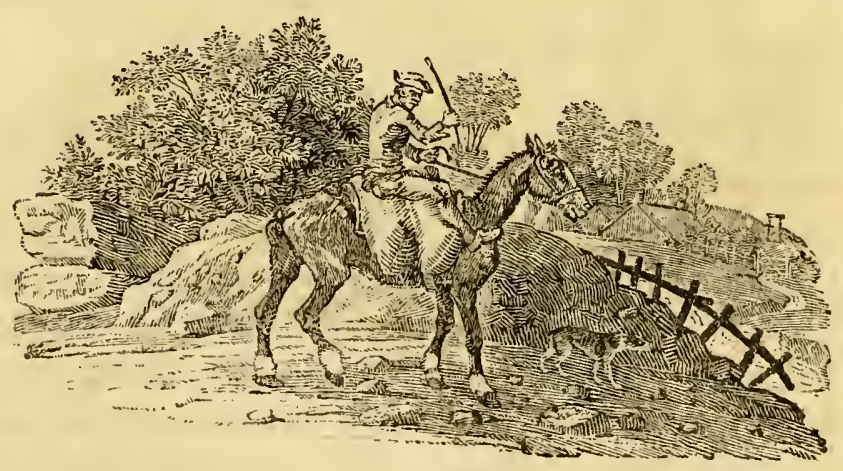




\section{HISTORY OF QUADRUPEDS.}

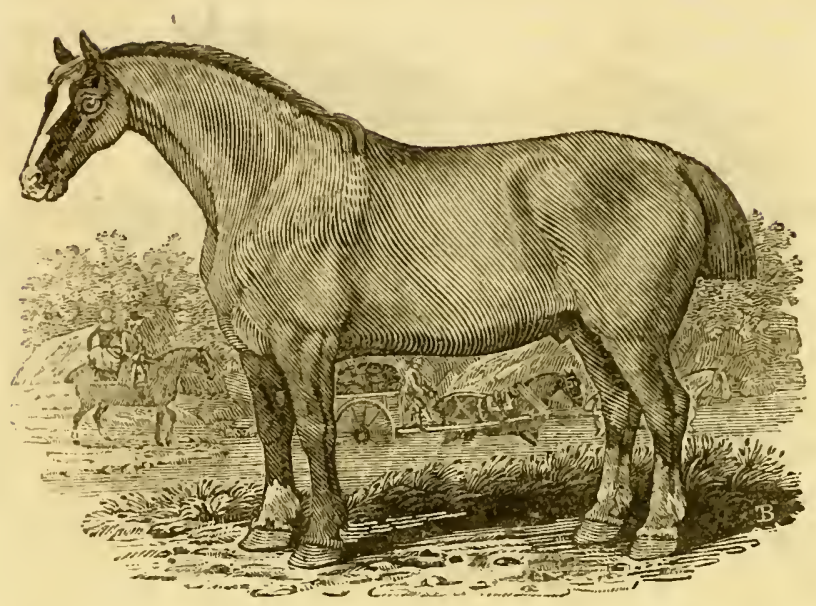

THE IMPROVED CART-HORSE.

IT will be gratifying to moft of our readers to know that the fpirit of improvement has extended itfelf greatly to this ufeful breed; and, to the advantages of ftrength and docility, has added thofe of form, activity, and vigour. - George Baker, Efq. of Elemore, in the county of Durham, has a remarkably fine Horfe of this kind, from which this figure was drawn.

Till of late years, Pack-Horfes were employed, in the northern counties of England, to carry the different manufactures and articles of traffic from one part of the kingdom to another; but the improved ftate of our roads has caufed that mode of conveyance to be almolt entirely laid afide. In their journies over tracklefs moors, they ftrictly adliere to the line of order and regularity cuftom has taught them to obferve: The leading Horfe, which is 
always chofen for his fagacity and fteadinefs, being furnifhed with bells, gives notice to the reft, who follow the found, and generally without much deviation, though fometimes at a confiderable diftance. The following anecdote will thew with what obftinate perfeverance they have been known to obferve the line of their order:-Some years ago, one of thefe Horfes, which had been long accuftomed to follow his leader, by accident or fatigue, was thrown into an inferior rank: The poor animal, as if fenfible of his difgrace, by the moft ftrenuous exertions, at length recovered his ufual ftation, which he maintained during the remainder of the journey; but, on his arrival in the inn-yard, he dropped down dead upon the fpot, his life falling a facrifice to his ambition,-a fpecies of heroifm we muft admire even in the brute creation.

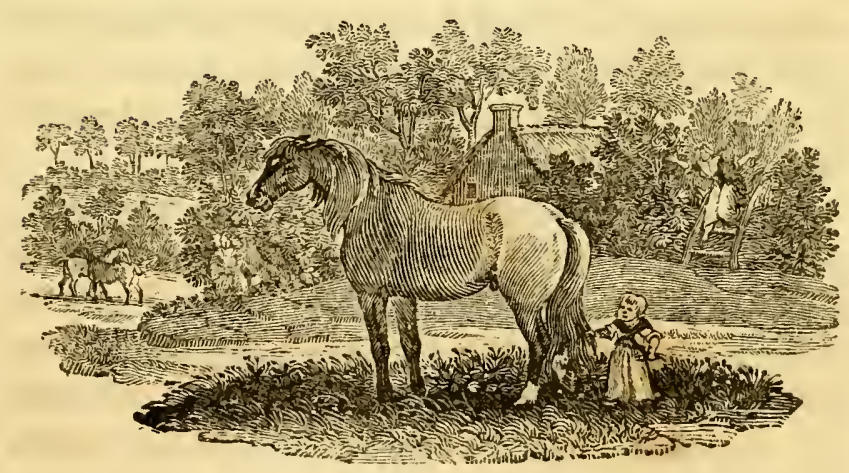




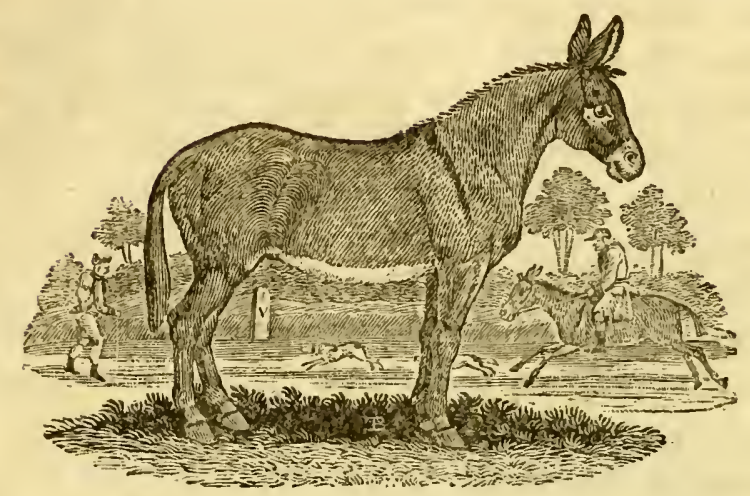

THE MULE.

THIs ufeful and hardy animal is the offspring of the Horfe and the Afs, and being generally barren, furnifhes an indifputable proof that the two fpecies are perfectly diftinct. Nature has providently ftopped the further propagation of thefe heterogencous productions, to preferve, uncontaminated, the form of each animal; without which regulation, the races would in a fhort time be mixed with each other, and every creature, lofing its original perfection, would rapidly degenerate.

Mules have not unfrequently been known to bring forth young, efpecially in hot countries; and inftances have not been wanting, though they are rare, both in England and Scotland. But it would require a fucceffion of experiments to prove that Mules will breed with each other, and produce an offspring equally capable of continuing the race.

The common Mule is very healthy, and will live above thirty years. It is found very ferviceable in carrying 
burthens, particularly in mountainous and ftony places, where Horfes are not fo fure-footed.- The fize and frength of our breed have lately been much improved by the importation of Spanifh Male-Afies; and it were much to be wifhed, that the ufeful qualities of this animal were more attended to: For, by proper care in its breaking, its natural obftinacy would in a great meafure be corrected; and it might be formed with fuccefs for the faddle, the draught, or the burthen.

People of the firft quality in Spain are drawn by Mules, where fifty or fixty guineas is no uncommon price for one of them; nor is it furprizing, when we confider how far they excel the Horfe in travelling in a mountainous country, the Mule being able to tread fecurely where the former can hardly ftand.-Their manner of going down the precipices of the Alps, the Andes, \&c. is very extraordinary; and with it we will conclude their hiftory. In thefe paffages, on one fide, are fteep eminences, and, on the other, frightful abyffes; and, as they generally follow the direction of the mountain, the road, inftead of lying in a level, forms, at every little diftance, deep declivities of feveral hundred yards downward. Thefe can only be defcended by Mules; and the animal itfelf feems fenfible of the danger, and the caution that is to be ufed in fuch defcents. When they come to the edge of one of thefe precipices, they ftop without being checked by the rider; and if he inadvertently attempt to fpur them on, they continue immoveable. They feem all this time ruminating on the danger that lies before them, and preparing themfelves for the encounter. They not only attentively view the road, 
but tremble and fnort at the danger. Having prepared for the defcent, they place their fore feet in a pofture, as if they were ftopping themfelves; they then alfo put their hind feet together, but a little forward, as if they were going to lie down. In this attitude, having taken as it were a furvey of the road, they flide down with the fwiftnefs of a meteor. In the mean time, all the rider has to do is to keep himfelf faft on the faddle without checking the rein, for the leaft motion is fufficient to diforder the equilibrium of the Mule; in which cafe they both unavoidably perinh. But their addrefs in this rapid defcent is truly wonderful; for in their fwiftent motion, when they feem to have loft all government of themfelves, they follow exactly the different windings of the road, as if they had previoufly fettled in their minds the route they were to follow, and taken every precaution for their fafety. In this journey, the natives place themfelves along the fides of the mountains; and, holding by the roots of the trees, animate the beafts with fhouts, and encourage them to perfevere. Some Mules, after being long ufed to thefe journies, acquire a kind of reputation for their fafety and $1 k$ ill ; and their value rifes in proportion to their fame.

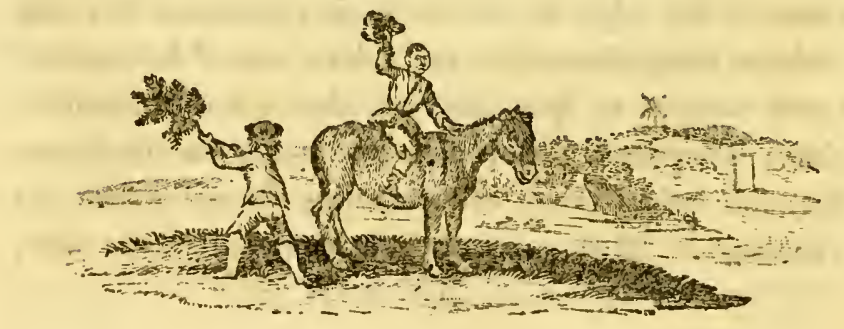




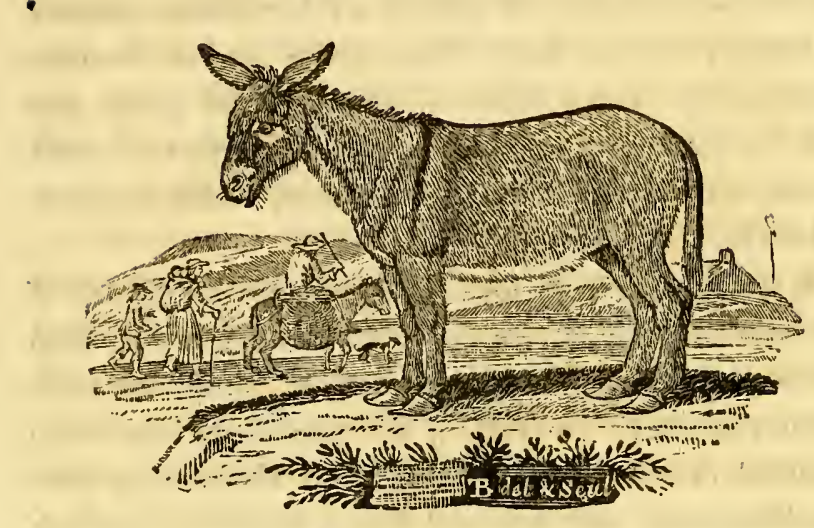

THE ASS.

(Equus Afrnus, Lin.-L'Ane, Buff.)

The Afs, it is probable, was originally a native of Arabia and other parts of the Eaft: The deferts of Lybia and Numidia, and many parts of the Archipelago, contain vaft herds of wild Affes, which run with fuch amazing fwiftnefs, that even the fleetert Horfes of the country can hardly overtake them. They are chiefly caught by the natives on account of their flefl, which is eaten by them, and confidered as a delicious repant. The flefh of the common or tame Afs is however drier, more tough, and difagreeable than that of the Horfe; Galen fays, it is even unwholefome: Its milk, on the contrary, is an approved remedy for certain diforders.

The Afs, like the Horfe, was originally imported into America by the Spaniards, where it has run wild, and become extremely numerous. Ulloa informs us that, in the kingdom of Quito, they hunt them in the following 
manner :-A number of perfons on horfeback, attended by Indians on foot, form a large circle in order to drive them into a narrow compars, where at full fpeed they throw a noofe over them, and having fecured them with fetters, leave them till the chace is over, which frequent ly lafts for feveral days.

A warm climate is moft favourable to the growth of this animal: The Afs produced in this country is much inferior in fize and beauty to thofe of Spain and other warm countries: In Guinea, they are larger and more beautiful than even their Horfes: In Perfia, they have two kinds, - the one flow and heavy, which is made ufe of for carrying burthens; the other nimble, fmooth, and ftately, ufed chiefly for the faddle.

Holingthed informs us, that, in the reign of queen Elizabeth, there were no Affes in this country: How foon after they might be introduced, is uncertain. However, they are at prefent naturalized in this kingdom, where their utility becomes daily more univerfally experienced.

The qualities of this animal are fo well known, as to need no defcription: His gentlenefs, patience, and perfeverance, are without example: $\mathrm{He}$ is temperate with regard to food, and eats contentedly the coarfeft and moft neglected herbage: If he give the preference to any vegetable, it is to the plantain, for which he will neglect every other herb in the pafture. In his water he is fingularly nice, drinking only from the cleareft brooks. He is fo much afraid of wetting his feet, that, even when loaden, he will turn afide, to avoid the dirty parts of the road.

$\mathrm{He}$ is fronger, in proportion to his fize, than the Horfe; but more fluggifh, ftubborn, and untractable. 
He is hardier than the Horfe ; and, of all other quadrupeds, is leaft infefted with lice or other vermin; probably owing to the extreme hardnefs and drynefs of his fkin. For the fame reafon, perhaps, he is lefs fenfitive of the goads of the whip, or the ftinging of flies.

$\mathrm{He}$ is three or four years in coming to perfection; and lives to the age of twenty, or fometimes twenty-five years. He fleeps much lefs than the Horfe, and never lies down for that purpofe but when he is much fatigued. The She-Afs goes eleven months with young, and feldom produces more than one at a time.

The fervices of this ufeful creature are too often repaid by hard fare and cruel ufage; and being generally the property of the poor, it partakes of their wants and their diftreffes: Whereas, by due cultivation and care in its education, the Afs might be ufefully and profitably employed in a variety of domentic purpofes, and in many cafes fupply the place of the Horfe, to which only it is fecond, though generally degraded into the molt ufelefs and neglected of domeftic quadrupeds.

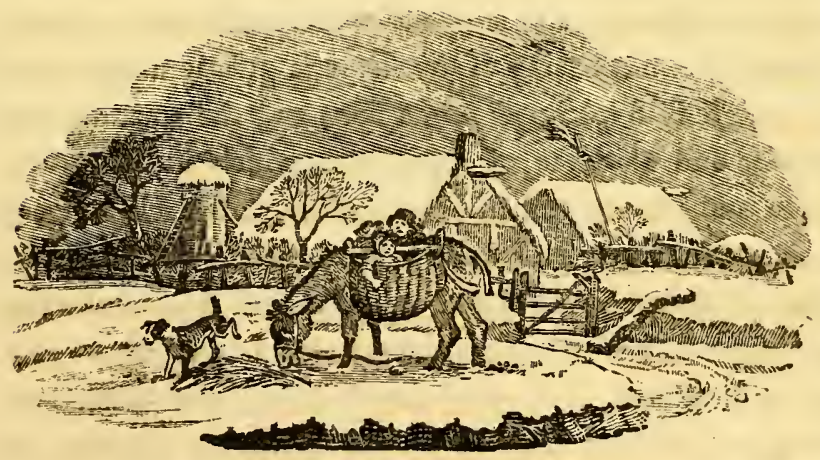

B 3 


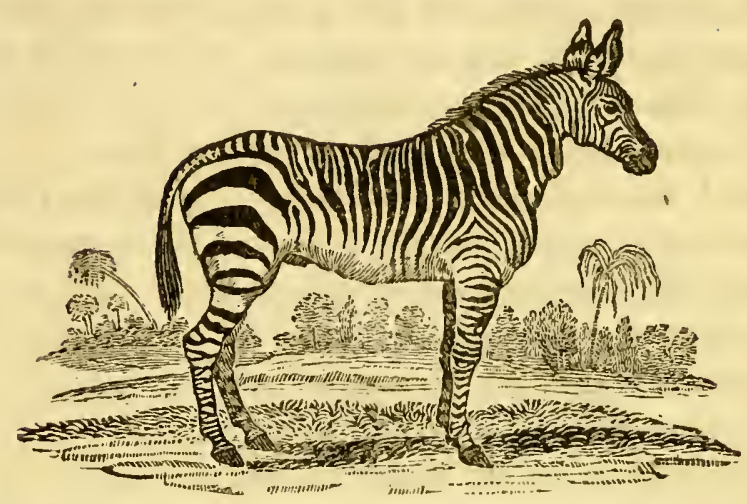

THE ZEBRA.

(Equus Zebra, Lin.-Le Zebre, Buff.)

MANY authors have miftaken the Zebra for a wild Afs; it is the moft beautiful, as well as the wildeft, moft timid, and untameable animal in nature. It is larger than the Afs, and rather refembles the Mule in flape: Its head is large; its ears long; its legs beautifully fmall, and well placed; and its body well formed, round, and flenly: But the beauty of its fhape is greatly heightened by the gloffy fmoothnefs of its $\mathrm{kin}$, and the amazing regularity and elegance of its colours, which in fome are white and brown, and in others white and black, ranged in alternate ftripes over the whole body, in a ftile fo beautiful and ornamental, that it would at firft fight feem rather the effect of art, than the genuine production of nature: The head is ftriped with fine bands of black and white, which form a center in the forehead; the rreck is adorned with ftripes of the fame colour running round 
it; the body is beautifully variegated with bands running acrofs the back, and ending in points at the belly; its thighs, its legs, its ears, and even its tail, are all beautifully ftreaked in the fame manner.

The Zebra inhabits the fouthern parts of Africa, where whole herds are feen feeding in thofe extenfive plains that lie towards the Cape of Good Hops. However, their watchfulnefs is fuch, that they will fuffer nothing to come near them; and their fwiftnefs fo great, that they eafily leave their purfuers far behind.

Such is the beauty of this creature, that it feems by nature fitted to gratify the pride, and formed for the fervice of man; and it is moft probable, that time and affiduity alone are wanting to bring it under fubjection. As it refembles the Horfe in regard to its form, as well as manner of living, there can be little doubt but it poffeffes a fimilitude of nature, and only requires the efforts of an induftrious and fkilful nation, to be added to the number of our ufeful dependents. Neverthelefs, its liberty has hitherto remained uncontrouled, and its natural fiercenefs has as yet refifted every attempt to fubdue it: Thofe that have been brought to this country, have difcovered a degree of vicioufnefs that rendered it unfafe to approach them too familiarly; but it is by no means to be concluded from hence, that they are untameable. They have continued to be wild, becaufe they are natives of a country where the wretched inhabitants have no other idea of advantage from the animal creation than as they are good for food, paying more regard to that which affords the moft delicious repaft, than to delicacy of colouring, or beauty of conformation. 


\section{RUMINATING ANIMALS.}

THE various animals of this kind are entirely confined to grain and herbage for their nourifhment and fupport; it is therefore neceffary that they fhould be enabled to receive a large quantity into the ftomach, as well as to retain it a confiderable time before it be reduced to proper chyle: For this purpofe, their inteftines are remarkably long and capacious, and formed into a variety of foldings. They are furnifhed with no lefs than four ftomachs. The food, after maftication, is thrown into the firft ftomach, where it remains fome time; after which, ' it is forced up again into the mouth, and undergoes a fecond chewing: It is then fent directly into the fecond ftomach, and gradually paffes into the third and fourth; from whence it is tranfmitted through the convolutions of the inteftines. By this conformation, ruminating animals are cnabled to devour large quantities of vegetable aliment, to retain it long in their bowels, and confequently extract from it a quantity of nutritious matter fufficient for their growth and fupport.

The great obligations we are under to thofe of this clais, render them objects of the higheft importance to us. We are nourifhed with their milk, we are fupported by thcir flefh, and we are cloathed and warmed with their fleeces: Their harmlefsuefs and innocence endear them to us, and claim from us that protection which their natures feem to require; and, in return, they fupply us with the neceffaries and comforts of life. 


\section{THE OX KIND.}

\section{(Bos Taurus, Lin.-Le Taureau, Buff.)}

OF all quadrupeds, the Cow feems moft extenfively propagated: It is equally capable of enduring the rigours of heat and cold; and is an inhabitant of the frozen, as well as the moft fcorching climates. Other animals preferve their nature or their form with inflexible perfeverance; but thefe, in every refpect, fuit themfelves to the wants and conveniencies of mankind. In no animal is there to be met with a greater varicty of kinds; and in none, a more humble and pliant difpofition.

The climate and paftures of Great-Britain are well adapted to the nature of this animal; and we are indebted to the variety and abundance of our wholefome vegetables, for the number and excellence of our cattle, which range over our hills, and enliven our plains-a fource of inexhauftible wealth-the pride and boaft of this happy country.

Being deftitute of the upper fore teeth, the Cow prefers the high and rich grafs in paftures, to the fhort and more delicate herbage generally felected by the Horfe. For this reafon, in our Englih paftures, where the grafs is rather high and flourifhing, than fucculent and nutritious, the Cow thrives admirably; and there is no part of Europe in which this animal grows larger, yields more milk, or fattens fooner.

It has often been remarked, that the Horfe and Sheep impoverifh the foil on which they graze; whilf the pafture where the Cow is fed, acquires a finer furface, and every year becomes more level and beautiful: The Horfe 
felects the grafs that is moft delicate and tender; and, being furnifhed with fore teeth on each jaw, nips it clofe, and frequently pulls it up by the roots, thereby preventing its future growth and propagation: The Sheep alfo, though formed like the Cow with refpect to its teeth, only bites the moft fucculent parts of the herbage.

The age of a Cow is known by its horns: At the age of four years, a ring is formed at their roots; and every fucceeding year, another ring is added. Thus, by allowing three years before their appearance, and then reckoning the number of rings, the creature's age may be exactly known.

The quantity of milk given by Cows is very various: Some will yield only about fix quarts in one day; while others give from ten to fifteen, and fometimes even twenty. The richnefs of the pafture contributes not a little to its increafe. There have been inftances of Cows giving upwards of thirty quarts of milk in one day. In fuch cafes, there is a neceffity for milking them thrice.-From the milk of fome Cows, twelve or fourteen pounds of butter are made in a week.

It has been advanced by fome naturalifts, as a general principle, that neither animals, nor parts of animals, appear to be primarily intended for the ufe of man; but are only capable of a fecondary application to his purpofes: Yet it muft be allowed that, in many. inftances, what they term the fecondary ufe, is fo manifeft and inportant, that it cannot, with propriety, be fuppofed to be excluded from the original defign of the all-wife Creator: And it mut be allowed that the Cow, in its faeulty of giving, in fuch abundance and with fo much eafe, its milk, which forms fo rich and nutritive an ati- 
ment for the human fpecies, is a ftriking example of this fubordination to the interefts of mankind: For this animal differs, in fome parts of its organization, from moft others, having a larger and more capacious udder, and longer and thicker teats, than the largeft animal we know of : It has likewife four teats, whilft all other animals of the fame nature have but two: It alfo yields the milk freely to the hand, whilft moft animals, at leaft thofe that do not ruminate in the fame mamer, refufe it, exeept their own young, or fome adopted animal, be allowed to partake.

The Cow, having four teats, is a ftriking peculiarity; the number in all other animals bearing fome proportion to the number of young ones they bring forth at a time; as in the Bitch, the Cat, the Sow, \& c c.

The Cow will yield her milk as freely, and will continue to give it as long, without the aid of the calf, as if it were permitted to fuck her conftantly. This is not the cafe with the Afs; which, it is well known, will foon grow dry, if her foal be not permitted to fuck part of her milk every day.

Upon the whole, it appears, that the property of yielding milk, without the young one, is confined to thore kinds of ruminating horned animals which have cloven hoofs, four ftomachs, long inteftines, are furnifhed with fuet, and have no fore teeth in the upper jaw; that Cows, Sheep, Goats, and Deer, are of this kind, and no other; and that the Cow has this property in a more eminent degree than others, owing to the capacioufnefs of her udder, and the fize and form of her teats.

The Cow goes nine months with young, and feldom produces more than one at a time. 
It is a curious fact, that when a Cow happens to bring forth two calves, - one of them a male, the other a female, - the former is a perfect animal, but the latter is incapable of propagation, and is well known to farmers under the denomination of a Free Martin. It refembles the $\mathrm{Ox}$, or fpayed Heifer, in figure; and is confiderably larger than the Cow. It is fometimes preferved by the farmer, for the purpofe of yoking with the Oxen, or fattening for the table.-Mr Hunter obferves, that the flefh of the Free Martin, like that of the Ox, is much finer in the fibre than either the Bull or Cow. It is fuppofed to exceed that of the Heifer in delicacy of flavour, and bears a higher price at market.

By great induftry and attention to their breed, and by judicious mixtures with thofe of other countries, our horned cattle are univerfally allowed to be the fineft in Europe; although fuch as are purely Britifh are inferior in fize to thofe on many parts of the continent.

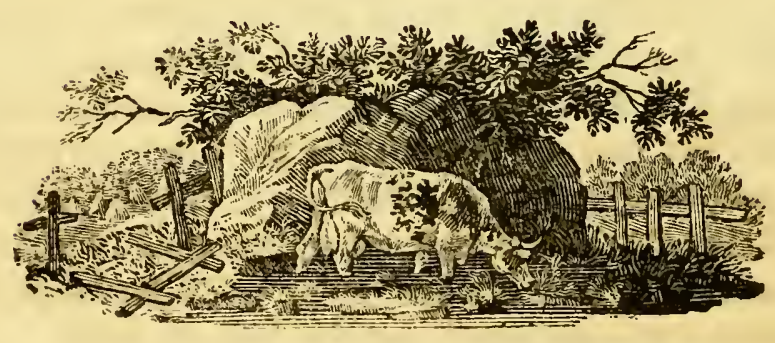




\section{HISTORY OF QUADRUPEDS.}
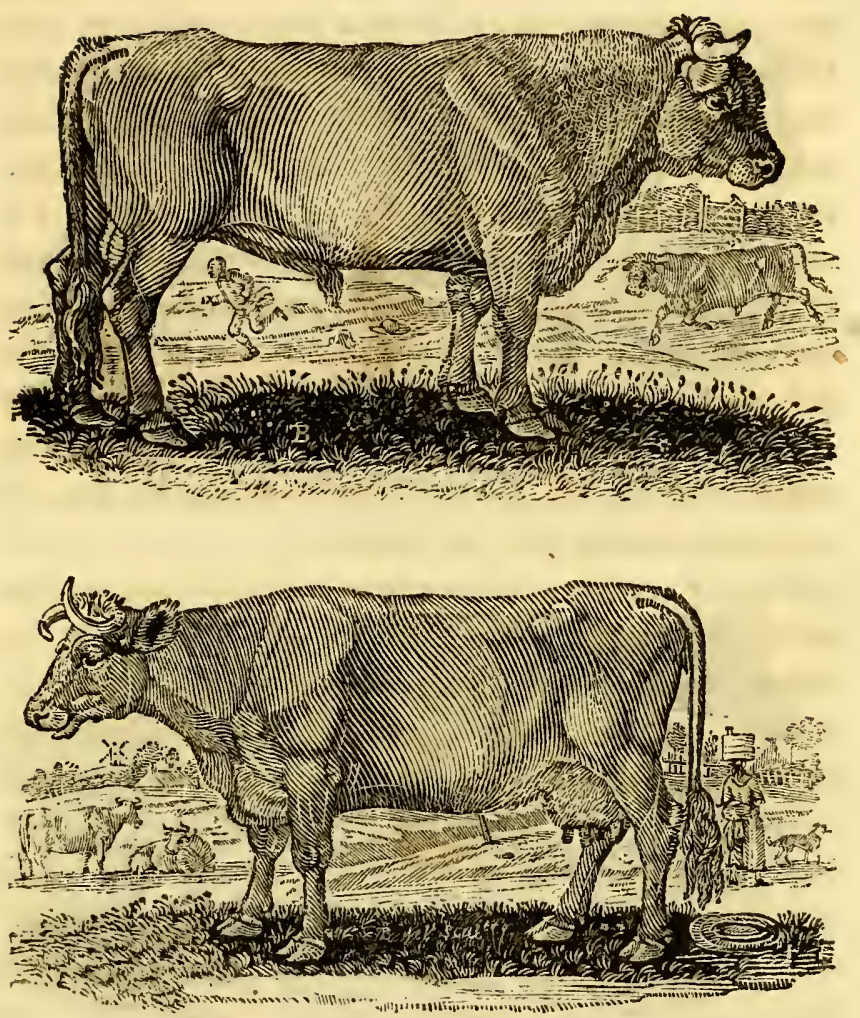

\section{THE HOLSTEIN, OR DUTCH BREED,}

$\mathrm{H}_{\mathrm{AS}}$ been introduced with great fuccefs, and is now the prevailing ftock in all the counties on the eaftern coaft of this kingdom.-In good paftures, cattle of this kind grow to a great fize*; and the Cows yield a greater abundance of milk than thofe of almoft any other kind.

* An Ox, fed by Mr Edwatd Hall, of Whitley in Northumberland, and killed in March, 1;89, when feven years old, meafured, frum the head to the rump, nine feet eight inches and an 

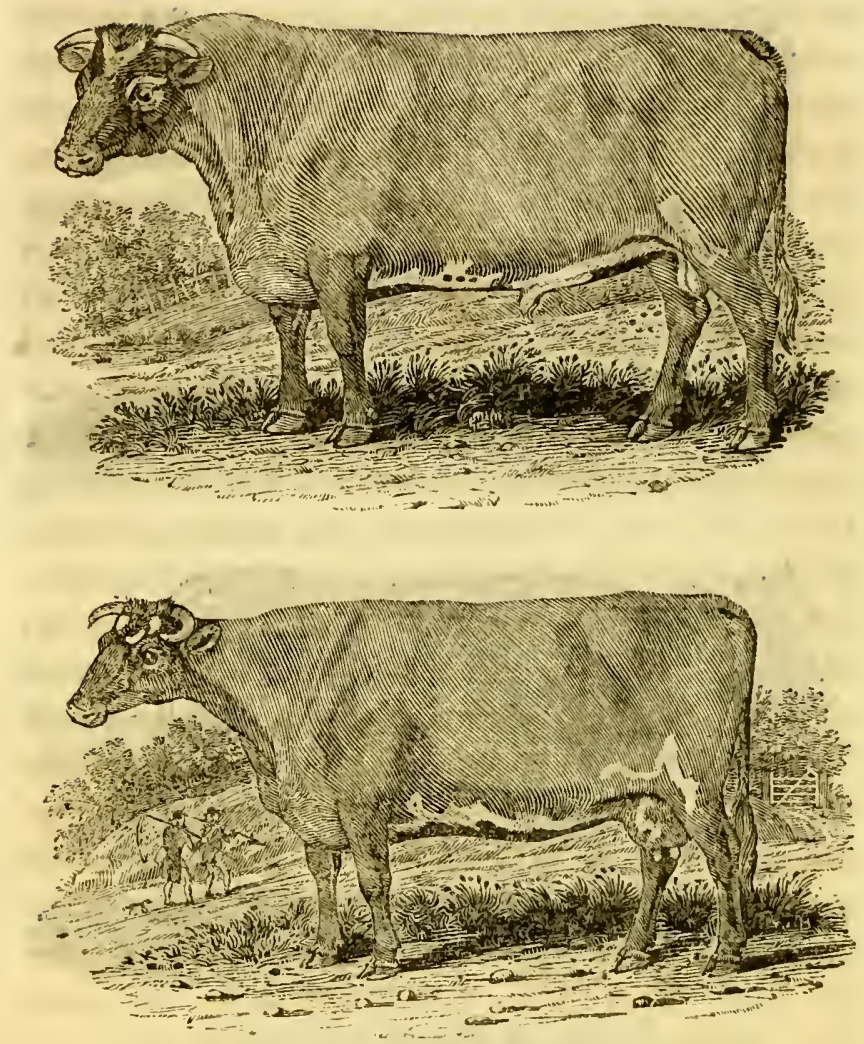

\section{THE IMPROVED HOLSTEIN, OR DUTCH BREED.}

THE rapid improvements which have taken place in this and other kinds, form an interefting fubject of enquiry, of which the limits of our work will only allow us

laif; the height, at the moulder, was five feet ten inches; and it weighed, without the offal, one hundred and eighty-feven flone five pounds-fourteen pounds to the ftone. 
to give the outlines. We thall however notice the general principles which have been laid down, and fteadily adhered to, in the improvement of the feveral breeds of cattle; and which have been fo fuccefsfully brought into practice. The firft, and moft obvious, is beauty of form, -a principle which has been in common applied to every fpecies of domeftic cattle; and, with great feeming propriety, was fuppofed to form the bafis of every kind of improvement; under an idea, that beauty of form and utility were infeparable. But at prefent, a diftinction is made, by men who have been long converfant in practice, between a ufeful fort and a fort that is merely handfome. Utility of form is therefore the next general principle, and may be confidered as arifing from a larger proportion of thofe parts which are the moft ufeful: Thus, for inftance, all thofe parts which are deemed offal, or which bear an inferior price, thould be fmall in proportion to the better parts. A third principle of improvement, laid down by breeders, confifts in the finenefs of the mufcular parts, or what is termed $f e / 3$. But the : great object which engroffes the attention of breeders at prefent, is the fattening quality, or a natural propenfity in cattle to arrive at a ftate of fatnefs at an early age, and in a fhort fpace of time: And it appears, from obfervation, that beauty and utility of form, the quality of the flefh, and its propenfity to fatnefs, are principles confiftent with each other, are frequently found united in the fame individual, and hereditary in particular lines or families of cattle.-In regard to the means of improvement, it has long been an eftablifhed maxim, that, to improve the breed, it is neceffary to crofs it with others of an alien ftock, under an opinion, that, continuing to breed from 
the fame line, weakens the ftock. This idea, however rooted it may have been in the minds of former practitioners, is now entirely fet afide by the modern practice of breeding, not from the fame line only, but from the fame family: The fire and the daughter, the fon and the mother; the brother and fifter, are now permitted to improve their own kind. This practice is well known unter the term of breeding, in-and-in; and, in this way, the improvement of the feveral breeds has advanced rapidly to a height unknown before in any age or nation.

The practice of letting out Bulls by the feafon has contributed very materially towards the improvement of this valuable breed; as, by this means, one Bull, inftead of being ufeful to his proprietor only, may, in a few years, extend the benefits of his ftock through a whole diftrict; and fo fully are the ftock-mafters convinced of its advantages, that eighty guineas have been given for the ufe of a Bull for one feafon. Some Bulls are in fuch eftimation, as to leap at the extraordinary price of five guineas a Cow: And it is, perhaps, a circumftance worth mentioning, that Mr Fowler, of Rollright, in Oxfordthire, in 1789 , for ten Bull calves, refufed five hundred guineas.*

* This valuable ftock was fold off in March, I 79I, at the following cnormous prices, viz.
Garrick, a five-year old bull,
Sultan, two years old, 205 guineas.
Wathington, wo years old, . 205
Young Sultan, a ycarling bull, 200
Two yearling bulls,
245
lBrimlled Beauty, a cow,
260
Washington's mother, in calf 185
Some of the Rams fold as higb as 60 


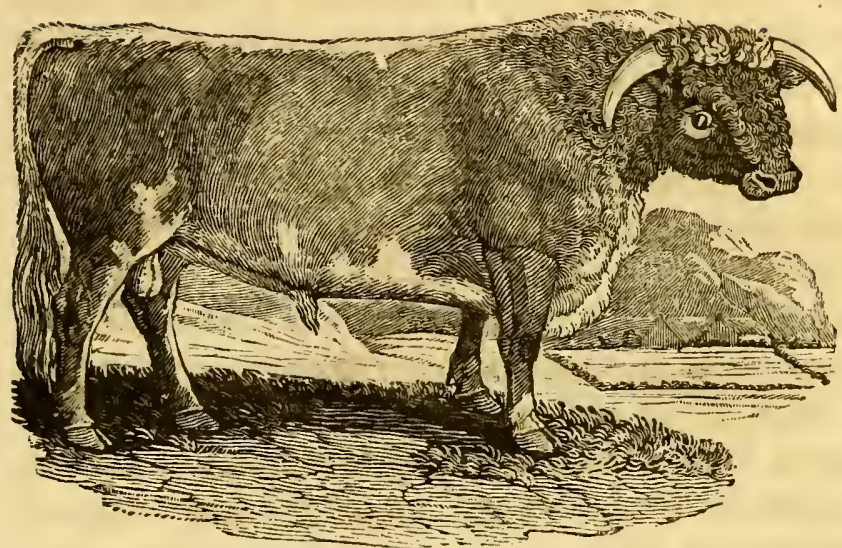

THE LONG-HORNED, OR LANCASHIRE. BREED,

Is common in Lancafhire, Wertmorland, and Cumberland, and fome of the neighbouring counties; and, notwithftanding the changes which have taken place by the introduction of foreign kinds, there is reafon to believe that this, for a confiderable time at leaft, has been the prevailing ftock of the kingdom at large.

Mr Marfhall, in his excellent treatife on the "Economy of the Midland Counties," obferves, that, from this kind the prefent improved breed of cattle in Leicefterfhire is traceable, by the moft indifputable evidence. From Bulls brought out of Weftmorland and Lancafhire, and Cows from the banks of the Trent, the celebrated Canley breed, the property of Mr Webfter, derived its origin; and about fifty years ago it was efteem- 
ed the moft valuable at that time in the kingdom. From this breed, the late $\mathrm{Mr}$ Bakewell obtained the fource of his fuperior ftock of cattle; and feveral other eminent breeders are alfo indebted to the fame origin for the celebrity they have fince attained.

Great improvements have of late years been made in the old Lancafbire kind, both in fize and beauty.-Craven, in Yorkfhire, has long been celebrated for a fuperior variety of the long-horned kind: And from thence the graziers of Weftmorland and Lancafhire purchafed the flower of their Heifers; which, by crofling with the original ftock of thofe counties, have produced a breed, which is now had recourfe to, for the improvement of this kind of cattle, in every part of the kingdom.-Some of the Bulls are extremely large. Their horns are not long, but beautifully turned; their hair thort and fmooth; their crefts rife extremely high; their chefts are let down to their knees; their bodies are long, and in the form of a perfect cylinder.

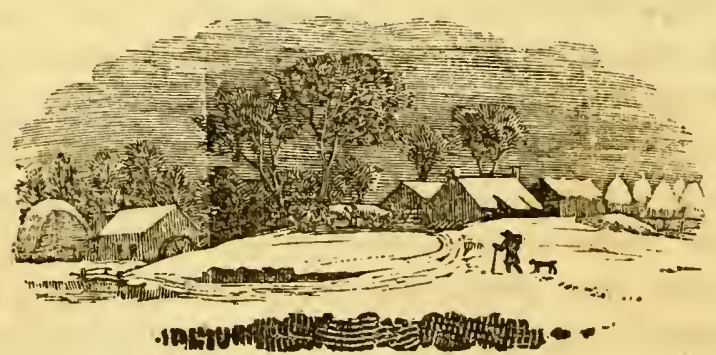




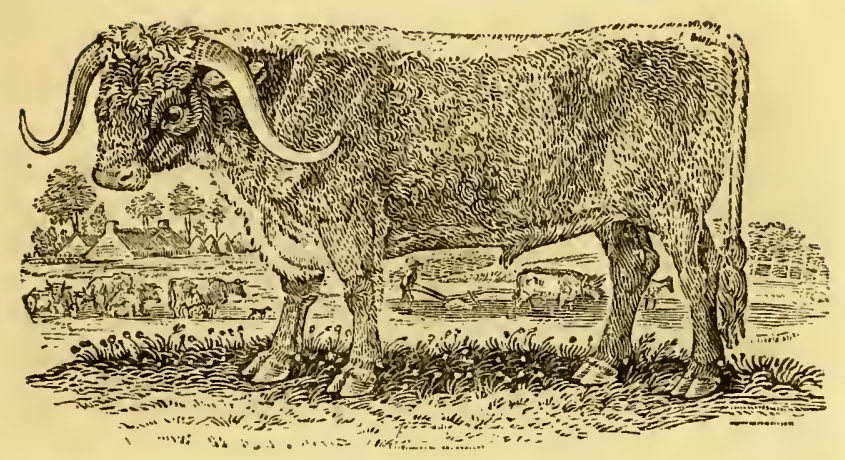

THE LANCASHIRE OX.

The Cows and Oxen are fmaller. Their horns are long and fmall, very fmooth; and their colour, in general, approaches to yellow: Their hair is beautifully curled; and their whole form extremely handfome-The Oxen frequently grow to a confiderable fize, are very active, and confequently ufeful in the draught. They are well fuited to a cold climate, and grow fat on indifferent paftures.

In Scotlanid there are two kinds, which differ greatly from each other, as well as from all thofe in the fouthern parts of this ifland.

Thofe of the county of Galloway are without horns, and generally of a reddin-brown colour, mixed with black. Large droves of thefe are yearly brought into the fouthern parts of this kingdom, where they foon greatly improve. 


\section{$3^{6}$ HISTORY OF QUADRUPEDS.}

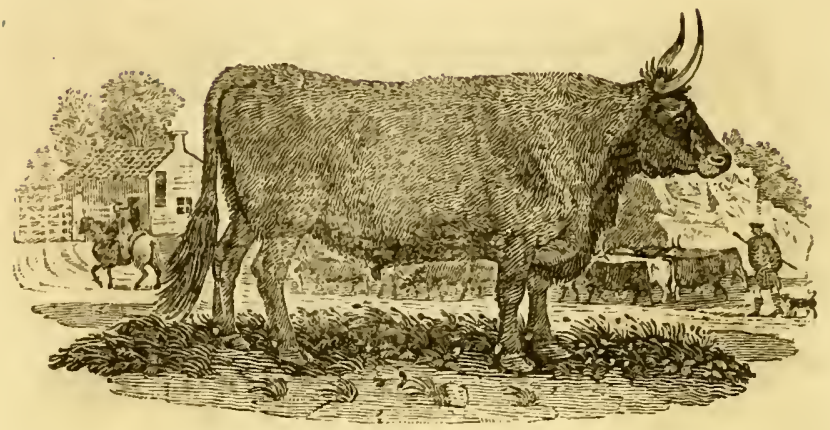

THE KYLOE OX.

THE Highland cattle, and thofe bred in the Weftern Iflands, are very fmall, and partake much of the wildnefs of the country in which they are bred. They are moftly black, with fine white horns, very fharp, and black at the points; their hair is thick and furry. Great numbers of thefe are likewife fold into England at the great northern fairs. They are greatly efteemed for the finenefs and fweetnefs of their beef, as well as for the facility with which they acquire a confiderable degree of fatnefs, even with moderate feeding.

Although the Oxen of this breed, when fed in the ordindry way, do not exceed forty ftone the four quarters, one of them, fed by Mr Spearman of Rothley Park, in Northumberland, weighed, when killed in $\mathbf{1 7 9 0}$, at the age of fix years, eighty-one ftone.

In Great-Britain the $O x$ is the only horned animal that will apply his ftrength to the fervice of mankind; and, in general, is more profitable than the Horfe for 
the plough or the draught. There is fcarcely any part of this animal without its ufe: The fkin is made into various kinds of leather; the hair is mixed with lime for: plaiftering; the bones are made ufe of as a fubftitute for ivory, and, being calcined, are ufed by the refiner as an abforbent to carry off the bafer metals in refining filver, \&c. : combs, and many other articles are made of the horns; we are fupplied with candles from the tallow; and from the feet is procured an oil, of great ufe in preparing and foftening leather; befides the well-known benefits derived from butter, milk, and cheefe ; its blood, gall, liver, and urine, have their refpective ufes in manufactures and medicine.

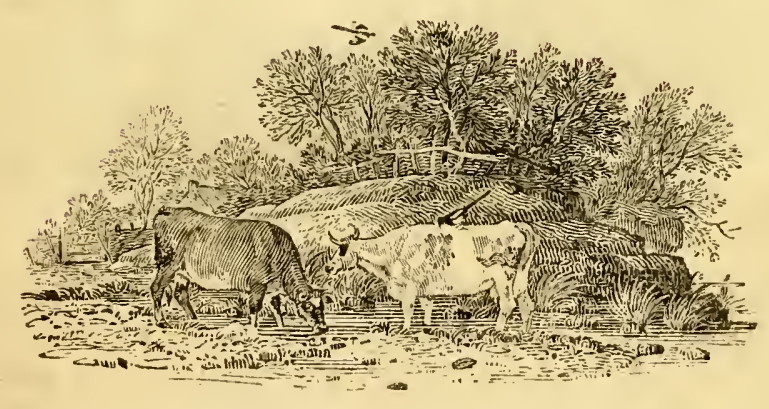

C 3 

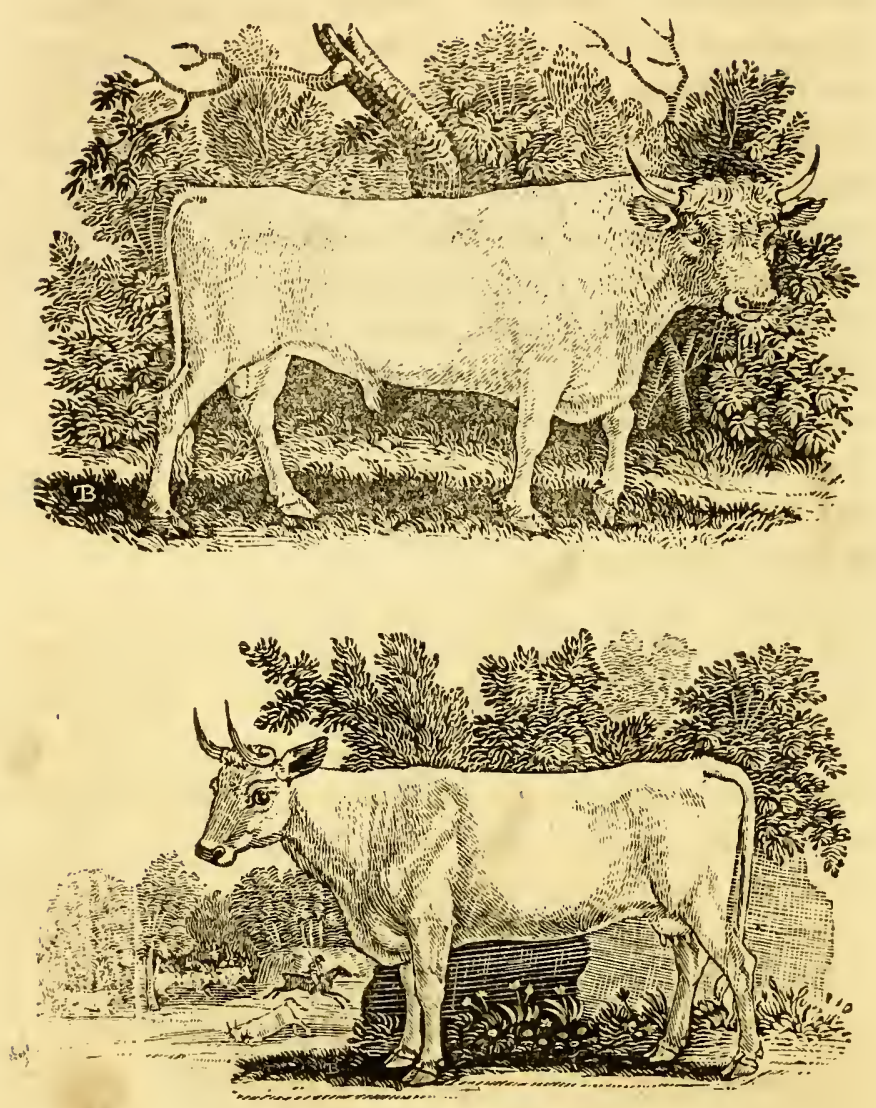

\section{WILD CATTLE.}

THERE was formerly a very fingular fpecies of wild cattle in this country, which is now nearly extinct. $\mathrm{Nu}$ merous herds of them were kept in feveral parks in England and Scotland; but they have been deftroyed by various means: And the only breeds now remaining in the 
kingdom, are in the park at Chillingham-cafte, in Northumberland; at Wollaton, in Nottinghamphire, the feat of Lord Middleton; at Gifburne, in Craven, Yorkhire; at Lime-hall, in Chefhire ; and at Chartley, in Staffordnire.

The principal external appearances which diftinguifh this breed of cattle from all others, are the following :Their colour is invariably white; muzzles black; the whole of the infide of the ear, and about one-third of the outfide, from the tip downwards, red*; horns white, with black tips, very fine, and bent upwards: Some of the Bulls have a thin upright mane, about an inch and an half, or two inches long.

At the firft appearance of any perfon they fet off in full gallop, and, at the diftance of two or three hundred yards, make a wheel round, and come boldly up again, toffing their heads in a menacing manner: On a fudden they make a full ftop, at the diftance of forty or fifty yards, looking wildly at the object of their furprife ; but, upon the leaft motion being made, they all again turn round, and fly off with equal fpeed; but not to the fame diftance: Forming a fhorter circle, and again returning with a bolder and more threatening afpect than before, they approach much nearer, probably within thirty yards;

* About twenty years fince, therc were a few, at Chillingham, with BLACK EARS, but the prefent park-keeper leflroyed them; -fince which period there has not been one with black ears.The ears and nofes of all thofe at Wollaton are BLACK.-At Gifburne there are fome perfectly WHITE, except the infide of their cars, which are BROWN. They are without horns, very frongboned, but not high. They are faid to have been originally brought from Whalley-abbey, in Lancafhire, upon its diffolution in the thirty-third of Henry the Eighth. Tradition fays, they were drawn to Gifburne by the 'power of mulic.'

C 4 . 
when they make another ftand, and again fly off: This they do feveral times, fhortening their diftance, and advancing nearer, till they come within ten yards; when moft people think it prudent to leave them, not chufing to provoke then further; for there is little doubt but in two or three turns they would make an attack.

The mode of killing them was, perhaps, the only modern remains of the grandeur of ancient hunting. On notice being given that a wild Bull would be killed on a certain day, the inhabitants of the neighbourhood came mounted, and armed with guns, \&c. fometimes to the amount of an hundred horfe, and four or five hundred foot, who ftood upon walls, or got into trees, while the horfemen rode off the Bull from the reft of the herd, untill he ftood at bay; when a markfman difmounted and fhot. At fome of thefe huntings twenty or thirty fhots have been fired before he was fubdued. On fuch occafions, the bleeding victin grew defperately furious, from the fmarting of his wounds, and the fhouts of favage joy that were echoing from every fide: But, from the number of accidents that happened, this dangerous mode has been little practifed of late years; the park-keeper alone generally fhooting them with a rifled gun, at one fhot.

When the Cows calve, they hide ther calves for a week or ten days in fome fequeftered fituation, and go and fuckle them two or three times a-day. If any perfon come near the calves, they clap their heads clofe to the ground, and lie like a hare in form, to hide themfelves: This is a proof of their native wildnefs, and is corroborated by the following circumitance that happened to the writer of this narrative, who found a hidden calf, two days old, very lean and very weak :-On froking its 
head, it got up, pawed two or three times like an old Bull, bellowed very loud, ftepped back a few fteps, and bolted at his legs with all its force; it then began to paw again, bellowed, ftepped back, and bolted as before; but knowing its intention, and ftepping afide, it miffed him, fell, and was fo very weak that it could not rife, though it made feveral efforts: But it had done enough; the whole herd were alarmed, and coming to its refcue, obliged him to retire; for the dams will allow no perfon to touch their calves, without attacking them with impetuous ferocity.*

When any one happens to be wounded, or is grown weak and feeble through age or ficknefs, the reft of the herd fet upon it, and gore it to death.

The weight of the Oxen is generally from forty to fifty ftone the four quarters; the Cows about thirty. The beef is finely marbled, and of excellent flavour.

Thofe at Burton-Conftable, in the county of York, were all deftroyed by a diftemper a few years fince. They varied flightly from thofe at Chillingham, having black ears and muzzles, and the tips of their tails of the fame colour: They were alfo much larger, many of them weighing fixty ftone; probably owing to the richnefs of the pafturage in Holdernefs, but generally attributed to the difference of kind between thofe with black and with red ears, the former of which they ftudioufly endeavoured to preferve. The breed which was at Drumlanrig, in Scotland, had alfo black ears.

* Tame Cows, in feafon, are frequently turned out amongft the Wild Cattle at Chillingham, and admit the Bull. It is fomewhat extraordinary, that the calves produced by this means are invariably of the fame colour with the wild breed, (white, with red ears) and retain a good deal of the fiercenefs of their fire. 


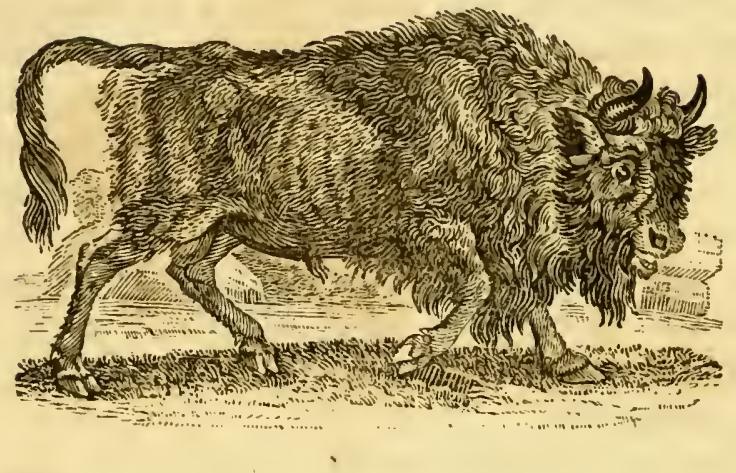

THE URUS, OR WILD BULL,

Is chiefly to be met with in the extenfive forefts of $\mathrm{Li}$ thuania. It grows to a fize almoft equal to the Elephant, and is quite black; the eyes are red and fiery, the horns thick and fhort, and the forehead covered with a quantity of curled hair; the neck is fhort and ftrong, and the fkin has an odour of mufk. The female, though not fo big as the male, exceeds the largeft of our bulls in fize: Neverthelefs, her udder is extremely fmall. Upon the whole, however, this animal, which greatly refembles thofe of the tame kind, probably owes its variety to its natural wildnefs, and the richnefs of the paftures where it is produced.

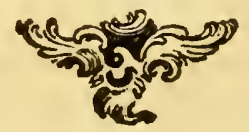




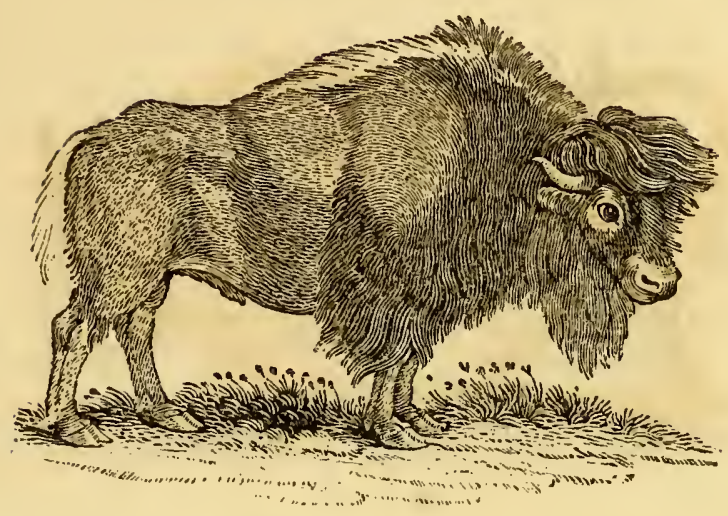

THE BISON

(Bos Bifon, Lin.-Le Bifon, Amerique, Buff.)

Differs from the reft of the Ox kind, in having a large lump between its fhoulders, almoft as high as that of a Camel. He has a long thaggy mane, which forms a kind of beard under his chin; his eyes are fierce, his forehead large, and his horns extremely wide. It is dangerous to purfue him, except in forefts abounding with trees large enongh to conceal the hunters. $\mathrm{He}$ is generally taken in pits covered with branches of trees and grafs, on the oppofite fide of which the hunters tempt the animal to purfue them; and the enraged creature running towards them, falls into the trap prepared for it, and is then overpowered and flain.

The Bifon, or the animal with the hump, is found in all the fouthern parts of the world, though greatly differing from each other in fize and form. 


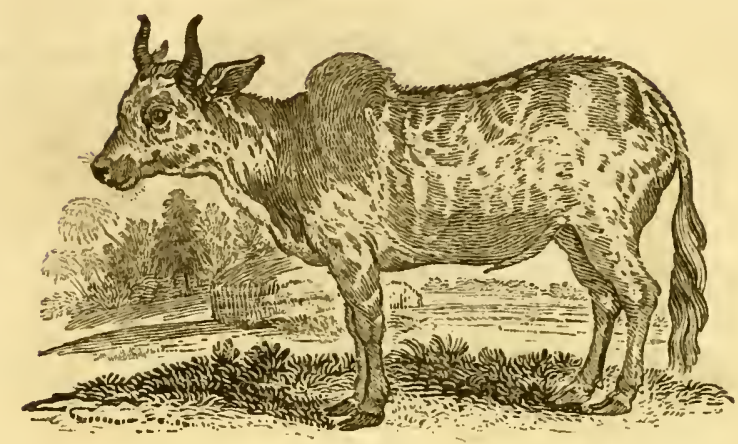

THE ZEBU.

THEY are all equally docile and gentle, when tamed; and are in general covered with fine gloffy hair, fofter and more beautiful than that of the common Cow.Their humps are of different fizes, in fome weighing from forty to fifty pounds, but in others lefs. That part is in general confidered as a great delicacy; and, when drefled, has much the appearance and tafte of udder.

The Bifons of Madagafcar and Malabar are of the great kind; thofe of Arabia Petrea; and moft parts of Africa, are of the Zebu or fmall kind.

In America, efpecially towards the North, the Bifon is well known. They herd together, in droves of from one to two hundred, on the banks of the Miffifippi; where the inhabitants hunt them;-their flefh is efteemed good eating.

They all breed with the tame Cow. The hump, which is only an accidental characteriftic, gradually declines; and, in a few generations, no veftiges of it re- 
main.-Thus we fee, whether it be the wild or the tame Ox, the Bonafus or the Urus, the Bifon or the Zebu, by whatever name they are diftinguifhed, or however varioufly claffed by naturalifts, in reality they are the fame; and, though diverfified in their appearance and properties, are defcendants of one common ftock; of which the moft unequivocal proof is, that they all mix and breed with each other.

The Oxen of India are of different fizes, and are made ufe of in travelling, as fubftitutes for Horfes. Inftead of a bit, a fmall cord is paffed through the cartilage of the noftrils, which is tied to a larger cord, and ferves as a bridle. They are faddled like Horfes; and, when pufhed, move very brifkly. They are likewife ufed in drawing chariots and carts. For the former purpofe, white Oxen are in great efteem, and much admired. They will perform journies of fixty days, at the rate of from twelve to fifteen leagues a day; and their travelling pace is generally a trot.

In Perfia, there are many Oxen entirely white, with imall blunt horns, and humps on their backs. They are very ftrong, and carry heavy burthens. When about to be loaded, they drop down on their knees like the $\mathrm{Ca}$ mel, and rife when their burthens are properly faftened. 
HISTORY OF QUADRUPEDS.

\section{THE GRUNTING OX.}

(Bos Grumiens, Lin._La Vacbe de Tartarie, Buff.)

The Sarluc, or Grunting-Cow of Tartary, from its refemblance to the Bifon, may be confidered as belonging to the fame fpecies: Its horns are fhort, upright, flender, and very fharp; the hair on its body is black, except the mane and ridge of the back, where it is white; its whole body is covered with very long hair, which hangs down below its knees, and makes its legs appear fhort; it has a hump on its back; its tail refembles that of a horfe, is white, and very bufhy; it ftrikes with its head like a goat, and is very unruly; its diftinguifhing peculiarity is, that it makes a grunting noife like a hog, inftead of lowing like the $\mathrm{Ox}$, which in every other inftance it greatly refembles. It abounds in the kingdom of Thibet, where it is domefticated.

The wild breed, called Bucha, is extremely fierce. When wounded, it will fometimes turn upon its affailant, and attack him with great fury. It copulates with the tame Cow. Their produce is employed in domeftic purpores.

Its tail is very valuable, and is fold at a great price in Thibet. When mounted on a filver handle, it is ufed, by the principal men in India, as a brufh to chafe away the flies. It is fometimes faftened, as an ornament, to the ear of the Elephant.-The Chinefe dye the hair red, and form it into tufts to adorn their bonnets. 


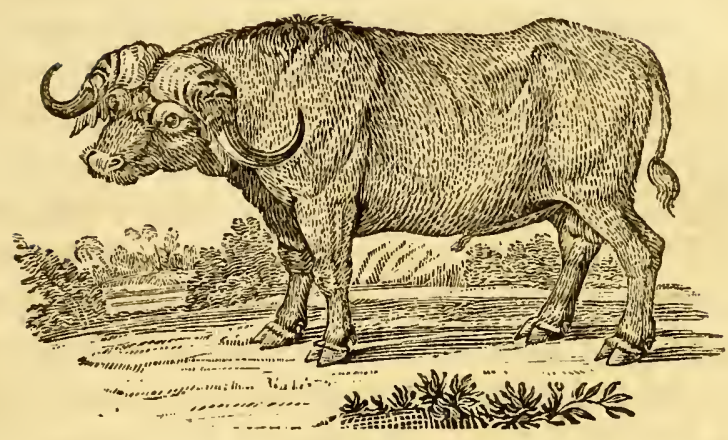

THE BUFFALO.

(Bos Bubalus, Lin._Le Buffle, Buff.)

There is the moft ftriking general refemblance between the Buffalo and the common Ox; their habits and propenfities are nearly fimilar; they are both equally fubmiffive to the yoke, and may be employed in the fame domeftic fervices; yet it is certain, from experience, that no two animals carn, in reality, be more diftinct: The Cow refufes to breed with the Buffalo, while it is known to propagate with the Bifon, to which it bears, in point of form, a much more diftant fimilitude.

The Buffalo is found, in a wild ftate, in many parts of Africa and India, and is common in the countries near the Cape of Good Hope, where he is defcribed, by Sparrman, as a fierce, cruel, and treacherous animal. He frequently rufhes from behind a thicket upon fome unwary paffenger; and, having thrown him down, tramples him to death with his feet and knees, tearing him with his horns and teeth, and licking him with his rough 
tongue, till the fkin is nearly ftripped from the body.The following accurate defcription we owe to the fame author:-The length of the Buffalo, from head to tail, is eight feet; the height five and a half; and the fore legs two feet and a half long: From the tip of the muzzle to the horns, twenty-two inches: His limbs, in proportion to his fize, are much ftouter than thofe of the Ox; his fetlocks likewife hang nearer the ground: The horns ate. fingular, both in their form and pofition; the bafes of them are thirteen inches broad, and only an inch diftarit: from each other, having a narrow channel or furrow between them; from this furrow the horns affume a fpherical form, extending over a great part of the head; the diftance between the points is often above five feet: The cars are a foot lorig, fomewhat pendulous, and in a great meafure covered and defended by the lower edges of the horns, which bend down on each fide, and form a curve upwards with the points: Their hair is of a dark brown colour, about an inch long, harfh, and, upon thofe males that are advanced in years, ftraggling and thin, efpecially on each fide of the belly, which gives them the appearance of being girt with a belt: The tail is fhort, and tufted at the end: The eyes are large, and fomewhat funk within their prominent orbits, which are almoft covered with the bafes of the horns overhanging its dangling ears; this, with a peculiar inclination of the head to one.fide, produces an afpect at once fierce, cunning, and tremendous: The flefh is coarfe, rather lean, but full of juice of a high but not unpleafant flavour: The hide is thick and tough, and of great ufe in making thongs and harnefs; it is fo hard, as not to be penetrated by a common mufket-ball; thofe made ufe of for thooting the Buffalo 
are mixed with tin; and even thefe are frequently flattened by the concuffion.

In Italy the Buffalo is domefticated, and conftitutes the riches and food of the poor, who employ them for the purpofes of agriculture, and make butter and cheefe from their milk.

The female produces but one at a time, and continues pregnant twelve months; another ftriking characteriftic difference between the Buffalo and the common Cow.

\section{THE MUSI-BULL}

INHABIT's the interior parts of North-America, on the weft fide of Hudfon's Bay, between Churchill and Seal rivers. They are very numerous in thofe parts, and live in herds of twenty or thirty. The Indians eat the flefh, and make coverings of their fkins. They are brought down in. fledges, to fupply the forts during the winter. Notwithitanding the fleth is faid to have a ftrong flavour of mulk, it is reckoned very good and wholefome.

The Mufk-Bull is fomewhat lower than a Deer, but more bulky. Its legs are fhort; and it has a fmall hump on its fhoulder: Its hair is of a dufky-red colour, very fine, and fo long, as to reach to the ground: Beneath the hair, its body is covered with wool of an afh colour, which is exquifitely fine, and might be converted into várious articles of ufeful manufacture- $-\mathrm{Mr}$ Jeremie fays, that ftockings made of it are finer than filk: Its tail is only three inches long, and is covered with long, hairs, of which the Efquimaux Indians make caps, which are fo contrived, that the long hair, falling round their 
faces, defends them from the bites of the mufquitos: Its horns are clofe at the bafe, they bend downwards, and, turn out at the points; they are two feet long, and two feet round at the bafe; fome of them will weigh fixty pounds.

Thefe animals delight chiefly in rocky and mountainous countries: They run nimbly, and are very active in climbing fteep afcents.

\section{- \\ THE SHEEP. \\ (Ovis Aries, Lin.-La Brebis, Buff.)}

THE Sheep, in its prefent domeftic ftate, feems fo far removed from a ftate of nature, that it may be deemed. a difficult matter to point out its origin. Climate, food, and, above all, the unwearied arts of cultivation, contribute to render this animal, in a peculiar manner, the creature of man; to whom it is obliged to truft entirely for its protection, and to whofe neceffities it largely contributes. Though fingularly inoffenfive, and harmiers even to a proverb, it does not appear to be that ftupid, inanimate creature defcribed by Buffon, "devoid of every art of felf-prefervation, without courage, and even deprived of every inftinctive faculty, we are led to conclude that the Sheep, of all other animals, is the moft contemptible and ftupid:" But amidft thofe numerous flocks. which range without controul on extenfive mountains, where they feldom depend upon the aid of the thepherd, 


\section{HISTORY OF QUADRUPEDS.}

it will be found to affume a very different character: In thofe fituations, a Ram or a Wedder will boldly attack a fingle dog, and often come off victorious; but when the danger is more alarming, they have recourfe to the collected ftrength of the whole flock. On fuch occafions they draw up into a compact body, placing the young and the females in the centre; while the males take the foremoft ranks, keeping clofe by each other. Thus an armed front is prefented to all quarters, and cannot eafily be attacked without danger or deftruction to the affailant. In this manner they wait with firmnefs the approach of the enemy; nor does their courage fail them in the moment of attack: For, when the aggreffor advances within a few yards of the line, the Rams dart upon him with fuch impetuofity, as to lay him dead at their feet, unlefs he fave himfelf by flight. Againf the attacks of fingle Dogs or Foxes, when in this fituation, they are perfectly fecure.-A Ram, regardlefs of danger, will fometimes engage a Bull; and, as his forehead is much harder than that of any other animal, he feldom fails to conquer: For the Bull, by lowering his head, receives the ftroke of the Ram between his eyes, which ufually brings him to the ground.

In the felection of their food, few animals difcover greater fagacity than the Sheep; nor does any domeftic animal fhew more dexterity and cunning in its attempts to elude the vigilance of the fhepherd, in order to fteal fuch delicacies as are agreeable to its palate.

Befides its hardinefs in enduring great feverities of weather, the natural inftinct of the Sheep, in forefeeing the approach of a ftorm, is no lefs remarkable: In their

D 2 
endeavours to fecure themfelves under the fheiter of fome hill, whole flocks have frequently been buried for many days under a covering of fnow, and have afterwards been taken out without any material injury. Thus beautifully defcribed by Thomfon :-

"Oft the whirlwind's tring

"Sweeps up the burthen of whole wintry plains

“At one wille waft; and o'er the haplefs flocks,

"Hid in the hollow of two neighbouring hills,

"The billowy tempeft whelms."

There have been infances where Sheep, at the approach of a ftorm, have fled for fhelter to a neighbouring cottage, and taken refuge under the fame roof with their thepherd.

The variety in this creature is fo great, that fcarcely any two countries produce Sheep of the fame kind:There is found a manifeft difference in all, either in the fize, the covering, the thape, or the horns.

The woolly Sheep is found only in Europe, and in the temperate provinces of Afia. When tranfported into warmer climates, it lofes its wool, and becomes hairy and rough; it is likewife lefs fertile; and its flefh no longer retains the fame flavour.

No country produces finer Sheep than Great-Britain : Their fleeces are large, and well adapted to the various purpofes of cloathing. The Spanifh fleeces are indeed finer, but ftand in no degree of comparifon with thofe of Lincolnfhire or Warwickfhire for weight or utility.-In Edward the Third's time, when wool was allowed to be exported, it brought 150,0001. per annum, at 21. Ios. a pack, which was a great fum in thofe days. At this time, when our woollen manufactory ftands unrivalled by any nation in the world, and every method is taken 


\section{HISTORY OF QUADRUPEDS.}

to prevent this valuable commodity from being fent out of the kingdom, the annual value of wool, fhorn in England, is fuppofed to be about five millions fterling; and, when manufactured conjointly with the Spanifh wool imported, amounting to about fix hundred thoufand pounds, muft be above twenty millions.

Like other ruminating animals, the Sheep wants the upper fore teeth: It has eight in the lower jaw; two of which drop out, and are replaced at two years old; four of them are renewed at three years, and the remainder at the age of four.

The Ewe produces one or two lambs at a time, and fometimes, though rarely, three or four. She bears her young five months, and brings forth in the fpring*.The Ram lives to the age of about fifteen years, and begins to procreate at one. When caftrated, they are called Wedders: They then grow fooner fat, and the flefh becomes finer and better flavoured.

There is hardly any part of this animal that is not ferviceable to man: Of the fleece we make our cloaths; the fkin produces leather, of which are made gloves, parchment, and covers for books; the entrails are formed into ftrings for fiddles and other mufical inftruments, likewife coverings for whips; its milk affords both butter and cheefe; and its flefh is a delicate and wholefome food.

* An Ewe, of the finall black-faced Scotch breed, produced two Ewe lambs before the had completed her firt year; and befure the end of the fecond year, thefe two produced each of them two lambs alfo. It is a remarkable circumftance, that this great increafe took place in the coldeft and moft mountainous part of Northumberland; and it is further neceffary to obferve, that this breed of Sheep feldom produces more than one lamb at a time, and that not till they are two years of age. 
The following remarks, taken from Mr Culley's “Obfervations on Live Stock," will not be unacceptable to many of our readers, as they convey a juft idca of fome of the moft noted kinds of Sheep at this time in the ifland.-He begins with thofe of Lincolnfhire, which are of a large fize, big-boned, and afford a greater quantity of wool than any other kind, owing to the rich, fat marfles on which they feed; but their flefh is coarfe, lcaner, and not fo finely flavourcl as that of fmaller Shecp. The fame breed cxtends, with fome variations, through moft of the midland counties of England. - The Dorfethire breed is likewife remarkably prolific, the Ewes being capable of bringing forth twice a year. It is from thefe that the tables of our nobility and gentry are fupplied with early lamb at Chriftmas, or fooner, if required.Great numbers of thofe early victims to luxury are yearly fent to the Loindon markets, where they are fold at the chormous price of Ios. Gl. or perhaps I $5^{5}$ per quarter. The manner of rearing the lambs is curious: They are imprifoned in little dark cabins; the Ewes are fed with oil-cakes, hay, corn, turnips, cabbages, or any other food which the feafon of the year affords; thefe are given thom in a field contiguous to the apartments where the lambs are kept; and, at proper intervals, the nurfes are brought in to give fuck to their young ones; while the attendants, at the fame time, make their lodgings perfectly clean, and litter them with frefh fraw. Great attention is paid to this, as much of the fuccels of rearing thefe unfeafonable productions depends upon warmth and cleanlinefs.

The Dorfetflire Sheep are moltly white-faced; their legs are long and fmall; and great numbers of them have 


\section{HISTORY OF QUADRUPEDS.}

no wool upon their bellies, which gives them an uncouth appearance. They produce a fmall quantity of wool, but of a good quality; from which our fine Wilthire cloths are made. The mutton of thefe Sheep is very fweet and well flavoured.-The variations of this breed are fpread through moft of the fouthern counties; but the true kind is only to be found in Dorfethire and Wilthire.-There is a breed, not unlike this, in Norfolk and Suffolk; but they are all gray or black-faced.

The South Down Sheep are of the fame hardy nature as the Cheviot breed, and, like them, can live and thrive on the bareft heaths; their wool is alfo fine, and their mutton well flavoured.

The Sheep in the low parts of Northumberland are of a mixed breed, between the long kind, the Tees water, and the Lincolnfhire. The Mug or Muff kind was formerly common in that county. They were fo called, from their wool growing round their heads into their very eyes, fo as almoft to prevent them from feeing. This breed is now nearly exploded, being confidered, by every breeder of experience, as unprofitable, from their thriving flowly, and being very tender.

In the northern diftricts of Scotland, and in many of the inlands, there is a breed of Sheep, which differs from the others in the fmallnefs of their fize; many of them, when fed, weighing no more than fix, feven, or eight pounds per quarter. They have dun faces, without horns; and their wool, which is very fine, is varioufly mixed, and ftreaked with black, brown, and red. 


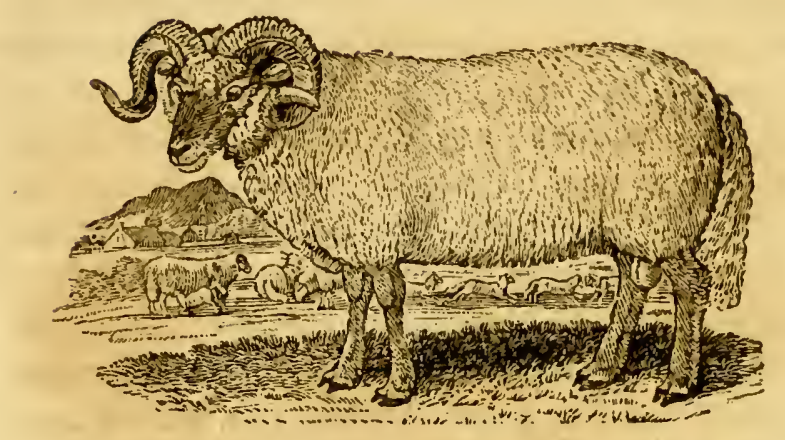

THE BLACK-FACED, OR HEATH RAM.

THE north-weft part of Yorkfhire, with all that mountainous tract of country running towards Lancafhire fouthward, and to Fort William northward, is occupied by a hardy, black-faced, wild-looking tribe, generally called Bort Shecp, which differ from our other breeds, not only in the darkners of their complexions and horns, but principally in the coarfe fhaggy wool which they produce. Their eyes have a fiery, tharp, and wild caft. They run with great agility, and feem quite adapted to the heathy mountains they inhabit. Their flefh is peculiarly fine and high-flavoured. The three great fairs for thefe Sheep (where amazing numbers of them are fold every year) are, Stagthaw-bank, in Northumberland; Brough, in Weftmorland; and Linton, in Scotland. There is likewire a breed of Sheep inhabiting the fame country as the former; but peculiarly diftinguifhed from them by long, thin bodies, white legs, white faces, and by having no horns. Their wool is fine, and thickly planted. 


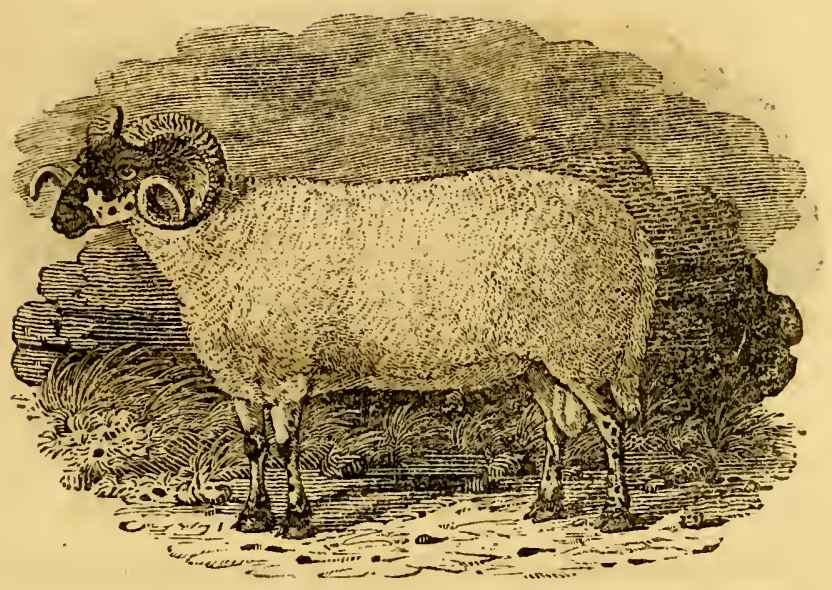

\section{HEATH RAM OF THE IMPROVED BREED.}

The Ram from which we took this drawing, in July, 1798, belongs to the Bithop of Durham. It obtained the premium given for the beft Tup, thewn for that purpofe, at Blanchland, in the county of Durham, in 1797. Exclufive of the fymmetry of proportions and beauty of its form, a more important object has been obtained in the quality of the wool. They are alfo as hardy as the unimproved breed, and can equally endure the feverity of the cold and wet to which they are expofed on the bleak heaths which they are doomed to inhabit. 


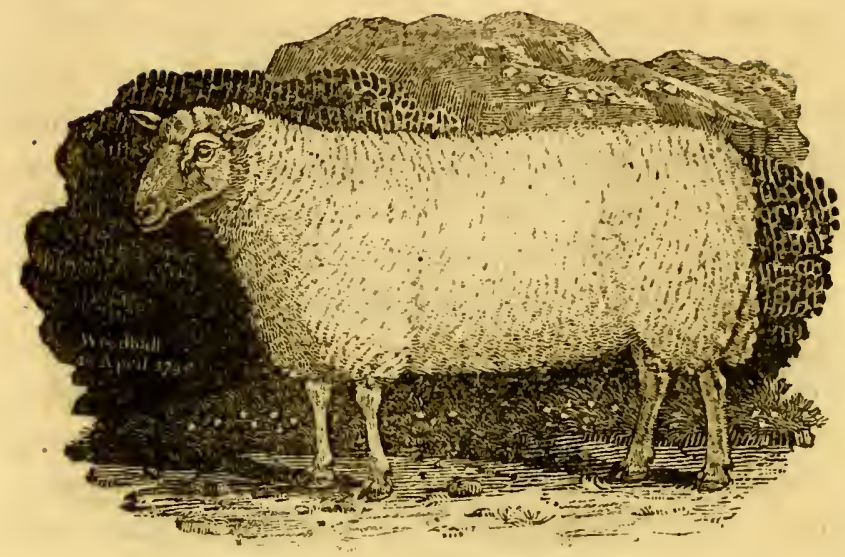

THE CHEVIOT RAM.

TuE Cheviot breed have a fine open countenance, lively prominent eyes, have no horns, and are moltly white-faced and white-legged; the body long, with fue, clean, fmall-boned legs: Weight of the carcafe from 12 to s $8 \mathrm{lb}$. per quarter; and the mutton is highly efteemed for its flavour.

The beft breeds of thefe Sheep are to be found in the north-weft parts of the county of Northumberland, and on the range of hills adjoining them in Scotland, and are maintained (except when prevented by fnow) folely from the natural produce of the grounds on which they depafsure, which, in general, are very mountainous, and confift of ling, mofs, hather, deer-hair, and wire-bent, with a mixture of green fward.-We can find no account from whence this valuable breed originally fprung, which, as mountain Sheep, are unrivalled, as well on account of their carcafes and hardinefs, as from the fuperior value of 


\section{HISTORY OF CUADRUPEDS.}

their wool, which is in the higheft eftination for cloathing, and fells from 2 d. to $2 \frac{2}{2} \mathrm{~d}$. per pound higher than the beft in the diftrict. - The great demand that has been made for this wool, added to the encouragement given by Sir John Sinclair, (who, for a few years, bought confiderable numbers of thefe Sheep, which he took to the Highlands of Scotland, and now breeds them upon the fame kiad of heathy mountains as the original ftock were taken from) caufed an emulation amongft the breeders, which has been productive of confiderable improvement in their ftocks, both in the wool and fore-quarter, in which they were generally deficient. But as inprovements in ftock can only be effected by flow gradations, and as this improved breed is but of a few years ftanding, it will probably be advantageous, not only to individuals but to the public at large, to encourage exertions which, if fortunatcly fuccefsful, might place thefe Sheep upon a level with thofe produced upon well cultivated grounds, which might be otherwife more advantageoufly employed for the ufe of the public.

Thus the difficulty of producing an improved breed for heath paftures has, in a great meafure, been removed by the fill and attention of the Northumberland farmers, to whom we think the community much indebted; and we doubt not that, in the courfe of a few years, this breed will become the parent ftock of all the Sheep bred for grazing on heathy, and what are called wafte, grounds. They thrive on the moft fterile heaths, their wool is of the moft defirable texture, they are eafily fattened, and their whole conformation is fo properly fuited to mountainous pafture, that we are furprifed the breed has not already been more generally diffufed. 


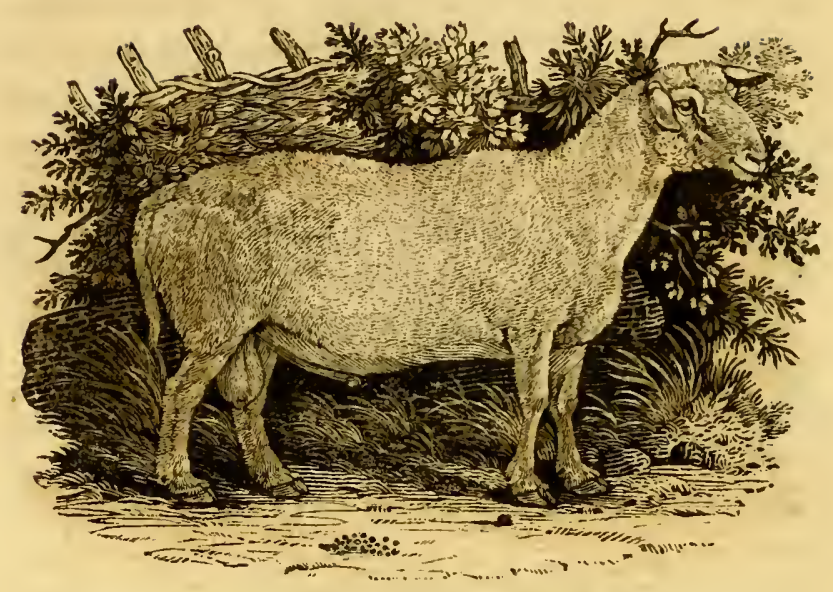

\section{TEES-WATER OLD OR UNIMPROVED BREED.}

THE largeft breed of Sheep in this ifland is to be met with on the banks of the Tees, which runs through a rich and fertile country, dividing the two counties of Yorkfhire and Durham. This kind differs from the Lincolnhire Sheep, in their wool not being fo long and heavy; their legs are longer, but finer boned, and fupport a thicker, firmer carcafe ; their flefh is likewife much fatter, and finer grained.

Our figure was taken in July, 1798 , from a Ram which had been purchafed for the purpofe of fhewing its uncouth and uncultivated appearance, in contraft to thofe of the improved kind. 


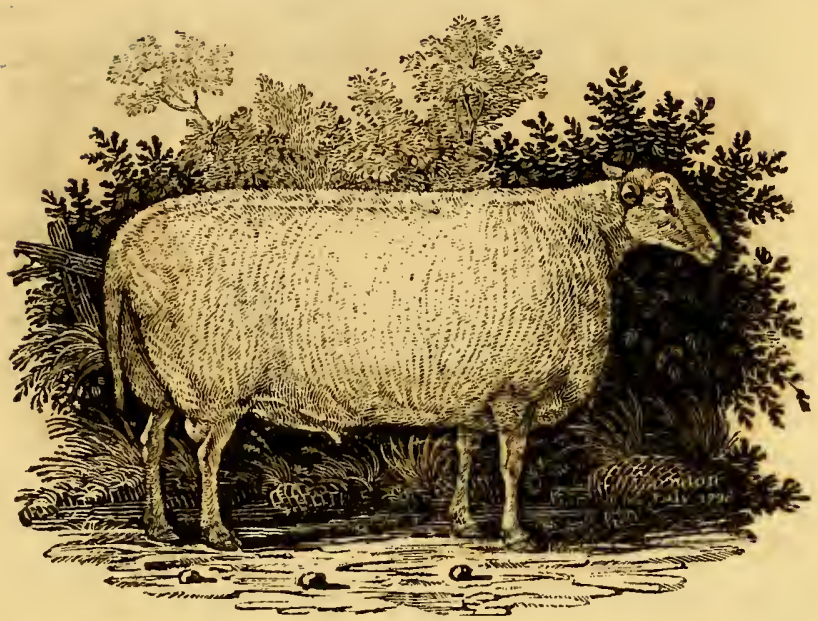

TEES-WATER IMPROVED BREED.

By perfevering in the fame laudable plan of improve* ment fo fuccefsfully begun by the late Mr Bakewell, the Itock-farmers or graziers of Tees-water have produced a kind which is looked upon by judges as nearly ap. proaching to perfection. Many of their Sheep poffefs the thriving or fattening quality of the Difhley breed, and are fit for the butcher at as early an age.

Thefe Sheep weigh from twenty-five to forty-five pounds per quarter; fome have been fed to fifty pounds; and one in particular was killed, which weighed fixtytwo pounds ten ounces per quarter, avoirdupois; a circumftance never before heard of in this inland. The Ewes of this breed generally bring forth two lambs each feafon; fometimes three, four, and even five. As 


\section{HISTORY OF QUADRUPEDS.}

an infance of extraordinary fecundity, it deferves to be mentioned, that one of thefe Ewres, at the age of two years, brought forth four lambs at one time; the next feaion five; both within eleven months.

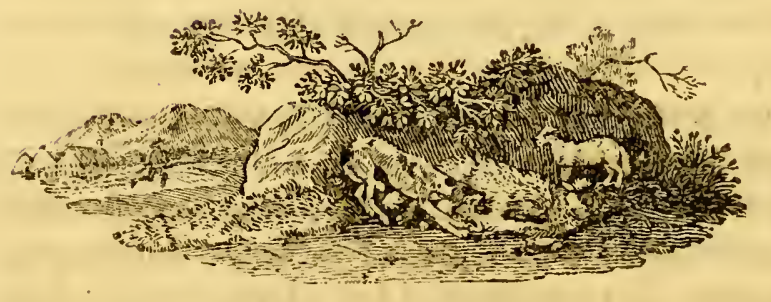




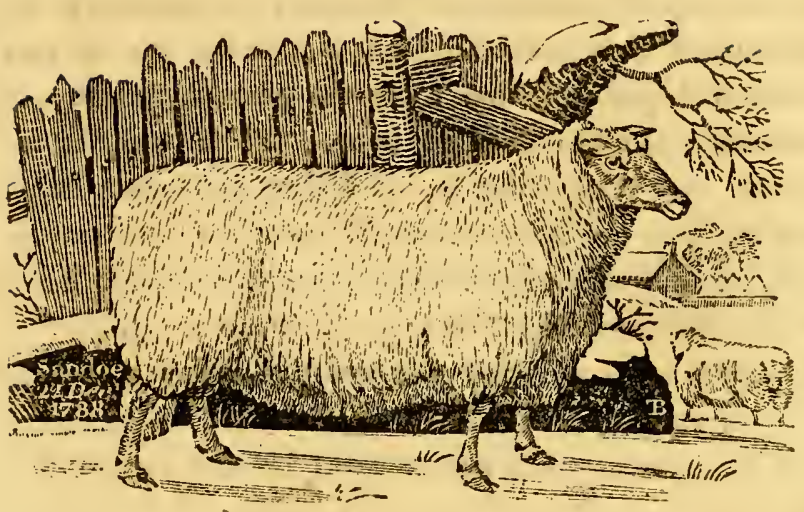

\section{THE LEICESTERSHIRE IMPROVED BREED.}

To thefe various and numerous tribes of this ufeful animal, we muft add, that, by the perfevering induftry and attention of Mr Bakewell, of Difhley, in Leicefterhire, our breed of Sheep has been greatly improved; and he has been followed by many eminent breeders with nearly equal fuccefs.

It feems to be generally agreed, that in Sheep, as well as in all other animals, there is a certain fymmetry or proportion of parts, which is beft adapted to the fize of each particular animal: All thofe of each kind that exceed or fall fhort of this pitch, are more or lefs difproportioned, according to the fize they attain; and in the degree they are advanced beyond this line of perfection, we find them lefs active, weaker, and always lefs able to endure hardhip. Thus, by felecting the handfomeft and beft proportioned of their kinds, the judicious breeder has gradually arrived at a degree of perfection in improving this animal, unknown at any former period. 
The fuperior qualities of the Leicefterfhire breed are, that they will feed quickly fat at almoft any age, even on indiffercnt paftures, and carry the greateft quantity of mutton upon the fmalleft bone. Their carcafes are round, have remarkably broad backs, and fhort legs; and to fhew the immenfe weight to which they may be fed, we give the meafurement of a Ram of Mr Bakewell's, mentioned by Young in his " Eaftern Tour :"At three years old, his girt was five feet ten inches; height, two feet five inclies; breadth over his fhoulders, one foot eleven inches and an half; breadth over his ribs, one foot ten inches and an half; breadth over his hips, one foot nine inches and an half.

The great importance of this breed of Sheep will beft be fhewn, by ftating the following facts refpecting the modern practice of letting out Rams for hire by the feafon; which, from very fmall beginnings, has already rifen to an aftonifhing height; and is likely, for fome time, to prove a copious fource of wealth to the country at large. About forty years ago, Mr Bakewell let out Rams at fixteen and ferenteen fhillings a-piece; and from that time, the prices kept gradually rifing from one guinea to ten. But the moft rapid increafe has taken place fince the year 1780. Four hundred guineas have been repeatedly given. $\mathrm{Mr}$ Bakewell, in the year 1789 , made twelve hundred guineas by three Rams; two thoufand of feven; and, of his whole ftock, three thoufand guineas. Aftonifhing as this may appear, it is neverthelefs an undoubted fact. But it ought to be obferved, that thefe great prices are not given by graziers, for the purpofe of improving their grazing 1tock; but by principal breeders, in orice to procure a ftock of Rams of the improved breed, 
which they let out again to breeders of an inferior clafs. The prices given by graziers, for the fole purpofe of getting grazing ftock, feldom exceed ten guineas, which is confidered as an extraordinary price, five or fix guineas being moft frequently given.

This valuable breed has likewife found its way into Northumberland. Meff. Culley, of Fenton; Mr Thompfon, of Lilburn ; and Meff. Donkin and Co. of Hexhambrewery, with great fpirit, and at confiderable expence, have greatly improved their refpective breeds of Sheep, by an admiflion of the Difhley blood.

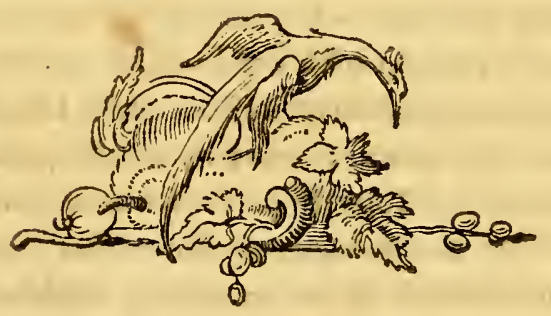




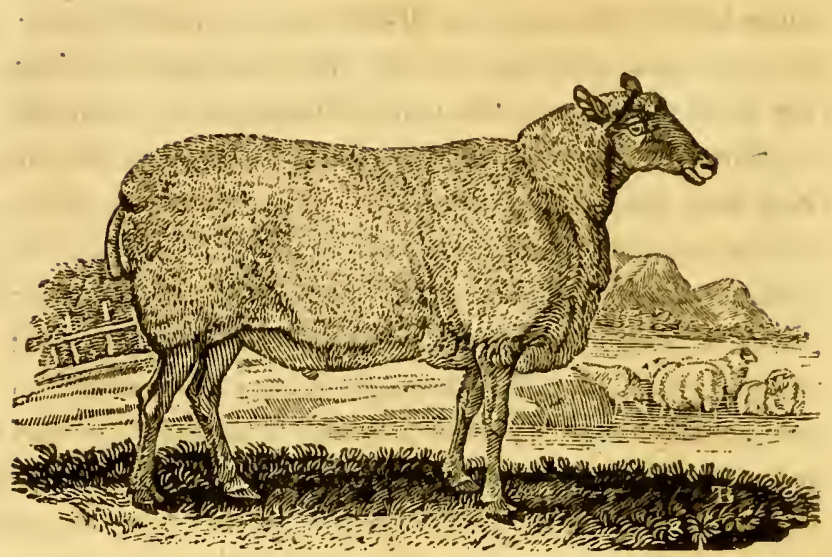

A WEDDER OF MR CULLEY'S BREED.

WE are favoured, by Mr Culley, with the following account of a Wedder of his breed, fed at Fenton in Northumberland, and killed at Alnwick in October, 1787 , when four years old :-His dimenfions were as follow :Girt, four feet eight inches and an half; breadth over his Thoulders, one foot three inches; over his middle, one foot feven inches and a quarter; acrofs the breaft, from the infide of one fore leg to the infide of the other, nine inches. "At the dividing of the quarters, through the ribs, it meafured feven inches and one-eighth of folid fat, cut ftraight through without any flope; and his mutton was of the moft beautiful bright colour. But in nothing was he fo remarkable as in the fmallnefs of his bones.The proprietor of this Sheep laments that he, had not the offals exactly weighed (by offals, we would be underftood to mean not only the tallow, but the head, pluck, and pelt, with the blood and entrails); becaufe it is now well 
known, that this breed of Sheep have a 'greater quantity of mutton, in proportion to the offal, than any other kind we know of, and is confequently cheaper to the confumer.

[The drawing from which the preceding cut was taken, was made by Mr Bailey, of Chillingham, foon after the Sheep had been fhorn.]

Before we quit this article, we muft take notice of a breed of Sheep which have hitherto been but little known or attended to; although, it is probable, they poffefs advantages of equal importance with thofe we have juft mentioned; and, in all likelihood, they might have continued ftill longer in the fame neglected ftate, but for the endeavours of a fet of men, who, actuated by a truly patriotic zeal, are labouring to draw out the natural refources of their country, and fecure, to the moft diftant and long-neglected parts of this kingdom, thofe permanent advantages to which they are by their fituation entitled. In purfuing thefe important objects, the Highland Society of Scotland have difcovered, that the Shetland inlands, and fome parts of the Highlands of Scotland, are in poffeffion of a breed of Sheep, which produces wool. infinitely fuperior to that of any other in the kingdom, and equal to Spanifh wool in finenefs and texture.By order of the Society, fpecimens of thefe Sheep have been obtained, for the purpore of a fair inveftigation into the nature and quality of their wool, which, upon examination, proves much finer than was at firft imagined. -We are favoured, by Dr James Anderfon, with the following particulars: 


\section{THE SHETLAND SHEEP}

ARE handfome, fmall, and in general hornlefs; and are peculiarly difinguined by the unufual fhortnefs and fmallners of their tails. They weigh, when fat, from eight to ten pounds per quarter. Their fleeces are, on an average, about two pounds weight. The wool, when properly dreffed, is of a pure and glofly white: Some fmall fpecimens of it, compared with Vigognia wool, were allowed, by good judges, to be fully as fine; and, in foftnefs, equal to that of which the Indian fhawls are made. The Sheep producing this fine wool, are faid to be of the hardieft nature: They are never houfed, and, in the winter feafon, are often fo pinched for food, that they are obliged to feed upon the fea-ware driven upon the fhore. Befides the wool with which they are covered, they have long hairs growing amongt it, which ferve to thelter it.

It is a fingular circumftance, that the Shetland Sheep are never fhorn; but, about the beginning of June, the wool is pulled off, without the fmalleft pain or injury to the animal, leaving the long hairs already mentioned, which contribute to keep the creature warm and comfortable, at a feafon of the year when cold and piercing winds may be expected, in fo northern a latitude.

From the fpirited meafures which are now taking to preferve this valuable breed*, we are led to hope, that Britifh wool may in time regain that great fuperiority for

* See the Report of the Committee of the Highland Society, on the fubject of wool. 1789 . 


\section{HISTORY OF QUADRUPEDS.}

which it was once fo famous; and that, by perfeverance and attention to this important object, we may in time be enabled to produce not only as fine wool as can be obtained from any other country, but may alfo, in the fame breed, be able to conjoin with it every other defirable peculiarity,-fuch as clofenefs of fleece, beauty and utility of form, hardinefs, a capability of being eafily fattened, largenefs of fize, and other valuable qualities, adapted to every peculiarity of fituation in thefe iflands.

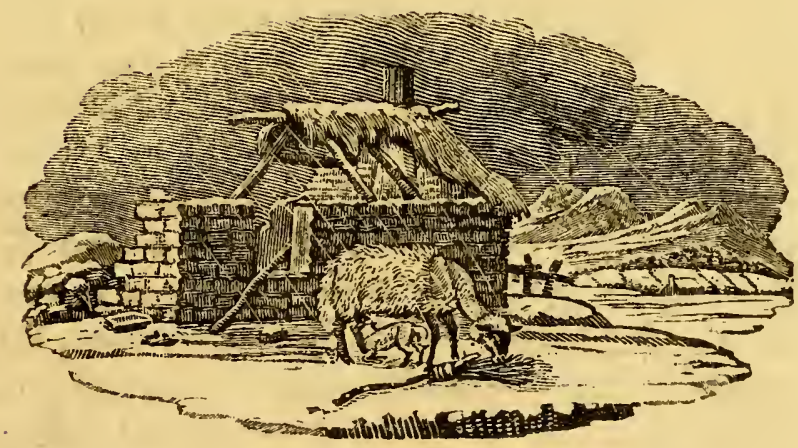




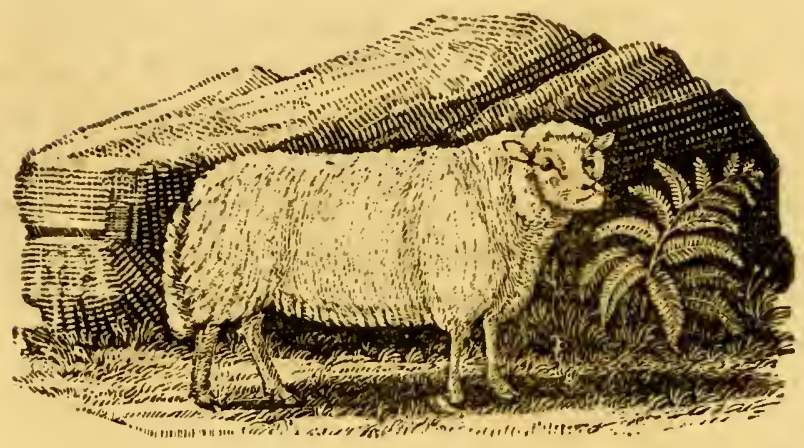

THE DUNKY, OR DWARF SHEEP,

Another variety of the Sheep kind, deferves to be noticed for the fingular and grotefque formation of its features. The wool, growing round its head, forms a kind of hood or ruff, before which ftand, its fhort erect ears : The uncommon protrufion of its under jaw confiderably before the upper, by which the fore teeth are left expofed, and the fhortnefs of the nofe, which lies under its high-projecting forehead, altogether give it the appearance of deformity, and make a ftriking contraft to moft animals of the Sheep kind.-A Ram, from which the drawing was made, came from abroad, with two Ewes, as a prefent to a gentleman in the county of Northumberland. They are very fmall, and have no horns.-In Lincolnfhire there is a fmall kind, mentioned, by $\mathrm{Mr}$ Culley, under the name of Dunkies: which we fuppofe to be the fame with this. 


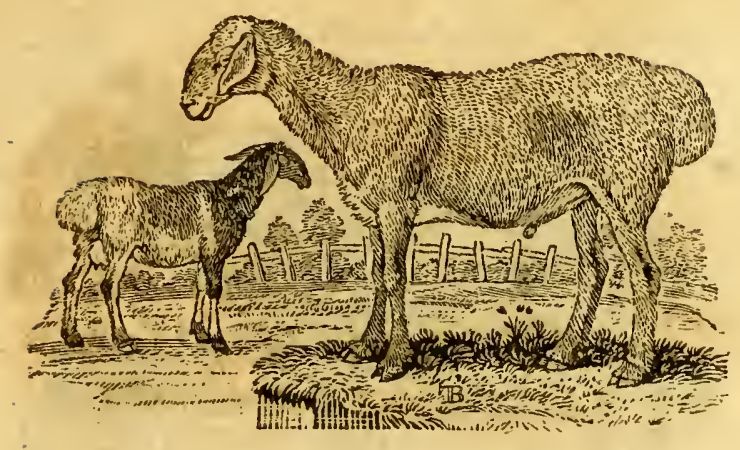

THE TARTARIAN SHEEP.

THE Sheep, of which the annexed cut is an accurate reprefentation, feem to be the fame with thofe defcribed by Mr Pennant, under the name of the fat-rumped Sheep. A pair of them was brought to this country, by way of Ruflia, from the borders of Tartary. They are rather larger than the Englifh Sheep. The colour of the male is roan, or light-brown mixed with white; that of the female, black and white: Their ears are pendulous; and, inftead of a tail, they have a large protuberance of fat behind, which covers the rump. When the drawing was made, they had juft been fhorn; at other times, the wool is fo long and thick, that their form cannot well be diftinguifhed.

The African or Guinea Sheep are found in moft of the tropical climates. They are large, ftrong, and fwift; with coarfe hairy fleeces, fhort horns, pendulous ears; have a kind of dew-lap under the chin; and, though domefticated, feem to approach neareft to a ftate of nature, 


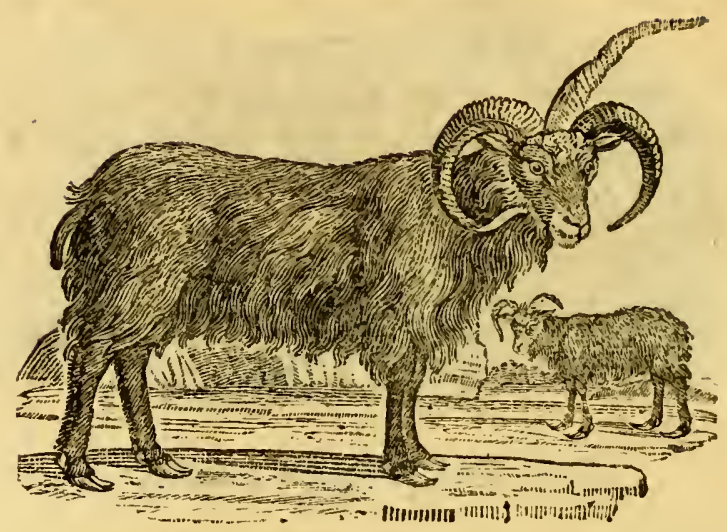

\section{THE MANY-HORNED SHEEP.}

THE Iceland Sheep, as well as thofe of Mufcovy and the coldeft climates of the north, refemble our own in the form of the body, but differ in the number of thcir horns, having generally four, and fometimes eight, growing from the forehead. Their wool is long, fmooth, and hairy: They are of a dark-brown colour; and, under the outward coat of hair, which drops off at ftated periods, there is an internal covering refembling fur, which is fine, fhort, and foft: The quantity produced by each Sheep is about four pounds.

The broad-tailed Sheep, common in Perfia, Barbary, Syria, and Egypt, are remarkable chiefly for their large and heavy tails, which grow a foot broad, and fo long, that the fhepherds are obliged to put boards with fmall wheels under them, to keep them from galling. The flefh of thefe tails is efteemed a great delicacy: It is of a fub- 


\section{HISTORY OF QUADRUPEDS.}

ftance between fat and marrow, and eaten with the lean of the mutton: They generally weigh from twenty to fifty pounds each.

The Sheep bred on the mountains of Thibet produce wool of extraordinary length and finenels, of which is made the Indian fhawl, frequently fold in this country. for fifty pounds or upwards.

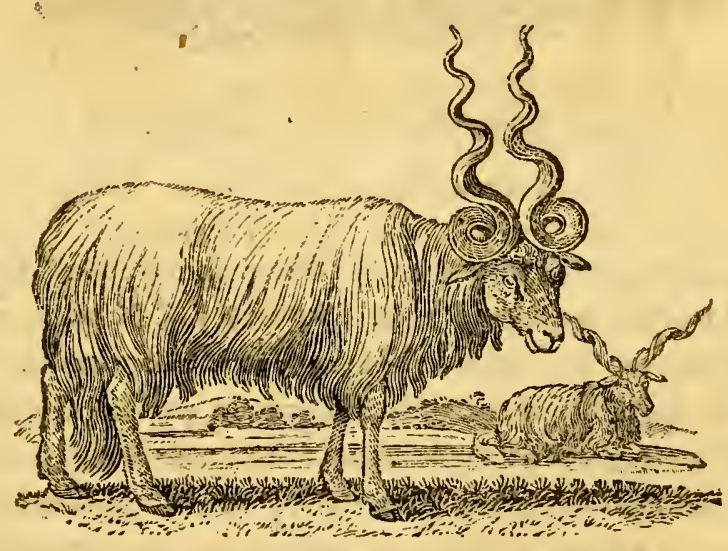

THE WALLACHIAN SHEEP.

(Ovis Strepficeros, Lin.-La Chevre de Crete, Buff.)

IN Wallachia, they have Sheep with curious fpiral horns, ftanding upright, in the form of a fcrew; long fhaggy: fleeces; and, in fize and form, nearly refembling ours. They are alfo found in the ifland of Crete, and in nuany of the iflands of the Archipelago. - This is faid to be the Strepficleros of the ancients. 


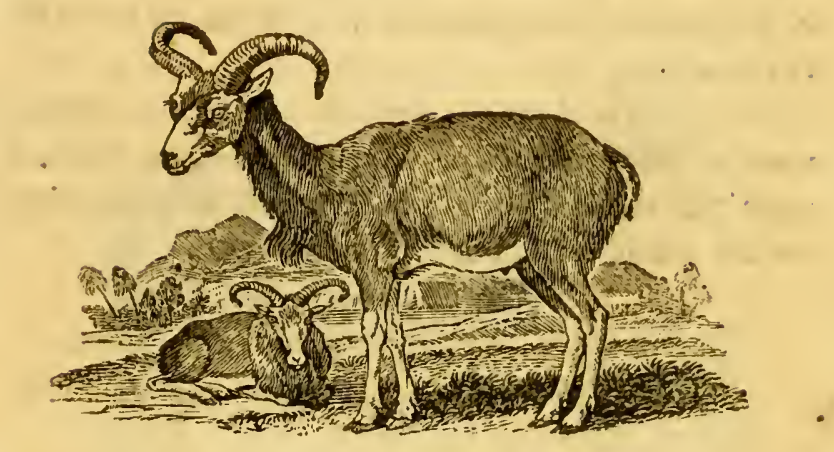

THE MOUFLON, OR MUSMON,

(Capra Amton, Lin._Le Mouflon, Buff.)

HAS been claffed both with the Sheep and the Goat kind, and may be confidered as ftanding in a middle place, and forming the link between each ; for it is curious to obferve, that Nature, in all her variations, proceeds by flow and almoft infenfible degrees, fcarcely drawing a firm and diftinguirhing line between any two races of animals that are effentially different, and yet, in many refpects, nearly allied to each other. In all tranfitions from one kind to the other, there is to be found a middle race, that feems to partake of the nature of both, and that can precifely be referred to neither. Thus it is hard to difcover where the Sheep kind ends, or the Goat begins. The Mufmon, therefore, which is neither Sheep nor Goat, has a ftrong affinity to both. Though covered with hair, it bears a ftrong fimilitude to the Ram: Its eyes are placed near the horns; and its ears are fhorter than thofe of the Goat: Its horns refemble thofe of the 
Ram, in beíng of a yellow colour and a triangular hape; they likewife bend backward behind the ears: In fome they grow to an amazing fize, and meafure above two yards long. The general colour of the hair is reddifhbrown; the infide of the thighs and belly white, tinctured with yellow; the muzzle and infide of the ears are of a whitifh colour; the other parts of the face are of a brownifl-grey.

The Mufmon is found in the wild and uncultivated parts of Greece, Sardinia, Corfica, and in the defarts of Tartary.

The form of this animal is ftrong and mufcular, and it runs with great agility. It is very timorous, and, when old, is feldom taken alive. It frequents the higheft fummits of the mountains, and treads fecurely on the moft dangerous precipices.-The old Rams have often furious battles with each other, in which one of the contending parties will fometimes be thrown down from the heights on which they ftand, and dafhed in pieces at the bottom. If their horns fhould by accident entangle, they have been known to fall and perifh together.

The chafe of the Mufmon is attended with great darto ger. At the fight of a man, they fly to the higheft parts of the rocks, where they cannot eafily be followed:They are fometimes taken in pit-falls. The Tartars purfue them with horfes and dogs, and, furrounding a pretty large tract of land, drive them towards the centre, where they are caught.

The Kamfclatkans pafs the latter part of the fummer, with all their families, among the mountains, in purfuie of thefe animals.-The flefh and fat of the young Mufmons are efteemed, by the natives, as moft delicious eat- 
ing. The fkins ferve them for warm raiments and coverings : The horns are made ufe of for a variety of ufeful purpofes.

This creature has been known to breed with the Sheep; and, from that circumftance, is fuppofed, by $M$. Buffon and others, to be the primitive race.

The female of this fpecies is rather lefs than the male; and her horns never grow to that prodigious fize.

Thofe of Kamfchatka are fo ftrong, that ten men can fcarcely hold one; and the horns fo large, that young foxes often thelter themfelves in the hollow of fuch as fall off by accident. They grow to the fize of a young ftag, copulate in autumn, and bring forth one young at a time, though fometimes two.

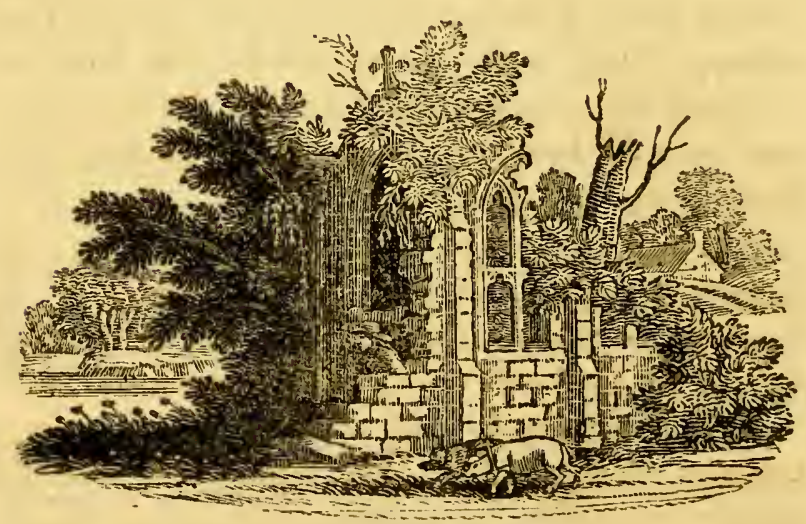




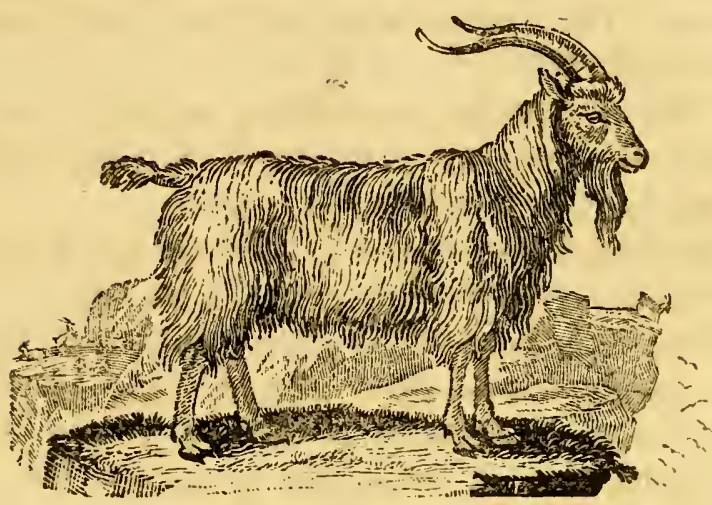

THE COMMON GOAT.

(Capra Hircus, Lin.-Le Bouc, La Cheore, Buff.)

This lively, playful, and capricious creature occupies the next ftep in the great fcale of Nature; and, though inferior to the Shèp in value,'in various inftances bears a Atrong affinity to that ufeful animal. The Goat and the Sheep will propagate together: The He-Goat copulates with the Ewe, and the Ram with the She-Goat; the offspring likewife is prolific.

The Goat is much more hardy than the Sheep, and is, in every refpect, more fitted for a life of liberty. It is not eafily confined to a flock, but chufes its own pafture, ftraying wherever its appetite or inclination leads. -It chiefly delights in wild and mountainous regions, climbing the loftieft rocks, and ftanding fecure on the verge of inacceffible and dangerous precipices; although, as Ray obferves, one would hardly fuppofe that their 
feet were adapted to fuch perilous achievements; yet, upon a nearer infpection, we find that Nature has provided them with hoofs well calculated for the purpofe of climbing; they are hollow underneath, with tharp edges, like the infide of a fpoon, which prevent them from fliding off the rocky eminences they frequent.

The Goat is an animal eafily fuftained, and is chiefly therefore the property of thofe who inhabit wild and uncultivated regions, where it finds an ample fupply of food from the fpontaneous productions of Nature, in fituations inacceffible to other creatures. It delights in the heathy mountain, or the fhrubby rock, rather than the fields cultivated by human induftry. Its favourite food are the tops of the boughs, or the tender bark of young trees. It bears a warm climate better than the Sheep, and frequently fleeps expofed to the hotteft rays of the fun.

- The milk of the Goat is fweet, nourifhing, and medicinal, and is found highly beneficial in confumptive cafes: It is not fo apt to curdle upon the ftomach as that of the Cow. From the fhrubs and heath on which it feeds, the milk of the Goat acquires a flavour and wildnefs of tafte very different from that of either the Sheep or Cow, and is highly pleafing to fuch as have accuftomed themfelves to its ufe: It is made into whey for thofe whofe digeftion is too weak to bear it in its primitive ftate. Several places in the north of England and the mountainous parts of Scotland are much reforted to for the purpofe of drinking the milk of the Goat; and its effects have been often falutary in vitiated and debilitated habits.

In many parts of Ireland, and in the Highlands of Scotland, their Goats make the chief poffeffions of the 
inhabitants; and, in moft of the monntainous parts of Europe, fupply the natives with many of the neceffaries of life: They lie upon beds made of their fkins, which are foft, clean, and wholefome; they live upon their milk, and oat bread ; they convert part of it into butter, and fome into cheefe. The fleth of the kid is confidered as a great rarity; and, when properly prepared, is efteemed by fome as little inferior to venifon.

The Goat produces generally two young at a time, fometimes three, rarely four: In warmer climates, it is more prolific, and produces four or five at once; though the breed is found to degenerate. The male is capable of propagating at one year old, and the female at feven months; but the fruits of a generation fo premature are generally weak and defective: Their beft time is at the age of two years, or eighteen months at leaft.

The Goat is a fhort-lived animal, full of ardour, but foon enervated. His appetite for the female is exceflive, fo that one buck is fufficient for one hundred and fifty females. 


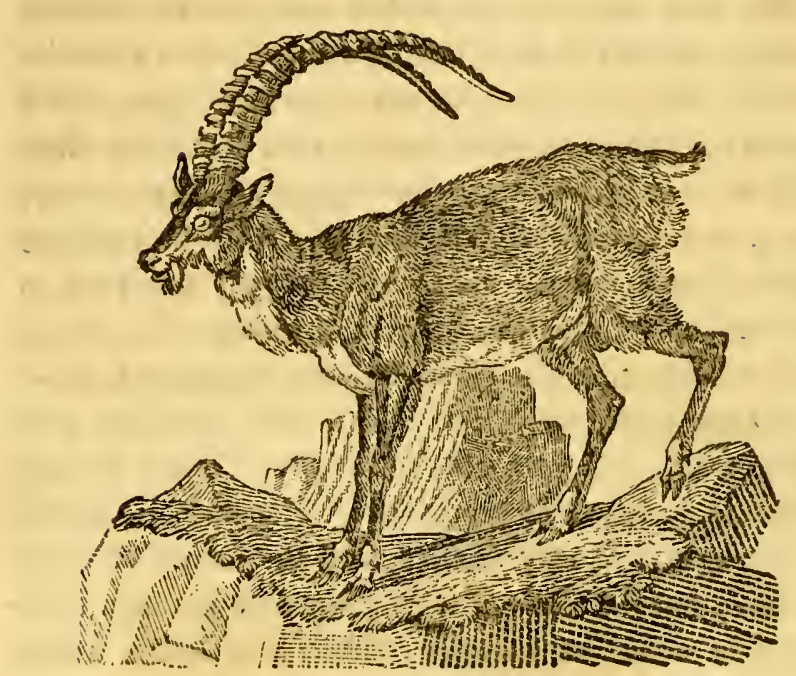

THE IBEX,

(Capra Ibex, Lin.-Le Bouquetin, Buff.)

IF we believe M. Buffon, is the ftock from whence our domeftic Goat is defcended; it is larger, but refembles it much in the fhape of its body; its horns are much larger; they are bent backward, and are full of knobs: Every year the creature lives, it is afferted, one is added to the number of them. Some of thefe horns have been found at leaft two yards long. The head of the Ibex is fmall, adorned with a dufky beard; and has a thick coat of hair of a deep brown colour, mixed with afh : A freak of black runs along the top of its back: The belly and thighs are of a delicate fawn colour.-The female is one-third lefs than the male; her horns are very fmall, and not above eight inches long. 
The Ibex inhabits the higheft Alps of the Grifons country and the Vallais, and is alfo found in Crete:They are very wild, and difficult to be fhot; and as they always keep on the higheft points of the rocks, the chafe of them is attended with great danger: They are very ftrong, and often turn upon the incautious huntfman, and tumble him down the precipice, unlefs he have time to lie down, and let the animal pafs over him. They bring forth one young at a time, feldom two; and are faid not to be long-lived.

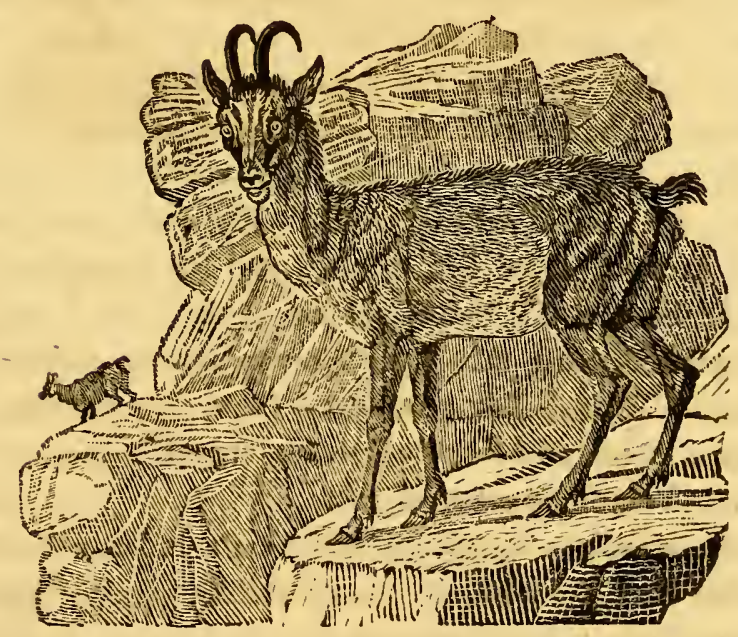

THE CHAMOIS-GOAT.

(Capra Rupicapra, Lin.-YJarus ou Sarrus, Buff.)

The Chamois, though a wild animal, is very eafily made tame and docile. It is to be found only in rocky 
and mountainous places; is about the fize of the domeftic Goat, and refembles it in many refpects. It is moft agreeably lively, and active beyond expreffion. The hair is fhort, like that of the Doe: In fpring, it is of an afh colour; in autumn, dun, inclining to black; and in winter, of a blackinh-brown.

This animal is found, in great plenty, in the mountains of Dauphiny, Piedmont, Savoy, Switzerland, and Germany. They are very gentle, and live in fociety with each other. They are found in flocks from four to fourfcore, and even an hundred, difperfed upon the crags of the mountains. The large males are feen feeding, detached from the reft; except in rutting time, when they approach the females, and drive away the young. The time of their coupling is from the beginning : of October to the end of November; and they bring forth in March and April. The young keep with the dam for about five months, and fometimes longer, if the hunters and the wolves do not feparate them. It is afferted, that they live between twenty and thirty years. Their flefh is good to eat; and they yield ten or twelve pounds of fuet, which far furpaffes that of the Goat in hardnefs and goodnefs.

The Chamois has farcely any cry: It has a kind of feeble bleat, by which the parent calls its young : But in cafes of danger, and when it is to warn the reft of the flock, it ufes a hiffing noife, which is heard at a great diftance: For it is to be obferved, that this creature is extremely vigilant, and has an eye remarkably quick and piercing: Its fmell alfo is not lefs diftinguifhing. When it 'fees its enemy diftinctly, it ftops for a noment ; and, if the perfon be near, it flies off in an inftant. In the 
fame manner, by its fmell, it can difcover a man at half a league diftance, and give immediate notice: Upon the leaft alarm, the Chamois begins its hiffing note with great force. The firt hifs continues as long as the time of one refpiration: In the beginning it is very harp, and deeper towards the clofe. The animal having, after this firft alarm, repofed a moment, again looks round; and, perceiving the reality of its fears, continues to hirs by intervals, until it has fpread the alarm to a very great diftance. During this time; it feems in the moft violent agitation; it ftrikes the ground with one fore foot, and fometimes with both; it bounds from rock to rock, turns and looks round, runs to the edge of the precipice, and, ftill perceiving the enemy, flies with all its fpeed. The hiffing of the male is much louder and tharper than that of the female: It is performed through the nofe, and is properly no more than a very ftrong breath driven violently through a fmall aperture.

The Chamois feeds upon the beft herbage, and chufes the moft delicate parts of the plants, the flowers, and the tender buds. It is not lefs delicate with regard to feveral aromatic herbs, which grow upon the fides of the mountains. It drinks very. little whilft it feeds upon the fucculent herbage, and chews the cud in the intervals of feeding.

This animal is greatly admired for the beauty of its eyes, which are round and fparkling, and mark the warmth of its conftitution. Its head is furnifhed with two fmall horns of about half a foot long, of a beautiful black, rifing from the forehead almoft betwixt the eyes: Thefe, inftead of going backwards or fideways, F 2 
ftand forward, and bend a little backward at their extremities, ending in a very fharp point. The ears are placed, in a very elegant manner, near the horns; there are two ftripes of black on each fide of the face, the reft is of a whitifh-yellow. The horns of the female are lefs, and not fo much bent: The natives have been known to bleed cattle with them.

Thefe animals are fo much incommoded by heat, that they are never found in fummer, except in the caverns of rocks, amidft fragments of unmelted ice, under the thade of high and fpreading trees, or of rough and hanging precipices, that face the North, and keep off entirely the rays of the fun. They go to pafture both morning and evening, and feldom during the heat of the day. They run along the rocks with great eafe and feeming indifference, and leap from one to another, fo that no dogs are able to purfue them. Nothing can be more extraordinary than the facility with which they climb and defcend precipices, that, to all other quadrupeds, are inacceffible: They always mount or defcend in an oblique direction, and throw themfelves down a rock of thirty feet, and light with great fecurity upon fome excrefcence or fragment, on the fide of the precipice, which is juft large enough to place their feet upon: They ftrike the rock, however, in the defcent, with their feet, three or four times, to ftop the velocity of their motion; and, when they have got upon the bafe below, they at once feem fixed and fecure. In fact, to fee them jump in this manner, they feem rather to have wings than legs. Certain it is, that their legs are formed for this arduous employment; the hind being rather longer than the fore 
legs, and bending in fuch a manner, that, when they defcend upon them, they break the force of their fall.

During the rigours of winter, the Chamois fleeps in the thickeft forefts, and feeds upon the fhrubs and the buds of the pine-tree.

The hunting of the Chamois is very laborious and difficult. The moft ufual way is to thoot them from behind the clefts of the rocks. Some alfo purfue them as they do the Stag, by placing proper perfons at all the paflages of a glade or valley, and then fending in others to roufe the game. Dogs are quite ufelefs in this chafe, as they rather alarm than overtake: Nor is it without danger to the men; for it often happens, that, when the animal finds itfelf overpreffed, it drives at the hunter with its head, and often tumbles him down an adjoining precipice.-The Chamois cannot go upon ice when fmooth; but if there be the leaft inequalities on its furface, it then bounds along in fecurity, and quickly evades all purfuit.

The $\mathrm{k}$ in of the Chamois was once famous, when tanned, for its foftnefs and warmth: At prefent, however, fince the art of tanning has been brought to greater perfection, the leather called frammoy is made alfo from thofe of the tame Goat, the Sheep, and the Deer.

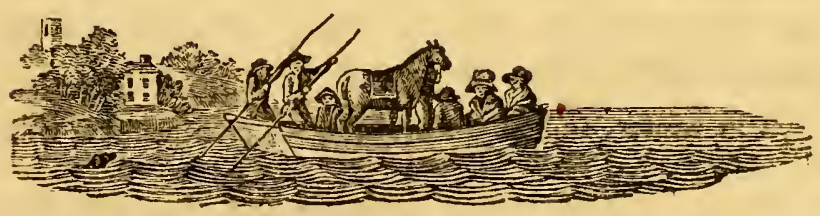

F 3 


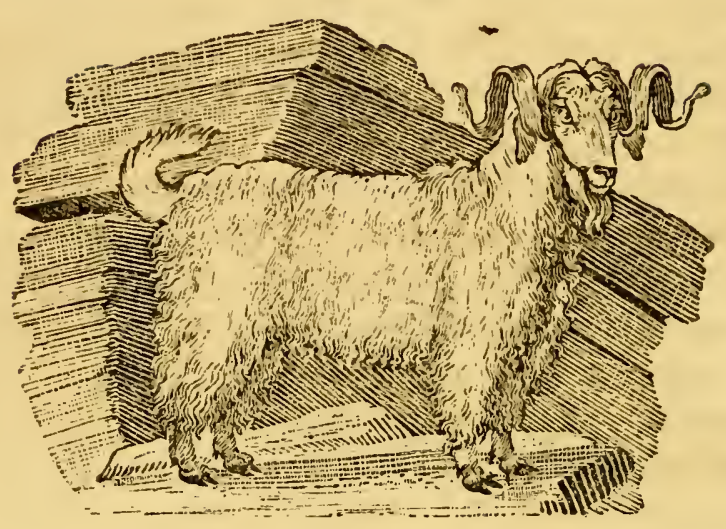

\section{THE GOAT OF $\triangle$ NGORA}

Is well known for its long hair, which is thick, gloffy, of a dazzling whitenefs, and fo fine, that cloths as beautiful as filk, known among us by the name of camblets, are made of it. Its ears are long and pendulous. The male is furnifhed with horns, curioufly twifted, which proceed horizontally from each fide of the head, forming a fcrew; thofe of the female are fhorter, and encircle the ear fomewhat like thofe of the common Ram. They inhabit the rocky mountains of Pontus, where they experience a confiderable degree of cold: 'They would probably thrive in Britain as well as in their native country. The fame might be faid of the Goat. of Thibet, fo famous for the finenefs of its wool: It lives in a climate colder than ours in winter, and might probably be tranfplanted with fuccefs.

In Portugal there is a breed of fine large Goats, remarkable for yielding a great quantity of milk, -a gallon 
and a half per day. Thefe, if introduced into our navy, might be of infinite fervice in long voyages.

Experiments of "this kind would certainly be attended with many great advantages; and it were much to be wifhed, that the great and opulent would employ fome portion of their time and affluence in procuring, from diftant countries, fuch ufeful animals as would propagate in our ifland, and are yet unknown in it. By this means many of our lofty mountains might contribute to fupport a variety of ufeful creatures, that would, at the fame time, beautify the moft barren and rugged parts of our country.

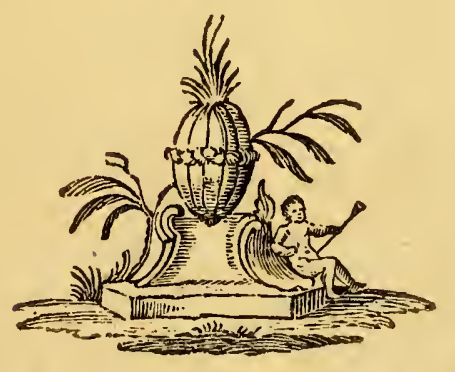




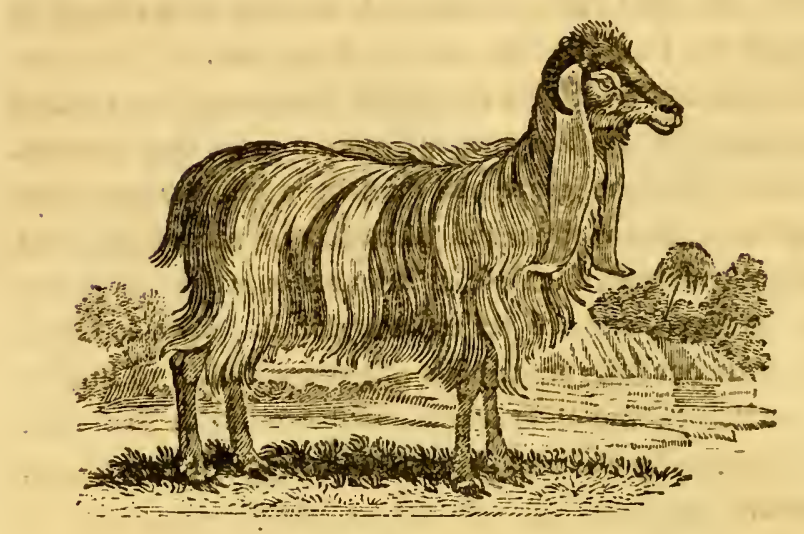

THE SYRIAN GOAT.

M. Buffon makes this a variety of the Goat of Angora ; it differs from ours in nothing more than the length of its ears, which are pendulous, and from one to two feet long: They are often troublefome to the creature in feeding; for which reafon, the owners are fometimes obliged to cut one of them off. Their horns are fhort and black.-They are very numerous in the neighbourhood of Aleppo, and fupply the inhabitants with milk, which they prefer to that of the Cow or the Buffalo.

Thefe are the principal varieties of the Goat kind; of which there are others of lefs note; fuch as the African

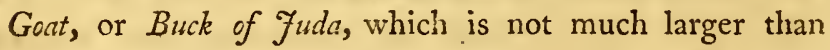
a Hare; it is extremely fat, and its flefh is well tafted: The horns are thort, fmooth, and turn a little forward. It is common in Guinea, Angola, and all along the coaft of Afriça.

In America there are Goats of a fmall kind, not much larger than a kid, with long hair: The horns, which are 


\section{HISTORY OF QUADRUPEDS.}

fhort and thick, bend downwards fo clofe to the head, as almoft to penetrate the fkull. Thefe are, in every refpect, fimilar to the dwarf Goat found in Africa; and, according to Buffon, have been fent from that country. - It is certain that, before the difcovery of America by the Spaniards, the Goat, and every other domentic animal, were unknown there.

\section{THE GAZELLES, OR ANTELOPES.}

THESE are a numerous and beautiful race of animals, inhabiting the hotteft parts of the globe. They are claffed, by fyrtematic writers, with the Goat kind; and, like them, have hollow horns, which they never caft: In other refpects they greatly refemble the Deer, efpecially in the elegance of their form and the fwiftnefs of their motions. They are of a reftlefs and timid difpofition, remarkably agile; their boundings are fo light and elaftic, as to ftrike the fpectators with aftonifhment.

Of all animals, the Gazelle has the moft beautiful eye; to which the eaftern poets have made frequent allufions, in defcribing thofe of their favourite beauties.

The diftinguifhing marks of this tribe of animals, in which they differ both from the Goat and Deer, are principally thefe:-Their horns are different, being annulated or ringed round, and at the fame time marked with longitudinal depreffions or furrows, running from the bafe to the point: Befides the extreme beauty and meeknefs of its afpect, the Gazelle is more delicately and finely limbed than the Roe-buck; its hair is finer and more gloffy: Its fwiftnefs is fo great, that the Greyhound, the fleeteft of Dogs, is unequal to the courfe; 
and the fportfman is obliged to call in the aid of the Falcon, which, being trained to the work, feizes on the animal, and impedes its motion, fo as to enable the Dogs to overtake it. In India and Perfia a fort of Leopard is fometimes made ufe of in the chafe, which takes its prey by the greatnefs of its fprings; but thould he fail in his firft effay, the game efcapes.

Some fpecies of the Antelope form herds of two or three thoufand, while others keep in fmall troops of five or fix. They for the moft part live in hilly countries. They often browfe like the Goat, and feed on the tender thoots of young trees, which give their fleth an excellent flavour.

- There are many varieties of this animal; fome of them little known or defcribed.

\section{THE BLUE-GOAT. \\ (Antelope Leucopboe, Pallas.)}

$M_{R}$ Pennant confiders this as being next to the Goat, from the length of its hair, and form of its horns.

The colour of this creature is a fine blue, refembling velvet; but when dead, it is faid to change to a bluifhgrey: Its belly is white; beneath each eye it has a large white mark: Its tail is feven inches in length, with Jong hairs at the end: Its horns incline backward, and form a curve; three-fourths of their length are decorated with with twenty-four rings; the uppermoft quarter is fmooth, and runs tapering to a point. It inhabits the hotteft parts of Africa.-Sparrman defcribes one which he faw at the Cape of Good Hope, and calls it a Blaaru-bok. 


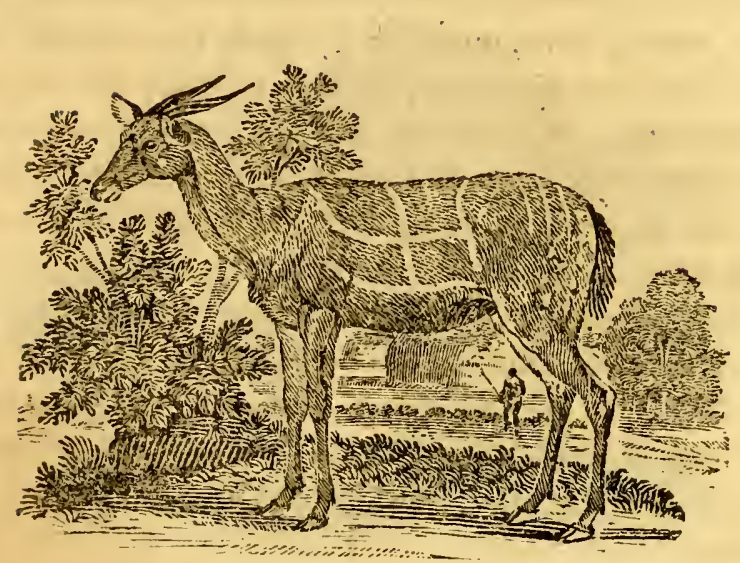

\section{THE PIED-GOAT.}

THrs animal is likewife an inhabitant of the Cape, as well as the plains and woods of Senegal, where large herds of them are to be feen.

It is remarkable for having a white band running along each of its fides, croffed by two others from the back to the belly, difpofed fomewhat like a harnefs, from whence it is called the Harneffed Antelope: On each fide of the rump it has three white lines pointing downwards; its thighs are fpotted with white; the colour of the body is a deep-tawny; beneath each eye there is a white fpot; its horns are ftraight, nine inches long, pointed backward, with two fpiral ribs. Great flocks of them are found in the plains and the woods of the country of Poder, in Africa.-It is called, by M. Buffon, the Guib; and, by Sparrman, the Bonti-bok, or Spotted Goat. 


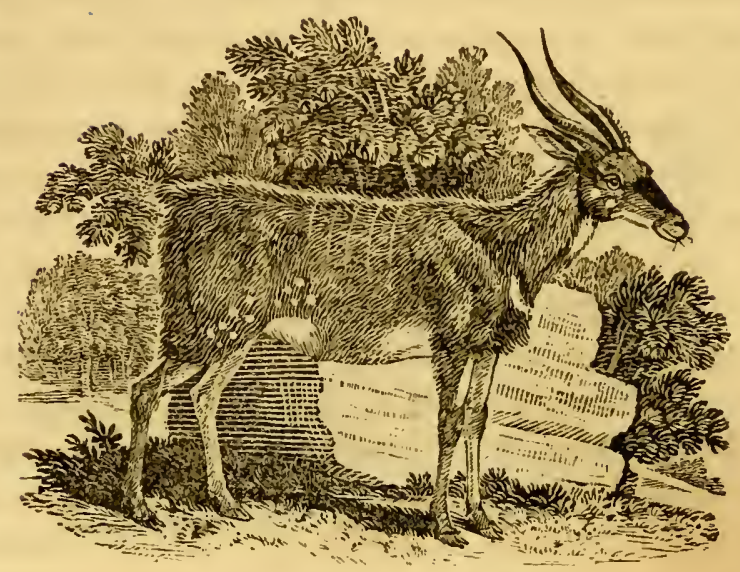

THE WOOD-GOAT.

WE are indebted to the indefatigable labours of $\mathrm{Dr}$ Sparrman, for an accurate defcription of this rare animal, which is found in the country about the Cape of Good Hope, and lives chiefly in woods and groves; from whence it derives its name.

Its horns are black, fomewhat more than ten inches. long, and have three fides wreathed in a fpiral direction towards the top; at the bottom, they are rough, in confequence of a number of wavy rings, which, however, are not elevated much above the furface; at the top, they are round, fharp-pointed, and in that part as fmooth as if they had been polifhed; their pofition is almoft in the fame line with the forehead, inclining a little forwards, and, by means of the twift they make, recede from each other towards the middle, where they are three inches and a half diftant; at the bafe, they are only one inch. 
The Wood-Goat is fomewhat more than two feet and a half high, of a dark-brown colour, in fome parts bordering upon black: On each cheek-bone there are two large round white fpots; another, ftill larger, occupies the fore part of the neck, fomewhat below the top of the windpipe; and feveral fmaller white fpots are fcattered over the haunches: A narrow line of white hair extends from the neck all along the back and tail, but is not eafily diftinguifhed, being hid by the length of the darkbrown hairs on the top of the back, which are three or four inches long, fo as to form a kind of mane: The lair on the head is very fhort and fine ; in other parts of the body it is longer, refembling that of Goats: Its tail is not more than a finger's breadth in length, covered with long hairs, which extend down the hind part of the thighs and buttocks; the legs and feet are flender; the fetlock joints are likewife fmall; the nofe and under lip, which are white, are decorated with black whifkers about an inch long.

As this creature runs but flowly, it is fometimes caught with dogs. When it finds there is no other refource, it boldly puts itfelf into a pofture of defence; and, when going to butt, kneels down, and in that pofition fells its life at a very dear rate, killing and goring fome of the beft and moft fpirited hounds. It carries its head ftraight forward whilft it runs, laying its horns upon its neck, to prevent their being entangled in the bufhes. The female is without horns; and, being lighter than the male, runs more freely through the forefts, and is not fo eafily caught. Her breaft is faid to be very plump: But the flefh of this animal is not very tender. 


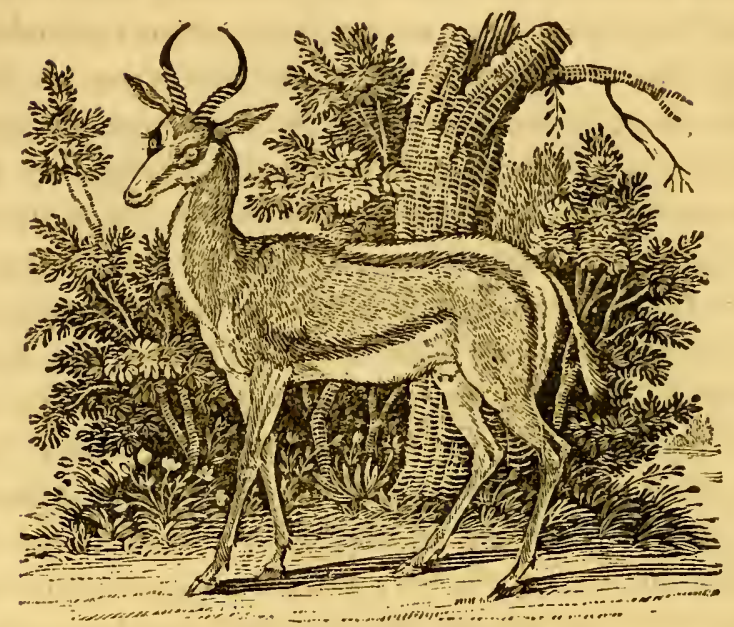

THE SPRINGER.

THE Wbite-Antelope, which is fuppofed to be the fame with the Pygarg, mentioned in the book of Numbers, is an inhabitant of the Cape of Good Hope, where it is called the Spring-bok, and is to be feen in herds of feveral thoufands, covering the plains as far as the eye can reach. Sparrman fays, that having fhot at a large herd of them, they formed a line, and immediately made a circular movement, as if to furround him; but afterwards flew off in different directions.

The height of this beautiful creature is two feet and a half; it meafures, from the ears to the tail, fomewhat above three feet: The tail is rather lefs than a foot long: The length of the ears $f x$ inches and a half; that of the horns, meafuring them along their curvatures, nine inches; their diftance at the bafe, where they arc nearly three 
inches thick, is one inch; they gradually widen from thence to the diftance of five inches from each other, when they turn inwards, fo that at the tip they are not above three inches and a half afunder; they are of a deep-black colour, annulated above half way up; toward the top they are quite fmooth, and end in a fharp point.

The predominant colour of this animal is brown, or a light ruft colour: The breaft, belly, and infide of the limbs, are white; as is alfo the head, excepting a darkbrown lift, which paffes from each corner of the mouth, over the eyes, to the bafe of the horns: A ftripe of the fame dark colour extends, on each fide, from the fhoulders to the haunches, forming a boundary between the fnowy whitenefs of the belly and the rufty colour of the fides: The buttocks are white; and, from the tail half way up the back, is a ftripe of white, bounded on each fide by a dark-brown lift: The tail, at leaft the lower part of it, is not thicker than a goofe quill; the under fide is quite bare; towards the tip there are a few darkbrown hairs, from one to two inches and a half long: The ears are of an afh colour, tipt on the edges with fine light-gray hairs: The eye-brows and whifkers are black: The hair in general is fine and fhort; but the dark line which borders upon the white confifts of longer hairs, which the animal is able to expand to the breadth of eight or nine inches, particularly on taking a high leap. When purfucd, it is no lefs pleafant than curious to fee the whole herd jumping over each other's heads to a confiderable height: Some of them will take three or four high leaps fucceffively. In this fituation, they feem fufpended in the air; looking over their thoul- 
ders at their purfuers, and at the fame time fhewing the white part of their backs in a molt beautiful manner.

'The Springers are fo extremely fwift, as to require a good Horfe to overtake them; although they are fometimes bold enough to allow a fportfman, either on foot or on horfeback, to come within gun-fhot of them.Their flefh is very palatable, and has a more juicy and delicate tafte than that of the other Gazelles.

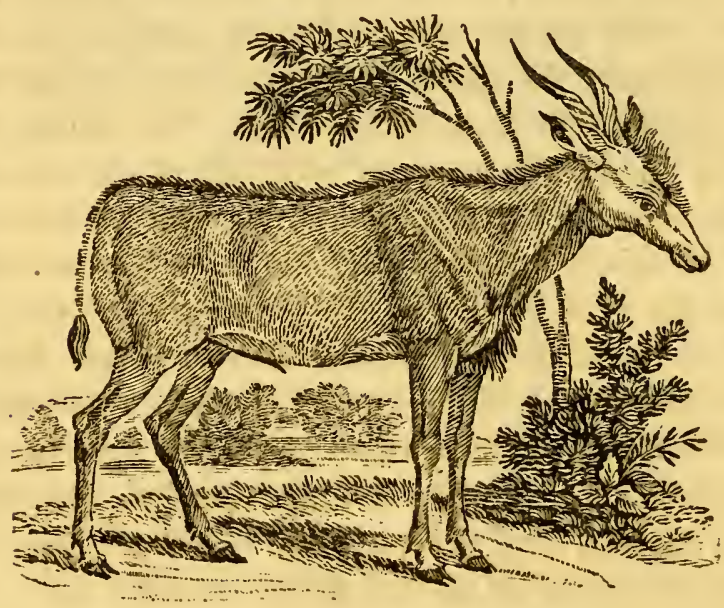

THE ELK-ANTELOPE.

\section{(Le Codous, Buff.)}

THis is an inhabitant of the Cape, as well as the greateft part of India, and is one of the larger kinds of Gazelles. It has ftraight horns, two feet in length, of a dark-brown colour, marked with two prominent fpiral ribs ranning near two-thirds of their length, but finooth 
towards the ends, which are turned a little inwards: The forehead is flat, and broad at the top; and has a forelock, ftanding erect, the whole length of it: Its nofe is Tharp; and its breaft is covered with a loofe $\mathrm{fkin}$.

This animal is of an afh colour, inclining a little towards blue; has a thin upright mane, quite black, which extends from the nape of its neck along the top of the back; it has a tuft of black hair at the end of the tail.

The Elk-Antelopes live chiefly in plains and vallies; and, when hunted, always run, if poffible, againt the wind: They are not very fwift; and being in general fat, efpecially the males, which are always the largeft and fatteft in the herd, are foon tired. The hunter generally endeavours to get to windward of the animal, which when he has accomplifhed, he takes an opportunity of throwing himfelf from his horfe, and inftantly fhoots the flying game: At this practice, the Dutch colonifts at the Cape are fo expert, as feldom to fail. Sparrman fays, there have been many inftances where keen fportfmen, as well for their own pleafure as convenience, have hunted Elk-Antelopes and other Gazelles, for many miles together, from the open plains, and driven them to their own doors, before they thought it worth while to thoot them.

The female has horns like the male, but fmaller. They are ufed by the Hottentots for tobacco-pipes.

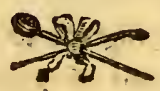




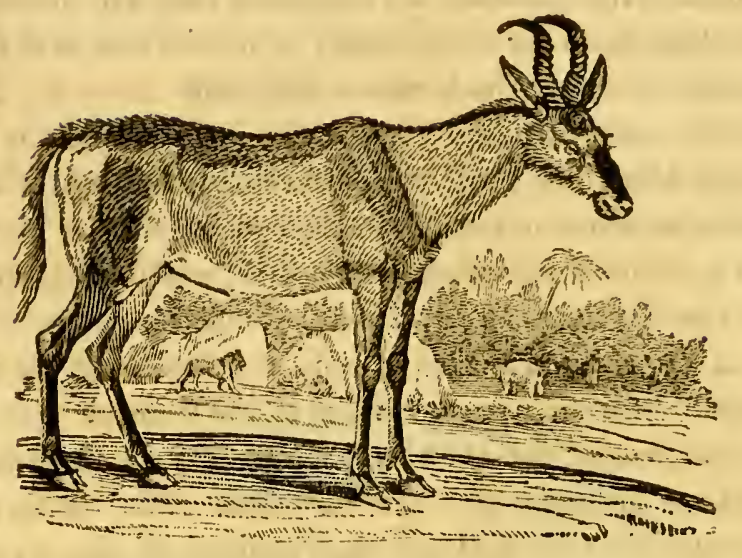

THE HART-BEEST.

(Le Bubale, Buff.)

THIs is the moft common of all the larger Gazelles, known in any part of Africa. The following accurate defcription is taken from Sparrman, to whom we are indebted for the beft accounts of fuch of thefe rare animals as are to be met with near the Cape. Its height is fomewhat above four feet: The horns are from fix to nine inches long, very ftrong and black, almoft clofe at the bafe, diverging upwards, and at the top bending backwards in an horizontal direction almoft to the tips, which turn a little downwards; they are emboffed with about eighteen rings of an irregular form. The general colour of the Hart-Beeft is that of cinnamon; the front of the head is marked with black, as is likewife the fore part of the legs; the hind part of the haunch is covered with a 


\section{HISTORY OF QUADRUPEDS.}

wide black ftreak, which reaches down to the knee; a narrow ftripe of black begins behind each ear, and runs all along the ridge of the neck; a dark-brown oval fpot extends over the back, terminating juft above the tail, which is flender, fomewhat like that of an Afs, and is covered with ftrong black hairs about $\mathrm{f} x$ inches long: There is a pore about an inch below the eye, from which a matter is diftilled, fomewhat like ear-wax, which the Hottentots preferve as a rare and excellent medicine.

This animal is fuppofed to be the Bubalus of the ancients; it is the Cervine Antelope of Mr Pennant.

The hair of the Hart-beeft is very fine; and its long ears are covered with white hair on the infide: It has only eight teeth in the lower jaw, none in the upper; the legs are rather flender, with fmall fetlocks and hoofs.

The large head and high forehead, together with the affinine ears and tail, of the Hart-beeft, render it one of the leaft handfome of the whole tribe of Antelopes. Its pace, when at full fpeed, appears like a heavy gallop; nowithftanding which, it runs as faft as any of the larger Antelopes. When it has once got a-head of its purfuers, it is very apt to turn round, and ftare them full in the face.-Its flefh is fine, rather dry, but of an agreeably high flavour.

G 2 


\section{THE KOEDOE, OR STRIPED ANTELOPE,}

\section{(Le Condoma, Buff.)}

Is a beautiful, tall Gazelle, inhabiting the Cape of Good Hope; has long, flender fhanks; is larger, though not fo - clunfy, as the Elk-Antelope : Its horns are finooth, twifted fpirally, with a prominent edge or rib following the wreaths; they are three feet nine inches long, of a palebrown colour, clofe at the bafe, and at the points round and tharp.

The colour of this animal is a rufty-brown; along the ridge of the back there is a white ftripe, mixed with brown; from this are eight or nine white ftripes, pointing downwards; the forehead and the fore part of the nofe are brown; a white fripe runs from the corner of each eye, and meets juft above the nofe; upon each cheek-bone there are two fmall white fpots; the inner edges of the ears are covered with white hair, and the upper part of the neek is adorned with a brown mane, an inch long; beneath the neck, from the throat to the breaf, are fome long hairs hanging down; the breaft and belly are gray; the tail is two feet long, brown above, white beneath, and black at the end.

The Koedoe, though a tall and flender animal, is not fo fwift as many of the Gazelle kind, and is eafily overtaken by the hounds: On thefe occafions, the males defend themfelves with great fpirit with their horns, and will come to clofe quarters with the dogs; but the females, having no horns, are obliged to depend on their fpeed. 


\section{THE GEMSE-BOK.}

(Capra Gazella, Lin._Le Pafan, Buff.)

Ir is called, by Mr Pennant, the Egyptian Antelope. The horns are ftraight, flender, of a black colour, about three feet long, with above twenty rings reaching half way to the points, which are fmooth and taper; it is of an afh colour, inclining to red; the belly, legs, and face are white; a black line extends from the neck to the loins; the tail is about two feet long, terminated with black hairs.

This animal is famous for a concretion in its ftomach or inteftines, called the oriental bezoar, which was much efteemed in former times for its great virtue in expelling poifon in the human frame, and was fold at enormous prices, its value increafing in proportion to its fize.There was a time, when a ftone of four ounces fold in Europe for above $200 \mathrm{l}$; at prefent, however, its eftimation and price are.greatly decreafed. The virtues which ignorance and inexperience attributed to it, are now found no longer to exift; and this once-celebrated medicine is now only confumed in countries where the knowledge of Nature has been but little advanced. Similar concretions are likewife found in a variety of animals of the Gazelle and Goat kind: Even Apes, Serpents, and Hogs are faid to have their bezoars. In thort, there is fcarcely an animal, except of the carnivorous kind, that does not produce fome of thefe concretions in the ftomach, inteftines, kidnies, and even the heart. 
Thefe are the principal animals of the Gazelle kind defcribed by Dr Sparrman, in his Voyage to the Cape of Good Hope: He mentions a variety of others that are to be met with there, of which he gives us little but. their names.

\section{THE REE-BOK,}

Is two fect in height; of an anh colour, fomewhat refembling that of a Hare, but a little more inclining to red: The belly and anus are white: The tail is fhort: The horns are black and ftraight, very fimilar to thofe of the Gemfe-bok, but barcly a foot long, very taper, and tharp-pointed; they are ufed by the Hottentots as awls or bodkins, for boring holes in making their fhoes or cloaks.

The flefh of this animal is dry, and accounted worfe to eat than that of any other Gazelle.

\section{THE RIET-REE-BOK,}

Is twice as big as the laft-mentioned animal; is monogamous (or keeps in pairs); it generally lies concealed among the reeds and marfhy places, and refembles the Ree-bok.

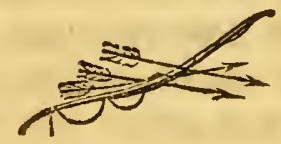




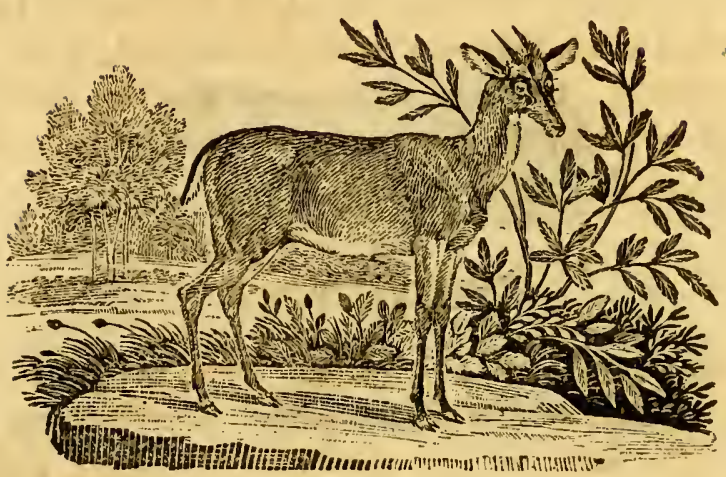

THE GR Y S - B O K,

(La Grimme, Buff.)

Is of a grayifh or afh colour, with large black ears, and a black fpot round the eyes; ftraight black horns, flender and tharp-pointed, not three inches long, flightly annulated at the bafe: Its height is about eighteen inches; and it is moft elegantly formed: Beneath each eye is a cavity, that contains a ftrong-fcented oily liquor, which fmells fomething like murk, and, when expofed to the air, becomes hard and black.-It is the Guinea Antelope of Mr Pennant.

\section{THE KLIP-SPRINGER,}

Is of a light-red colour, inclining to yellow, intermixed with black ftreaks; the tips and edges of its ears are black: It runs with great fwiftnefs, and makes large bounds, even on the fteepeft precipices, and in the moft rocky places, where it cannot eafily be caught with hounds. 


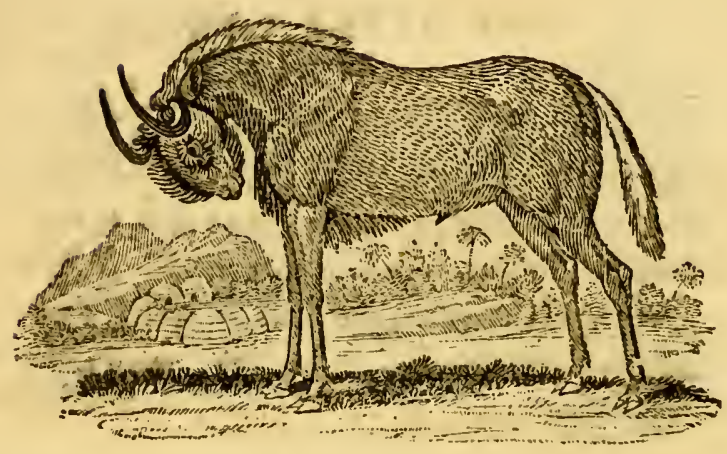

\section{THE GNU.}

To there we may add the Ginu, the Hottentot name for a fingular animal, which, with refpect to its form, is between the Horfe and the $O x$. It is about the fize of a common Galloway, the length of it being fomewhat above five feet, and the height rather more than four.

This animal is of a dark-brown colour; the tail and mane of a light-gray; the thag on the chin and breaft, and the ftiff hairs which ftand erect on the forehead and upper part of the face, are black: The curvature of the horns is fingular; and the animal is reprefented in the cut in the attitude of butting, to give an idea of its form and pofition.

The legs of the Gnu are fmall; its hair is very fine; and it has a cavity beneath each eye, like mort of the Antelope kind. 


\section{HISTORY OF QUADRUPEDS.}

\section{THE STEEN-BOK,}

$$
\text { (Le Nagor, Buff.) }
$$

Is found in Senegal, and at the Cape of Good HopeIts whole body is of a pale-red colour; it is as large as a Roe-buck; its horns, which do not exceed fix inches in length, are almoft fmooth, and bend a little forward; its ears are five inches long; and it has a white fpot over each eye.-It is called, by Mr Pennant; the Red Antitelope.

\section{THE SWIFT-ANTELOPE,}

\section{(Le Nanguer, Buff.)}

Is likewife a native of Africa, and is found in Senegal.It is three feet and a half in length, and two and a half high; the horns are black and round, eight inches in length, and, what is fingular, bend forward at the points; its general colour is tawny; belly and thighs white; it has likewife a white fpot under the neck, is a very handIome animal, and eafily tamed; its fwiftnefs is compared to that of the wind.

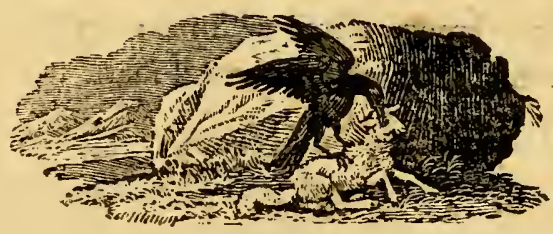




\section{IO6 HISTORY OF QUADRUPEDS.}

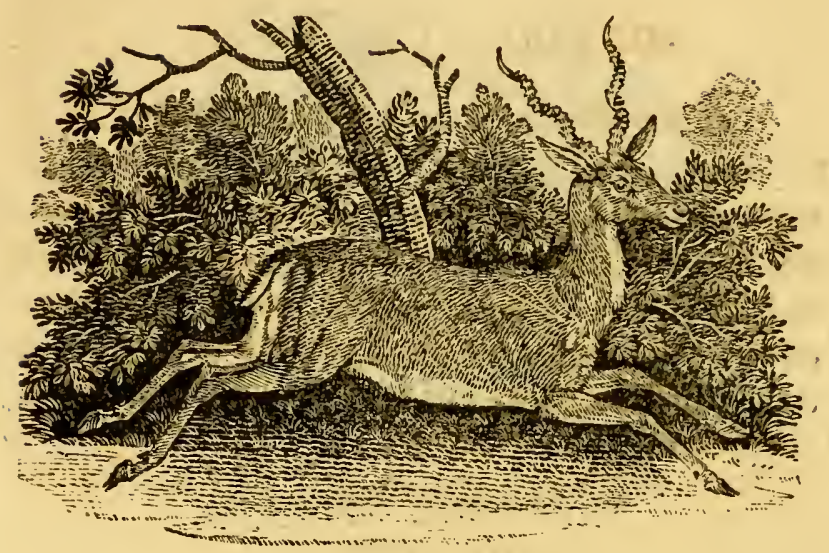

\section{THE COMMON ANTELOPE.}

(Capra Cervicapra, Lin._L'Antelope, Buff.)

ThE Antelope, properiy fo called, abounds in Barbary, and in all the northern parts of Africa.-It is fomewhat lefs than the Fallow-deer: Its horns are about fixteen inches long, furrounded with prominent rings almoit to the top, where they are twelve inches diftant from point to point. The horns of the Antelope are remarkable for a beautiful double flexion, which gives them the appearance of the lyre of the ancients. 'The colour of the hair on the back is brown, mixed with red; the belly and infide of the thighs are white; the tail hort. 


\section{THE BARBARY ANTELOPE, \\ (Capra Dorcas, Lin.-La Gazelle, Buff.)}

Is likewife common in all the northern parts of Africa, in Syria, and Mefopotamia ; and feems to be a variety of the laft-mentioned animal, which it ftrongly refembles; only the two colours on the back are feparated from each other by a ftrong dufky line on each fide, and on each knee there is a tuft of hair.

\section{THE KEVEL, \\ (Le Kevel, Buff.)}

Is a native of Senegal; and, in colour and marks, very much refembles the preceding animal. It is about the fize of a fmall Roe-buck; and its horns, inftead of being round, are flatted on their fides, and the rings are more numerous. It lives in great flocks, may be eafily tamed, and is excellent meat.

\section{THE CORIN,}

\section{(Le Corina, Buff.)}

Is Atill lefs than the two former animals: Its horns are very flender, only fix inches long, and almoft fmooth, the annular prominences being fcarcely difcernible; each fide of its face is marked with a white line, and beneath 
that a black one; the upper part of the body is tawny; the belly and infide of the thighs white; a dark line on each fide forms a feparation between the two colours on the back and belly; on each knee is a tuft of hair.Some of thefe animals are irregularly fpotted with white.

\section{THE KOBA,}

\section{(Le Koba, Buff.)}

Is remarkable for the form of its horns, which are almolt clofe at the bafe, bending out towards the middle, where they form a curve inwards, and again fly off at the points, which bend backward; they are feventeen inches long, furrounded with fifteen rings; the ends are fmooth and fharp.

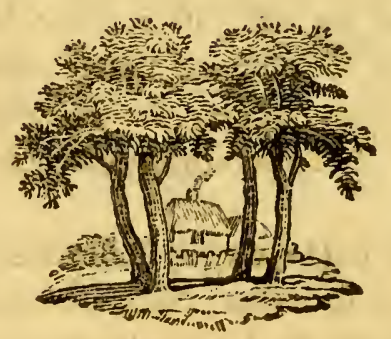




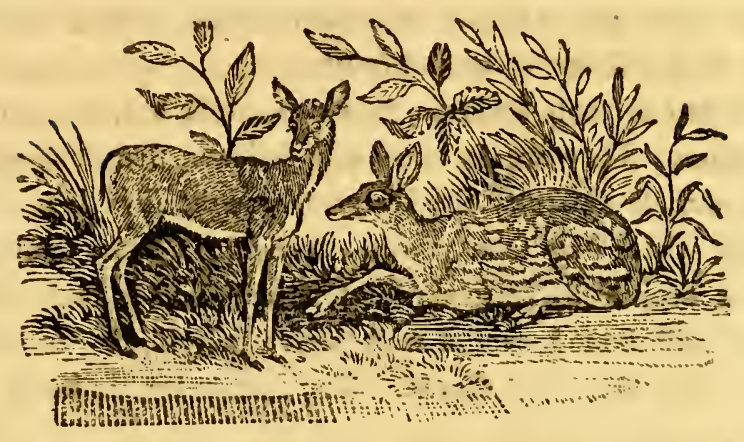

\section{THE CHEVROTAIN AND MEMINNA.}

\section{(Le Cbevrotain de Guinea, Buff.)}

The Chevrotain, or little Guinea Deer, is the fmalleft of all the Antelope kind, the leaft of all cloven-footed quadrupeds, and; we may add, the moft beautiful. Its fore legs, at the fmalleft part, are not much thicker than a tobacco-pipe; it is not more than feven inches in height, and about twelve from the point of the nofe to the infertion of the tail; its ears are broad; and its horns, which are Araight, and fcarcely two inches long, are black and fhining as jet; the colour of the hair is a reddifh-brown; in fome a beautiful yellow, very fhort and gloffy.

Thefe elegant little creatures are natives of Senegal and the hotteft parts of Africa; they are likewife found in India, and in many of the iflands adjoining to that vaft continent.

In Ceylon, there is an animal of this kind called $M$ e- $^{-}$ minna, which is not larger than a Hare, but perfectly re- 
fembling a Fallow-deer. It is of a gray colour; the fides and haunches are fpotted and barred with white; its ears are long and open; its tail fhort.

None of thefe fmall animals can fubfift but in a warm climate. They are fo extremely delicate, that it is with the utmoft difficulty they can be brought alive into Europe, where they foon perifh. They are gentle, familiar, moft beautifully formed; and their agility is fuch, that they will bound over a wall twelve feet high. In Guinea, they are called Guevei. The female has no horns.

\section{THE SCYTHIAN ANTELOPE.}

\section{(Capra Tatarica, Lin._Le Saiga, Buff.)}

THIs is the only one of the fpecies that is to be found in Europe. The form of its body refembles the domentic Goat; but its horns are thofe of an Antelope, being marked by very prominent rings, with furrows between; they are a foot long, the ends fmooth, of a pale-yellow colour, almont tranfparent.

The male, during winter, is covered with long rough hair, like the He-Goat, and has a ftrong fcent; the female is fmoother, and without horns. The general colour is gray, mixed with yellow; the under part of the body is white.

Thefe animals inhabit Poland, Moldavia, about Mount Caucafus, the Cafpian Sea, and Siberia; are fond of falt, and frequent the places where falt-fprings abound, In the rutting feafon, at the latter end of autumn, great flocks of them, confifting of feveral thoufands, migrate 
towards the fouth, and return in the fpring, in fmaller flocks, to the great northern deferts; where the females bring forth their young, and rear them.

The males, the females, and their young, generally feed together; and, when a part of them are refting, others, by an inftinctive kind of caution, are always keeping watch; thefe again are relieved in due time; and, in this manner, they alternately reft and keep watch; frequently preferving themfelves, by this means, from the attacks of men and wild beafts.

Their common pace is a trot; but, when they exert their fpeed, they bound like the Roe-buck, and exceed it in fleetnefs. They are fo timid, as to fuffer themfelves to be taken through fear: If once bitten by a dog, they inftantly fall down, and give themfelves up without further effort to efcape.-When taken young, they are eafily tamed; but the old ones are fo wild and obftinate, as to refufe all food, whilft in a ftate of captivity.--They are hunted for the fake of their flefh, horns, and fkins; the latter are excellent for gloves, belts, \&c. The huntfman is extremely cautious in approaching a herd of thefe animals, left they fhould difcover him by the excellency of their fmell. They are either fhot, or taken by dogs; and fometimes by the black eagle, which is trained for that purpofe. In running, they feem to incline to one fide; and their motion is fo rapid, that their feet feem fcarcely to touch the ground.

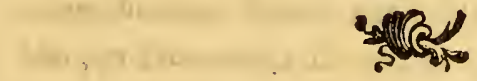




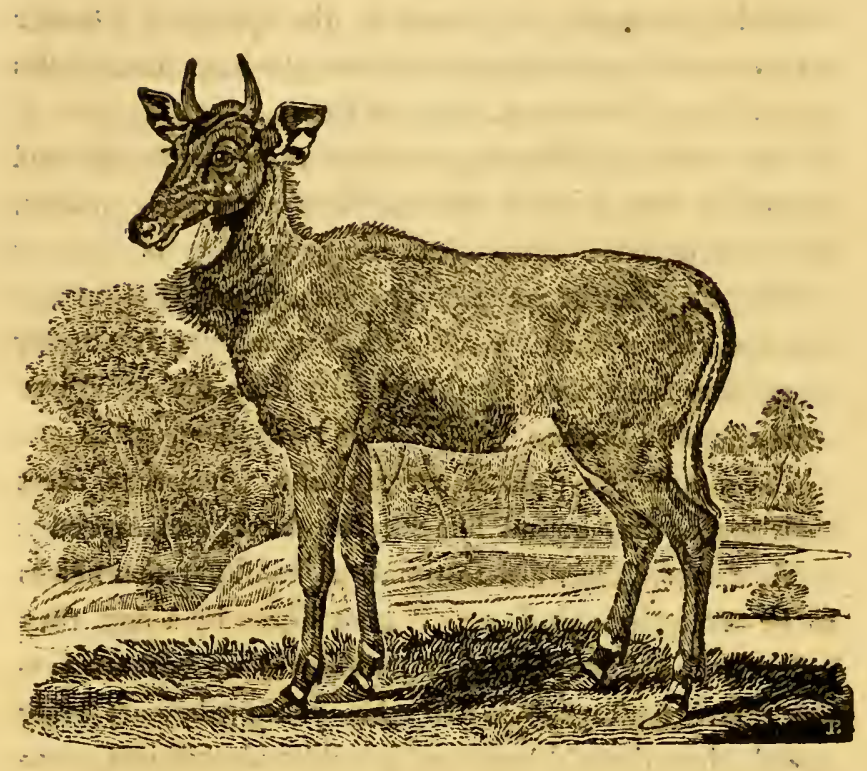

\section{THE NYL-GHAU.}

Thrs animal is a native of the interior parts of India. It feems to be of a middle nature, between the Cow and the Deer, and carries the appearance of both in its form. In fize, it is as much fmaller than the one, as it is larger than the other: Its body, horns, and tail, are not unlike thofe of a Bull; and the head, neck, and legs, are fimilar to thofe of a Deer. The colour, in general, is afh or gray, from a mixture of black hairs and white: All along the ridge or edge of the neck, the hair is blacker, longer, and more erect, making a fhort, thin, and upright mane, reaching down to the hump: Its horns are feven inches long, fix inches round at the root, tapering by degrees, and terminating in a blunt point: The ears are large and 
beautiful, feven inches in length, and fpread to a confiderable breadth; they are white on the edge and on the infide, except where two black bands mark the hollow of the ear with a Zebra-like variety. The height of this animal, at the fhoulder, is four feet one inch; behind the loins, it only meafures four feet.

The female differs confiderably from the male, both in height and thicknefs; it is much finaller; in fhape and colour it very much refembles a Deer, and hás no horns : She has four nipples, and is fuppofed to go nine montlis with young: She has commonly one at a birth, and fometimes two.

Several of this fpecies were brought to this country in the year 1767 , which continued to breed annually for fome years after.-Dr Hunter, who had one of them in his cuftody for fome time, defcribes it as a harmlefs and gentle animal; that it feemed pleafed with every kind of familiarity, always licked the hand that either ftroked or fed it, and never once attempted to ufe its horns offenfively. It feemed to have much dependence on its organs of finell, and fnuffed keenly whenever any perfon came in fight: It did fo likewife, when food or drink was brought to it; and would not tafte the bread which was offered, if the hand that prefented it happened to fmell of turpentine.

Its manner of fighting is very particular, and is thus defcribed :-Two of the males at Lord Clive's being put into an inclofure, were obferyed, while they were at fome diftance from each other, to prepare for the attack, by falling down upon their knees: They then fhuffled towards each other, ftill keeping upon their knees; and, 
at the diftance of a few yards, they made a fpring, and darted againft each other with great force.

The following anecdote will ferve to thew, that, during the rutting feafon, thefe animals are fierce and vicious, and not to be depended upon :-A labouring man, without knowing that the animal was near him, went up to the outfide of the inclofure; the Nyl-ghau, with the quicknefs of lightning, darted againft the wood-work with fuch violence, that he dafhed it to pieces, and broke off one of his horns clofe to the root. The death of the animal, which happened foon after, was fuppofed to be owing to the injury he fuftained by the blow.

Bernier fays, that it is the favourite amufement of the Mogul Emperor to hunt the Nyl-ghau; and that he kills them in great numbers, and diftributes quarters of them to his omrahs; which thews that they are efteemed good and delicious food.

The Nyl-ghau is frequently brought from the interior parts of Afra, as a rare and valuable prefent to the nabobs and other great men at our. fettlements in India.

It remains to be confidered, whether this rare animal might not be propagated with fuccefs in this country. That it will breed here, is evident from experience; and, if it fhould prove docile enough to be eafily trained to labour, its great fwiftnefs and confiderable ftrength might be applied to the moft valuable purpofes. 


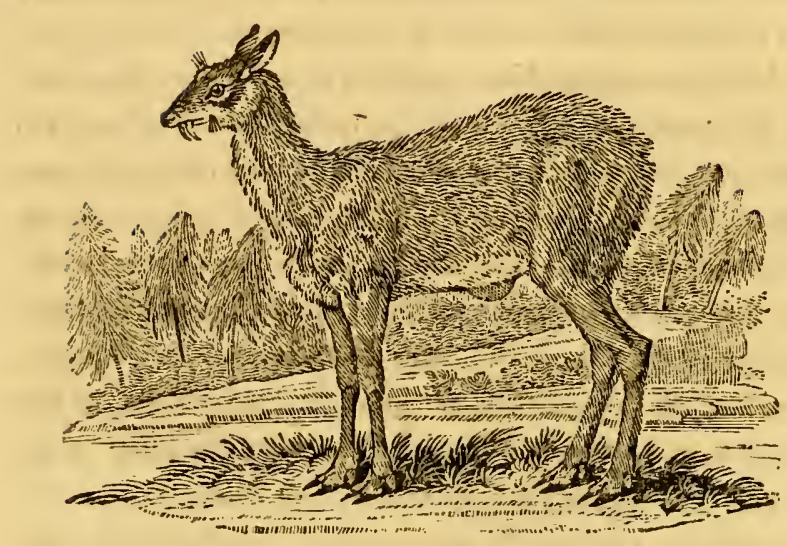

THE MUSK.

(Mofcbus Mofcbiferus, Lin.-Le Mufc, Buff.)

There have been various accounts given of this animal by naturalifts and travellers; by whom it feems to have been taken notice of more for the perfume which it produces, than for the information of the curious enquirer into its nature and qualities: For we are ftill at a lofs what rank to affign it among the various tribes of quadrupeds.

It has no horns; and whether it ruminates or not, is uncertain : But, by its wanting the fore teeth in the upper jaw, we are led to fuppofe that it belongs either to the Goat or the Deer kind; and have therefore given it a place after the Gazelles, relying upon thofe characteriftic marks which are known, and leaving it to thofe naturalifts, who may be poffeffed of better means of information, to afcertain its genuine character.

$\mathrm{H} 2$, 
The Muk of Thibet refembles the Roe-buck in form. It is fomewhat above two feet in height 'at the fhoulder; the hind legs, which are longer than the fore legs, are two feet nine inches high at tlie launches; the length is three feet fix inclies from the head to the tail; the head is above half a foot long: Its upper jaw is much larger than the lower; and on each fide of it there is a flender tufk, near two inches long, which hangs down, bending inwards like a hook, and very tharp on the inner edge: Its lower jaw contains eight fmall cutting teeth; and in each jaw there are fix grinders: Its ears are long, fmall, and erect, like thofe of a Rabbit: The hair on the whole body is long and rough, marked with fmall waves from top to bottom: The colour is a rufty-brown; under the belly and tail it is white: On each fide of the lower jaw there is a tuft of thick hair, about an inch long: Its hoofs are deeply cloven, flender, and black; the fpurious hoofs are likewife very long: Its tail is not more than two inches in length, and hid in the hair.-The ufe it makes of its tufks is not well known: The moft probable is that of hooking up roots out of the ground, and catching at fmall twigs and branches of trees, upon which it feeds. - The female has no tuks, is lefs than the male, and has two fmall teats.

The Mufk is found in the kingdom of Thibet, in feveral of the Chinefe provinces, about the lake Baikal, and near the rivers Jenifea and Argun, from lat. 60 to 45 ; but feldom fo far fouth, except driven by great falls of fnow to feek for food in more temperate climates.-It is naturally a timid animal, and endowed with a quick fenfe of hearing. Its folitary haunts are ufually mountains, covered with pines; where it avoids mankind, and, 
when purfued, flies to the higheft and moft inacceffible fummits.

The perfume produced by this animal, which is fo well known in the fafhionable circles, and of late fo much ufed in the practice of phyfic, needs little defcrip. tion. It is found in a bag or tumour, nearly of the fize of a hen's egg, on the belly of the male only. Thefe bags the hunters cut off, and tie them up for fale; many thoufands of which are fent over annually to Eúrope, befides what are confumed in different parts of the Eaft. To account for this great confumption, it is fuppofed that the mufk is frequently adulterated and mixed with the blood of the animal. It comes to us from China, Tonquin, Bengal, and Mufcovy; but that of Thibet is reckoned the beft, and fells at a much higher price.

The flefh of the males, efpecially in the rutting feafon, is much infected with the flavour of the muik; but is, neverthelefs, eaten by the Ruffians and Tartars,

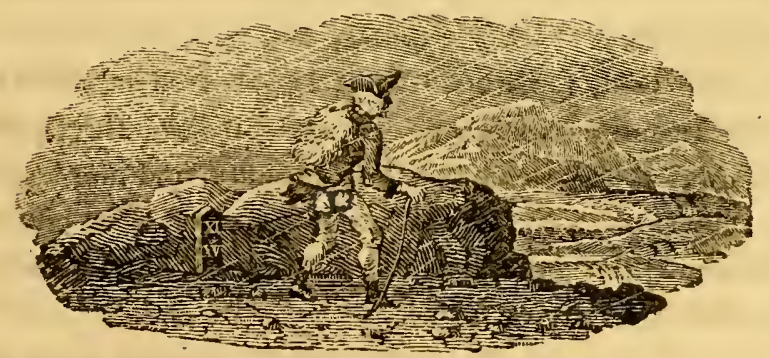

$H_{3}$ 


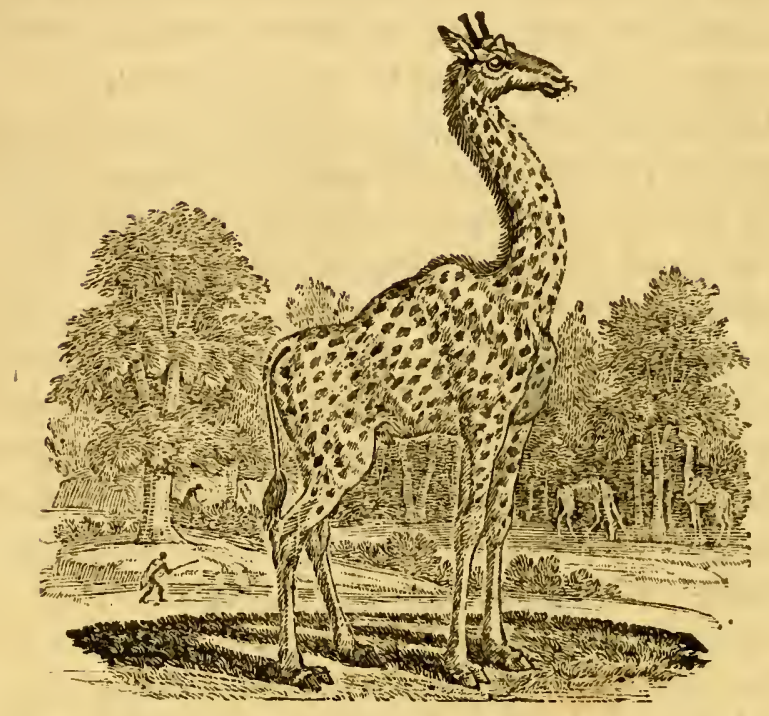

THE CAMELEOPARD.

(Cervus Camelopardalis, Lin.-La Giraffe, Buff.)

This animal, (the exiftence of which has frequently been called in queftion) is a native of the wild and unfrequented defarts of Ethiopia, and other interior parts of Africa, where it leads a folitary life, far from the habitations of men, for whofe ufe it is rendered unfit by the enormous difproportion of its parts. It has hitherto been regarded chiefly as an object of curiofity, and may lead us to admire the wonderful productions of that creative Power, which has filled the earth with life in fuch a boundlefs variety of forms.

The height of this extraordinary animal, from the crown of the head to the ground, is feventeen feet; 
while at the rump it only meafures nine; the neck alone is feven feet long; and the length, from the extremity of the tail to the end of the nofe, is twenty-two feet : The fore and hind legs are nearly of an equal height; but the fhoulders rife fo high, that its back inclines like the roof of a houfe: Its neck is flender and elegant, adorned on the upper fide with a fhort mane: On the higheft part of the head it has two perpendicular horns, fix inches long, covered with hair, and round at the ends, where they are encompaffed with a circle of fhort black hairs*: On the middle of the forehead there is a protuberance, about two inches high: Its ears are long, and its eyes large and beautiful.

The colour of the male is light-gray, interfperfed with large dark-brown fpots over the whole body; the fpots on the female are of a pale-yellow colour.

It is a timid and gentle creature, but not fwift; from the great length of its fore legs, it is obliged to divide them to a great diftance when it grazes, which it does with great difficulty; it lives chiefly by browfing on the leaves and tender branches of trees; it lies on its belly, and has hard protuberances on its breaft and thighs, like the Camel; its tail is fimilar to that of an $\mathrm{Ox}$, with ftrong black hair at the end; it is cloven-footed, has no teeth in the upper jaw, and is a ruminating animal.The female has four teats, and is lefs than the male.This animal was known to the Romans in early times.

M. Vaillant, who thot feveral of thefe animals, fays, that thefe horns differ from thofe of the Stag or the Ox, in being formed by a continuation of the bone of the $\{k u l l$. 


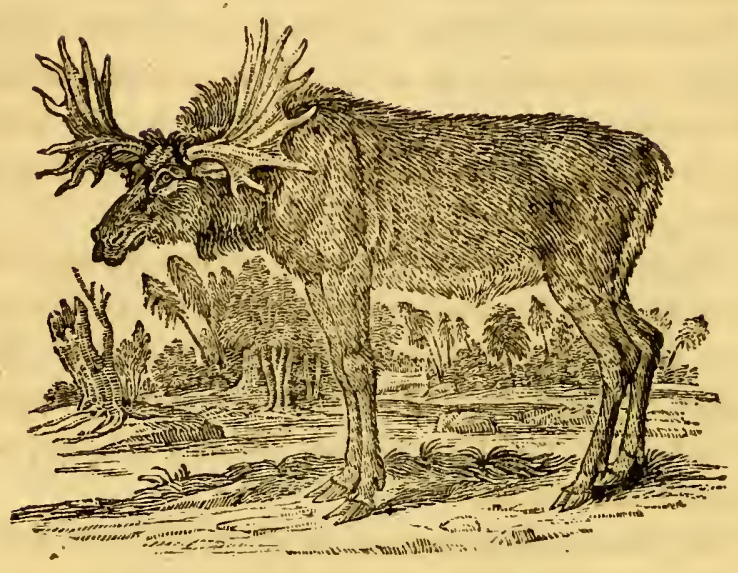

THE ELK,

(Gervus Alces, Lin.-L'Elan, Buff.).

Is the largeft and moft formidable of all the Deer kind. It is a native of both the old and the new continent, being known in Europe by the name of the Elk, and in America by that of the Moofe-deer. It is fometimes taken in the forefts of Ruffia and Germany; though it is rarely to be feen, on account of its extreme wildnefs. It likewife inhabits Norway, Sweden, Poland, and Tartary, as far as the North of China. It is common in Canada, and in all the northern parts of America.

- 'The Elk has been varioully defcribed by naturalifts and travellers: By fome, it is fiid to be twelve feet high; whilf others, with greater appearance of probability, defcribe it as being not much higher than a Horfe. It is, 
however, a matter of doubt to which a greater degree of credibility fhould be given.

From a variety of Elks' horns preferved in the cabinets of the curious, fome of which are of a moft enormous fize, there is every reafon to conclude, that the animal "which bore them muft have been of a proportionable bulk and ftrength.

Thofe who fpeak of the gigantic Moofe, fay, their horns are fix feet long, and meafure, from tip to tip, above ten feet: The beams of the horns are thort; from which they fpread out into large and broad palms; one fide of which is plain, but on the cutfide are feveral fharp fnags or thoots.

The European Elk grows to the height of feven or eight feet; and in length, from the end of the muzzle to the infertion of the tail, meafures ten feet: The head is two feet long; the neck, on which is a fhort upright mane, of a light-brown colour, is much fhorter: Its eye is fmall; and, from the lower corner of it, there is a deep flit, common to all the Deer kind, as well as moft of the Gazelles: The ears are upwards of a foot in length, very broad, and fomewhat flouching; the noftrils are wide; and the upper lip, which is fquare, and has a deep furrow in the middle, hangs greatly over the lower, from whence it was imagined by the ancients, that this creature could not graze without going backward: The withers are very high, the hind legs much fhorter than the fore legs, and the hoofs deeply cloven : From a fmall excrefcence under the throat, hangs a long tuft of coarfe - black hair : The tail is very thort, dußky above, and white beneath: The hair is long and rough, like a Bear, and of 
a hoary-brown colour, not much difiering from that of the Afs:

The pace of the Elk is a high, fhambling trot; but it goes with great fwiftnefs.-Formerly thefe animals were made ufe of in Sweden to draw flediges; but as they were frequently acceffary to the efcape of fuch as had been guilty of murders or other great crimes, this ufe of them was prohibited under great penalties.

In paffing through thick woods, thefe animals carry their heads horizontally, to prevent their horns being entangled in the branches.

The Elks are timid and inoffenfive; except when wounded, or during the rutting feafon, when the males become very furious, and at that time will fwim from ifle to ifle in purfuit of the females. They ftrike with both horns and hoofs, and poffers fuch agility and ftrength of limbs, that, with a fingle blow of the fore feet, they will kill a Wolf or a Dog.

Their flefh is extremely fweet and nourifhing. The Indiaus fay, they can travel farther after eating heartily of the flefl of the Elk, than any other animal food. Their tongues are excellent; but the nofe is efteemed the greateft delicacy in all Canada. The fkin makes excellent buff leather, and is ftrong, foft, and light \& The Indians make their fnow-fhoes, and likewife form their canoes, with it. The hair on the neck, withers, and hams, of a full-grown Elk, from its great length and elafticity, is well adapted to the purpofe of making mattraffes and faddles.

The methods of hunting thefe animals in Canada are curious. The firft, and moft fimple, is,-before the lakes or rivers are frozen, multitudes of the natives affemble in 
their canoes, with which they form a vaft crefcent, each horn touching the fhore; whilf another party on the fhore furround an extenfive tract: They are attended by dogs, which they let loofe, and prefs towards the water with loud cries. The animals, alarmed by the noife, fly before the hunters, and plunge into the lake, where they are killed by the people in the canoes with lances and clubs.-Another method requires a greater degree of preparation and art. The hunters inclofe a large fpace with ftakes and branches of trees, forming two fides of a triangle; the bottom opens into a fecond inclofure, which is faft on all fides: At the opening are huing numbers of fnares, made of the lips of raw hides. They affemble, as before, in great troops; and, with all kinds of hidcous noifes, drive into the inclofure not only the Moofe, but various other kinds of Deer, with which that country abounds. Some, in forcing their way through the narrow pafs, are caught in the fnares by the neck or horns; whilft thofe which efcape thefe, meet their fate from the arrows of the hunters, directed at them from all quarters.-They are likewife frequently killed with the gun. When they are firft difcovered, they fquat with their hind parts, and make water; at which inftant the fportfman fires: If he mifs, the Moofe fets off in a moft rapid trot, making, like the Rein-deer, a prodigious rattling with its hoofs, and running twenty or thirty miles before it ftops or takes the water. The ufual time for this diverfion is in winter. The animal can run with eafe upon the firm furface of the fnow; but the hunters avoid entering on the chafe till the heat of the fun is frong enough to melt the frozen cruft with which it is covered, and render it fo foft as to impede the flight of the Moofe, which 
finks up to the fhoulders, flounders, and gets on with great difficulty: The fportfman purfues in his broadrackets, or fnow-fhoes, and makes a ready prey of the diftreffed animal.

"As weak againft the nountain-hcaps they purh

"Their beating breafts in vaio, and piceous bray,

"He lays them quiv'ring on ' $b$ ' enfanguin'd fnows,

"And with loud houts rejoicing bears them home."

The female is lefs than the male, and has no horns. They are in feafon in the autumn; and bring forth in April, fometimes one, but generally two young ones at a time, which arrive at their full growth in fix years.

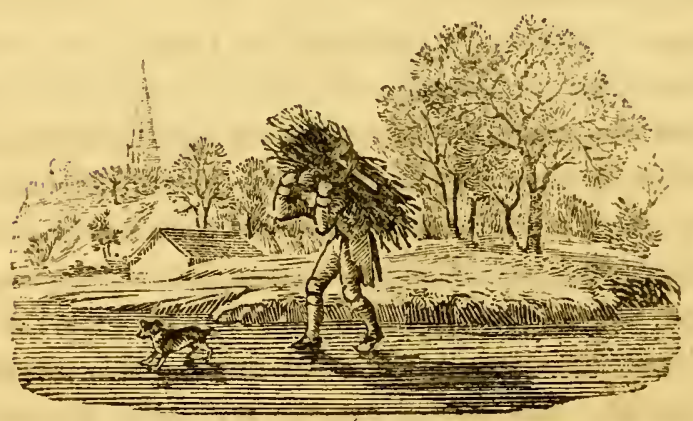




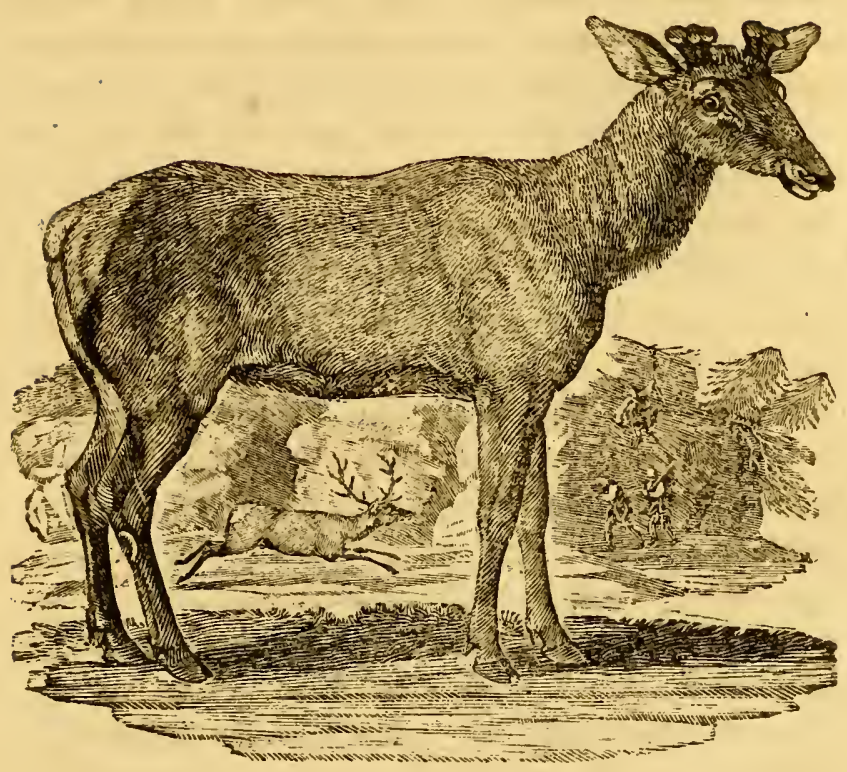

THE AMERICAN ELK.

WE have given a faithful portrait of this animal', from a living one lately brought from the interior parts of America. It feems to be very different from that generally defcribed under the name of the Elk or Moofe-deer, to which it has very little refemblance. It feems, indeed, to belong to a diftinct fpecies, and is probably the Elk or Orignal of Canada and the northern parts of America.

At the age of five years, the length of this creature was nine feet, from the end of the muzzle to the infertion of the tail, the head and reck being extended in a line with the body: Its height at the fhoulder was four 
feet fix inches; length of the head, one foot fix inches; breadth over the forehead, feven inches; length of the fore legs, two feet five inches; length of the neck, two feet fix; its ears, nine inches; and tail, three. Its horns, which it had juft thed, are not palmated, like thofe of the Moofe: They are large; and, when full grown, meafure above fix feet, from tip to tip. The antlers are round, and pointed at the ends: The lowermoft antler forms a curve downward over each eye, to which it appears a defence. Its hair was long, of a dark-dun colour on the back and fides; on the head and legs dark-brown : Its eyes full and lively; and below cach there is a deep flit, about two inches in length, the ufe of which we are unable to difcover.

It was very lively and active; of great ftrength of body and limbs: Its hoofs fhort, and like thofe of a calf; the divifion between them is lefs than in thofe of the Rein-deer; and, when the animal is in motion, they do not make a rattling noife. It has no mane; but the hair under its neck is longer than that on any other part of the body.

We were told by the owner of this very rare and beautiful animal, that it does not attain its full growth till. twenty years old, and that it fheds its horns every thirc. year. 


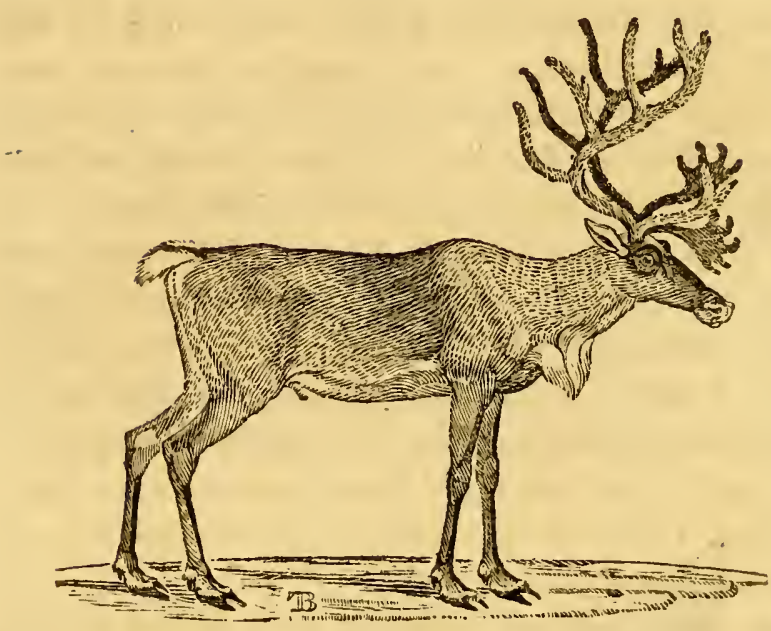

THE REIN-DEER.

(Cervus Tarandus, Lin._Le Renne, Buff.)

THIs extraordinary animal is a native of the icy regions of the North; where, by a wife and bountiful difpenfation, which diffufes the common goods of Nature over every part of the habitable globe, it is made fubfervient to the wants of a hardy race of men inhabiting the countries near the pole, who would find it impoffible to fubfift among their fnowy mountains without the aid of this molt ufeful creature.

In more temperate regions, men are indebted to the unbounded liberality of Nature for a great variety of valuable creatures to ferve, to nourifh, and to cloath them. To the poor Laplander, the Rein-deer alone fupplies the place of the Horfe, the Cow, the Sheep, the Goat, \&c. : 
and from it he derives the only comforts that tend to foften the feverity of his fituation in that molt inhofpitable climate.

The Rein-deer of Lapland are of two kinds,-the wild and the tame: The former are lar jer, ftronger, and more hardy than the latter; for which reafon, the tame females, in the proper feafon, are often fent out into the woods, where they meet with wild males, and return home impregnated by them. The breed from this mixture is Atronger, and better adapted for drawing the fledge, to which the Laplanders accuftom them at an

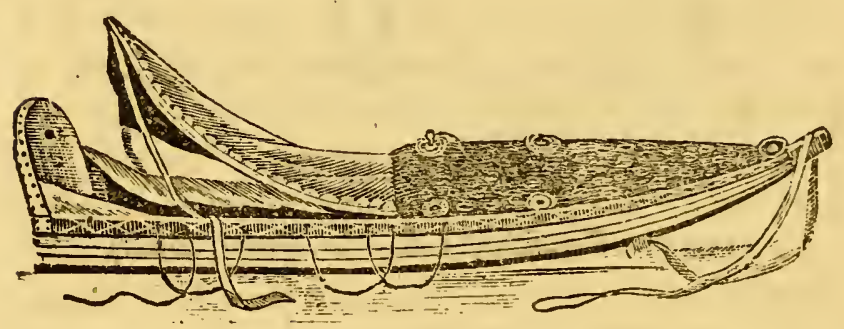

THE SLEDGE.

early age. They are yoked to it by a collar, from which a trace is brought under the belly between the legs, and faftened to the fore part of the fledge. Thefe carriages are extremely light, and covered at the bottom with the fkin of the Rein-deer. The perfon who fits in it guides the animal with a cord faftened to its horns; he drives it with a goad, and encourages it with his voice. -Thofe of the wild breed, though by far the Atrongeft, aften prove refractory, and not only refufe to obey their mafter, but 
turn againft him, and ftrike fo furioufly with their feet, that his only refource is to cover himfelf with his fledge, upon which the enraged creature vents its fury: The tame Deer, on the contrary, is patient, active, and willing.-When hard purhed, the Rein-deer will trot the diftance of fixty miles without ftopping; but, in fuch exertions, the poor obedient creature fatigues itfelf fo exceedingly, that its mafter is frequently obliged to kill it immediately, to prevent a lingering death that would enfue. In general, they can go about thirty miles without ftopping, and that without any great or dangerous effort. - This mode of travelling can be performed only in the winter feafon, when the face of the country is covered with fnow; and, although the conveyance is fpeedy, it is inconvenient, dangerous, and troublefome.

As the Rein-deer conftitutes the fole riches of the Laplander, it may well be fuppofed that a conftant attention to preferve and fecure it, forms the chief employment of his life. It is no uncommon thing for one perfon to poffefs above five hundred in a fingle herd.

As foon as fummer appears, which forms but a fhort interval from the moit piercing cold, the Laplander, who had fed his Rein-deer upon the lower grounds during the winter, drives them up to the mountains, leaving the woody country and the low paftures, which at that feafon are in a ftate truly deplorable. Myriads of infects, bred by the heat of the fun in the woods and fens with which this country abounds, are all upon the wing; the whole atmofphere fwarms with life; every place and every creature is infefted; the natives are obliged to cover their faces with a mixture of pitch and milk, to fhield 
them from thefe minute invaders, which are drawn in with the breath, and enter the noftrils, and even the eyes: But they are chiefly inimical to the Rein-deer: The horns of that animal being then tender, and covered with a $\mathrm{fkin}$, which renders them extremely fenfitive, a cloud of thefe infects fettle upon them, and drive the poor animal almoft to diftraction. In this extremity, there is no refource but flight. The herdfmen drive their flocks from the plains to the fummits of the mountains, whither the foe cannot follow them: There they will continue the whole day, with little or no food, rather than venture down into the lower parts, where they have no defence againft their unceafing perfecutors.

Befides the gnat, the gadfly is a common peft to the Rein-deer. In the autumn, this infect depofits its eggs in their fkin, where the worms burrow, and often prove fatal to them. The moment a fingle fly is feen, the whole herd is in motion: They know their enemy, and endeavour to avoid it, by tofling up their heads, and running among each other; but all this too often proves ineffectual.

Every morning and evening during the fummer, the herdfman returns to his cottage with the Deer to be milked, where a large fire of mors is prepared, for the purpofe of filling the place with fmoke, to drive off the gnats, and keep the Deer quiet whilft milking.-The quantity of milk given by one female in a day, is about a pint. It is thinner than that of a Cow but fveeter and more nourifhing.

The female begins to breed at the age of two years, is in feafon the latter end of September, goes with young eight months, and generally brings forth two at a time. 
-The fondnefs of the Dam for her young is very remarkable. They follow her two or three years, but do not acquire their full ftrength until four. It is at this age that they are trained to labour; and they continue ferviceable four or five years. They never live above fifteen or fixteen years. At eight or nine years old, the Laplanders kill them for their fkins and their flefh. Of the former they make garments, which are warm, and cover them from head to foot: They alfo ferve them for beds; they fpread them on each fide of the fire upon the leaves of trees, and in this manner lie both foft and warm. The latter affords a conftant fupply of good and wholefome food, which, in the winter, when other kinds of provifions fail, is their chief fubfiftence. The tongue of the Rein-deer is confidered as a great delicacy; and, when dried, great numbers of them are fold into other countries. The finews ferve for thread, with which the Laplanders make their cloaths, fhoes, and other neceffaries; and, when covered with the hair, ferve them for ropes.'

Innumerable are the ufes, the comforts, and advantages, which the poor inhabitants of this dreary climate derive from this animal. We cannot fum them up better than in the beautiful language of the poet:-

\footnotetext{
"Their Rein-deer form their riches. Thefe their tents,

"Their robes, their beds, and all their homely wealth,

"Supply, their wholefome fare, and chcarful cups :

"Obfequious at their call, the docile tribe

"Yicld to the fled their necks, and whirl them fwift

"O'er hill and dale, beap'd into one expanfe

"Of marbled foow, as far as eye can fweep,

" W"ith a blue cruft of ise unbounded glaz'd."
} 
The horns of the Rein-decr are large and flender, bencing forward, with brow antlers, which are broad and palmated. A pair in our poffeffion are in length two feet eight inches, and from tip to tip two feet five; they weigh nine pounds: The projecting brow antler is fourteen inches long, one foot broad, and ferrated at the end: It fhould feem, both from its fituation and form, an excellent inftrument to remove the fnow, under which its favourite mors lics. Both fexes have horns: Thofe of the female are lefs, and have fewer branches.

We are happy in being able to give an accurate reprefentation of this fingular creature. The drawing was taken from one in the poffeffion of Sir H. G. Liddell, Bart. which he brought over from Lapland, with four others, in 1786 . The height at the fhoulder was three feet three inches. The hair on the body was of a darkbrown colour; and on the neck brown, mixed with white: A large tuft of hair, of a dirty-white colour, hung down from the throat, near its breaft; and it had a large white fpot on the infide of each hind leg, clofe by the joint: Its head was long and fine; and round each eye was a large black fpace: Its horns were covered with a fine down, like velvet. 'The hoofs of this animal are large, broad, and deeply-cloven: They fpread out to a great breadth on the ground; and, when the animal is in motion, make a crackling noife, by being drawn up forcibly together.

Not many attempts have been made to draw the Reindeer from its native mountains, and tranfport it to milder climes; and of thefe, few have fucceeded. Naturalifts from thence have concluded, that it cannot exift but amidnt ice and fnow. M. Buffon regre ts the impoffibi- 
lity of procuring the animal alive; and fays, that, when tranfported to another climate, it foon dies. M. Regnard mentions fome that were brought to Dantzick; where, being unable to endure the heat of the climate, they alk perifhed. Queen Chriftina of Sweden procurcd five and twenty, which fhe purpofed fending to Oliver Cromwell : They were brought as far as Stockholm; but the Laplanders who attended them refufing to come to England, fifteen of the number were killed by the wolves, and the remaining ten did not long furvive, the climate being confidered as too warm.

To thofe brought over by Sir H. G. Liddell, five more were added the year following. They produced young ones, and gave promifing hopes of thriving in this courtry : But, unfortunately, fome of them were killed; and the others died, in confequence of a diforder fimilar to that called the rot in Sheep, which was attributed to the richners of the grafs whereon they fed. Nor can we wonder at the failure of this fpirited enterprize, when we confider, that it is the fole employment of the Laplander to tend and herd his Rein-deer, to drive them in the fummer time to the fummits of the mountains, to the fides of clear lakes and ftreams, and to lead them where they can find the moft proper food. Want of knowledge or attention to minute particulars, is fufficient to overturn the bef-laid plans.

There is, however, little doubt but this animal will live without the Lapland licken; to which, perhaps, it only hath recourfe, becaufe there is in thofe latitudes no other fuftenance during the winter. It is alfo, in England, free from its mortal enemy-the gadfly. But as 
the defire of poffeffing this animal has hitherto been excited only by curiofity, it is not likely that much attention will be paid to it in a country like this, abounding with fuch variety of ufeful quadrupeds.

The Rein-deer is wild in America, where it is called the Caribou.-It is found in Spitzbergen and Greenland, and is very common in the moft northern parts of Europe, and in Afia as far as Kamfchatka, where fome of the richeft of the natives keep lierds of ten or twenty thoufand in number.

In the neighbourhood of Hudfon's Bay there are great herds of wild Rein-deer: Columns of many thoufands annually pafs from North to South in the months of March and April. In that feafon the mufkatoes are very troublefome, and oblige them to quit the woods, and feek refrefhment on the fhore and open country. Great numbers of beafts of prey follow the herds. The wolves fingle out the ftragglers, detach them from the flock, and hunt them down: The foxes attend at a diftance, to pick up the offals left by the former. In autumn, the Deer, with the Fawns bred during the fumner, remigrate northward. 


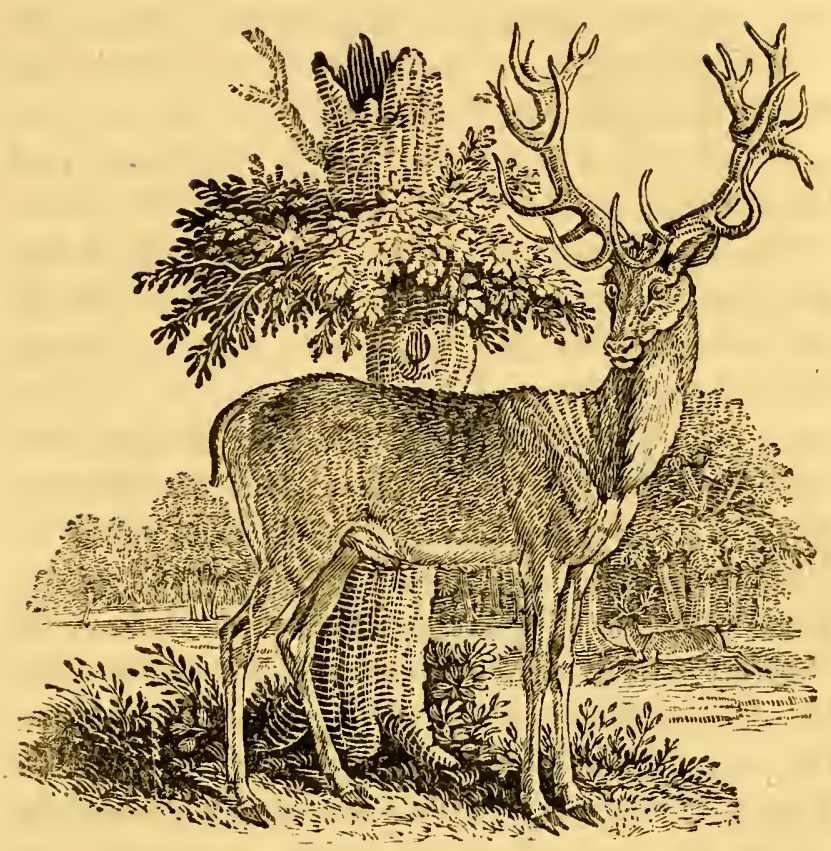

THE STAG, OR RED-DEER.

\section{(Cervius Elephas, Lin.-Le Cerf, Buff.)}

THIs is the moft beautiful animal of the Deer kind: The elegance of his form, the lightnefs of his motions, the flexibility of his limbs, his bold, branching horns, which are annually renewed, his grandeur, ftrength, and fwiftnefs, give him a decided pre-eminence over every other inhabitant of the foreft.

The age of the Stag is known by its horns. The firft 
year exhibits only a thort protuberance, which is covered with a hairy $\mathrm{fkin}$; the next year, the horns are ftraight and fingle; the third year produces two antlers, the fourth three, the fifth four; and, when arrived at the fixth year, the antlers amount to fix or feven on each fide; but the number is not always certain.

The Stag begins to fhed his horns the latter end of February, or the beginning of March. Soon after the old horn has fallen off; a foft tumour begins to appear, which is foon covered with a down like velvet: This tumour every day buds forth, like the graft of a tree; and, rifing by degrees, thoots out the antlers on each fide: The fkin continues to cover it for fome time, and is furnifhed with blood-veffels, which fupply the growing horns with nourifhment, and occafion the furrows obfervable in them when that covering is fript off: The impreffion is dceper at the bottom, where the veffels are larger, and diminifhes towards the point, where they are fmooth. When: the horns are at their, full growth, they acquire ftrength and folidity; and the velvet covering or fhin, with its blood-veffels, dries up, and begins to fail off; which the animal endeavours to haften, by rubbing them againt the trees; and, in this manner, the whole head gradually acquires its complete hardnefs, expanfion, and beauty.

Soon after the Stags have polifhed their horns, which is not compleated till July or Auguit, they quit the thickets, and return to the forefts: They cry with a loud and tremulous note, and fly from place to place, in fearch of the females, with extreme ardour: Their necks fwell; they ftrike with their horns againft trees and other obitacles, and become extremely furious.-At 


\section{HISTORY OF QUADRUPEDS.}

this feafon, when two Stags meet, their contefts are often defperate, and terminate in the defeat or flight of one of them; while the other remains in poffeffion of his miftrefs and the field, till another rival approaches, that he is alfo obliged to attack and repel. During this time, which ufually lafts about three weeks, the Stag is frequently feen by the fides of rivers and pools of water, where he can quench his thirft, as well as cool his ardour. He fwims with great eafe and ftrength; and, it is faid, will even venture out to fea, allured by the Hinds, and fwim from one ifland to another, though at a confiderable diftance.

The Hinds go with young eight months ant a few days, and feldom produce more than one young, called a Fawn. They bring forth in May, or the begimning of June, and conceal their young with great care in the moft obfcure retreats. They will even expofe themfelves to the fury of the hounds, and fuffer all the terrors of the chafe, in order to draw off the logs from their hidingplace. The Hind is alfo very bold in the protection of her offspring, and defends it with great courage againft her numerous and rapacious enemies: The Wild Cat, the Dog, and even the Wolf, are frequently obliged to give way to her upon thefe occafions. But what appears to be ftrangely unnatural, the Stag himfelf is frequently one of her moft dangerous foes, and would deftroy the fawn, if not prevented by the maternal care of the Hind, which carefully conceals the place of its retreat.

The calf never quits the dam during the whole fummer; and in winter, the Stags and Hinds of all ages keep together in herds, which are more or lefs numerous, according to the mildnefs or rigour of the feafon. They 


\section{HISTORY OF QUADRUPEDS.}

feparate in the fpring: The Hinds retire, to bring forth; while none but the young ones remain together.

Stags are gregarious, and fond of grazing in company: It is danger or neceflity alone that feparates them.

The ufual colour of the Stag, in England, is red; in other countries, it is generally brown or yellow. His eye is peculiarly beautiful, foft, and fparkling: His hearing is quick; and his fenfe of fmelling acute. When liftening, he raifes his head, erects his ears, and feems attentive to every noife, which he can hear at a great diftance. When he approaches a thicket, he ftops to look round him on all fides, and attentively furveys every object near him: If the cunning animal perceive nothing to alarm him, he moves flowly forward; but, on the. leaft appearance of danger, he flies off with the rapidity of the wind. . He appears to liften with great tranquillity and delight to the found of the fhepherd's pipe, which is fometimes made ufe of to allure the poor animal to its deftruction.

The Stag eats flowly, and is nice in the choice of his pafture. When his ftomach is full, he lies down to chew the cud at leifure. This, however, feems to be attended with greater exertions than in the $\mathrm{Ox}$ or the Sheep; for the grafs is not returned from the firft ftomach without violent ftraining, owing to the great length of his neck, and the narrownefs of the paffage. This' effort is made by a kind of hiccup, which continues during the time of his ruminating.

The voice of the Stag is ftronger and more quivering as he advances in age: In the rutting feafon, it is even terrible. That of the Hind is not fo loud; and is fel- 


\section{HISTORY OF QUADRUPEDS.}

dom heard, but when excited by apprehenfion for herfelf or her young.

The Stag has been faid to be an uncommonly longlived animal; but later obfervations have fully confuted this unfounded opinion. It is a generally received maxim, that animals live feven times the number of years that bring them to perfection: Thus the Stag, being five or fix years in arriving at maturity, lives feven times that number, or from thirty-five to forty years.

The following fact, recorded in hiftory, will ferve to fhew that the Stag is poffefled of an extraordinary thare of courage, when his perfonal fafety is concerned :Some years ago, William, Duke of Cumberland, caufed a Tiger and a Stag to be inclofed in the fame area; and the Stag made fo bold a defence, that the Tiger was at length obliged to give up.

The hunting of the Stag has been held, in all ages, a diverfion of the nobleft kind; and former times bear witnefs of the great exploits performed on thefe occafions. In our ifland, large tracts of land were fet apart for this purpofe; villages and facred edifices were wantonly thrown down, and converted into one wide wafte, that the tyrant of the day might have room to purfue his favourite diverfion. In the time of William Rufus and Henry the Firft, it was lefs criminal to deftroy one of the human fpecies than a beaft of chafe. Happily for us, thefe wide-extended fcenes of defolation and oppreffion have been gradually contracted; ufeful arts, agriculture, and commerce, have extenfively fpread themfelves over the naked land; and thefe fuperior beafts of the chafe have given way to other animals more ufeful to the community. 
In the prefent cultivated ftate of this country, therefore, the Stag is almoft unknown in its wild ftate. The few that remain are kept in parks among the Fallowdeer, and are diftinguifhed by the name of Red Deer.-Its vicioufnefs during the rutting feafon, and the badnefs of its flefh, which is poor and ill-flavoured, have occafioned almoft the extinction of the fpecies. Some few are yet to be found in the forefts that border on Cornwall and Devonfhire, on moft of the large mountains of Ireland, and in the Highlands of Scotland, where Dr Johnfon defcribes them as not exceeding the Fallow-deer in fize, and their flefh of equal flavour.

The Red Deer of this kingdom are nearly of the fame fize and colour, without much variefy: In other parts of the world, they differ in form and fize, as well as in their horns and the colour of their bodies.

\section{THE CORSICAN STAG,}

Is very fmall, not exceeding half the height of ours; his body is thort and thick, his hair of a dark-brown colour; and his legs thort.

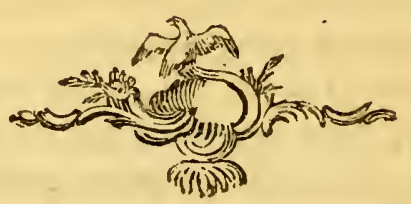




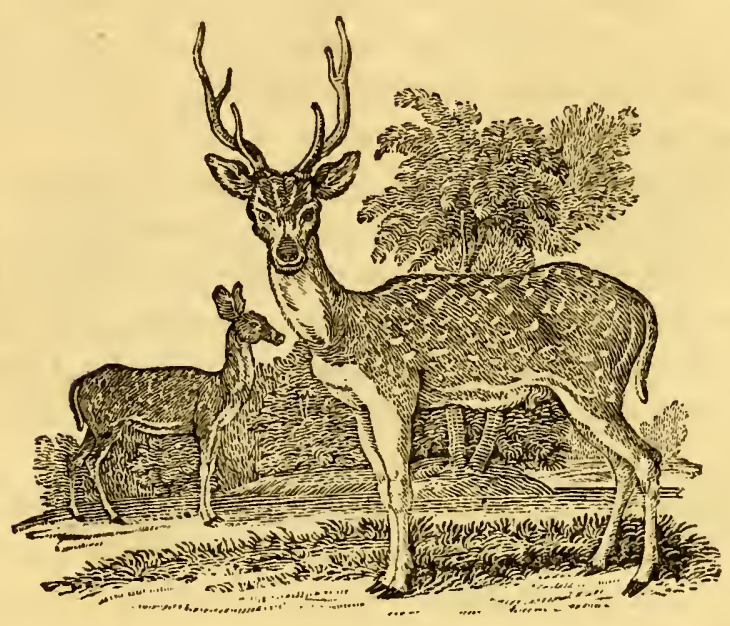

THE AXIS, OR GANGES STAG.

\section{(L'Axis, Buff.)}

THIs animal is an inhabitant of thofe immenfe plains of India watered by the river Ganges.-M. Buffon confiders it as a variety or fhade between the Stag and the Fallow-deer. It is of the fize of the latter; but its horns are round, like thofe of the Stag; and it has no brow antlers. Its whole body is marked with white fpots, elegantly difpofed, and diftinct from each other; the belly, infide of the thighs, and legs, are white; along the back there are two rows of fpots, parallel to each other; thofe on the other parts of the body are irregular; the head and neck are gray; and the tail, which is red above and white beneath, is as long as that of the Fallow-deer. 


\section{HISTORY OF QUADRUPEDS.}

The continent of America abounds with Stags, and other animals of the Deer kind, in great variety. In fome parts of that vaft country, the inhabitants have domefticated them, and live chiefly upon the milk and cheefe with which they fupply them.

Thus we find, that the fame animal, which, in fome parts, contributes only to the amufement of man, may, in others, be brought to fupply his neceffities. The ftores of Nature are various and abundant: It is neceffity alone that draws them out to fupply our wants, and contribute to our comforts.

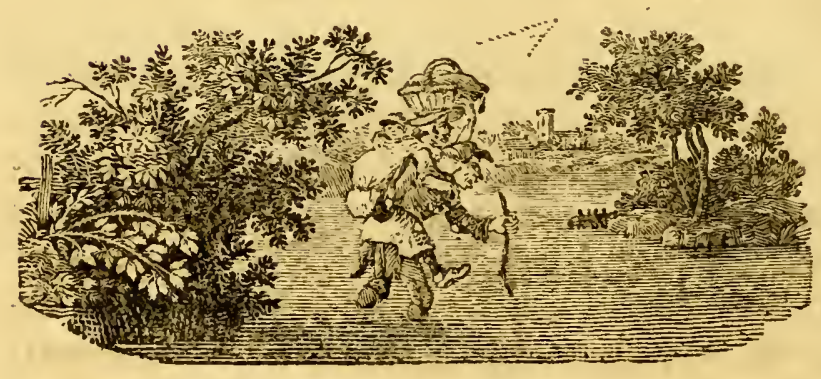




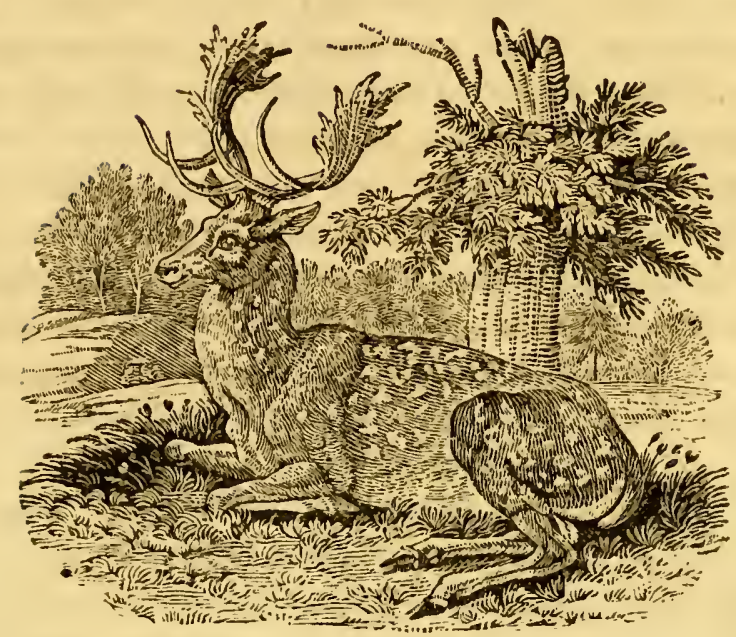

THE FALLOW-DEER.

(Cervus Dama; Lin._Le Dain, Buff.)

THE principal difference between the Stag and the Fallow-deer, feems to be in their fize and in the form of their horns; the latter is much fmaller than the former, and its horns, inftead of being round, like thofe of the Stag, are broad, palmated at the ends, and better garnifhed with antlers: The tail is alfo much longer than that of the Stag, and its hair is brighter; in other refpects they nearly refemble each other.

The horns of the Fallow-deer are thed annually, like thofe of the Stag; but they fall off later, and are renewed nearly at the fame time. Their rutting feafon arrives fifteen days or three weeks after that of the Stag. The 
males then bellow frequently, but with a low and interrupted voice. They are not fo furious at this feafon as the Stag, nor exhauft themfelves by any uncommon ardour. They never leave their pafture in queft of the females, but generally fight with each other, till one buck becomes mafter of the field.

They affociate in herds, which fometimes divide into two parties, and maintain obftinate battles for the poffeffion of fome favourite part of the park: Each party has its leader, which is always the oldeft and ftrongeft of the flock. They attack in regular order of battle; they fight with courage, and mutually fupport each other; they retire, they rally, and feldom give up after one defeat: The combat is frequently renewed for feveral days together; till, after many defeats, the weaker party is obliged to give way, and leave the conquerors in poffeffion of the object of their contention.

The Fallow-deer is eafily tamed, feeds upon a variety of things which the Stag refufes, and preferves its condition nearly the fame through the whole year, although its flefh is efteemed much finer at particular feafons.

They are capable of procreation in their fecond year; and, like the Stag, are fond of variety. The female goes with young eight months; and produces one, fometimes two, and rarely three, at a time. They arrive at perfection at the age of three years, and live till about twenty.

We have in England two varieties of the Fallow-deer, which are faid to be of foreign origin: The beautiful fpotted kind, fuppofed to have been brought from Bengal; and the deep-brown fort, now common in this country. Thefe laft were introduced by King James the Firft, out of Norway; where having obferved their har- 


\section{HISTORY OF QUADRUPEDS.}

dinefs in bearing the cold of that fevere climate, he brought fome of them into Scotland, and from thence tranfported them into his chafes of Enfield and Epping. Since that time they have multiplied exceedingly in many parts of this kingdom, which is now become famous for venifon of fuperior fatnefs and flavour to that of any other country in the world.

The Fallow-deer, with fome variation, is found in almoft every country of Europe. Thore of Spain are as large as Stags, but darker; their necks are alfo more flender; and their tails, which are longer than thofe of ours, are black above, and white beneath.

In Guiana (a country of South-America) according to Labat, there are Deer without horns, fmaller than thofe of Europe, but refembling them in every other particular. They are very lively, light, and exceflively timid; of a reddifh colour; with tharp, piercing eyes, and hort tails. When purfued, they fly into places of difficult accefs. The natives frequently ftand and watch for them in narrow paths; and, as foon as the game appears within reach, hoot them unperceived. Their fleh is confidered as a great delicacy.

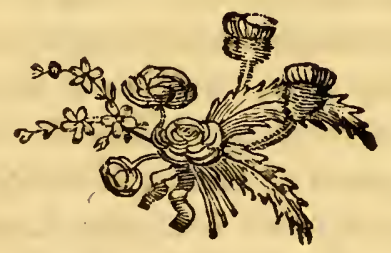

K 


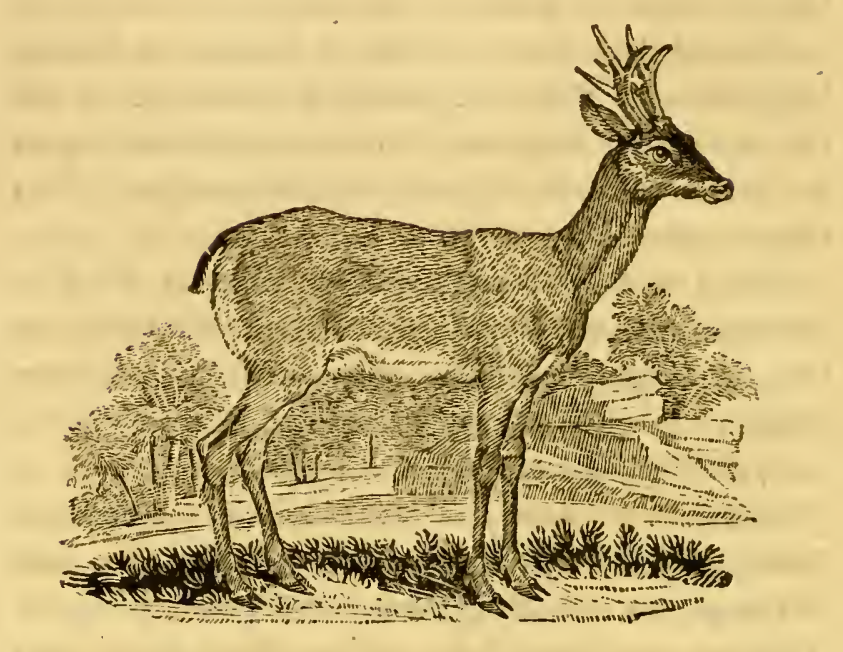

THE ROE-BUCK.

(Cervus Capreolus, Lin.-Le Chevreuil, Buff.)

THE Roe was formerly common in many parts of England and Wales; but at prefent it is only to be found in the Highlands of Scotland. It is the fmalleft of all the Deer kind, being only three feet four inches long, and fomewhat more than two feet in height: The horns are from eight to nine inclies long, upright, round, and divided into three braches; the body is covered with long hair; the lower part of each hair is afh colour; near the end is a narrow bar of black, and the point is yellow; the hairs on the face are black, tipped with afh colour; the ears are long, their infides of a pale-yellow, and covered with long hair; the cheft, belly, legs, and the in- 
fide of the thighis, are of a yellowifh-white; the rump is of a pure white, and the tail very fhort.

The form of the Roe-buck is elegant, and its motions light and eafy. It bounds feemingly without effort, and runs with great fwiftnefs. - When hunted, it endeavours to elude its purfuers by the moft fubtle artifices: It repeatedly returns upon its former, fteps, till, by various windings, it has entirely confounded the fcent. The cunning animal then, by a fudden fpring, bounds to one fide; and, lying clofe down upon its belly, permits the hounds to pafs by, without offering to ftir.

They do not keep together in herds, like other Deer, but live in feparate families. The fire, the dam, and the young ones, affociate together, and feldom mix with others.

Their rutting feafon continues but fifteen days, - from the latter end of October till about the middle of November. During this period, they will not fuffer the fawns to remain with them: The buck obliges them to retire, in order that the dam and her fucceeding progeny may remain undifturbed.

The female goes with young five months and a half, and brings forth about the end of April, or beginning of May. On thefe occafions, fhe feparates from the male, and conceals herfelf in the thickeft and moft retired part of the woods. She generally produces two fawns at a time, fometimes three. In ten or twelve days, thefe are able to follow their dam. When threatened with danger, the hides them in a thicket; and, to preferve them, offers herfelf to be chafed: But, notwithftanding her care, the is frequently robbed of her young. Numbers

K 2 
of fawns are found out and taken alive by the peafants; and many more are worried by dogs, foxes, and other carnivorous animals. By thefe continual depredations, this beautiful creature is daily becoming more fcarce; and, in many countrics, where it once was common, the race is now wholly extinct.

When about eight or nine months old, their horns begin to appear in the form of two knobs: The firf year they are without antlers. They thed their horns the latter end of autumn, and renew them in the winter; in which they differ from the Stag, whofe horns fall off in the fpring, and are renewed in fummer.

The life of the Roe-buck feldom exceeds twelve or fifteen years.

They are very delicate in the choice of their food, and require a large tract of country, fuited to the wildnefs of their nature, which can never be thoroughly fubdued. No arts can teach them to be familiar with their keeper, nor in any degree attached to him. They are eafily tcrrified; and, in their attempts to efcape, will run with fuch force againft the walls of their inclofure, as fometimes to difable themfelves: They are alfo fubject to capricious fits of fiercenefs; and, on thefe occafions,

- will ftrike furioufly with their horns and feet at the object of their diflike.

Some years ago, one of thefe animals, after being hunted out of Scotland, through Cumberland, and various. parts of the North of England, at laft took refuge in the woody receffes bordering upon the banks of the Tyne, between Prudhoe Caftle and Wylam. It was repeatedly feen and hunted, but no dogs were equal to its fpeed: It frequently croffed the river; and, either by fwiftnefs 
or artifice, eluded all its purfuers. It happened, during the rigour of a fevere winter, that, being purfued, it croffed the river upon the ice with fome difficulty; and, being much ftrained by its violent exertions, was taken alive. It was kept for fome weeks in the houfe, and was then again turned out; but all its cunning and activity were gone; it feemed to have forgotten the places of its former retreat; and, after running fome time, it laid down in the midft of a brook, where it was killed by the dogs.

- The flefh of the Roe-buck is fine and well-tafted: That of the male, after the age of two years, is hard; the flefh of the females, though farther advanced in years, is more tender: When very young, it is loofe and foft; but at the age of eighteen months, is in its higheft ftate of perfection.

In America, the Roe-buck is much more common than in Europe.-In Louifiana, it is very large. - The inhabitants live chiefly upon its flefh, which is good and well-flavoured.

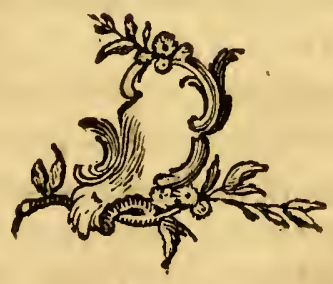

K. 3 


\section{I5० HISTORY OF QUADRUPEDS.}

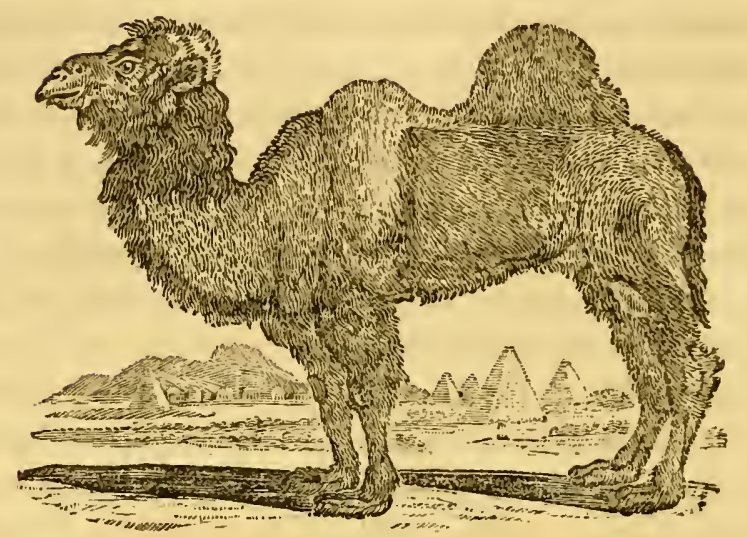

THE CAMEL,

(Camelus Bactrianus, Lin.-Le Chameau, Buff.)

Possusses the various qualities of the Horfe, the Cow, and the Sheep; and is to the Arabian, in a great meafure, what thofe ufeful creatures are to us. Its milk is rich and nourinling: and, being mixed with water, makes a wholefome and refrefhing beverage, much ufed by the Arabs in their journies: The fleth of young Camels is alfo an excellent and wholefome food. Their hair or fleece, which falls off entirely in the fpring, is fuperior to that of any other domeftic animal, and is made into very fine ftuff, for cloaths, coverings, tents, and other furniture,

Poffeffed of his Camel, the Arabian has nothing either to want or to fear: In one day, he can perform a journey of fifty leagues into the defert, where he is fafe from 


\section{HISTORY OF QUADRUPEDS.}

every enemy; for, without the aid of this ufeful animal, no perfon could purfue him amidft fandy defarts, where nothing prefents itfelf to the eye but one uniform roid, naked and folitary.

The Arabian regards the Camel as the mot precious gift of Heaven; by the affiftance of which he is enabled to fubfint in thofe frightful intervals of Nature, which ferve him for an afylum, and fecure his independence.

But it is not to the plundering Arab alone that the fervices of this ufeful quadruped are confined: In Turkey, Perfia, Barbary, and Egypt, every article of merchandife is carried by Camels. Merchants and travellers unite together, and form themfelves into numcrous bodies, called caravans, to prevent the infults of the Arabs. One of thefe caravans frequently confifts of many thoufands: the Camels are always more numerous than the men. Each Camel is loaded in proportion to his ftrength. At the command of their conductor, they lie down on their belly, with their legs folded under them, and in this pofture receive their burdens. As foon as they are loaded, they rife of their own accord, and will not fuffer any greater weight to be impofed upon them than they can bear with eafe; when overloaded, they fet up the molt piteous cries, till part of the burden be taken off. The common load of a Camel is from three to four hundred weight; and the medium of the expence of the conveyance for each hundred appears to be about one farthing per mile. The ufual rate of travelling is three miles in the, hour; and the number of hours that are actually employed on the route, exclufive of thofe allotted to refrefhment, is feldom more than feven or eight in a day. Of 


\section{2}

HISTORY OF QUADRUPEDS.

the number of days which are confumed in a long journey, many are devoted to the purpofes of occafional trade, recruiting the ftrength of the Camels, and procuring additional ftores of provifions and water.-A particular mode of eafy conveyance is provided for women and children, and for perfons oppreffed with infirmity or illnefs : Six or ight Camels are yoked together in a row; and a number of tent polcs are placed in parallel lines upon their backs: Thefe are covered with carpets; and bags of corn are fuperadded to bring the floor to a level, as well as to foften the harfhnefs of the Camel's movements : Other carpets are then fpread, and the travellers fit or lie down with the moft perfect eafe.-The general food of the Camels is fuch only as their nightly pafture affords; and is frequently confined to the hard and thorny thrubs of the defart, where a fullen kind of vegetation is created by the rains of the winter, and fuftained by the dew that defcends in copious abundance through all the remainder of the year.

But the peculiar and diftinguifhing characteriftic of the Camel is, its faculty of abfaining from water for a greater length of time than any other animal; for which Nature has made a wonderful provifion, in giving it, befides the four ftomachs which it has in common with other ruminating animals, a fifth bag, ferving as a refervoir for water, where it remains without corrupting or mixing with the other aliments. When the Camel is preffed with thirft, and has occafion for water to macerate its food while ruminating, it makes part of it pafs into its ftomach, by a fimple contraction of certain mufcles. By this fingular ftructure, it can take a prodigious quantity of water at one draught, and is enabled. to pafs 
feveral days without drinking; Leo Africanus fays fifteen.-Camels can difcover water by their fmell at half a league's diftance; and, after a long abftinence, will haften towards it, long before their drivers perceive where it lies.

The feet of the Camel are peculiarly adapted to the foil on which it treads. On moift or flippery ground he cannot well fupport himfelf; and his broad and tender feet are liable to be injured by the refiftance of ftones: But he is obferved to tread with perfect eafe and fecurity on the dry and yielding fand; and whilf, from its peculiar ftructure, his hoof is incapable of faftening with any degree of fecurity on the ground of a fteep afcent or flelving declivity, his movements on a fmooth and level furface are fingularly firm and fafe.

Many attempts have been made to introduce this ferviceable animal into other countries; but, as yet, none have fucceeded. The race feems to be confined to certain diftricts, where its utility has been known for ages.

Though a native of warm climates, the Camel dreads thofe which are exceffively hot: It can neither fubfift in the burning heat of the torrid zone, nor in the milder air of the temperate. It feems to be an original native of Arabia ; for, in that country, it is not only more numerous, but thrives better than in any other part of the world.

There are two varieties of this animal, which have been diftinguifhed previous to all hiftorical record: That which is called the Bactrian Camel has two hunches on its back, and is found chiefly in Turkey and the countries of the Lerant; whilf the Arabian Camel has only one hunch. 


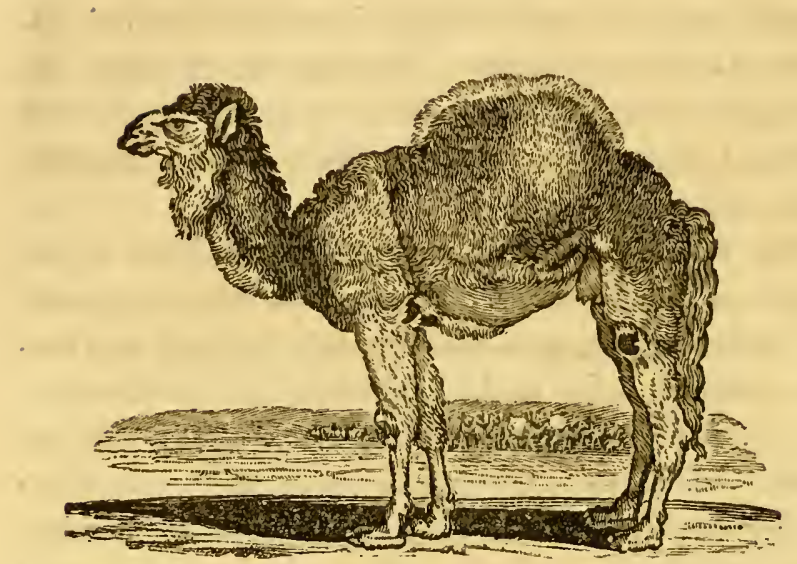

\section{THE ARABIAN CAMEL, OR DROMEDARY,}

(Camelus Dromedarius, Lin.-Le Dromedaire, Buff.)

Is common in Arabia and all the northern parts of Africa, from the Mediterranean Sea to the river Niger; and is infinitely more numerous, and more generally diffufed, than the Camel: It is alfo much fwifter, and is therefore chiefly employed on bufinefs which requires difpatch.

In Arabia, they are trained for running matches; and, in many places, for carrying couriers, who can go above a hundred miles a day on them, and that for nine or ten days together, over burning and uninhabitable defarts. They require neither whip nor fpur to quicken their pace, but go freely, if gently treated; and are much enlivened by finging or the found of the pipe, which gives them fpirits to purfue their journey.

They are mild and gentle at all times, except when they are in heat: At that period they are feized with a 
fort of madnefs; they eat little, and will fometimes attempt to bite their mafters; fo that it is not fafe to approach them.

The Camel arrives at its full ftrength at the age of fix years, and lives forty or fifty.

The females are not ufually put to labour, but are allowed to pafture and breed at full liberty. Their time of geftation is nearly twelve months; and they generally bring forth one at a birth.

\section{THE LAMA,}

(Camelus Glama, Lin.-Le Lama, Buff.)

Is the Camel of Peru and Chili; and, before the conqueft of thofe countries by the Spaniards, was the only beaft of burden known to the Indians. Its difpofition is mild, gentle, and tractable.

Before the introduction of Mules, thefe animals were ufed by the natives to plough the land, and now ferve to carry burdens. They march flowly, and feldom accomplifh journies of more than four or five leagues a day; but what they want in fpeed is made up by perfeverance and induftry. They travel long journies in countries impaffable to moft other animals; are very fure-footed; and are much employed in tranfporting the rich ores, dug out of the mines of Potofi, over the rugged hills and narrow paths of the Andes: Bolivar remarks, that, in his time, three hundred thoufand of them were conftantly employed in this work. They lie down to be loaded, 


\section{HISTORY OF QUADRUPEDS.}

and, when weary, no blows can excite them to quicken their pace. They neither defend themfelves with their feet' nor their teeth. When angry, they have no other method of revenging injuries, but by fpitting. They can throw out their faliva to the diftance of ten paces; and if it fall on the $\mathrm{fkin}$ it raifes an itching, accompanied with a light inflammation. Their flefh is eaten, and faid to be as good as mutton.

Like the Camel, they have the faculty of abftaining long from water (fometimes four or five days); and, like that animal, their food is coarfe and trifling. They are neither allowed corn nor hay; green herbage, of which they eat very moderately, is fufficient for their nourifhment.

The wild Lamas, called Guanacos, are ftronger and more active than the domeftic kind. They live in herds, and inhabit the higheft regions of the Cordelieres. They run with great fwiftnefs in places of difficult accefs, where dogs cannot ieafly follow them. The moft ufual way of killing them is with the gun. They are hunted for the fake of their flefh and their hair: Of the latter the Indians make cloth.

The Lama refembles the Camel in the form of its body, but is without the dorfal hunch: Its head is Imall and well thaped; its neck long, and very protuberant near its junction with the body: In its domeftic ftate, its hair is thort and fmooth; when wild, it is coarfe and long, of a yellowifh colour: A black line runs along the top of the back, from the head to the tail. The tame ones vary in colour: Some of them are white, others black, others of a mixed colour-white, gray, and ruffet, difperfed in fpots. Its tail is hort: Its ears are four 
inches long: Its feet are cloven, like thofe of the $\mathrm{Ox}$, and are armed behind with a fpur, by which the animal is enabled to fupport itfelf on rugged and difficult ground. The height of the Lama is about four feet; and its length, from the neck to the tail, fix feet.

\section{THE PACOS,}

(Camelus Pacos, Lin.-Le Paco, Buff.)

VERY much refembles the Lama in figure, but is much fmaller. Its body is covered with very fine long wool, of the colour of dried rofes, or a dull purple : the belly is white.-They live in vaft herds, and inhabit the moft elevated parts of the higheft mountains, where they endure the utmoft rigour of froft and fnow. They are exceedingly fwift; and fo timid, that it is very difficult to come near them.

The manner of taking them is fingular. The Indians tie cords, with fmall picces of wool or cloth hanging from them, acrofs the narrow pafles of the mountains, about three or four feet from the ground: They then drive a herd of thefe animals towards them, and they are fo terrified by the flutter of the rags, that they dare not pafs, but huddle together, and fuffer themfelves to be killed in great numbers.

Their wool is a valuable article of commerce, and is made into gloves, ftockings, bed-cloaths, carpets, \&c.

The Pacos is domefticated; and, like the Lama, is employed in carrying burdens, but cannot bear more 
than from fifty to feventy-five pounds; and is ftill more fubject to capricious fits of obftinacy. When once they lie down with their load, no blows can provoke them to rife.

The great advantages derived from the wool of thefe creatures, induced the Spaniards to attempt their introduction into Europe. Some of them were brought over to Spain ; but, by not fufficiently attending to the neceffity of placing them in fituations fimilar to thofe which they had always been accuftomed to, the experiment proved unfuccefsful.

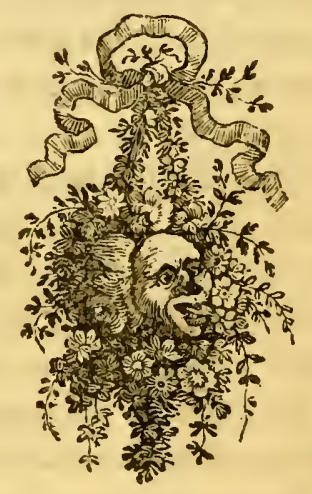




\section{THE HOG KIND.}

Animals of the Hog kind feem to poffers a middle nature, between thofe that live upon grafs and fuch as are carnivorous, and unite in themfelves moft of thofe diftinctions which are peculiar to each clafs. Like the one, they will feed on animal fubftances, and do not ruminate; like the other, they are cloven-hoofed, live chiefly on vegetables, and feldom feek after animal food, except when urged by neceffity.

The moft numerous breed of Hogs in this inland is that generally known by the name of the Berkflire Pigs, now fpread through almoft every part of England, and fome parts of Scotland. They are in yeneral of a reddifh-brown colour, with black fpots upon them; have large ears hanging over their eyes; are fhort-legged, fmall-boned, and are readily made fat. Some of thefe have been fed to almoft an incredible fize. Mr Culley, in his Treatife on Live Stock, gives an account of one that was killed at Congleton, in Chefhire, which meafured, from the nofe to the end of the tail, three yards eight inches; in height, it was four feet and a half; and weighed, after it was killed, eighty-fix ftones eleven pounds, avoirdupoife.

The Hog fpecies, though very numerous, and diffured over Europe, Afia, and Africa, did not exift in America, till tranfported thither by the Spaniards. In many places they have multiplied exceedingly, and become wild. They refemble the domeftic Hog; but their bodies are fhorter, and their fnout and Ikin thicker. 


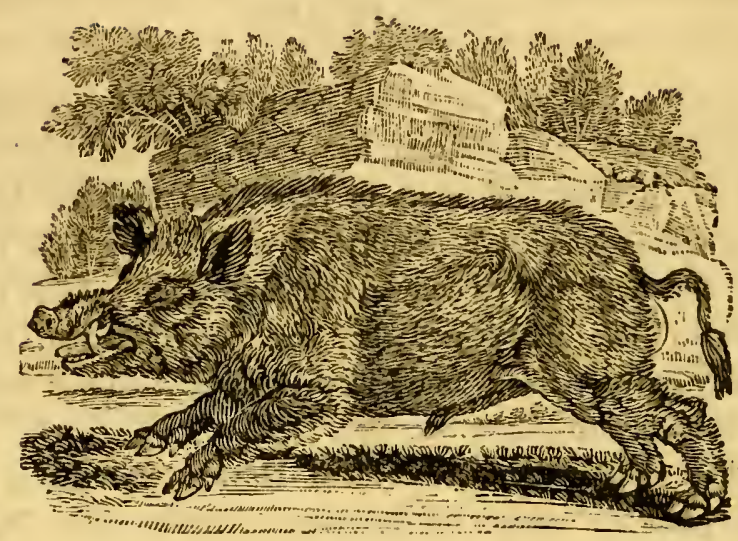

THE WILD-BOAR,

(Sus Aper, Lin.-Le Sanglier, Buff.)

WHICH is the original of all the varieties to be found in this creature, is much fmaller than thofe of the domeftic kind, and does not, like them, vary in colour, but is nniformly of a brinded or dark-gray, inclining to black.His fnout is longer than that of the tame Hog; and his ears are fhort, round, and black. He is armed with formidable turks in each jaw, which ferve him for the double purpofe of annoying his enemy, or procuring his food, which is chiefly roots and vegetables: Some of thefe turks are almoft a foot long: Thofe in the upper jaw bend upwards in a circular form, and are exceedingly fharp at the points; thofe of the under jaw are always moft to be dreaded, for with them the animal defends himfelf, and frequently gives mortal wounds. 
Wild Boars are not gregarious; but, while young, live together in families, and frequently unite their forces againft the wolves, or other beafts of prey. When likely to be attacked, they call to each other with a very loud and fierce note: The ftrongeft face the danger, and form themfelves into a ring, the weakeft falling into the center. In this pofition, few beafts dare venture to engage them, but leave them to purfue a lefs dangerous chafe. -When the Wild-Boar is arrived at a ftate of maturity, he walks the foreft alone and fearlefs. At that time he dreads no fingle foe; nor will he turn out of his way even for man himfelf. He offends no animal; at the fame time he is furnifhed with arms, which render him a terror to the fierceft.

The hunting of the Wild-Boar is a dangerous but common amufement of the great in thofe countries where it is to be found. The Dogs chiefly ufed for this fport are of a flow and heavy lind.-When the Boar is roufed, he goes flowly forward, not much afraid, nor very far before his purfuers. He frequently turns round, fops till the hounds come up, and offers to attack them: After keeping each other at bay for a while, the Boar again goes flowly forward, and the Dogs renew the pur fuit. In this manner the chafe is continued till the Boar becomes quite tired, and refufes to go any farther: The Dogs then attempt to clofe in upon him from behind; and in this attack the young ones, being generally the moft forward, frequently lofe their lives: The old feafoned Dogs keep the animal at bay until the hunters come un, who kill him with their fpears. 


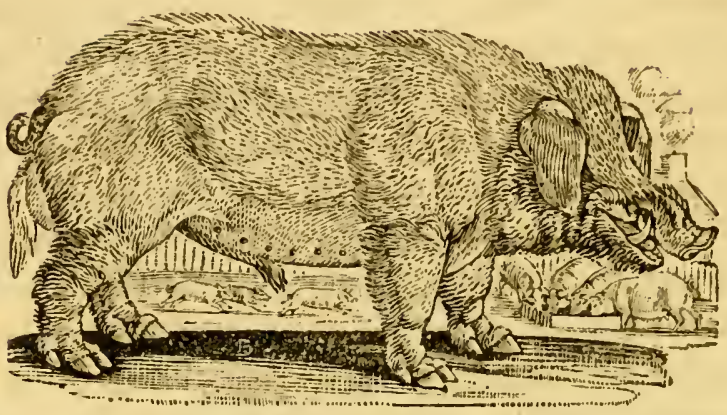

THE COMMON BOAR,

(Sus Scrofa, Lin._Le Cocbon, Buff.)

Is, of all other domeftic quadrupeds, the moft filthy and impure. Its form is clumfy and difgufting, and its appetite gluttonous and exceffive.-In no inftance has Nature more confpicuoufly fhewn her œconomy than in this race of animals, whofe ftomachs are fitted to receive nutriment from a variety of things that would be otherwife wafted: The refufe of the field, the garden, the barn, or the kitchen, affords them a luxuriant repaft.

Ufelefs during life, and only valuable when deprived of it, this animal has been fometimes compared to a mifer, whofe hoarded treafures are of little value till death has deprived them of their rapacious owner.

The parts of this animal are finely adapted to its mode of living. Nature has given it a form more prone than that of other animals. Its neck is ftrong and brawny; its frout is long and callous, well calculated for the purpofe of turning up the earth for roots of various kinds, 
of which it is extremely fond; and it has a quick fenfe of fmelling, by which it is enabled to trace out its food. It is naturally ftupid, inactive, and drowfy; much inclined to increafe in fat, which is difpofed in a different manner. from that of other animals, and forms a thick and regular coat between the flefh and the fkin. It is reftlefs at a change of weather; and, during certain high winds, is fo agitated, as to run violently, fcreaming horribly at the fame time. It appears to forefee the approach of bad weather, as it previoufly carries ftraw in its mouth to its fty, prepares a bed, and feems endeavouring to hide itfelf from the impending ftorm.

Linnæus obferves, that the flefh of the Hog is a wholefome food for thofe that ufe much exercife, but bad for fuch as lead a fedentary life. It is of univerfal ufe, and makes in various ways a conftant article in the elegancies of the table. It is of great importance to this country, as a commercial nation; for it takes falt better than any other kind, and confequently is capable of being preferved longer: It is therefore of great ufe in Ihips, and makes a principal part of the provifions of the Britifh navy.

The domeftic Sow generally brings forth twice a year, and produces from ten to twenty at a litter: She goes four months with young, and brings forth in the fifth. At that time the muft be carefully watched, to prevent her from devouring her young: Still greater attention is neceffary to keep off the male, as he would deftroy the whole litter. 


\section{HISTORY OF QUADRUPEDS.}

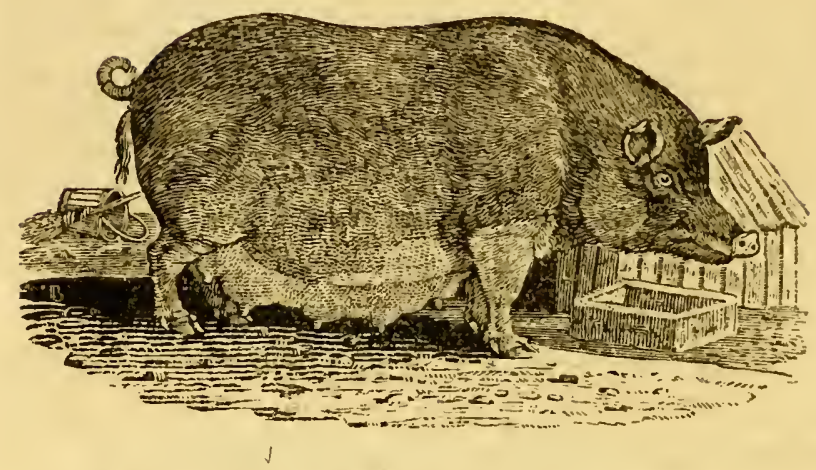

SOW OF THE IMPROVED BREED.

By a mixture of the Chinefe black Swine with others of the larger Britifh breed, a kind has been produced which poffeffes many qualities fuperior to either of the original ftocks. They are very prolific, are fooner made fat than the larger kind, upon lefs provifions, and cut up, when killed, to more ufeful and convenient portions.

Our figure was taken from a Sow of this kind in the poffeffion of Arthur Mowbray, Efq. of Sherburn, in the county of Durham. She lad a litter of nineteen pigs to fupport at the time, which was the third within ten months: The whole amounted, in that time, to fifty pigs.

The Chinefe or black breed are now very common in England. They are fmaller, have fhorter legs, and their flefl is whiter and fweeter than the common kind.

A kind fimilar to this were thofe found in New Guinea, which proved fo feafonable a relief to our circumnavigators, when that country was firft vifited by them. 
There are likewife great numbers of them in the Friendly and Society Ines, the Marquefas, and many other of the newly-difcovered iflands in the South Seas. Thefe are fed with plantains, bread-fruit, and yams, and are exceedingly fat. They are frequently fcen by the natives in their canoes, fwimming from one ifland to another, and killed by them with lances and arrows.

Another breed of Swine has lately been introduced into this kingdom, which is expected to rival or excel all the others: The original ftock was produced from a WildBoar brought from America, and a Sow of the improved Chinefe breed. The Sows are extremely prolific, and the colour of the pigs in general is moft fancifully diverfified; fome are Atriped longitudinally, with brown and black; others, brown and blue; and others, with black and white. The colour of the Boar was a rufty-brown.

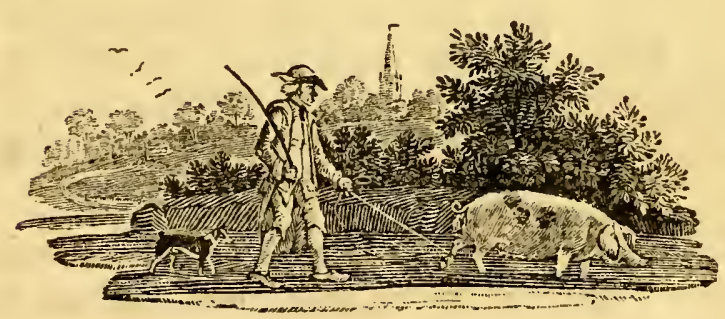




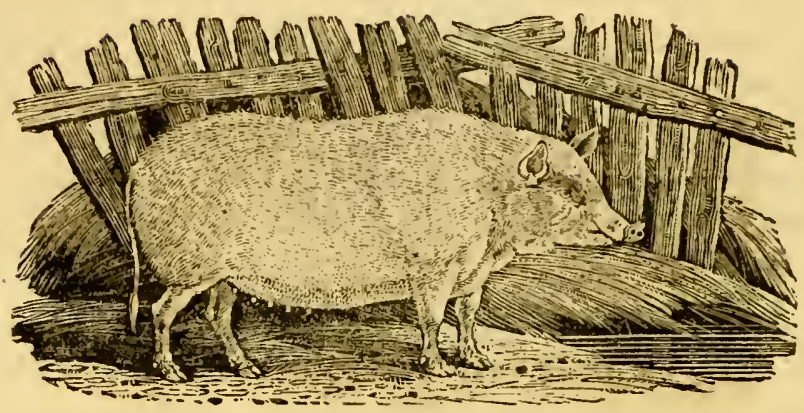

THE CHINESE KIND.

AN unceafing attention to improvement has produced or new-modelled the Chinefe breed in this country to what is deemed to be nearer perfection. The delicacy of appearance, the thin tranfparent ears, fmall head, fhort fmall legs, and even the colour of the hair, are all confidered as requifite qualities which ought to be attended to in this kind. They are feldom fed for the fame purpofes as the larger kinds of fwine, being accounted too fmall for being dried into bacon; but they are preferred as the beft and moft delicate for pork and roafting pigs.

Our figure was taken from one of this defcription in the poffeffion of Geo. Baker, Efq. of Elemore, in the county of Durham. 


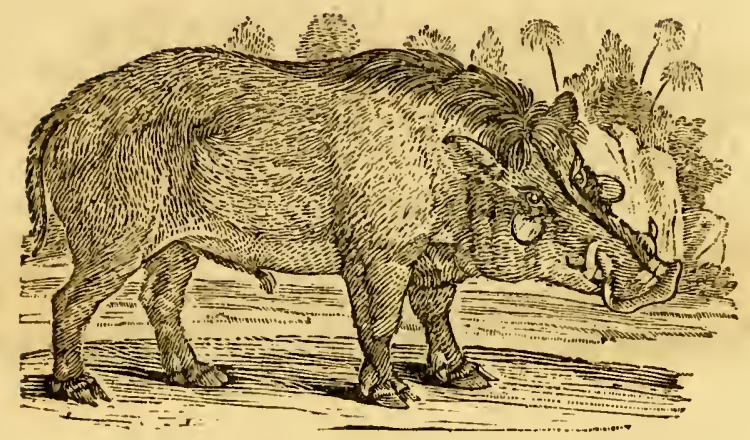

THE AFRICAN WILD-BOAR, OR WOOD. SWINE,

(Sus AEtbiopicus, Lin.-Sanglier du Cap Verd, Buff.)

LIVEs in a wild, uncultivated ftate, in the hotteft parts of Africa. It is a very vicious animal, and quick in all its motions. It is as dangerous to attack one of them, as a Lion: For, though much fmaller, it rufhes upon a man as fwift as an arrow; and throwing him down before he has time to ftrike with his javelin, breaks his legs, and almoft at the fame inftant rips up his belly.

It has four tufks: Two very large ones proceed from the upper jaw, and turn upwards like a horn; they are nine inches long, and full five inches round at the bafe; the two other tufks, which come from the lower jaw, project but three inches from the mouth. There tufks the animal makes ufe of as the dreadful inftruments of his vengeance. He will attack a man on horfeback, if 
he fhould venture to come too near him; and, firft breaking the Horfe's legs, kills both him and the rider.

Sparrman defcribes it as being of a bright-yellow colour, like the domeftic kind. Its nofe is broad, flat, and of a horny hardnefs; its liead is very large, in proportion to the fize of its body; underneath each eye it has a great lobe or wattle, lying almoft horizontally, broad, flat, rounded at the end, and placed fo as to intercept the view of any thing immediately beneath it; the ears are large and tharp-pointed, lined on the infide with long whitifh hairs; its tail is flender and flat, and when the animal is purfued it always holds it quite erect.

They live in holes under ground, the avenues to which are exceedingly narrow. The natives feldom dare attack them in their retreats, as there is always danger of their rufhing out unawares. When purfued with their young ones, it is no uncommon thing to fee them take them up in their mouths, and run with them in that manner at a great rate.

From the fhortnefs of their necks, they frequently fall on their knees to feed; and change this pofture to that of ftanding with the greateft eafe.

The flefh of this animal is good, and very much re. fembles that of the common Hog. 


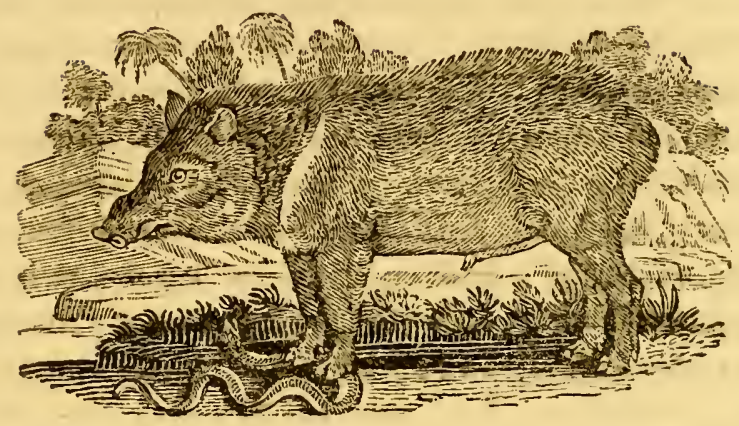

THE PECCARY, OR MEXICAN HOG, (Sus Tajaca, Lin.)

INHABITs the hotteft parts of South-America, where the fpecies is very numerous: Herds, confifting of two or three hundred, are fometimes to be feen together.-It is very fierce, and will fight ftoutly with beatts of prey, when attacked by them. The Jaguar, or American Leopard, is its mortal enemy, and frequently lofes its life in engaging a number of thefe animals. They aflift each other, furround their enemies, and often come off victorious.

They live chiefly in mountainous places, and are not fond of wallowing in the mire, like the common Hog. 'They feed on fruits, roots; and feeds: They likewife eat' ferpents, toads, and lizards; and are very dexterous in firft taking off the fkins with their fore feet and teeth.

The Peccary in appearance refembles the Hog, though fomewhat fmaller: Its body is covered with ftrong briftles, which, when the creature is irritated, rife up like 
the prickles of a Hedgehog, and are nearly as ftrong; they are of a dufky colour, with alternate rings of white; acrofs the shoulders to the breaft, there is a band of white; its head is flort and thick; it has two tufks in each jaw; its ears are fmall and erect; and inftead of a tail, it has a fmall flefhy protuberance, which does not cover its pofteriors. It differs moft effentially from the Hog, in having a fmall orifice on the lower part of the back, from whence a thin watery humour, of a moft difagreeable fmell, flows very copioufly. In the Philofophical Tranfactions, Dr Tyfon has defcribed this orifice very minutely, as well as fome other peculiarities in the conformation of its ftomach and inteftines.

Like the Hog, the Peccary is very prolific. The young ones, if taken at firf, are eafily tamed, and foon lofe all their natural ferocity; but can never be brought to difcover any figns of attachment to thofe that feed them. They do no mifchief, and may be allowed to run about at pleafure: They feldom itray far from home, and return of their own accord. When angry, they grunt like the Hog, but much ftronger and harher; and when fuddenly alarmed, make a fharp noife with their breath, and ereet their brifles.

The flefh of the Peccary, though drier and leaner than that of our Hog, is by no means difagreeable, and may be greatly improved by caftration. When killed, the dorfal gland muft be immediately cut off. If this operation be deferred for the fpace of half an hour, the flefh becomes utterly unfit to be eaten.

Aithough the European Hog is common in America, and in many parts has become wild, the Peccary has never been known to breed with it. They frequently ga 
together, and feed in the fame woods; but hitherto no intermediate breed has been known to arife from their intercourfe.

M. de la Borde defcribes two kinds of this animal,one fmaller than the other.-He relates, that being one day engaged with fome others in hunting a drove of Peccaries, they were furrounded by them, and obliged to take refuge upon a piece of rock; and, notwithftanding they kept up a confant fire among them, the creatures did not retire till a great number of them were flain.

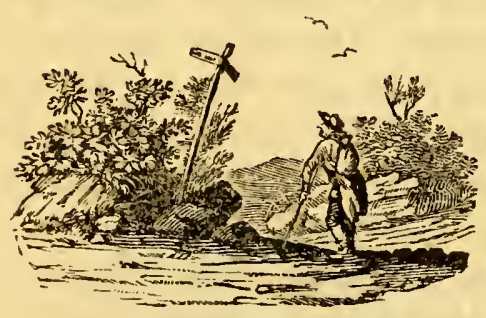




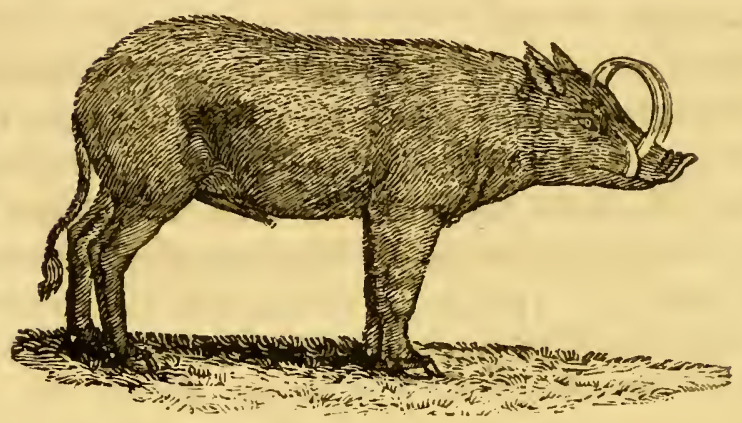

THE BABIROUSSA,

(Sus Babyrouffa, Lin._Le Babiroufa, Buff.)

THougr claffed by naturalifts with the Hog kind, differs from animals of that fpecies in a variety of particulars: Its legs are longer, and its body more flender; it is covered with thort hair as foft as wool, and of a dark-gray colour, mixed with red; its ears are fhort and pointed; its tail is long, tufted at the end, and twifted. Its moft diftinguifhing characteriftic confifts in fotr large tufks, the two ftouteft of which proceed, like thofe of the WildBoar, from the under jaw, pointing upwards, and ftanding near eight inches out of the fockets; the two others rife up like horns on the outfide of the upper jaw, juft above the nofe, and extend in a curve above the eyes, almoft touching the forehead, and are twelve inches in length. Thefe tufks are of the moft beautiful ivory, but not fo hard as thofe of the Elephant.

The Babirouffa abounds in feveral of the iflands of the 
Eaft-Indies, particularly Buero, a fmall ifle near Amboyna.

It is eafily tamed; and its flefh is well tafted. It lives on leaves of trees and other vegetables. Its fcent is exquifite: It can difcover the approach of Dogs at a diftance. When clofely purfued, it plunges into the fea, fwims and dives with great facility from one ifland to another, and by that means frequently efcapes from its purfuers.

They live in herds; and, when any number of them are together, their odour is fo ftrong, that the dogs can fcent them at a confiderable diftance. When attacked, they growl frightfully, and defend themfelves with their under tufks: The upper ones are ferviceable to them in taking their repofe, by hooking them on the branches of trees.

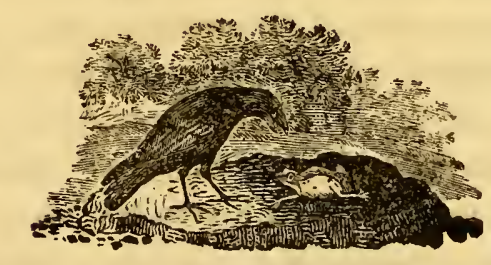




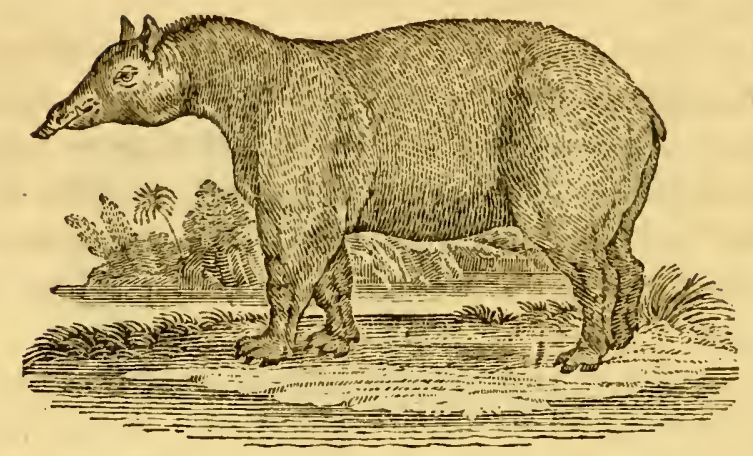

THE LONG-NOSED TAPIIR,

(Hippopotamus Terrefris, Lin.-Le Tapir, Buff.)

Is the Hippopotamus of the new world, and has by fome authors been miftaken for that animal. It inhabits the woods and rivers on the eaftern fide of South-America, from the ifthmus of Darien to the river of the Amazons. - It is a folitary animal, fleeps during the day, and goes out in the night in fearch of food; lives on grafs, fugar-canes, and fruits. If difturbed, it takes to the water, fwims with great eafe, or plunges to the bottom; and, like the Hippopotamus, walks there as on dry ground.

It is about the fize of a fmall Cow: Its nofe is long and flender, and extends far beyond the lower jaw, forming a kind of probofcis, which it can contract or extend at pleafure; each jaw is furnifhed with ten cutting teeth, and as many grinders; its ears are fmall and erect; its body formed like that of a Hog; its back arched; legs hort; and hoofs, of which it has four upon each foot, 
fmall, black, and hollow; its tail is very fmall; its hair Ihort, and of a dufky-brown colour.

The Tapiir is mild and inoffenfive, avoids all hoftilities with other animals, and flies from every appearance of danger. Its $\mathrm{kin}$, of which the Indians make bucklers, is very thick; and, when dried, is fo hard as to refift the impreffion of an arrow. The natives eat its flefh, which is faid to be very goõd.

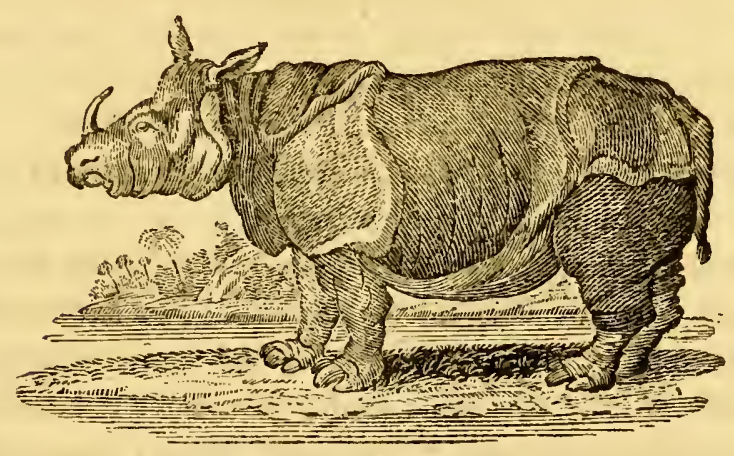

THE RHINOCEROS.

(Rbinoceros Unicornis, Lin.-Rbinoceros, Buff.)

WE are indebted to the labours of many learned and ingenious naturalifts for accurate defcriptions of this wonderful creature, which in fize is only exceeded by the Elephant, and in ftrength and power is inferior to no other animal. Bontius fays, that in the bulk of its body it equals the Elephant, but is lower only on account of the fhortnefs of its legs. 
The length of the Rhinoceros, from the extremity of the muzzle to the infertion of the tail, is ufually twelve feet; and the circumference of its body nearly equal to its length. Its nofe is armed with a formidable weapon, peculiar to this creature, being a very hard and folid horn, with which it defends itfelf from every adverfary. The Tiger will rather attack the Elephant, whofe trunk it can lay hold of, than the Rhinoceros, which it cannot face, without danger of having its bowels torn out.

The body and limbs of the Rhinoceros are covered with a fkin fo hard and impenetrable, that he fears neither the claws of the Tiger, nor the more formidable probofcis of the Elephant: It will turn the edge of a fcimitar, and even refint the force of a mufket-ball. The fkin, which is of a blackifh colour, forms itfelf into large folds at the neck, the fhoulders, and the crupper, by which the motion of the head and limbs is facilitated; round the neck, which is very fhort, are two large folds; there is alfo a fold from the fhoulders, which hangs down upon the fore legs; and another from the hind part of the back to the thighs. The body is every where covered with fmall tuberofities or knots, which are fmall on the neck and back, but larger on the fides: The thighs, legs, and even the feet, are full of thefe incruftations, which have been miftaken for fcales by fome authors: They are, however, only fimple indurations of the fkin, without any uniformity in their figure, or regularity in their pofition. Between the folds, the $\mathrm{fkin}$ is penetrable and delicate, as foft to the touch as filk, and of a light flefh colour: The fkin of the belly is nearly of the fame colour and confiftency. 
The body of the Rhinoceros is long and thick: Its belly is large, and hangs near the ground; its legs thort, round, and very ftrong; and its hoofs are divided into three parts, each pointing forward. The head of this animal is large; its ears long and erect; and its eyes fmall, funk, and without vivacity: The upper lip is long, overhangs the lower, and is capable of great extenfion: It is fo pliable, that the Rlinoceros can move it from fide to fide, twift it round a ftick, collect its food, or feize with it any thing it would carry to its mouth.

The Rhinoceros, without being ferocious, carnivorous, or even extremely wild, is, however, totally untractable and rude. It feems to be fubject to paroxyfms of fury, which nothing can appeafe. 'That which Emanucl, king of Portugal, fent to the pope in the year 1513 , deftroyed the veffel in which they were tranfporting it.

Like the Hog, the Rhinoceros is fond of wallowing in the mire.-It is a folitary animal, loves moint and marthy grounds, and feldom quits the banks of rivers.-It is found in Bengal, Siam, China, and other countries of . Afia; in the ifles of Java, Sumatra, Ceylon, \&c; in Ethiopia, and the country as low as the Cape of Good Hope: But, in general, the fpecies is not numerous, and is much lefs diffufed than that of the Elephant.

The female produces but one at a time, and at confiderable intervals.-During the firf month, the young Rhinoceros exceeds not the fize of a large dog. At the age of two years, the horn is not more than an inch long; at fix years old, it is nine or ten inches long; and grows to the length of three feet and a half, and fometimes four feet. The horn is much efteemed by the na- 
tives as an antidote againft poifon, as well as a remedy for particular difeafes.

The Rhinoceros feeds on the groffeft herbs, and prefers thiftles and Ahrubs to foft or delicate pafturage. It is fond of the fugar-cane, and eats all kinds of grain.

Dr Parfons remarks, that this animal has an acute and very attentive ear. It will liften, with a deep and longcontinued attention, to any kind of noife; and, though it be eating, lying down, or obeying any preffing demands of Nature, it will raife its head, and liften till the noife ceafe.

From the peculiar conftruction of his eyes, the Rhinoceros can only fee what is immediately before him. Whien he purfues any object, he proceeds always in a direct line, overturning every obftruction. With the horn on his nofe, he tears up trees, raifes ftones, and throws them behind him to a confiderable diftance. His fenfe of fmelling is fo exquifite, that the hunters are obliged to avoid being to windward of him. They follow him at a diftance, and watch till he lies down to fleep: They then approach with great precaution, and difcharge their mufkets all at once into the lower part of the belly.

The Rhinoceros is fuppofed to be the Unicorn of holy writ, and poffeffes all the properties afcribed to that animal,-rage, untameablenefs, great fwiftnefs, and immenfe ftrength. - It was known to the Romans in very early times, and is handed down to us in fome of the works of that celebrated people. Auguftus introduced one into the fhews, on his triumph over Cleopatra.

Its flefh is eaten and much relifhed by the natives of India and Africa. 


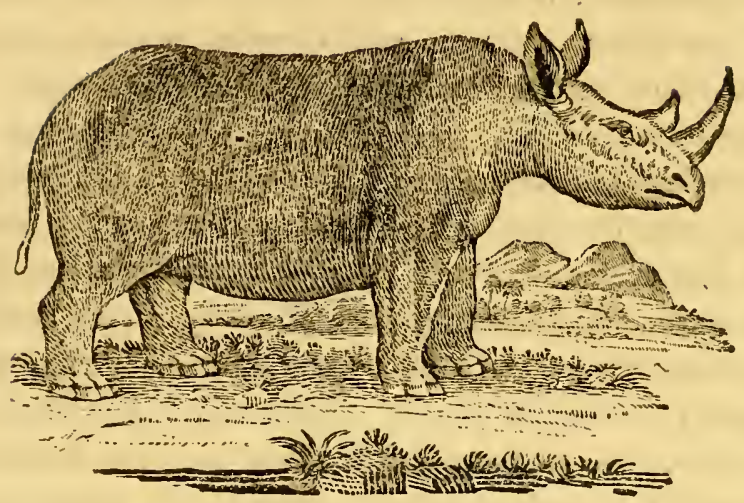

THE TWO-HORNED RHINOCEROS.

(Rbinoceros Bicornis, Lin.)

WE have given the figure of this hitherto undefcribed animal from Mr Sparrman, whofe authenticity there is every reafon to depend upon, and who has given a moft. exact anatomical defcription of it. Of two that were fhot, he only mentions the fize of the fmaller of them; which was eleven feet and a half long, feven feet high, and twelve in circumference. Its fkin was without any folds, and of an an colour; excepting about the groin, where it was fiefh-coloured: The furface was fcabrous and knotty, of a clofe texture, and, when dry, extremely hard. There were no hairs on any part of the body, except the edges of the ears and the tip of the tail, on which were a few dark briftly hairs, about an inch long. 
The horns are placed one behind the other, in a line with the nofe: The foremoft of them meafures about eighteen inches in length, and is always the larger of the two. They are of a conical hape, and the tips incline a little backward; the lower parts are rough, and feem as if compofed of thorny fibres; the upper parts are fmooth and plain, like thofe of an Ox. It is remarkable, that the Rhinoceros makes ufe of the fhorter horn only for the purpofe of digging up roots, of which its food chiefly confifts, being endued with the power of turning the larger horn on one fide out of the way.-The feet are round, and do not fpread much; there are three hoofs on each of them, which project but little; the middle one is the longeft.

The eyes of this animal are fmall, and funk into its head; in confequence of which it fees indiftinctly. But its organs of hearing and fmelling are very acute: At the leat noife, the creature takes the alarm, pricks up its ears, and liftens with great attention: If it happen to catch the fcent of any perfon within a fmall diftance, it rufhes out with aftonifhing rapidity; and it is difficult to avoid the impetuous attack of this powerful animal.

It has been generally faid of the Rhinoceros, that its tongue is fo hard and rough, as to take away the $\mathrm{fkin}$ and flefh wherever it licks any perfon that has unfortunately fallen a victim to its fury. Mr Sparrman fays, however, that he thruft his hand into the mouth of one that had juft been fhot, and found the tongue perfectly foft and fmooth.-From the account of its inteftines, given us by the fame ingenious author, we fhall juft mention the following, which will enable our readers to form a more perfect idea of its enormous bulk:-The ftomach was 
four feet in length, and two in diameter; to which was annexed a tube or canal, twenty-eight feet long, and fix inches diameter; the kidnies were a foot and a half in breadth; the heart was a foot and a half long, and nearly the fame in breadth; the liver, when meafured from right to left, was found to be three feet and a half in breadth, and two fect and a half deep, as it hangs in the animal's body when in a ftanding pofition: It had no gall-bladder, in which it refembles the Horfe. Upon opening the ftomach, the contents of it were found to confift of roots and fmall branches of trees mafticated, fome of which were as big as the end of a man's finger; in the mafs there appeared a great quantity of fucculent plants, as well as fome that were harfh and prickly: The effluvium arifing from this mafs was fo far from being offenfive, that it diffufed around a very ftrong and not difagreeable aromatic odour. We fhall conclude this account by obferving, that the cavity which contained the brains was fmall, being only fix inches long, and four high, and of an oval thape: Being filled with peafe, it was found to contain barely one quart; a human fkull, meafured at the fame time, did not require much lefs than three pints to fill it.

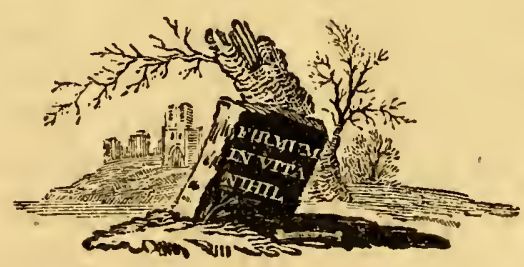




\section{HISTORY OF QUADRUPEDS.}

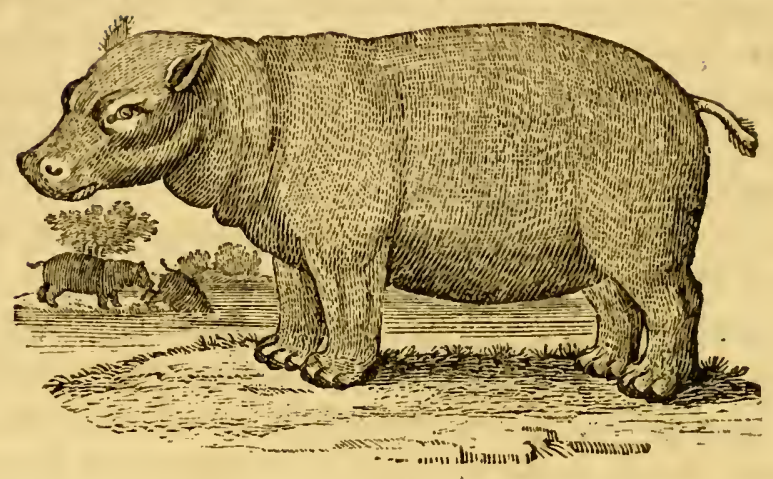

THE HIPPOPOTAMUS.

(Hippopotamus Amphibius, Lin.-L'Hippopotame, Buff.)

THE great difficulties that have always attended a complete invertigation of this huge animal, have arifen as well from the remotenefs of its fituation, as from its peculiar habits and difpofition.

Though the Hippopotamus has been celebrated from the remoteft antiquity; though the facred writings mention him under the name of Behemoth; and though his figure is to be feen engraven on Egyptian obelifks and on Roman medals, yet his hiftory was very imperfectly known to the ancients. Ariftotle fays, that he has a mane like a Horfe, and hoofs like an Ox ; tufks and tail like a Boar; that he is of the fize of an Afs, and has the voice of a Horfe; with other things equally abfurd;all which Pliny has copied; and, infead of correcting, has added to the number of his errors.-Of the accounts of later writers, it is much to be lamented that fuitable 
delineations have not accompanied their accurate defcriptions,-a general defect, by which the ftudy of nature has been much retarded, the laborious refearches of many learned and ingenious naturalifts greatly fruftrated, and the errors, of former times repeatedly copied, and multiplied without number.

The fize of the Hippopotamus is nearly equal to that of the Elephant. M. Vaillant fays, that one which he killed, meafured, from the tip of the nofe to the infertion of the tail, ten feet feven inches, and was eight feet eleven inches in circumference; but, from the fmallnefs of its tufks, he fuppofed it to be a young one. In its ftomach were found leaves and reeds, grofsly chewed; likewife fmall branches of trees, a little bruifed.

It inhabits all the larger rivers of Africa, from the $\mathrm{Ni}$ ger to the Cape of Good Hope; but is found in none of the African rivers that run into the Mediterranean, except the Nile, and in that part of it only which runs through the Upper Egypt, and in the fens and lakes of Ethiopia.

The head of this animal is enormoufly large; its mouth vaftly wide./ Ray fays, that the upper mandible is moveable, like that of a Crocodile. In each jaw there are four cutting teeth; thofe in the lower jaw point ftraight forward: It has four large tuks; the largeft, which are always in the lower jaw, are fometimes above two feet long: It is faid that the canine teeth are fo hard, as to emit fire on being ftruck with fteel ; they are perfectly white, and preferable to ivory for making artificial teeth: The grinders are fquare or oblong, like thofe of a man; and fo large, that a fingle tooth weighs 
above three pounds: The fkin is of a dufky colour, bears a refemblance to that of the Rhinoceros, but is thicker, and is made into whips: The tail is ncarly a foot long, taper, and flatted at the end, which is thinly furnifhed with hairs like briftles: Its legs are fo fhort, that its belly almoft touches the ground: The hoofs are divided into four parts, unconnected by membranes.

When alarmed or purfued, it takes to the water, plunges in, and finks to the bottom; where it walks at full eafe. It often rifes to the furface, and remains with its head out of the watcr, making a bellowing noife, which may be heard at a great diftance.-It feeds during night on the banks of the rivers, and fometimes does great damage in the adjacent plantations of rice and other grain.

The Hippopotamus is naturally mild and gentle, very flow, and heavy in its movements upon land, but in the water bold and active; and, when provoked or wounded, will rife, and attack boats or canoes with great fury. Dampier fays, he has known one of thefe animals fink a boat full of people, by biting a hole in the bottom with its tuks. - The method of taking it is by digging pits in the fand, in thofe parts through which the animal paffes in its way to the river after it has been feeding.

The flefh of the Hippopotamus is tender and good: The fat is fine and well-tafted, and much in requeft with the colonifts at the Cape, who look upon it as the moft wholefome meat that can be eaten: The gelatinous part of the fect in particular is accounted a great delicacy: 'The tongue, when dried, is alfo confidered at the Cape as a rare and excellent difh. 
Sparrman has given an engraving of this animal, taken from a young one which he caught at the Cape, from which ours is copicd._. The female brings forth one young at a time.

Scaurus treated the Romans with one of thefe cream tures, and five crocodiles, during his adilethip, and exhibited them on a temporary lalee.

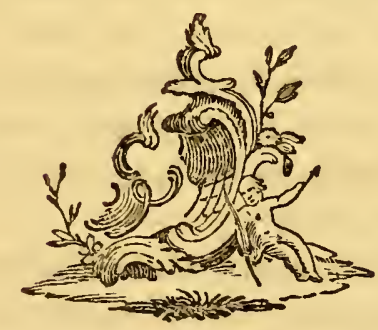




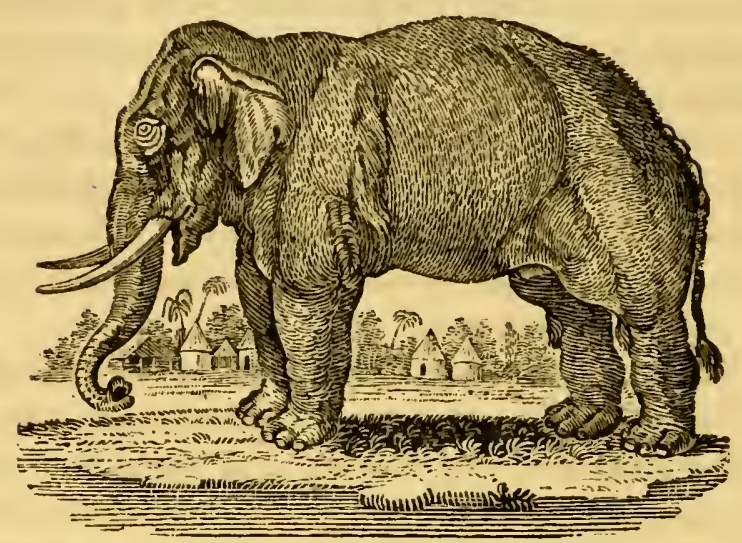

- THE ELEPHANT.

(Elephas Maximus, Lin.-L'Elephant, Buff.)

OF all the creatures that have hitherto been taken into the fervice of man, the Elephant is pre-eminent in the fize and ftrength of his body, and inferior to none in fagacity and obedience.

From time immemorial this animal has been employed either for the purpofes of labour, of war, or of oftentatious parade; to increafe the grandeur of eaftern princes, extend their power, or enlarge their dominions.

The Elephant is a native of Afia and Africa, and is not to be found in its natural ftate either in Europe or America. From the river Senegal to the Cape of Good Hope, they are met with in great numbers. In this extenfive region, as they are more numerous than in any other part of the world, fo are they lefs fearful of man. 
The favage inhabitants of this dreary country, inflead of attempting to fubduc this powerful animal, and render it fubfervient to their neceflities, feem defirous only of avoiding its fury.

Sparrman fays, that in the country near the Cape they are fometimes feen in large herds, confifting of many hundreds; and thinks it probable, that, in the more remote and unfrequented parts of that vaft country, they are ftill more numerous.

They are frequently hunted by the colonifts at the Cape; who are very expert in fhooting them, and make great advantage of their teeth. The largeft teeth weigh an hundred and fifty Dutch pounds, and are fold to the governor for as many guilders; fo that a man may earn three hundred guilders at one hot. It is not therefore to be wondered at, that a traffic fo lucrative fhould tempt the hunter to run great rifks. In approaching this animal, great care muft be taken to fteal upon him unperceived. If the Elephant difcovers his enemy near, he rufhes out, and endeavours to kill him. One of thefe hunters being out upon a plain, under the fhelter of a few fcattered thorn trees, thought he could be able to advance near enough to thoot an Elephant that was at a little diftance from him; but he was difcovered, purfued, and overtaken by the animal, which laid hold of him with his trunk, and beat him inftantly to deatl.

The height of the Elephant at the Cape is from twelve to fifteen feet. The female is lefs than the male, and her tufks do not grow to fuch a fize.

In proportion to the fize of the Elephant, his eyes are very fmall; but they are lively, brilliant, and capable of great expreflion. He turns them flowly, and with gen- 
tlenefs, towards his mafter. When he fpeaks, the animal regards him with an eye of mildnefs and attention. - His ears are very large, and much longer, in proportion to his body, than thofe of the Afs: They lie flat on the head, and are commonly pendulous; but he can raife and move them with great facility, and frequently ufes them as a fan to cool himfelf, or defend his eyes from duft and infects. His hearing is likewife remarkably fine; for he delights in the found of mufical inftruments, and moves in cadence to the trumpet and tabor.-There are four grinders in each jaw, clofely united together; forming, with the jaw-bone, one hard and compact body. One of thefe grinders fometimes meafures nine inches broad, and weighs four pounds and a half. The texture of the fkin is uneven, wrinkled, and knotty; full of deep fiffures, nearly refembling the bark of an old oak tree, which run in all directions over its furface. It is of a tawny colour, inclining to citron. In the fiffures there are fome briftly hairs, which are alfo thinly fcattered over the body. The legs refemble maffy columns, of fifteen or eighteen inches diameter, and from five to fix feet high. The foot is fhort, and divided into five toes, covered with the fkin, fo as not to be vifible. To each toe there is affixed a nail or hoof, of a horny fubftance.

The moft remarkable feature of the Elephant is his trunk or probofis, which is compofed of membranes, nerves, and mufcles. It is both an organ of feeling and of motion. The animal can not only move and bend it, but can contract, lengthen, and turn it in every direction. 'The extremity of the trunk terminates in a protuberance, which fretches out on the upper fide in the form of a finger, and poffeffes in a great degree the nicenefs and 


\section{HISTORY OF QUADRUPEDS.}

dexterity of that ufeful member. It is equally flexible, and as capable of laying hold of objects as the fingers of a man. He lifts from the ground the fmalleft piece of money; he felccts herbs and flowers, and picks them up one by one; he untics the knots of ropes, opens and huts gates, \&c. With his trunk he grafps any body which it is applied to, fo firmly, that no force can tear it from his gripe.

Of all the inftruments which Nature has fo liberally beftowed on her moft favourite productions, the trunk of the Elephant is perhaps the moft complete and admirable. Ray fays, it is divided into three partitions or chambers, two of which run in fpiral directions, and the other in a right line. It is eight feet long in an Elephant of fourteen feet high, and five feet in circumference at the thickeft part. The noftrils are fituated at the extremity, through which it draws in water by a ftrong fuction, either for the purpofe of quenching its thirft, or of wahhing and cooling itfelf, which it frequently does, by taking up a large quantity, part of which it carries to its mouth, and drinks; and by elevating the trunk, allows the remainder to run over every part of its body.

Roots, herbs, leaves, and tender wood, are the ordinary food of the Elephant. He does not ruminate, and has but one ftomach: This want, however, is amply fupplied by the magnitude and length of his inteftines, and particularly of the colon, which is from fifteen to twenty feet in length, and two or three in diameter. When one of them difcovers a plentiful pafture, he calls to the others, and invites them to partake. As they require a great quantity of forage, they frequently change their 
pafture, and do incredible damage whenever they happen to ftray into cultivated ground. From the weight of their bodies and the fize of their feet, they deftroy much more than they ufe for food. The Indians and negroes ufe every artifice to prevent the approach of thefe unwelcome vifitants, by making loud noifes, and kindling fires round their habitations ; but in fpite of all their precautions, the Eleplants often break thirongh their fences, deftroy their whole harveft, and overturn their huts. It is not eafy to feparate them: They generally act in concert, whether they attack, march, or fly.

The ordinary walk of the Elephant is not quicker than that of a Horfe; but when prined, he affumes a kind of ambling pace, which in fleetnefs is equal to a gallop. He goes forward with eafe and celerity; but it is with great difficulty that he turns himfelf round; and that not without taking a pretty large circuit. It is generally in narrow and hollow piaces that the negroes attack him, and cut off his tail, which they value above every other part of his body. He fwims well, and is of great ufe in carrying great quantities of baggage over large rivers. When fivinming, he raifes his long trunk above the furface of the water for the fake of refpiration, every other part of his body being below: In this mamner feveral of thefe animals fwim together, and fteer their courfe without danger of runining foul of each other.

The Elephant, when tamed, is gentle, obedient, and docile: Patient of labour, he fubmits to the moft toilfome drudgery; and fo attentive to the commands of his governor, that a word or a look is fufficient to ftimulate him to the moft violent exertions. Mis attachment to his keeper is fo great, that he carefles him with his trunk, 
and frequently will obey no other mafter: He knows his voice, and can diftinguifh the tone of command, of anger, or of approbation; and regulates his actions accordingly: He receives his orders with attention, and executes them with eagernefs, but without precipitation. All his motions are orderly, and feem to correfpond with the dignity of his appearance, being grave, majeftic, and cautious. He kneels down for the accommodation of thofe who would mount upon his back, and with his pliant trunk even affifts them to afcend. He fuffers himfelf to be harneffed, and feems to have a pleafure in the finery of his trappings. He is ufed in drawing chariots, waggons, and various kinds of machines. One of them will perform with eafe the work of many horfes.

The conductor of the Elephant is ufually mounted on its neck, and makes ufe of a rod of iron, fharp at the end, and hooked; with which he urges the animal forward, by pricking its head, ears, or muzzle: But in general, a word from the keeper is fufficient to encourage this intelligent creature to proceed on its way, or perform the tafk affigned to it.-In India, where they were once employed in launching fhips, one of them was directed to force a large veffel into the water, which proving fuperior to his ftrength, the mafter, in an angry tone, cried out ' Take away that lazy beaft' and bring another in its place.' The poor animal inftantly redoubled its efforts, fractured its $\mathrm{fkull}$, and died upon the fpot.

The Indians, from very early periods, have employed Elephants in their wars: Porus oppofed the paffage of Alexander over the Hydafpes with eighty-five of them. M. de Buffon imagines, that it was fome of the Elephants taken by that monarch, and afterwards tranfport- 
ed into Greece, which were employed by Pyrrhus againft the Romans. - Since the invention of fire-arms, the Eleplant has been of little ufe in deciding the contefts of hoftile nations; for, being terrified with the flath of the powder, and the report that immediately fucceeds, they are foon thrown into confufion, and then become dangerous to their employers.- They are now chiefly ufed for the purpofes of labour, or magnificent parade.

The Indian princes, in their travels, are attended by hundreds of thefe animals: Some are employed to convey the ladies which compofe the feraglio, in latticed cages made for that purpofe, and covered with branches of trees; whilft others tranfport immenfe quantities of baggage, with which the fovereigns of the Eaft are always accompanied in their marches from one place to another. They are likewife made ufe of as the dreadful inftruments of executing condemned criminals-a tafk which they perform with great dexterity. At the word of command, they break the limbs of the criminal with their trunks; they fometimes trample him to death, or impale him on their enormous tufks, juft as they are directed by their more barbarous keeper.

It is a fingular circumftance in the hiftory of this extraordinary animal, that, in a ftate of fubjection, it is unalterably barren; and, though it has been reduced under the dominion of man for ages, it has, never been known to breed, as if it had a proper fenfe of its degraded condition, and obftinately refufed to increafe the pride and power of its conquerors by propagating a race of flaves. It therefore follows, that of all the numerous bands of Elephants that are trained to fervice, there is not one that has not been originally wild, nor one that 
lias not been forced into a fate of fubjection. To recruit, therefore, the numbers that are unavoidably confumed by difeafe, accident, or age, the eaftern princes are obliged every year to fend into the forefts, and ufe various methods to procure frefh fupplies.

The manner of taking, taming, and rendering thefe animals fubmiffive, is curious, and well deferves a place in the hiftory of the Elephant. In the midft of a foreft abounding with Elephants, a large piece of ground is marked out, and furrounded with ftrong palifades, interwoven with branches of trees: One end of the inclofure is narrow; from which it widens gradually, fo as to take in a great extent of country. Several thoufand men are employed upon the occafion, who place themfelves in fuch a manner as to prevent the wild Elephants from making their efcape: They kindle large fires at certain diftances, and make a dreadful noife with drums and various kinds of difcordant inftruments, calculated for the purpofe of ftunning and terrifying the poor animals; whilf another party, confifting of fome thoufands, with the affiftance of tame female Elephants trained for the purpofe, drive the wild Elephants flowly towards the great opening of the inclofure, the whole train of hunters clofing in after them, fhouting, and making a great noife, till they are driven by infenfible degrees into the narrow part of the inclofure, through which there is an opening into a fmaller fpace, ftrongly fenced in, and guarded on all fides. As foon as one of the Elephants enters this ftrait, a ftrong bar clofes the paffage from behind, and he finds himfelf completely environed. On the top of this narrow paffage fome of the huntfmess $\mathrm{N}$. 


\section{3) HISTORY OF QUADRUPEDS.}

ftand with goads in their hands, urging the creature forward to the end of the paffage, where there is an open- ing juft wide enough to let him pafs. He is now received into the cuftody of two females, who ftand on each fide of him, and prefs him into the fervice: If he be likely to prove refractory, they begin to difcipline him with their trunks, till he is reduced to obedience, and fuffers himfelf to be led to a tree, where he is bound by the leg with ftout thongs, marle of untanned elk or buck fkin. The tame Elephants are then led back to the inclofure, and the others are made to fubmit in the fame manner. They are all fuffered to remain faft to the trees for feveral days. Attendants are placed by the fide of each animal, who fupply him with food by little and little, till he is brought by degrees to be fenfible of kindnefs and carefres, and allows himfelf to be led to the ftable. In the fpace of fourteen days, his abfolute fubmiffion is completed. During that time, he is fed daily with cocoa-nut leaves, and led once a day to the water by the tame ones. He becomes accultomed to the voice of his keeper, and at laft quietly refigns his prodigious powers to the dominion and fervice of man.

The time of geftation of the Elephant is hitherto but imperfectly known: Ariftotle fays, it goes two years with young; which is the more likely, as the feafon of defire in the male returns but once in three years. The female produces one young at a time. The young Elephants are faid to fuck with their trunk, the teats of the female being fituated between its fore legs.

The Elephant is thirty years in arriving at its full growth; and is faid to live, though in a ftate of capti. vity, to the age of an hundred and twenty or an hundred. 


\section{HISTORY OF QUADRUPEDS.}

and thirty years: In a ftate of unreftrained freedom, it is fuppofed to live much longer.

The Elephant will drink wine, and is fond of fpirituous liquors. By fhewing him a veffel filled with arrack, he is induced to exert the greateft efforts, and perform the moft painful tafks, in hopes of receiving it as the reward of his labour. To difappoint him is dangerous, as he feldom fails to be revenged. The following infance is given as a fact, and deferves to be recorded:-An Elephant, difappointed of its reward, out of revenge killed his cornac or governor. The poor man's wife, who beheld the dreadful fcene, took her two infants, and threw them at the feet of the enraged animal, faying, "Since you have flain my hurband, take my life alfo, as well as that of my children.' 'The Elephant inftantly ftopped, relented, and, as if ftung with remorfe, took the eldeft boy in its trunk, placed him on its neck, adopted him for its cornac, and would never allow any other perfon to mount it.

We might quote many other facts equally curious and interefting: Thofe we have already recited are fufficient to fhew that the Elephant is poffeffed of inftinctive faculties fuperior to thofe of any other animal. We mutt at the fame time admire the admirable order of that difpenfation, which, to an animal of fuch unequalled powers, has added a difpofition fo mild and tractable: What ravages might we not expect from the prodigious ftrength of the Elephant, combined with the fiercenefs and rapacity of the Tiger!

We cannot clofe our account of the Elephant, without taking fome notice of the teeth of that animal, which 


\section{I96 HISTORY OF QUADRUPEDS.}

have been fo frequently found in a foffil ftate in various parts of the world. Some years ago, two great grindingteeth, and part of the tufk of an Elephant, were difcovered, at the depth of forty-two yards, in a lead mine, in Flinthire, lying in a bed of gravel: The grinders were almoft as perfect as if they had been juft taken from the living animal; the tufk was much decayed, and very foft. - Near the banks of many rivers in Siberia, large tulks and teeth have been frequently dug up, which were formerly attributed to a creature called the Mammouth; but they are now univerfally believed to have belonged to the Elephant. The molares or grinders are perfectly the fame with thofe of the prefent race; but both they and the tufks are much larger: Some of the latter have been known to weigh four hundred pounds; and grinders, of the weight of twenty-four pounds, have not unfrequently been difcovered. One of thefe was taken from a fkeleton of the fame head in which the tufks were found: And as the ivory of the latter was in every refpect the fame as that generally known, and made ufe of for the purpofes of ufeful and ornamental works, we cannot deny our affent to the opinion of thofe who fuppofe them to have been once parts of the animal we have juft defcribed.-Tufks of a prodigious fize, teeth, jaw-bones, thigh-bones, and vertebra, have likewife been frequently found on the banks of the river Ohio, in America, five or fix feet beneath the furface. Some of the tufks are near feven feet long; one foot nine inches in circumference at the bafe, and one foot near the point. 'They differ from thofe of the Elephant, in having a larger twift or fpiral curve towards the fmall end. There is a ftill greater difference in the form of 
the grinders, which are made like thofe of a carnivorous animal, not flat and ribbed tranfverfely on their furface, like thofe of an Elephant, but furnifhed with a double row of high and conic projections, as if intended to mafticate, not grind, their food. Specimens of thefe teeth. and bones are depofited in the Britifh Mufeum, that of the Royal Society, and in the cabinet of the late ingenious Dr Hunter. Thefe folfil bones are alfo found in Peru and in the Brazils._- As yet, the living animal has evaded the fearch of the curious naturalift; but it is not improbable, that it may exift in fome of thofe remote parts of that vaft continent, yet unpenetrated by Europeans.

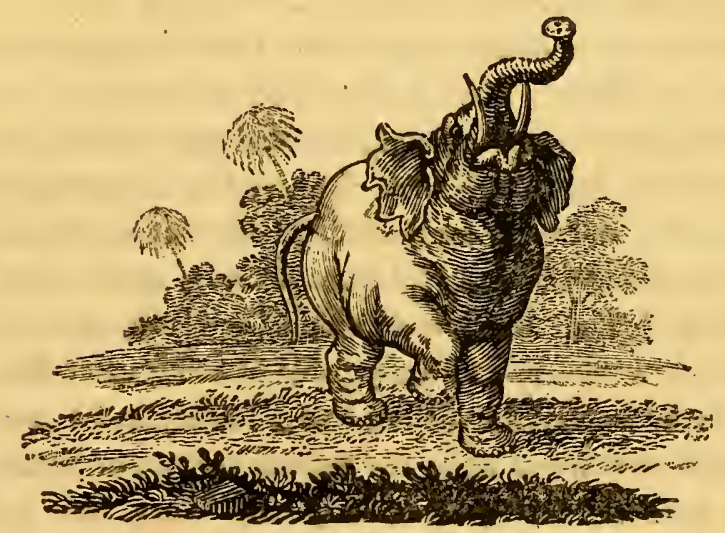




\section{ANIMALS OF THE CAT KIND.}

WE have hitherto been employed in the pleafing tafk of defcribing mot of thofe numerous tribes of animals that are more nearly connected witl the interefts of mankind; that ferve as the inftruments of man's happiners, or at leaft that do not openly oppofe him; that depend upon his care for their fubfiftence; and in their turn contribute largely to his comfort and fupport. We have taken an ample range among the wilder inhabitants of the foreft, which, though in a more remote degree dependant on man, are neverthelefs objects of his attention and purfuit. We have followed Nature to her moft retired receffes, and have feen and admired her works under a variety of the moft beautiful living forms; but our progrefs has hitherto been unftained with blood.

The attention of our readers will now be engaged in a different purfuit. The fcene muft be diverfified.

We come now to a fanguinary and unrelenting tribe, the bold and intrepid enemies of man; that difdain to own his power, and carry on unceafing hoftilities againft him.

This numerous and ferocious tribe is chiefly diftinguifhed by their tharp and formidable claws, which are lodged in a theath, and are capable of being extended or drawn in at pleafure.-They lead a folitary and a ravenous life, and never unite for mutual defence or fupport, like thofe of the herbivorous kinds. They feek their food alone, and are frequently enemies to each other. 'Though differing greatly in fize and in colour, they are nearly allied to each other in form and difpofition, being equally fierce, rapacious, and artful. 


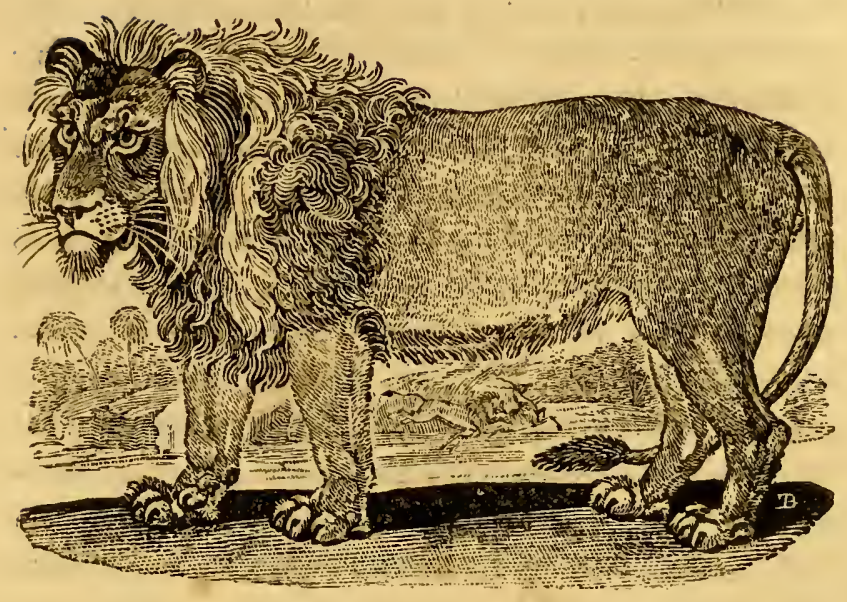

\section{THE LION,}

(Felis Leo, Lin.-Le Lion, Buff.)

Is eminently diftinguifhed from the reft, as well in fize and ftrength, as by his large and flowing mane.

This animal is produced in Africa, and the hotteft parts of Afia. It is found in the greateft numbers in the fcorched and defolate regions of the torrid zone, in the defarts of Zaara and Biledulgerid, and in all the interior parts of the vaft continent of Africa. In thefe defart regions, from whence mankind are driven by the rigorous heat of the climate, this animal reigns fole mafter: Its difpofition feems to partake of the ardour of its native foil : Inflamed by the influence of a burning fun, its rage is moft tremendous, and its courage undaunted. Happi- 
ly, indeed, the fpecies is not numerous, and is faid to be greatly diminifhed; for, if we may credit the teftimony of thofe who have traverfed thefe vaft defarts, the number of Lions is not nearly fo great as formerly. $\mathrm{Mr}$ Shaw obferves, that the Romans carried more Lions from Lybia in one year for their public fpectacles, than could be found in all that country at this time. It is likewife remarked, that in Turkey, Perfia, and the Indies, Lions are not now fo frequently met with as in former times.

It is obferved of this animal, that its courage dimiminifhes, and its caution and timidity are greater, in proportion as it approaches the habitations of the humain race. Being acquainted with man, and the power of his arms, it lofes its natural fortitude to fuch a degree, as. to be terrified at the found of his voice. It has been known to fly before women and even children, and fuffer itfelf to be driven away by them from its lurking places in the neighbourhood of their villages.

This alteration in the Lion's difpofition fufficiently hews, that it will admit of a certain degree of education: And it is a well-known fact, that the keepers of wild beafts frequently play with him, pull out his tongue, hold him by the teeth, and even cliaftife him without caufe. The animal feems to bear all with a fullen kind of compofure, and rarely retaliates this unmerited treatment. It is dangerous, however, to provoke lim too far, or to depend upon his temper with too great fecurity. Labat tells us of a gentleman who kept a Lion in his chamber, and employed a fervant to attend it; who, as is ufual, mixed his blows with careffer. This illjudged affociation continued for fome time. One morn- 


\section{HISTORY OF QUADRUPEDS.}

ing the gentleman was awakened by an unufual noife in his room, and, drawing his curtains, he perceived it to proceed from the Lion, which was growling over the body of the unhappy man, whom it had juft killed, and had feparated his head from his body. The terror and confufion of the gentleman may be eafily conceived: He flew out of the room; and, with the affiftance of fome people, had the animal fecured from doing further mifchief.

As the paffions of this animal are ftrong, and its appetites vehement, we ought not io prefume that the impreffions of education will always be fufficiently powerful. It muft be dangerous, therefore, to fuffer it to remain too long without food, or to perfift in irritating or abufing it.

However, numberlefs accounts affure us, that the anger of the Lion is noble, its courage magnanimous, and its temper fufceptible of grateful impreflions. It has been often feen to defpife weak and contemptible enemies, and even to pardon their infults, when it was in its power to punilh them: It has been known to fpare the life of an animal that was thrown to be devoured by it, to live in habits of perfect cordiality with it, to fhare its fubfiftence, and even to give it a preference where its portion of food was fcanty.

The form of the Lion is ftrikingly bold and majeftic: His large and haggy mane, which he can erect at pleafure, furrounding his awful front; his huge eye-brows his round and fiery eye-balls, which, upon the leaft irritation, feem to glow with peculiar luftre; together with the formidable appearance of his teeth,--exhibit a picture of terrific grandeur, which no words can defcribe. 
The length of the largeft Lion is between eight and nine feet, the tail about four, and its height about four feet and a half. The female is about one-fourth part lefs, and without the mane.

As the Lion advances in years, its mane grows longer and thicker. The hair on the reft of his body is thort and fmooth, of a tawny colour, but whitilh on the belly.

The roaring of the Lion is loud and dreadful: When heard in the night, it refembles diftant thunder. Its cry of anger is much louder and fhorter.

The Lion feldom attacks any animal openly, except when compelled by extreme hunger: In that cafe, no danger deters him; but as moft animals endeavour to avoid him, he is obliged to have recourfe to artifice, and take his prey by furprife. For this purpofe, he crouches on his belly in fome thicket, where he waits till his prey approaches; and then, with one prodigious fpring, he leaps upon it at the diftance of fifteen or twenty feet, and generally feizes it at the firft bourd. If he mirs his object, he gives up the purfuit; and, turning back towards the place of his ambufh, he meafures the ground ftep by ftep, and again lies in wait for another opportu'nity.-The lurking-place of the Lion is generally chofen near a fpring, or by the fide of a river; where he frequently has an opportunity of catching fuch animals as come to quench their thirft.

There are, however, inftances where the Lion dcviates from his ufual method of taking his prey, of which the following, related by Sparrman, is remarkable :-A Hottentot, perceiving that he was followed by a Lion, and concluding that the animal only waited the approach of night to make him his prey, began to confider of the bett 
method of providing for lis fafety, which he at length effected in the following fingular manner: Obferving a piece of broken ground, with a precipitate defcent on one fide, he fat down by the edge of it; and found, to his great joy, that the Lion alfo made a halt, and kept at the fame diftance as before. As foon as it grew dark, the Hottentot, fliding gently forward, let himfelf down a little below the edge of the hill, and held up his cloak and hat upon his ftick, making at the fame time a gentle motion with it: The Lion, in the mean while, came creeping foftly towards him, like a Cat; and miftaking the fkin cloak for the man himfelf, made a fpring, and fell headlong down the precipice: By which means, the poor Hottentot was fafely delivered from his infidious enemy.

That the Lion does not always kill whatever animal happens to be in his power, has already been obferved; and this peculiarity in its temper is remarkably obvious, with regard to the human fpecies. Of this there have been many inftances. At St. Catherine Cree's church, Leadenhall-ftreet, London, provifion is made, under the will of Sir John Gager, who was lord-mayor in the year 1646 , for a fermon to be annually preached on the 16 th of November, in commemoration of his happy deliverance from a Lion, which he met in a defart as he was travelling in the Turkifh dominions, and fuffered him to pafs unmolefted. The minifter is to have 20s. for the fermon, the clerk 2s. $6 \mathrm{~d}$. and the fexton is. The fum of 81. $x 6 \mathrm{s.} 6 \mathrm{~d}$. is likewife to be diftributed among the neceffitous inhabitants, purfuant to the will of Sir John. - Sparrman, among feveral inftances of the fame nature, mentions a perfon who, though he was thrown down by 
a Lion, and wounded by it in feveral places, was after all generoufly left with life.

The ftrength of this animal is great: One of them was obferved to feize a heifer, which it carried off in its mouth with eafe, and leaped over a ditch without much apparent difficulty.

At the Cape of Good Hope, the Lion is frequently hunted by the colonifts.-In the day time, and upon an open plain, twelve or fixteen dogs will eafily get the better of a large Lion. As the Lion is not remarkably fwift, the dogs foon come pretty near him; when, with a fullen kind of magnanimity, he turns round, and waits for the attack, thaking his mane, and roaring with a fhort and fharp tone. The hounds furround him; and, rufhing upon him all at once, foon tear him to pieces. It is faid, that he has feldom time to make more than two or three ftrokes with his paws; each of which is attended with the death of one of his affailants.

'The Lionefs goes with young five months, and brings forth three or four at a time. The young ones are about the fize of a large pug-dog, harmlefs, pretty, and playful. They continue at the teat twelve months, and are above five years in coming to perfection.

The attachment of the Lionefs to her young is remarkably ftrong: For their fupport, the is more ferocious than the Lion himfelf, makes her incurfions with greater boldnefs, deftroys, without diftinction, every animal that falls in her way, and carries it reeking to her cubs.-She ufually brings forth in the moft retired and inaccefrible places; and, when afraid of her retreat being difcovered, endeavours to hide her track, by brufhing the ground with her tail. When much difturbed or alarm- 
ed, the will fometimes tranfport her young from one place to another in her mouth; and, if obftructed in her courfe, will defend them to the laft extremity.

The Lion is a long-lived animal, although naturalifts have differed greatly as to the precife period of its exiftence. Buffon limits it to twenty, or twenty-two years at moft. It is however certain, that it lives much beyond that time. The great Lion, called Pompey, which died in the year 1760, was known to have been in the Tower above feventy years; and one, brought from the river Gambia, died there not long ago, at the age of fixty-three. Several of thefe animals have been bred in the Tower: So that the time of their geftation, the number they produce, and the time of their arriving at perfection, are all pretty well known.

The flefh of the Lion is faid to have a ftrong difagreeable flavour; yet it is frequently eaten by the negroes. The fkin, which was formerly a robe of diftinction for heroes, is now made ufe of by thofe people as a mantle or a bed. They alfo preferve the greafe, which is of a penetrating nature, and is ufed in medicine.

The reprefentation we have given was drawn from a remarkably fine one, exhibited at Newcaftle in the year 1 788 . It was then young, extremely healthful, active, and in full condition.

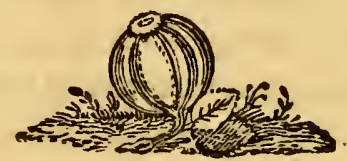




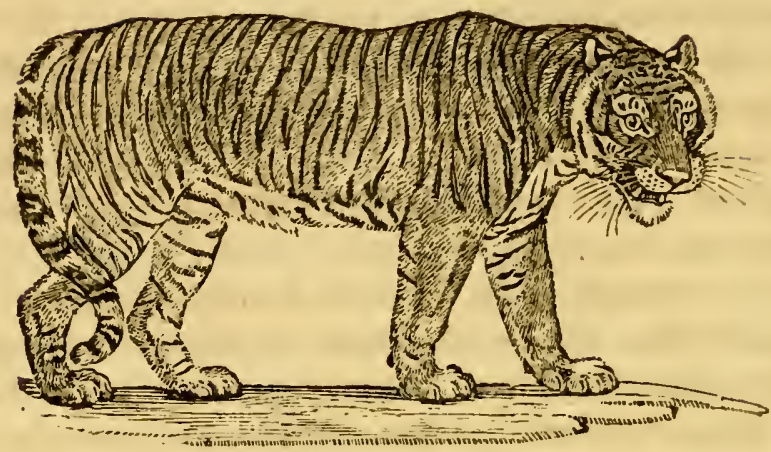

THE TIGER,

(Folis Tigris, Lin.-Le Tigre, Buff.)

Is the molt rapacious and deftructive of all carnivorotis animals. Fierce without provocation, and cruel without neceflity, its thirft for blood is infatiable: Though glutt:d with flaughter, it continues its carnage, nor ever gives up fo long as a fingle object remains in its fight: Flocks and herds fall indifcriminate victims to its fury: It fears neither the fight nor the oppofition of man, whom it frequently makes its prey; and it is even faid to prefer human fleth to that of any other animal.

The Tiger is peculiar to Afia, and is found as far Nortì as China and Chinefe Tartary: It inhabits Mount Ararat and Hyrcania, of old famous for its wild beafts. The greatef numbers are met with in India and its iflands. They are the fcourge of the country: They l.rk among the buthes, by the fides of rivers, and al- 
moft depopulate many places. They feldom parfue their prey, but bound upon it from the place of their ambafh, with an elafticity, and from a diftance, fcarcely credible. It is highly probable that, from this circumftance, the Tiger may derive its name, which, in the Armenian language, fignifies an arrow; to the flight of which this creature may very properly be compared, in the quicknefs and agility of its bounds.

The ftrength of this animal is fo great, that, when it has killed a Deer or other animal, it carries it off with fuch eafe, that it feems no impediment to its flight. If it be undifturbed, it plunges its head into the body of the animal up to its very eyes, as if to fatiate itfelf with blood.

The Tiger is one of the few animals whofe ferocity can never be wholly fubdued. Neither gentlenefs nor conftraint has any effect in foftening its temper. It does not feem fenfible of the attention of its keeper; and would equally tear the hand that feeds, with that by which it is chaftifed.

A beautiful young male Tiger, lately brought over from China, in the Pitt Eaft-Indianan, at the age of ten months, was fo far domefticated, as to admit every kind of familiarity from the people on board. It feemed to be quite harmlefs, and was as playful as a kitten. It frequently flept with the failors in their hammocks, and would fuffer two or three of them to repofe their heads upon its back, as upon a pillow, whilft it lay ftretched out upon the deck. In return for this, it would, however, now and then fteal their meat. Having one day taken a piece of beef from the carpenter, he followed the animal, took the meat out of its mouth, and beat it 
feverely for the theft; which punifhment it fuffered with all the patience of a Dog. It would frequently run out on the bowfprit; climb about the fhip, like a Cat; and perform a number of tricks, with an agility that was truly aftonifhing. There was a Dog on board the fhip, with which it would often play in the molt diverting manner.-From thefe circumftances, one might be led. to fuppofe, that the difpofition of the Tiger, like that of many other animals, was capable of fome degree of culture. But it ought to be remembered, that at the time this one was taken on board the thip, it was only a month or fix weeks old; and when arrived in this country, it had not quite compleated a year. How much longer its good-humour might have continued, it is impoffible to fay: But it is much to be doubted, that the fame innocent playfulnefs would have formed a part of its character when arrived at its full ftate of maturity.

Notwithftanding the cruelty of this creature's difpofition, a fudden cheek has fometimes had a good effect in preventing its meditated attack. Some badies and gentlemen being on a party of pleafure, under a thade of trees, on the banks of a river in Bengal, were fuddenly furprifed at feeing a Tiger ready to make its fatal fpring: One of the ladies, with amazing prefence of mind, laid hold of an umbrella, and unfurling it directly in the animal's face, it inftantly retired.-Another party had not the fame good fortune. A Tiger darted among then whilft they were at dinner, feized on a gentleman, and carried him off in the fight of his difconfolate companions.

They attack all kinds of arimals, even the Lion; and 
furious combats have frequently been maintained between them, in which both have perifhed.

Father Tachard gives an account of a battle between a Tiger and two Elephants, at Siam; of which he was an eye-wițnefs. The heads, and part of the trunks of the Elephants, were defended from the claws of the Tiger by a covering made for the purpofe. They were placed in the midft of a large inclofure. One of them was fuffered to approach the Tiger, which was confined by cords, and received two or three heavy blows from the trunk of the Elephant upon its back, which beat it to the ground, where it lay for fome time as if it were dead: But, though this attack had a good deal abated its fury, it was no fooner untied, than, with a horrible roar, it made a fpring at the Elephant's trunk, which that animal dexteroufly avoided by drawing it up ; and, receiving the Tiger on its tufks, threw it up into the air. The two Elephants were then allowed to come up ; and, after giving it feveral heavy blows, would undoubtedly have killed it, if an end had not been put to the combat.Under fuch reftraints and difadvantages, we cannot wonder that the iffue was unfavourable to the Tiger. We may, however, by this, judge of its great ftrength and fiercenefs, - that, after being difabled by the firft attack of the Elephant, whilft it was held by its cords, it would venture to continue fuch an unequal engagement.

We are happy in being able to prefent our curious readers with an engraving of this rare animal, drawn from the life, from. a Tiger that was exhibited at Newcaftle in 1787 , and was generally allowed to be one of the fineft creatures of its kind ever feen in England. 
The beautiful bars of black with which every part of its body was ftreaked, are accurately copied: The colour of the ground was yellow, deeper on the back, and foftening by degrees towards the belly, where it was white; as were alfo the throat and infides of the legs: A white fpace, fpotted with black, furrounded each eye; and on each cheek, a ftripe of the fame colour extended from the ears to the throat. It was nearly the fame height as the Lion, and was of the largeft fpecies of the Tiger, which is called the Royal Tiger. The finalleft of them is not above two feet high, faid to be extremely cunning, and delights in human flefh. The fecond kind is about three feet high, and is fond of Deer, Wild Hogs, \&c. which it frequently takes by the fides of rivers, as they come down to quench their thirft.

The $\mathrm{fkin}$ of this animal is much efteemed all over the Ealt, particularly in China. The Mandarins cover their feats of juftice with it; and, during the winter, ufe it for cufhions and pillows.

We have now defcribed the two great heads of this mifchievous family, which are eminently diftinguifhed from the reft in fize, ftrength, and colour.

The three fucceding fpecies have been frequently confounded with each other; and, although there is fome difference in their fize, and in the difpofition of their fpots, yet thefe have been fo indifcriminately defined, as to make it difficult to form a true criterion, fo as accurately to diftinguilh each fpecies. Strikingly fimilar in the form of their bodies, in the beauty of their fRins, as well as in their difpofitions and habits, which feem to be equally formed for rapine and cruelty,-there is great 
room to conjecture, that commixture may be one great caufe of producing the flight differences obfervable in them.-If we regard the figure and diverfity of the fpots, we thall find many varietics not taken notice of by naturalifts; if we be led to judge by the fize, we fhall find an almoft imperceptible gradation from the Cat to the Tiger. It would be vain, therefore, to make as many varieties in thefe animals, as we fee differences in fpots or ftature: It will be fufficient to point out the moft general diftinctions.

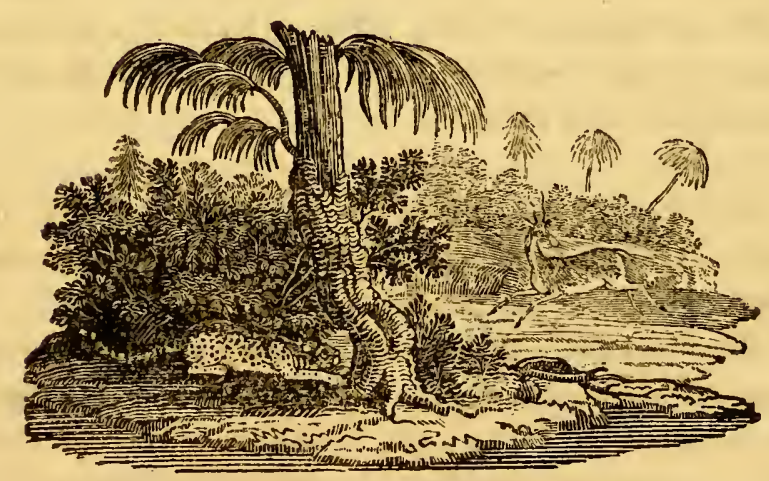

$\mathrm{O}_{2}$ 


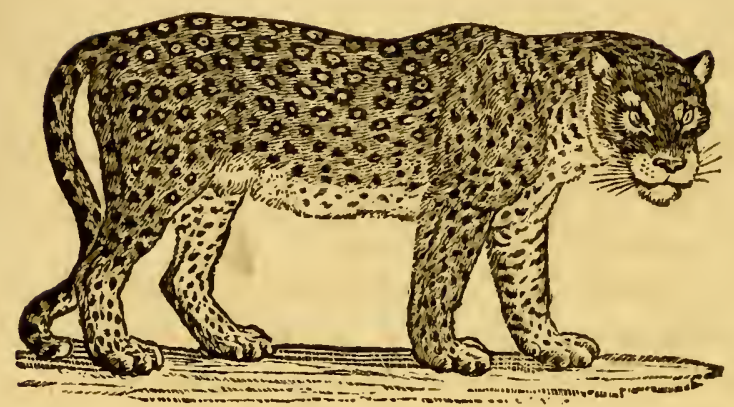

THE PANTHER,

(Felis Pardus, Lin._La Panthere, Buff.)

Is next in fize to the Tiger, and has, by many naturalifts, been miftaken for that animal.- - Its hair is Thort and Imooth; and, inftead of being ftreaked like the Tiger, is beautifully marked on the back, fides, and flanks, with black fpots, difpofed in circles, from four to five in each, with a fingle fpot in the center; on the face, breaft, and legs, the. fpots are fingle: The colour of the body on the back and fides is yellow, deep on the back, and paler towards the belly, which is white: Its ears are fhort -and pointed; its eye is reftlefs; and its whole afpect fierce and cruel.

It is an untameable: animal, and inhabits Africa, from Barbary to the remoteft parts of Guinea.

Its manner of taking its prey is the fame with that of the Tiger,-always by furprize, either lurking in thickets, or creeping on its belly till it comes within reach. When preffed with hunger, it attacks every living crea- 


\section{HISTORY OF QUADRUPEDS.}

ture without diftinction, but happily prefers the flefh of brutes to that of mankind: It will even climb up trees in purfuit of monkies and lefier animals; fo that nothing is fecure from its attacks.

The Panther is about the frze of a large Maftiff Dog, but its legs are not quite fo long. Its voice is ftrong and hoarfe, and it growls continually.

The ancients were well acquainted with thefe animals. The Romans drew prodigious numbers from the defarts of Africa, for their public fhows; fufficient, one might fuppofe, to have entirely exhaufted them. Scaurus exhibited an hundred and fifty of them at one time; Pompey four hundred and ten; and Auguftus four hundred and twenty. They probably thinned the coafts of Mauritania of thefe animals; but they ftill fwarm in the fouthern parts of Guinea.

In China, there is a moft beautiful animal of this kind, called Loucbu, the fkin of which fells for fix pounds fterling.

An animal of this fpecies is likewife found in Afiatic Tartary, called there the Babr. It is feven feet long, extremely rapacious, and very deftructive of Horfes and $\mathrm{Ca}-$ mels. Its fkin is very fine, and valued in Ruffia at one pound fterling.

$\mathrm{O}_{3}$ 


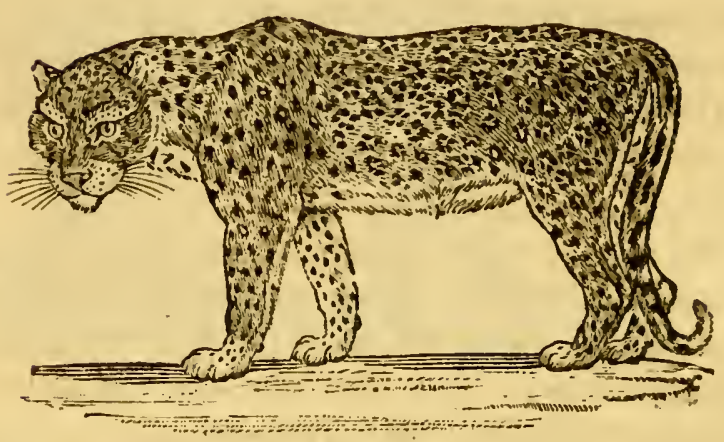

THE LEOPARD.

\section{(Le Leopard, Buff.)}

ГHE very trifling difference between this and the laftmentioned animal gives reafon to fuppofe, that it confifts chiefly in the name. It inhabits the fame countries; and in fome places goes by the fame name, being called the Panther of Senegal; and is chiefly found there. It is mentioned by Ray as the female Pantber, but is rather fmaller than that animal. Its length, from nofe to tail, is about four feet: The colour of the body is a more lively yellow; and the fpots with which it is diverfified, are fmaller and clofer than thofe of the Panther.

The interior parts of Africa abound with thefe animals; from whence they come down in great numbers, and make dreadful havock among the numerous herds that cover the plains of the Lower Guinea. When beafts of chafe fail, they fpare no living creature. 
The negroes take them in pitfalls, flightly covered at the top, and baited with flefh. Their chief inducement for purfuing them is their flefh, which they cat; and it is faid to be as white as veal, and well-tafted. The negreffes make collars of their teeth, and wear them as charms.

The fkins of thefe animals are brouglt to Lurope, where they are greatly efteemed.

In India, there is a fpecies of Leopard about the fize of a large Greyhound, with a fmall head, and fhort ears: Its face, chin, and throat, are of a pale-brown colour, inclining to yellow; the body is of a light tawny-brown, marked with fmall round black fpots, fcattered over the back, fides, head, and legs; the hair on the top of the neck is longer than the reft; the belly is white; the tail very long, marked on the upper fide with large black fpots.

This is the animal, mentioned in our account of the Antelope, which is made ufe of in India for hunting that and other beafts of the chafe,-It is carricd in a fmall kind of waggon, chained and hoodwinked till it approaches the herd; when it is unchained, and fuffered to purfue the game. It begins by creeping along, with its belly clofe to the ground, ftopping and concealing itfelf till it gets an advantageous fituation; it then darts on its prey with great agility, frequently making five or fix amazing bounds. If it thould not fucceed in its firft effort, it gives up the point for that time, and readily returns to its mafter. 


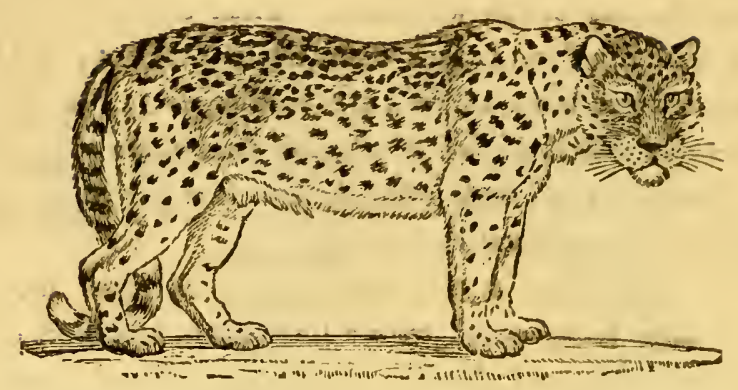

THE OUNCE,

\section{(L'Once, Buff.)}

Is fmaller than the Leopard, being three feet and a half long from the nofe to the tail, very ftrong, long-backed, and Thort-legged. The hair is long, and of a light-gray colour, tinged with yellow; lighter on the breaft. and belly: The head is marked with fmall round fpots: Behind each ear there is a large black fpot: The back is beautifully varied with a number of oval figures, formed by fmall fpots almoit touching exch other; the fpots on the fides are more irregular; thiofe on the legs and thighs fmall, and thinly difperfed: The tail is full of hair, irregularly marked with large black fpots, and upwards of three feet long.

It is common in Barbary, Perfia, and China; is much more gentle than the Leopard; and, like the HuntingLeopard, is fometimes trained to the chafe. Inftead of being conveyed in a waggon, it is carried on the crupper of the Horfe, is as much under command as a SettingDog, returns at a call, and jumps up behind its mafter. 
The fcent of the Ounce is not fo fine as that of the Dog. It neither follows animals by their foot, nor is it able to overtake them in a continued chafe: It hunts folely by the eye, and makes only a few fprings at its prey. It is fo nimble, as to clear a ditch or a wall of many feet. It often climbs trees to watch animals that are paffing, and fuddenly darts upon them.

It is fuppofed to be the Leffer Panther of Oppian, and the Panthera of Pliny.

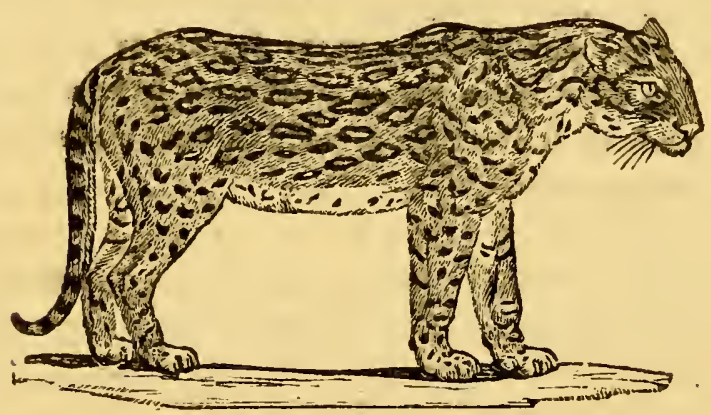

THE JAGUAR,

(Felis Onca, Lin.-Lie Faguar, Buff.)

Is the moft formidable animal of the new continent, rather larger than the Panther, with hair of a bright-tawny colour. The top of the back is marked with long ftripes of black; the fides beautifully variegated with irregular oblong fpots, open in the middle; the tail not fo long as that of the Ounce, and irregularly marked with large black fpots. 
It is found in the hotteft parts of South-America; is very fierce; and, when prefled with hunger, will fometimes venture to feize a man.

The Indians are much afraid of it, and think it prefers them to the white inhabitants, who, perhaps, are better prepared to repel its attacks. In travelling through the defarts of Guiana, they light great fires in the night, of which thefe animals are much afraid.

They howl dreadfully; their cry, which is expreflive of the two monofyllables-bou, bou, is fomewhat plaintive, grave, and ftrong, like that of an $\mathrm{Ox}$.

The Ant-eater, though it has no teeth to defend itfelf with, is the moft cruel enemy the Jaguar has to encounter. As foon as the Jaguar attacks this little animal, it lies down on its back, and, with its long claws, feizes and fuffocates him.

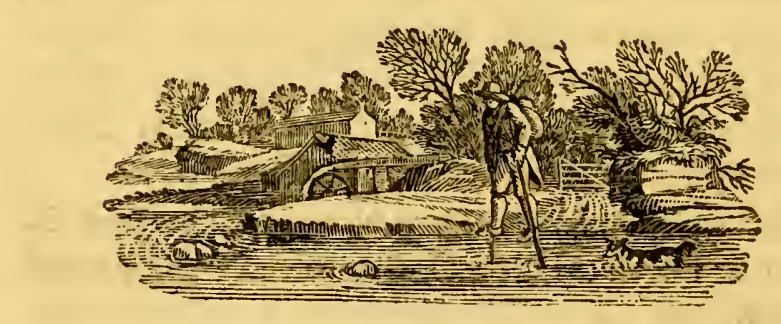




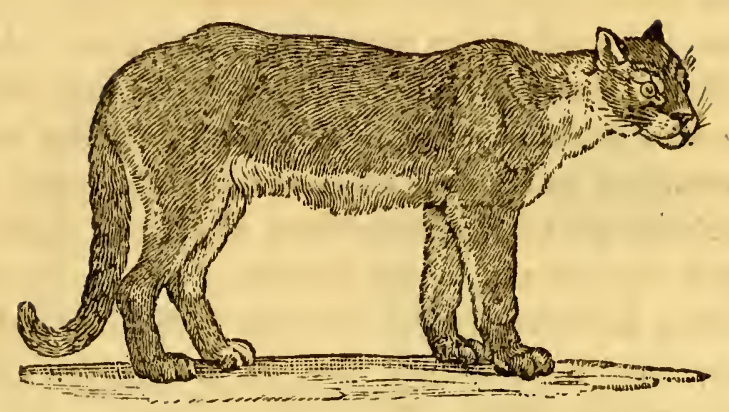

THE COUGUAR,

(Felis Concolor, Lin.-Le Couguar, Buff.)

INHABITs the continent of America, and is called by fome the Puma, or American Lion; but differs fo much from that noble animal, as not to admit of any comparifon.Its head is fmall; it has no mane; its length, from nofe to tail, is five feet three inches; the tail two feet : The predominant colour is a lively red, mixed with black; efpecially on the back, where it is darkeft: Its chin, throat, and all the inferior parts of its body, are whitifh: Its legs are long; claws white; and the outer claw of the fore feet much longer than the others.

It is found in many parts of North-America, from $\mathrm{Ca}_{\mathrm{a}}$ nada to Florida: It is alfo common in Guiana, Brazil, and Mexico.

It is fierce and ravenous in the extreme, and will fwim rivers to attack cattle even in their inclofures.-In North-America, its fury feems to be fubdued by the rigour of the climate, for it will fly from a Dog in com- 
pany with its mafter, and take fhelter by running up a tree.

It is very deftructive to domentic animals, particularly to Hogs. It preys alfo upon the Moofe and other Deer; lies lurking upon the branch of a tree till fome of thefe animals pafs underneath, when it drops down upon one of them, and never quits its hold till it has drunk its blood. It will even attack beafts of prey. In the Mufeum of the Royal Society is preferved the fhin of one of thefe animals, which was fhot juft as it had feized a Wolf.-When fatisfied with eating, it conceals the reft of the carcafe, covering it carefully with leaves._- It purrs like a Cat, and fometimes howls dreadfully.

The fur is foft, and is ufed by the Indians for a winter habit; when dreffed, it is made into gloves and thoes. The flefh is white, and, by the natives, reckoned excellent food.

The Couguar, when brought into captivity, is almoft as gentle as the domeftic Cat, allows itfelf to be careffed, and will permit boys to mount on its back. - It is fometimes called the Poltron Tiger.

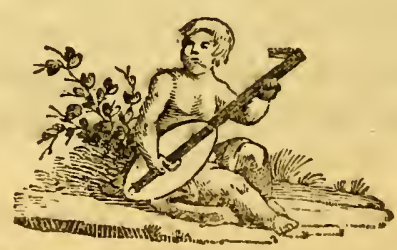




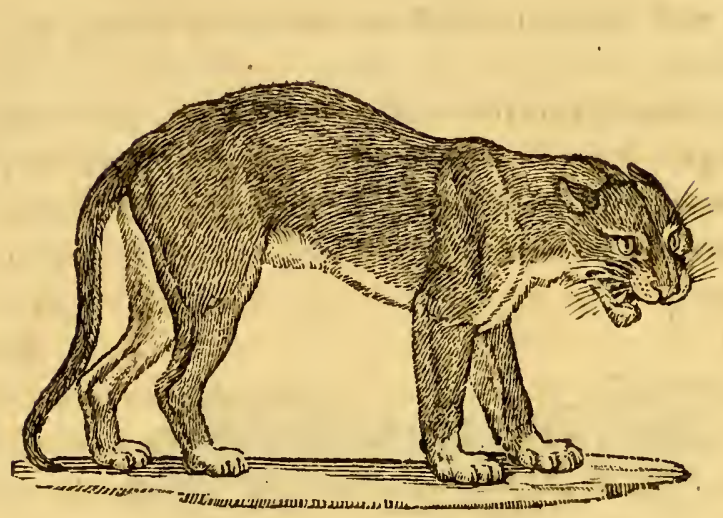

THE BLACK-TIGER,

(Le Cougar noir, Buff.)

DIFFERs from the former chiefly in the colour, which is dulky, fometimes fpotted with black, but generally plain. The throat, belly, and infide of the legs, are of a paleafh colour; the upper lip white, covered with long whifkers: Above each eye it has very long hairs; and at the corner of the mouth a black fpot: Its paws are white; and its ears tharp and pointed.

It grows to the fize of a heifer of a year old, and has great Atrength in its limbs.

It inhabits Brazil and Guiana, is a cruel and fierce animal, much dreaded by the Indians; but fortunately the fpecies is not numerous.

M. de la Borde, in his defcription of thefe animals, fays, that they frequent the fea-hore, and eat the eggs depofited there by the turtles. They likewife eat caimans or alligators, lizards, and fines, and fometimes 
the buds and tender leaves of the Indian fig. - They are excellent fwimmers.-In order to catch the alligator, they lie down on their belly at the edge of the river, ftrike the water to make a noife, and as foon as the alligator raifes its head above the water, dart their claws into its eyes, and drag it on fhore.

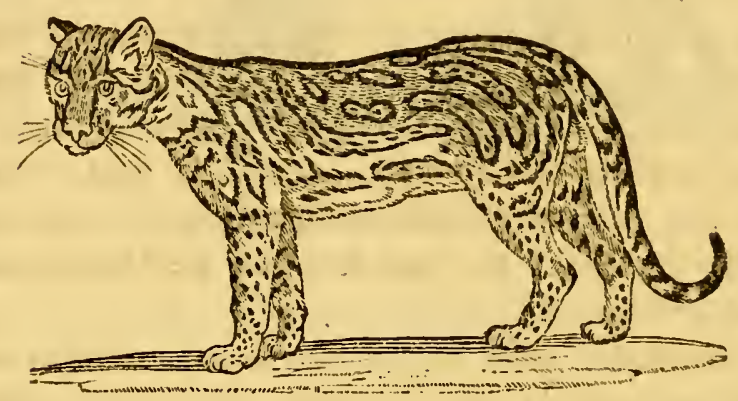

THE OCELOT.

(Felis Pardalis, Lin._L'Ocelot, Buff.)

THE fkin of the male Ocelot is extremely beautiful, and moft elegantly variegated. Its general colour is that of a bright-tawny; a black ftripe extends along the top of the back, from head to tail; its forehead is fpotted with black, as are alfo its legs; its fhoulders, fides, and rump, are beautifully marbled with long ftripes of black, forming oval figures, filled in the middle with fmall black fpots; its tail is irregularly marked with large fpots, and black at the end.-The colours of the female are not fo vivid as thofe of the male; neither is it fo beautifully marked. 
The Ocelot very much refembles the common Cat in the form of its body, although it is a great deal larger. Buffon makes its height two feet and a half, and about four feet in length.

It is a native of South-America, inhabits Mexico and Brazil, is very voracious, but timid, and feldom attacks men. It is afraid of Dogs; and, when purfued, flies to the woods.

It lives chiefly in the mountains, and conceals itfelf amongt the leaves of trees; from whence it darts upon fuch animals as come within its reach. It fometimes extends itfelf along the boughs, as if it were dead, till the monkies, tempted by their natural curiofity, approach within its reach. It is faid to prefer the blood of animals to their flefh.

The Ocelot cannot eafily be tamed, and retains its original wildnefs in a ftate of captivity. Nothing can foften the natural ferocity of its difpofition, nor calm the reftleffnefs of its motions. For this reafon, it is always kept in a cage.-One of there animals, thewn at Newcaftle in 1788 , although extremely old, exhibited great marks of ferocity. It was kept clofely confined, and would not admit of being careffed by its keeper in the fame manner as the Lion; but growled confantly, and always appeared in motion.-A male and female Ocelot were brought to France fome years ago, which had been taken when very young. At the age of three months, they became fo ftrong and fierce, as to kill a bitch that was given them for a nurfe. When a live Cat was thrown to them, they fucked its blood, but would not tafte its flefh. The male feemed to have a great fuperiority orer the fe- 
male, as he never allowed her to partake till his own appetite was fatisfied.

The female Ocelot, like all the larger animals of the Cat kind, produces a fmall number at a time. The two above-mentioned were the only young ones found with the mother, which was killed at the time they were taken; and makes it probable, that they bring forth only that number.

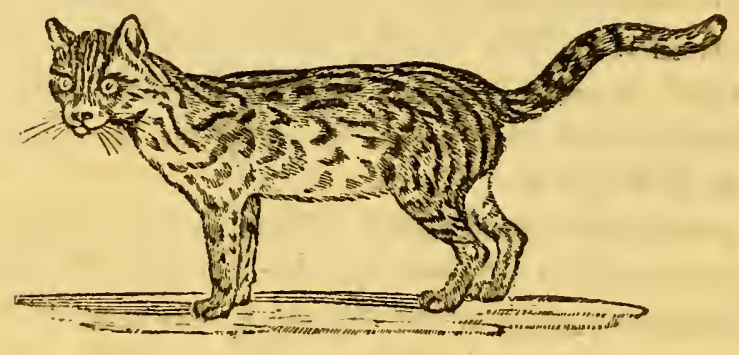

THE MARGAY,

(Le Margay, Buff.)

Is another beautiful animal of the fpotted tribe, and known in many places by the name of the Tiger Cat. The ground colour of the body is tawny; the face is ftriped with black; the body is marked with ftripes and large fpots of black; the breaft and infides of the legs are white, fpotted with black; the tail is long, marked with alternate fpots of black, tawny, and gray.

The Margay is fmaller than the Ocelot, and about the fize of the Wild Cat, which it refembles in difpofition 
and habits, living on fmall animals, birds, \&c.-It is very wild, and cannot eafily be brought under fubjection.

Its colours vary, though they are generally fuch as have been defcribed.

It is common in Guiana, Brazil, and various parts of South-America.

It is called the Cayenne Cat, and is not fo frequent in temperate as in warm climates.

In taking a furvey of this beautiful race of animals, we are unavoidably led to obferve, that much remains for the laborious refearches of the natural hiftorian, before a complete account can be made out of the various kinds of which it is compofed.-Several fpecies are frequently found in the Eaft-Indies, in the woods near the Cape of Good Hope, and on the continent of America; but in general thefe have been fo negligently or fo injudicioufly mentioned, as to render it impoffible to form a perfect defcription of them.-A good hiftory of thefe animals is one of the many defiderata of the naturalift; but when we confider the great diftance which moft of this ferocious tribe obferve in their feparation from mankind, and the dangers that muft be encountered in approaching their folitary habitations, we are obliged to lament that this defirable object is not likely to be foon accomplifhed.

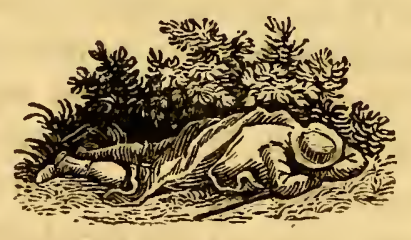




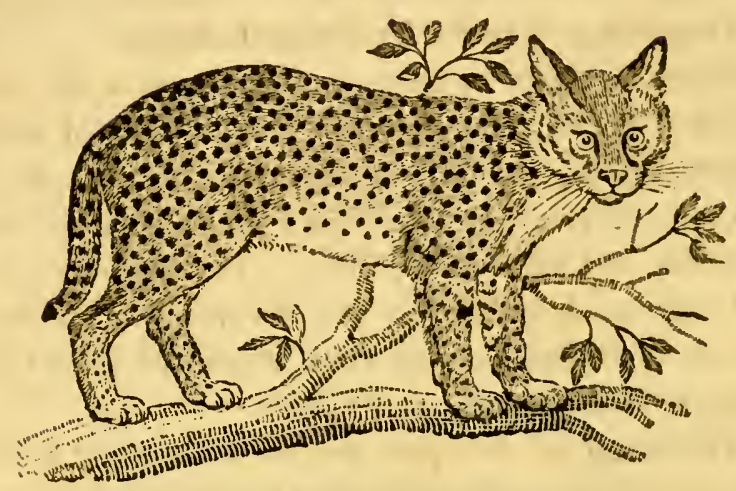

THE SER VAL,

\section{(Le Serval, Buff.)}

INHABITS the mountainous parts of India, and is called by the natives of Malabar, the Marapute.-It is larger than the Wild-Cat.-Its general colour is a pale-yellow; white on the breaft and belly; variegated with round fpots, which are equally diftributed over every part of its body : Its eyes are extremely brilliant, and have a wild, piercing look; its whifkers are long and ftiff; its tail fhort; and its feet are armed with long hooked claws.

It is feldom to be feen upon the ground; but lives chiefly in trees, where it makes its neft, and breeds its young. It feeds on young birds, and leaps with great agility from tree to tree. It is extremely fierce; but avoids mankind, unlefs provoked; when it darts furiounly upon the offender, and tears and bites nearly in the fame manner as the Panther. 
Sparrman mentions an animal of this kind, found at the Cape of Good Hope, which he calls the Tiger Cat, and fuppofes it to be the fame with the Serval.

The fame author mentions another animal of this kind, called at the Cape the Wild Red Cat; the fkin of which is fuppofed by the natives to poffers great medicinal powers, and give eafe to perfons afflicted with the gout, lumbago, and pains in the joints. The fur is very fine and foft; and, probably, there are many other fkins, which, if applied with an equal degree of good faith, might have the fame falutary effects.

The colour of the upper part of this creature is of a very bright-red; towards the fides it is mixed with white and gray ; the belly is white; the upper part of the ears, which have tufts of hair on their tips, is dark-brown, fprinkled with gray. Its body is long, and about two feet in height.

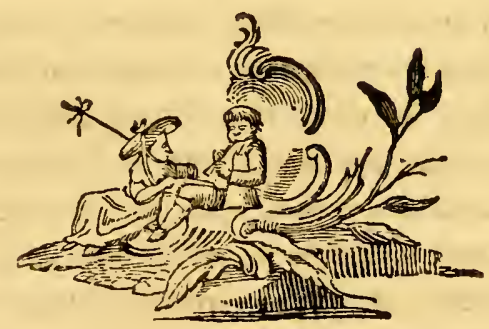




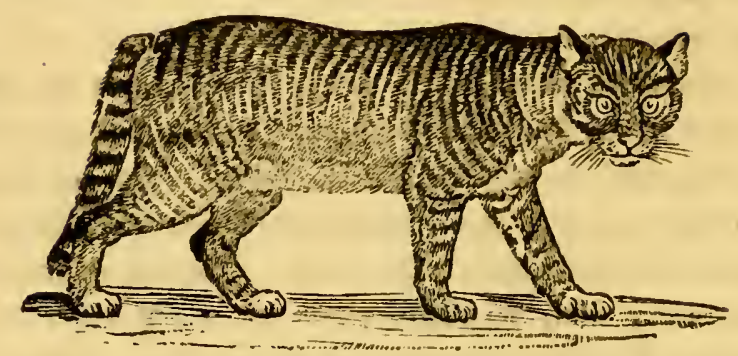

THE WILD-CAT.

(Felis Catus, Lin.-Le Chat Jauvage, Buff.)

THE hiftory of this animal is fo intimately connected with that of the common or domeftic kind, that we thall include our account of bath under one general head, and defcribe them as conftituting the fame fpecies.

The domeftic Cat, if fuffered to efcape into the woods, becomes wild, and lives on fmall birds and fuch other game as it can find there; it likewife breeds with the wild one. It is no uncommon thing for females of the tame fpecies to quit their houfes during the time they are in feafon, go in queft of male Wild-Cats, and return to the fame habitations impregnated by them. It is by this means that fome of our domeftic Cats fo perfectly refemble thofe of the wild breed.

The hair of the Wild-Cat is foft and fine, of a paleyellow colour, mixed with gray; a dufky lift runs along the middle of the back, from head to tail; the fides are ftreaked with gray, pointing from the back downwards; the tail is thick, and marked with alternate bars of black 
and white. It is larger and ftronger than the tame Cat, and its fur much longer.

It inhabits the moft mountainous and woody parts of this ifland, lives in trees, and hunts for birds and fmall animals; fuch as Rabbits, Hares, Rats, Mice, Moles, \&c. It frequently makes great havock among poultry; will even kill young Lambs, Kids, and Fawns; and is the fierceft and molt deftructive beaft of prey in this kingdom.

It is taken either in traps, or by thooting. There is frequently danger in the latter mode; for, if it be only flightly wounded, it will attack the perfon who has injured it, and is not eafily repelled.

Wild-Cats are found, with very little variety, in almoft every climate.-They exifted in America before its difcovery by the Europeans. One of them was brought to Columbus, which was of the ordinary fize, of a brownifh-gray colour, with a long tail.-They are common in many places of Afia and Africa. Sparrman gives a defcription of one which he fhot at the Cape, which was in every refpect fimilar to thofe of this country: It was of a gray colour; and meafured, from the nofe to the tail, nearly twenty-two inches: The tail was thirteen inches long: Its height was about a foot and a half. Its intertines were full of Moles and Rats.

Some Wild-Cats have been taken in this kingdom of a moft enormous fize. We recollect one having been killed in the county of Cumberland, which meafured, from its nofe to the end of its tail, upwards of five feet.

The province of Chorazan, in Perfia, is particularly famous for a molt beautiful Cat, about the fize of the 
tame one, of a fine gray colour, without any mixture, and as foft and hining as filk. It is darker on the back, foftening by degrees towards the breaft and belly, where it is almoft white. The tail is long, and covered with hair, five or fix inches in length. The animal frequently turns it upon its back, like a Squirrel; the point of it refembling a plume of feathers.

The Cat of Angora differs greatly from the Wild-Cat, in having much longer hair, efpecially about the neck, where it forms a fine ruff, and gives it a Lion-like appearance. Some of thefe are of a filvery whitenefs, and filky texture; others are of a dun colour, mixed with yellow.

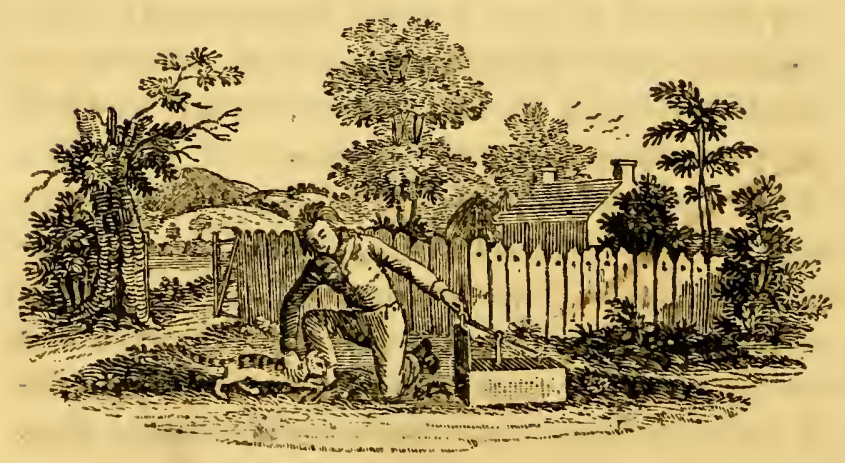




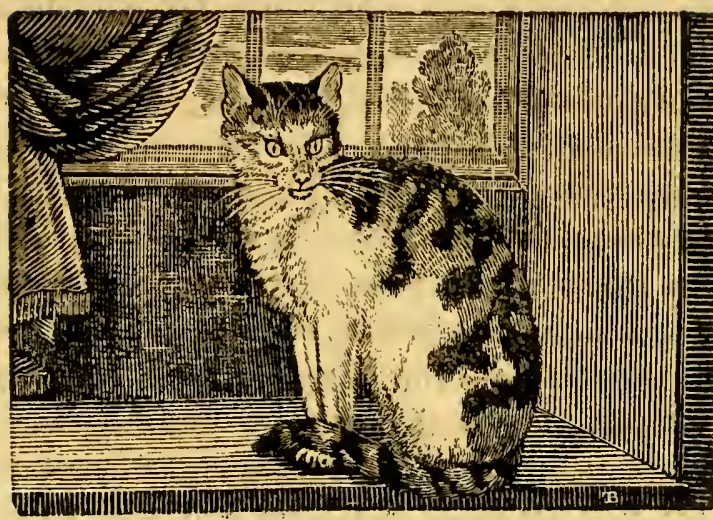

\section{THE DOMESTIC CAT}

Differs from the Wild-Cat, in being fomewhat lefs; and, inftead of being uniformly the fame, is diftinguifhed by a great variety of thades and colouring.

To defcribe an animal fo well known, might feem a fuperfluous tafk: We fhall only, therefore, felect fuch of its peculiarities as are leaft obvious, and may have efcaped the notice of inattentive obfervers.

It is generally remarked, that Cats can fee in the dark; but, though this is not abfolutely the cafe, yet it is certain that they can fee with much lefs light than moft other animals, owing to the peculiar ftructure of their eyes, the pupils of which are capable of being contracted or dilated in proportion to the degree of light by which they are affected. The pupil of the Cat, during the day, is perpetually contracted; and it is with difficulty that it can fee by a ftrong light: But in the twilight, the pupil. 
refumes its natural roundnefs, the animal enjoys perfect vifion, and takes advantage of this fuperiority to difcover and furprife its prey.

The cry of the Cat is loud, piercing, and clamorous; and whether expreffive of anger or of love; is equally violent and hideous. Its call may be heard at a great diftance, and is fo well known to the whole fraternity, that on fome occafions feveral hundred Cats have been brought together from different parts. Invited by the piercing cries of diftrefs from a fuffering fellow-creature, they aflemble in crouds; and, with loud fqualls and yells, expreis their horrid fympathies. They frequently tear the miferable object to pieces; and, with the moft blind and furious rage, fall upon each other, killing and wounding indifcriminately, till there is fcarcely one left. Thefe terrible conflicts happen only in the night; and, though rare, inftances of very furious engagements are well authenticated.

The Cat is particularly averfe to watcr, cold, and bad fmells. It is fond of certain perfumes, but is more particularly attracted by the fmell of valerian, marum, and cat-mint: It rubs itfelf againft them; and, if not prevented from coming at them in a garden where they are planted, would infallibly deftroy them.

- The Cat brings forth twice, and fometimes thrice, a year. The period of her geftation is fifty-five or fifty-fix days, and fhe generally produces five or fix at one litter. She conceals her kittens from the male, left he fhould devour them, as he is fometimes inclined; and, if apprehenfive of being difturbed, will take them up in her month, and renove them one by one to a more fecure retreat: Evex the femalc lierfelf, contrary to the efta- 
blifhed law of Nature, which binds the parent to its offfpring by an almolt indiffoluble tie, is fometimes known to eat her own young the moment after the has produced them.

Though extremely ufeful in deftroying the vermin that infeft our houfes, the Cat feems little attached to the perfons of thofe who afford it protection. It feems to be under no fubjection, and acts only for itfelf. All its views are confined to the place where it has been brought up; if carried elfewhere, it feems loft and bewildered: Neither careffes nor attention can reconcile it to its new fituation, and it frequently takes the firft opportunity of efcaping to its former haunts. Frequent inftances are in our recollection, of Cats having returned to the place from whence they had been carried, though at many miles diftance, and even acrofs rivers, when they could not poffibly have any knowledge of the road or fituation that would apparently lead them to it.-This extraordinary faculty is, however, poffeffed in a much greater degree by Dogs; yet it is in both animals equally wonderful and unaccountable.

In the time of Hoel the Good, King of Wales, who died in the year 948 , laws were made as well to preferve, as to fix the different prices of animals; among which the Cat was included, as being at that period of great importance, on account of its fearcenefs and utility. The price of a kitten before it could fee was fixed at one penny; till proof could be given of its having caught a moufe, two-pence; after which it was rated at fourpence, which was a great fum in thofe days, when the value of fpecie was extremely high: It was likewife required, that it fhould be perfect in its fenfes of hearing 
and feeing, fhould be a good moufer, have its claws whole, and, if a female, be a careful nurfe: If it failed in any of thefe good qualities, the feller was to forfeit to the buyer the third part of its value.-If any one thould fteal or kill the Cat that guarded the Prince's granary, he was either to forfeit a milch ewe, her fleece and lamb, or as much wheat as, when poured on the Cat fufpended by its tail (its head touching the floor), would form a heap high enough to cover the tip of the former.-From hence we may conclude, that Cats were not originally natives of thefe iflands; and, from the great care taken to improve and preferve the breed of this prolific creature, we may fuppofe; were but little known at that period.Whatever credit we may allow to the circumftances of the well-known ftory of Whittington and his Cat, it is another proof of the great value fet upon this animal in former times.

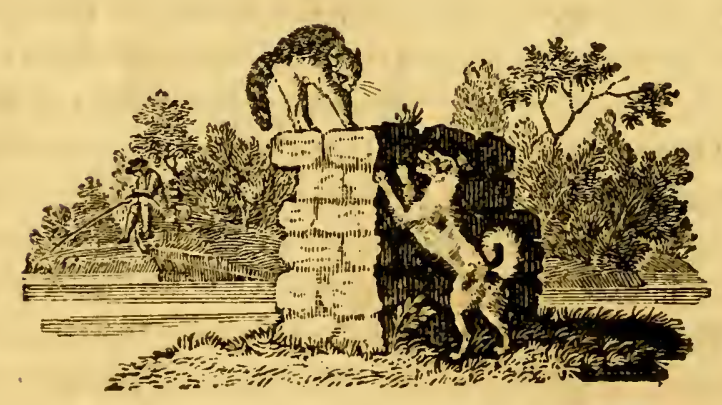




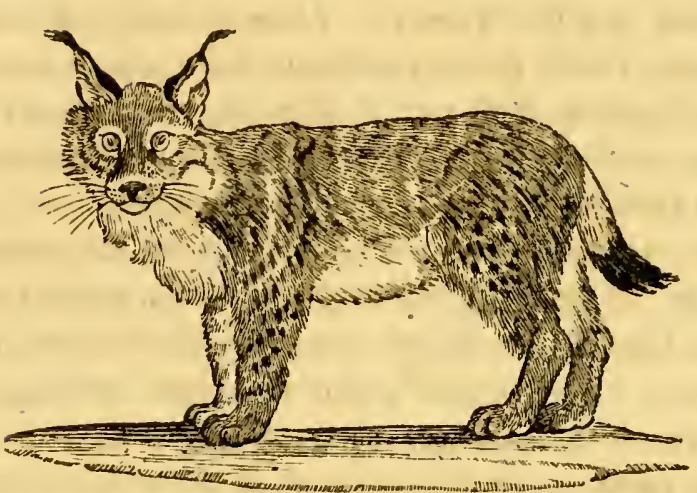

THE LYNX,

(Felis Lynx, Lin.-Le Lynx; ou Loup Cervier, Buff.)

Differs greatly from every animal of the Cat kind we have hitherto defcribed. Its ears are long and erect, tufted at the end with long black hairs, by which this fpecies of animals is peculiarly diftinguifhed: The hair on the body is long and foft, of a red-afh colour, marked with dufky fpots, which differ according to the age of the creature; fometimes they are fcarcely vifible: Its legs and feet are very thick and ftrong; its tail fhort, and black at the extremity; its eyes are of a pale-yellow colour; and its afpect fofter and lefs ferocious than that of the Panther or the Ounce. The fkin of the male is more fpotted than that of the female.

The fur is valuable for its foftnefs and warmth, and is imported in great quantities from America and the North of Europe. The farther North they are taken, the whiter they are, and the fpots more diftinct.-The moft ele- 
gant of thofe is called the Irbys; and is taken near Lake Balkafh, in Ufbec Tartary. It is much larger than the common kind. Its $\mathrm{fkin}$ fells in that country for one pound fterling.- The colour of its hair changes with the climate and the feafon. The winter furs are richer and more beautiful than thofe taken in fummer.

The Lynx is faid to be very long-lived, is a very deftructive animal, lives by hunting, and purfues its prey to the tops of the higheft trees. It feeds on Weafels, Ermines, Squirrels, \&c. which are unable to efcape it. It watches the approach of the Fallow-deer, Hare, and other animals, and darts upon them from the branches of trees, where it lies concealed; feizes them by the throat, and drinks their blood; after which, it abandons them, and goes in queft of frefh game. Its fight is remarkably quick, and it fees its prey at a great diftance. -It often eats no more of a Sheep or a Goat than the brain, the liver, and the inteftines. It will fometimes dig under the doors to gain admifion into the fheepfold. -When attacked by a Dog, it lies down on its back, ftrikes defperately with its claws, and frequently obliges its affailant to retreat.

Although the Lynx has nothing in common with the Wolf, it has been difinguifhed by the name of LupusCervarius, or the Stag-Wolf. Its manner of howling is fimilar to that of the Wolf; and when heard at a diftance, is not eafily diftinguifhed from the cry of that aniInal. The epithet Cervarius has been added, becaufe its fain is rariegated with fpots like that of a young Stag.

A variety is found in the inner parts of the province of $\mathrm{New}-\mathrm{York}$, which is called the Bay $L j n x$, and is about swice the fize of a large Cat. Its hair is fhort and 
fmooth; its general colour is a bright-bay, obfcurely marked with dufky fpots; on its face there are black ftripes, pointing downward towards the nofe; on each fide of the upper lip it has three rows of fmall black fpots, with long whifkers iffuing from them; each cheek is marked with long black ftripes, of a circular form, proceeding from the corners of the eyes; the under part of the body, and infides of the legs, are white; the infide of each fore leg is marked on the upper part with two black bars; its tail, which is fhort, is marked with bars of a duky colour, and at the end with one of a deep-black; the tip and under fide are white.

The Lynxes of our days muft be very different animals from thofe which have been defcribed by poets as drawing the chariot of Bacchus; for, befides the impracticability of training thefe animals to the yoke, we find, that the Lynx is not an inhabitant of India, nor of any of the warmer countries of Afia conquered by that hero.- It prefers cold to even temperate climates, and is common in the forefts of the northern parts of Europe, Afia, and America.

The ancients feem to have giren the name of $L_{y n x}$ to an animal which exifted only in imagination, and may be ranked with their other ideal monfters and prodigies, the Sphynx, the Pegafus, and the Unicorn.-Its fight was faid to penetrate the moft opaque bodies, and its urine to be converted into a precious ftone. 


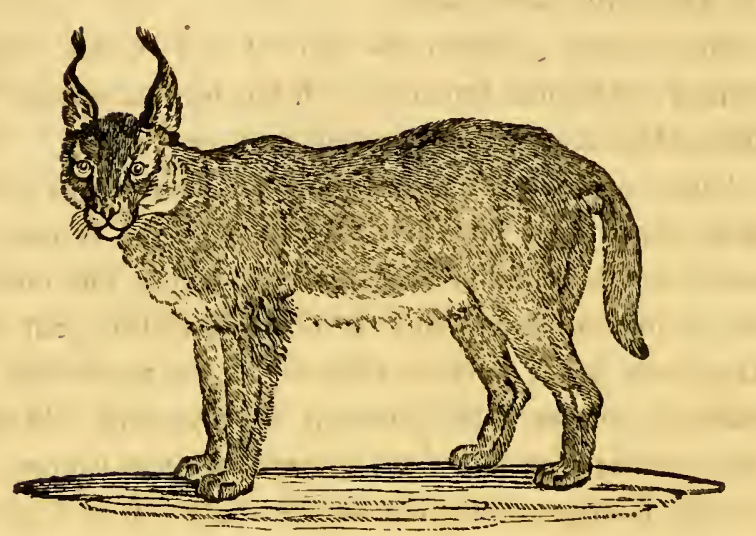

THE CARACAL,

\section{(Le Caracal, Buff.)}

Resembles the Lynx in fize, figure, and afpect, as well as in having its ears tipt with a pencil of black hairs.-It differs from the laft-mentioned animal in not being fpotted; its hair is rougher, and of a pale reddifh-brown; its tail is longer, and of an uniform colour; its face is more lengthened, its look more fierce, and its nature and difpofition more favage.

- This animal is found only in warm climates, and is common in Perfia, India, Barbary, and in all the countries inhabited by the Lion, the Panther, and the Ounce. -It is called in Perfia the Syab-Gufh; and in the Turkifh language, the Karrab-Kulak. Both thefe names fignify the Cat wuith black Ears.-It is faid to follow the Lion, and to feed on the remains which that animal 
leaves of his prey; for which reafon it is called among the Arabs the Lion's Guide.

The Caracal is about the fize of a Fox, but much ftronger, and more ferocious. It has been known to attack a Hound, and inftantly tear it to pieces.

This animal is extremely difficult to tame; but when taken young, and reared with great caution, it may be trained to the chafe.-It is ufed in taking the fmaller fort of animals, in which it is very fuccefsful; but it is active only in the purfuit of thofe that are too feeble for refiftance, or too timid to exert their powers. Whenever it meets with one that is fuperior to it in ftrength, it lofes its courage, and gives up the chafe.-It is likewife employed in catching birds; fuch as cranes, pelicans, peacocks, \&c. which it furprifes with fingular addrefs.When it has feized its prey, it holds it faft in its mouth, and lies upon it for fome time quite motionlefs.

There are fome varieties in this animal.-The face of the Nubian Caracal is rounder; the ears black on the outfide, interfperfed with filver-coloured hairs; on the breaft, belly, and infides of the thighs, there are fmall bright-yellow fpots; and it has the Mule-crofs on the withers, like moft of the Barbary Caracals.

In Lybia, there are Caracals with white ears, tufted at the end with thin black hairs: They have white tails, the extremities of which are furrounded with four black rings; and on the hind part of each leg there are four black fpots. They are fmall, not exceeding the fize of a domeftic Cat.

We have now gone through all the principal varieties which conftitute this numerous race; in all of which, as has been already obferved, from the Lion to the common 
Cat, we may perceive a friking fimilitude in difpofition, form, and manners. This agreement is likewife obfervable in their internal conformation, which is Atill more exact,-in the fhortnefs of their inteftines, the fharpnefs and number of their teeth, and in the ftructure of their feet and claws. They are all equally carnivorous; and tear, rather than chew their meat. They eat flowly, and growl whilft they feed, as if afraid of lofing their prey. They are all cowardly, and feldom make an attack but where conqueft is certain.

Animals of this race may be confidered as the moft formidable enemies of mankind. There are others more powerful, but their difpofitions are milder, and they feldom offend till they find themfelves injured: Others are more numerous, but they are weaker, and find their fafety not in oppofing, but in flying from man. Thefe are the only quadrupeds that in any degree make good their ground againft him, and maintain a kind of divided fway over many fair and fertile tracts, that feem, in other refpects, formed for the comfort and convenience of focial life.

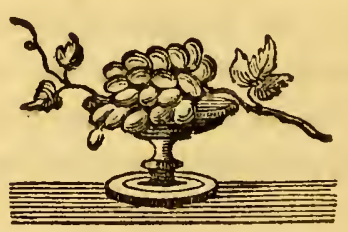




\section{ANIMALS OF THE WEASEL KIND.}

THEsE little, active, and enterprifing animals are parm ticularly diftinguifhed from other carnivorous kinds by the length and flendernefs of their bodies, which are admirably adapted to their manner of living, and methods of taking their prey. They are fo fmall and flexible, as to wind like worms into very fmall crevices and openings; whither they eafily follow the little animals that ferve them for food.

All the animals of this kind are furnifhed with fmall glands, placed near the anus, from which an unctuous matter continually exudes : The effluvia of it is extremely offenfive in the Polecat, Ferret, Weafel, \&c.; but in the Civet Cat, Martin, and Pine Weafel, it is an agreeable perfume.-They are all equally marked for rapine and cruelty; they fubfint only by theft, and find their chief protection in their minutenefs. They are all, from the hortnefs of their legs, flow in purfuit; and make up that deficiency by, patience, affiduity, and cunning.

As their prey is precarious, they can live a long time without food. When they fall in with plenty, they immediately kill every thing within their reach, before they begin to fatisfy their appetite; and always fuck the blood of every animal they kill, before they eat its flem.

Thefe are the principal peculiarities common to this kind; all the fpecies of which have fo ftriking a refemblance to each other, that having feen one, we may form a very juft idea of the reft.-The moft obvious difference confifts in their fize. We thall therefore begin with the fmalleft of this numerous clafs, and proceed gradually upwards to the largeft. 


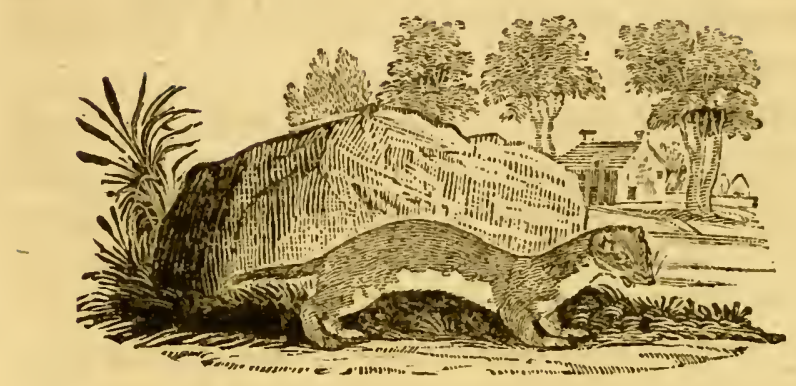

THE WEASEL.

(Muffela Nivalis, Lin.-La Belette, Buff.)

THE length of this animal does not exceed feven inches, from the nofe to the tail, which is only two inches and a half long, and ends in a point: Its height is not above two inches and a half; fo that it is nearly five times as long as it is ligh.

The moft prevailing colour of the Weafel is a pale reddiflt-brown on the back, fides, and legs; the throat and belly are white; beneath the corners of the mouth, on each jaw, is a fpot of brown. It has whifkers, likè a Cat: Its ears are large, and have a fo'd at the lower part, that gives them the appearance of being double; its eyes are fmall, round, and black; its teeth are thirtytwo in number, and extremely fharp.

The Weafel is very common, and well known in moft parts of this country; is very deftructive to young birdś, poultry, rabbits, \&xc.; and is a keen devourer of eggs, which it fucks with great avidity. It will follow a Hare, which is terrified into a ftate of abfolute imbecility at the 
fight of this little animal, and gives itfelf up to it without refiftance, making at the fame time the moft piteous outcries.

The bite of the Weafel is generally fatal. It feizes its prey near the head, and fixes its fharp teeth into a vital part. A Hare, Rabbit, or any other fmall animal, bit in this manner, is never known to recover; but lingers for fome time, and dies. The wound is fo fmall, that the place where the teeth enter can fcarcely be perceived.

It is remarkably active, and will run up the fides of a wall with fuch facility, that no place is fecure from it.

The Wearel is very ufeful to the farmer, and is much encouraged by him. During winter it frequents his barns, out-houfcs, and granaries; which it effectually clears of Rats and Mice. It is, indeed, a more deadly enemy to them than even the Cat itfelf; for, being more active and flender, it purfues them into their holes, and kills them aifer a fhort refiftance. It creeps alfo into pigeon loles, and deftroys the young ones; catches fparrows, and all kinds of fmall birds; and when it has brought forth its young, it hunts-with ftill greater boldnefs and avidity.-In fummer, it ventures at a diftance from its vifual haunts; is frequently found by the fide of waters, near corn-mills; and is almoft fure to follow wherever a fwarm of Rats has taken poffeffion of any place.

The evening is the time when it begins its depredations. Towards the clofe of the day it may frequently be feen ftealing from its hole, and creeping about the farmer's yard in fearch of its prey. If it enter the place where poultry are kept, it feldom attacks the cocks or the old hens, but always aims at the young ones. It 
does not eat its prey on the fpot where it has killed it; but, where it is not too large, carries it away to its retreat. It alfo breaks and fucks all the eggs it can meet with; and, not unfrequently, kills the hen that attempts to defend them.

The Weafel is a wild and untractable little animal. When kept in a cage, it feems in a continual ftate of agitation, is terrified at the fight of every perfon that approaches to look at it, and hides itfelf in the wool or hay which is given to it for that purpore.

It conveys all its food to its hiding-place, and will not touch it till it begin to putrefy.-It paffes the greateft part of the day in fleeping, and ufually employs the night in exercife and eating.

The female brings forth in the fpring, and generally produces four or five at one litter. She prepares a bed for them, of ftraw, leaves, and mois. The young are brought forth blind, but very foon acquire ftrength enough to follow their dam, and affift in her excurfions. They will attack ferpents, water-rats, moles, field-mice, \&c.: They overrun the meadows, and frequently kill the partridges, and fuck their eggs.

The motion of the Weafel confifts of unequal and precipitant leaps; and, in climbing a tree, it makes a confiderable fpring of fome feet from the ground. It jumps in the fame manner upon its prey; and being extremely limber, evades the attempts of much ftronger animals to feize it.

We are told, that an eagle having feized a Weafel, mounted into the air with it, and was foon after obferved to be in great diftrefs. Its little enemy had extricated itfelf fo far, as to be able to bite it feverely in the throat; 
which prefently brought the eagle to the ground, and gave the Weafel an opportunity of efcaping.

Notwithftanding the wildnefs of its nature, there are not wanting inftances to prove, that it is capable of being thoroughly tamed. M. Buffon, who afferted the impoffibility of bringing the Weafel into any degree of fubjection, is afterwards corrected by a lady, who affures him, that the had tried the experiment upon a young Weafel taken in her garden; which foon learned to recognife and lick the hand from which it received its food, and became as familiar, careffing, and frolicfome as a Dog or a Squirrel. The fame author mentions another experiment, made by a gentleman, who trained a young Weafel fo completely, that it followed him wherever he went. -The method of taming them is to ftroke them gently over the back; and to threaten, and even to beat them, when they bite.

Thefe facts may ferve to thew the poffibility of rendering this animal domeftic; and hold out a ufeful hint to us, that its fervices might be very great in clearing thips, granaries, and other places, from the vermin with which they are frequently infefted: For it is very well known, that one of thefe animals will kill more rats and mice than any Cat, being better able to purfue them into their holes and lurking-places.

The odour of the Weafel is very ftrong, efpecially in the fummer time, or when it is irritated or purfued; it is then intolerable, and may be fmelt at fome diftance,

The following circumftance, related by Buffon, will fhew, that this animal has a natural attachment to every thing that is corrupt:-A Weafel was taken in his neigh- 
bourhood, with three young ones, out of the carcafe of a Wolf that had been hung on a tree by the hind feet. 'The Wolf was almoft entirely putrefied; and the Weafel had made a neft of leaves and herbage for her young in the thorax of the putrid carcafe.

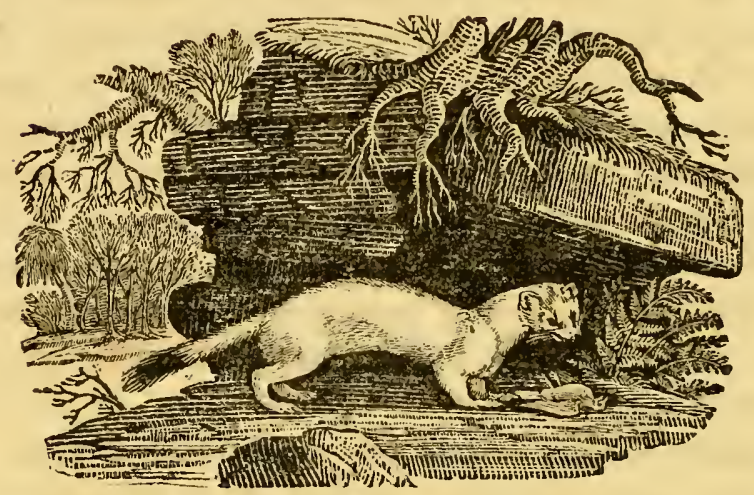

THE STOAT.

(Muftela Erminea, Lin.-Le Rojelet, Buff.)

THE difference in thape between this animal and the Wearel is fo fmall, that they have frequently been defcribed under the fame denomination; the fmall Stoat being fometimes miftaken for a Weafel.

Its length is about ten inches; the tail five inches and a half, very hairy, and tipt with black at the end; the edges of the ears, and ends of the toes, are of a yellowifh-white: In other refpects, it perfectly refembles the Weafel in colour as well as form. 


\section{HISTORY OF QUADRUPEDS.}

In the moft northern parts of Europe, it regularly changes its colour in winter, and becomes perfectly white, except the end of the tail, which remains invariably black. 'It is then called the Ermine, and is much fought after for its valuable fur, which makẹs a confiderable article of commerce in Norway, Lapland, Ruflia, and other cold countries; where it is found in prodigious numbers. It is alfo very common in Kamfchatka and Siberia, and is taken in traps baited with flefh. The thins are fold in the country for from two to three pounds fterling per hundred. - In Norway, they are eiwher fhot with blunt arrows, or taken in traps made of two fiat fiones, one being propped up with a ftick, to which is faftened a baited ftring; and as foon as the animal begins to nibble, the ftone falls down, and crufhes it to death.-The Stoat is likewife found white in the svinter time in Great Britain, and is then erroneoufly called a $W$ thite $W$ eafel. Its fur, however, among us, is of little value, having neither the thicknefs, the clofenefs, nor the whitenefs, of thofe which come from Siberia.

One of them, which we had in our poffeffion, had entirely affimed its winter robe; but with a confiderable mixture of yellow, efpecially on the top of the head and back.

They begin to change from brown to white in November, and refume their fummer vefture in March.

The natural hiftory of this animal is much the fame with that of the Werfel; its food being young birds, rabbits, mice, Stc.; its agility the fame; and its fcen equally fetid.

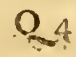




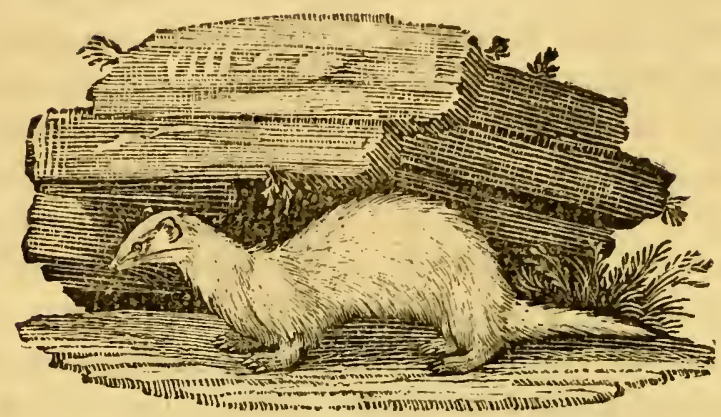

THE FERRET,

(Mufela Furo, Lisı,-Le Furet, Buff.)

Is only known to us in a kind of domeftic ftate.-It is originally a native of Africa; from whence, according to Strabo, it was brought into Spain; and, from its known enmity to the Rabbit, was made ufe of to reduce the numbers of them with which that kingdom abounded. It has fince been cmployed for the fame purpole in various parts of Europe; but as it is not able to bear the feverity of a cold climate, it cannot fubint without great care and fhelter. It is ufually kept in a box, with wool; of which it makes itfelf a warm bed. It fleeps a great part of the day; and the moment it awakes, feems eager for its food, which is commonly bread and milk.

It breeds twice a year. The female goes fix weeks with young. Some of them devour their offspring as foon as they are brought forth; when they immediately come in feafon again, and have three litters, which gene- 
rally confint of five or fix, but fometimes feven or eight, and even nine.

It is apt to degenerate in this country, and lofe in fome degree its ferocity. Warreners are therefore obliged to procure an intercourfe between the female and the Foumart. The produce is a breed of a much darker colour than the Ferret, partaking more of that of the Foumart.

Its length is about fourteen inches; that of the tail five: Its nofe is tharper than that of the Weafel or the Foumart; its ears are round; and its eyes red and fiery: The colour of the whole body is a very pale yellow.

The Ferret is naturally fuch an enemy to the Rabbit, that if a dead Rabbit be laid before a young Ferret, it inftantly feizes upon it, although it has never feen one before: If a living Rabbit be prefented to it, the Ferret is ftill more eager, feizes it by the neck, winds itfelf round it, and continues to fuck its blood till it be fatiated.-When employed in the bufinefs of the warren, it muft be muzzled, that it may not kill the Rabbits in their holes, but only oblige them to come out, that the warrener may catch them in his nets. If the Ferret be fuffered to go in without a muzzle, or hould difengage itfelf from it whilft in the hole, there is great danger of lofing it: For, after fatisfying itfelf with blood, it falls afleep, and it is then almoft impoffible to come at it.'The moft ufual methods of-recovering the Ferret are, by digging it out, or fmoking the hole. If thefe do not fucceed, it continues during the fummer among the Rabbit holes, and lives upon the prey it finds there; but being unable to endure the cold of the winter, is fure to perifh. 
It is fometimes employed with grent fuccefs in killing Rats, and is frequently, kept in granaries and mills for that purpofe. It is extremely vigilant in the purfuit of them, and will not fuffer one to live where it is.-A young Ferret, after it has feized a Pat, will fuffer itfelf to be dragged by it a confiderable way before it has killed it, which it never fails to do in a fhort time.

If the Ferret could be kept warm enough at fea, it might be extremely ferviceable in deftroying the Rats, which frequently commit fuch grent deprcdations on board of thips, and have fometimes been the occafion of their total lofs.

The Ferret, though eafily tamed, is foon irritated.-Its odour is fetid; its nature voracious; it is tane without attachment; and fuch is its appctite for blood, that it has been known to attack and kill children in the cradle. -When angry, it is apt to bite; and the wound is cilficult to cure.

The Madagafcar Weafel, or Vanfire of M. Buffon, may be referred to this fpecies; to which its fize and form are ftrikingly fimilar.-It is about fourteen inches in length: The hair is of a dark-brown colour, mixed with black: It differs from the Ferret in the number of its grinding-teeth, which amount to twelve; whereas, in the Ferret, there are but eight: The tail is longer than that of the Ferret, and better furnifhed with hair.

The fame author mentions another animal of this fpecies under the name of the Nems, which is a native of Arabia.-It refembles the Ferret in every thing but the colour, being of a dark-brown, mixed with white; the belly is of a bright-yellow colour, without any mixture; the prevailing colour on the head and round the eyes is a 


\section{HISTORY OF QUADRUPEDS.}

clear yellow; on the nofe, cheeks, and other parts of the face where the hair is fhort, a tincture of brown more or lefs prevails, and terminates gradually above the eyes; the legs are covered with fhort hair, of a deep-yellow colour; on each foot there are four toes, and a fmall one behind; the claws are fmall and black; the tail, which is more than double the length of that of the Ferret, is very thick at its origin, terminates in a point, and is covered with long hair, fimilar to that on the body.

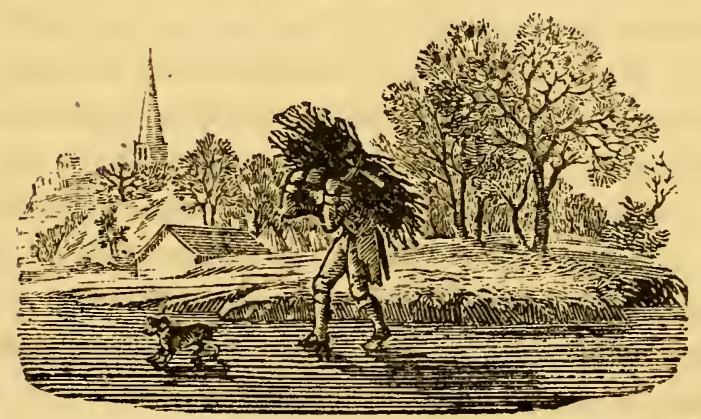




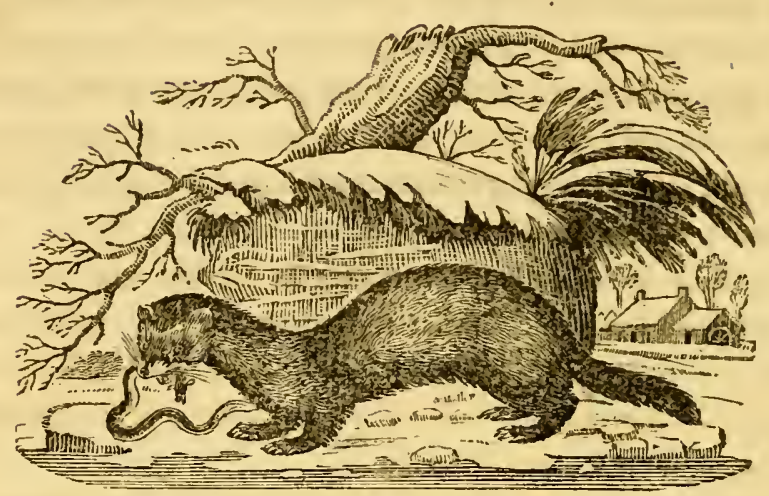

THE FOUMART,

(Muftela Putorius, Lin._Le Putois, Buff.)

So called from its offenfive fmell, as well as to diftinguifh it from the Martin, to which it bears a ftrong refemblance. It is likewife called the Polecat, or Fitchet.

Its length is about feventeen inches, exclufive of the tail, which is fix inclies; its cyes are fmall, very brilliant, and, when the animal is irritated or afraid, fhine in the dark with fingular luftre; its ears are fhort, broad, and tipt with white on their edges; it is white about the mouth; the reft of the body, is for the moft part of a deep-chocolate colour; the fides are covered with hairs of two colours; the ends being dark like the reft of the body, and the middle of a full tawny colour.

The fhape of the Foumart, like all others of this genus, is long and flender, the nofe tharp-pointed, and the legs thort; the toes are long, and the claws tharp. It is 
in every refpect admirably formed for that peculiar mode of life affigned to it by the all-wife Author of Nature.

It is vcry active and nimble, runs very fant, and will creep up the fides of walls with great agility. In running, its belly fcems to touch the ground; in preparing to jump, it arches its back, and makes its fpring with great forcc.

It is very deftructive to poultry, pigeons, and young game of all kinds. It makes great havock amongft Rabbits; and its thirft for blood is fo great, that it kills many more than it can eat. One or two of them will almoft deftroy a whole warren.

It is never feen abroad in the day-time, unlefs forced from its hole; and is feldom hunted but in the winter, being at that feafon eafily found by tracing its footfteps in the fnow.- It generally refides in woods or thick brakes; where it burrows under ground, forming a fhallow retreat about two yards in length, commonly ending among the roots of trees.

In the winter feafon, it frequents houfes, barns, \&c. feeding on poultry, eggs, and fometimes milk.-But it has another mode of procuring fubfiftence, which has hitherto efcaped the obfervation of the naturalift; and which, though fingular, we can vouch for the truth of. During a fevere ftorm, one of thefe animals was traced in the fnow from the fide of a rivulet to its hole, at fome difance from it: As it was obferved to have made frequent trips, and as other marks were to be feen in the fnow which could not eafily be accounted for, it was thought a matter worthy of greater attention: Its hole was accordingly examined, the Foumart taken, and eleven fine eels were difcovered to be the fruits of its noc- 
turnal excurfions. The marks in the fnow were found to have been made by the motion of the eels in the creature's mouth.

From the above curious circumftance, we have given a reprefentation of this animal (which was drawn from the life) in poffeffion of this fingular booty.-It may be matter of amufing inveftigation for fome future naturalift to enquire by what arts this wily animal finds a booty fo apparently difficult to attain.

In attending to the inftinctive faculties of animals, there is room for deep and diligent enquiry; and, though our progrefs is liable to many interruptions, it is a delightful tafk to follow the workings of Nature through all her intricate and curious windings: Every fep we gain is a fufficient reward for our trouble, and leads us to admire the wifdom and goodnefs of that Difpenfation which furnifhes every creature with fufficient and ample powers to provide for all its wants, neceffities, and comforts.

The female Foumart brings forth in the fummer, generally five or fix at a time. She fuckles them but a Thort time, and accuftoms them early to live upon blood and eggs.

Though the fmell of this animal is rank and difagreeable, even to a proverb, yet the fin is dreft with the hair on, and ufed as other furs, without retaining its offenfive odour.

The Foumart is very fierce and bold. When attacked by a Dog, it will defend itfelf with great fpirit, attack in its turn, and faften upon the nofe of its enemy with fo keen a bite, as frequently to oblige him to defift. 


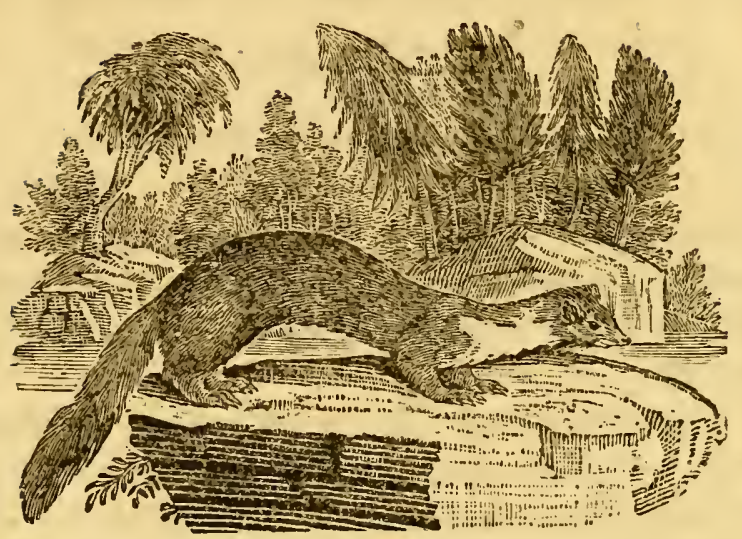

THE PINE-WEASEL, OR YELLOW-BREASTED MARTIN, (La Marte, Buff.)

Ingabits the North of Europe, Afia, and America: It is likewife found in Great-Britain, but is not numerous there.-It lives chiefly in large forefts, efpecially where the pine-tree abounds, of the tops of which it is very fond.

North-America abounds with thefe animals. Prodigious numbers of their 1 kins are annually imported from thence: Above thirty thoufand fkins have been brought over from Canada in one year, and from Hudfon's Bay nearly fifteen thoufand in the fame time.

The principal difference between the Pine-Weafel and the Martin is in the colour. The breaft of the former is yellow; the colour of the body much darker; and the fur, in general, greatly fuperior in finenefs, beaty, and value. 


\section{THE MARTIN, (Mufela Marle, Lin.-La Fosine, Buff.)}

Is much more common in this country than the PineWeafel.-It lives wholly in woods, and breeds in the hollows of trees. It produces from four to fix young ones at a time.

This fpecies is the moft beautiful of all the Weafel kind. Its head is fmall, and elegantly formed; its eyes are lively: and its motions quick and graceful.

When taken young, it is eafily tamed, and becomes extremely playful and good-humoured. Its attachment, however, is not to be depended upon. It readily takes advantage of the firt opportunity to regain its liberty, and retire to the woods, its natural haunts.

The food of the Martin is much the fame with other animals of its kind. It makes inceffant war with Rats, Mice, and other vermin : Poultry, game, and fmall birds, are its conftant prey: It feeds alfo on grain, and is extremely fond of honey.

M. Buffon tells us of one of them that he had tamed, which, he remarks, drank frequently. It fometimes. flept two days fucceffively, and at other times would continue awake as long. In preparing itfelf for fleep, it folded itfelf up in a round form, and covered its head with its. tail. When awake, its motions were fo violent, fo conStant, and fo troublefome, that it was neceffary to keep it chained. From the flexibility of its body, it eafily eluded its fetters; and, after returning once or twice, at laft abfented itfelf entirely. 
The Martin is about eighteen inches long; the tail ten, and full of hair, efpecially towards the end, which is thick and bufhy; the ears are broad, rounded, and open; the body is covered with a thick fur, of a darkbrown colour; the head brown, mixed with red; the throat and breaft are white; the belly is of the fame colour with the back, but a little paler; the feet are broad, and covered on the under fide with a thick fur; the claws white, large, and flarp, well adapted for climbing trees, which in this country are its conftant refidence.

The fkin and excrements have an agreeable muky fcent, and are entirely free from that ranknefs which is fo difgufting in other animals of this kind. Its fur is valuable, and in high eftimation. 


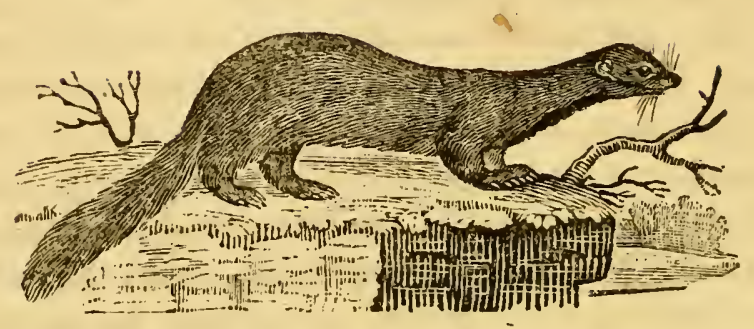

THE SABLE,

(Muffela Zibellina, Lin.-La Zibeline, Buff.)

So highly efteemed for its $\mathrm{fkin}$, is a native of the fnowy regions of the North: It is found chiefly in Siberia, Kamfchatka, and fome of the iflands which lie between that country and Japan. It is alfo found in Lapland.

The darkeft furs are the moft valuable. A fingle fkin, though not above four inches broad, is fometimes valued as high as fifteen pounds. The fable differs from all other furs in this, that the hair turns with equal eafe to either fide.

The Sable refembles the Martin in form, and is about the fame fize. It lives in holes in the earth, by the banks of rivers, and under the roots of trees. It makes its neft of mofs, fmall twigs, and grafs.

The female brings forth in the fpring, and produces from three to five at one time. Sometimes, like the Martin, it forms its neft in the hollow of a tree.

It is very lively and active, and leaps with great agility from tree to tree, in purfuit of fmall birds, wood- 
cocks, fquirrels, \&c. It likewife lives upon rats, fifhes, pine tops, and wild fruits.

It is affirmed by naturalifts, that the Sable is not averfe to the water; and, from the finenefs and clofenefs of its fur, there is great reafon to fuppofe that it is much accuftomed to that element, from which it alfo derives a part of its fubfiftence: And as a farther proof that this animal is in fome degree amphibious, we are told by travellers*, that it is very numerous in fmall iflands, where the hunters go in queft of them. It is mentioned by Ariftotle as a water animal, and is defcribed by him under the name of Satberius.

The hunting of the Sables is chiefly carried on by criminals confined to the defart regions of Siberia, or by foldiers fent thither for that purpofe, who generally remain there feveral years. They are obliged to furnifh a certain quantity of furs, and fhoot with a fingle ball, to injure the fkin as little as poflible. They frequently take them in traps, or kill them with blunt arrows.-As an encouragement to the hunters, they are allowed to fhare among themfelves whatever fkins they take above the allotted number; and this, in a few years, amounts to a confiderable premium.--The liunters form themfelves into fmall troops, each of which is directed by a leader of their own chufing.

The feafon of hunting is from November to February; for at that time the Sables are in the higheft perfection: Thofe caught at any other time of the year are full of thort hairs, and are fold at inferior prices. The beft

* Avril's Travels, p. I 40.

$\mathrm{R}_{2}$ 
fkins are fuch as have only long hair, which is always black, and of a gloffy brightnefs. Old furs do not retain their glofs.-Both the Rufians and Chinefe have a method of dying their furs; but the dyed fables are eafily, difcovered, having neither the finoothnefs nor the brightnefs of the natural hair.

'The bellies of Sables, which are fold in pairs, are about two fingers in breadth, and are tied together in bundles of forty pieces, which are fold at from one to two pounds fteprling. The tails are fold by the hundred, from four to eight pounds.

There are inftances of Sables being found of a fnowy whitenefs; but they are rare, and bought only as curiofities.

The hunters of thefe animals are frequently obliged to endure the utmoft extremity of cold and hunger in the purfuit of their booty. They penetrate deep into immenfe woods, where they have no other method of finding their way back but by marking the trees as they advance: If this fhould by any means fail them, they are inevitably loft. They fometimes trace the Sables on the new-fallen fnow to their holes, place their nets at the entrance, and wait frequently two or three days before the animal comes out.-It has happened by the failure of their provifions, that thefe poor wretches have been reduced to the necefrity of tying thin boards tight to their ftomachs to prevent the cravings of appetite.-Such are the hardfhips our fellow-creatures undergo to fupply the wants of the vain and luxuriant!

An animal, fimilar to the Sable, is mentioned by $\mathrm{Mr}$ Pennant under the name of the Fifber. It is found in North-America; and, by the number of Akins imported, 


\section{HISTORY OF QUADRUPEDS.}

muft be very numerous there, nearly fix hundred of them having been brought in one feafon from New-York and Penfylvania.-The hair on the body is moftly black; the fides browin; the ears are broad and round, dufky on their outfides, and edged with white; the face and fides of the neck pale-brown, mixed with black; the feet are very broad, and covered with hair, even to their foles; the tail is full and bufhy; the length, from nofe to tail, is twenty-eight inches; the tail feventeen.

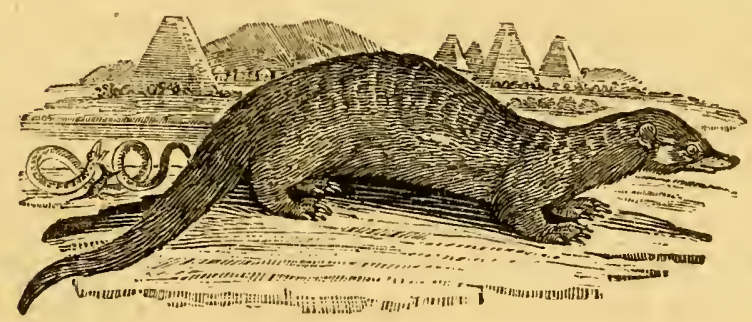

THE ICHNEUMON.

(Viverra Icbneumon, Lin._La Mangoufte, Buff.)

This animal, in Egypt, is domeftic, like the Cat; and is retained by the natives for the fame ufeful purpofes of clearing their houfes of rats and mice.-With all the ftrength and agility of the Cat, it has a more general appetite for carnage. It attacks, without dread, the moft 2 deadly ferpents, and preys on every noxious reptile of the torrid zone, which it feizes and kills with great avidity.-It is faid, that when it is wounded by a ferpent,

R 3 
and begins to fecl the effect of the poifon, it immediately has recourfe to a certain root, which the Indians call after its name, and affert that it is an antidote for the bite of any venomous reptile.

The Ichneumon is the noft formidable enemy of the Crocodile: It deftroys its eggs, which it digs out of the fand, where they are laid to latch by the lieat of the fun; and kills great numbers of young Crocodiles foon after their production, before they are able to reach the water. It was for this reafon that the ancient Egyptians worhipped this animal, and ranked the Ichneumon among thofe deities that were moft propitious to them.

In its domentic ftate, it is perfectly tame and gentle. M. d'Obfonville fpeaks of one which he reared from a young one. It became tamer than a Cat, was obedient to the call of its mafter, and followed him wherever he went. One day he brought a fmall water-ferpent alive, being defirous to know how far its inftinct would carry it againft a being with whom it was hitherto entirely unacquainted. Its firft emotion feemed to be aftonifhment mixed with anger: Its hair became erect; in an inftant it llipped behind the reptile; and, with remarkable fwiftrefs and agility, leaped upon its head, feized it, and crufhed it with its tecth. This firft effay feemed to have awakened in it its natural appetite for blood, which till then had given way to the gentlenefs of its education: It no longer fuffered the poultry, among which it was brought up, to pafs unregarded; but took the firft opportunity, when it was alone, to ftrangle them: It eat a part of their fiefh, and drank only the blood of others.

Thefe animals are numerous in all the fouthern regions of Afia, from Egypt to the ifland of Java: They 
are alfo found in Africa, in the country about the Cape of Good Hope.-They frequent the banks of rivers, are fond of fifh, are faid to take the water like an Otter, and will continue in it a confiderable time without rifing to take breath.

The Ichneumon varies in fize. The domeflic kind is generally larger than thofe that are wild, and its colours more variegated. It is in general about the fize of a common Cat ; fomewhat longer in the body, and fhorter in the legs. Its fur contains tints of white, brown, fawn-colour, and a dirty filver-gray, which altogether form a mixture very agreeable to the eye. Its form is like that of the Polecat. Its eyes are fmall, but inflamed, and fparkle with a fingular vivacity; its nofe is long and flender; its ears fmall, rounded, and almoft naked; its tail is very thick at the bafe, and tapers to a point; underneath the tail is an orifice, from which a moft fetid humour is fecreted; its claws are long.-It darts upon its prey like an arrow, and feizcs it with inevitable certainty.

It has a fmall foft voice, fomewhat like a murmur; and, unlefs ftruck or irritated, never exerts it. When it fleeps, it folds itfelf up like a ball, and is not eafily awaked. It frequently fits up like a Squirrel, and feeds itfelf with its fore feet; catches any thing that is thrown to it; and will often feign itfelf dead, till its prey come within its reach. 


\section{HISTORY OF QUADRUPEDS.}

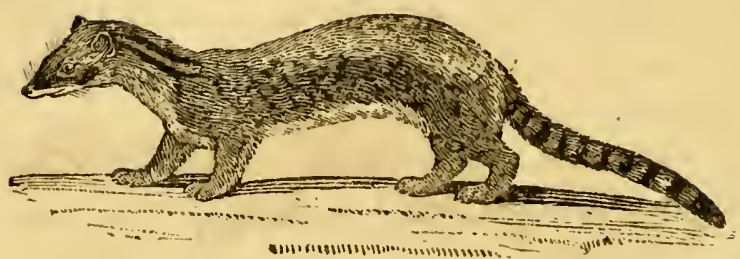

THE FOSSANE.

(La Foglane, Buff.)

Is rather fmaller than the Martin. Its body is flender, and covered with hair of an afh colour, mixed with tawny; the fides of the face are black; at the hind part of the head there are four black lines, extending from thence toward the fhoulders; the tail is long, and annulated with black; its eye is full, round, and black, which gives it a wild and mifchievous afpect.

It inhabits the illand of Madagafcar, Guinea, Cochinchina, and the Philippine Inles. It feeds on flem and fruits, but prefers the latter, and is peculiarly fond of bananas. It is very fierce, and not eafily tamed.

In Guinea, it is called the Berbe; and, by Europeans, the Wine-bibber, being very greedy of palm-wine.-When young, its fleih is reckoned very good to eat.

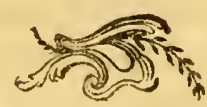




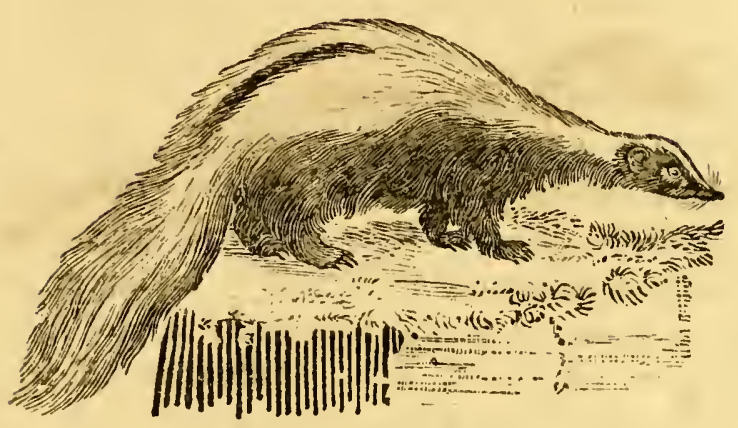

\section{THE SKUNK.}

\section{(Viverra Putorius, Lin.-Le Conepate, Buff.)}

Ir is called the Chinche by the natives of Brazil, and is about the fize of a common Cat. Its nofe is long and flender, and extends a confiderable way beyond the lower jaw; its ears are large, fhort, and rounded; a white fripe extends from the nofe over the forehead and along the back, where it is interfected with a fmall line of black, commencing at the tail, and extending upwards along the middle of the back; its belly and legs are black; its hair is long, efpecially on the tail, which is thick and bufhy.

It inhabits Peru, Brazil, and other parts of SouthAmerica; and is likewife found in North-America, as far as Canada.

It is remarkable for a molt intolerable, fuffocating, fetid vapour, which it emits from behind, when attacked, purfued, or frightened. The ftench of this effuvia is infupportable, and is the creaturc's beft means of defence. 
There are three or four varieties, mentioned by M. Buffon under the name of the Stinking Polecats; all of which poffefs this wonderful faculty of annoying their enemies from the fame quarter.

Some turn their tail to their purfuers, and emit a moft horrible ftench, which keeps both Dogs and men at a confiderable diftance. Others eject their urine to the diftance of feveral feet; and it is of fo virulent a quality, as almoft to occafion blindnefs, if any of it fhould happen to fall into the eyes. Clothes infected with it, retain the fimell for many days: No wafhing can make them fweet; but they muft be even buried in freth foil before they can be thoroughly cleanfed. Dogs that are not properly bred, turn back as foon as they perceive the finell: Thofe that have been accuftomed to it, will kill the animal; but are obliged to relieve themfelves by thrufting their nofes into the ground.

- The Stifling, or Squafh, which is the fecond variety, is nearly of the fame fize with the Skunk. Its laair is long, and of a deep-brown colour. It lives in holes and clefts of rocks, where the female brings forth her young. It is a native of Mexico, and feeds on beetles, worms, and finall birds. It deftroys poultry, of which it only eats the brains. When afraid or irritated, it voids the fame offenfive kind of odour, which no creature dares venture to approach. Profeffor Kalm was in danger of being fuffucated by one that was purfued into a houfe where he flept; and it affected the cattle fo much, that they bellowed through pain. Another, which was killed by a maid-fervant in a cellar, fo affected her with its ftench, that fle lay ill for feveral days: All the provifions that 
were in the place were fo tainted by the fmell, as to be utterly unfit for ufe.

Another variety is called the Conepate, and is, perhaps, no more than the female of the laft-mentioned animal. It is fomewhat fmaller, and differs chiefly from the Squarh in being marked with five parallel white lines, which run along its back and fides from head to tail.

It is a native of North-America.-When attacked, it briftes up its hair, throws itfelf into a round form, and emits an odour which no creature can fupport.

The latt of this peftiferous family which we fhall mention is the Zorilla.

This animal is a native of New-Spain, where it is called the Mariputa. It is found on the banks of the river Oronoque; and, although extremely beautiful, it is at the fame time the moft offenfive of all creatures. Its body is beautifully marked with white ftripes upon a black ground, running from the head to the middle of the back, from whence they are croffed with other white bands, which cover the lower part of the back and flanks: Its tail is long and bufhy, black as far as the middle, and white to its extremity. It is an active and mifchievous little animal. Its ftench is faid to extend to a confiderable diftance, and is fo powerful, as to overcome even the Panther of America, which is one of its greateft enemies.

Notwithftanding this offenfive quality in thefe animals, they are frequently tamed, and will follow their mafter. They do not emit their odour, unlefs when beaten or irritated. They are frequently killed by the native Indians, who immediately cut away the noxious glands; thereby preventing the flen, which is good eating, from 
being infected. Its tafte is faid nearly to refemble the flavour of a young Pig. The favage Indians make purfes of their fkins.

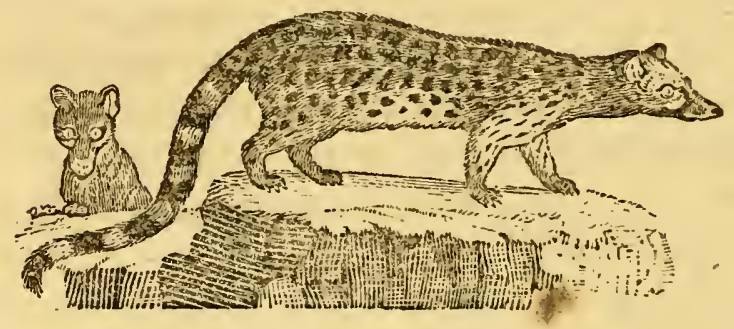

\section{THE GENET,}

(Viverra Genetta, Lin.-La Genette, Buff.)

Is as much diftinguifhed for the agreeable perfume which it yields, as thofe we have juft defcribed are for the rankeft and moft difagreeable odour in nature.

The body of the Genet is longer than that of the Martin; its head is long and flender, with a tharp muzzle; its ears are a little pointed; its hair foft, fmooth, and Ihining; of a tawny-red colour, fpotted with black; along the ridge of the back there is a kind of mane of long hair, which forms a black line from head to tail; the fpots on the fides are round and diftinct, thofe on the back almoft ciofe; its tail is long, and marked with feven or eight rings of black. From an orifice beneath. its tail, it yields a kind of perfume, which fmells faintly of muik. 
It is found in Turkey, Syria, and Spain.-We are told by Belon, that he faw Genets in the houfes at Conftantinople as tame as Cats; and that they were ufeful to the inhabitants in deftroying Rats, Mice, and other vermin.

It is a moft beautiful, cleanly, and induftrious animal, and very active in purfuing its prey. Its nature is mild and gentle, its colours beautifully variegated, and its fur valuable. Upon the whole, it feems to be one of thofe animals that, with proper care and attention, might become a ufeful addition to our ftock of domeftic quadrupeds.

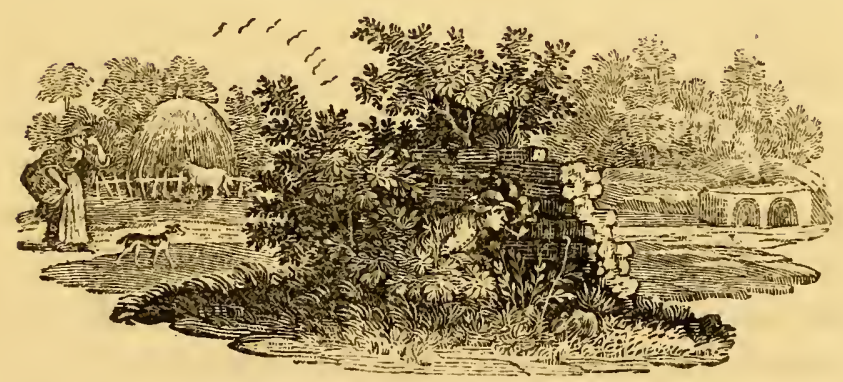




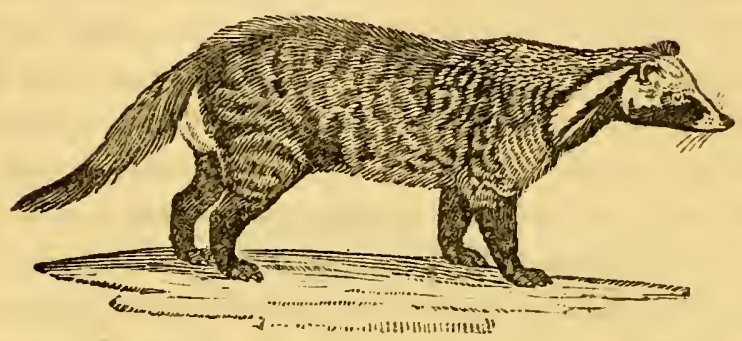

THE CIVET,

(Viverra Zibetka, Lin.-La Civette, Buff.)

Is larger than the Genet, and yields a perfume in much greater quantities, and of a ftronger quality.

Though originally a native of the warm climates of Africa or Afia, it can live in temperate, and even in cold countries; but it muft be fed with nourifhing diet, and carefully defended againt the feverities of the weather.

Numbers of them are kept in Holland, for the purpore of collecting this valuable perfume. The civet procured at Amfterdam is more efteemed than that which comes from the Levant, or India, being lefs adulterated.-To collect this perfume, the Civet is put into a cage, fo narrow, that it cannot turn itfelf: The cage is opened at one end, and the animal drawn backwards by the tail, and fecurely held by its hind legs: A fmall fpoon is then introduced into the pouch which contains the perfume, with which it is carefully fcraped, and the matter put into a veffel properly fecured. This operation is performed two or three times a week. 
The quantity of odorous humour depends much on the quality of the nourifhment and the appetite of the animal, which always produces more in proportion to the goodnefs of its food. Boiled fleth, eggs, rice, fmall animals, birds, and particularly fifh, are the kinds of food the Civet moftly delights in; and thefe ought to be varied, fo as to excite its appetite, and preferve its health. It requires very little water; and, though it drinks feldom, it difcharges its urine frequently. It is fomewhat remarkable, that in this operatian the male is not to be diftinguifhed from the female.-From this circumftance, it has been fuppofed that this was the Hyena of the ancients; and it is certain, that moft of the fables related concerning that monfter are in a certain way applicable to the Civet.

The ancients were well acquainted with the pomatum of the Civet, and afcribed to it certain powers of exciting love; for. which purpofe it ftill conftitutes one of the luxuries of the Eaft.

What has been fabuloufly related concerning the uncertainty of fex in the Hyena, applies much more ftrongly to the Civet; for in the male nothing appears externally but three apertures, fo perfectly fimilar to thofe of the female, that it, is impoffible to diftinguifh the fex otherwife than by diffection.

The perfume of this animal is fo ftrong, that it infects every part of its body: The hair and the fkin are fo thoroughly penetrated with it, that they retain it long after being taken from the body. If a perfon be fhut up in the fame apartment, it is almont infupportable; and, when heated with rage, it becomes ftill more pungent. 
The Civet is naturally favage, and fomewhat ferom cious; yet it is eafily tamed, fo as to be handled without danger.

The teeth are ftrong and fharp; but its claws are weak. It is very active and nimble, leaps like a Cat, and runs with great fwiftners. It lives by hunting; furprifes fmall animals and birds; and, like the Weafel, will fometimes fteal into the yard, and carry off poultry. -Its eyes thine in the dark; and it is probable, that it can fee well enough to purfue its prey during the night, as it is known to be moft active at that time.

The Civet is very prolific in its native climate; but, though it lives and produces its perfume in temperate regions, it is never known to breed there.-Its voice is ftronger than that of the $\mathrm{Cat}$, and has fome refemblance to the cry of an enraged Dog.

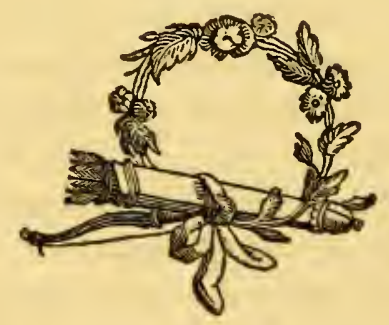




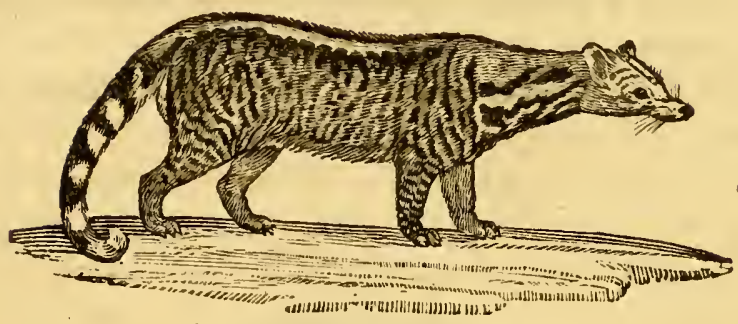

THE ZIBET,

(Le Zibet, Buff.)

Is fo fimilar to the Civet, as to be confidered by fome authors as only a variety of that animal; and it muft be allowed, that they have many effential relations, both in their external and internal ftructure; but they differ from each other by fuch diftinguifhing characteriftics, as entitle them to be regarded as two difinct fpecies. The ears of the Zibet are larger and more erect; and its muzzle is thinner and flatter: Its body is longer than that of the Civet; and its tail, which is longer, is marked with annular fpots, like that of the Genet: It has no mane or long hair on the neck and fpine; and its hair is thorter and fofter.

The perfume of the Zibet is peculiarly violent and piercing, beyond that of either the Civet or the Genet.This odorous liquor is found in a fiffure near the organs of generation. It is a thick humour, of the confiftence of pomatum; and, though very ftrong, is agreeable, even as it iffues from the body of the animal.-This mat- 


\section{HISTORY OF QUADRUPEDS.}

ter of the Zibet muft not be confounded with mulk, which is a fanguinous humour, derived from a fpecies of the Roe-buck, or Goat without Horns*; and has nothing in common with the Zibet, but its ftrong perfume.

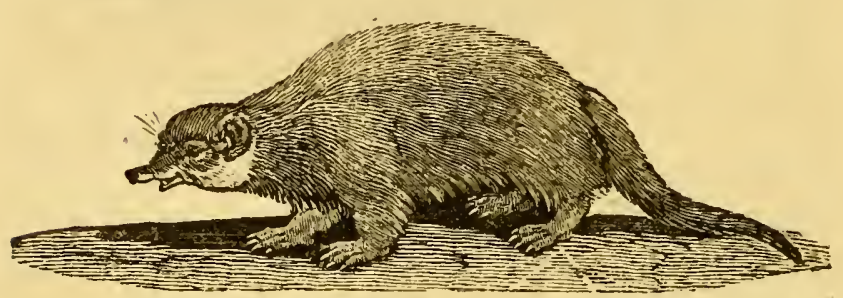

\section{THE SURICATE, OR FOUR-TOED WEASEL,}

Is rather lefs than the Rabbit; it pretty much refembles the Ichneumon, both in fize and in the colour of its hair; only it is rougher, and its tail is not quite fo long. Its upper jaw is much longer than the lower, and very pliant and moveable. It has only four toes on each foot.

One of them, in the pofferfion of M. de Seve, was obferved fometimes to walk on its hind legs, and frequently to fit upright, with its fore feet hanging down on its breaft.

The Suricate is carnivorous, and preys on fmall animals. It is fond of fifh, and ftill more fo of eggs. Like the Squirrel, it makes ufe of its fore paws to convey its victuals to its mouth. In drinking, it laps like a Dog; but will not drink water, except when it is warm. 
That kept by M. de Seve was extremely playful and familiar, knew its own name, and would return at a call. What was remarkable, it feemed to have an averfion to particular perfons, whom it would always bite on their approaching it: Some people were fo difagreeable to it, that even when reftrained, it would make ufe of feveral artifices to come near enough to bite them; and when it could not lay hold of their legs, would fly at their thoes or petticoats. When difcontented, it makes a noife like the barking of a whelp; and when pleafed or careffed, would utter a found like the thaking of a rattle.

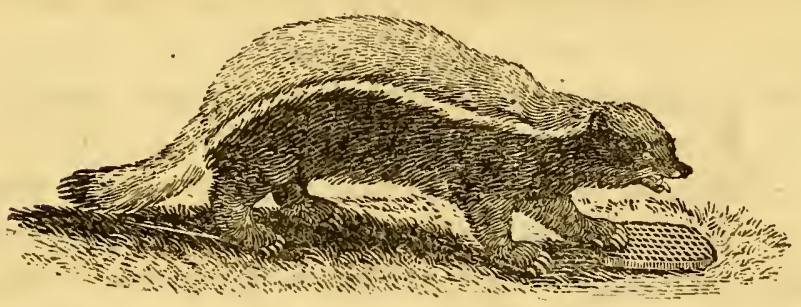

\section{THE RATEL,}

Described by Mr Pennant under the name of the Fizzler, is a native of the Cape of Good Hope. It lives chiefly upon honey, and is endowed with a wonderful faculty of difcovering the fecret retreats where the bees depofit their ftores. About fun-fet, the Ratel is particularly attentive in watching the motions of thefe induftrious infects; and, having obferved their route, it follows with great care the direction in which they fly. It is fre- 
quently affifted in difcovering its delicious booty by a bird called the Honey Guide, (cuculus indicator) which is extremely fond both of honey and the eggs of bees; and, in the purfuit of its food, excites the attention of the Ratel by a loud grating cry of cherr, cherr, cherr; at the fame time flying flowly on towards the place where the fwarm of bees have taken up their abode. The $\mathrm{R}_{\mathrm{a}}$ tel follows the found with great attention; and having plundered the neft, leaves fufficient behind it as a reward for the fervices of its faithful guide. The Ratel is well adapted to this purpofe, as the toughnefs and thicknefs of its fkin effectually defends it from the ftings of the bees. On this account, it is not eafily killed; for its fkin is fo loofely attached to its body, that when feized by a hound, it gives way, and the animal has an opportunity of turning round, and biting its affailant, which it frequently does fo feverely, as to oblige him to defift.

The Ratel, according to Mr Pennant, is two feet long from the nofe to the tail, which is eight inches; its legs are fhort; on each foot it has four toes, armed with long claws; thofe on the fore feet are above an inch long, and very fharp; its tongue is rough; it has no ear-laps; the orifice of the ear is wide, and furrounded by a callous rim; a broad ftripe, of an afh-colour, extends along the back from the forehead to the tail, which is feparated from the black hair on the fides and belly by a light-gray lift running from behind each ear to the tail. It burrows in holes under ground, is faid to be very fetid, and is called the Stinking Badger by M. de la Caille. 


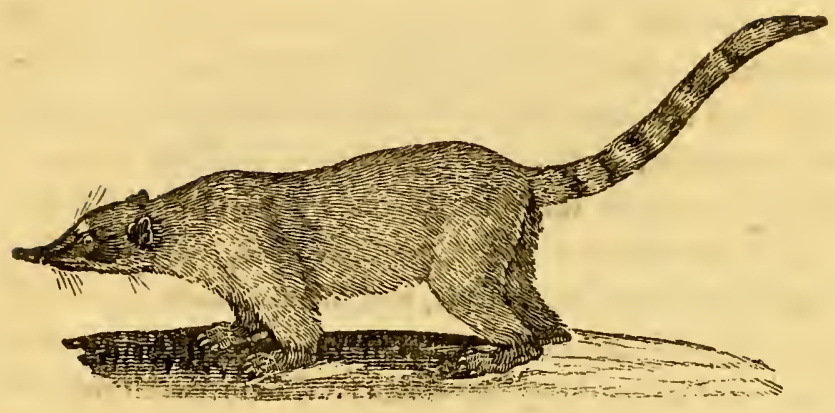

THE COATI, OR BRAZILIAN WEASEL,

\section{(Viverra Nafwa, Lin.-Le Coati, Buff.)}

Has fome refemblance to the Bear in the length of its hind legs, in the form of its feet, in the bufhinefs of its hair, and in the ftructure of its paws. It is fmall. Its tail is long, and variegated with different colours; its upper jaw is much longer than the lower, and very pliant; its ears are rounded; its hair is fmooth, foft, and gloffy, of a bright-bay colour; and its breaft is whitifh.

'Linnæus defcribes one of them, which he kept a collfiderable time, and in vain attempted to bring into fubjection. It was very obftinate and capricious. It killed the poultry, tore off their heads, and fucked their blood. It defended itfelf with great force whenever any perfon attempted to lay hold of it contrary to its inclination; and it ftuck faft to the legs of thofe with whom it was familiar, when it wanted to ranfack their pockets, and, carry off any thing that it found in them. It had an ex- 
treme averfion to hog's briftes, and the fmalleft brufh made it defift. Its mode of living was very fingular: It flept from midnight to noon, kept awake the reft of the day, and uniformly walked about from fix in the evening till midnight, without the leaft regard to the weather. This is probably the time affigned by Nature to this fpecies of animals for procuring their food, which confifts chiefly of young birds, eggs, and fmall animals.

It inhabits Brazil and Guiana, runs up trees very nimbly, eats like a Dog, and holds its food between its fore legs like the Bear.

The Coati ftands with eafe on its hind feet.-It is faid to gnaw its own tail, which it generally carries erect, and fweeps it about from fide to fide.

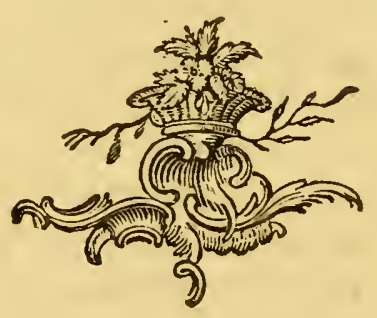




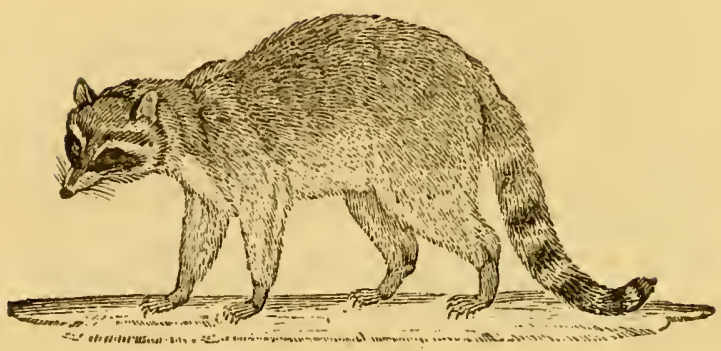

\section{THE RACCOON,}

(Urgius Lotor, Lin.-Le Raton, Buff.)

Is very common in the warm regions of America. It is found alfo in the mountains of Jamaica; from whence great numbers of them frequently defcend into the plantations, and make great havock among the fugar-canes, of which they are particularly fond. The planters confider thefe animals as their greateit enemies,-as they frequently do infinite mifchief in one night's excurfion:They have contrived various methods of deftroying them, yet ftill they propagate in fuch numbers, that neither traps nor fire-arms can repel them.

The Raccoon is fomewhat lefs than the Badger: Its head refembles that of a Fox, but its ears are round and much fhorter, and its upper jaw very pointed, and longer than the lower: Its eyes, which are large, are furrounded with two broad patches of black: Its body is thick and fhort, covered with long hair, black at the points, and gray underneath; its tail is long and bufly, 
and marked with alternate rings of black and white; its fcet and toes are black.

The Raccoon is very active and nimble. Its claws, which are extremely fharp, enable it to climb trees with great facility. It moves forward chiefly by bounding; and, though it proceeds in an oblique direction, runs very fwiftly.

When tamed, it is good-natured and fportive; but is almoft conftantly in motion, and as unlucky and inquifitive as a Monkey, examining every thing with its paws, which it makes ufe of as hands to lay hold of any thing that is given it, and to carry its meat to its mouth. It fits up to eat, is extremely fond of fweet things and ftrong liquors, with which it will get exceflively drunk. It has all the cunning of the Fox, is very deftructive of poultry, but will eat all forts of fruits, grain, and roots. It has a peculiar method of dipping every thing in water it intends to eat, and will feldom tafte bread till it be well foaked. It opens oyfters with aftonifhing dexterity, feparates the fhells, and leaves not a veftige of the fifh. It does this without looking at the oyfter, but places it under its hind paws, and with its fore feet fearches for the weakeft part, where it fixes its claws, forces it open, and fnatches out the fifh. It likewife devours all kinds of infects, delights in hunting fpiders, and, when at liberty in a garden, will eat grafhoppers, fnails, worms, \&c. It is very cleanly, and always retires to obey the calls of Nature. It is familiar, and even carefling, leaps upon thofe it is fond of, plays fportively, and moves about with great agility.

This animal is hunted for its $\mathrm{kin}$, which is next in vaIue to that of the Beaver for making hats. 


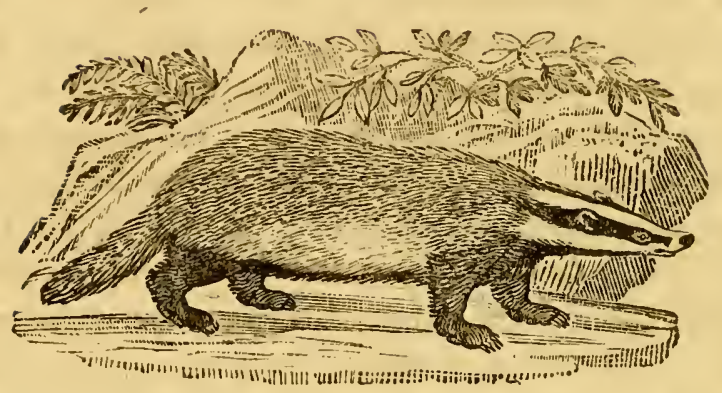

\section{THE BADGER.}

\section{(Urfus Meles, Lin.-Le Blaireau, ou Taifon, Buff.)}

Although Nature has furnifhed this animal with formidable weapons of offence, and has befides given it ftrength fufficient to ufe them with great effect, it is notwithftanding very harmlefs and inoffenfive; and, unlefs attacked, employs them only for its fupport.

The Badger retires to the moft fecret receffes; where it digs its hole, and forms its habitation under ground.Its food confints chiefly of roots, fruits, grafs, infects, and frogs. It is charged with deftroying Lambs and Rabbits, but there feems to be no other reafon to confider it as a beaft of prey, than the analogy between its teeth and thofe of carnivorous animals.

Few creatures defend themfelves better, or bite with greater keennefs, than the Badger. On that account it is frequently baited with Dogs trained for that purpofe. This inhuman diverfion is chiefly confined to the idle and the vicious, who take a cruel pleafure in feeing this 
harmlefs animal furrounded by its enemies, and defending itfelf from their attacks, which it does with aftonifhing agility and fuccefs. Its motions are fo quick, that a Dog is frequently defperately wounded in the firt moment of affault, and obliged to fly. The thicknefs of the Badger's $\mathrm{kin}$, and the length and coarfenefs of its hair, are an excellent defence againt the bites of the Dogs: Its fkin is fo loofe, as to refit the impreffions of their teeth, and give the animal an opportunity of turning itfelf round, and wounding its adverfaries in their tendereft parts. In this manner this fingular creature is able to refint repeated attacks both of men and dogs, from all quarters; till, being overpowered with numbers, and enfeebled by many defperate wounds, it is at laft obliged to fubmit.

The Badger is an indolent animal, and fleeps much. It confines itfelf to its hole during the whole day, and feeds only in the night. It is fo cleanly, as never to defile its habitation with its ordure. It breeds only once in a year, and brings forth four or five at a time.

It is not known to exift in warm countries. It is an original native of the temperate climates of Europe; and is found, without any variety, in Spain, France, Italy, Germany, Britain, Poland, and Sweden.

The ufual length of the Badger is fomewhat above two feet, exclufive of the tail, which is about fix inches long; its eyes are fmall, and are placed in a black ftripe, which begins behind the ears, and runs tapering towards the nofe; the throat and legs are black; the back, fides, and tail, are of a dirty-gray, mixed with black; the legs and feet are very fhort, Atrong, and thick; each foot confints of five toes; thofe on the fore feet are armed with ftrong 
claws, well adapted for digging its fubterranean habitation.

In walking, the Badger treads on its whole heel, like the Bear; which brings its belly very near the ground.

Immediately below the tail, between that and the anus, there is a narrow tranfverfe orifice, from whence a white fubftance, of a very fetid fmell, conftantly exudes.

The fkin, when dreffed with the hair on, is ufed for piftol furniture.-Its fleth is eaten: The hind quarters are fometimes made into hams, which, when cured, are not inferior in goodnefs to the beft bacon.-The hairs are made into brufhes, which are ufed by painters to foften and harmonife their thades.

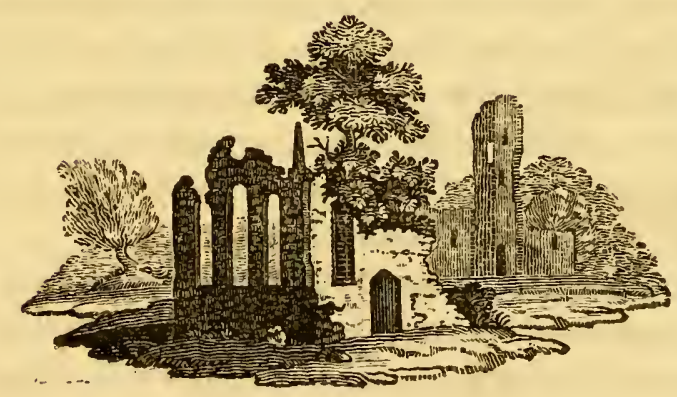



HISTORY OF QUADRUPEDS.

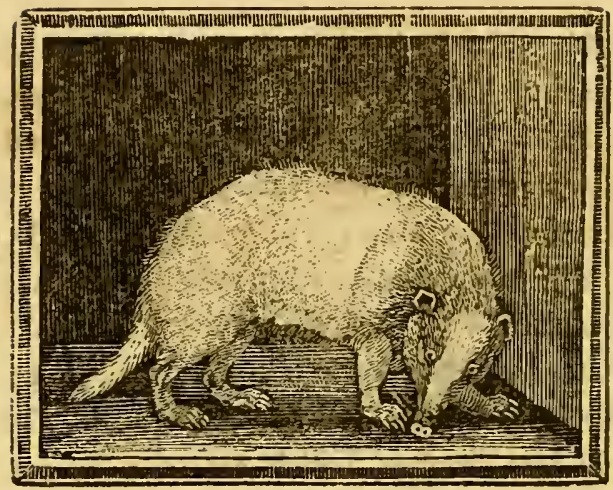

THE SAND-BEAR.

WE lave given the figure of this animal, draw'n from one kept in the Tower; of which we have not been able to obtain any further defcription, than its being fomewhat le[s than the Badger, almoft without hair, extremely fenfible of cold, and burrows in the ground. From thefe circumftances, as well as from the ftriking fimilarity of its figure to that of the Badger, we are inclined to think it is a variety of that animal, mentioned by naturalifts under the name of the Sorv-Badger.

Its colour is a yellowifh-white: Its eyes are fmall; and its head thicker than that of the common Badger: Its legs are fhort; and on each foot there are four toes, armed with fharp white claws.

M. Briffon defcribes a white Badger, from New-York, fo fimilar to this, that we fufpect it to be the fame fpe cies. 


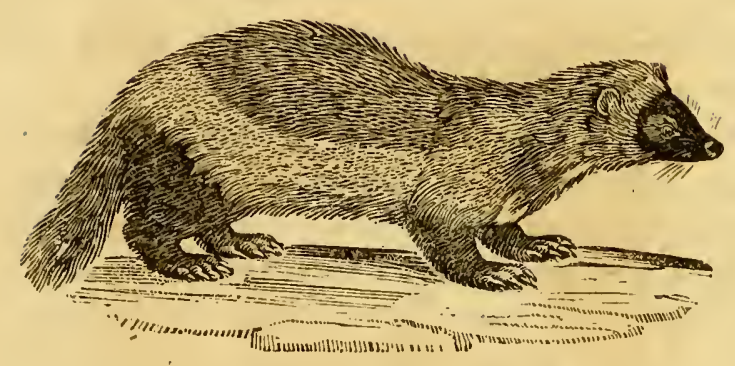

THE WOLVERINE, OR GLUTTON.

\section{(Muftela Gulo, Lin.-Le Glutton, Buff.)}

THIs voracious animal is found in all the countries bordering on the Northern Ocean, both in Europe and Afra: It is likewife common in Canada, the country about Hudfon's Bay, and other parts of North-America; $\therefore$ where it is known by the name of the Carcajou.

It has been varioufly defcribed by naturalifts. We have felected the account given by M. Buffon, which was taken from a living one in his poffeffion. Its length, from the nofe to the infertion of the tail, was two feet two inches; the tail eight inches long; the length of the fore legs was eleven inches, and the hind ones twelve; it had five toes on each foot, armed with long fharp claws; the middle claw of the fore foot was one inch and a half long; the muzzle, as far as the eye-brows, was black; its eyes were fmall and black, and its ears fhort; its breaft and under jaw were fpotted with white; the back, legs, belly, and tail, were black.-During its confinement, it did not difcover fymptoms of great ferocity. It 
eat voracioully; and, after a full meal, covered itfelf in its cage with ftraw. It eat no bread, but would devour more than four pounds of fleth every day, which it fwallowed greedily, almont without chewing.

In a ftate of liberty, it is faid to lead a life of continual rapine. It lurks in the branches of trees, in order to furprife Deer and other animais that pafs under them. It waits with great patience the arrival of its prey, and darts from its hiding-place with unerring certainty. In this manner it indifcriminately furprifes the Horfe, the Elk, the Stag, or the Rein-deer, and fixes itfelf between their fhoulders with its teeth and claws.

The wild Reir-deer, which are numerous both in Lapland and North-America, frequently fall victims to the Glutton. When feized by this blood-thirfy animal, it is in vain that the wounded Deer endeavours to difengage itfelf from its enemy by rufling among the branches of the trees: No force can oblige it to quit its hold: It maintains its pofition, and continues to fuck the blood of the flying animal till it falls down exhaufted with pain and fatigue. - It then devours the carcafe with infatiable voracity, and gorges itfelf with the flefh till it is almoft in danger of burting.

In Kamfchatka, the Glutton makes ufe of a fingular frat?gem for killing the Fallow-deer. It climbs up a tree, taking with it a quantity of that fpecies of mors of which the Deer is very fond. When one of them approaches the tree, the Glutton throws down the mofs; and if the Deer ftop to eat it, the Glutton darts upon its back, and fixing itfelf firmly between its horns, tears out its eyes, and by that means fccures its prey. It then. divides the fleth of the Deer into a number of portions, 
which it conceals in the earth to ferve for future provifions.

The motions of the Glutton are flow. There are few quadrupeds that camnot efcape from it, except the Beaver, which it frequently purfues and overtakes.-In America, it is called the Beaver-eater. - It fometimes lies in wait, and furprifes thofe animals coming out of their burrows, or breaks into their habitations, and kills great numbers of them.

The Glutton often defeats the labour of the hunitmen, by ftealing away the Sables and other animals that have been caught in their traps; and it is fometimes taken in the fnares laid for them.

When attacked, it makes a ftrong refiftance. It will tear the ftock from the gun with its teeth, or break the trap in pieces in which it is caught.-Notwithftanding its fiercenefs, it is capable of being tamed, and of learning feveral entertaining tricks.

It is hunted only for its kin, which is very valuable, of a moft beautiful gloffy black, which fhines with a peculiar luftre, and reflects the light like damaik filk.

The fkins are fold in Siberia at five or fix fhillings exch, at Jakut/k at twelve, and ftill dearer in Kamfchatka. There the women drefs their hair with its white paws, which they efteem a great ornament.

The furs of this animal, from the North of Europe and Afia, are infinitely finer, blacker, and more gloffy, than thofe of the American kind. 


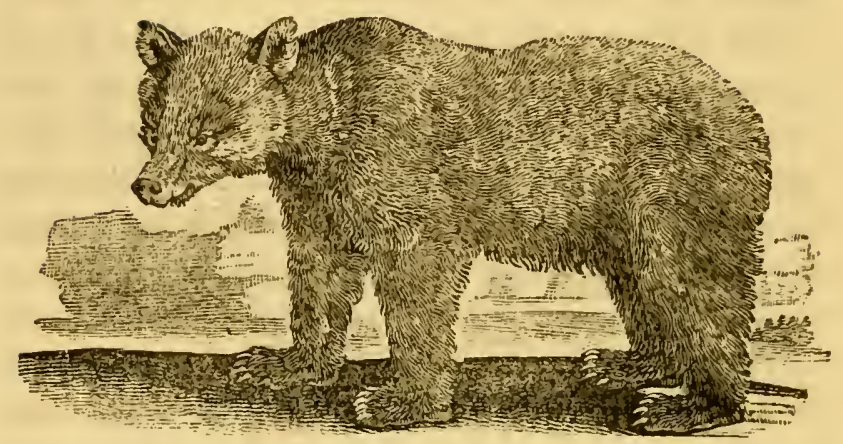

THE BROWN BEAR.

(Uifus cauda abrupta, Lin._L'Ours, Buff.)

THERE are two principal varieties of the Bear,-the brorun and the black. The former is found in almoft every climate, the black Bear chiefly in the forefts of the northern regions of Europe and America.

The brown Bear is fometimes carnivorous; but its general food is roots, fruits, and vegetables.

It is a favage and folitary animal, lives in defart and unfrequented places, and chures its den in the moft dangerous and inacceffible precipices of unfrequented mountains. It retires alone to its den about the end of autumn, (at which time it is exceedingly fat) and lives for feveral weeks in a ftate of total inactivity and abftinence from food.-During this time, the female brings forth her young, and fuckles them. She chufes her retreat for that purpofe, in the moft retired places, apart from the male, left he flould dcrour them. She makes 
a warm bed for her young, and attends them with unremitting care during four months, and in all that time fcarcely allows herfelf any nourifhment. She brings forth two, and fometimes three young at a time. The cubs are round and thapelefs, with pointed muzzles; but they are not licked into form by the female, as Pliny and other ancient naturalifts fuppofed. At firft they do not exceed eight inches in length. They are blind during the firft four weeks, are of a pale-yellow colour, and have fcarcely any refemblance of the creature when arrived at maturity.-The time of geftation in thefe animals is about fix months, and they bring forth in the beginning of January.

In the fpring, the old Bears, attended by their young, come out from their retreats, lean, and almoft famined by their long confinement. They then ranfack every quarter in fearch of food. They frequently climb trees, and devour the fruit in great quantities, particularly the date-plumb tree, of which they are exceedingly fond. They afcend thefe trees with fuprifing agility, keep themfelves firm on the branches with one paw, and with the other collect the fruit.

The Bear is remarkably fond of honey, which it will encounter great difficulties to obtain, and feeks for with great cunning and avidity.

It enjoys, in a fuperior degree, the fenfes of hearing, fmelling, and touching.- Its ears are fhort and rounded; and its eyes fmall, but lively and penetrating, and defended by a nictating membrane: From the peculiar formation of the internal parts of its nofe, its fenfe of fmelling is exceedingly exquifite: The legs and thighs 
are ftrong and mufcular: It has five toes on each foot, and ufes its fore foot as a hand, although the toes are not feparated as in molt animals that do fo; the largeft finger is on the outfide.

The voice of the Bear is a deep and furly kind of growl, which it frequently exerts without the leaft caufe. It is very eafily irritated, and at that time its refentment is furious, and often capricioufly exerted.

When tamed, it appears mild and obedient to its marter; but it is not to be trufted without the utmoft caution.-It may be taught to walk upright, to dance, to lay hold of a pole with its paws, and perform various tricks to entertain the multitude, who are highly pleafed to fee the awkward meafures of this rugged creature, which it feems to fuit to the found of an inftrument, or to the voice of its leader. But to give the Bear this kind of education, it muft be taken when young, and accuftomed early to reftraint and difcipline: An old Bear will fuffer neither, without difcovering the moft furious refentment; neither the voice nor the menaces of his keeper have any effect upon him; he equally growls at the hand that is held out to feed, as at that which is raifed to correct him.

The exceffive cruelties practifed upon this poor animal in teaching it to walk erect, and regulate its motions to the found of the flagelet, are fuch as make fenfibility fhudder. Its eyes are put out, and an iron ring being put through the cartilage of the nofe to lead it by, it is kept from food, and beaten, till it yield obedience to the will of its favage tutors. Some of them are taught to perform by fetting their feet upon hot iron plates, and then playing to them whilft in this uneafy fituation.-It is truly flocking to every feeling mind to reflect, that 


\section{HISTORY OF QUADRUPEDS.}

fuch cruelties fhould be exercifed upon any part of the brute creation by our fellow-men. That they thould be rewarded by numbers of unthinking people, who crowd around them to fee the animal's rude attempts to imitate human actions, is not to be wondered at: But it is much to be wifhed, that the timely interference of the magiftrate would prevent every exhibition of this kind, that, in Britain at leaft, we might not be reproached with tolerating practices fo difgraceful to humanity.

One of thefe animals, prefented to the Prince of Wales, a few years ago, was kept in the Tower. By the careleffnefs of the fervant, the door of his den was left open; and the keeper's wife happening to go acrofs the court at the fame time, the animal flew out, feized the woman, threw her down, and faftened upon her neck, which he bit; and, without offering any further violence, lay upon her, fucking the blood out of the wound. Refiftance was in vain, as it only ferved to irritate the brute; and the muft inevitably have perifhed, had not her hufband luckily difcovered her fituation. By a fudden blow, he obliged the Bear to quit his hold, and retire to his den, which he did with great reluctance, and not without making a fecond attempt to come at the woman, who was almoft dead through fear and lofs of blood. It is fomewhat remarkable, that whenever it happened to fee her afterwards, it growled, and made moft violent ftruggles to get out to her.-The Prince, upon hearing of the circumftance, ordered the Bear to be killed.

The flefh of the young Bear is reckoned a great delicacy; and the paws of an old one are efteemed as a moft exquifite morfel. The fat is white, and very fweet; and 


\section{HISTORY OF QUADRUPEDS.}

the oil is faid to be of great ufe in foftening fwellings proceeding from fprains.

Great numbers are killed annually in America for the fake of their lkins, which form a confiderable article of commerce.

The Bear was once an inhabitant of this ifland, and was included in the ancient laws and regulations refpecting beafts of chafe-Long after their extirpation, they were imported for the cruel purpofe of baiting them, which at that time was a favourite amufement of our anceftors. We find it, in Queen Elizabeth's days, among the various entertainments prepared for her Majeity on her vifit at Kenilworth.

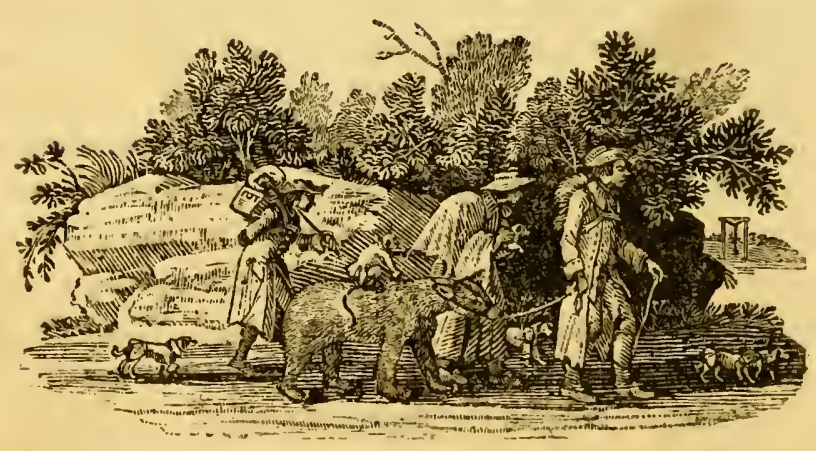




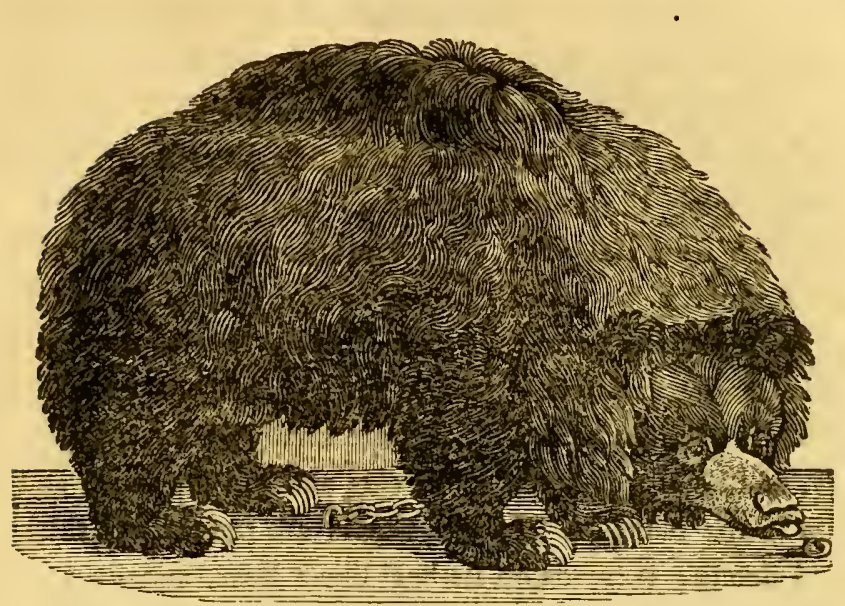

WE have here given a faithful reprefentation, drawn from the life, of an animal which has hitherto efcaped the obfervations of naturalifts.-Its features and leading characters feem to be fo ftrong, as to leave no room for doubt with refpect to its rank in the animal creation: And, from the ftriking correfpondence of parts obfervable between it and the common Bear, we are induced to difpofe of them in the fame clafs. We are the more confirmed in this opinion, from an attentive examination of its difpolition and manners; notwithftanding, it feems to differ in fome of thofe characteriftics which have been pointed out by naturalifts as the guides to a regular and fyftematic arrangement.

Its body is covered with a long, rough, and fhaggy coat of hair, which gives it, when lying down, the appearance of a rude and fhapelefs mafs; on the top of its back, the hair, which is twelve inches long, rifes up like 
a hunch, feparates in the middle; and falls down in different directions; its head is large, very broad at the forehead, and is the only part on which the hair is thort; its fnout is long, and ends in a thin, broad cartilage, overhanging the noftrils about an inch and a half; its lips are thin and very long, and feem to be furnifhed with mufcles, by which the animal can protrude them in a moft fingular manner, which it never fails to do when its attention is directed to any particular object, or when food is held out to it; its eyes are fmall, black, and heavy, and its afpect louring; its ears and tail are fhort, and hid in the hair; its legs and thighs are remarkably thick and ftrong; it treads on its heel like a Bear, and its toes are not divided; it has five long crooked white claws on each foot, which it ufes with great dexterity, either feparately or together, like fingers, to break its food into fmaller portions, or to convey it to its mouth. Its colour is a deep, fhining black; excepting the fnout, and a fpot above each eye, which are of a yellowifh-white colour; there is likewife a crefcent of white underneath the throat: It has no cutting teeth, but two very ftrong canine teeth, and fix grinders, in each jaw.

It appears to be a gentle, good-natured animal; but when irritated or difturbed, utters a thort abrupt roar, like a Bear, ending in a whining tone, expreffive of impatience.-It feeds on bread, fruit, and nuts; is fond of honey; and will eat marrow, or the fat of meat, either raw or dreffed; but refufes roots of all kinds, and the lean or mufcular parts of flefh.

This rare animal is faid to have been brought from the interior parts of Bengal; and that it burrows in the ground. 


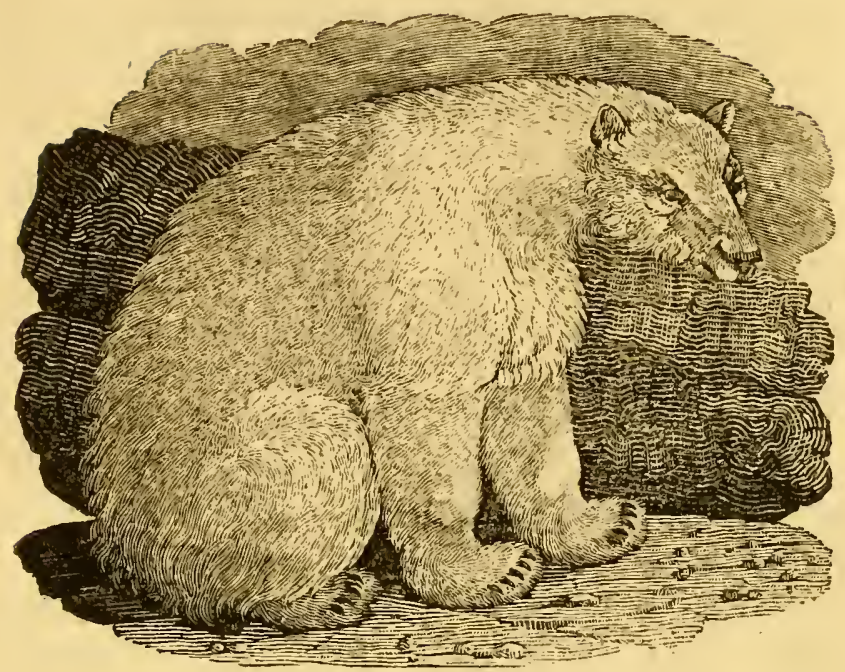

THE POLAR OR GREAT WHITE BEAR, (Urfus Albus, Lin.-L'Ours Blanc, Buff.)

Difrers greatly from the common Bear in the length of its head and neck, and grows to above twice the fize. Some of them are thirteen feet long.-Its limbs are of great fize and ftrength; its hair long, harh and difagreeable to the touch, and of a yellowinh-white colour; its ears are fhort and rounded; and its teeth large.

It inhabits only the coldeft parts of the globe, and has been found above latitude 80 , as far as navigators have penetrated northwards. Thefe inhofpitable regions feen 1 adapted to its fullen nature. 
"There the thapelefs Bear,

" With dangling ice all horrid, ftalks forlorn:

"Slow-pac'd, and fourer as the ftorms increafe,

"He makes his bed beneath th' inclement drift;

"And, with ftcrn patience, fcorning weak complaint,

" Hardens his heart againft afTailing want."

It has been feldom feen farther fouth than Newfound. land, but abounds chiefly on the fhores of Hudfon's Bay, Greenland, and Spitzbergen on one fide, and thofe of Nova-Zembla on the other. It has been fometimeș found in the intermediate countries of Norway and Iceland; but fuch as have appeared in thofe parts have always been driven thither upon floating theets of ice; fo that thofe countries are only acquainted with them by accident.

During fummer, they take up their refidence on large iflands of ice, and frequently pafs from one to another. -They fwim well, and can go to the diftance of fix or feven leagues: They likewife dive, but do not continue long under water. - When the pieces of ice are detached by ftrong winds or currents, the Bears allow themfelves to be carried along with them, and as they cannot regain the land, or abandon the ice on which they are embarked; they often perifh in the open fea. Thofe which arrive with the ice on the coafts of Iceland and Norway, are almoft famifhed with hunger from the length of their voyage, and are extremely voracious. As foon as the natives difcover one of them, they arm themfelves, and prew fently difpatch him.

The ferocity of the Bear is as remarkable as its attachment to its young. A few years fince, the crew of a boat belonging to a thip in the whale-fifhery thot at a Bear at a Mhort diftance, and wounded it. The animal 


\section{HISTORY OF QUADRUPEDS.}

immediately fet up the moft dreadful yells, and ran along the ice towards the boat. Before it reached it, a fecond thot was fired, and hit it. This ferved to increafe its fury. It prefently fwam to the boat; and in attempting to get on board, reached its fore foot upon the gunnel; but one of the crew having a hatchet, cut it off. The animal ftill, however, continued to fwim after them till they arrived at the fhip; and feveral flots were fired at it, which alfo took effect: But on reaching the fhip, it immediately afcended the deck; and the crew having fled into the fhrowds, it was purfuing them thither, when a thot from one of them laid it dead upon the deck.

Its flefh is white, and is faid to tafte like nutton. The fat is melted for train-oil; and that of the feet is ufed in medicine.

The White Bear brings forth two young at a time. Their fondnefs for their offspring is fo great that they will die rather than defert them: Wounds ferve only to make the attachment more violent: They embrace their cubs to the laft, and bemoan them with the moft piteous cries.

They feed on fin, feals, and the carcafes of whales. Allured by the fcent of feal's flefh, they often break into the huts of the Greenlanders.-They fometimes attack the Morfe, with which they have terrible conflicts; but the large teeth of that animal give it a decided fuperiority over the Bear, which is generally worfted. 


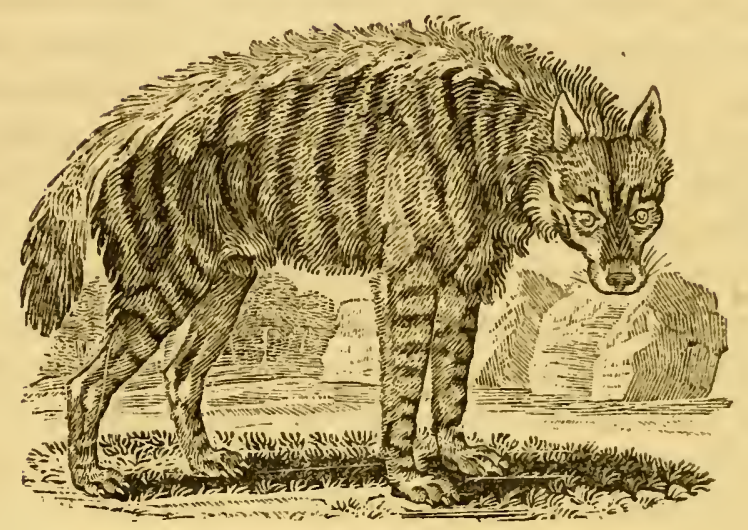

THE STRIPED HYENA.

(Canis Hyana, Lin.-L'Hyane, Buff.)

AlThough naturalifts, both ancient and modern, have defcribed the Hyena under different denominations, and have afcribed to it properties which it is now known not to poffefs, yet its characters are fo fingular, that it is impoffible to miftake them, and fo peculiar, as to diftinguifh it from every other clafs of animals. In many refpects it refembles thofe of the Dog kind, has fome fimilitude to the Wolf in form and difpofition, and is about the fame fize.

The Hyena has only four toes on each foot; its head is broad and flat, and its muzzle fhorter than that of the Wolf; its fore legs are longer than the hind ones; its ears are long, pointed, and bare; and its eyes are remarkably wild, fullen, and ferocious. 


\section{HISTORY OF QUADRUPEDS.}

There are two varieties, - the one ftriped, and the other fpotted.-The hair of the former is of an afh colour, marked with long black ftripes, difpofed in waves, from the back downward; there are others acrofs the legs; the hair in general is coarfe and rough; its tail is fhort and bufhy, with pretty long hair, fometimes plain, and fometimes barred with black; immediately underneath the tail, and above the anus, there is an orifice like that of the Badger, which opens into a kind of pouch, and contains a fubftance of the confiftence of civet, but of a rank, difagreeable odour. This opening may probably have given rife to the error of the ancients, who afferted, that the Hyena was every alternate year male and female. Its manner of holding its head is fomewhat like a Dog purfuing a fcent with its nofe near the ground. This pofition of the head makes the houlders appear more elevated. A briftly mane runs along the top of the back from head to tail, which gives it an appearance fomething like a Hog; from whence, probably, it may have derived its name; the word buaina being a Greek word derived from bus, which fignifies a Sow.-Such are the moft ftriking diftinctions of the Hyena, which has been pictured by ignorance and timidity under cvery form that can ftrike terror into the imagination. Wonderful powers were afuribed to it by the ancients; who believed that it changed its fex; that it imitated the human voice, and by that means attracted unwary travellers, and deftroyed them; that it had the power of charming the thepherds, and as it were rivetting them to the place where they ftood. Many other things, equally abfurd, have been told of this animal: But thefe are fufficient to thew, that objects of terror and fuperfti- 
tion are nearly allied; and when once they have taken poffeffion of the human mind, the moft improbable ftories are eafily received and credited.

It refides in the caverns of mountains, in the clefts of rocks, or in holes and dens, which it digs in the earth.Its difpofition is extremely ferocious; and, though taken young, it never can be tamed.-It lives by depredations, like the Wolf, but is ftronger, and more daring and rapacious. It follows the flocks, ravages the fheepfold, and deftroys every thing within its reach with the moft infatiable voracity.-Its eyes fhine in the dark; and it is afferted, with fome appearance of probability, that it can fee nearly as well by night as by day.-When deftitute of other provifions, it ranfacks the graves, and devours putrid human bodies that have been long buried.

The voice of the Hyena is very peculiar: Its beginning feems to be fomewhat like the moaning of a human voice, and the ending like one making a violent effort to vomit.

It inhabits Afratic Turkey, Syria, Perfia, and Barbary, -The fuperftitious Arabs, when they kill one of them, carefully bury the head, left it fhould be applied to ma-

\section{zical purpofes.}

The courage of the Hyena is equal to its rapacity. It will defend itfelf with great obftinacy againft much larger quadrupeds: It is not afraid of the Lion nor the Panther, will fometimes attack the Ounce, and feldom fails to conquer. 


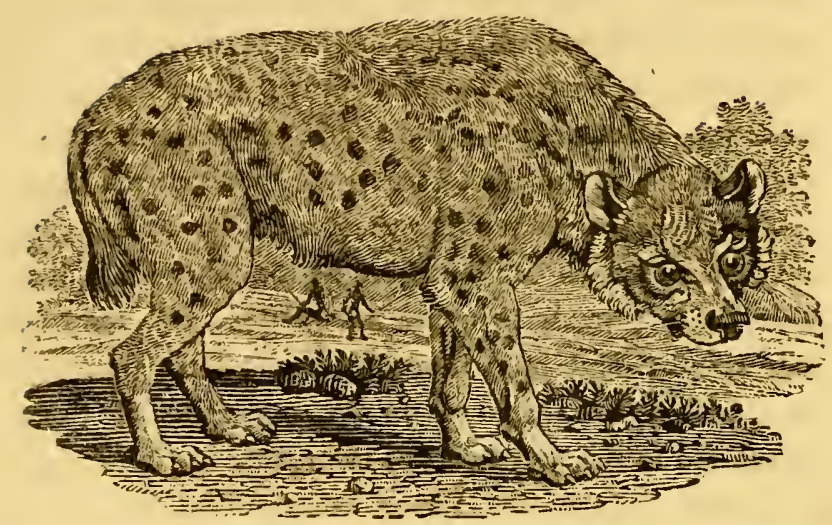

THE SPOTTED HYENA, OR TIGER-WOLF,

Is called, at the Cape of Good Hope, the Tiger-Wolf, and is very common in that part of the world.-Sparrman defcribes it as a cruel, mifchievous, and formidable animal.-Its horrid yells are to be heard every night, whilit it prowls about for its prey, and lurks near farmyards, where cattle are kept. Thefe are well defended by Dogs, of which the Hyena, though larger and ftronger, is much afraid; and will not venture an attack, unlefs preffed by the moft urgent neceffity: Neither will it dare to feize upon any of the larger animals, fuch as Oxen, Cows, Horfes, \&xc. whilft they make the leaft appearance of defending themfelves, or even if they do not betray any fymptoms of fear. It fometimes endeavours to difperfe the cattle by its hideous roaring; after which it felects and purfues one of them, which it foon difables by a deadly bite, and then devours. 
Thefe animals were formerly fo bold, as to moleft the Hottentots in their huts, and fometimes carry off their children; but, fince the introduction of fire-arms, thofe and other wild beafts keep at a greater diftance from the habitations of mankind.-It is a fact, however, that numbers of them attend almoft every night about the fhambles at the Cape, where they meet with bones, fkin, and other offals, which are left there by the inhabitants, who fuffer thefe animals to come unmolefted, and carry off their refufe; and it is fomewhat remarkable that they have feldom been known to do any mifchief there, though fed in the very heart of the town.

The howlings of the Hyena are dreadful beyond all conception, and fpread a general alarm: They are almoft inceffant, and feem to be the natural confequence of its craving appetite. Perhaps it may not be going too far to fay, that Nature has kindly imprefled this involuntary difpofition to yelling upon this animal, that every living creature might be upon its guard, and fecure itfelf from the attacks of fo cruel an enemy.

The general colour is a reddifh-brown, marked with roundifh dark fpots; the hind legs, in fome, with tranfverfe black bars,-in others, with fpots; its head is large and flat; above each eye, as well as on the lips, it has whikkers; a fhort thagged kind of mane runs along from the middle of the back to its head, the hair pointing forward; its ears are fhort and rounded; the hair on its face and the upper part of its head is fhort; the fkin on its brow is wrinkled.

Our figure was drawn from a male Hyena exhibited in Newcaftle in the fpring and fummer of 1799. 


\section{THE FOX.}

(Canis Vulpes, Lin.-Le Renard, Buff.)

THIs lively and crafty animal is common to every part of Great Britain, and is fo well known as not to require a particular defcription.

M. Buffon has taken great pains to prove, that the Dog and the Fox will not breed together. For this purpore, he kept two males and a female for a confiderable time, and tried to make the males copulate with bitches, which they uniformly refufed; and from thence he concludes, that no mixture can take place between the two fpecies. But it hould be remembered, that the Foxes were in a ftate of confinement; and of courfe, many circumitances might concur to difguft them, and render the experiment abortive. In confirmation of this, we need only obferve, that the fame Foxes, which, when at liberty, darted on the poultry with their ufual eagernefs, never attempted to touch a fingle fowl after they were chained: And we are told further, "that a living hen was generally fixed near them for a whole night; and, though food was kept from them for many hours, yet, in fpite of hunger and opportunity, they never forgot that they were chained, and difturbed not the hen." Now if any one fhould be fo hardy as to affert from this, that Foxes have a natural averfion to poultry, one may eafily conceive how little credit would be given to the conclufion, and how much laughter it would excite. We juft mention this to fhew, that experiments of this kind, where Nature is thwarted in her procefs, or reftrained in any of her operations, are not always to be depended up- 
on.-That the Fox and the Dox will breed together, is a fact, too well known in feveral parts of the North of England, to admit of the fmalleft doubt.-It is a common practice in many places to tie up a bitch that is in feafon, where the may be vifited by a Fox, and be impregnated by him. The fruits of the connection are fufficiently obvious: Moft, if not all the puppies, have a ftrong refemblance to the Fox: The tharp nofe, prick ears, long bo$\mathrm{dy}$, and thort legs of the Fox, evidently point out their origin.-Thefe Dogs are highly efteemed by farmers and graziers, as the moft ufeful kind for driving cattle:They bite keenly, are extremely active and playful, and are very expert at deftroying Weafels, Rats, and other vermin.

The Fox fleeps much during the day; but the night is its feafon of activity, and the time when it roams about in fearch of prey.- It will eat flefh of any kind, but prefers that of Hares, Rabbits, poultry and all kinds of birds. Thofe that refide near the fea-coaft will, for want of other food, eat crabs, fhrimps, mufcles, and other thellfifh.

In France and Italy, the Fox does great damage among the vineyards, by feeding on the grapes, of which it is extremely fond.- It boldly attacks the wild bees, and frequently robs them of their ftores; but not with impunity: The whole fwarm flies out, and faftens upon the invader; but he retires only for a few minutes, and rids himfelf of the bees by rolling upon the ground; by which means he cruphes fuch as fick to him, and then returns to his charge, and devours both wax and honey.

The cunning of the Fox, in furprifing and fecuring its prey, is equally remarkable. When it has acquired more 
than it can devour, its firft care is to fecure what it has killed, which is generally all within its reach. It digs holes in different places, where it conceals its booty by carefully covering it with earth to prevent a difcovery. If a flock of poultry have unfortunately fallen victims to its Itratagems, it will bring them, one by one, to thefe hiding-places; where it leaves them till hunger demands frefh fupplies.

The chafe of the Fox is a very favourite diverfion in this kingdom, and is no where purfued with fuch ardour and intrepidity. Both our Dogs and Horfes are confeffedly fuperior to thofe of any other country.-The inftant the Fox finds he is purfued, he flies towards his hole; and finding it ftopped, which is always carefully done before the chafe begins, he has recourfe to his fpeed and his cunning for fafety. He does not double and meafure his ground back like the Hare, but continues his courfe ftraight forward before the Hounds with great ftrength and perfeverance. Both Dogs and Horfes, particularly the latter, have frequently fallen victims to the ardour of the purfuit, which has fometimes continued for upwards of fifty miles without the fmalleft intermifion, and almoft at full fpeed*.-As the fcent of the Fox is very

* Mr Charles Turner's Hounds hunted at Ayreyholm, near Hurworth, in the county of Durham, and found the noted old - Fox CESAR, which made an extraordinary chafe. After a round of four miles, he led to Smeaton, through Hornby and Appleton; then back again to Hornby, Worfet-mour, Pierfburgh, Limpton, Craythorn, Middleton, Hilton, Seamer, Newby, Marton, Ormfby ; then upon Hambleton, through Kirkleatham-park, Upleatham, Skelton, and Kelton. Mr Turner tired three Horfes; and only three Hounds were in purfuit, when he thought proper to call them off, it being near five in the evening. The chafe was upwards of fifty miles. 


\section{HISTORY OF QUADRUPEDS.}

ftrong, the Dogs follow with great alacrity and eagernefs, and have been known to keep up a conftant chafe for eight or ten hours together; and it is hard to fay, whether the fpirited eagernefs of the Hounds, the ardour of the Horfes, or the enthufiam of the hunters, is moft to be admired. The Fox is the only one of the party which has the plea of neceffity on his fide; and it operates fo ftrongly, that he often efcapes the utmoft efforts of his purfuers, and returns to his hole in fafety. The fmell of his urine is fo offenfive to the Dogs, that it fometimes proves the means of his efcape from them. When all his thifts have failed him, and he is at laft overtaken, he then defends himfelf with great obftinacy, and fights in filence till he is torn in pieces by the Dogs.

There are three varieties of Foxes in this ifland, which differ from each other more in form than in colour.

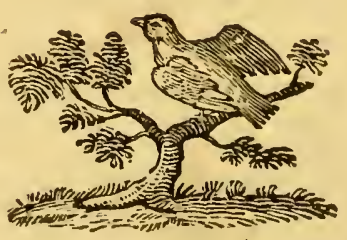




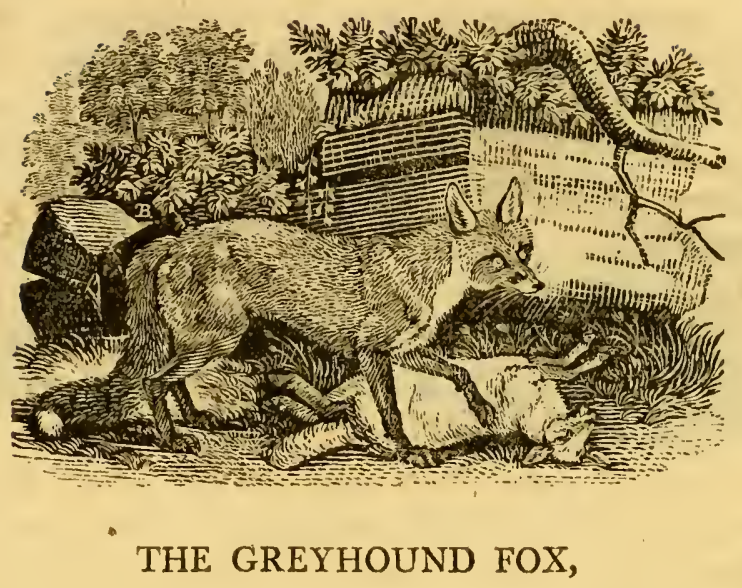

Is the largeft, and is chiefly found in the mountainous parts of England and Scotland: $\mathrm{He}$ is likewife the bold eft, and will attack a well-grown Sheep.-His ears are long and erect, and his afpect wild.

\section{THE MASTIFF FOX,}

Is rather lefs; but his limbs are more ftrongly formed.

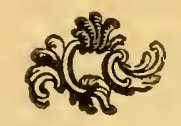




\section{HISTORY OF QUADRUPEDS.}

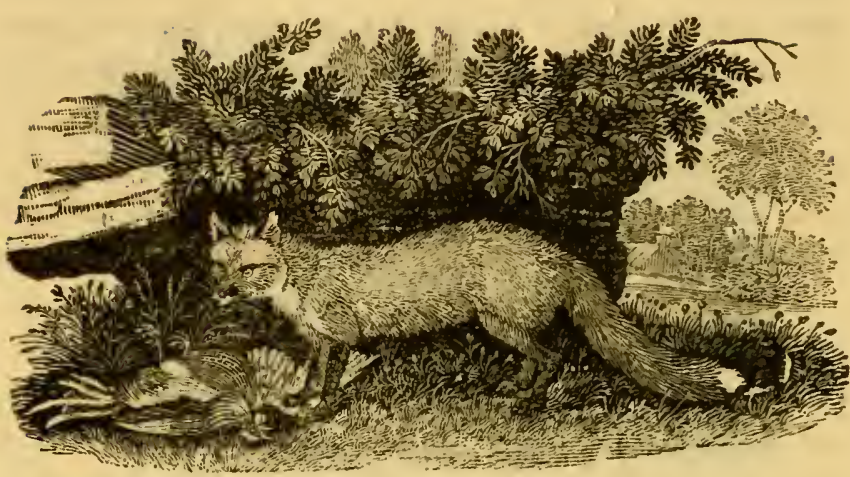

THE CUR FOX,

Is the leaft, but the mort common, and approaches neareft to the habitations of mankind. It lurks about the out-houfes of the farmer, and carries off all the poultry within its reach.-It is remarkably playful and familiar when tamed; but, like all wild animals half reclaimed, will, on the leaft offence, bite thofe it is moft familiar with

The eye of the Fox is of a lively hazel colour, very fignificant and expreffive; and difcovers very fenfibly the different emotions of love, fear, or anger, by which it may be affected.-It feems greatly to admire its bufhy tail, and frequently amufes itfelf by endeavouring to catch it as it runs round. In cold weather, when it lies down, it folds it about its head.

The Fox fleeps found; and, like the Dog, lies in a round form. When he is only repoling himfelf, he ftretches out his hind legs, and lies on his belly. In this pofition, he fpies the birds as they alight on the hedges 
or places near him, and is ready to fpring upon fuch as are within his reach. He rarely lies expofed, but chufes the cover of fome thick brake, where he is pretty fecure from being furprifed. Crows, magpies, and other birds, which confider the Fox as a common enemy, will often give notice of his retreat by the moft clamorous notes, and frequently follow him a confiderable way from tree to tree, repeating their outcries.

Foxes produce but once a year, from three to fix young ones at a time. When the female is pregnant, the retires, and feldom goes out of her hole, where the prepares a bed for her young. She comes in feafon in the winter; and young Foxes are found in the month of April. If the perceive that her habitation is difcovered, fhe carries them off, one by one, to a more fecure retreat. The young are brought forth blind, like puppies. They grow eighteen months or two years, and live thirteen or fourteen years.

The Fox is frequently taken in traps; but great caution muft be ufed to deceive this wily animal. The trap muft be placed in the midnt of a field, where there is neither hedge nor path near it, and fo nicely covered with mould, that not the leaft veftige can be feen where it lies: About the trap, and at a fmall diftance from it; in different places, a few pieces of cheefe, or other ftrongly-fcented food, muft be carelefsly fcattered: Then with a Theep's paunch, or fome other animal fubftance, a trail is made, of about a mile in length, to the different places where the bait is laid, and from thence to the trap: The thoes of the perfon who carries the trail muft be likewife well rubbed with the paunch, that the Fox may not dif- 
cover his fcent. He then approaches with more confidence, and if the defign be well conducted, feldom fails of being caught.

There are many varieties of this animal, apparently produced by the influence of climate. Thofe of this country are moftly of a tawny-red, mixed with afh colour; the fore part of the legs is black, and the tail tipt with white.-In colder countries, Foxes are of various colours.

\section{THE: BLACK FOX,}

Is moft valuable for its fur, which is efteemed in Ruffia fuperior to that of the fineft fable. A fingle fkin will fell for four hundred rubles.

\section{THE CROSS FOX, \\ (Le Renard Croijé, Bufl.)}

INHABITs the coldeft parts of Europe, Afia, and NorthAmerica.-Its fur is vcry valuable, being thicker and fofter than the common fort.-Great numbers of fkins ,Ire imported from Canada.

It derives its name from a black mark which paffes over its back acrofs the fhoulders, and another along the back to the tail.

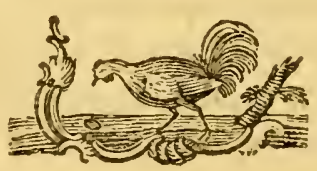




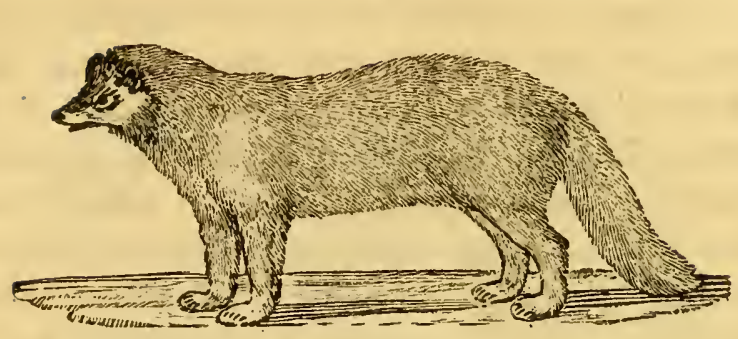

THE ARCTIC FOX,

\section{(Canis Lagopus, Lin.-Ifatis, Buff.)}

INHABITs the countries bordering on the Frozen Sea. It is found in Greenland, Iceland, Spitzbergen, Nova-Zembla, and Lapland; in Kamfchatka, and the oppofite parts of America. It burrows, and makes holes in the ground, feveral feet in length; at the end of which it forms a neft with mofs. In Greenland and Spitzbergen, it lives in the clefts of rocks, being unable to burrow on account of the froft. Two or three of 'them inhabit the famie hole.

It is endowed with all the cunning of the common Fox, preys on young geefe, ducks, and other water-fowl, before they are able to fly; likewife on hares, wild-birds, and eggs: And in Greenland, for want of other food, it feeds on berries and thell-fifh. In Lapland and the North of Afia, its principal food is the Leming, or Lapland Marmot ; immenfe thoals of which fometimes cover the face of the country. The Foxes follow them, in their migrations, from one place to another; and as the return of the Marmot is very uncertain, and frequently after great intervals of time, they are fometimes abfent three or four years in purfuit of this their favourite preys 


\section{$3^{12}$}

HISTORY OF QUADRUPEDS.

The hair of the Arctic Fox is of an anh. colour, but changes to white in the winter, when it is long, foft, and fomewhat woolly: Its tail is fhorter than that of the common Fox, and more bufhy; and its toes are covered with fur on the under part, like thofe of a Hare: It is fmaller and more flender than the European Fox: Its nofe is tharp and black; and its ears fhort, and almoft hid in the fur. It is fometimes taken in traps; but its Akin is of little value.

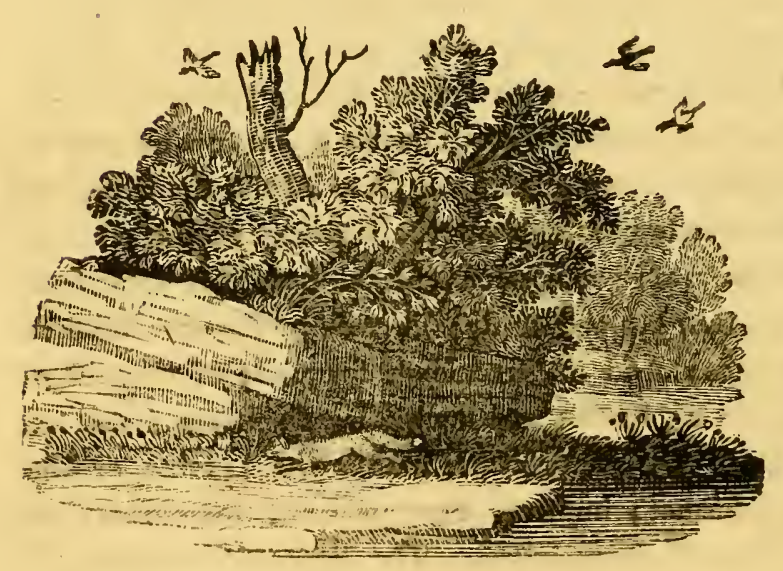




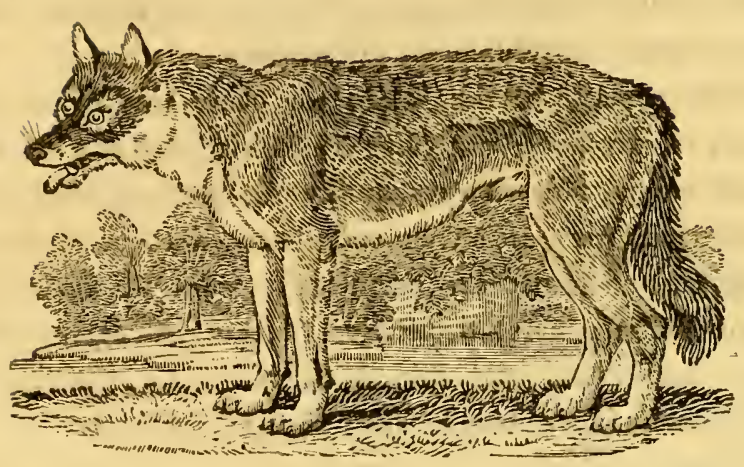

THE WOLF.

(Canis Lupus, Lin.-Le Loup, Buff.)

ALL naturalifts agree in placing the Wolf and the Dog in the fame clafs; and, from the flightent infpection of its external form only, it would feem that the Wolf was in every refpect a Dog in its ftate of natural freedom. The fhape of its head is different; and its eyes, being fixed in a more oblique pofition, give it a look of more favage fiercenefs: Its ears are fharp and erect; its tail long, bufhy, and bending inwards between its hind legs; its body is ftronger than that of almoft any fpecies of Dog, its jaws and teeth larger, and its hair coarfer and thicker. The internal ftructure of thefe animals is perfectly fimilar. The Wolf couples in the fame manner as the Dog; and its immediate feparation is prevented from the fame caufe: The time of geftation is alfo nearly the fame; and, from a variety of fuccefsful experiments related by the celebrated Dr Hunter, there is no 
longer any room to doubt, that the Wolf and the Dog will copulate together, and produce an intermediate fpecies, capable of fubfequent propagation.

The appetite of the Wolf, for every kind of animal food, is exceffively voracious; and, although Nature has furnifhed it with every requifite for purfuing and conquering its prey, it is frequently reduced to the laft extremity, and fometimes perifhes for want of food. So great is the general deteftation of this deftructive creature, that all the wild animals endeavour to avoid it, and moft commonly efcape by their fuperior fwiftnefs.

When preffed with hunger from repeated difappointments, the Wolf becomes courageous from neceflity. It then braves every danger, and even attacks thofe animals that are under the protection of man. Sometimes whole. droves of them join in the cruel work of general devaftation, roam through the villages, and attack the fheepfolds: They dig the earth under the doors, enter with dreadful ferocity, and put every living creature to death before they depart. The Horfe is the only tame animal that can defend itfelf againft them: All the weaker animals become their prey: Even man himfelf, upon thefe occafions, frequently falls a victim to their rapacity; and it is -faid, that when once they have tafted human blood, they always give it the preference.-From hence, many fuperfitious ftories have been told of the Wolf. The old Saxons believed, that it was poffeffed by fome evil fpirit, and called it the $W$ erc-IVulf; and the French peafants, from the fame reafon, call it the Loup-garou.

The language of the poet is beautifully defcriptive of his creature's infatiable fury :- 


\section{HISTORY OF QUADRUPEDS.}

"By wintry famine rous'd, from all the tract

" Of horrid mountains, which the fhining Alps,

"And wavy Appenine, and Pyrenees,

"Branch out, ftupendous, into diftant lands,

"Cruel as death! and hungry as the grave!

"Burning for blaod! bony, and ghaunt, and grim!

"Affembling Wolves, in raging troops, defcend;

"And, pouring o'er the country, bear along,

" Keen as the north wind fweeps the gloffy fnow,

"All is their prize."

The Wolf has great ftrength, efpecially in the mufcles of his neck and jaws: He can carry a Sheep in his mouth, and eafily run off with it in that manner. His bite is cruel and deadly, and keener as it meets with lefs refiftance; but when oppofed, he is cautious and circumfpect, and feldom fights but from 'neceffity. He is harder and more robuft, but not fo fenfible as the Dog. He almoft inceffantly prowls about for prey, and of all animals is the mont difficult to conquer in the chafe. His fenfe of fmelling is peculiarly ftrong: He fcents the track of animals, and follows it with great perfeverance : The odour of carrion ftrikes him at the diftance of near a league.

Wolves are capable of bearing want of food for a long time. To allay their hunger, they will fometimes fill their ftomachs with mud.- They have been known to follow armies, and affemble in troops upon the field of battle; tear up fuch bodies as have been carelefsly interred, and devour them with infatiable avidity.

In all ages, the Wolf has been confidered as the mott favage enemy of mankind, and rewards were given for its head. Various methods have been taken to rid the world of this rapacious invader: Pit-falls, traps, and poifon, have all been employed againft him; and, happily for thefe illands, the whole race has long been ex- 
tirpated here. King Edgar attempted to effect it in England by remitting the punifhment of certain crimes on producing a number of Wolves' tongues; and in Wales, the tax of gold and filver was commuted for an annual tribute of Wolves' heads.-Some centuries after that, they increafed to fuch a degree, as to become an object of royal attention; and great rewards were given for deftroying them. Camden informs us, that certain perfons held their lands on condition of hunting and deftroying the Wolves that inferted the country; whence they were called the Wolve-gunt. - In the reign of Athelitan, Wolves abounded fo much in Yorkfhire, that a retreat was built at Flixton, to defend paffengers from their attacks. As the ravages of thefe animals were greateft during winter, particularly in January, when the cold was fevereft, our Saxon anceftors diftinguifhed that month by the title of Wolfe-moneth. They alfo called an outlaw Wolffled, as being out of the protection of the law, and as liable to be killed as that deftructive beaft.They inferted Ireland many centuries after their extinction in England; the laft prefentment for killing Wolves was made in the county of Cork about the year 1710 .

There animals abound in the immenfe forefts of Gernany, where the following methods are taken to deftroy them:- In fome very fequeftered part of the foreft, they hang up a large piece of carrion on the branch of a tree, having previouly made a train of fome miles long, leaving fmall pieces of putrid flefh here and there to allure the Wolves to the fpot: They then wait till it is dark, and approach the place with great circumipection; where they fometimes find two or three Wolves affembled, leaping up, and ftraining themfelves to catch the bait, which 
is placed juft within their reach; and while the animals are bufily employed in this way, the hunters being provided with fire-arms, feldom fail to difpatch them. - In a convenient place, at the foot of a declivity, they make a fmall inclofure of ftrong pales, fo high, that the Wolf, having once entered, cannot return again. An opening is left at the top of the bank; and a Sheep that has been long dead, is the bait; to which he is allured by long trains, made from different places where he is known to haunt. As foon as he arrives at the fpot, he examines every part of the inclofure; and finding no other way to come at the booty, he precipitates himfelf.to the bottom; and having made a plentiful meal, endeavours in vain to re-afcend. His difappointment at not being able to get back is productive of the moft dreadful howlings, which alarm his enemies; and they either take him alive, or difpatch him with bludgeons. It is remarkable, that when this animal finds there is no poffibility of efcaping, his courage entirely forfakes him, and he is for fome time fo ftupified with fear, that he may be killed without offering to refift, or taken alive without much danger.Wolves are fometimes taken in ftrong rets, into which they are driven by the hunters, who furround a large tract of land, and with drums, horns, and other inftruments, accompanied with loud cries from a large company affembed upon the occafion, drive the animals towards the entrance of the nets, where they are entangled, and killed with clubs and hatchets. Great care muft be taken to fecure them at firft: If they recover from their confternation, they eafily efcape by tearing the net to pieces.| 
Wolves are found, with fome variety, in almoft every country of the world. Thofe of Senegal are larger and fiercer than thofe of Europe.-In North-America, they are fmall, of a dark colour, and may be eafily tamed. Before the introduction of Dogs, the favages made ufe of them in hunting the wild animals of the country; and they are fill employed for the fame purpofe in the more remote parts of that vaft continent. They are faid to hunt in packs, and run down the Deer by their fcent. The appearance of thefe animals near the habitations of the Indians, fometimes indicates that the Bifon or the Deer is at no great diftance; and when any of thofe are taken, the Wolves are rewarded with the offal. Catefby affirms, that the Wolves of that country have mixed with the Dogs carried thither by the Europeans, and produced an intermediate race.-In the northern regions there are Wolves entirely white, and others of a deep-black.-In Mexico there is a variety of the Wolf, with a very large head, ftrong jaws, and great teeth: On the upper lip it has ftrong briftles, not unlike the fofter fpines of the Porcupine, of a gray and white colour; its ears are large and erect; its body is afh-coloured, fpotted with black; on its fides there are black ftripes from the back downward; its neck is fat and thick, covered with a loofe fkin, marked with a long tawny ftroke; on the breaft is another of the fame kind; the tail is long, and tinged in the middle with tawny; the legs and feet are ftriped with black. It inhabits the hot parts of Mexico or NewSpain, is equally voracious with the European Wolf, attacks cattle, and fometimes men.-There are no Wolves further fouth on the new continent. 


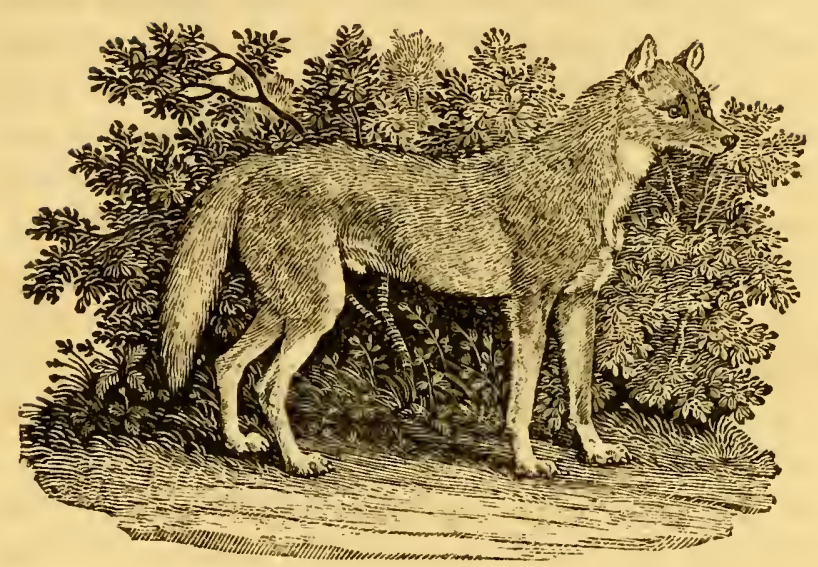

THE NEW SOUTH-WALES WOLF,

Has been called a Dog; but its wild and favage nature feems ftrongly to point out its affinity to the Wolf; to which, in other refpects, it bears a great refemblance. It neither barks nor growls; but when vexed, erects the hairs of its whole body like briftles, and appears extremely furious.-It is fond of Rabbits and poultry, which it eagerly devours raw; but will not touch dreffed meat.

One of them, fent to this country from Botany-Bay, was extremely nimble; and fo fierce, as to feize on every animal it faw. If not reftrained, it would have run down Deer and Sheep: An Afs had alfo mearly fallen a victim to its fury.

Its height is rather lefs than two feet; the length two feet and a half: It is formed much like a Wolf; its ears fhort and erect, and its tail long and buthy: The general colour is a pale-brown, lighter on the belly; the feet and infide of the legs are white. 


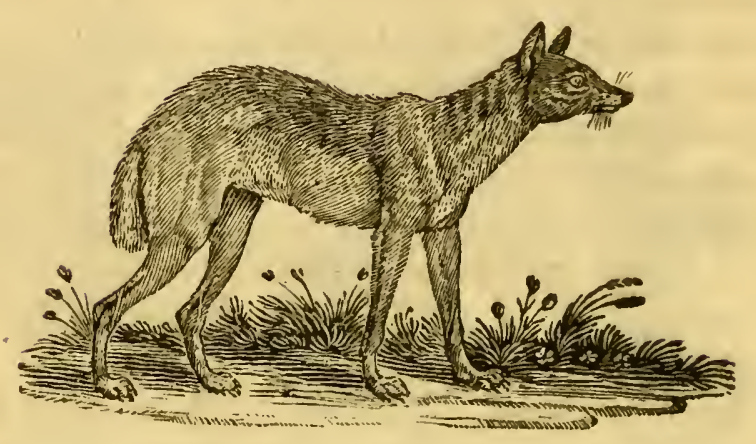

THE JACKAL.

(Canis Aureus, Lin.-Le. Chacal, Buff.)

WE beg leave to make our acknowledgments to $\mathrm{Mr}$ Pennant for the drawing of this animal, which he affures us was drawn from the life; and we doubt not, therefore, its being a faithful reprefentation.

The fpecies of the Jackal is diffufed, with fome variety, through almoft every part of Afia; and is found in Barbary, and other parts of Africa, as far as the Cape of Good Hope.

- Although it is one of the moft numerous of all the wild animals of the Eaft, there is fcarcely any one lefs known in Europe, or more confufedly defcribed by natural hiftorians.

They vary in fize. Thofe of the warment climates are faid to be the largeft. They are of a reddifh-brown colour.-The fmaller Jackal is about the fize of a Fox, and its colour is a bright-yellow.

That the Jackal is nearly allied to the Dog, has been 
clearly proved, from a circumftance related by Mr Hunter, of a female Jackal taken on board an Eaft-Indiaman at Bombay whilft a cub, and being impregnated by a Dog during the voyage, brought forth fix puppies; one of which afterwards produced young ones, from an intercourfe with a Dog.-From thefe and other recent facts, it appears, that the Fox, the Wolf, the Jackal, and the Dog, may be confidered as different fpecies of the fame genus; and that the Jackal makes nearer approaches to the Dog than either the Fox or the Wolf.

Jackals go in packs of forty or fifty, and hunt like hounds in full cry from evening till morning. They deftroy the poultry, and attack the flocks: They roam through the villages and gardens, and carry off every thing they can eat: They enter ftables, yards, and outhoufes, and devour fins, and every thing that is made of leather; fuch as harneffing, boots, fhoes, \&c. Nothing can efcape their rapacity. They will ranfack the repofitories of the dead, and greedily devour the moft putrid bodies; for which reafon, in thofe countries where they abound, the inhabitants are obliged to make the graves of a great depth, and fecure them with fpines, to prevent the Jackals from raking up the earth with their feet. They are faid to attend caravans, and follow armies, in hopes of being furnifhed with a banquet by difeafe or battle. They may be confidered as the vulture among quadrupeds; and, like that deftructive bird, devour every thing indifcriminately that has once had animal life.-They hide themfelves in holes and dens by day, and feldom appear abroad till the evening, when they fill the air with the moft horrid howlings, and begin 
the chafe. The Lion, the Panther, and other beafts of prey that do not follow by the fcent, take advantage of the general confternation, and follow in filence behind till the Jackals have hunted down their prey: They then devour the fruits of their labours, and leave them only the remains of the fpoil; from whence the Jackal has been vulgarly called the Lion's Provider, as if thofe two animals acted in concert, and had formed a plan for their mutual fupport.

The Jackal frequently purfues the Gazelle; and is fo bold, as to follow it even into the midit of a town or village, whither that timid animal frequently flies for protection, and by that means fometimes efcapes.

Sparrman's defcription of thofe he faw at the Cape differs materially from the accounts we have been able to collect from other authors. He fays they are about three feet in length, and their tails little more than a foot long: The predominant colour is a reddifh-yellow; the legs are of a pale gold colour; under the belly, and on the infide of the legs, the colour inclines to white; the nofe and ears are of a brighter red; the head; neck, and back are gray; the tail is partly gray, and partly of an umber colour, and black at the tip. He fays it refembles the European Fox in form, manners, and difpofition ; and is not known to affemble in packs for the purpofe of hunting; neither is its voracity equal to that afcribed to it by other naturalifts._- It is probable it may have been confounded with the Wild Dog, which is common at the Cape, and hunts its prey in packs. It is very fierce and mifchievous, and very deftructive to the flocks of Sheep and Goats in thofe parts.-There are two kinds of thefe Dogs, - the one large, and of a reddih co- 


\section{HISTORY OF QUADRUPEDS.}

lour; the other lefs, and browner. They are very bold, and wander about night and day in fearch of prey.They make a noife fomewhat like the cry of our common Hounds, and hunt with great fagacity, acting perfectly in concert with each other till the game falls a prey to the pack. They are faid to be always extremely lean, and very ugly.

M. Buffon mentions an animal of the Jackal kind by the name of the Adive; of which he gives a drawing, fomewhat refembling a fmall Fox. It is lefs than the common Jackal, and is fometimes tamed, and kept in a domeftic Itate.

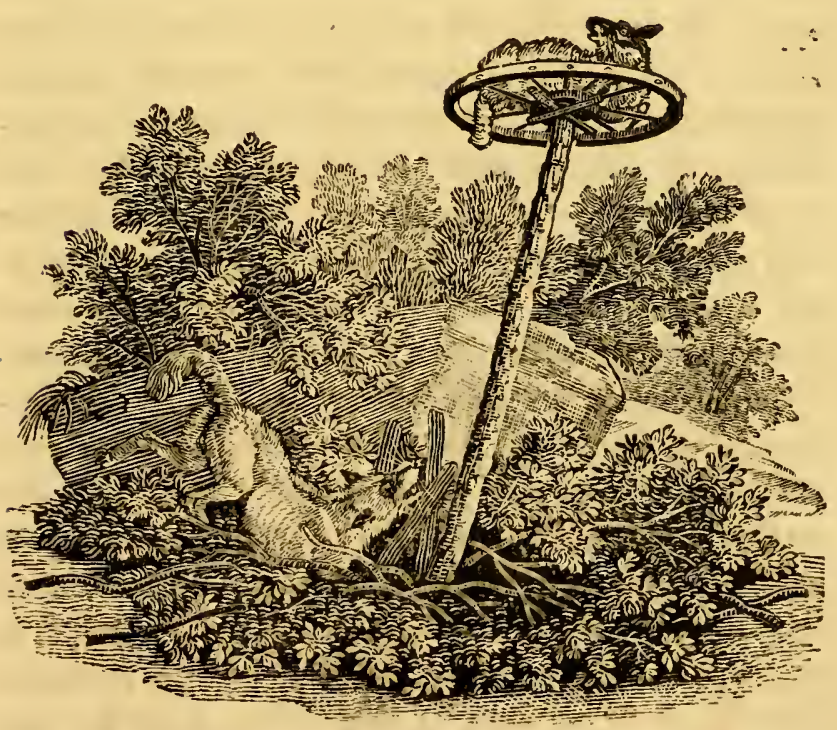

$X_{2}$ 


\section{THE DOG.}

THE fervices of this truly valuable creature have been fo eminently ufeful to the domeftic interefts of men in all ages, that to give the hiftory of the Dog would be little lefs than to trace mankind back to their, original ftate of fimplicity and freedom, to mark the progrefs of civilization through the various changes of the world, and to follow attentively the gradual advancement of that order which placed man at the head of the animal world, and gave him a manifeft fuperiority over every part of the brute creation.

If we confider for a moment the ftate of man without the aid of this ufeful domeftic; - with what arts thall he oppofe the numerous hoft of foes that furround him on all fides, feeking every opportunity to encroach upon his poffeffions, to deftroy his labours, or endanger his perfonal fafety; or how thall he bring into fubjection fuch as are neceffary for his well-being? His utmoft vigilance will not be fufficient to fecure him from the rapacity of the one, nor his greateft exertions enable him to overcome the fpeed of the other. To maintain his independence, to infure his fafety, and to provide for his fupport, it was neceffary that fome one among the animals fhould be brought over to his affiftance, whofe zeal and fidelity might be depended on: And where, amidnt all the various orders of animated being, cauld one be found fo entirely adapted to this purpofe ? where could one be found fo bold, fo tractable, and fo obedient as the Dog? -To confirm the truth of thefe obfervations, we need. only turn our attention to the prefent condition of thofe 
nations not yet emerged from a ftate of barbarifm, where the ufes of the Dog are but little known or attended to, and we will find that they lead a precarious and wretched life of perpetual warfare with the ftill more favage inhabitants of the foreft, with which they are obliged to difpute the poffeffion of their uncultivated fields, and, not unfrequently, to divide with them the fruits of their labours.-From hence we may conclude, that the attention of mankind, in the earlieft ages, would be engaged in training and rendering this animal fubfervient to the important purpofes of domeftic utility; and the refult of this art has been the conqueft and peaceable poffeffion of the earth.

Of all animals, the Dog feems moft fufceptible of change, and moft eafily modified by difference of climate, food, and education; not only the figure of his body, but his faculties, habits, and difpofitions, vary in a furprifing manner: Nothing appears conftant in them but their internal conformation, which is alike in all; in every other refpect, they are very diffimilar: They vary in fize, in figure, in the length of the nofe and thape of the head, in the length and direction of the ears and tail, in the colour, quality, and quantity of the hair, \&c. To enumerate the different kinds, or mark the difcriminations by which each is diftinguifhed, would be a tafk as fruitlefs as it would be impoffible; to account for this wonderful variety, or inveftigate the character of the prim mitive ftock from which they have fprung, would be equally vain. Of this only we are certain, that, in every age, Dogs have been found poffeffed of qualities moft admirably adapted for the various purpofes to which they 
have been from time to time applied.-We have reen, in the hiftory of the Cow and the Sheep, that thofe animals which have been long under the management of man, never preferve the ftamp of nature in its original purity. In wild animals, which ftill enjoy their natural freedom from reftraint, and have the independent choice of food and climate, this impreffion is ftill faithfully preferved; but thofe which man has fubdued, tranfported from climate to climate, changed their food, habits, and manner of living, muft neceffarily have fuffered the greateft alterations in their form; and as the Dog, of all other domeftic animals, is moft accuftomed to this influence, is endowed with difpofitions the moft docile and obedient, is fufceptible of every impreffion, and fubmiflive to every reftraint, we need not wonder that he fhould be fubject to the greateft variety. To an attentive obferver of the canine race, it is truly wonderful and curious to obferve the rapid changes and fingular combinations of forms, arifing from promifcuous intercourfe, which every where prefent themfelves: They appear in endlefs fucceffion, and feem more like the effect of whimfical caprice than the regular and uniform production of Nature: So that, in whatever light we confider the various mixtures which at prefent abound, and render every idea of a fyftematic arrangement dubious and problematical, we may fairly prefume, that the fervices of the Dog would be firft required in maintaining and preferving the fuperiority of man over thofe animals which were deftined for his fupport. 


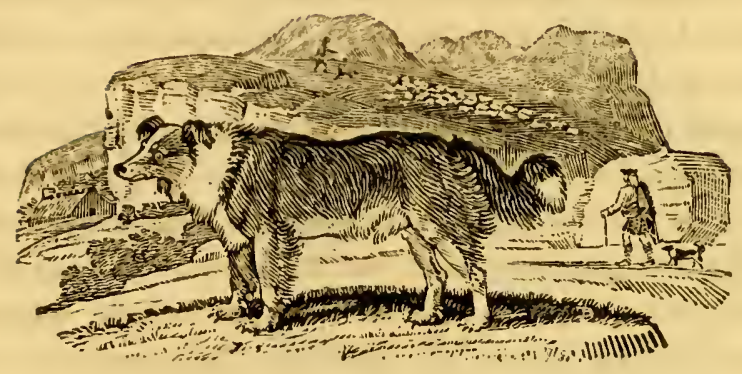

THE SHEPHERD'S DOG.

(Canis domefticus, Lin.-Le Chien de Berger, Buff.)

THrs ufeful animal, ever faithful to his charge, reigns at the head of the flock; where he is better heard, and more attended to, than even the voice of the fhepherd. Safety, order, and difcipline, are the fruits of his vigilance and activity.

In thofe large tracts of land which, in many parts of our ifland, are folely appropriated to the feeding of Sheep and other cattle, this fagacious animal is of the utmoft importance. Immenfe flocks may be feen continually ranging over thofe extenfive wilds, as far as the eye can reach, feemingly without controul: Their only guide is the thepherd, attended by his Dog, the conftant companion of his toils : It receives his commands, and is always prompt to execute them; it is the watchful guardian of the flock, prevents them from ftraggling, keeps them together, and conducts them from one part of their 
pafture to another; it will not fuffer any ftrangers to mix with them, but carefully keeps off every intruder. In driving a number of Sheep to any diftant part, a welltrained Dog never fails to confine them to the road, watches every avenue that leads from it; where he takes his ftand, threatening every delinquent: He purfues the ftragglers, if any fhould efcape, and forces them into order, without doing them the leaft injury. If the herdfman be at any time abfent from the flock, he depends upon his Dog to keep them together; and as foon as he gives the well-known fignal, this faithful creature conducts them to his mafter, though at a confiderable diftance.

There is a very remarkable fingularity in the feet of the Shepherd's Dog, which we have likewife obferved in thofe of the Cur and the Spaniel. All of them have one, and fome two toes more than moft Dogs, though they feem not to be of much ufe. They appear to be deftitute of mufcles, and hang dangling at the hind part of the leg more like an unnatural excrefcence than a neceffary part of the animal. But the adage, that ' Nature las made nothing in vain,' ought to correct our decifion on their utility, which probably may exift unknown to us.

This breed of Dogs, at prefent, appears to be prea ferved, in the greateft purity, in the northern parts of Scotland; where its aid is highly necefiary in managing the numerous herds of Sheep bred in thofe extenfire wilds. 


\section{HISTORY OF QUADRUPEDS.}

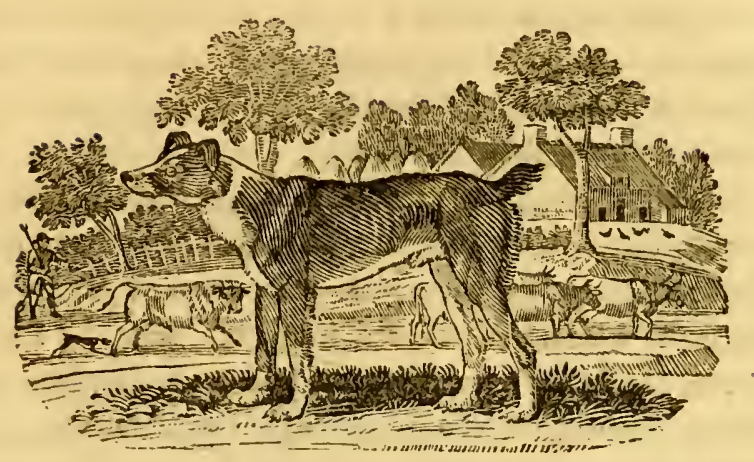

\section{THE CUR DOG,}

Is a trufty and ufeful fervant to the farmer and grazier; and, although it is not taken notice of by naturalifts as a diftinct race, yet it is now fo generally ufed, efpecially in the North of England, and fuch great attention is paid in breeding it, that we cannot help confidering it as a permanent kind.

They are chiefly employed in driving cattle; in which way they are extremely ufeful. They are larger, ftronger, and fiercer than the Shepherd's Dog; and their hair is fmoother and fhorter. They are moftly of a black and white colour; their ears are half-pricked; and many of them are whelped with hort tails, which feem as if they had been cut: Thefe are called Self-tailed Dogs. They bite very keenly; and as they always make their attack at the heels, the cattle have no defence againft them: In this way, they are more than a match for a Bull, which they quickly compel to run.-Their fagacity is uncommonly great: They know their mafter's fields, 
and are fingularly attentive to the cattle that are in them: - A good Dog watches, goes his rounds; and, if any ftrange cattle fhould happen to appear amongt the herd, although unbidden, he quickly flies at them, and with keen bites obliges them to depart.

Similar to the Cur, is that which is commonly ufed in driving cattle to the flaughter: And as thefe Dogs have frequently to go long journies, great ftrength, as well as fwiftnefs, is required for that purpofe. They are therefore generally of a mixed kind, and unite in them the feveral qualities of the Shepherd's Dog, the Cur, the Martiff, and the Greyhound.-Thus, by a judicious mixture of different kinds, the fervices of the Dog are rendered ftill more various and extenfive, and the great purpofes of domeftic utility more fully anfwered.

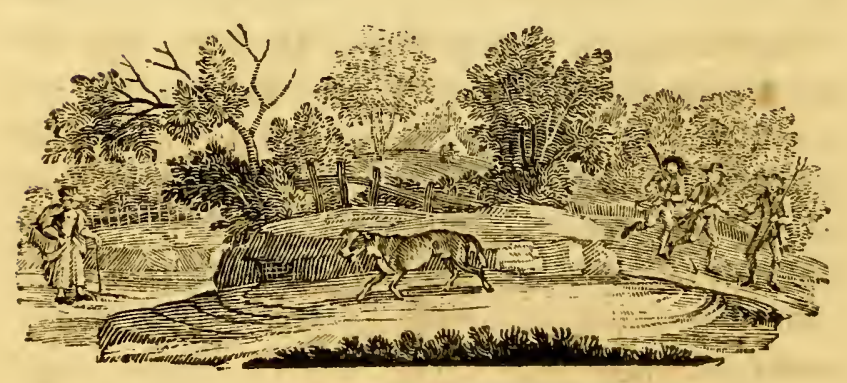




\section{HISTORY OF QUADRUPEDS.}

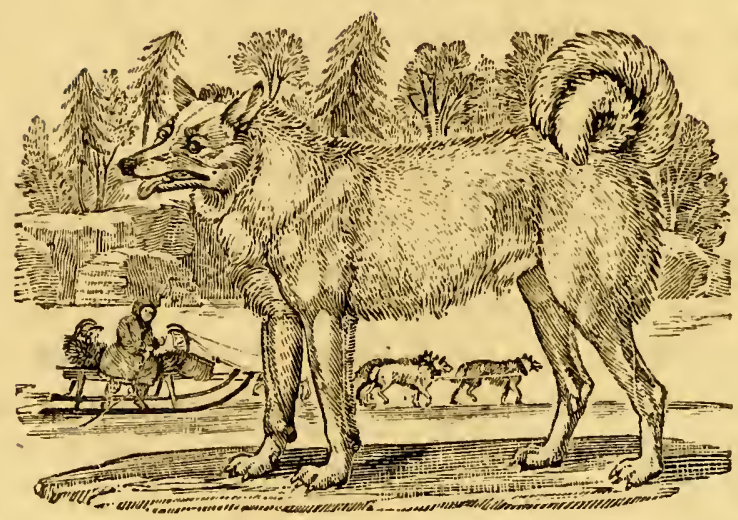

THE GREENLAND DOG.

(Le Chien de Sibirie, Buff.)

The favage afpect and difpofition of this Dog feem to bear fome affinity to the rigours of the climate it inhabits.

The Pomeranian or Wolf Dog of M. Buffon, the Siberian, Lapland, and Iceland Dogs are fomewhat fimilar to it in the fharpnefs of their muzzles, in their long fhaggy hair, and bufhy curling tails. 'The principal difference is in their fize.-Though much larger, they all of them have fome refemblance to the Shepherd's Dog.

Moft of the Greenland Dogs are white; but fome are fpotted, and fome black. They may rather be faid to howl than bark.-The Greenlanders fometimes eat their fleth: They make garments of their fkins, and ufe them in drawing fledges; to which they yoke them, four, five, 
and fometimes fix together.*-The Dogs of Kamfchatka are commonly black or white. They are ftrong, nimble, and active, and are very ufeful in drawing fledges, the only method of travelling in that dreary country du: ring the winter. They travel with great expedition. Captain King relates, that, during his ftay there, a courier with difpatches, drawn by them, performed a journey of 270 miles in lefs than four days.

The fledges are ufually drawn by five Dogs, four of them yoked two and two abreaft: The foremoft acts as a leader to the reft. The reins being faftened to a collar round the leading Dog's neck, are of little ufe in directing the pack; the driver depending chiefly upon their obedience to his voice, with which he animates them to proceed. Great care and attention are confequently ufed in training up thofe for leaders, which are more valuable according to their fteadinefs and docility; the fum of forty roubles, or ten pounds, being no unufual price for one of them.-The rider has a crooked Atick, anfwering the purpofe both of whip and reins; with which, by ftriking on the fnow, he regulates the fpeed of the Dogs, or ftops them at his pleafure. When they are inattentive to their duty, he often chaftifes them by throwing it at them. He difcovers great dexterity in regaining his ftick, which is the greatef difficulty attending his fituam tion; for if he Should happen to lofe it, the Dogs immediately difcover the circumftance, and never fail to fet off at full fpeed, and continue to run till their ftrength is exhaufted, or till the carriage is overturned, and dafhed to piecès, or hurried down a precipice.

* Five of thefe Dogs, that had efcaped with their trappings, were found in Greenland, and brought to this country a few years zoto by one of our finips in the fintery. 
In December, 1784 , a Dog was left by a fmuggling veffel near Boomer, on the coaft of Northumberland.Finding himfelf deferted, he began to worry Sheep; and did fo much damage, that he became the terror of the country within a circuit of above twenty miles. We are affured, that when he caught a Sheep, he bit a hole in its right fide, and after eating the tallow about the kidneys; left it: Several of them, thus lacerated, were found alive by the fhepherds; and being taken proper care of, fome of them recovered, and afterwards had lambs.From his delicacy in this refpect, the deftruction he made may in fome meafure be conceived; as it may be fuppofed, that the fat of one Sheep in a day would hardly fatisfy his hunger. The farmers were fo much alarmed by his depredations, that various means were ufed for his deftruction. They frequently purfued him with Hounds, Grayhounds, \&c. ; but when the Dogs came up with him, he laid down on his back, as if fupplicating for mercy; and in that pofition they never hurt him: He therefore laid quietly, taking his reft till the hunters approached, when he made off, without being followed by the Hounds, till they were again excited to the purfuit, which always terminated unfuccefsfully. -It is worthy of notice, that he was one day purfued from Howick to upwards of thirty miles diftance; but returned thither, and killed Sheep the fame evening.His conftant refidence, during the day, was upon a rock on the Heugh-hill, near Howick, where he had a view of four roads that approached it; and in March, 1785, after many fruitlefs attempts, he was at laft thot there. 


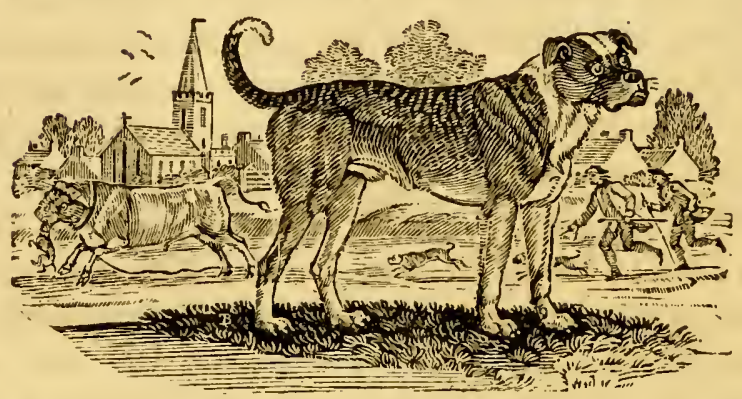

THE BULL-DOG,

Is the fierceft, of all the Dog kind; and is probably the moft courageous creature in the world. It is low in ftature, but very ftrong and mufcular. Its nofe is fhort; and the under jaw projects beyond the upper, which gives it a fierce and unpleafing afpect.-Its courage in attacking the Bull is well known: Its fury in feizing, and its invincible obftinacy in maintaining its hold, are truly aftonifhing. It always aims at the front; and generally faftens upon the lip, the tongue, the eye, or fome part of the face; where it hangs, in fpite of every effort of the Bull to difengage himfelf.

The uncommon ardour of thefe Dogs in fighting will be beft illuftrated by the following fact, related by an eye-witnefs; which at the fame time corroborates, in fome degree, that wonderful account of the Dogs of Epirus, given by Elian, and quoted by Dr Goldfmith in the hiftory of the Dog:-Some years ago, at a bullbaiting in the North of England, when that barbarous cuftom was very common, a young man, confident of 


\section{HISTORY OF QUADRUPEDS.}

the courage of his Dog, laid fome trifling wager, that he would, at feparate times, cut off all the four feet of his Dog; and that, after every amputation, it would attack the Bull. The cruel experiment was tried, and the Dog continued to feize the Bull as eagerly as if he had been perfectly whole.

Of late years this inhuman cuftom of baiting the Bull has been almoft entirely laid afide in the North of England; and, confequently, there are now few of this kind of Dogs to be feen.

As the Bull-Dog always makes his attack without barking, it is very dangerous to approach him alone, without the greateft precaution.

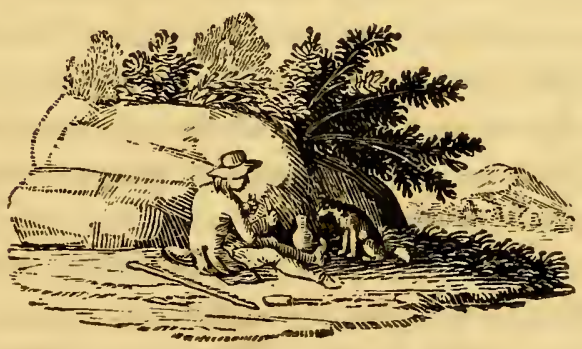




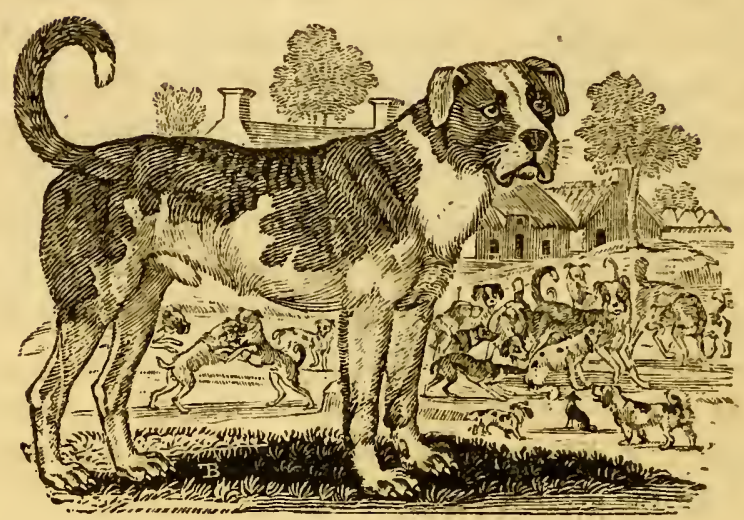

THE MASTIFF,

(Canis Molofus, Lin.-Le Dogue, Buff.)

Is much larger and ftronger than the Bull-Dog; its ears are more pendulous; its lips are large and loofe; its afpect is fullen and grave, and its bark loud and terrific.He feems every way formed for the important truft of guarding and fecuring the valuable property committed to his care. Houfes, gardens, yards, \&c. are fafe from depredations whilft in his cuftody. Confined during the day, as foon as the gates are locked, he is left to range at full liberty: He then goes round the premiffes, examines every part of them, and by loud barkings gives notice that he is ready to defend his charge.

Dr Caius, in his curious treatife on Britifh Dogs, tells us, that three of thefe animals'were reckoned a match for a Bear, and four for a Lion. 


\section{HISTORY OF QUADRUPEDS.}

We have a curious account, recorded in Stow's An1nals, of an engagement between three Maftiff's and a Lion, in the prefence of James the Firft. "One of the Dogs being put into the den, was foon difabled by the Lion, which took it by the head and neck, and dragged it about: Another Dog was then let loofe, and ferved in the fame manner: But the third being put in, immediately feized the Lion by the lip, and held him for a confiderable time; till being feverely torn by his claws, the Dog was obliged to quit its hold; and the Lion, greatly exhaufted in the conflict, refufed to renew the engagement; but taking a fudden leap over the Dogs, fled into the interior part of his den. Two of the Dogs foon died of their wounds: The laft furvived, and was taken great care of by the king's fon; who faid, "he that had fought with the king of beafts, hould never after fight with any inferior creature."

The Maftiffs of Great-Britain were noted in the time of the Roman Emperors, who appointed an officer, whofe fole bufinefs it was to breed and fend from hence fuch as would prove equal to the combats of the amphitheatre.

The following anecdote will thew, that the Maftiff, confcious of its fuperior ftrength, knows how to chaftife the impertinence of an inferior:-A large Dog of this kind, belonging to the late M. Ridley, Efq. of Heatton, near Newcafte, being frequently molefted by a Mongrel, and teazed by its continual barking, at laft took it up in his mouth by the back, and with great compofure dropped it over the quay into the river, without doing any farther injury to an enemy fo much his inferior.

The Maftiff, in its pure and unmixed ftate, is now fel- 
$33^{8}$ HISTORY OF QUADRUPEDS.

dom to be met with. The generality of Dogs diftinguifhed by that name, feem to be compounded of the Bull-Dog, Danifh Maftiff, and the Ban-Dog.

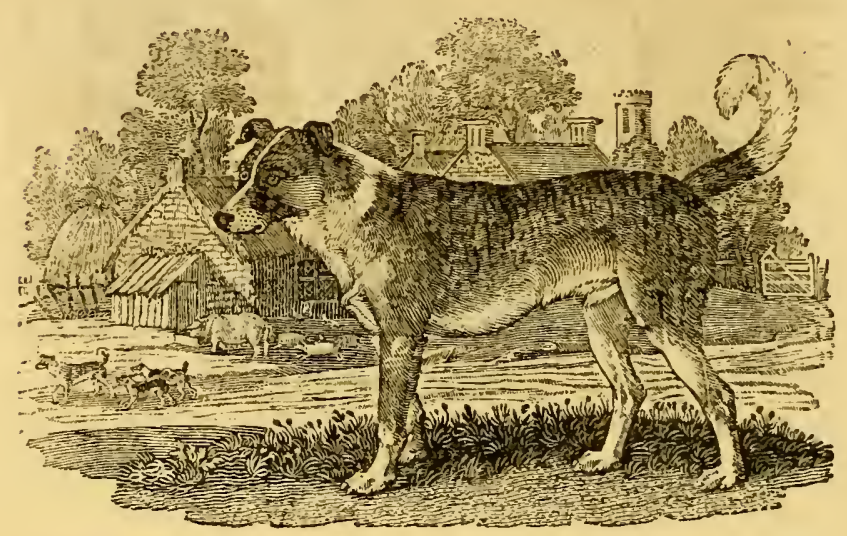

THE BAN-DOG,

Is a variety of this fierce tribe, not often to be feen at prefent. It is lighter, fmaller, more active and vigilant, than the Maftiff, but not fo powerful; its nofe is fmaller, and poffeffes, in fome degree, the fcent of the Hound ; its hair is rougher, and generally of a yellowintgray, ftreaked with thades of a black or brown colour. It does not invariably, like the preceding kinds, attack its adverfary in front, but frequently feizes cattle by the flank. It attacks with eagernefs, and its bite is keen and dangerous. 


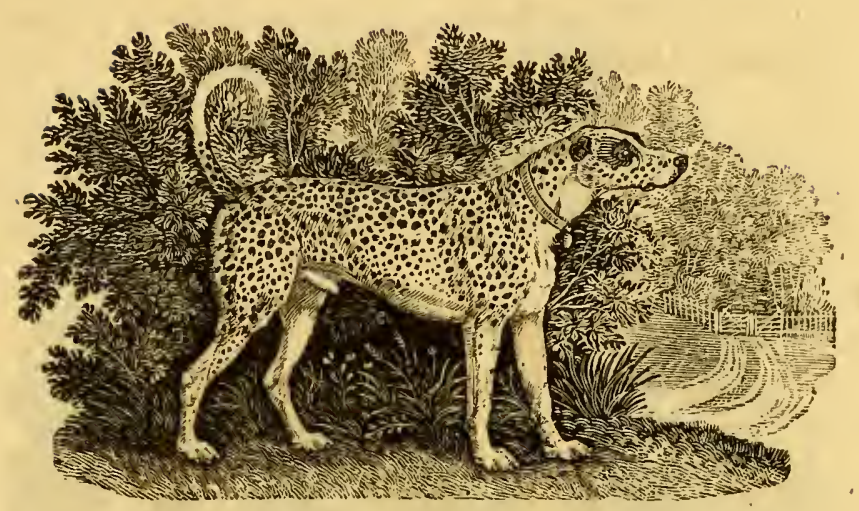

THE DALMATIAN, OR COACH DOG,

\section{(Le Braque de Bengal, Buff.)}

Has been erroneoufly called the Danifh Dog; and, by $M_{\text {. }}$ Buffon, the Harrier of Bengal; but for what reafon it is difficult to afcertain, as its incapacity of fcenting is fufficient to deftroy all affinity to any Dog employed in the purfuit of the Hare.

It is common in this country at prefent, and is frequently kept in genteel houfes, as an elegant attendant on a carriage.-We do not, however, admire the cruel practice of depriving the poor animal of its ears, in order to encreafe its beauty; a practice fo general, that we do not remember ever to have feen one of thefe Dogs unmutilated in that way. 


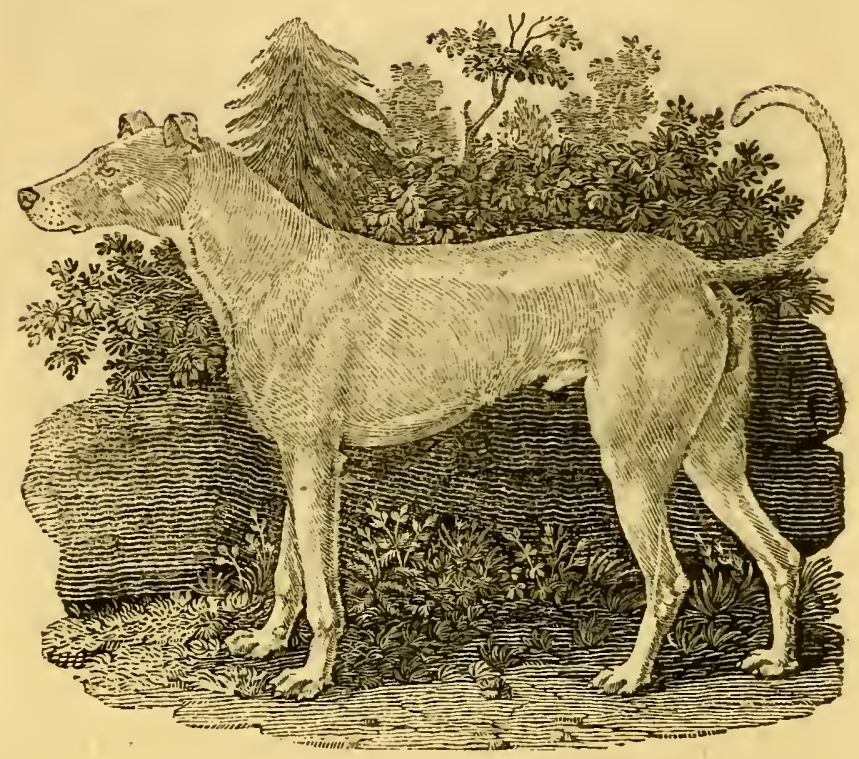

THE IRISH GREYHOUND,

(Canis Graius Hibernicus, Ray.-Le Matin, Buff.)

Is the largeft of the Dog kind, and its appearance the moft beautiful and majeftic.-It is only to be found in Ireland, where it was formerly of great ufe in clearing the country from Wolves.- It is now extremely rare, and is kept rather for thow than ufe, being equally unferviceable for hunting either the Stag, the Fox, or the Hare.

Thefe Dogs are about three feet high, generally of a white or cinnamon colour, and made fomewhat like a Greyhound, but more robuft: Their afpect is mild, and 


\section{HISTORY OF QUADRUPEDS.}

their difpofition gentle and peaceable: Their ftrength is fo great, that in combat the Maftiff or Bull-Dog is far from being equal to them. They moftly feize their antagonifts by the back, and flake them to death, which their great fize generally enables them to do with eafe.

M. Buffon fuppofes the Great Damifs Dog to be only a variety of the Irifh Greyhound.-Next to this, in fize and ftrength, is

\section{THE SCOTTISH HIGHLAND GREYHOUND, OR WOLF-DOG;}

WHICH was formerly ufed by the chieftains of that coun. try in their grand bunting parties.-One of them, which we faw fome years ago, was a large, powerful, fiercelooking Dog; its ears wrere pendulous, and its eyes half hid in the hair; its body was ftrong and mufcular, and covered with harfh, wiry, reddinh hair, mixed with white.

\section{THE GAZEHOUND,}

Was fomewhat fimilar to the Greyhound; and, like that animal, hunted only by the eye. It was formerly in great repute, but is now unknown to us. It was ufed in hunting either the Fox, the Hare, or the Stag. It would felect from the reft the fatteft Deer, purfue it by the eye, and though it thould rejoin the herd, would infallibly fix upon the fame, and purfue it till taken. 


\section{HISTORY OF QUADRUPEDS.}

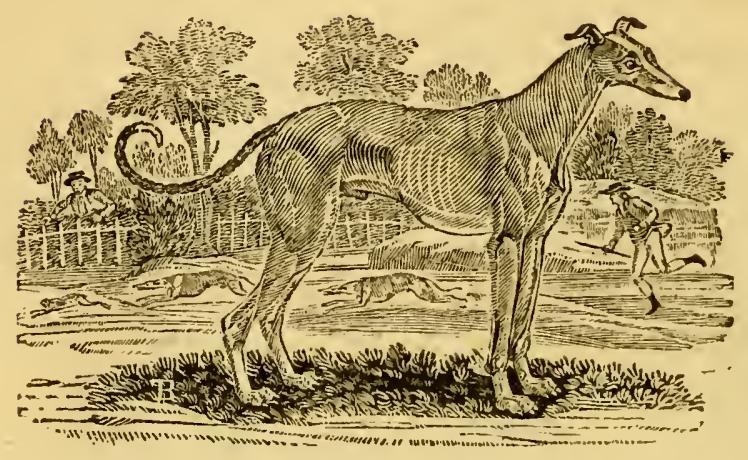

THE GREYHOUND,

(Canis Graills, Lin.-Le Levrier, Buff.)

M. Buffon fuppofes to be the Irifh Greyhound, rendered thinner and more delicate by the difference of climate and culture: But whatever truth there may be in the fanciful arrangements of that ingcnious author, there is an evident fimilarity of form in all of thofe juft mentioned; particularly in the depth of the cheft, in the length of the legs, and in the fmallnefs of the muzzle.

'The Greyhound is the fleeteft of all Dogs, and can outrun every animal of the chafe; but as it wants the faculty of fcenting, it only follows by the eye. It was formerly held in fuch eftimation, as to be confidered the peculiar companion of gentlemen; and, by the foreft laws of King Canute, it was enacted, that $n o$ perfon under that degree fhould prefume to keep a Greyhound.

The Sinall Italian Greybound is not above half the fize, but perfectly frmilar in form. Its thape is exquifitely 


\section{HISTORY OF QUADRUPEDS.}

beautiful and delicate. It is not common in this country, the climate being too rigorous for the extreme delicacy of its conftitution.

\section{THE LYEMMER,}

So called from its being led in a thong, and flipped at the game.-Dr Caius informs us, that it hunted both by the fcent and fight; and, in its form, was between the Hound and the Greyhound--It is now unknown to us.

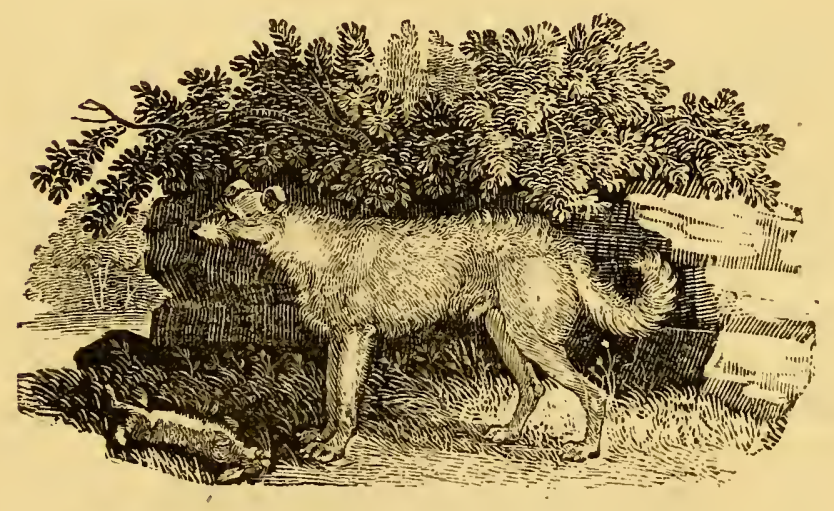

THE LURCHER,

Is lefs and fhorter than the Greyhound, and its limbs ftronger : Its body is covered with a rough coat of hair, moft commonly of a pale-yellow colour; its afpect is fullen, and its habits, from whence it derives its name, are dark and cunning.

$$
Y_{4}
$$


As this Dog poffefles the advantage of a fine fcent, it is often employed in killing Hares and Rabbits in the night time. When taken to the warren, it fteals out with the utmolt precaution, watches and fcents the Rabbits while they are feeding, and darts upon them without barking or making the leaft noife. One of them will fingly make incredible havock in a fhort time; and is fo trained, as to bring its booty to its mafter, who waits in fome convenient place to receive it*. They are fo deftructive, and have been fo often employed in illicit practices, that they are now, with great propriety, profcribed, and the bred is almoft extinct.

Another Dog of this family, formerly in ure, but now only known to us by its name, is

\section{THE TUMBLER;}

WHICH was fo called from its cunning manner of taking Rabbits and other game. It did not run directly at them, but, in a carelers and inattentive manner, tumbled itfelf about till it came within reach of its prey, which it always feized by a fudden fpring.

* We have feen a Dog and Bitch of this kind in the poffeffion of a man who had formerly ufed them for the purpofe above defcribed. He declared, that he could at that time procure in an evening as many Rabbits with them as he could carry home.

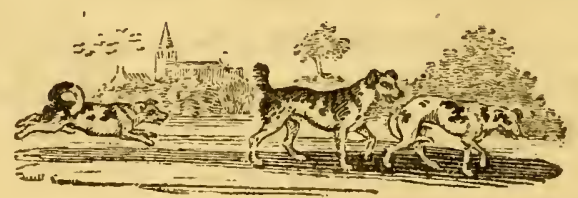




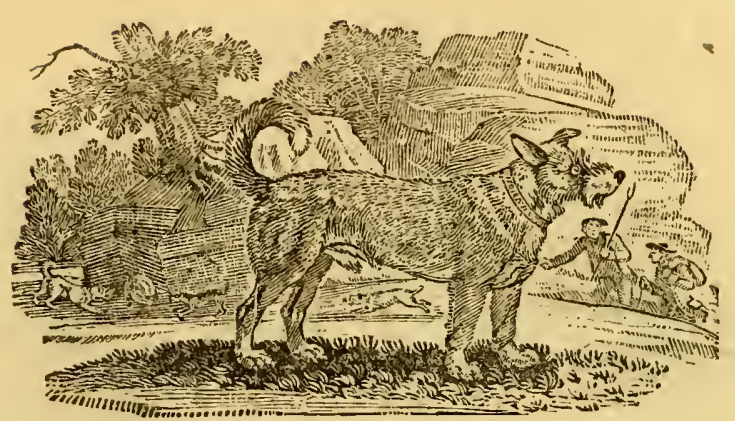

THE TERRIER,

Has a moft acute fmell, is generally an attendant on every pack of Hounds, and is very expert in forcing Foxes or other game out of their coverts. It is the determined enemy of all the vermin kind; fuch as Weafels, Foumarts, Badgers, Rats, Mice, \&rc. It is fierce, keen, and hardy; and, in its encounters with the Badger, fometime meets with very fevere treatment, which it fuftainis with great courage and fortitude. A well-trained veteran Dog frequently proves more than a match for that hardbitten animal.

There are two linds of Terriers,-the one rough, fhort-legged, long-backed, very ftrong, and moft commonly of a black or yellowin colour, mixed with white; the other is fmooth, fleek, and beautifully formed, having a fhorter body, and more fprightly appearance: It is generally of a reddifh-brown colour, or black, with tanned legs; and is fimilar. to the rough Terrier in difpofition and faculties, but inferior in fize, ftrength, and hardinefs. 
346 HISTORY OF QUADRUPEDS.

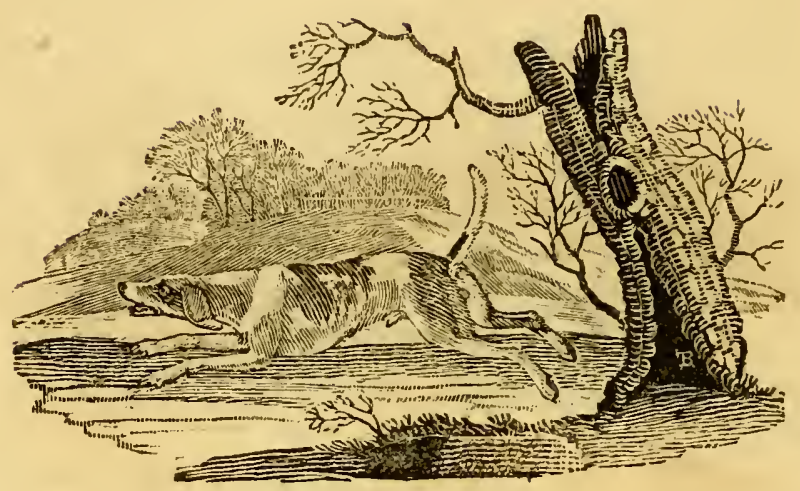

THE BEAGLE.

OF thofe Dogs that are kept for the bufinefs of the chafe in this country, the Beagle is the fmalleft, and is only ufed in hunting the Hare. Although far inferior in point of fpeed to that animal, it follows by the exquifitenefs of its fcent, and traces her footfteps through all her various windings with great exactners and perfeverance. Its tones are foft and mufical, and add greatly to the pleafures of the chafe.

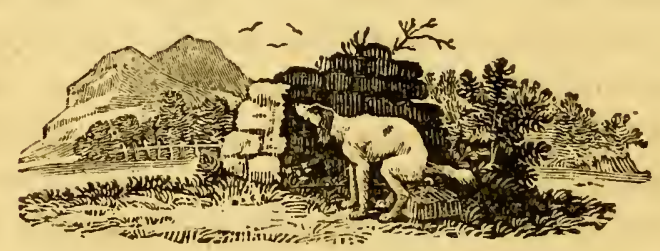




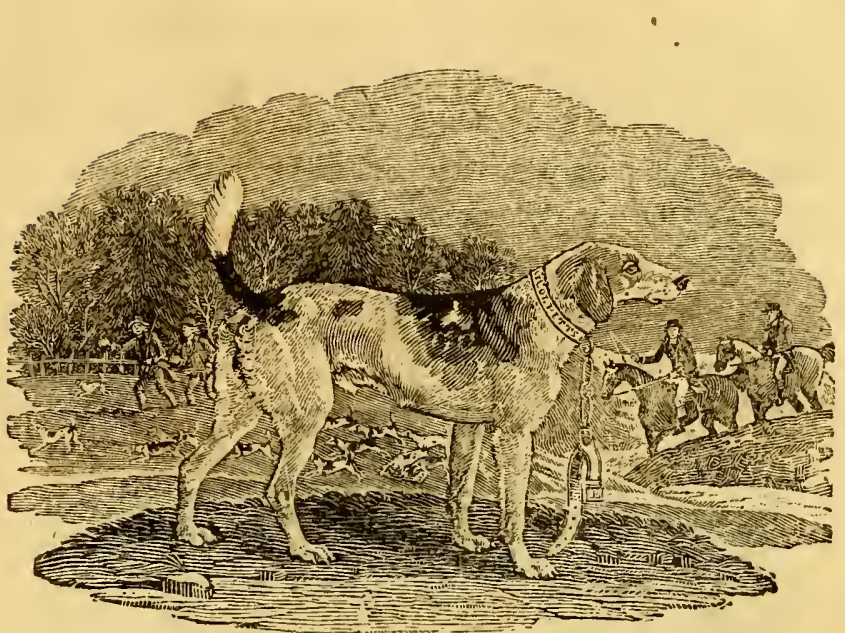

THE HARRIER,

$$
\text { (Le Braque, Buff.) }
$$

Which chiefly differs from the Beagle in being fomewhat larger, is very nimble and vigorous. It purfues the Hare with the moft impetuous eagernefs, and gives her no time to breathe nor double. The moft eager fportfmen generally find it fufficient exercife to keep in with their fpeed.-They exert their voices with great chearfulnefs, and make delightful harmony.

A mixt breed, between this and the large Terrier, forms a ftrong, active, and hardy Hound, ufed in hunting the Otter.-It is rough, wire-haired, thick-quartered, long-eared, and thin--houldered.

There is reafon to fuppofe, that the Beagle and the Harrier mut have been introduced into Great-Britain after the Romans became mafters of the illand; as, before 
that period, the Britons were occupied in clearing their extenfive forefts of the various wild beafts, fuch as WildBoars, Bears, Wolves, \&c. witl which they abounded; and, for that purpofe, larger and ftronger Dogs than the Harrier or the Beagle would be required.

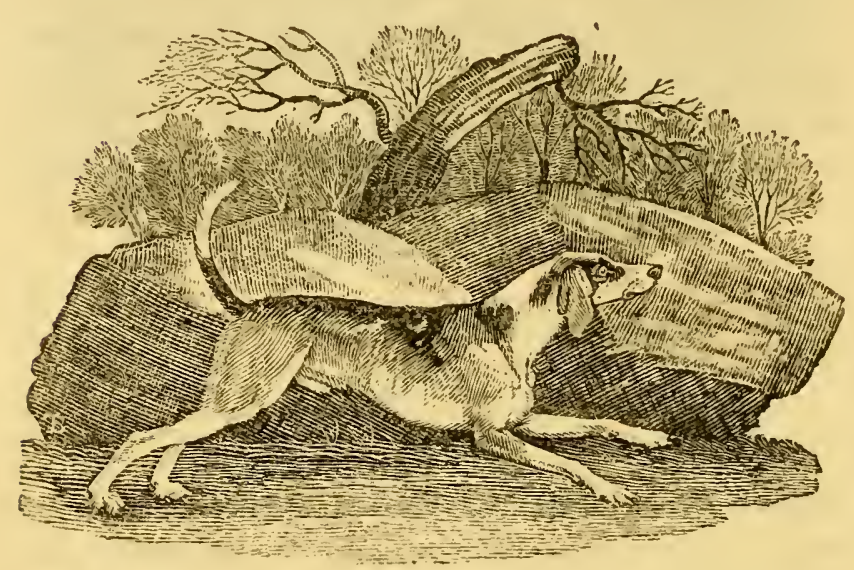

THE FOX-HOUND.

No country in Europe can boaft of Fox-Hounds equal in fwiftnefs, ftrength, or agility, to thofe of Britain; where the utmof attention is paid to their breeding, education, and maintenance. The climate alfo feems congenial to their nature; for it has been faid, that when Hounds of the Englifh breed have been fent into France or other countries, they quickly degenerate, and in fome degree lofe thofe qualities for which they were originally fo admirable 


\section{HISTORY OF QUADRUPEDS.}

In England, the attachment to the chafe is in fome meafure confidered as a trait in the national character; confequently, it is not to be wondered at that our Dogs and Horfes thould excel all others in that noble diverfion. This propenfity appears to be increafing in the nation; and no price feems now thought too great for Hounds of known excellence*.

The Fox-Hounds generally preferred are tall, lightmade, but ftrong, and poffeffed of great courage, fpeed, and activity.

The habits and faculties of thefe Dogs are fo generally known, as to render any defcription unneceffary.

Dogs of the fame kind are alfo trained to the hunting of the Stag and other Deer.

The following anecdote affords a proof of their wonderful fpirit in fupporting a continuity of exertion:-

"Many years fince, a very large Stag was turned out of Whinfield Park, in the county of Weftmorland, and purfued by the Hounds till, by fatigue or accident, the whole pack were thrown out, except two ftaunch and favourite Dogs, which continued the chafe the greateft part of the day. The Stag returned to the park from whence he fet out; and, as his laft effort, leapt the wall, and expired as foon as he had accomplifhed it. One of the Hounds purfued to the wall; but being unable to get over it, laid down, and almoft immediately expired: The other was alfo found dead at a fmall diftance.

"The length of the chafe is uncertain: But, as they were feen at Red-kirks, near Annan, in Scotland, diftant,

* In 1788, Mr Noel's pack was fold to Sir Wm Lowther Bart. for toco guineas. 
by the poft-road, about forty-fix miles, it is conjectured, that the circuitous and uneven courfe they might be fuppofed to take, would not be lefs than one bundred and twenty miles.

"To commemorate this fact, the horns of the Stag, which were the largeft ever, feen in that part of the country, were placed on a tree of a moft enormous fize, in the park, (afterwards called the Hart-horn tree) accompanied with this infcription :-

" Hercules kill'd Hart o'Greece;

"And Hart o'Greece kill'd Hercules."

"The horns have been fince removed, and are now at Julian's Bower, in the fame county."

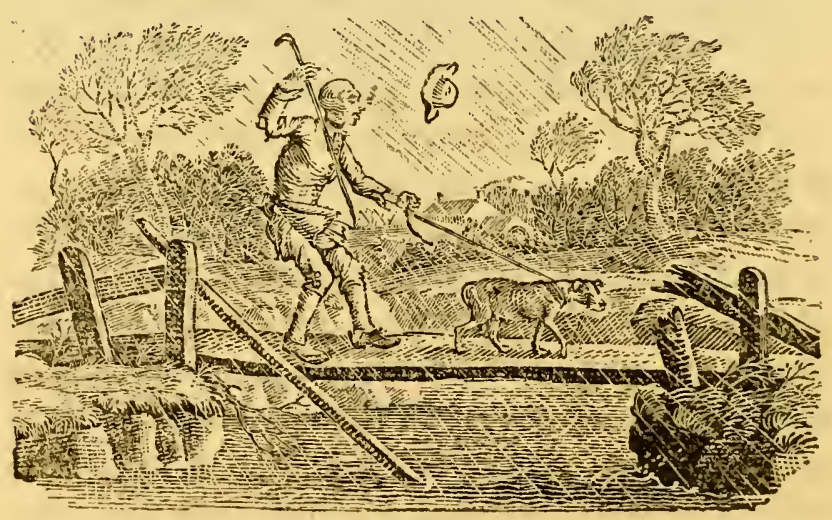




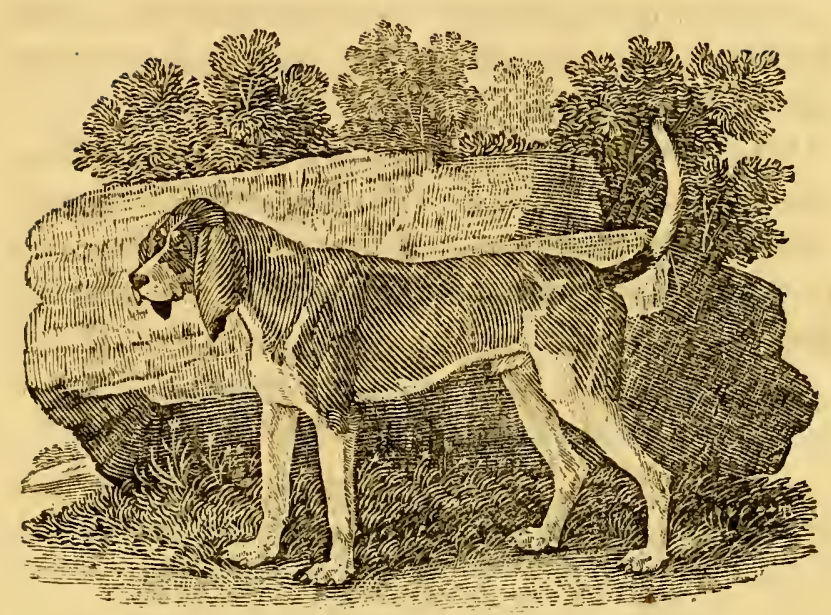

THE OLD-ENGLISH HOUND,

(Canis Sagax, Lin._Le Chien courant, Buff.)

Is defcribed by Whitaker, in his Hiftory of Manchefter, as the original breed of this ifland, ufed by the ancient Britons in the chafe of the larger kinds of game, with which their country abounded.

This valuable Hound is diftinguifhed by its great fize and ftrength. Its body is long, its cheft deep, its ears long and fweeping, and the tone of its voice is peculiarly deep and mellow.-From the particular formation of its organs, or from the extraordinary moifture that always adheres to its nofe and lips, or perhaps from fome other unknown caufe, it is endued with the moft exquifite fenfe of fmelling, and can often diftinguifh the fcent an hour after the lighter Beagles have given it up. Their 
flowners alfo difpofes them to receive the directions of the huntfman : But as they are able to hunt a cold fcent, they are too apt to make it fo by their want of fpeed, and tedious exactnefs.

Thefe Dogs were once common in every part of this ifland, and were formerly much larger than at prefent.

The breed, which has been gradually declining, and its fize ftudiounly diminifhed by a mixture of other kinds in order to increafe its fpeed, is now almoft extinct.

It feems to have been accurately defcribed by Shakefpeare, in the following lines.

" My Hounds are bred out of the Spartan kind,

"So flew'd, fo fanded; and their heads are hung

"Wish ears that fweep away the morning dew;

"Crook-knce'd and dew-lap'd, like Theffalian bulls;

"Slow in purfuit; but mateh'd in mouth like bells,

"Each under each."

Befides thefe, there is a variety called the Kibble-Hound, produced by a mixture of the Beagle and the Old Englifli Hound.

\section{THE BLOOD-HOUND,}

WAs in great requeft with our anceftors; and as it was remarkable for the finenefs of its fcent, it was frequently employed in recovering game that had efcaped wounded from the hunter. It could follow, with great certainty, the footfteps of a man to a confiderable diftance: And in barbarous and unciviiized times, when the thief or mur-

- derer had fled, this ufeful creature would trace him through the thickeft and moft fecret coverts; nor would it ceafe its purfuit till it had taken the felon. For this reafon, there was a law in Scotland, that whocver dc- 
nied entrance to one of thefe Dogs, in parfuit of -ftolen goods, fhould be deemed an acceflary.

Blood-Hounds were formerly ufed in certain diftricts lying between England and Scotland, which were much infefted by robbers and murderers; and a tax was laid upon the inhabitants for keeping and maintaining a certain number of them. But, as the arm of juftice is now extended over every part of the country, and there are no fecret receffes where villainy may lie concealed, thefe fervices are no longer neceffary.

In Scotland, it was diftinguifhed by the name of the Sleuth-Hound.

Some few of thefe Dogs are ftill kept in the fouthern part of the kingdom, and are ufed in purfuit of Deer that have been previoufly wounded by a fhot to draw blood, the fcent of which enables them to purfne with moft unerring fteadinefs.-They are fometimes employed in difcovering deer-ftealers, whom they infallibly trace by the blood that iffues from the wounds of their victims. - They are alfo faid to be kept in convents, fituated in the lonely and mountainous countries of Switzerland, both as a guard to the facred manfion, as well as to find out the bodies of men that have been unfortunately loft in croffing thofe wild and dreary tracts.

The Blood-Hound is taller than the Old Englifh Hound, moft beâutifully formed, and fuperior to every other kind in activity, fpeed, and fagacity.-They feldom bark, except in the chafe; they are commonly of a reddifh or broxpy colour.

A Hound bitch', belonging to the Rivington hunt, near Lclton, puípped four whelps during a hard chafe, 
which the carefully covered in a rufh aifle, and immediate ly after joined the pack. Shortly after, the pupped another, which the carried in her mouth during the remainder of a chafe of many miles: After which, the returned to the place where the had dropped the four.

Somervile thus beautifully defcribes their mode of purfuing the nightly fpoiler.

\footnotetext{
"Soon the fagacious' brute, his curling tail

" Flourifh'd in air, low bending, plies around

" His bufy riofe, the fteaning vapour fnufls

"Inquifitive, nor leaves one turf untry'd,

"Till, confcious of the recent ftains, his heart

" Beats quick; his fnuffling nofe, his active tail,

"Attel his joy: 'Then with deep-op'ning nouth,

"That makes the welkin tremble, he proclaims

" Th' audacious felon: Fooc by foot he marks

"His winding way, while all the lif'ning crowd

"Applaud his reas'nings: O'er the wat'ry ford,

"Dry fandy heaths, and fony barren hills;

" O'er beaten paths, with men and beafts difain'c,

"Unerring he purfues, till at the cot

"Arriv'd, and feizing by his guilty throat

"The caiciff vile, redeens the captive prey;

"So exquifitely delicate his fenfe!"
}

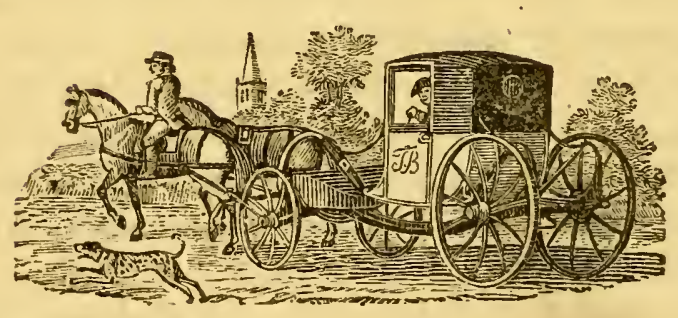




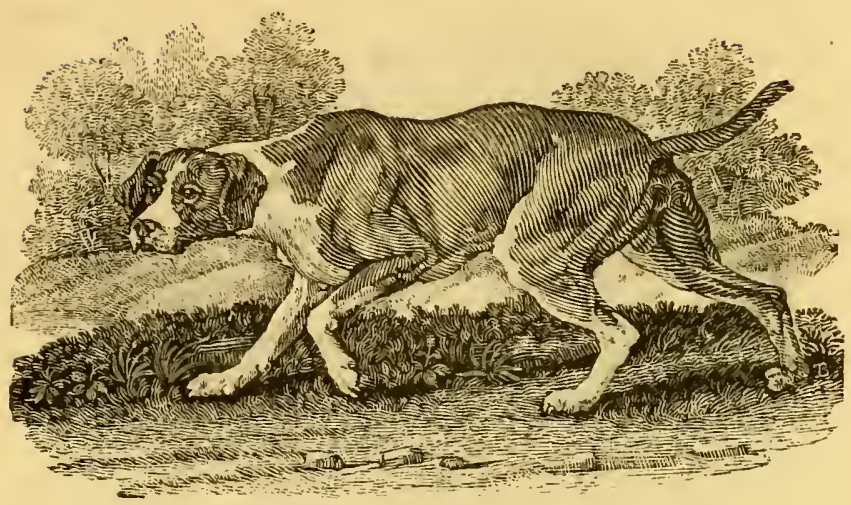

\section{THE SPANISH POINTER,}

(Canis Avicularius, Lin.)

Is of foreign origin, as its name feems to imply; but it is now naturalized in this country, which has long been famous for Dogs of this kind ; the greateft attention being paid to preferve the breed in its utmoft purity.

This Dog is remarkable for the aptnefs and facility with which it receives inftruction. It may be faid to be almoft felf-taught; whilf the Englifh Pointer requires the greateft care and attention in breaking and training to the fport. The Spanifh Pointer, however, is not fo durable and hardy, nor fo able to undergo the fatigues of an extenfive range. It is chiefly employed in finding partridges, pheafants, \&c. either for the gun or the net.

It is faid, that an Englih nobleman (Robert Dudley, Duke of Northumberland) was the firft that broke a Setting-Dog to the net. 


\section{HISTORY OF QUADRUPEDS.}

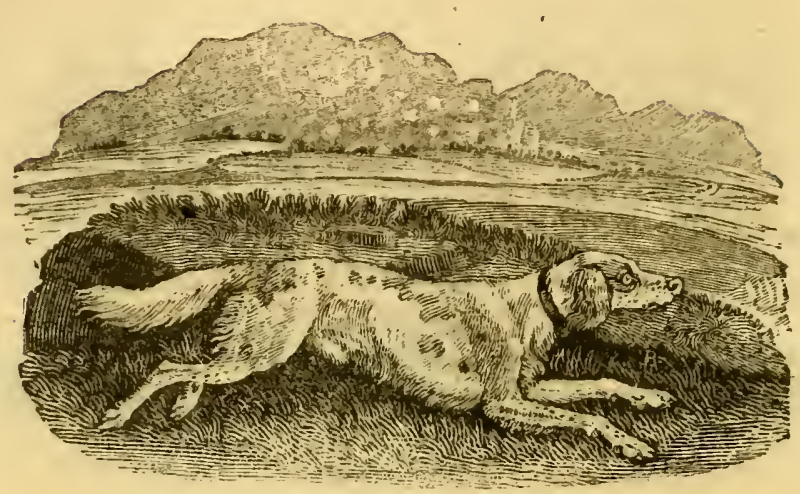

THE ENGLISH SETTER,

Is a hardy, active, handfome Dog.-Its fcent is exquifite; and it ranges with great fpeed and wonderful perfeverance. Its fagacity in difcovering the various kinds of game, and its caution in approaching them, are truly aftonifhing. But as the ufes of this valuable. Dog are fo. well known, we will conclude with the following beautiful quotation from Somervile :-

"When autumn fmiles, all-bcauteous in decay,

"A And paints each chequer'd grove with various hues,

"My Sctter ranges in the new-fhorn fields,

"His nofe in air crect; from ridge to tidge

" Panting he bounds, his quarter'd ground divides

"In equai intervals, nor carelefs leaves

"One inch untry'd: At length the tainted gales

" His noftrils wide inhale; quick joy elates

"Hisobeating heart, which, aw'd by difcipline

"Severe, he dares not own, but cautious creeps,

"Low-cow'ring, ftep by ftep; at laft attains

"His proper diftance; there he ftops at once,

"And points with his inftructive nofe upon

"The trembling prey." 


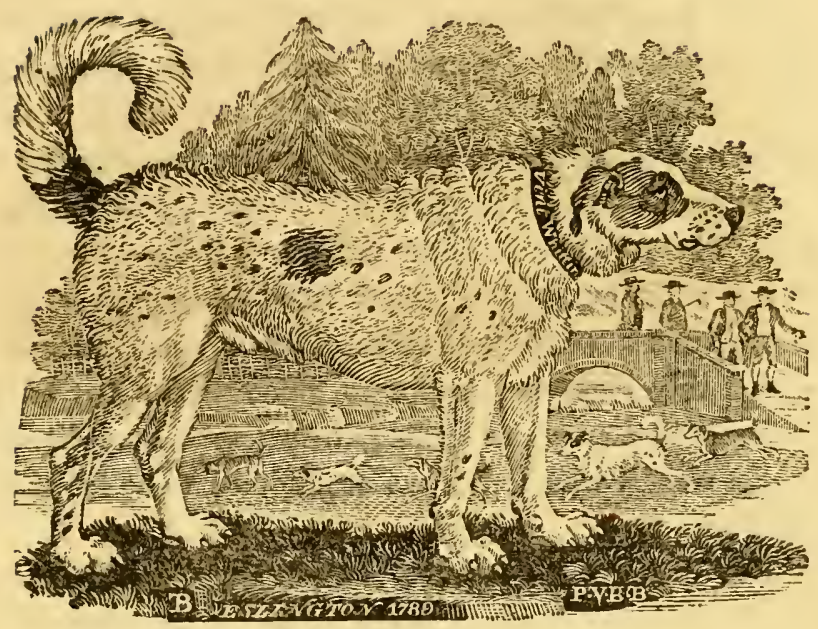

THE NEWFOUNDLAND DOG:

THE drawing of this Dog, was taken from a very fine one at Eflington, in the county of Northumberland. Its dimenfions were as follow :-

From its nofe to the end of its tail, it meafured $f_{1 x}$ feet two inches; the length of its tail, one foot ten inches; from one fore foot right over its fhoulders to the other, five feet feven inches; girt behind the fhoulder, three feet two inches; round its head over its ears, two feet; round the upper part of its fore leg, nine inches and a half. It was web-footed, could fwim extremely faft, dive with great eafe, and bring up any thing from 
the bottom of the water. It was naturally fond of fifhs and ate raw trouts, or other fmall fifh, out of the nets.

This breed of Dogs was originally brought from the country of which they bear the name, where their great ftrength and docility render them extremely ufeful to the fettlers on thofe coafts, who ufe them in bringing down wood from the interior parts of the country to the feafide: Three or four of them yoked to a fledge will draw two or three hundred weight of wood piled upon it, for feveral miles, with great eafe: They are not attended with a driver, nor any perfon to guide them; but after having delivered their loading, they return immediately to the woods, where they are accuftomed to be fed with dried fifl, \&x.

The extraordinary fagacity of thefe Dogs, and their attachment to their mafters, render them highly valuable in particular fituations.

During $a^{\bullet}$ fevere ftorm, in the winter of 1789 , a fhip, belonging to Newcaftle, was loft near Yarmouth; and a Newwoundland Dog alone efcaped to fhore, bringing in his mouth the captain's pocket book. He landed amidft a number of people, feveral of whom in vain endeavoured to take it from him. The fagacious animal, as if fenfible of the importance of the charge, which in all probability was delivered to him by his perifhing mafter, at length leapt fawningly againft the breaft of a man, who had attracted his notice among the crowd, and delivered the book to him. The Dog immediately returned to the place where he had landed, and watched with great attention for every thing that came from the wrecked veffel, feizing them, and endeavouring to bring them to lond. 


\section{HISTORY OF QUADRUPEDS.}

The following is another inftance of their great docility and ftrength of obfervation:- A gentleman walking by the fide of the river Tyne, and obferving, on the oppofite fide, a child fall into the water, gave notice to his Dog, which immediately jumped in, fwam over, and catching hold of the child with its mouth, brought it fafe to land.

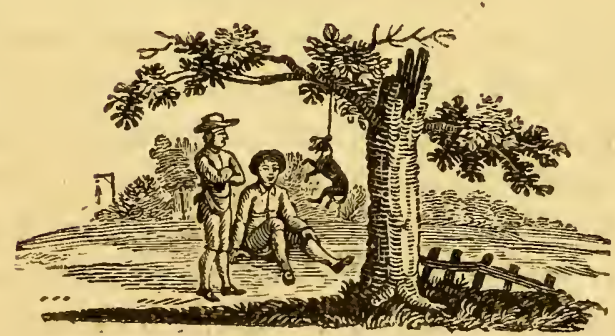




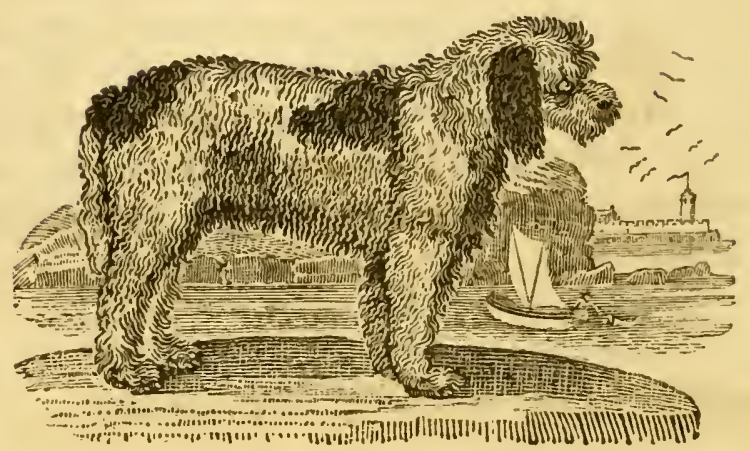

THE LARGE ROUGH WATER-DOG,

(Canis aviarius Aquaticus, Lin.-Le Grand Barbet, Buff.)

Is web-footed, fwims with great eafe, and is ufed in hunting ducks and other aquatic birds. - From its aptnefs to fetch and carry; it is frequently kept on board of thips, for the purpofe of recovering any thing that has fallen overboard; and is likewife ufeful in taking up birds that are fhot, and drop into the fea.

There is a variety much fmaller.—-They are both re. markable for their long and fhaggy coat, which frequently incommodes them by growing over their eyes.

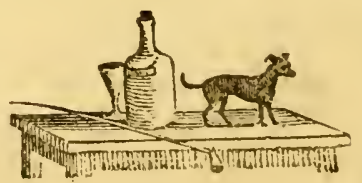




\section{HISTORY OF QUADRUPEDS.}

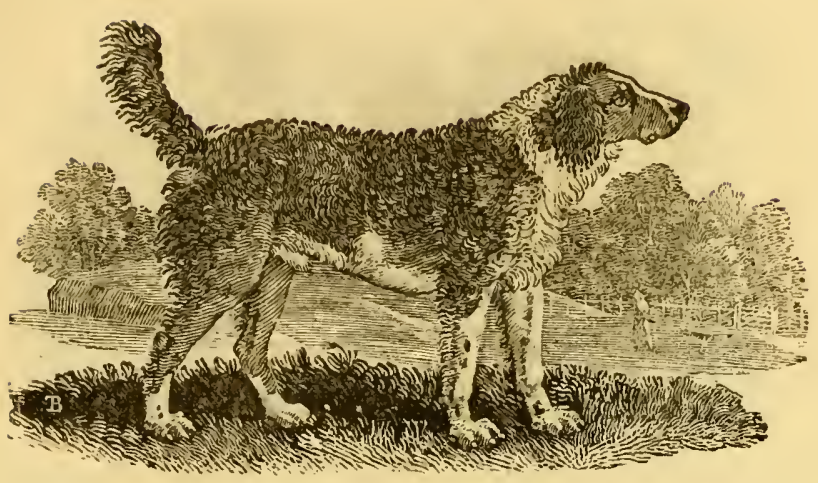

THE LARGE WATER-SPANIEI.

THE drawing of this beautiful animal was made from one of the fineft of its kind, in the poffeffion of $\mathrm{J}$. E. Blackett, Efq. of Newcaftle upon Tyne.

This kind of Dog is valuable for its great docility and attachment to its mafter. It receives inftructions with readinefs, and obeys with uncommon alacrity.-Its form is elegant, its hair beautifully curled or crifped, its ears long, and its afpect mild and fagacious.-It is fond of the water, and fwims well. It is chiefly ufed in difcovering the haunts of wild-ducks and other water fowl, and alfo in finding birds that have been thot or difabled. -It is probably the Finder, defcribed by Caius.'

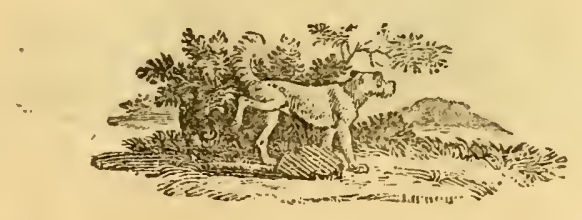




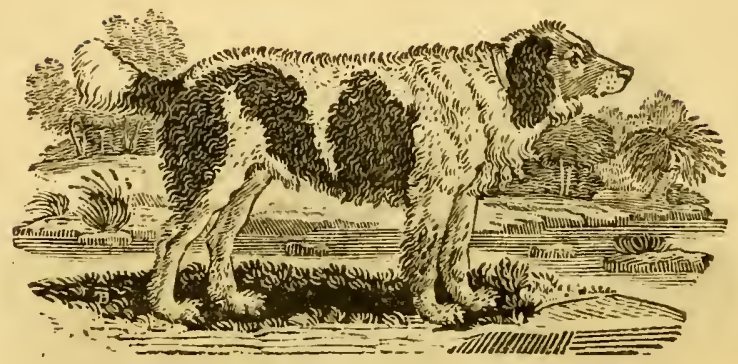

THE SMALL WATER-SPANIEL,

Is fimilar to the other in form, habits, and difpofition; and its capacity for receiving inftruction is equally good. With looks of extreme attention and fenfibility, it obferves the motions of its mafter, and catches the wellknown fignal with amazing promptitude.

The various tricks which thefe Dogs are fometimes taught to perform, feem more like the effect of reafoning powers, than of undifcerning.inftinct.

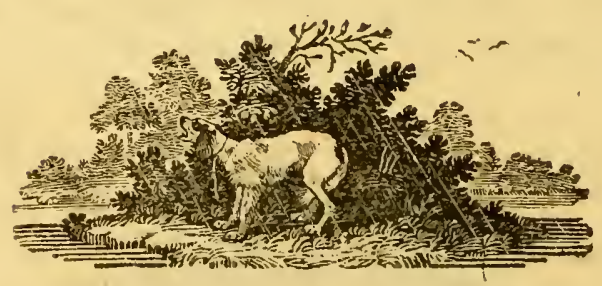




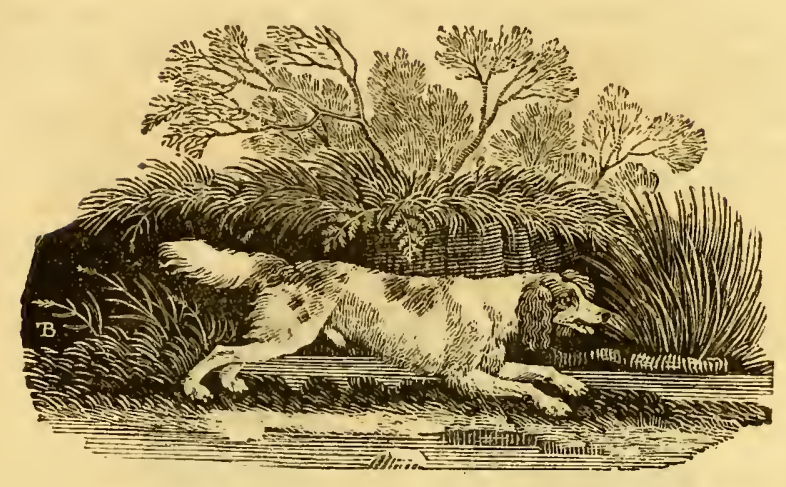

\section{THE SPRINGER, OR COCKER,}

Is lively, active, and pleafant; an unwearied purfuer of its game; and very expert in raifing woodcocks and fnipes from their haunts in woods and marfhes, through which it ranges with amazing perfeverance.

Of the fame kind is that beautiful little Dog, which, in this country, is well known under the appellation of King Charles's Dog; the favourite and confant companion of that monarch, who was generally attended by feveral of them.- It is Atill preferved as an idle but innocent companion.-Its long ears, curled hair, and webfeet, evidently point out its alliance with the more ufeful and active kind laft mentioned.

Similar to this, but fmaller, is the Pyrame-Dog.-It is generally black, with reddifh legs; and above each eye is a fpot of the fame colour.

Still farther removed, we have the Shock-Dog; a diminutive creature, almoft hid in the great quantity of its hair, which covers it from head to foot. 


\section{$3^{64}$ HISTORY OF QUADRUPEDS.}

Another variety is the Lion-Dog; fo called from the fhaggy hair which covers the head and all the fore part of the body; whilft the hinder part is quite fmooth, faving a tuft of hair at the end of the tail.- This fpecies is become extremely rare.

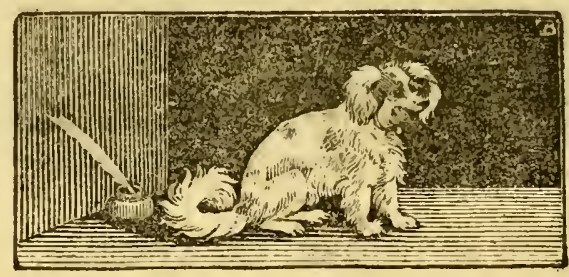

THE COMFORTER,

Is a moft elegant little animal, and is generally kept by the ladies as an attendant of the toilette or the drawing room.-It is very fnappifh, ill-natured, and noify; and does not readily admit the familiarity of frangers.

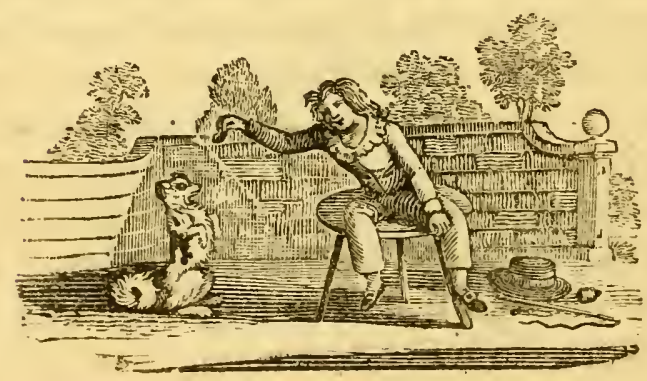




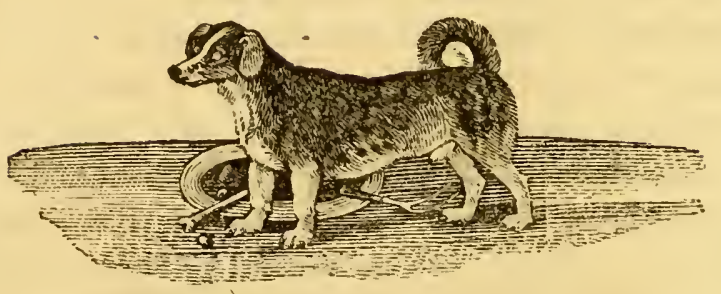

? THE TURNSPIT,

Is generally long-bodied, has fhort crooked legs, its tail curled upon its back, and is frequently fpotted with black upon a blue-gray ground. It is peculiar in the colour of its eyes; the fame Dog often having the iris of one eye black, and the other white.

It is a bold, vigilant, and fpirited little Dog. At prefent, however, its fervices feem but little attended to; a more certain method of doing the bufinefs of the fpit having fuperfeded the labours of this induftrious animal.

\section{THE PUG-DOG,}

In outward appearance, is every way formed like the Bull-Dog; but much fmaller, and its tail is curled upon its back. It was formerly very common in many parts of England; however, at prefent, it is rarely to be met with.-Although it has no longer its admirers here, Mrs Piozzi informs us, that the faw great numbers at Padua, in Italy, and that it ftill maintains its place in the favour of the fair-ones of that country.

From thefe, and a mixture of others, proceeds a num. 
berlefs variety of Meffets, Lap-Dogs, Dancers, Waps, Mongrels, and compounds without end.

That all thefe, however divided, compofe one general family, is apparent, from the facility with which they intermix, produce, and re-produce. In all of them the fame attachment to mankind, the fame pliant and humble difpofition, fubmitting with patience to the various indignities to which they are expofed by their dependent fituation, is eminently obfervable. Even thofe that, by accident or neglect, have been abandoried, and become wild, when taken home, are eafily reclaimed by kindnefs and attention: They quickly become familiar, and continue faithfully attached to their mafters.-Multitudes of thefe are to be found in South-America, which have fprung from thofe taken thither by the Europeans. They breed in holes in the ground, are formed fomewhat like a Greyhound, have erect ears, are very vigilant, and excellent in the chafe.

To mention fome of the more common inftances of this creature's fagacity, by way of elucidating its general character, may not be amifs; and amongft thefe, its care in directing the fteps of the blind man is not the leaft worthy of notice. There are few who have not feen an unfortunate object of this defcription, led by his Dog; through the various paffages of a populous town, to the accuftomed place where he fits to fupplicate the contributions of paffengers. It may fometimes be feen to ftop at particular houfes, to receive the morfel from the hand of charity, or pick from the ground the money thrown out to relieve its miferable owner. When the day is paffed, it conducts him home again; and gratefully re- 


\section{HISTORY OF QUADRUPEDS.}

ceives, as the reward of its fervices, the fcanty pittance which poverty and wretchednefs can beftow.

Dogs will fometimes imitate the actions of their mafters, will open a door that is faftened with a latch, or pull a bell, where they are defirous of gaining admittance.-Faber mentions one, belonging to a nobleman of the Medici family, which always attended at its mafter's table, took from him his plates, and brought him others; and if he wanted wine, would carry it to him, in a glafs placed upon a filver plate, which it held in its mouth, without fpilling the fmalleft drop. The fame Dog would alfo hold the ftirrups in its teeth, whilft its mafter was mounting his horfe.

That Dogs are capable of mutual attachment, is evident, from the well-known ftory of the Dog at St. Alban's; which, being left by its mafter at an inn'there till he returned from London, and being ill-treated by a large Dog belonging to the houfe, ftole privately off. It foon returned with a friend, that was much larger and ftronger than itfelf; and both fell upon the aggreffor, and punifhed him feverely for his cruelty to a ftranger. $:$

There are feveral peculiarities common to all animals of the Dog kind, briefly mentioned by Linnæus, with which we fhall conclude its hiftory; the principal of which are as follow:- The Dog is carnivorous; its ftomach digefts bones; it eats grafs for a vomit; voids its urine fideways, and commonly where other Dogs have done fo before; fmells at a ftranger; fcarcely ever fweats, but lolls out its tongue when hot; remembers injuries done to it; is fubject to the hydrophobia; its fenfe of hearing very quick; when afleep, is fuppofed to dream; goes with young fixty-three days, and brings 
forth from four to eight at one time. It barks at ftrange Dogs, fnaps at a ftone thrown at it, howls at certain mufical notes; when about to lie down, frequently goes round the place; fawns at the approach of its mafter, and will not patiently fuffer any one to frike him; runs before him on a journey, often going over the fame ground; on coming to crofs ways, ftops, looks back, and waits to obferve which of them he takes; fits up and begs; and, when it has committed a theft, ninks away with its tail between its legs; is an enemy to beggars and ill-looking people, and attacks them without the leaft provocation; is alfo faid to be fick at the approach of bad weather.-We cannot, however, agree with the learned naturalint when he afferts, that the male puppies refemble the Dog, and the female the Bitch; or that it is a character common to the whole fpecies, that the tail always bends to the left fide. To thefe we may add, as equally void of foundation, a remark of M. Buffon, that a female Hound, covered with a Dog of her own kind, has been known to produce a mixed race, confifting of Hounds and Terriers. - We barely mention thefe to fhew, that too much caution cannot be ufed in forming general characters or fyftematic arrangements; and we leave it to the experience of the moft inattentive obferver to detect fuch palpable abfurdities.

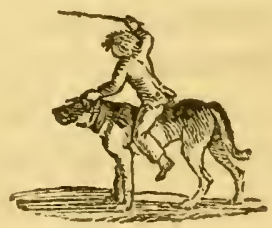




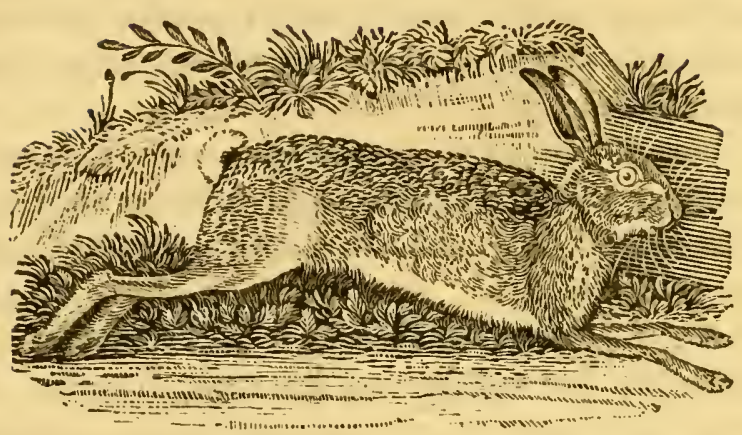

THE HARE.

(Lepus timidus, Lin.-Le Lievre, Buff.)

THis harmlefs and inoffenfive animal, deftitute of every means of defence, and furrounded on all fides by its. enemies, would foon be utterly extirpated, if Nature, ever kind and provident, had not endowed it with faculties, by which it is frequently enabled to evade their purfuit.

Fearful of every danger, and attentive to every alarm, the Hare is continually upon the watch; and being provided with very long ears, moveable at pleafure, and eafily directed to every quarter, is warned of the moft diftant approaches of danger. Its eyes are large and prominent, adapted to receive the rays of light on every fide, and give notice of more inmediate alarms. To thefe may be added its great fwiftnefs, by which it foon leaves moft of its purfuers far behind.-The hind are much longer than the fore legs, and are furnifhed with ftrong 
nufcles, which give the Hare a fingular advantage in running up a hill: Senfible of its powers in this refpect, it is always obferved to fly towards rifing ground when firft ftarted.

Thus formed for efcape, the Hare might be fuppofed to enjoy a ftate of tolerable fecurity'; but as every rapacious creature is its cnemy, it is feldom permitted to live out its natural term. Dogs and Foxes purfue it by inftinct; Wild-Cats, and Weafels of all kinds, catch and devour it; birds of prey are ftill more dangerous enemies; whilft man, far more powerful than all, makes ufe of every artifice to obtain an animal which conftitutes one of the numerous delicacies of his table.-If we were to enumerate the various ftratagems which ingenuity has fuggefted to circumvent this perfecuted creature, we would willingly omit. the notable achievements and gallant exploits of the chafe ; which, to a cool and difparfionate obferver, feem to demand a nobler game.

" Poor is the triumpli o'er the timid Hare."

Another remarkable means of fafety to the Hare is its colour, which, being fimilar to the ground where it fits, fecures it from the fight of its enemies; and, as a further inftance of the care of Providence in the prefervation of its creatures, thefe, as well as fome other animals in more northern regions, are obferved to change their colour, and become perfectly white during winter, which renders them lefs confpicuous in the fnow. Some rare inftances occur, of white Hares being met with in Great Britain.

The Hare is very prolific, and breeds three or four times in the year. The female goes with young thirty 


\section{HISTORY OF QUADRUPEDS.}

days, and generally brings forth three or four at a litter. The rutting feafon begins in February.

During the day, Hares fleep or repofe in their feats, and feldom remove from them: The night is the feafon when they go about in fearch of food; and they are fure to return to their forms or feats by the fame paths which they took in leaving them.

cc 'Tis inftinct that directs the jealous Hare

"To chure her roft abode. With ftep revers'd,

"She forms the doubling maze; then, ere the morn

"Peeps through the clouds, leaps to her clofe recefs."

The following inftances of the fagacity of the Hare in endeavouring to efcape from its enemies are worthy of notice :-Fouilloux fays he has feen a Hare ftart from its form at the 'found of the hunter's horn, run towards a pool of water at a confiderable diftance, plunge itfelf in, and fwim to fome rufhes in the middle, where it lay down, and concealed itfelf from the purfuit of the Dogs. He mentions another, which, after running two hours before the Dogs, pufhed a Hare from its feat, and took poffeffion of it. Others he has feen run into a fheepfold, and lie down among the Sheep; and fome have effected their efcape by mounting an old wall, and clapping themfelves down in the midft of the ivy which covered it.

The fur of the Hare is of great ufe in making hats, for which purpofe many thoufands of their fkins are annually imported from Ruffia.

The Hare was reckoned a great delicacy among the Romans, but was forbidden to the Jews, and held facred among the ancient Britons, who religioufly abftained from eating it.-We are told, that Boadicea, immedi-

$$
\text { A a } 2
$$


ately before her laft conflict with the Romans, let loofe a Hare the had concealed in her bofom; which, taking what was deemed a fortunate courfe, was looked upon as a good omen.- It is to this day deemed unclean by the Mahometans.

The Hare is found in moft parts of the world, with very little variety.-Thofe of North-America are rather lefs than the European. They frequent marhes and meadows, and when purfued take refuge in hollow trees.

\section{THE ALPINE HARE,}

Is gray in fummer, with a flight mixture of black and tawny. Its hair is foft, its ears thorter, and its legs more flender, than the common Hare's. In winter, the whole body changes to a fnowy whitenefs, except the tips and edges of the ears, which remain black.

This animal lives on the higheft hills in Scotland, Norway, Lapland, Ruflia, and Siberia; never defcends from the mountains, nor mixes with the common Hare, although they abound in the fame parts.-It does not run faft; and, when purfued, often takes thelter in clefts of rocks. It is eafily tamed, is very frolicfome, and fond of honey and other fweets. It changes its colour in September, and refumes its gray coat in April.-Troops of five or fix hundred are fometimes feen, which migrate towards the fouth in fpring, and return in autumn.

A variety is found in thofe mountains of Tartary which extend as far as the lake Baikal. It inhabits the middle regions of the hills, among thick woods, and in moift places abounding with grafs and herbage. It lives 


\section{HISTORY OF QUADRUPEDS.}

in the crevices of rocks, and fometimes burrows in the earth lodged between the clefts.-Its voice is a harp whifte, not unlike the chirping of a fparrow.

In the autumn, great numbers of them affemble together, and collect vaft quantities of the fineft herbs, which, when dried, they form into pointed ricks of various fizes; fome of them four or five feet in height, and of proportionable bulk. Thefe they place under the thelter of an overhanging rock, or pile round the trunks of trees. By this means, thefe induftrious little animals lay up a ftock of winter food, and wifely provide againt the rigours of thofe ftormy regions; otherwife, being prevented by the depth of the fnow from quitting their retreats in queft of food, they muft all inevitably perin.

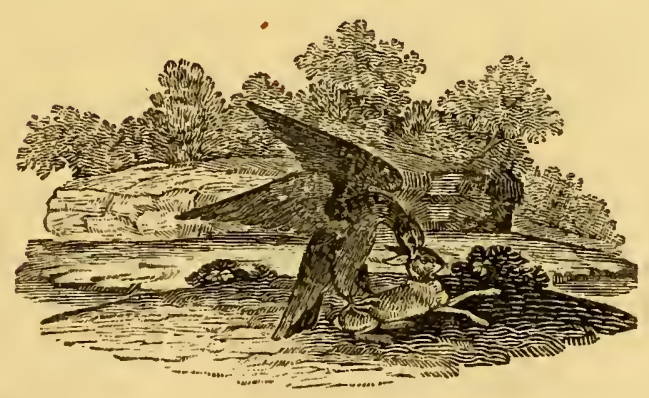




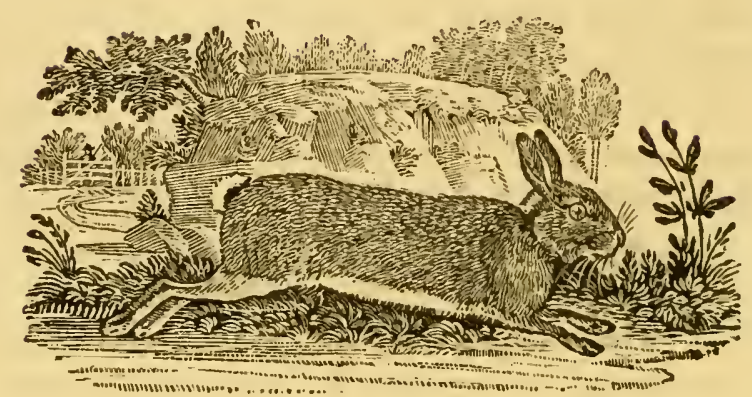

THE RABBIT.

(Lepus Cuniculus, Lin._Le Lapin, Buff.)

Notwithistanding the great fimilarity between the Hare and the Rabbit, Nature has placed an infeparable bar between them, in not allowing them to intermix, to which they mutually difcover the moft extreme averfion. Befides this, there is a wide difference in their habits and propenfities: The Rabbit lives in hules in the earth, where it brings forth its young, and retires from the approach of danger; whilft the Hare prefers the open ficlds, and trufts to its fpeed for fafety.

The fecundity of the Rabbit is truly aftonifhing. It breeds feven times in the year, and generally produces eight young at a time; from which it is calculated, that one pair may increafe, in the courfe of four years, to the amazing number of $1,274,840$ : So that, if frequent reductions were not made in various ways, there is reafon to apprehend they would foon exceed the means of their fupport, and over-run the face of the country. But as their increafe is great, fo is the number of their enemies; 
for, befides thofe that are taken for the ufe of man, great numbers are devoured by Foxes, Weafels, Foumarts, and other beafts of prey.-In Spain, they formerly increafed to fuch a degree, as to become fo obnoxious, that the inhabitants were obliged to procure Ferrets from Africa to deftroy them.

The Rabbit is capable of procreating at the age of five or fix months. The female goes with young about thirty days. Previous to her bringing forth, the makes a bed with down, which the pulls off her own coat. She never leaves her young but when preffed with hunger, and returns as foon as that is allayed, which the effects with furprifing quicknefs. During the time the tends and fuckles her young, the carefully conceals them from the male, left he fhould devour them; and frequently covers up the mouth of the hole, that her retreat may not be difcovered.

It lives to the age of eight or nine years, and prefers warm and temperate climates.-Pliny and Ariftotle mention it as being anciently known only in Greece and Spain: It is now, however, common in various parts of Europe; but in Sweden and other cold countries it can only be reared in houfes.

It abounds in Great-Britain, where its fkin forms a very confiderable article in the manufacture of hats.Lincolnfhire, Norfolk, and Cambridgefhire, are moft noted for the production of them.

The fleth of the Rabbit, as well as the Hare, was for bidden to the Jews and the Mahometans. 


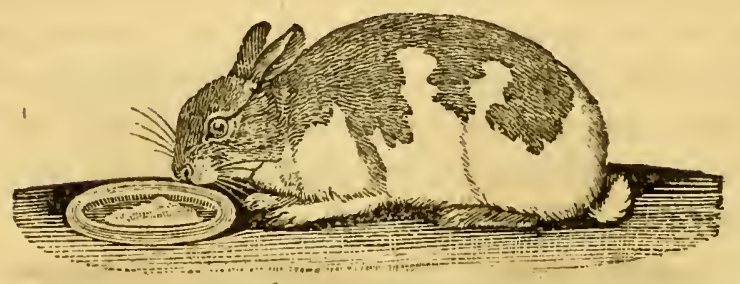

THE DOMESTIC RABBIT,

Is of various colours-white, brown, black, and variegated. It is fomewhat larger than the wild Rabbit; but its flem is not fo good, being fofter and more infipid.Its food is generally cabbage leaves, colewort, blades of corn, four-dock, and other fucculent plants; but fweet fhort hay, with a little clean oats, make the beft diet.

The Rabit of Angora, like the Goat and Sheep of that country, is covered with long hair, which falls down its fide in wavy curls, and is of a filky finenefs.

Mr Pennant defcribes a remarkable variety under the name of the Hooded Rabbit, which has a double fkin over its back, into which it can withdraw its head: It likewife conceals its fore legs in a part which falls down under its throat. There are fmall holes in this loofe fkin, which admit light to the eyes.-The colour of the body is cinereous; that of the head and ears is brown.

A manufcript account of this animal, with a drawing by Mr G. Edwards, is preferved in the Britif Mufeum.

The Rabbit is not a native of America. There are great numbers of them in many of the Weft-India illands, which have originated from a ftock carried thither from Europe. 


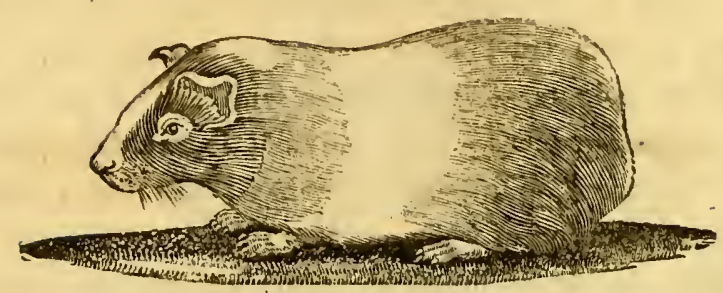

\section{THE GUINEA-PIG, OR RESTLESS CAVY.}

\section{(Mus Porcellus, Lin._Le Cochon d'Inde, Buff.)}

Thrs little animal, though a native of Brazil, lives and propagates in temperate, and even in cold climates, when protected from the inclemency of the feafons.Great numbers are kept in a domeftic ftate, but for what purpofe can hardly be determined. They have neither beauty nor utility to recommend them; their thins are of little value; and their flefh, though eatable, is far from being good. Their habits and difpofitions are equally unpleafant and difgufting: Void of attachment even to their own offspring, they fuffer them to be devoured the moment they are brought forth, without making the fmalleft attempt to defend them. The males frequently deftroy their own young; and are fo ftupid, as to allow themfelves to be killed by Cats without refiftance. They pafs their whole lives in fleeping, eating, and in the propagation of their fpecies. They are by nature gentle and tame; they do no mifchief, but feem to be equally incapable of good.-Rats are faid to avoid the places where they refide. 


\section{HISTORY OF QUADRUPEDS.}

The Guinea-Pig is confiderably lefs than the Rabibit; its upper lip is only half divided; it has two cuttingteeth in each jaw; large and broad ears; its hair is of different colours,-white, varied with orange and black, in irregular patches; it has no tail; is a reftlefs animal; feeds on bread, grain, and vegetables; and makes a noife like the grunting of a pig.

It is capable of breeding at the age of two months, and produces from four to twelve at one time.

The fpecies would be innumerable, if many of them were not taken off by various means: Some are killed by Cats, others by the males, and more, both young and old, perifh by the feverity of the climate, and want of proper care

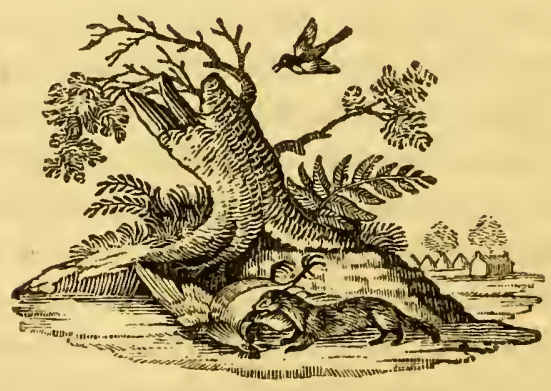




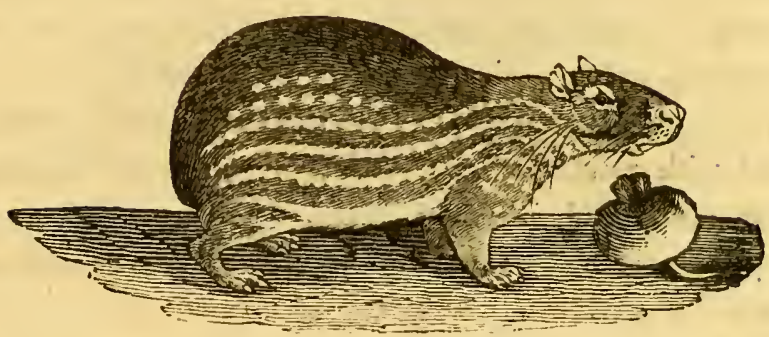

THE SPOTTED CAVY,

(Mus Paca, Lin.-Le Paca, Buff.)

Is about the fize of a Hare, but its body is much thicker, plumper, and fatter. 'The colour of the hair on the back is dark-brown, or liver-coloured; it is lighter on the fides, which are beautifully marked with lines of white fpots, running in parallel directions from its throat to its rump; thofe on the upper part of the body are perfectly diftinct; the belly is white. Its head is large; its ears fhort and naked; its eyes full, and placed high in its head, near the ears; in the lower part of each jaw, immediately under the eye, it has a remarkably deep flit or furrow, which feems like the termination of the jaw, and has the appearance of an opening of the mouth; its upper jaw projects beyond the under; it has two ftrong yellow cutting-teeth in each jaw; its mouth is fmall, and its upper lip is divided; it has long whikers on its lips, and on each fide of its head, under the ears; its legs are fhort; it has four toes on the fore, and three on the lind foot; it has no tail. 
The Spotted Cavy is a native of South-America, and lives on the banks of rivers in warm and moift places. It digs holes in the ground, fecretes itfelf during the day, and goes out at night in queft of food.

Its motions are heavy and ungraceful. It runs feldom, and with extreme aukwardnefs; fits frequently upon its pofteriors; and, in that fituation, fmooths and dreffes itfelf with its paws, drawing them over its body with the utmoft nicety.

It is a cleanly animal, and will not bear the fmalleft degree of dirtinefs in its apartment.

In a domeftic itate, it is gentle and tractable, fond of attention, and licks the hand of any one that careffes it. When irritated, it is apt to bite. Its anger is expreffed by chattering its teeth, and is always preceded by a kind of grunting. - It feeds on grain, roots, fruits, and almolt every kind of vegetable.

When purfued, it takes to the water, and efcapes by diving. If attacked by Dogs, it makes a vigorous defence.

Its flefh is efteemed a great delicacy by the natives of Brazil.

We have been minute in our defcription of this curious little animal, which was drawn from the life; and think there is good reafon to conclude that the fpecies might be eafily naturalifed in this country, and added to our ftock of ufeful animals. It is not much afraid of cold; and being accuftomed to burrow, it would by that means defend itfelf againft the rigours of our winter.

There are feveral varieties of them; fome of which weigh from fourteen to twenty, and even thirty pounds. 


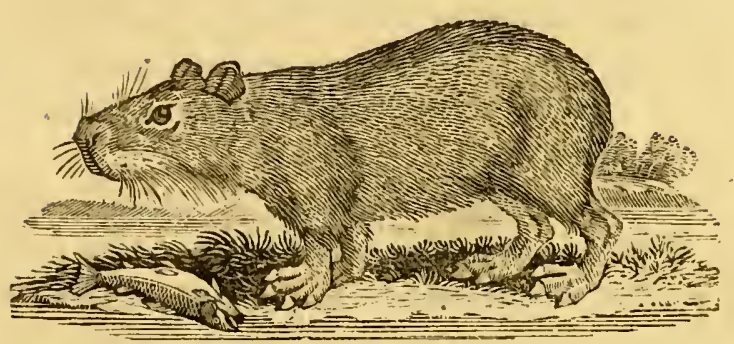

THE CAPIBARA,

(Sus Hydrocharus, Lin._Le Cabiai, Buff.)

Is a native of South-America, and lives on the banks of great rivers, fuch as the Oronoque, Amazons, and Rio de la Plata; fwims and dives remarkably well, and is very dexterous in catching filh, upon which it chiefly fubfifts : It likewife eats grain, fruits, and fugar-canes, feeds moftly in the night, and commits great ravages in the gardens.-They generally keep in large herds, and make a noife not much unlike the braying of an Afs.

Its fle'th is fat and tender; but, like that of the Otter, has an oily and fifiny tafte.

It is about the fize of a fmall Hog; and, by fome naturalifts, has been claffed with that animal.

Its fore hoofs are divided into four, the hind ones into. three; its head is large and thick, and on the nofe there are long whifkers; its ears are fmall and rounded, and its eyes large and black; there are two large cutting-teeth and eight grinders in each jaw, and each of thefe grinders forms on its furface what appears to be three teeth, flat at their ends; the legs are fhort; the toes long, and 
connected at the bottom with a fmall web; the end of each toe is guarded by a fmall hoof; it has no tail; the hair on the body is hort, rough, and of a brown colour.

It is a gentle animal, eafily tamed, and will follow thofe who feed it and treat it kindly.

As it runs badly, on account of the peculiar conftruction of its feet, its fafety confifts not in flight: Nature has provided it with other means of prefervation: When in danger, it plunges into the water, and dives to a great diftance.

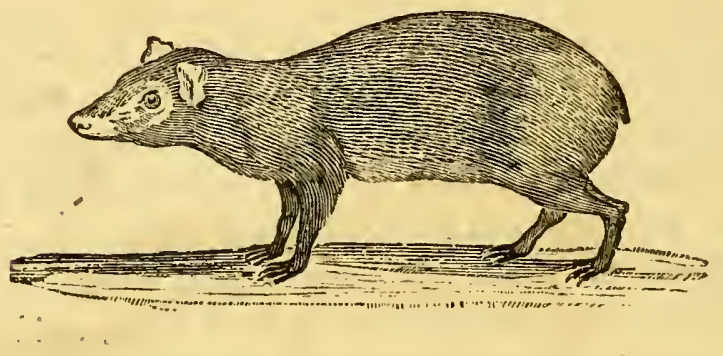

THE AGOUTI, OR LONG-NOSED CAVY, (Cavia Aguti, Lin.-L'Agouti, Buff.)

Is about the fize of a Hare; its nofe is long, upper lip divided, fkin fleek and fhining, of a brown colour mixed with red, tail fhort, legs flender and almoft naked; has four toes on the fore, and three on the hind foot; grunts like a Pig; fits on its hind legs, and feeds itfelf with its paws; and when fatiated with food, it conceals the remainder._- It eats fruits, roots, nuts, and almoft every kind of vegetable; is hunted with Dogs; runs faft, and 
its motions' are like thofe of a Hare._-Its flefh, which refembles that of a Rabbit, is eaten by the inhabitants of South-America.

Great numbers of them are found in Guiana and Brazil. They live in woods, hedges, and hollow trees.

The female brings forth at all times of the year, and groduces three, four, and fometimes five, at a time.

If taken when young, the Agouti is eafily tamed, and will go out and return of its own accord._- It delights in cutting or gnawing every thing with its teeth.When irritated, the hair of its back rifes, it ftrikes the ground with its hind feet, and at the fame time makes a noife like the grunting of a Pig.

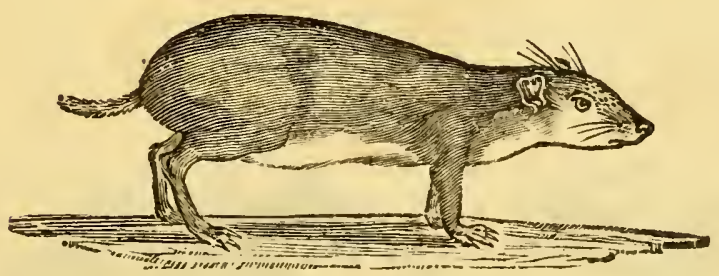

\section{THE AKOUCHI,}

SeEms to be a variety of the Agouti; and, though fomewhat lefs, is nearly of the fame form, but its tail is longer. It inhabits the fame countries, is of an olive colour ; its flefh is white, delicate, and has the flavour of a young Rabibit; is much efteemed by the natives, who hunt it with Dogs, and reckon it among the fineft game of South-America. 


\section{THE ROCK CAVY,}

\section{(L'Aperea, Buff.)}

Is likewife found in Brazil, is about twelve inches in length; the colour of the upper part of its body refembles that of the Hare, its belly is white, the upper lip divided, the ears fhort and rounded like thofe of a Rat, and has no tail. It moves like the Hare, its fore legs being fhorter than the hind. It has four toes on the fore feet, and only three on the hind. Its flen is like that of the Rabbit; and its manner of living is alfo very fimilar.

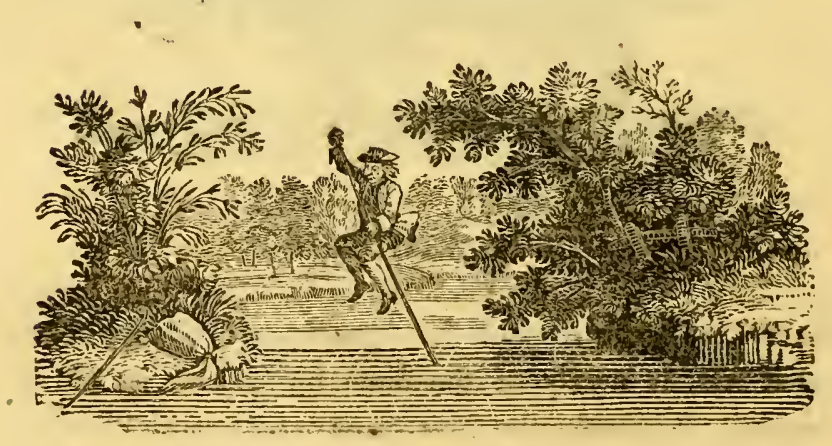




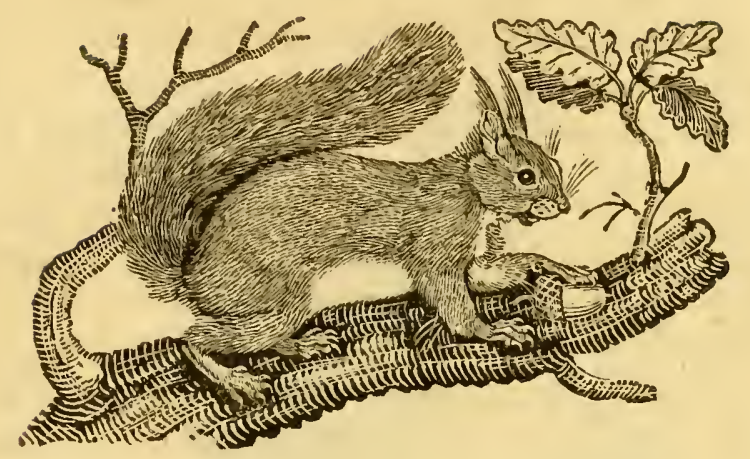

THE SQUJRREL.

(Sciurus Vulgaris, Lin.-L'Ecureuil, Buff.)

This beautiful little animal is equally admirable for the neatnefs and elegance of its formation, as for its livelinefs and activity.-Its difpofition is gentle and harmlefs.-Though naturally wild, it is foon familiarifed to confinement and reftraint; and, though exceffively timid, it is eafily taught to receive with freedom the mort familiar careffes from the hand that feeds it.

It ufually lives in woods, and makes its neft of mors or dry leaves in the hollows of trees.-It feldom defcends upon the ground, but leaps from tree to tree with great agility.

Its food confifts of fruits, almonds, nuts, acorns, \&c.; of which it accumulates great ftores for winter provifion, and fecures them carefully near its neft. In the fummer it feeds on buds and young thoots, and is particularly fond of the cones of the fir and pine trees.

$\mathrm{B} \mathrm{b}$ 
The fpring is the feafon of love with Squirrels. At that time the males purfue the females, and exhibit wonderful proofs of agility; whilft the latter, as if to make trial of the conftancy of their lovers, feem to avoid them by a variety of entertaining fallies; and, like true coquets, feign an efcape, by way of enhancing the value of the conqueft.-They bring forth four or five young at a time.

The Squirrel is of a bright-brown colour, inclining to red; the breaft and belly are white; the ears are ornamented with long tufts of hair; the eyes are large, black, and lively; the fore teeth ftrong and fharp; the fore legs are curioufly furnifhed with long ftiff hairs, which project on each fide like whifkers. When it eats, it fits erect, and ufes its fore feet as hands to convey food to its mouth.

The tail of the Squirrel is its greateft ornament, and ferves as a defence from the cold, being large enough to cover the whole body; it likewife affifts it in taking leaps from one tree to another; and we may add a third application of it, which would feem altogether improbable, were we not affured of it by Linnæus and other naturalifts:-In attempting to crofs a lake or river, the Squirrel places itfelf upon a piece of bark; and, erecting its tail to catch the wind, boldly commits itfelf to the mercy of the waves. The fmalleft guft of wind is fufficient to overfet a whole navy of thefe little adventurers; and in fuch perilous voyages many hundreds of them are faid to perifh.

Of the Squirrel there are feveral varieties; fome of which are to be found in almot every country; but they chiefly abound in northern and temperate climates. 


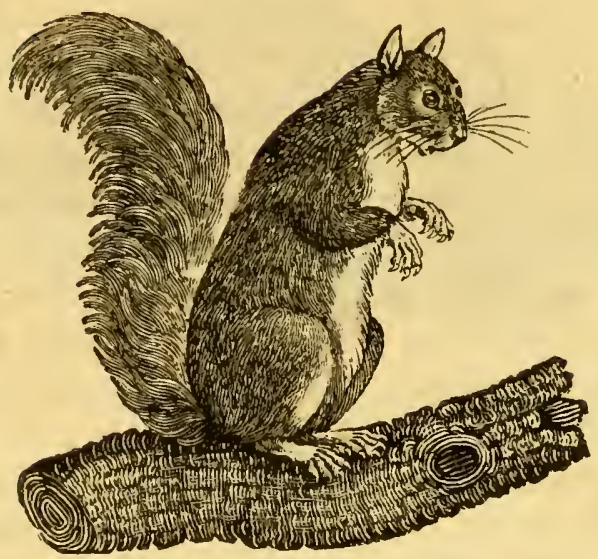

THE GRAY SQUIRREL,

(Sciurus Cinereus, Lin._Le Petit Gris, Buff.)

Is about the fize of a young Rabbit: Its ears are fhort, and not tufted at the ends; its hair is gray, mixed with black; on each fide there is a red ftreak, which runs lengthwife; its tail is long and bufhy, of a gray colour, variegated with black and white.-It is common to both continents.-In Sweden and other northern countries, it changes its colour in the winter.

It is very numerous in North-America, and does incredible damage to the plantations. Great flocks of them defcend from the mountains, and lay wafte the fields of maize, by eating the young ears.-A reward of threepence per head was given for every one that was killed; 
and fuch numbers were deftroyed in one year, that Penfylvania alone paid in rewards the fum of 80001 . of its currency.

It makes its neft in hollow trees, with mofs, ftraw, wool, \&c.-It lays up ftores of provifions in holes made in the ground, for its winter fuftenance. Thefe hoards are often deftroyed by Swine; they are fometimes fo long covered with fnow, that the Squirrels perifh for want of food.

The fur is very valuable, and is imported under the name of petit-gris.

\section{THE BLACK SQUIRREL, \\ (Sciurus Niger, Lin.-L'Ecureuil noir, Buff.)}

Is about the fame fize and form with the laft; but its tail is not fo long. It is generally black, with white on the nofe, ears, and end of the tail.

Its difpofitions and habits are fo fimilar to the Gray Squirrel, that it might be taken for a variety of that kind; but it is faid to affociate in feparate troops, and is equally numerous.

It is found in the northern parts of Afia, North-America, and Mexico. .

In the latter country, there is a variety with plain round ears, the upper part of the body variegated with black, white, and brown. It is twice the fize of the common Squirrel, lives under ground, where it brings forth its young, and lays in its ftock of provifions. It feeds on maize, and is extremely lively, gentle, and docile.-It is the Coguallin of M. Buffon. 


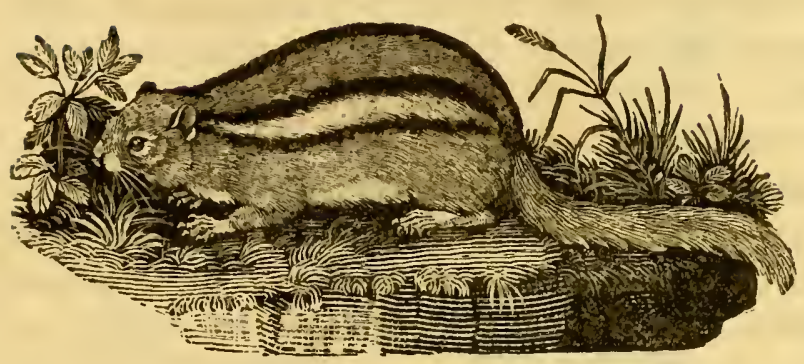

THE DORMOUSE, OR GROUND SQUIRREL,

(Sciurus Striatus, Lin.-Le Suiffe, Buff.)

Is very numerous in the forefts of North-America, as well as the North of Afia.-It burrows in the grousd, and makes two entrances to its habitation; that if one fhould be ftopped up, it may have accefs by the other. Its hole is formed with great fkill, having feveral branches from the principal paffage, each of which is terminated by a ftore-houfe, in which its winter food is depofited: In one is contained acorns, in another nuts, in a third maize, and in another chefnuts, which are its favourite food.

Thefe animals feldom ftir out during winter, nor fo long as their provifions laft: When thofe fail, they fometimes work their way into places where apples are laid up, or in barns where maize is ftored, and make great havock. During harveft, they fill their mouths fo full with corn, that their cheeks are quite diftended; and in this manner carry it to their concealed ftore. They give: B b 3 
great preference to certain kinds of food; and if, after filling their mouths with rye, they chance to meet with wheat, they difcharge the one, that they may fecure the other.

The Ground Squirrel is marked with a ftripe of black, which runs along the ridge of the back; and on each fide a yellow ftripe, bordered with black: Its head, body, and tail are of a reddifh-brown; breaft and belly white; its nofe and feet of a pale red colour; its eyes full and lively.

It is very wild, bites feverely, and is tamed with diffculty.-Its fin is of little value.

\section{THE HUDSON'S-BAY SQUIRREL,}

Is fmaller than the European. It is marked along the middle of the back with a dufky line, from head to tail; the belly is of a pale afh colour, mottled with black; and the tail, which is dufky and barred with black, is not fo long, nor fo full of hair, as that of the common kind.

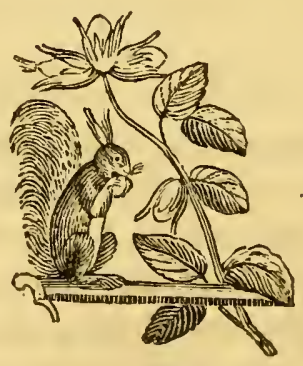




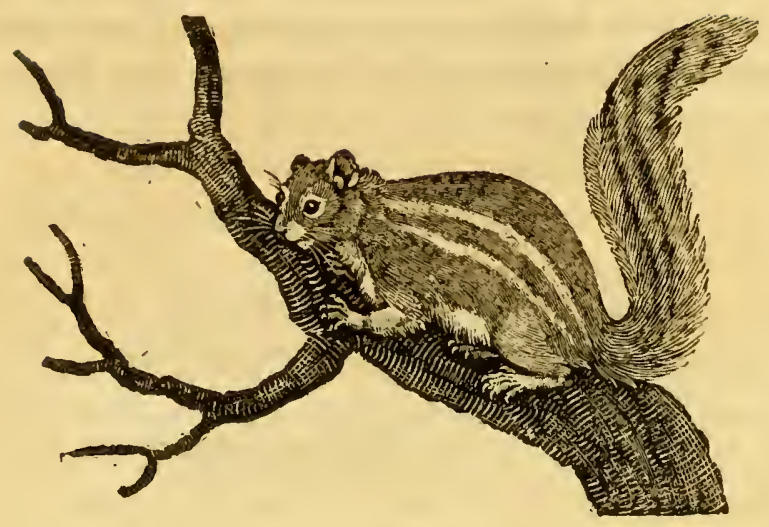

THE BARBARY SQUIRREL,

(Sciurus Getulus, Lin._Le Barbarefque, Buff.)

Is of an afh colour, inclining to red; each fide is bealltifully marked with two white ftripes, running lengthwife; its belly is white; its tail bufhy, and variegated with regular thades of black, one beneath the other; its eyes are full and black, with white orbits.-It is about the fize of the common Squirrel.

\section{THE PALM SQUIRREL,}

(Sciurus Palnarum, Lin.-Le Palmifte, Buff.)

Is fimilar to the laft, having a pale-yellow ftripe on the middle of the back, and two on each fide parallel to it; the belly is of the fame colour; the reft of the body black and red clofely mixed : Its tail is long, does noț lie

$\mathrm{B} \mathrm{b} 4$ 
on its back like that of the Squirrel, but is carried erect.

Both thefe Squirrels inhabit Barbary and other hot countries.-They live chiefly in palm trees, from. whence the latter has its name.

\section{THE , FAT SQUIRREL, (Sciurus Glis, Lin.-Le Loir, Buff.)}

Is found in France and the fouthern parts of Europe.Its body is covered with foft hair, of an afh colour; its belly whitifh; its ears thin and naked. It is about fix inches long, and thicker than the common Squirrel. It dwells chiefly in trees, leaps from bough to bough, feeds on fruits and acorns, and lodges in the hollows of trees. It remains in a torpid ftate during winter, and grows very fat.

It was confidered as a great delicacy among the Romans, who had places conftructed on purpofe to keep and feed them in, which they called gliraria.

\section{THE GREATER DORMOUSE, OR GARDEN SQUIRREL,}

$$
\text { (Mus 2uercinus, Lin.-Le Lerot, Buff.) }
$$

Is rather lefs than the laft-mentioned. Its eyes are furrounded with a large black fpot, which reaches to the ears; its body is of a tawny colour; its throat and belly white, tinged with yellow; its tail is long, and bufhy at the end.

It is common in the South of Europe, infefts gardens, is particularly fond of peaches, and very deftructive of all 
kinds of fruit.-It lodges in holes in the walls, and brings forth five or fix young at a time.

It has a ftrong odour, like a Rat; and, like the Fat Squirrel, remains torpid during the winter.

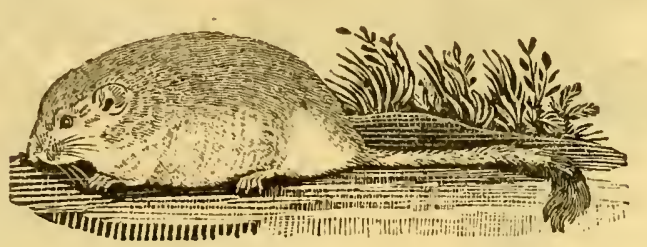

THE LESSER DORMOUSE,

(Mus Avellanarius, Lin.-Le Mufcardin, Buff.)

Is rather larger than the Moufe, of a tawny-red colour, with a white throat, and full black eyes.-It lives in woods or thick hedges; makes its neft with grafs, dried leaves, or mofs, in the hollow of a tree, or the bottom of a thick bufh, and brings forth three or four young at a time.

It lays up ftores of nuts, acorns and beans; and retires at the approach of cold weather to its retreat; where it rolls itfelf up in a warm neft, made of foft mofs, \&c. and remains in a torpid ftate during the continuance of winter. The warmth of a funny day, or a temporary change from cold to heat, will fometimes revive it; but, after taking a little food, it foon relapfes into its former ftate. 


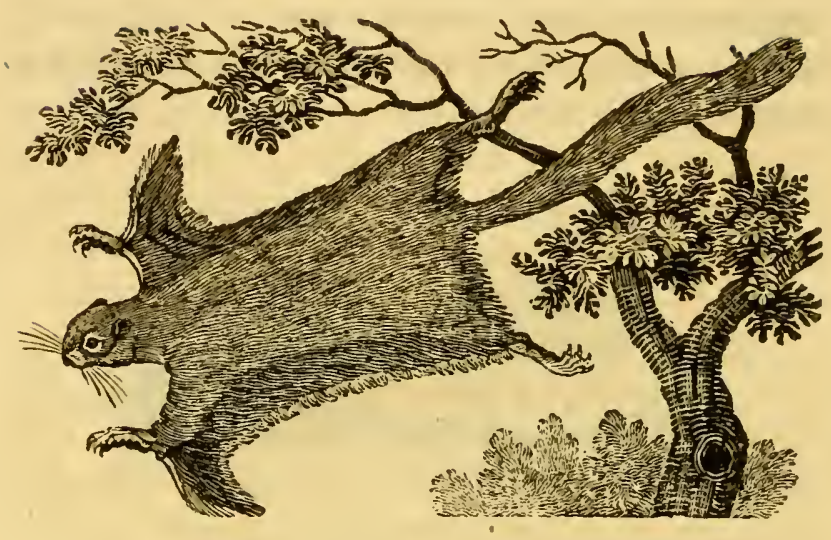

THE FLYING SQUIRREL,

(Sciurus Volans, Lin._Le Poulatoucbe, Buff.)

Is peculiarly diftinguifhed by a membranous continuation of the fkin of the fides and belly, which extends from the fore to the hind feet, and affifts it greatly in making leaps from one tree to another, frequently at the diftance of twenty or thirty yards. Its head is fmall and round; its eyes are full, round, and black; and its ears fmall and naked.

It is found in all the northern regions, both of the old and new continents. It is more numerous in America than in Europe, is lefs than the common Squirrel, lives in trees, and fleeps in the day, but is extremely active during the night.

In the act of leaping, the loofe thin is ftretched out by the feet; whereby the furface of the body is augmented, che animal becomes lighter in proportion to its bulk, the 
acceleration of its fall is retarded, and it appears to fail or fly from one place to another. Where numbers of them are feen at a time leaping, they appear like leaves blown off by the wind.

There are feveral kinds, differing much in fize._In the iflands of the Eaft-Indies, there is a variety as large as a Hare, called the TAGUAN, or GREAT Flying SeUIRREL; which perfectly refembles the other in figure, and in the form of its lateral membrane. The head is fmaller in proportion to the fize of the body; the colour of the fkin is dark-brown, mixed with white; the upper part of the body whitilh; the tail is brown, and grows gradually deeper towards the end, where it is black; the claws are long, thin, and hooked, like thofe of a Cat, and enable it to keep hold where it happens to fall; it alfo catches hold with its tail, which is long and mufcular.

It is a wild and timid animal.-Its bite is fo ftrong, that it can make its efcape from a wooden cage with great facility.

A variety is found in Virginia, called, by Mr Pennant, the Hooded Seuirrel; the lateral membrane begins at the chin and ears, where it forms a kind of hood, and extends, like that of the former, from the fore to the hind legs: Its body is of a reddifh colour above, and of a yellowilh an beneath. - It is a rare fpecies, not much noticed by naturalifts. 


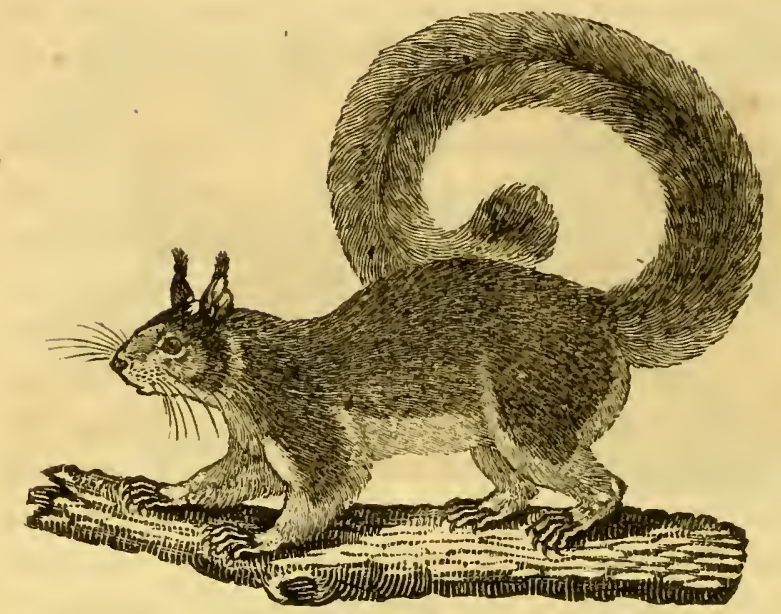

THE LONG-TAILED SQUIRREL.

THrs fpecies is found in Ceylon and Malabar.-In the Cingalefe tongue, it is called Dantoelana; and, from the noife it makes, Rockea.

It is about three times the fize of the European Squirrel: The ears are tufted with black hairs; the end of the nofe is pink-coloured; the cheeks, legs, and belly are of a dull yellow; between the ears there is a yellow fpot; the crown of the head and the back are black; from each ear is a bifurcated line of the fame colour, pointing down the cheeks; the upper part of the feet is covered with black hairs, the lower part naked and red: The tail is nearly twice the length of the bady, of a light afh colour, and extremely buiny.

We are indebted to $\mathrm{Mr}$ Pennant for the drawing of this curious animal. 


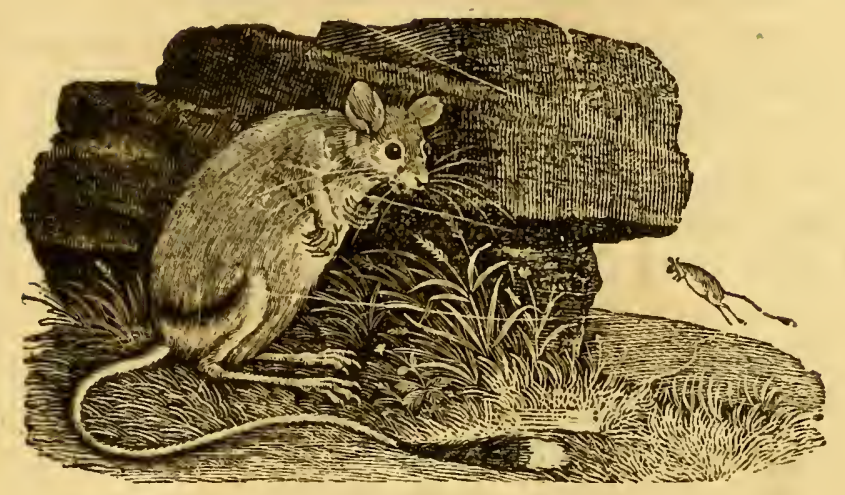

THE JERBOA.

(Mus Faculus, Lin. - Le ferbo, Buff.)

THis animal, remarkable for the fingular conftruction of its legs, is found in Egypt, Barbary, and Paleftine.It is fomewhat lefs than a Rat: Its head has a great refemblance to that of a Rabbit; its eyes are large and full; the fore legs are only one inch in length, and are ufed as hands to convey victuals to its mouth; the hind legs are, naked, and very much refemble thofe of a bird, having only three toes on each, the middle one longeft; its tail is much longer than its body, and terminated with a black tuft, the tip of which is white; its hair is long and foft, of a reddifh colour on the back; the under parts of the body are white; acrofs the thighs there is a large black band, in the form of a crefeent.

The motions of the Jerboa are fimilar to thofe of the 
Kanguroo. It goes forward very nimbly on its hind feet, taking leaps of five or fix feet from the ground.

It is a lively, harmlefs animal, lives entirely on vegetables, and burrows in the ground like a Rabbit.

It is the Daman Ifrael of the Arabs, or Lamb of Ifrael; and is fuppofed to be the Coney of holy writ, our Rabbit being unknown in Paleftine. It is alfo the Moufe mentioned in Ifaiah*; Acbbar, in the original, fignifying a Jerboa.

The Jerboa is eafily tamed, is fond of warmth, and feems to be fenfible of the approach of bad weather by wrapping itfelf up clofe in hay.

Among the Mongol Tartars, this animal is called the Alagbtaaga.-It is fuppofed to be the Troofooted Moufe, and the Egyptian Moufe of the ancients, which were faid to walk on their hind legs.

It makes its neft of the fineft and moft delicate herbage; rolls itfelf up, with its head between its thighs; and fleeps during the winter, without taking any nutriment.

When purfued, it fprings fo nimbly, that its feet fcarcely feem to touch the ground. It does not go ftraight forward, but turns here and there till it gains a burrow, where it quickly fecretes itfelf.-In leaping, it carries its tail ftretched out; but in ftanding or walking, carries it in the form of an $S$, the lower part touching the ground. 


\section{HISTORY OF QUADRUPEDS.}

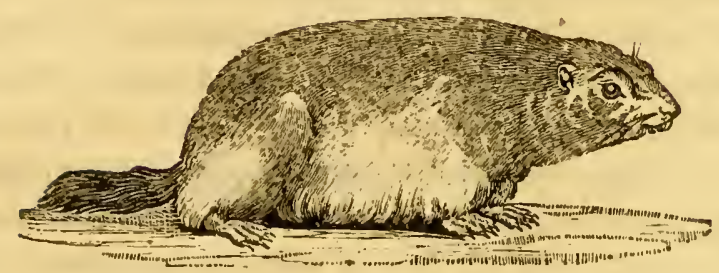

THE MARMOT,

(Mus Marmota, Lin._La Marmotte, Buff.)

$\mathrm{H}_{\text {As }}$ been placed by naturalifts in the fame clafs with the Hare and the Rat; and on examining its parts, we find a partial agreement with both thefe animals. In its nofe and lips, as well as in the general form of its head, it refembles the Hare; its ears are like thofe of the Rat, with which it likewife agrees in the number and form of its teeth and claws: In other refpects, it is no way fimilar to either of thofe kinds; and is ftill farther feparated from them by habitudes which feem peculiar to itfelf, and diftinguifh it from almoft every other fpecies of quadrupeds.

The Marmot inhabits the higheft regions of the Alps; and is likewife found in Poland, Ukraine, and Chinefe Tartary.

It is fomewhiat lefs than a Hare: Its ears are round, and fo fhort, that they are almoft hid in the fur; its tail is fhort and bufhy; the hair on the back is of a brownifh-afh colour; and that on the belly reddifh, foft, and bufhy. Its voice refembles the murmuring of a young 
puppy: When irritated, or frightened, it makes a whiftling noife, very loud and piercing.

It feeds on infects, roots, and vegetables; but when tamed, is remarkably fond of milk and butter.-It lives in holes, formed with great art in the fide of a mountain. There are two entrances to each; and the chamber to which they lead is deep and fpacious: The bottom is lined with mofs and hay, of which thefe provident animals lay in a ftore during fummer; and, at the approach of winter, thut themfelves up in their holes by ftopping the entrances with earth, fo effectually, that no difcovery can be made of the place of their retreat. The chamber in which they lodge is large enough to contain a family of from five to a dozen Marmots. They roll themfelves up; and, being well covered with hay, remain in a torpid ftate, infenfible to the rigours of the feafon, and perfectly fecure from the ftorm that rages without; till the cheering influence of the fun again calls them out to renew their exhaufted ftrength, to propagate their kind; and provide for their future retreat. The torpid ftate lafts from about Michaelmas till April. They go in extremely fat, but gradually wafte; and at the end of their long fleep, they appear lean and extremely emaciated.

The Marmot produces once a year, and the litter generally confifts of three or four.

When a number of them are feeding together, they place one as a centinel, which makes a whiftling noife on the leaf appearance of interruption; and the party immediately betake themfelves to their holes, the centinel driving up the rear.

The Marmot is, very playful, and eafily tamed. It learns to hold a ftick, to dance, and to exhibit various 


\section{HISTORY OF QUADRUPEDS.}

geftures: It will obey the voice of its mafter. Like the Cat, it has an antipathy to Dogs, which it attacks fiercely upor the leaft irritation. It is very apt to gnaw linen or woollen ftuffs, often fits upright, and walks with eafe on its hind feet.-It eats in the manner of a Squirrel, and carries its food to its mouth with its fore paws.

Its flefh is fometimes eaten, but is always attended with a difagreeable odour.

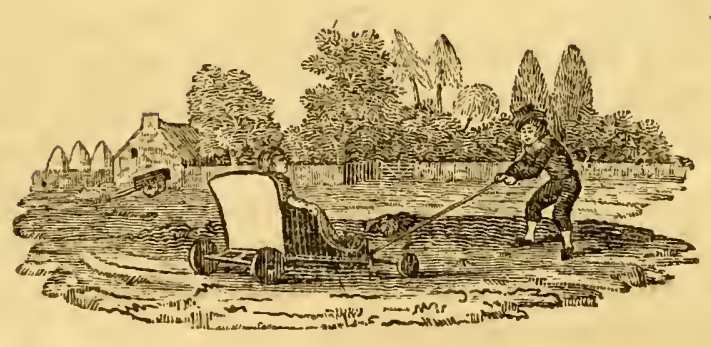

C. 


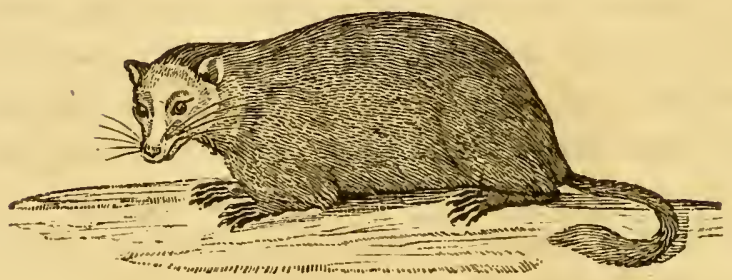

THE MONAX,

(Mus Monax, Lin._Glis Marmota, Buff.)

Is found in various parts of North-America, and feems to be the fame with the Marmot of Canada, defcribed by IM. Buffon.

It is larger than a Rabbit, and in form and colour refembles the Mufk-Rat: Its tail is fhort and rough; its ribs fo flexible, that it can eafily pafs through a hole of not more than two inches diameter; its eyes are black and prominent; its back is of a deep-brown colour, lighter on the fides and belly; and its feet and legs black.

It fleeps during winter in holes under the roots of trees, and lives on fruits and other vegetables. Its flefh is good and well tafted.

An animal of the fame kind is found in the Bahama inles; but whether it retires to fleep, in a climate fo mild, is not well known. 


\section{HISTORY OF QUADRUPEDS.}

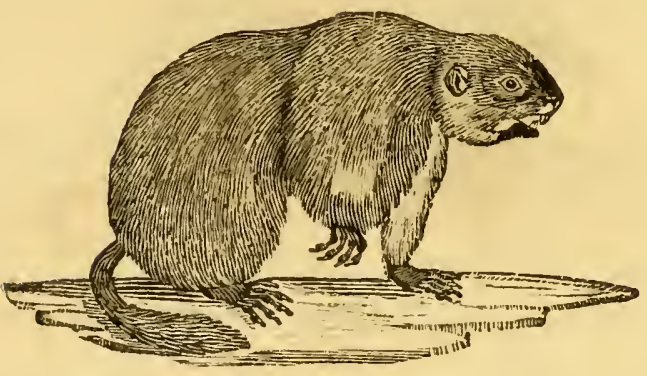

THE QUEBEC MARMOT,

Is rather larger than a Rabbit: Its ears are fhort, and its whole head round; its cheeks are of a gray colour, and its nofe black; its back is variegated, each hair being gray at the bottom, black in the middle, and white at the tips; its belly and legs are of an orange colour; its toes black and naked; and its tail fhort, and rather bufhy.It inhabits Hudfon's Bay and Canada.

One of them, exhibited in London fome years ago, was perfectly tame.

Mr Pennant fuppofes it to be the fpecies called the SIFfLeUR by the French of Canada.

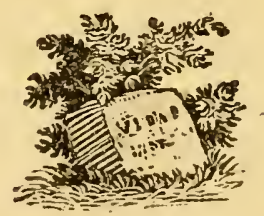

$\mathrm{C}_{\mathrm{C}} 2$ 


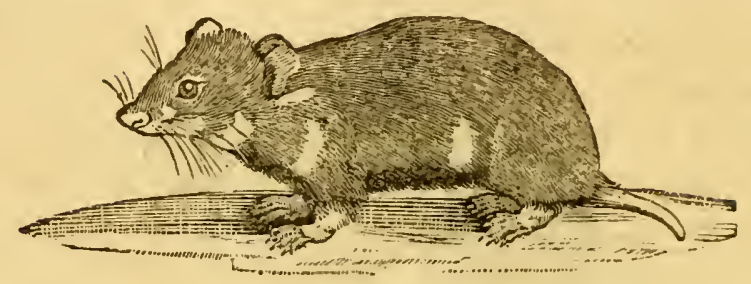

THE HAMSTER.

\section{(Mus Cricetus, Lin.-Le Hamfter, Buff.)}

Although the qualities of this animal are fufficiently. noxious to render it an object of univerfal deteftation in thofe countries where it abounds; yet, when confidered with regard to thofe inftincts which conduce to its own prefervation and fupport, it well deferves our higheft admiration.

Its habitation is curious, and conftructed with great art. It confifts of a variety of apartments, adapted to various purpofes, and extremely well fitted both for the comfort and convenience of the inhabitants. The firft entrance is formed in an oblique direction; at the end of which the male finks a perpendicular hole, which he referves for his own ufe. The female makes feveral, for the accommodation of herfelf and family, that her young, during the fhort time they are allowed to ftay with her, may have a free paffage to the general ftores. One of the holes is lined with ftraw, and ferves as a lodging; the others contain provifions, of which great quantities are always accumulated during the time of harveft.They begin to lay in their ftores in Auguft. To facilitate the tranfportation of their food, Nature has furnifhed them with two pouches in each clieek, which they fill with corn, beans, or peafe, till they feem ready to burft; 


\section{HISTORY OF QUADRUPEDS.}

and, on their return to their holes, empty them, by preffing their two fore feet againft their cheeks.-The quantity of provifion found in thefe magazines, depends on the age or fex of the inhabitants. The old Hamfters often amafs an hundred pounds weight of grain; but the young and the females are fatisfied with much lefs.

At the approach of winter, the Hamfters retire into their fubterraneous abodes, the entrance to which they Thut up with great care: There they remain in perfect tranquillity, and feed on their provifions till the froft becomes fevere, when they fink into a torpid ftate, in which they continue till the return of fpring. During this period, if any of the holes be opened, the Hamfter is always found lying upon a bed of foft ftraw, with its head turned under its belly between the two fore legs, whilft the hind ones reft upon the muzzle: Its eyes are fhut, every member perfectly ftiff, and fenfation fo totally fufpended, that neither refpiration nor any other fign of life can be perceived. When diffected in this $\mathrm{fl}_{1-}$ tuation, the heart may be feen alternately contracting and dilating very flowly; the fat appears to be coagulated; and the inteftines are quite cold. During this operation, the animal feems to feel very little: It fome. times opens its mouth, as if it wanted to refpire; but the lethargy is too ftrong to admit of its entirely awaking.

They copulate about the end of April, when the males enter the apartments of the females, but remain only a few days.-If two males happen to meet in the fame hole, a furious combat enfues, which generally ter. minates in the death of the weaker.

$$
\text { C \& } 3
$$


The females bring forth twice or thrice every year; each litter confifting of fix or eight.-In about three weeks the young are driven from their holes, and left to provide for themfelves. Their increafe is fo rapid in fome years, as to be almoft fufficient to occafion a dearth; but the ferocity with which they upon all occafions attack and devour each other, is fo great, as to be the happy means of preventing the ill effects of their fecundity.

It is not only its own fpecies to which the fury of the Hamiter is directed: He attacks and devours every animal, without diftinction, that he is able to conquer; and frequently oppofes himfelf to enemies much fuperior to himfelf in ftrength. Rather than fly, he allows limfelf to be beaten to death. If he feize a man's hand, he muft be killed before he can be made to quit his hold. A Horfe or a Dog are equally objects of his rage; and wherever he feizes, it is with difficulty he can be difengaged.

The Hamfter is about the fize of a large Water-Rat; has a fhort tail, almoft naked: Its head and back are of a reddifh-brown colour, not unlike that of a Hare; its throat is white, and it has three white fpots on each fide; its breaft and belly are black.

It is found in various parts of Germany, Poland, and Ukraine.

The Polecat is its greateft enemy. It purfues the Hamfter into its hole, and deftroys great numbers.

Mr Ray obferves, that the hair of this animal is fo clofely united to the $\mathrm{f}$-in, that it cannot be pulled off without great difficulty; on which account it is held in high eftimation. 


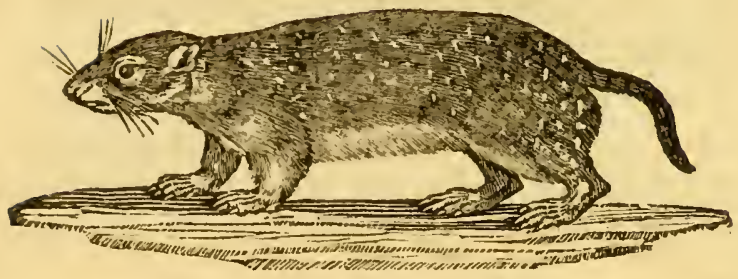

THE SOUSLIK,

(Mus Citellus, Lin._Le Souflik, Buff.)

Is about the fize of a large Rat. Its fkin is beautifully marked with fmall white fpots upon a yellowifh ground.

It is found upon the banks of the Wolga, and in the adjoining provinces as far as Auftria.-It burrows in the ground like a Rabbit, and lays in ftore of provifions, confifting of grain, herbs, and roots : It alfo feeds on young Mice, is very fond of falt, and is frequently taken on board the barges laden with that commodity.—The female brings forth from two to five at one time.

\section{THE EARLESS MARMOT,}

\section{(Le Zifel, Buff.)}

INSTEAD of ears, has only a fmall orifice on each fide of its head. It is of a dark-gray colour. Its body is long and flender, and its tail thort.

It is found in Bohemia, Auftria, Hungary, and Sibe? ria.--It forms its hole in the ground, with a double enfrance; and fleeps during the winter in the centre of its 


\section{8}

\section{HISTORY OF QUADRUPEDS.}

lodge.-It lays in a ftore of corn, nuts, \&c. ; and fits up like a Squirrel when it eats.-It is eafily provoked, and bites hard.

Its fur is of little value; but its flefh is reckoned good eating.

In Poland and Rufla, there is an animal of this kind, called the Zemnr; and, by Mr Pennant, the Podolian Marmot.

Its habits are fimilar to thofe of the Sonflik; but it is larger, ftronger, and more mifchievous.

The head is thick, the body flender, and the ears mort and round: It has two cutting teeth in each jaw; thofe of the under jaw are much longer than the upper: The eyes are fmall, and concealed in the fur like thofe of the Mole : Its tail is fhort, and of an afh colour.

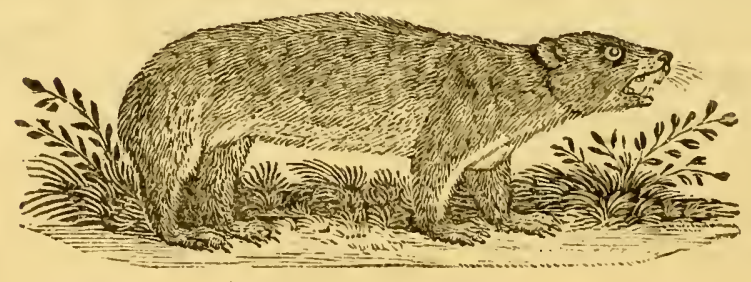

\section{THE TAIL-LESS MARMOT.}

WE are favoured by Mr Pennant with the drawing of this animal, which has hitherto been undefcribed. In the form of its body, it feems to agree with the defcription given, of the Zifel, and probably may be a variety of that anima!. 


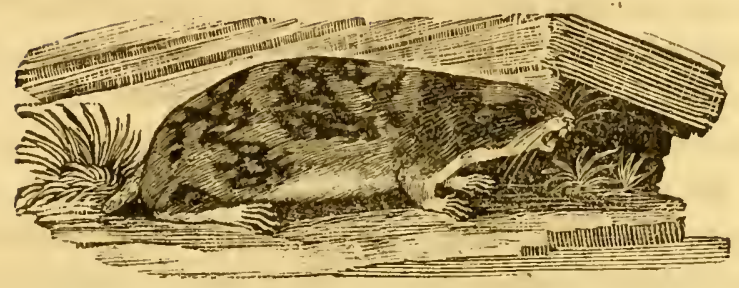

THE LAPLAND MARM̀OT.

(Mus Lemmus, Lin.-Le Leming Buff.)

THIs wonderful little animal is found only in the northern parts of Europe and Afia; and is fometimes feen in immenfe numbers, overfpreading large tracts of country, in Norway, Sweden, and Lapland. But as its appearance is at very uncertain periods, and the fource from whence it is derived has not been hitherto explored by any naturalift, its exiftence has been ferioufly attributed, by fuperftitious ignorance, to the generation of the clouds; from whence, it has been fuppofed, it was poured down in howers of rain.-Myriads of them march together; and, like a torrent, which nothing can refift, their courfe is marked with ruin and defolation. Neither fire nor water prevents their progrefs. They go ftraight forward, in regular lines, about three feet afunder, and generally in a fouth-eaft direction: They fwim acrofs lakes and rivers: No oppofition impedes them. If thoufands are deftroyed, thoufands fupply their places: The void is quickly filled up; and their number does not appear diminifhed. They perfift in their courfe, in fpite of every obftacle; and if prevented from proceeding, they either by afiduity furmount it, or die in the attempt. Their march is moftly in the night. They reft 
during the day, and devour every root and vegetable they meet with. They infect the very herbage; and cattle are faid to perifh that feed upon the grafs they have touched.

An enemy, fo numerous and deftructive, would foon render the countries they pafs through utterly uninhabitable, did it not fortunately happen, that the fame rapacity that excites them to lay wafte the productions of the earth, at laft impels them to deftroy each other.-Having nothing more to fubfift on, they are faid to feparate into two armies, which engage with the moft deadly hatred, and continue fighting and devouring each other till they are all entirely deftroyed. Thoufands of them have been found dead; and the air, infected by their putrid carcafes, has fometimes been the occafion of malignant diftempers. Great numbers of them are likewife deftroyed by Foxes, Lynxes, Weafels, and other beafts of prey, which follow them during their march.

The Leming runs fwiftly, although its legs are fhort and flender.-It is fomewhat lefs than the Rat: Its head is pointed; and in each jaw are two very long cuttingteeth, with which it bites keenly: Its ears are fhort, eyes fmall, fore legs fhorter than the hind: The colour of the head and body black and tawny, difpofed in irregular. patches; the belly white, tinged with yellow.

Though perfectly difgufting to every other people, its fleth is faid to be eaten by the Laplanders.

Where thefe emigrants are collected, as was before obferved, is not certainly known. Linnæus fays, they are produced among the Norwegian and Lapland Alps; and Pontoppidan fuppofes, that Kolen's Rock, which divides Nordland from Sweden, is their native place. 


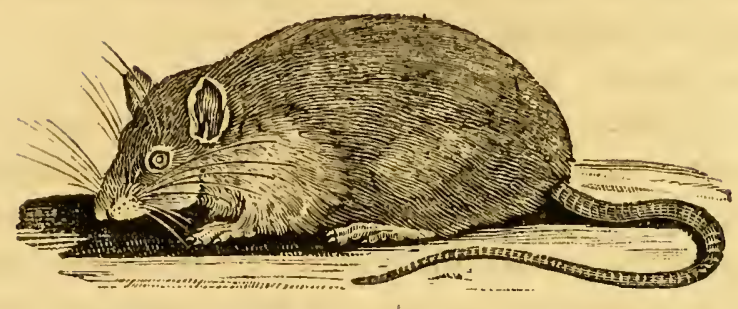

THE RAT,

(Mus Rattus, Lin.-Le Rat, Buff.)

THovgr fmall, weak, and contemptible in its appearance, poffeffes properties which render it a more formidable enemy to mankind, and more injurious to the interefts of fociety, than even thofe animals that are endued with the greateft ftrength and molt rapacious difpofitions. To the one we can oppofe united powers and fuperior arts; with regard to the other, experience has convinced us, that no art can counteract the effects of its amazing fecundity, and that force is ineffectually oppofed to an enemy poffefied of fuch variety of means to elude it.

'There are two kinds known in this country, - the Black Rat, which was formerly univerfal here, but is now very rarely feen, having been almoft extirpated by the large brown kind, generally diftinguifhed by the name of the NORWAY RAT.-This formidable invader is now univerfally diffufed through the whole country; from whence every method has been tried in vain to exterminate it.-It is about nine inches long; of a lightbrown colour, mixed with tawny and afh; the throat and belly are of a dirty white, inclining to gray; its feet 
are naked, and of a pale flefh colour; the tail is as long as the body, covered with minute dufky fcales, thinly interfperfed with flort hairs.

In fummer, it frequents the banks of rivers, ponds, and ditches; where it lives on frogs, fines, and fmall animals. But its rapacity is not confined entirely to thefe: It deftroys rabbits, poultry, young pigeons, \&c. : It infefts the granary, the barn, and the ftorehoufe; does infinite mifchief among corn and fruit of all kinds; and, not content with fatisfying its hunger, frequently carrics off large quantities to its hiding-place.

It is a bold and fierce little animal ; and, when clofely purfued, will turn and faften on its affailant.-Its bite is keen, and the wound it inflicts is painful, and difficult to heal, owing to the form of its teeth, which are long, tharp, and of an irregular form.

The Rat is amazingly prolific, ufually producing from twelve to eighteen at one time. Their numbers would foon increafe beyond all power of reftraint, were it not for an infatiable appetite, that impels them to deftroy and devour each other. The weaker álways fall a prey to the ftronger; and the large male Rat, which ufually lives by itfelf, is dreaded by thofe of its own fpecies as their moft formidable enemy.

It is a fingular fact in the hiftory of thefe animals, that the fkins of fuch of them as have been devoured in their holes have frequently been found, curioufly turned infide out; every part being completely inverted, even to the ends of the toes. How the operation is performed, it would be difficult to afcertain ; but it appears to be effected in fome peculiar mode of eating out the contents.

Befides the numbers that perifh in thefe unnatural con 
flicts, they have many fierce and inveterate enemies, that take every occafion to deftroy them. Several kinds of Dogs purfue them with great alacrity, and eagerly kill them, though they invariably refufe to eat their flefh: The Cat is alfo a very formidable enemy, but generally finds greater difficulty in the conteft: The Rat makes a vigorous refiftance, and fometimes effects its efcape :The Weafel is the moft determined enemy of the Rat kind; it hunts them with unceafing avidity, purfues them into their holes, where it foon kills them, and. fucks their blood: And in particular fituations, the Ferret is a ftill more deadly adverfary. Mankind have likewife contrived various methods of deftroying thefe bold intruders. For that purpofe, traps are often found ineffectual; fuch being their extreme fagacity, that when any are drawn into the fnare, the others by that means learn to avoid the dangerous allurement, notwithftanding the utmoft caution may have been ufed to conceal the defign. The fureft method of killing them is by poifon: Nux vomica ground, and mixed with oatmeal, with a fmall proportion of oil of rhodium and mulk, have been found from experience to be very effectual.

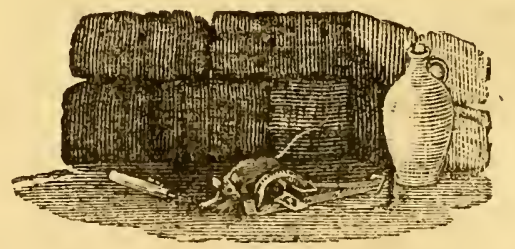




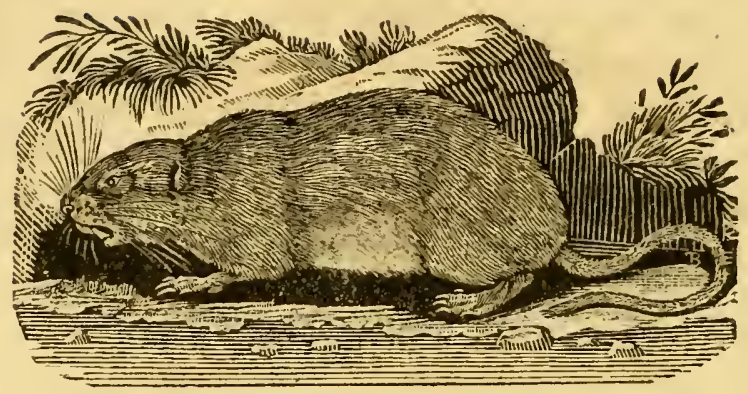

THE WATER-RAT,

(Mus Amplibius, Lin.-Le Rat d'eai,, Buff.)

Is fomewhat fmaller than the former; its head and nofe are thicker; its eyes are fmall; its ears fhort, fcarcely appearing through the hair; its teeth are large, ftrong, and yellow. In an old one which we examined, the lower incifors meafured fomewhat more than half an inch in length. The hair on its head and body is thicker and longer than that of the common Rat, and chiefly of a dark-brown colour, mixed with red; the belly is gray; the tail five inches long, covered with fhort black hairs, and the tip with white.

The Water-Rat generally frequents the fides of rivers, ponds, and ditches; where it burrows, and forms its neft._- It feeds on frogs, fmall fifh, and fpawn; fwims and dives remarkably faft; and can continue a long time under water. 


\section{HISTORY OF QUADRUPEDS.}

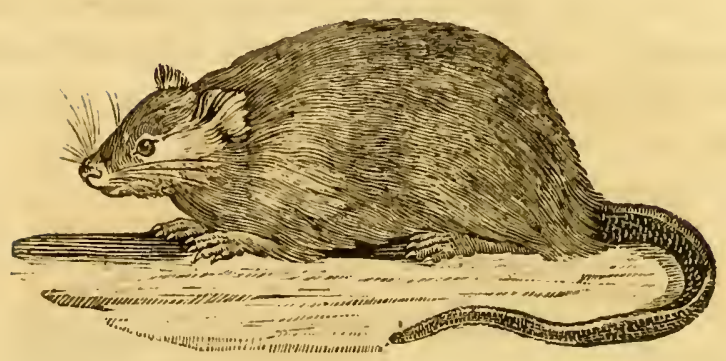

THE MUSK-RAT OF CANADA, . (Caffor Zibetbicus, Lin._L'Ondatra, Buff.)

Is about the fize of a young Rabbit: Its head is thick and fhort, refembling that of a Water-Rat; its hair foft and gloffy; beneath the outward hair there is a thick fine down, very ufeful in the manufacture of hats; it is of a reddifh-brown colour; its breaft and belly afh, tinged with red; its tail is long and flat, covered with fcales; its eyes are large; its ears fhort and hairy; it has two ftrong cutting-teeth in each jaw, - thofe of the under jaw are about an inch long, but the upper ones are fhorter.

This animal is a native of Canada, where it is called the Ondatra.

In many refpects, it very much refembles the Beaver, both in form and manners. It is fond of the water, and fwims well.-At the approach of winter, feveral families affociate together. They build little huts, about two feet in diameter, compofed of herbs and rufhes cemented with clay, forming a dome-like covering: From thefe are feveral paffages, in different directions, by which they go out in queft of roots and other food.-The hunters take them in the fpring, by opening their holes, 


\section{HISTORY OF QUADRUPEDS.}

and letting the light fuddenly in upon them.-At that time their flefh is tolerably good, and is frequently eaten; but in the fummer it acquires a fcent of mufk, fo ftrong, as to render it perfectly unpalateable.

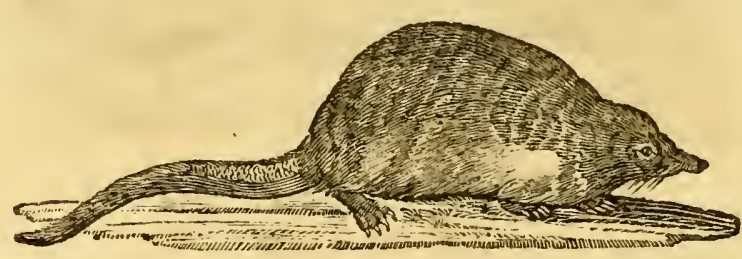

THE MUSCOVY MUSK-RAT,

(Cafor Mofcbatus, Lin._Dafman, Buff.)

Is about the fize of the common Rat: Its nofe is long and flender, like that of the Shrew-Moufe; it has no external ears, and its eyes are very fmall ; the tail is compreffed fideways, and its hind feet are webbed; it is of a dufky colour; the belly of a light afh.

It is a native of Lapland and Rufira, frequents the banks of rivers, and feeds on fmall fifhes. It is often devoured by pikes and other fifhes; to which it commilunicates fo ftrong a flavour of mufk, as renders them very unpleafant to the tafte.

From its tail is extracted a kind of mufk, very much refembling the genuine fort.-Their fkins are frequently laid amongft cloaths to preferve them from moths. - In Lapland, it is called the Defman. 


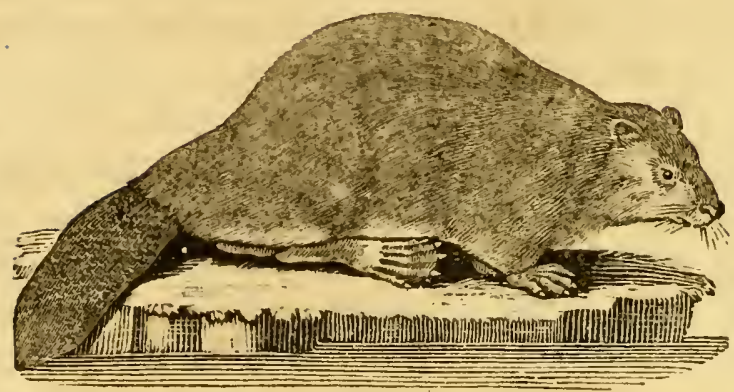

THE BEAVER,

(Caftor Fiber, Lin.-Le Bievre, Buff.)

ThE moft induftrious of animals. Its labours feem the refult of a focial compact, formed for mutual convem nierice, prefervation, and fupport; and as, in all well-regulated focieties, a due fubordination is neceffary ior the well-ordering and conducting each individual effort to the advartage of the whole; fo, amongft thefe curious animals, we find, that, in forning their habitations, all have their proper part of the work affigned to them, that, by dividing their labours, fafety, ftability, and expedition, may be the general effect. To this purpofe, a community of two or three hundred affemble together: An overfeer is chofen, whofe orders are punctually obeyed; and, by friking the water fmartly with his tail, gives the fignal where the united force of numbers is neceffary to be applied, in order to ftrengthen and fupport the fabric; or, at the approach of an enemy, to apprize the fociety

D d 
of their danger.-As foon as a converient place is chofen for the erection of their building, which is generally a level piece of ground, with a fmall rivulet running through it, they divide into companies: Some are employed in cutting down trees of great fize, which is done by gnawing them with their teeth: Thefe they lay acrofs the dam with furprifing labour and perfeverance, or form into piles, which others roll down to the water, where they make holes at the bottom for receiving the ends, and placing them upright, fecure them in that pofition; whilf another party is engaged in collecting twigs, interweaving and twifting them with the piles, and thereby ftrengthening the work: Some collect large quantities of earth, ftones, clay, and other folid materials, which they difpofe of on the upper fide of the piles next the ftream, forming a mound ten or twelve feet thick at the bottom, tapering gradually upwards, and capable of fuftaining a confiderable weight of water. The length of the dam, occafioned by this means, is fometimes not lefs than one hundred feet.-Having compleated the mole, their next care is to erect their apartments, which are built on piles: They are of a circular form, and generally confift of three ftories, about eight feet high above the water: 'The firft lies below the level of the dam, and is generally full of water; the other two are above it. The walls are two feet in thicknefs, neatly plaiftered with clay on the infide, which is arched like an oven, and at the top refembles a dome. In each houfe there is one opening toward the water, to which the animal has always accers, in cafe of furprife.-The number of loufes in one of thefe dams is from ten to twenty-five; fome of them large enough to contain a family of twenty or thirty 
Beavers. Each Beaver forms its bed of mofs, and each family lays in its magazine of winter provifions, which confifts of bark and boughs of trees: They pile up the latter with great ingenuity and regularity, and draw it out to their apartments as their wants require. They are faid to be forideft of the faffafras, anh, and fweet gum. During fummer, they feed on leaves, fruits, and fometimes crabs or cray-fifl, but fifh is not their favourite food.-Their time of building is early in the fummer. In winter, they never go farther than to their provifion ftores; and during that feafon are very fat.

They breed orice a year, and bring forth two or three at a birth.

Beavers are found chiefly in the northern parts of Europe, Afia, and America; particularly the latter, from whence many thoufands of their fkins are annually brought into Europe. In $\mathrm{I}_{7} \sigma_{3}$, the Hudfon's Bay company fold 54,670 Beaver fkins at one fale.-They vary in colour. The moft valuable are black; but the general colour is a chefnut-brown, more or lefs dark. Some have been found entirely white, others fpotted; but both thefe kinds are very rare.

The Beaver is remarkable for the fize and ftrength of its cutting-teeth, which enable it to gnaw down trees of great magnitude with eafe. Its ears are fhort, and almoft hid in the fur; its nofe blunt; tail broad and flat, nearly of an oval form, and covered with fcales-it ferves not only as a rudder to direct its motions in the water, but as a moft ufeful inftrument for laying on the clay, preffing it into the crevices, and fmoothing the outward covering; its fore feet are fmall, and not unlike thofe of a 
Rat; the hind feet are large and ftrong, with membranes between each toe; its length, from nofe to tail, is about three feet; the tail is eleven inches long, and three broad.

The caftor produced from thefe animals is found in a liquid ftate, in bags near the anus, about the fize of an egg. When taken off, the matter dries, and is reducible to a powder, which is oily, of a tharp bitter tafte, and a ftrong difagreeable fmell.-Thefe bags are found indifferently in males and females, and were formerly fuppofed to be the animal's tefticles, which, when purfued, it was faid to bite off, and by that means efcape with its life.

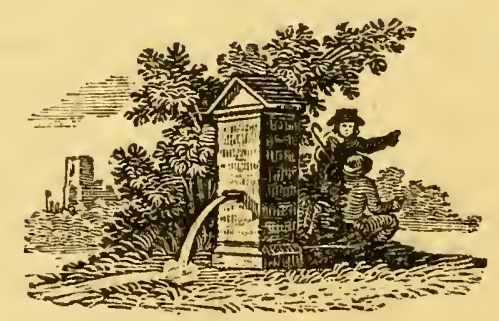




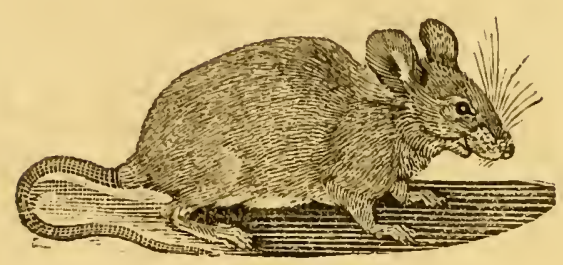

THE MOUSE.

(Mus Mufculus, Lin.-Le Souris; Buff.)

THrs well-known little animal is diffufed in great numbers over almoft every part of the world. It feems a conftant attendant on man, and is only to be found near his dwelling. Its enemies are numerous and powerful, and its means of refiftance weak and inconfiderable: Its minutenefs feems to be its beft fecurity; and it is faved from utter extinction only by its amazing fecundity.

The Moufe brings forth feveral times in the year, and generally from fix to ten each litter. The young are produced without hair, and in little more than fifteen days are able to fubfint by themfelves; fo that the increafe is prodigious. Ariftotle tells us, that having thut up in a veffel a Moufe big with young, and provided plenty of grain for her and her offspring, in a thort time he found 120 Mice, all fprung from the fame ftock.

The Moufe, when viewed without the difguft and apprehenfion which ufually accompany the fight of it, is a beautiful little animal: Its fkin is fleek and foft, its eyes

$$
\mathrm{Dd}_{3}
$$


bright and lively, all its limbs are formed with exquifite delicacy, and its motions are fmart and active.

Some few of this fpecies are of a pure white colour; but whether they be a permanent kind, or only an accidental variety, cannot well be determined. Its appearance is, however, very beautiful: Its fine full eyes, of a red colour, form an agreeable contraft with the fnowy whitenefs of its fur.

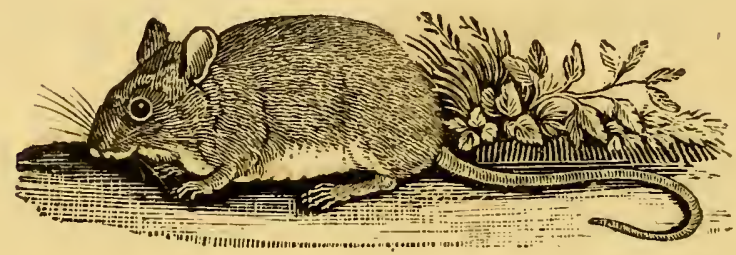

. THE LONG-TAILED FIELD-MOUSE,

(Mus Sylvaticus, Lin-Le Mulot, Buff.)

Is rather larger than the common Moufe, and very fimilar to it in form: It is of a yellowifh-brown colour, its belly white, and its eyes remarkably large and prominent. -It is found only in the fields, woods, and gardens; feeds on nuts, corn, and acorns; and lays up great ftores for its fupport during winter. It burrows in the earth, and generally forms its neft near the root of a tree or thick bufh. If provifions fail during a ftorm, they devour each other; are very prolific, and bring nine or ten young at a time.

Mr Pennant mentions a fpecies, found in Hamplhire, 


\section{HISTORY OF QUADRUPEDS.}

only two inches and a half long from nofe to tail, of a fine ruft colour above, and white beneath. It appears in great numbers in harveft-time among the fheaves and ricks of corn. During winter, it fhelters itfelf under ground, where it makes a warm bed of dry grafs and leaves. 'Its young are brought forth on a neft made between the ftraws of the ftanding corn, and are generally about eight in number each time.

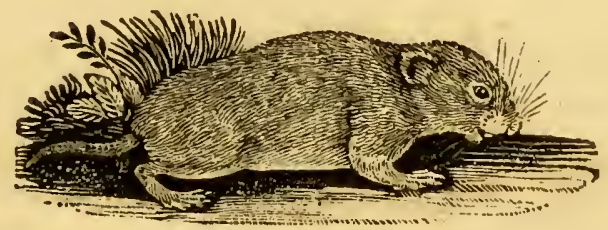

\section{THE SHORT-TAILED FIELD-MOUSE,}

Differs from the laft, in having a thicker head, and florter tail : Its ears are very thort, and almoft hid in the hair; its body is about three inches long, and the tail one; the upper part of the body is of a reddifh brown, and the belly a deep afh-colour.-Like the laft, it frequents the fields and woods, but is feldom troublefome in gardens: It alfo lives on the fame kinds, of food, which it hides in holes under ground.-It makes its neft in moift meadows, and brings forth feven or eight young at a time. 


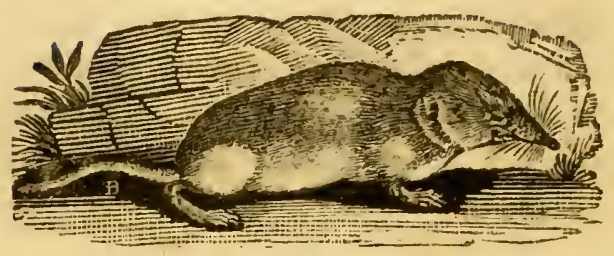

THE SHREW-MOUSE,

(Sorex Araneus, Lir.-La Mufaraigne, Buff.)

Is finaller than the common Moufe, being only two inches and a half long from the nofe to the tail: The nofe is long and flender; the ears fhort; and the eyes, like thofe of the Mole, almoft concealed in the fur. It is of a reddifh-brown colour; the belly white.-The two upper fore tecth of this animal are fingularly confructed, and deferve particular notice; having a fmall barb on each fide, fo fine, as to be fcarcely vifible.

The Shrew-Moufe frequents old walls and heaps of ftones; feeds on infects, corn, and putrid fubftances; and is fometimes feen on dunghills, where it roots with its nofe like a Hog.-It has fo ftrong and difagreeable a fmell, that the Cat, after the has killed, refufes to eat it. -It forms its neft of dry grafs, mofs, \&rc. on the furface of meadows or paftures, and is faid to breed four or five young at a time.

There feems to be an annual mortality of thefe animals in Auguft, numbers of them being found dead in the fields, highways, \&c. about that time. 


\section{HISTORY OF QUADRUPEDS.}

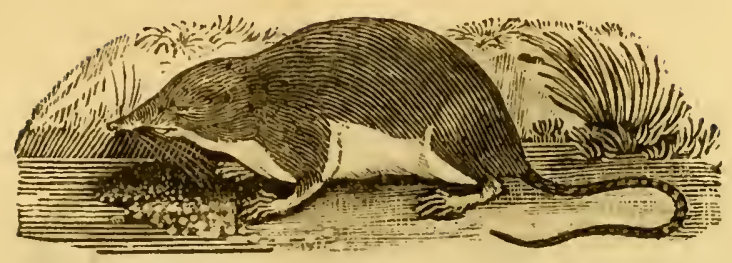

THE WATER SHREW-MOUSE,

(La Mufaraigne d'Eau, Buff.)

Is larger than the laft. The upper part of its body is black; the throat, breaft, and belly, of a light afh colour. -It is rarely to be feen; frequents the banks of rivulets and marfhy places, where it burrows.

It is very numerous in Lincolnfhire, but was never obferved there till about twenty years ago.-It is called, in that country, the Blind Moufe.

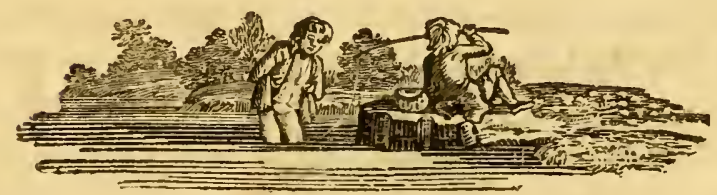




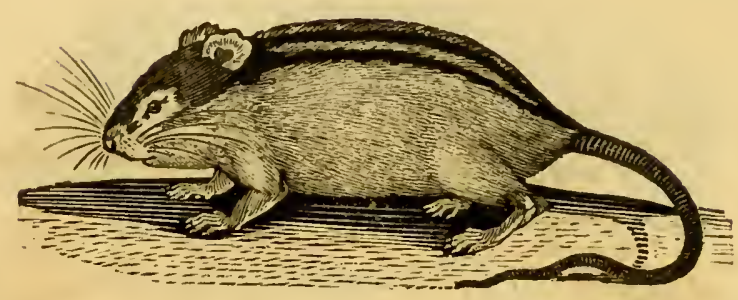

THE DWARF-MOUSE,

Is a native of the Cape of Good Hope, where it was difcovered, and firft defcribed, by Sparrman.-It is diftinguifhed from every other fpecies of the genus, by four black lines along its back, from the head to the tail.

It is fuppofed to be the moft diminutive quadruped in the world, being fcarcely two inches in length. In the annexed reprefentation, it is drawn the natural fize, and forms a ftriking contraft with thofe gigantic animals which inhabit that quarter of the world.

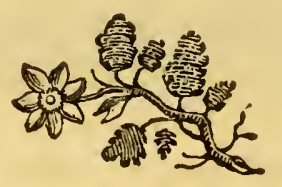




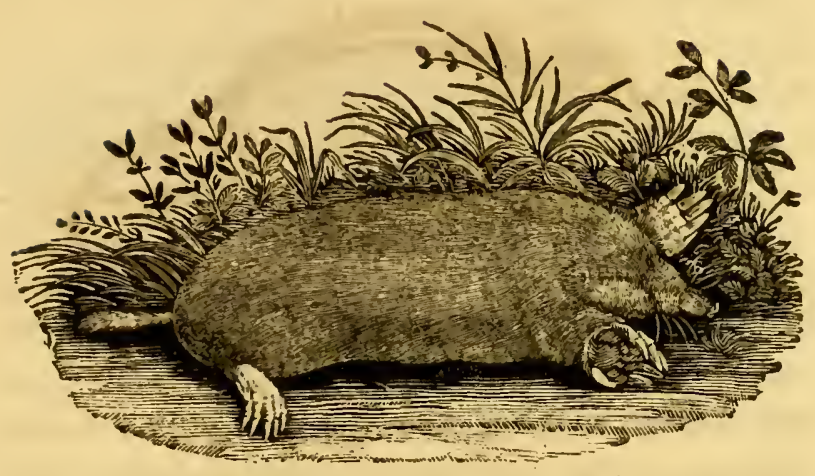

THE MOLE.

(Talpa Europeus Lin._La Taupe, Buff.)

THIs animal, deftined to feek its food and provide for its fubfiftence under the furface of the earth, is wonderfully adapted, by the all-wife Author of Nature, to its peculiar mode of living. It enjoys the fenfes of hearing and fmelling in a very eminent degree: 'The former gives notice of every approach of danger; whilft the latter enables it to find its prey in the midft of darknefs, and compenfates in a great meafure for an almoft total want of fight. To an animal fo circumftanced, a larger degree of vifion would be attended with manifeft inconveniences, as well as liable to continual injuries. We are told by anatomifts, that, for their better fecurity, the eyes of the Mole are furnifhed with mufcles, by which it has the power of withdrawing or exerting them at pleafure. Its eyes are extremely fmall, and perfectly hid in the fur. 
The form of this creature's body, and particularly the conftruction of its fore feet, are admirably adapted to the purpofe of making its way in the earth, which it does with wonderful facility: Thefe are quite naked, very broad, with large palms, almoft like a hand: There are five toes on each, terminated with ftrong nails, very concave on the under fide; and, in place of a thumb, a ftrong bone under the fkin. The hind feet are very fmall, with five flender toes, and a fmall thumb on the infide. Whenever it happens to be furprifed on the furface of the ground, it difappears in an inftant; and every attempt to prevent its fubterraneous retreat would be vain.

The Mole is moftly found in grounds where the foil is loofe and foft, and affords the greateft quantity of tworms and infects, on which it feeds.

The female brings forth in the fpring, and generally produces four or five at a time. The young are quite naked, and continue fo till they are grown to a corfiderable fize.-It makes its neft a little below the furface of the ground, forming a commodious apartment, where it prepares a warm bed of mofs and herbage: From this there are feveral paffages in different directions, to which it can retreat with its young ones in cafe of danger; into thefe likewife it makes excurfions in queft of food.-In the act of forming its tracks or runs, it throws up large heaps of mould, which are extremely injurious in meadows, grafs lands, and cultivated grounds. Its deftruction is confequently an object of importance to farmers, gardeners, \&c. .

The fkin of the Mole is extremely tough; its fur fhort, clofe-fet, and fofter than the fineft velvet, or perhaps the fur of any other animal. 


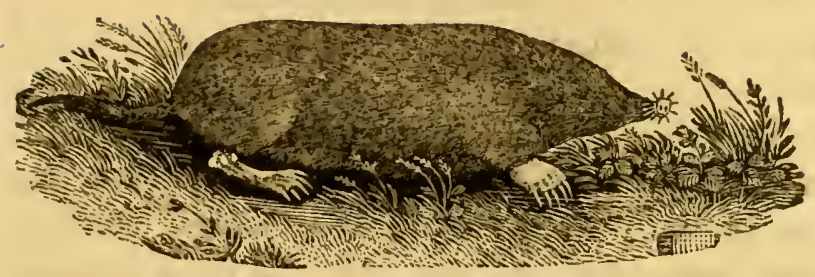

THE RADIATED MOLE,

(Sorex Crifatus, Lin.)

Is lefs than the common Mole, being not quite four inches long: Its fur is very clofe, fhort, and fine: It is a native of North-America, feeds on roots, and forms fubterraneous paffages in different directions.

There is a kind, found in Siberia, with a very Mort nofe, and no tail. It is of a beautiful green and gold colour, variable with the light.

There are fome other varieties, that differ chiefly in the colour of the hair; fuch as the rellow Mole of North-America, which is larger than the European. Its hair is foft, and of a filky glofs.

That which is found in Virginia, refembles the common Mole. It is of a black colour, mixed with deep purple.

It is faid that hats, peculiarly fine and beautiful, have. been made of the fur of the Mole. 


\section{THE OPOSSUM. \\ (Didelpbis, Lin._L'Opo/fum, Buff.)}

This animal is found in great numbers in various parts of North and South-America, and was fuppofed by Buffon to belong entirely to the new continent. We are now, however, affured, that it exifts in many of the Indian iflands. Several varieties of the Opoffum kind have been feen alfo in the newly-difcovered countries in the South Seas.

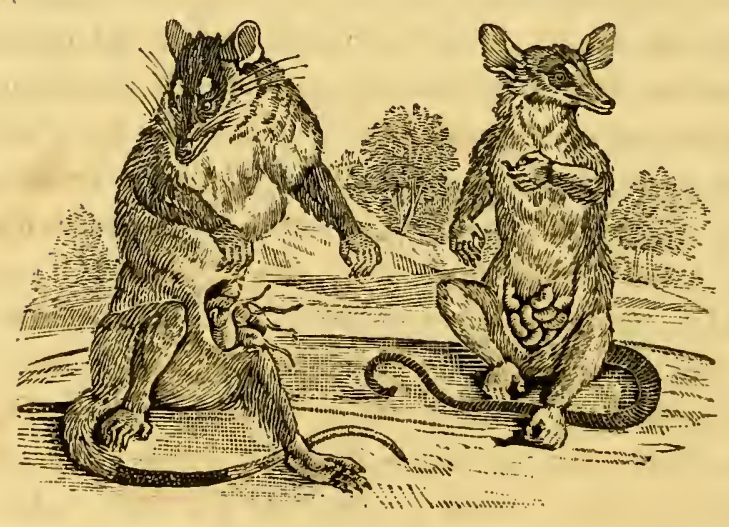

THE SARAGOY. THE MURINE.

The Saragoy, or Mulucca Opossum of Mr Pennant, is about the fize of a Cat :. Its head is long; nofe fharp and pointed; ears large, thin, and naked; eyes fmall, black, and lively, having a white fpot above each of them; its fur is foft, long, and of a dutky afh colour; its belly white; its tail is fimilar to that of a Rat, naked 
and fcaly, except a fmall part near the body, which is covered with hair; its legs are fhort; and its feet or hands not unlike thofe of a Monkey, having five toes or fingers on each; the thumbs on the hind feet are deftitute of nails. But the peculiar and diftinguifhing characteriftic of the Opoffum is a pouch or falfe belly, in which the female depofits her young immediately after they are brought forth, and nourifhes them in it till they are able to provide for themfelves.

The Chevalier d'Aboville, whilft in America during the late war, in order to be fatisfied refpecting the time of its geftation, manner of bringing forth, and fuckling its young, procured a male and female Opoffum, which he tamed, and kept in his chamber till they copulated. Ten days after, he obferved a confiderable alteration in the fize and form of the pouch; its aperture being wider than it was before, and its orifice thicker: From that time it gradually grew clofer, leaving only a fmall opening in the middle, fimilar to a navel: On the fifteenth day he introduced his finger, and found at the bottom of the bag a fmall round body, about the fize of a pea: The twenty-fifth day he could feel a motion under his finger. After the young had been a month in the pouch, they were plainly to be feen, on opening it a little. At the end of two months, on examining the pouch, there appeared to be fix young ones, all of them attached to the mother by a canal that entered the mouth, which, if withdrawn, could not be replaced; but when fix weeks old, the young Opoffum could refume it by ftrong fuction, the mouth being then large enough to receive the pap, which is about two lines in length, and the fize of the fecond or third ftring of a violin 
The number of the young varies from five to ten or eleven.

The paps are not difpofed in regular order, as in other animals, but feem as if they were formed in thofe places where the embryos attach themfelves to the mother.

The Opoffum is a flow, helplefs animal, when on the ground; but climbs trees with great eafe and quicknefs; fometimes conceals itfelf among the branches, and furprifes the birds that come within its reach. It frequently hangs, fufpended by its tail; and, in that fituation, watches for its prey, which it darts upon with great agility.

By mears of this tail, the Opoffum flings itfelf from one tree to another.-It feeds on birds, reptiles, infects, roots; leaves, and the bark of trees.-It is eafily tamed, is neither mifchievous nor ferocious; but its figure is difagreeable, and the odour that exhales from its $\mathrm{kin}$ rank and difgufting.

\section{THE MURINE OPOSSUM,}

(Didelphis Murina, Lin.-La Marmofe, Buff.)

INHABITs the warmeft parts of South-America.-It refembles the former, but is much lefs. Its food and manner of living are likewife very fimilar to it.

It brings forth from ten to fourteen young at a time; but, inftead of a bag, the female has two longitudinal folds under her belly, within which the young are fecured. When firft produced, they are not larger than beans, and remain clofely attached to the teat till they attain fufficient growth and ftrength to provide for themfelves. 


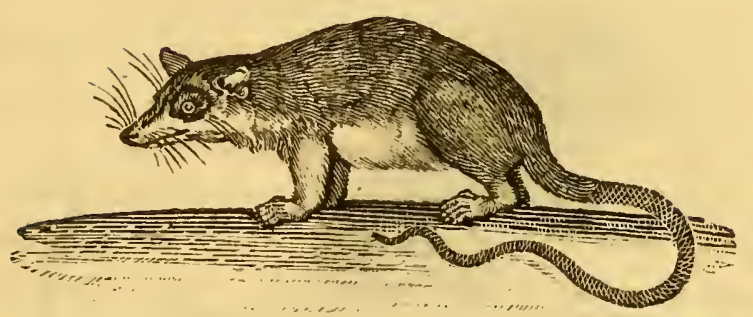

THE MEXICAN OPOSSUM,

Differs little from the preceding either in fize or form. It is found in the mountainous parts of New-Spain, lives in trees. Its tail is ufeful in twifting round the branches, and fecuring its hold.

The young attach themfelves to their mother by their hands and tails; and, upon the leaft alarm, embrace her clofely; whilft the carries thein to the thelter of fome neighbouring tree.

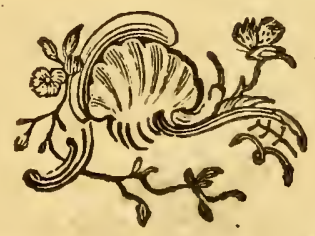

E. e 


\section{4 HISTORY OF QUADRUPEDS.}

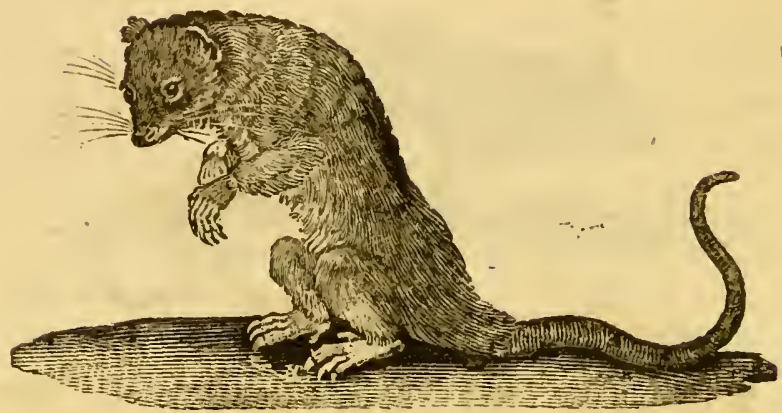

THE PHALANGER,

Is fomewhat larger than a Rat: Its nofe is thick; ears fhort and hairy; its fur is of a reddin colour, variegated with light an and yellow; the under part of the body yellowifh-white; it is diftinguifhed from all thofe of the Opoffum kind we have hitherto mentioned, in having the firft and fecond toes of the hind feet clofely united; its claws are large; tail long, very broad and thick at its junction with the body, and naked at the end.

It inhabits the Eaft-Indies.

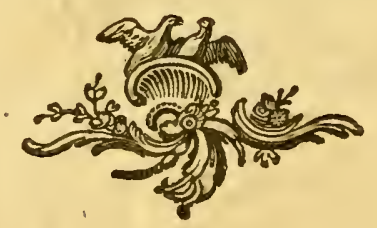




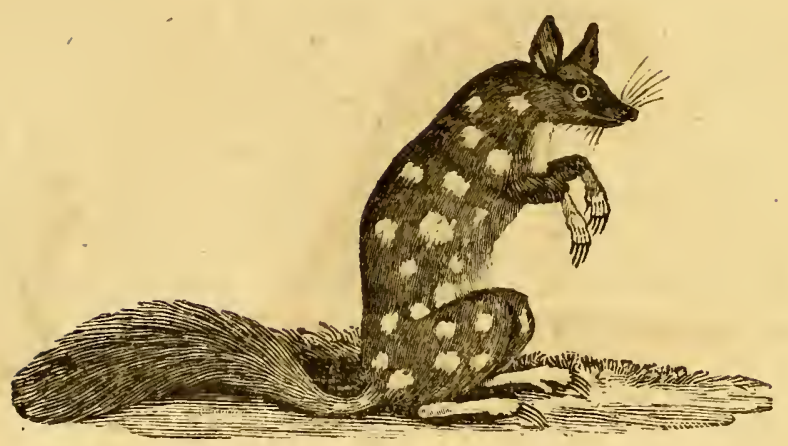

\section{THE SPOTTED OPOSSUM OF NEW SOUTH- WALES.}

THE general colour of this animal is black; the body fpotted with irregular roundifh patches of white; the ears are large and erect; muzzle long, pointed, and furnifhed with long flender whilkers; both fore and hind legs thinly covered with hair of an afh colour; on the fore feet it has five claws, and on the hind four; length, from nofe to tail, about twenty-five inches; tail thick and burhy, like that of a Squirrel, except a part near the body, which is fmall, and covered with fhort hairs. The female has fix teats, placed circularly within the pouch.

\section{THE VULPINE OPOSSUM OF NEW SOUTH- WALES,}

Is long-nofed and thort-legged; from the nofe to the infertion of the tail, meafures two feet two inches; tail fifteen inches; upper part of the body grifly, confifting of E e 2 
dufky, reddifh, and white hairs; the under parts lighttawny; two-thirds of the tail black; a blackifh fpace round each eye; long black whinkers; five toes on the fore feet, and four on the hind, with a thumb of two joints placed at the bafe of the inner toe; the toes of the fore feet are long, and anfwer the purpofe of a hand; the ears are about an inch and a half in length; in the upper jaw are fix cutting-teeth, four grinders, and two canine teeth; in the lower jaw, two long cutting teeth, like thofe of a Squirrel, and four grinders, but no canine teeth.

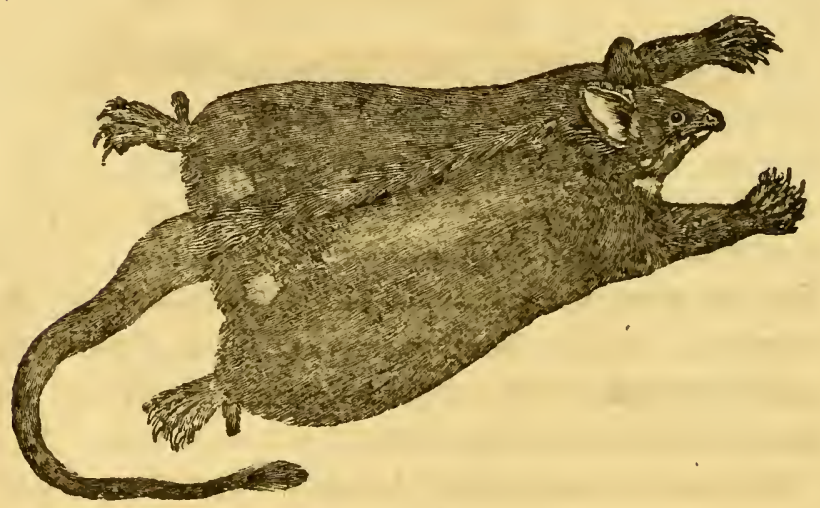

THE FLYING OPOSSUM OF NEW SOUTHWALES. .

ITs nofe is pointed; its ears large and ereet; the fur more delicate, and of a finer texture, than that of the Sea-Otter,-is of a beautiful dark colour, and very gloffy, mixed with gray; the under parts white; on each hip is 


\section{HISTORY OF QUADRUPEDS.}

a tan-coloured fpot; the fur is continued to the claws; the failing membrane is the fame as that of the Gray Squirrel, but broader in proportion; on the fore legs it lias five toes, with a claw on each; on the hind ones, four toes, and a long thumb, which enables the animal to ufe it as a hand; it is remarkable, that the three outfide claws of the hind feet are not feparated like the others.

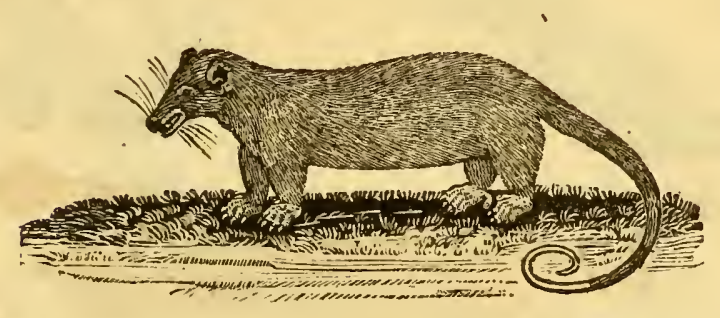

\section{THE OPOSSUM OF VAN DIEMEN'S LAND,}

Was difcovered by Captain Cook in January, 1777 ; who defcribes it as about twice the fize of a large Rat.-It is covered with long foft gloffy hair, of a rufty-brown $\mathrm{CO}_{4}$ lour; its belly is of a dirty white.

It inhabits Van Diemen's Land, the fouthern point of New-Holland. 


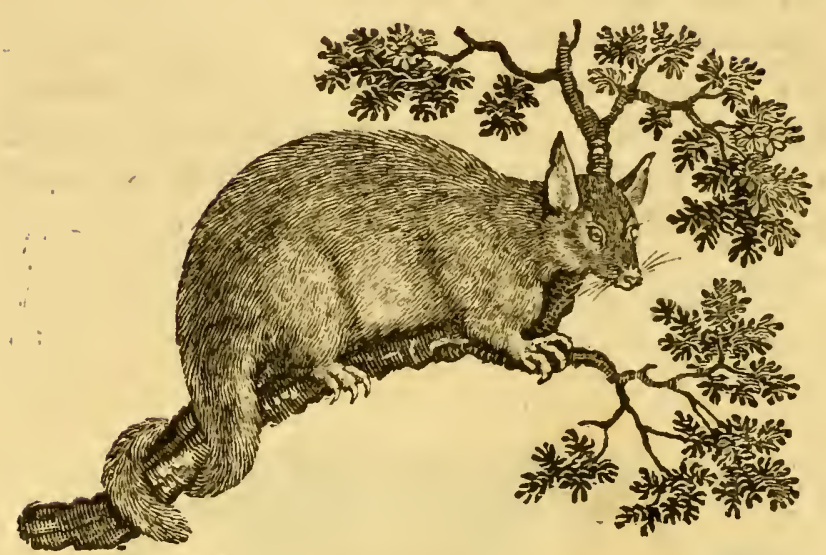

THE SQUIRREL OPOSSUM.

WE are favoured with a drawing of this beautiful animal, taken from a living one in the poffeffion of the reverend Mr Egerton, prebendary of Durham, by the ingenious Mr Carfrae.

It is a native of New South-Wales; is about eighteen inches long, exclufive of the tail, which is twelve: Its head is broad, and pointed at the muzzle, which is furnifhed with long whifkers; its eyes are full, exceedingly prominent, and of a fiery rednefs; it has five claws on the fore feet, -three on the hind, and a thumb; two cutting teeth in each jaw, the upper projecting beyond the under.-Its manners are fimilar to thofe of a Squirrel. It fits up, holds its food in its fore paws with great dexterity, and feeds itfelf. When irritated, it fits ftill more erect, or throws itfelf upon its back, making a loud 


\section{HISTORY OF QUADRUPEDS.}

and harfh noife._- It feeds on vegetables, fmall birds, \&c.

The fur is long, foft, and very clofe; of a mixed brown or grayifh colour on the back; the under parts of a yellowifh-white. Its tail is prehenfile, very broad at the bafe, tapers to the end, and is naked on the under fide.-The female is furnifhed with a pouch.

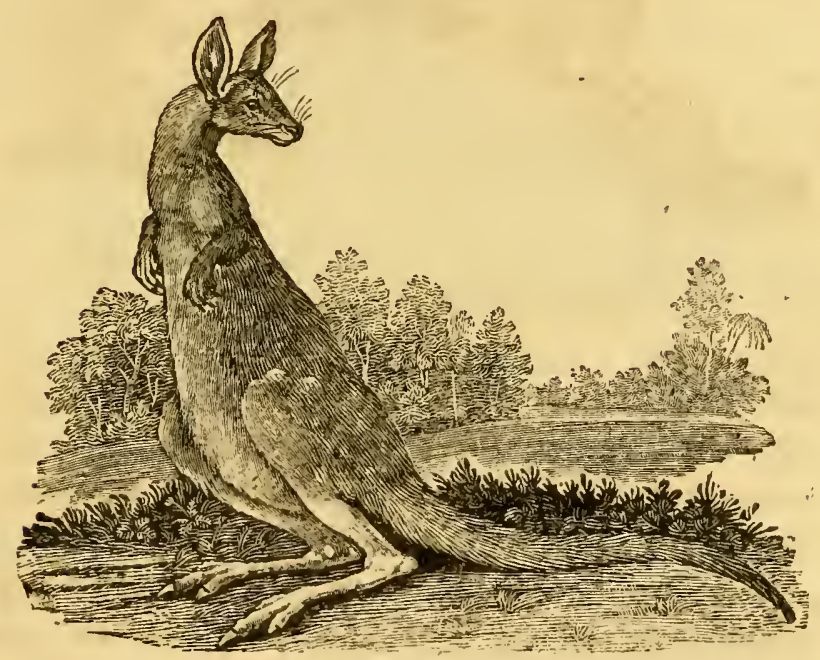

\section{THE KANGUROO,}

Is a native of New-Holland, where it was firft difcover ed by Sir Jofeph Banks._Its head is fmall and taper, ears large and erect, upper lip divided, the end of the nofe black, noftrils wide, lawer jaw fhorter than the upper, and there are whifkers on both; it likewife has ftrong hairs above and below the eyes; its head, neck L e 4 
and fhoulders, are fmall ; the lower parts of the body increafing in thicknefs to the rump; its tail is long, very thick near the rump, and taper; its fore feet are extremely thort, and are moftly ufed in digging or bringing its food to its mouth; it moves altogether on its hind Iegs, making fucceffive bounds of ten or twelve feet, with fuch rapidity as to outftrip the fleeteft Greyhound; it fprings from rock to rock, and leaps over bufhes feven or eight feet high, with great eafe; it has five toes on its fore feet,-three on the hind, the middle one very long; the inner claw is divided down the middle into two parts.

The Kanguroo refts on its lind legs, which are hard, black, and naked on the under fide. Its fur is fhort and foft, of a reddifh afh colour, lighter on the lower parts.

It is the only quadruped our colonifts have yet met with in New South-Wales that fupplies them with animal food._-There are two kinds. The largeft that had been thot weighed about I40lb.; and meafured, from the point of the nofe to the end of the tail, fix feet one inch; the tail, two feet one inch; head eight inches; fore legs, one foot; hind legs, two feet eight inches;. circumference of the fore part of the body, near the legs, one foot one inch; and of the hind part, three feet. The fmaller kind feldom exceed 6olb.

This animal is furnifhed with a pouch, fimilar to that of the Opoffum, in which its young are nurfed and theltered. 


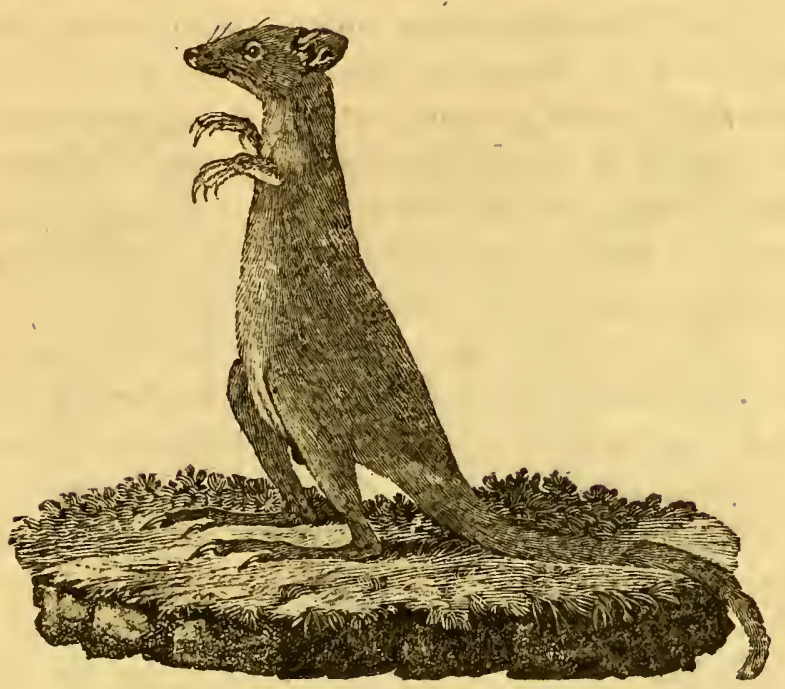

THE KANGUROO-RAT OF NEW SOUTHWALES.

Is about the fize of a Rabbit, and in fhape refembles the Kanguroo, both in refpect to the Thortnefs of the fore legs, and the peculiar ufe and conftruction of the hind ones; the form of the head is like that of a Rat, and its body nearly of the fame colour; in the upper jaw it has two long cutting teeth, with three fhort ones on each fide of them; in the lower jaw, two long cutting teeth, and three grinders on each fide.

The female, like moft of the animals of that country, has a pouch, like the Opoffum.

It feeds on vegetables, burrows in the ground, and is very tame and inoffenfive. 
THE YELLOW MACAUCO.

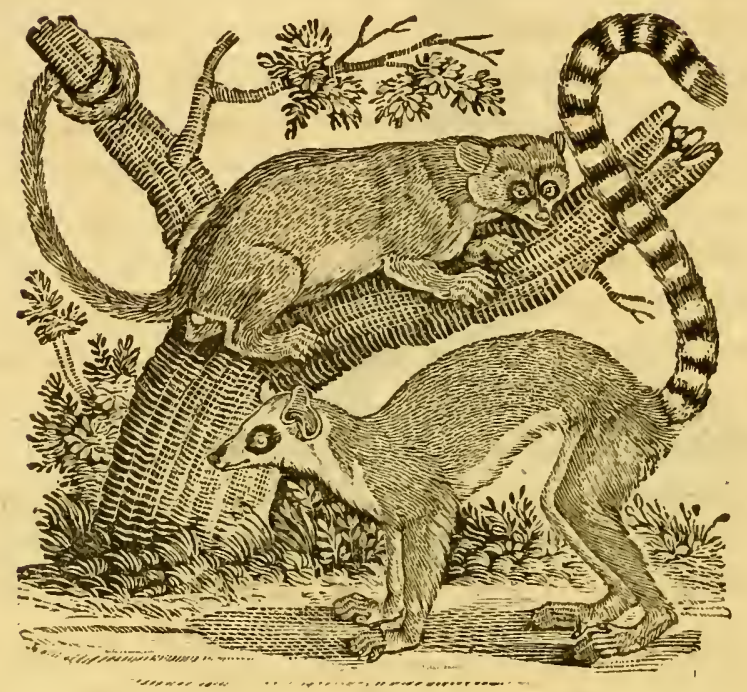

'THE RING-TAILED ,MACAUCO,

\section{(Lemur Catta, Lin.-Le Mococo, Buff.)}

Tre Ring-tailed Macauco is a very beautiful animal, about the fize of a Cat. Its body and limbs are long and flender; its tail very long, and marked with alternate bars of black and white: In the conformation of its paws, it feems to approach the Monkey kind; but its nofe is long and fharp, like that of a Fox, and its ears are alfo large' and pointed: Its head and throat are white; eyes large, and furrounded with black: Its fur is gloffy, foft, and delicate, - of a reddifli-afh colour on the back; belly white: 
It is found in Madagafcar and the neighbouring illes, is very playful, but not mifchievous. When in motion, it makes a fort of galloping progrefs in an oblique direction, and carries its tail almoft erect; but when fitting, it is twifted round the body, and brought over its head.-Troops of thirty or forty are fometimes feen together.

It is a cleanly animal; and, when taken young, may be eafily tamed.

The Yellow Macauco has been claffed with the Weafel tribe by Mr Pennant, in his Hiftory of Quadrupeds; and it feems to bear fome general refemblance to that fpecies of animals. Its head is flat and broad; its ears are fhort, eyes fmall, body long and flender, legs and thighs fhort and thick, and it has five ftraight toes on each foot: Its fur is thort, foft, and gloffy, of a black colour, mixed with yellow, on the back; the cheeks, infide of the legs, and belly, yellow; along the back, from head to tail, there is a broad duficy ftripe; and another on the belly, half way from the tail, which is nearly as long as its body, of a bright tawny colour, mixed with black, and has the fame prehenfile faculty as thofe of fome kinds of Monkies. Its length, from nofe to tail, is nineteen inches.

One of this fpecies was thewn in London fome years ago, and was faid to have been brought from Jamaica, where it is called the Potto. It was good-natured and fportive, would catch hold of any thing with its tail, and furpend itfelf by it. 


\section{HISTORY OF QUADRUPEDS.}

\section{THE TAIL-LESS MACAUCO. \\ (Lemur Tardigradus, Lin.)}

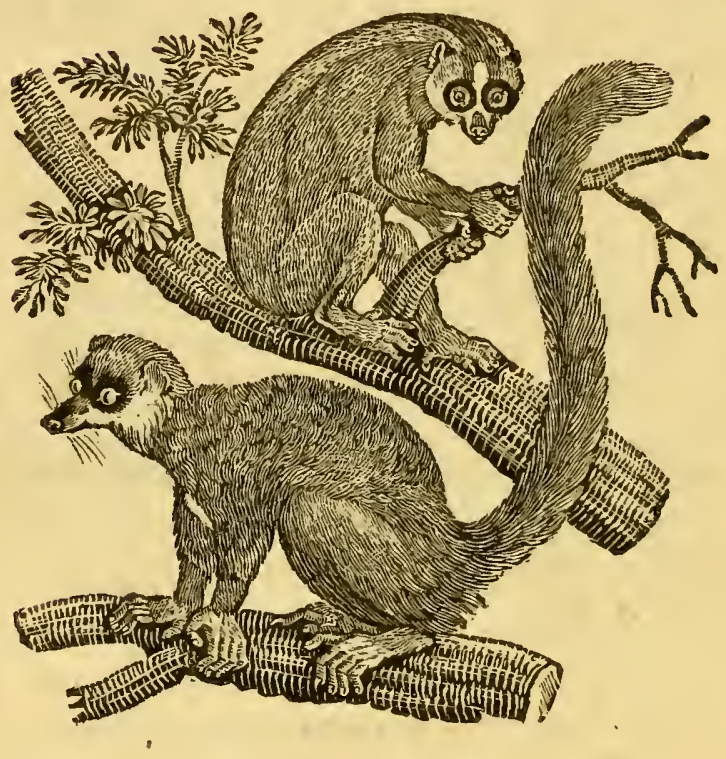

THE MONGOOZ.

(Lemur Mongooz, Lin._Le Mongooz, Buff.)

The Tall-iess Macauco is found in Ceylon and Bengal, lives in woods, and feeds on fruits; is fond of eggs and fmall birds, which it devours greedily.

It is a very inactive animal, and its motions flow; very tenacious of its hold, and makes a plaintive noife.

Its head is fmall, and nofe pointed ; each eye is edged with a circle of white, which is alfo furrounded with 


\section{HISTORY OF QUADRUPEDS.}

another of black; its body is covered with a fhort filky fur, of a reddifh-afh colour; the toes naked; nails flat, except thofe on the inner toes of the hind feet, which are fharp and crooked. Its length, from the nofe to the rump, is fixteen inches.

The Mongooz is nearly of the fame fize as the Ringtailed Macauco.

Its fur is fine, foft, and woolly, of a deep brownifhan colour; the eyes are of a beautiful orange colour, furrounded with black; the ears are thort; cheeks white; end of the nofe black; the tail very long, and covered with hair of the fame fort and colour as the body; its hands and feet are naked, and of a dufky colour; its nails, except one upon the inner toe of each hind foot, are flat.

It inhabits Madagafcar and the illes adjacent, fleeps in tree's, is very playful and good-natured, feeds on fruits, is extremely tender, and cannot bear any change to a lefs temperate climate.

\section{THE LORIS,}

Is a very flender animal, and differs greatly from the preceding, both in form and manners.

It is not much larger than a Squirrel, but its limbs are longer; the hind legs greatly exceed the fore in length; the thumbs on each foot are more diftinct and feparate from the toes than thofe of other Macaucos; its nofe is pointed, like that of a Dog; its forehead high; ears round and thin; its fur is thort and delicately foft, of a tawny colour on the back, and whitih below : It has no tail. 


\section{HISTORY OF QUADRUPEDS.}

The Loris is a native of Ceylon, 'very active, lives in trees, and feeds on fruit. Seba fays, the male climbs the trees, and taftes the fruit before he prefents it to his mate.

\section{THE BLACK MACAUCO, \\ (Lemur Niger, Lin.-Le Vari, Buff.)}

Is larger than the Mongooz. - It is a native of Madagafcar, is very fierce, and makes a loud noife in the woods; but, when tamed, is gentle and good-natured.-Its eyes are of a deep orange colour. Round its head, the hair is long, and ftands out like a ruff.

The general colour of this animal is black; but fome are white, fpotted with black. The feet are black and naked.

\section{THE TARSIER,}

Is remarkable for the great length of its hind legs, in which it refembles the Jerboa; has four flender toes and a diftinct thumb on each foot: Its vifage is pointed; eyes large and prominent; ears erect, broad, and naked: Its hair is foft and woolly, of a deep an colour, mixed with tawny: Its length, from the nofe to the rump, is nearly fix inches; the tail is nine inches long, round, fealy, almoft naked, like that of a Rat, and tufted at the end.

It is found in fome of the remote illands of India, efpecially Amboyna. 


\section{ANIMALS OF THE MONKEY KIND.}

WE now come to the defcription of a numerous race of animals, confifting of a greater variety of kinds, and making nearer approaches to the human fpecies, both in form and action, than any other clafs of quadrupeds.

Monkies are found only in the warment parts of the world, and chiefly in the torrid zone. They abound in the woods of Africa, from Senegal to the Cape of Good Hope, and from thence to Ethiopia ; in all parts of India, and its ifles; in the South of China; in Japan; and in South-America, from the Ifthmus of Darien as far as $\mathrm{Pa}$ raguay. A fpecies or two are alfo met with in Arabia and the province of Barbary.

On account of the numbers and different appearances of thefe animals, they have been divided into three claffes, and defcribed under the following denominations; viz.-ApEs, or fuch as have no tails; Baboons, or fuch as have fhort tails; Monkies or fuch as have long tails.

In the APE kind, we fee the whole external machine ftrongly impreffed with the human likenefs, and capable of fimilar exertions: They walk upright, their pofteriors are flefhy, their legs are furnifhed with calves, and their hands and feet are nearly like the human.

In the BABOoN, we perceive a more diftant refemblance of the human form: He generally goes upon all four, feldom upright, but when conftrained to it in a ftate of fervitude.-Some of them are as tall as a man. - They have thort tails, long faces; funk eyes, áre extremely difgufting, lafcivious, and poffeffed of the moft brutal fierceners. 


\section{$44^{8}$ HISTORY OF QUADRUPEDS,}

The Monkey kind are removed ftill farther, and are much lefs than the former. Their tails are generally longer than their bodies; and, although they fit upon their pofteriors, they always move upon all four.-They are a lively, active race of animals, full of frolic and grimace, greatly addicted to thieving, and extremely fond of - imitating human actions, but always with a mifchievous intention.

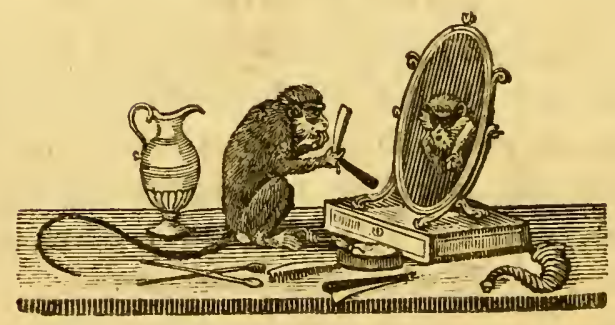




\section{HISTORY OF QUADRUPEDS.}

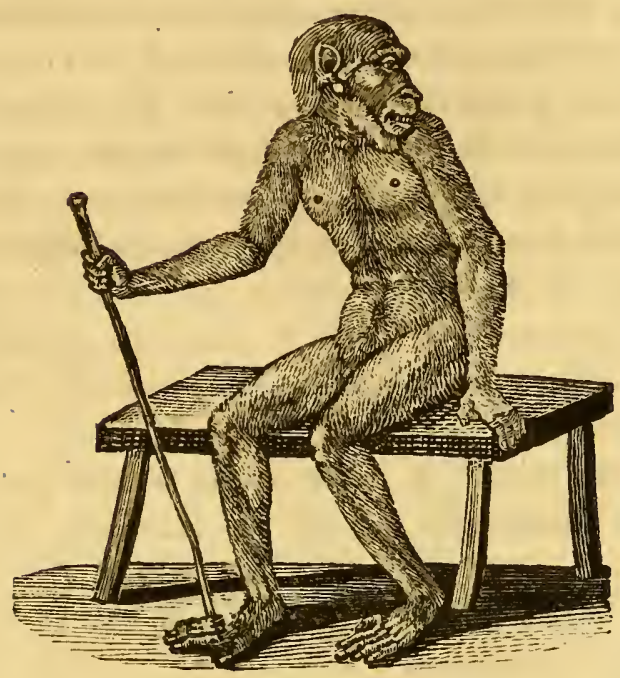

THE ORAN-OUTANG, OR WILD MAN OF THE WOODS,

(Simia Satyrus, Lin.-Le Pongo, Buff.)

Is the largeft of all the Ape kind, and makes the neareft approach to the human figure. One of this kind, diffected by Dr Tyfon, has been very accurately defcribed by him. The principal external differences, pointed out by that learned phyfician, confifted in the great length of the arms, and thortnefs of the thighs; the thumb is alfo much fimaller, and the palm of the hand longer and narrower, than in man; the form of the feet is very diffimilar, the toes being much longer, and the large toe placed at a greater diftance from the others; the forehead is 
higher, the nofe flat, and the eyes much funk: Befide thefe, that anatomift has enumerated a variety of effential differences in the internal conformation of the Oran-Outang; all of which fufficiently evince, that, though he has the ftrongeft affinity to the human form of any other quadruped; yet, as Buffon elegantly obferves, " the interval which feparates the two fpecies is immenfe; the refemblance in figure and organization, and the movements of imitation which feem to refult from thefe fimilarities, neither make him approach the nature of man, nor elevate him above that of the brute."

The Oran-Outang is found in the interior parts of Africa, in Madagafcar, Borneo, and fome parts of the Eaft-Indies.

It is a folitary animal, avoids mankind, and lives only in the moft defart places.

The largeft of the kind are faid to be about fix feet high, very active, ftrong, and intrepid, capable of overcoming the ftrongeft man: They are likewife exceedingly fwift, and cannot eafily be taken alive. - They live entirely on fruits and nuts, will fometimes attack and kill the negroes who wander in the woods, and drive away the Elephants that happen to approach too near the place of their refidence. It is faid that they fometimes furprife the female negroes, and carry them off into the woods, where they compel them to fay with them.

When taken young, however, the Oran-Outang is capable of being tamed, and rendered extremely docile.One of them, fhewn in London fome years ago, was. taught to fit at table, make ufe of a fpoon or fork in eating its victuals, and drink wine or other liquors out of a glafs. It was extremely mild, affectionate, and good-na- 
tured; much attached to its keeper, and obedient to his commands. Its afpect was grave, and its difpofition melancholy. It was young, and only two feet four inches high. Its body was covered with hair of a black colour, which was much thicker and clofer on the back than on the fore part of the body; the hands and foles of the feet were naked, and of a dufky colour.

\section{THE PIGMY APE:}

(Simia Sylvanus, Lin._Le Pitheque, Buff.)

A variety, found in Guinea, Ethiopia, and other parts of Africa, much fmaller than the laft, being not more than a foot and a half in length. It is very tractable, good-natured, and eafily tamed; is fuppofed to have been the Pithecos of the ancients. It lives in woods, and feeds on fruits and infects.-Troops of them affemble together, and defend themfelves from the attacks of wild beafts in the defart, by throwing a cloud of fand behind them, which blinds their purfuers, and facilitates their efcape.

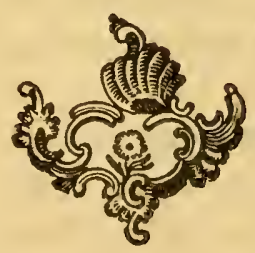

Ff 2 


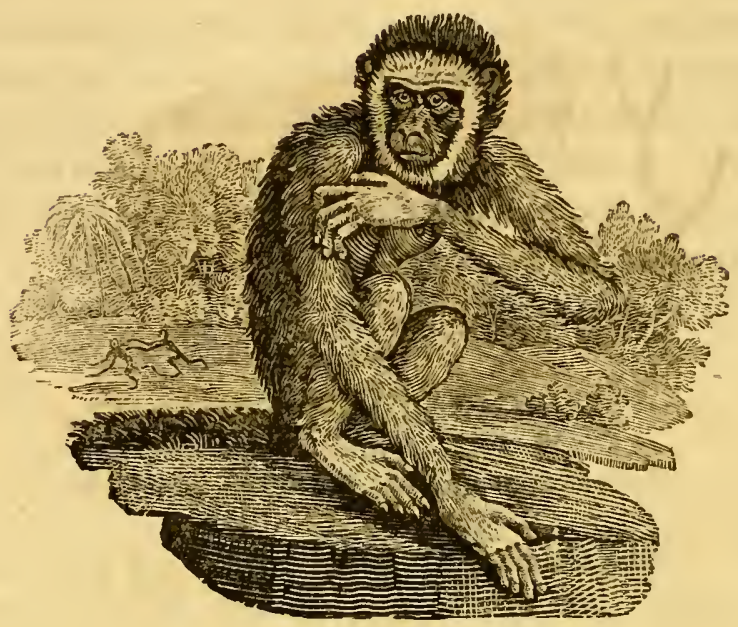

THE LONG-ARMED APE,

(Le Grand Gibbon, Buff.)

Is diftinguifhed by the extraordinary length of its arms, which reach to the ground when its body is upright, and give it a difgufting appearance. Its face is tlat, and of a tawny colour, furrounded with a circle of gray hairs, which adds to the fingularity of its afpect; its eyes are large and deep funk; ears round and naked; body covered on all parts with black rough hair, except its buttocks, which are quite naked.

It is a mild, gentle; and tractable animal; feeds on fruits, leaves, and the bark of trees; is a native of the Eaft-Indies, Sumatra, and the Molucca ifles; and meafures from three to four feet in height. 


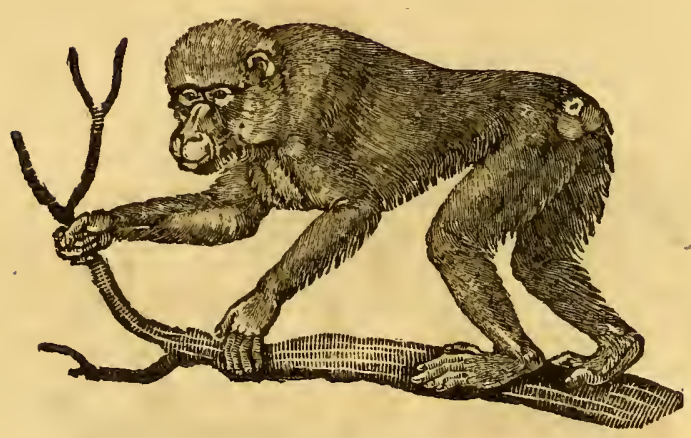

THE BARBARY APE,

(Simia Inuus, Lin.-Le Magot, Buff.)

Is wilder and more untractable than the others. His head is large, and his nofe prominent: He likewife differs from the laft, in having cheek pouches, which he frequently fills with food before he begins to eat: The canine teeth are large and ftrong; ears round, and fomewhat like thofe of a man; the body is covered with hair of a brown colour, inclining to green; lighter on the belly. When ftanding erect upon his hind legs, he is generally two feet and a half or three feet high. $\mathrm{He}$ walks oftener on four than on two feet; and, when refting, fupports his body on two prominent callofities, fitua ted on his buttocks.

This is a very common fpecies, and is found in moft parts of Africa, from Barbary to the Cape of Good Hope. 


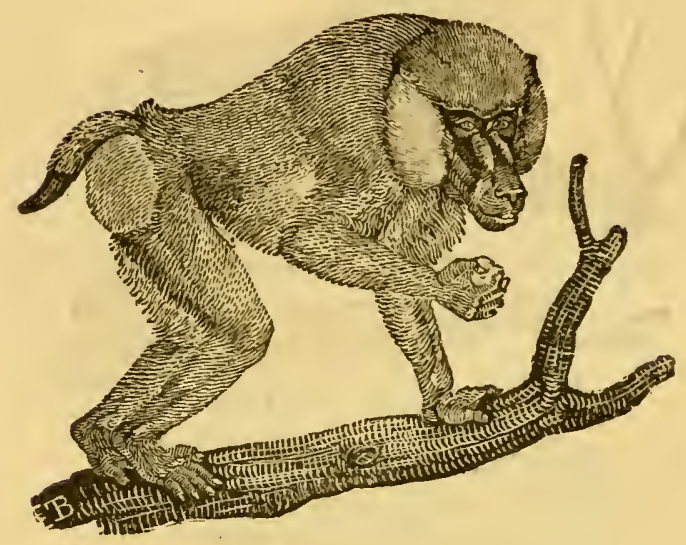

THE BABOON,

(Simia Spbynx, Lin.)

Differs from animals of the Ape kind, not only in external appearance, but alfo in temper and difpofition.Fierce, untractable, and libidinous, its difpofition feems to partake of the hideous and difgufting deformities of its outward figure.-Its body is thick, compact, and nervous, and its ftrength prodigious.-Neither art nor careffes can render it in any degree docile or obedient. It feems to be continually fretting with rage, and feeking every opportunity of fhewing its favage and vicious propenfities. - In a ftate of captivity, it muft be kept clofely confined; and, even in that fate, we have feen one fhake the bars of his cage fo powerfully with his hands, as to excite the utmoft terror in the fpectators.

This animal, of which we have given a very faithful 


\section{HISTORY OF QUADRUPEDS.}

reprefentation from the life, was about four feet high when ftanding on its hind legs: Its head was large, fhoulders of an amazing ftrength and thicknefs, its muzzle long and thick, eyes fmall and deep funk, its canine teeth very large and formidable, and it had pouches in its cheeks : The hair on its head was long, and formed a very elegant toupee from its forehead and each fide of its face, which, when angry, it erected; the hair on the body was uniformly of a light reddifh-brown; the tail fhort, and darker at the end; buttocks red and naked.

The Baboon inhabits the hotteft parts of Africa; feeds on fruits, roots, and other vegetables.-Numerous troops fometimes make their appearance, plundering gardens and cultivated grounds. They are extremely dexterous in throwing the fruit from one to another, and by this means will do incredible damage in a very thort time.

The female brings forth only one young at a time, which the carries in her arms, and fuckles at her breaft. -Notwithftanding its libidinous difpofition, it will not breed in temperate climates.

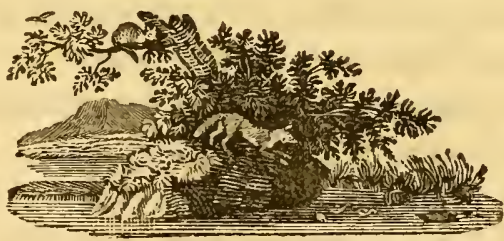




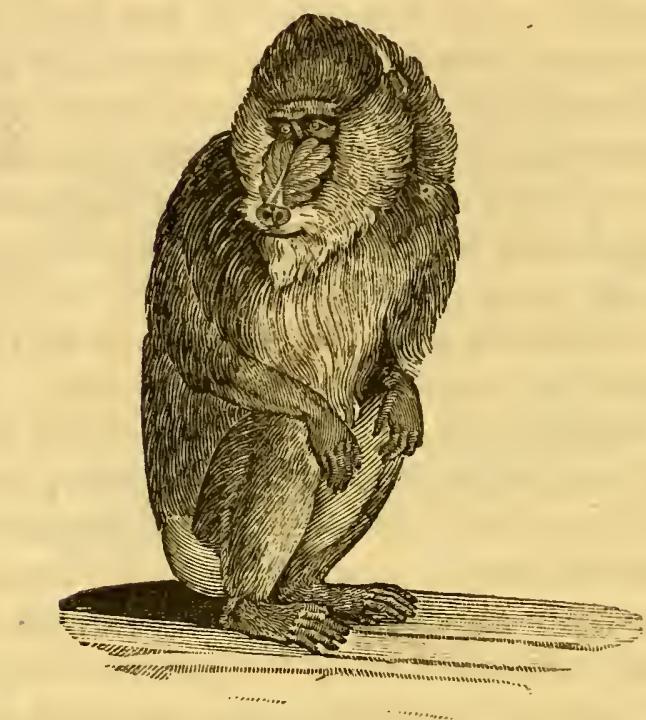

\section{THE RIBBED-NOSE BABOON.}

(Simia Maimon, Lin._Le Mandrill, Buff.)

THis fingular creature is no lefs remarkable for its great fize and ftrength, than for the variety of beautiful colours on different parts of its body. Its nofe is marked with broad ribs on each fide, of a fine violet-blue colour: $\Lambda$ vermilion line begins a little above the eyes; and, running down on each fide of the nofe, which is fomewhat fimilar to that of a Hog, fpreads over the tip of it: The infides of the ears are blue, which gradually foftens to a purple, and terminates in vermilion; the rump is alfo of a vermilion colour; and the beautiful colours on the hips 


\section{HISTORY OF QUADRUPEDS.}

are gradations from red to blue; the hair on the forehead is long, turns back, and forms a kind of pointed creft; its beard is dark at the roots, orange at the middle, and yellow at the end ; the back and legs are covered with thort hair, of a dark-brown colour, mixed with yellow, - the breaft and belly with long whitifh hair, fpeckled with fmall dark fpots; its tail is fhort and hairy, nails flat, feet and hands black and naked.

One of this kind was exhibited about twelve years ago in the North of England. It was five feet high, extremely fierce, libidinous, and ftrong. At the fight of women, it difcovered marks of the moft violent paffion: It once caught hold of a lady, who was fo incautious as to approach too near it; and the was with fome difficulty refcued by the interference of the keeper. Its voice was ftrong and harh, not unlike the ordinary growl of the Lion. It generally went upon its four feet, unlefs obliged by its keeper to ftand erect. Its moft ufual attitude was fitting on its rump, with its arms placed before it.

This creature inliabits the hotteft parts of Africa.Schreber fays, it lives on fucculent fruits and nuts, is fond of eggs, will put eight at once into its pouches, then take them out one by one, break them at the end, and fwallow the contents.

Our reprefentation of this animal was done from a drawing in the poffeffion of the Rev. Mr Egerton, taken from the life by an eminent painter. 


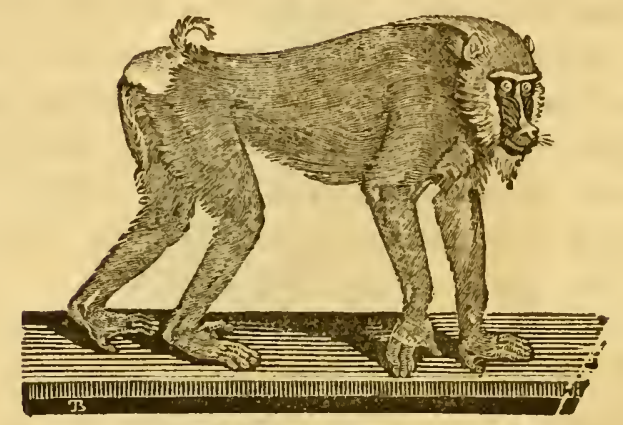

THE SMALL RIBBED-NOSE BABOON.

THE annexed cut was done from the living animal, in the poffeffion of Mr Rayne, furgeon, in Newcaftle.

It is about fifteen inches in height; its face flat, of a fine blue colour; eyes bright hazel; the cheeks marked with fmall ribs, bounded with thick bufhy hair, of a greenifh colour, finely fpeckled with black; the hair on the forehead is very long, and runs up to a point on the top of the fhoulders; the muzzle is thick, and furnifhed with thort hair, thinly fattered on each fide; it has a fhort thin beard, ending in a point, which is of an orange colour; the hair on the body is dark brown, mixed with fhades of green on the back and fides,-the haunches dufky; the ears are fmall, naked, and pointed; the tail fhort and hairy; the buttocks bare, and of a red flefh-colour; hands and feet naked : It has cheek pouches; feeds on fruits, nuts, roots, and other vegetables. It is lively and playful, walks commonly on all four, is in continual motion, and leaps with aftonifhing agility.-This fpecies is faid to come from the coaft of Guinea. 


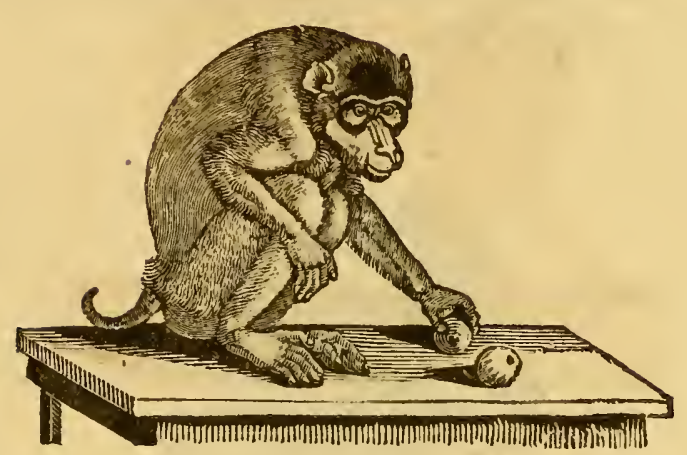

\section{THE PIG-TAILED BABOON,}

(Simia Nemefrina, Lin._Le Maimon, Buff.)

So termed from its thort, naked, pig-like tail, is the leaft of all the Baboon kind; a gentle, mild, and tractable animal; very lively and frolicfome, but has none of that impudent petulance fo peculiar to moft of its fpecies.Its muzzle is large and thick; face and ears naked, and of a flefh colour; the hair on the head and back is of a deep olive, paleft on the belly; it has hazel eyes, cheek pouches, callofities on the buttocks, which are naked, and of a red colour. - It is a native of Sumatra and Japan.

One of this kind was thewn in the North in 1788 , from which this drawing was made.

It is a curious circumftance, that not only this, but every animal of the Baboon and Monkey kind we have yet feen, have fhewn a remarkable greedinefs for tobac- 
co, muftard, and even fnuff, which they eat without expreffing the fmalleft inconvenience, and always feem extremely defirous of more.

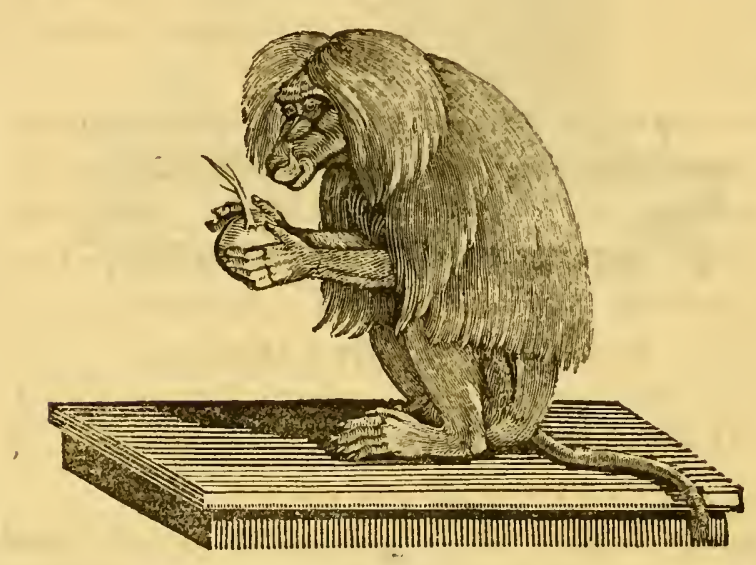

\section{THE DOG-FACED BABOON,}

(Simia Hamadryas, Lin.)

Is difinguifhed by a longer tail than the reft of its kind : In this refpect, it feems to bear fome affinity to the Monkey, and has been mentioned under that denomination by feveral naturalifts.

We may obferve here, that, in tracing the progrefs of animated Nature, we are led, by the moft imperceptible gradations, from one kind to another: The line of feparation feems fo faintly drawn, that we are frequently at a lors how to fix the boundaries of one clafs, without encroaching upon thofe of another; and, notwithftanding 
the regularity and order which every where prevail among the numerous families that inhabit the earth, the beft and molt approved fyftems of arrangement fall infinitely thort of precifion: They ferve, indeed, to direct us to the general characters which form the diftinguifhing features of each genus, but are very inadequate to difcriminate the intermingled fhades and nice touches by which all are diverfified.

The drawing of this animal was taken from one fhewn in London under the name of the Persian Savage.Its head was large; muzzle long and thick; eyes fmall; face naked, and of an olive colour; the hair on its forehead feparated in the middle, and hung down on each fide of the face, from thence down its back as far as its waif ; it was long and haggy, of a blueilh-gray colour, freckled with dark fpots; the hair on the lower part of the body fhort; its buttocks bare and red.

That defcribed by Mr Pennant, which feems to agree with this, is repreferted as very fierce and untractable.!

It inhabits the hottert parts of Africa and Afia, lives in troops, and commits great depredations in gardens and cultivated grounds; is above five feet high, exceedingly ftrong, vicious, and impudent.

\section{THE URSINE BABOON,}

Is not unlike the laft, but rather lefs. Its nofe is long; head large; ears thort; forehead high and prominent, terminating in a ridge; the body thick and ftrong, covered with long dufky hair, which gives it the appearance of a young Bear; its tail is half the length of the body; buttocks red. 
This animal is very numerous about the Cape of Good Hope.-Troops of them affemble together, and make expeditions for the fake of plunder, in which they obferve the utmoft precaution. To prevent furprife, they place a centinel, which, upon fight of a man, gives a loud yell; when the whole troop retreats with the greateft precipitation. It is highly entertaining to fee the females carrying off their young ones clinging to their backs; whilft their pouches are crammed fo full of fruit, that they feem ready to burft. They fometimes form a line, and throw the fruit from one to another, in order to carry it off the more expeditioufly.

\section{THE WANDEROU,}

Is a native of Ceylon and the Eaft-Indies.-Its head is thick and long, and furrounded with a large quantity of white hair, which falls down below the chin, forming a rough, fhaggy beard; the reft of the body is covered with a dark-brown coat, almoft black.-Like all animals of this kind, it is wild and vicious; but, when taken young, may eafily be tamed; and appears to be more fufceptible of education than other Baboons.

There are feveral varieties of this fpecies. - The bodies of fome are black, with white beards; in others, the body is whitifh, and the beard black: Some are found entirely white; but this fpecies is extremely rare, and is faid to be ftronger and more mifchievous than the others.

Thefe bearded Baboons are much efteemed for the gravity of their appearance; and are ufed by the Indians in their ceremonies and fhows, in which they are faid to acquit themfelves to the admiration of the fpectators. 
HISTORY OF QUADRUPEDS.

\section{THE HARE-LIPPED MONKEY.}

(Simia Cynomolgus, Lin.-Le Macaque, Buff.)

WE have placed this animal next to the Baboons, becaufe it makes the neareft approach to them in the form of its body, which is thort and thick: Its head and muzzle are large; its vifage ugly, naked, and wrinkled; and its noftrils divided, like thofe of a Hare : Its tail, however, is long, like that of a Monkey: The colour of the hair on the upper part of the body is a greenifh-afh, lighter on the breaft and belly.

There are feveral varieties, which differ both in fize and colour.

This animal is found in Guiana, Congo, and fome of the fouthern parts of Africa.-They go in troops, and do infinite mifchief to plantations of millet, which they carry off under their arms and in their mouths. They are extremely nice and delicate in their choice; and, by pulling up what does not pleafe them, do more damage than by what they really eat.

\section{THE PATAS, OR RED MONKEY,}

Is nearly of the fame fize with the laft, and inhabits the fame country; its body is, however, rather longer, its face lefs hideous, and its hair more beautiful. It is remarkable for the brilliancy of its coat, which is of fo bright a red, as to have the appearance of being painted.

There are two varieties of this kind: The one is diftinguifhed by a black line above the eyes, extending from 


\section{HISTORY OF QUADRUPEDS.}

- ear to ear; in the other, the line is white. Both have long hair under the chin, and round the cheeks; which in the firft is yellow, and in the fecond white: The nofe is black; the under part of the body of an afh colour, tinged with yellow.

Thefe Monkies are very numerous on the banks of the river Senegal. They are fo curious, as fometimes to defcend from the tops of trees to the extremities of the branches, while boats are paffing, and feem to obferve them with great attention. If not difturbed, their familiarity becomes troublefome: They break off branches, throw them at the paffengers, and frequently with fo fure an aim, as to annoy them not a little; but, upon being Thot at, they fet up moft hideous cries, endeavour to revenge themfelves by collecting more offenfive materials, fuch as ftones, dirt, \&c. which they throw at the enemy, and foon retire.

Travellers relate that, in Guinea, Monkies are frequently feen together in troops of forty or fifty, plundering gardens and fields of corn with great boldnefs. One of them ftands on a tree, liftens, and looks about on all fides, while the reft are bufy. Upon the leaft appearance of interruption, he fets up a loud cry to alarm the party; when they immediately fly off with the booty they have collected, leaping from tree to tree with prodigious agility.

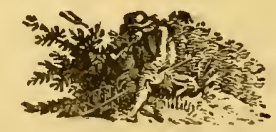




\section{HISTORY OF QÜADRUPEDS.}

465

\section{THE CHINESE BONNET MONKEY,}

Appears to be only a variety of the Malbrouck: The principal difference confifts in its having the hair on its head difpofed in the form of a flat bonnet, from which its name has been derived. It inhabits the fame country, and lives in the fame manner.

When fruits and fucculent plants fail, thefe animals are faid to eat infects, and fometimes watch by the fea-fide for crabs and other fhell-firh, which they are very dexterous in catching.

They are never thoroughly tamed, and cannot be trufted without a chain.-They do not breed when in a ftate of confinement, even in their own country; but require to be at perfect freedom in their native woods.

\section{THE MANGABEY,}

(Simia REthiops, Lin.)

Is diftinguifhed from all other Monkies by a very remarkable character. Its eye-lids are naked, of a pure white colour; and round each eye there is a prominent ring: The hair on the head and body is of a yellowifh-brown colour; that on the belly white. Some of them have a broad collar of white hair furrounding their neck and face.

$$
\operatorname{cin}
$$




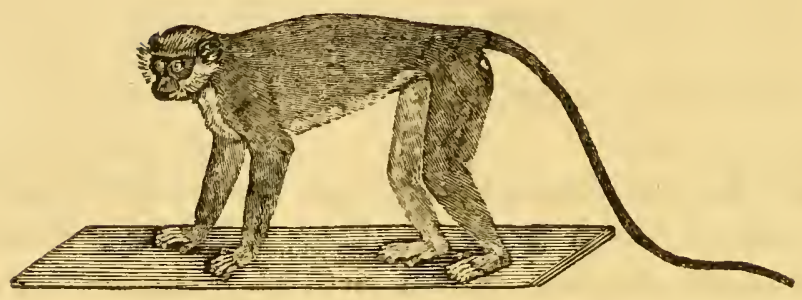

THE GREEN MONKEY,

(Simia Sabra, Lin._Le Callitriche, Buff.)

So called from its beautiful hair, which, on the upper part of the body and tail, is of a fine green colour; the throat, belly, and under fide of the limbs are of a filvery whitenefs: The tail is eighteen inches long, length of the body thirteen, height eight and a half.

It is common in the Cape de Verd illands and the Eaft-Indies, and is alfo found in Mauritania, and in the territories of ancient Carthage. Hence it is probable, fays M. Buffon, that it was known to the Greeks and Romans, and that it was one of thofe long-tailed Monkies to which they gave the general name of Callitrix.

It feems to be the fame kind as that mentioned by Adanfon; who relates, that the woods of Podor, along the river Niger, are full of Green Apes, which, from their colour, are fcarcely difcernible among the branches of the trees where they live.

The animal from which the above was taken was a female, in the poffeflion of William Hargrave, Efq. of Shawdon. 


\section{THE MUSTACHE,}

(Simia Cepbus, Lin._Le Mouftac, Buff.)

Is a beautiful little animal, having a tuft of yellow hair on each cheek, and another on the top of the head, which is long and upright: Its face is of a bluifh colour, body of a greenifh afh, breaft and belly lighter. Its length is only one foot; that of the tail eighteen inches. -It is a native of Guinea.

\section{THE TALAPOIN,}

Is a native of the Eaft-Indies, where it is fuffered to multiply without moleftation, owing to the religious fupertition of the Bramins, which forbids them to take the life of any kind of animal whatever. They are fo tame and familiar, that numbers of them frequently come into their towns, enter the houfes, and, if not prevented, help themfelves to whatever they meet with that is agreeable to them; fuch as fruits, fweetmeats, \&c.

The Talapoin is about twelve inches long: Its head is round; ears black, and thaped like the human; eyes of a bright hazel colour, with black pupils; the hair on the back, upper part of the body, and limbs, of a dufky yellow, tinged with green; the belly lighter; its tail very long, flender, and of an olive coleur. 


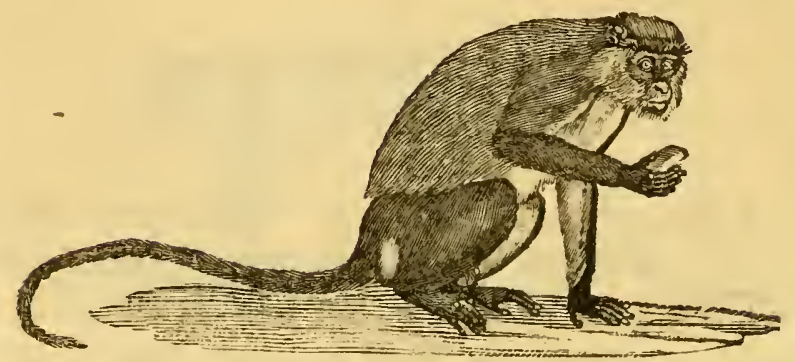

THE VARIED MONKEY, OR MONA,

\section{(La Mone, Buff.)}

Is beft known of all the Monkey tribe, being more frequently brought into Europe than any other._- It is a native of Barbary and other northern parts of Africa, Arabia, and Perfia; where it is called the Mona, from which our general term is derived.

Its nofe is thort and thick; its face of a dark lead colour; the beard on each fide long, and of a greenith-yellow; the top of the head is bright yellow, freckled with black; back and fides deep brown, with black freckles; legs, feet, and tail, black; infide of the thighs of a pale blue colour, thinly covered with whitin hairs; and on each fide of the rump, clofe by the tail, is a large white fpot.

The drawing and defcription were taken from the living animal, in the poffeflion of Robert Hedley, Efq. of Newcafte. It was remarkably gentle, tame, and familiar; and feened to have fome attachment to thofe with whom it was acquainted. Its length was eighteen inches; tail about two feet. It was fed with bread, roafted meat, and fruit of all kinds, of which it was particularly fond. 
All the Baboons and Monkies we have yet defcribed, are furnifhed with cheek-pouches, capable of containing food fufficient to fupply them for a day or two: They alfo ferve as receptacles for whatever they obtain more than fupplies their prefent wants. But we have thought it unneceffary to repeat this circumftance in the account of every animal of thofe kinds.

\section{THE DOUC,}

Differs from other Monkies, in having no callofities on its buttocks, which are entirely covered with hair; it is alfo much larger, being nearly four feet high when erect. Its face is thort and rather flat, furnifhed on each fide with long hairs of a pale yellow colour; its body is beautifully variegated with differently coloured hair; round the neck there is a collar of a bluifh-purple colour; the top of the head and body are gray; breaft and belly yellow; arms white below, and black above; tail . white; feet black; face and ears red; lips black; and round each eye there is a black ring.-It is found in Cochin-China, and in the ifland of Madagafcar; where it is called the Sirac.

M. Buffon places the Douc in the laft clafs of thofe animals of the Monkey kind that belong to the old continent, and defcribes it as, forming a fhade between them and the Monkies of America, which he diftinguifhes by the generic names of SAPajous and SaGorns.-They both of them differ from Monkies, in having neither cheek-pouches nor callofities on their buttocks; and they are diftinguifhed from each other by characters peculiag

$$
\text { Gg } 3
$$


to each. The Sapajou is furnifhed with a prehenfile tail, the under part of which is generally covered with a fmooth naked fkin: The animal can coil it up or extend it at pleafure, fufpend itfelf by its extremity on the branches of trees; or ufe it as a hand to lay hold of any thing it wants. The tails of all the Sagoins, on the contrary, are longer than thofe of the Sapajous, ftraight, flaccid, and entirely covered with hair.-This difference alone is fufficient to diftinguifh a Sapajou from a Sagoin.

We now proceed to the hiftory and defcription of the molt remarkable of this numerous race.

\section{THE PREACHER,}

(Simia Beelzebub, Lin.-L'Ouarine, Buff.)

Is the largeft of all the American Monkies, being about the fize of a large Fox. Its body is covered with long fmooth hair, of a fhining black colour, forming a kind of ruff round the animal's neck: Its tail is long, and always twifted at the end.

Great numbers of thefe Monkies inhabit the woods of Brazil and Guiana; and, from the noife they make, are called Howling Monkies. Several of them affemble together; and, placing themfelves in a kind of regular order, one of them begins firft with a loud tone, which may be heard to a great diftance; the reft foon join in a general chorus, the moft diffonant and tremendous that can be conceived: On a fudden they all ftop, except the firf, who finithes fingly; and the affembly breaks up.

Thefe Monkies are faid to be very fierce, and fo wild and mifchievous, that they can neither be conquered nor 
famed.-They feed on fruits, grain, herbs, and fometimes infects; live in trees, and leap from bough to bough with wonderful agility, catching hold with their hands and tails as they throw themfelves from one branch to another, and maintain themfelves fo firmly, that, even when thot, they remain fixed to the trees where they die.

The flefh of the Preacher is good; and is not only eaten by the natives, but alfo by Europeans who frequent thofe parts.

\section{THE COAITA,}

Is fomewhat lefs than the Preacher. Its face is naked and red; ears fhort; its body and limbs are long and flender; hair black and rough; tail long, and naked on the under fide.

This animal is found in the neighbourhood of Carthagena, in Guiana, Brazil, and Peru.-Great numbers affociate together. They feldom appear on the ground, but live moftly in trees, and feed on fruits: When thefe are not to be had, they are faid to eat fifhes, worms, and infects; are extremely dexterous in catching their prey, and make great ufe of their tails in feizing it.

The Coaitas are very lively and active.-In pafling from one tree to another, they fometimes form a chain, linked to each other by their tails; and fwing in that manner till the loweft catches hold of a branch, and draws up the reft.-When fruits are ripe, they are generally fat; and their flefh is then faid to be excellent.

There are many varieties of the Coaita, which differ Gg 4 
chiefly in colour. Some are totally black, others brown, and fome have white hair on the under parts of the body. -They are called Spider Monkies by 1 dwards, on account of the length and flendernefs of their legs and tails

M. Buffon fuppofes the Exeuria to be another variety of this fpecies. It is nearly of the fame fize; but its colour is variegated. The hair on its back is black and yellow; its throat and belly white.-Its manner of living is the fame with that of the Coaita; and it inhabits the fame countries. - Both kinds are remarkable in having only four fingers on each hand, being quite deftitute of the thumb.

\section{THE SAJOU, OR CAPUCIN, (Simia Capucina, Lin.-Le Sai, Buff.)}

There are two varieties of this fpecies, - the Brown and the Gray; which, in other refpects, are perfectly fimilar. Their faces are of a flefh colour, thinly covered with down; tails long, full of hair on the upper fide, naked below, and prehenfile; hands black and naked; length of the body about twelve inches.

Thefe animals inhabit Guiana, are extremely lively and agile, and their conftitution feems better adapted to the temperate climates of Europe than moft of the Sapajou kind. M. Buffon mentions a few inftances of their having produced in France.

The Sajous are very capricious in their attachments, being fond of particular perfons, and difcovering the greateft averfion to others. 


\section{HISTORY OF QUADRUPEDS.}

\section{THE WEEPER,}

(Simia Apella, Lin.)

INHABITS Brazil ; is very mild, docile, and timid; of a grave and ferious afpect; has an appearance of weeping; and, when irritated, makes a plaintive noife.-It is about fourteen inches long; the tail longer than the body; hair on the back and fides of a deep brown colour, mixed with red on the lower parts.-There is a variety with white hair on the throat and breaft.

Great numbers of thefe creatures affemble together, particularly in ftormy weather; and make a great chattering.-They live much in trees, which bear a podded fruit as large as beans, on which they principally feed.

\section{THE ORANGE MONKEY,}

(Simia Sciurea, Lin.-Le Saimiri, Buff.)

Is a moft beautiful animal; but fo extremely delicate, that it cannot well bear to be brought from its own climate to one lefs warm and temperate.

It is about the fize of a Squirrel: Its head is round; eyes remarkably lively and brilliant; ears large; hair on the body fhort and fine, of a fhining gold colour; feet orange; its tail is very long: Its prehenfile faculty is much weaker than the reft of the Sapajous; and, on that account, it may be faid to form a fhade between them and the Sagoins, which have long tails, entirely covered with hair, but of no ufe in fufpending their bodies from the branches of trees. 


\section{THE FOX-TAILED MONKEY.}

(Simia Pithecia, Lin.-Le Saki, Buff.)

THE tail of this animal, like that of the Fox, is covered with long bufhy hair. Its body is about feventeen inches in length; hair long, of a dark-brown colour on the back, lighter on the under fide; its face is tawny, and covered with a fine fhort whitifh down; the forehead and fides of the face are white; its hands and feet are black, with claws inftead of nails.

The Saki is a native of Guiana, where it is called the Saccarvinkee.

\section{THE GREAT-EARED MONKEY,}

(Simia Midas, Lin.-Le Tamarin, Buff.)

Is about the fize of a Squirrel: Its face is naked, of a fwarthy flefh colour; its upper lip fomewhat divided; its ears are very large and erect; its hair is foft, fhaggy, and of a black colour; hands and feet covered with orange-coloured hair, very fine and fmooth; its nails long and crooked; tail black, and twice the length of its body.

It inhabits the hotter parts of South-America; is a lively, pleafant animal; eafily tamed; but fo delicate, that it cannot bear a removal to a lefs temperate climate. 


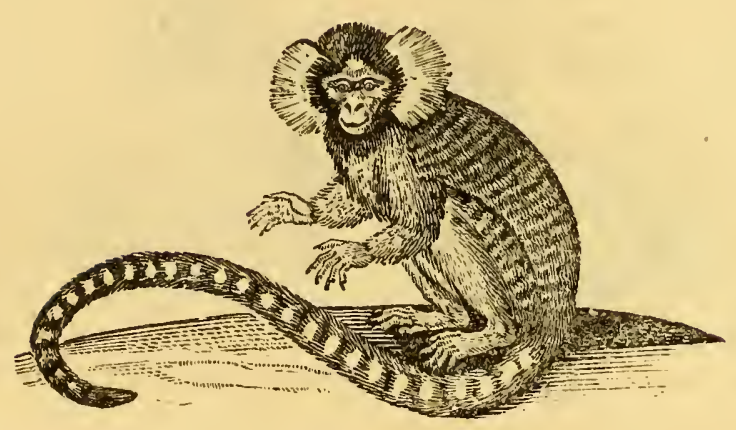

THE STRIATED MONKEY,

(Simia Iaccbus, Lin._L'Onifiti, Buff.)

Is ftill fmaller than the Great-eared Monkey, its head and body not exceeding twelve inches in length : Its tail is long, bufhy, and, like that of the Macauco, marked with alternate rings of black and an colour; its face is naked, of a fwarthy flefh colour; ears large, and like the human; body beautifully marked with dufky, afh-coloured, and reddifh bars; its nails are tharp; and its fingers like thofe of a Squirrel.

It inhabits Brazil; feeds on fruits, vegetables, infects, and fnails, and is fond of fifh.

$\mathrm{Mr}$ Edwards gives a defcription of one of thefe animals, accompanied with an excellent figure.-He fays, that, one day being at liberty, it darted upon a fmall gold-fifh that was in a bafon, which it killed and devoured with avidity; and that afterwards fmall eels were given to it, of which it feemed at firft afraid, from their 
twifting themfelves round its neck; hut that it foon overcame and eat them.-He likewife fays that it produced young ones in Portugal, which at firft were extremely ugly, having hardly any hair on their bodies. They adhered clofely to the teats of the mother; and, when grown a little larger, fixed themfelves upon her back, from whence the could not eafily difengage them, without rubbing them off againft a wall: Upon there occafions, the male always allowed them to mount upon his back to relieve the female.

\section{THE SILKY MONKEY,}

(Simia Rofalia, Lin.-Le Marikina, Buff.)

Is by fome called the LION-APE, from the quantity of hair which furrounds its face, falling backwards like a mane; its tail is alfo fomewhat bufhy at the end: Its face is flat, and of a dull purple colour; its hair long, bright, and filky; it is of a pale yellow colour on the body; the hair round the face of a bright bay, inclining to red; its hands and feet are without hair, and of the fame colour as the face; its body is ten inches. long, tail thirteen.

This creature is a native of Guiana, is very gentle and lively, and feems to be more hardy than the other $\mathrm{Sa}$ goins.-Buffon fays, that one of them lived at Paris feveral years, with no other precaution than keeping it in a warm room during winter. 


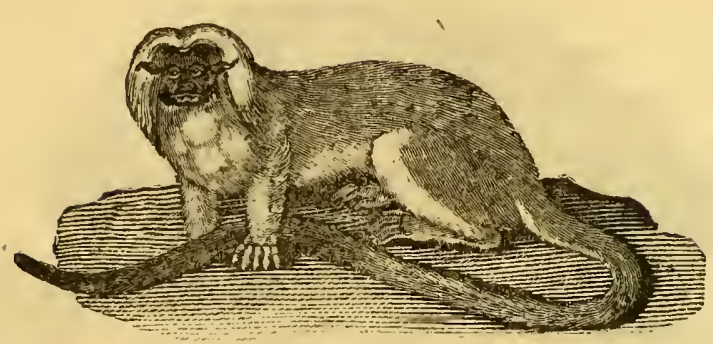

THE RED-TAILED MONKEY,

(Simia Oedipus, Lin:-Le Pinche, Buff.)

Is fomewhat larger than the Striated Monkey.-It is remarkable in having a great quantity of fmooth white hair, which falls down from the top of the head on each fide, forming a curious contraft with its face, which is black, thinly covered with a fine gray down: Its eyes are black and lively; throat black; hair on the back and fhoulders of a light reddifh-brown colour; breaft, belly, and legs, white; the tail is long, of a red colour from the rump to the middle; from thence to the end it is black.

It inhabits the woods on the banks of the river $A$ mazon; is a lively, beautiful little animal; has a foft whiftling voice, refembling more the chirping of a bird than the cry of a quadruped.-It frequently walks with its long tail over its back. 


\section{HISTORY OF QUADRUPEDS.}

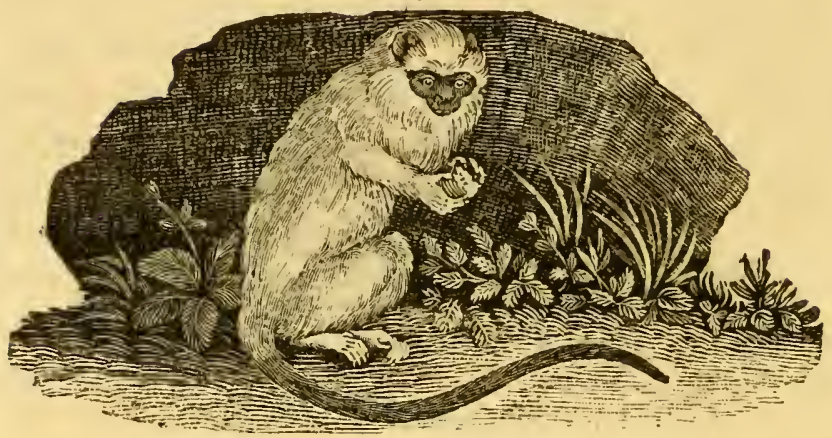

THE MICO, OR FAIR MONKEY,

Is the laft that we thall defcribe of this numerous race, and is the molt beautiful of them all.-Its head is fmall and round ; face and ears of fo lively a vermilion colour, as to appear the effect of art; its body is covered with long hair, of a bright filvery whitenefs, and uncommon elegance; tail long, end of a thining dark cheftnut colour.

It frequents the banks of the river Amazon, where it was difcovered by $M$. Condamine, who preferved one alive till almoft within fight of the French coaft ; but it died before his arrival.

We have now laid before our readers a few of the moft noted varieties of this numerous race: Many others might likewife be added to fwell the account; but of thefe, little more is known than their names and places of habitation. There are, probably, ftill more, which neither the affiduity of the naturalift, nor the curiofity of the traveller, have been able to draw from their native woods. Indeed, there is great room to conjecture, that he variations of the Monkey kind are fomewhat like 
thofe of the Dog, continually encreafing; for it is very obvious, that, among the fmaller kinds of Monkies, the characteriftic differences do not appear to be great, however they may vary in fize or in colour; and it is certain, that the modes of living, faculties, and propenfities of thefe animals, are ftrikingly fimilar: So that, if we reafon from analogy on that fubject, we may fairly conclude, that different kinds of Monkies may unite and propagate with the fame facility as the Goat and the Sheep, or the almoft innumerable kinds of Dogs.

The greater part of the cuts we have given of the $\mathrm{Ba}$ boons, Apes, and Monkies, we were fortunate in procuring from living objects, or drawings which might be depended on: And it is to be lamented, that, amongft the numbers that have been publined, fo few fhould poffefs that peculiar character fo obfervable in the various members of this imitative tribe, which it is wholly impoffible to trace from a ftuffed Ikin, void of every kind of expreffion; the mufcular parts, which fhould convey the idea of action, being generally ill fupplied, or entirely wanting.

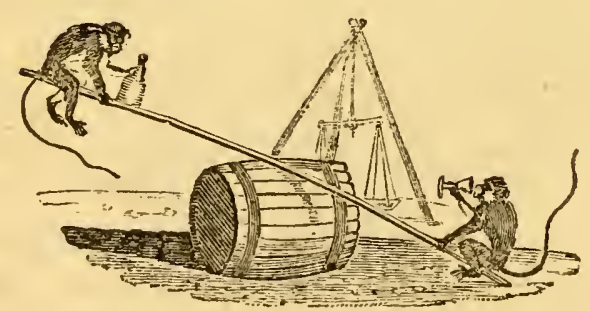




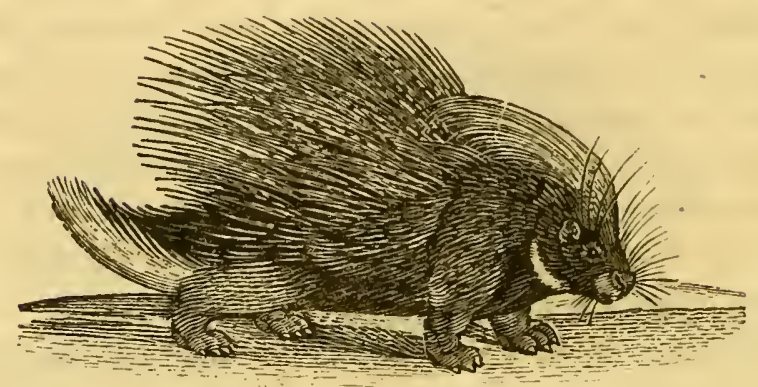

THE PORCUPINE.

\section{(Hiftrix Criftata, Lin.-Le Porc-epic, Buff.)}

THIs animal, fo formidable in its appearance, would be much more truly fo, if it poffeffed the power, erroneoufly afcribed to it, of darting its quills at its enemies, and wounding them at a diftance.

Though denied the privilege of making offenfive war, it is fufficiently armed to refift the attacks of animals much more powerful than itfelf.-Upon the fmalleft irritation, it raifes its quills, and thakes them with great violence, directing them to that quarter from whence it is in danger of being attacked, and ftriking at the object of its refentment with its quills at the fame time. We have obferved, on an occafion of this fort, at a time when the animal was moulting or cafting its quills, that they would fly out, to the diftance of a few yards, with fuch force, as to bend the points of them againft the board where they ftruck : and is is not improbable, that a circumftance of this kind may have given rife to an opinion of its power to ufe them in a more effectual manner. 
The largeft of the quills are from ten to fifteen inches in length, thick in the middle, and extremely fharp at the end : Between the quills, the hair is thin, black, and brifty: The tail is covered with white quills, which are nlort and tranfparent: Its legs are fhort; it has four toes before, and five behind.

The Porcupine is found in India, Perfia, and Paleftine: It is likewife common in all parts of Africa.-The Indians hunt it for its quills, of which they make a kind of embroidery: They alfo eat its flefh.

There are Porcupines in a wild ftate in Spain and Italy, though they are not originally natives of any part of Europe. Their flefh is fometimes expofed in the markets at Rome, where it is eaten.

The Italian Porcupines have fhorter quills and a fhorter creft than thofe of Afia or Africa.

The Porcupine is an inoffenfive animal; lives on fruits, roots, and vegetables; fleeps during the day, and feeds by night.

The female gocs with young feven months, and brings forth one at a time.-The drawing of this animal was made from the life.

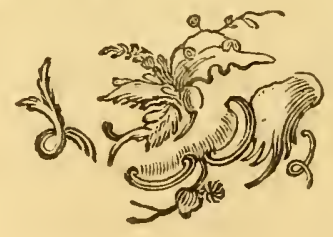

$\mathrm{Hh}$ 


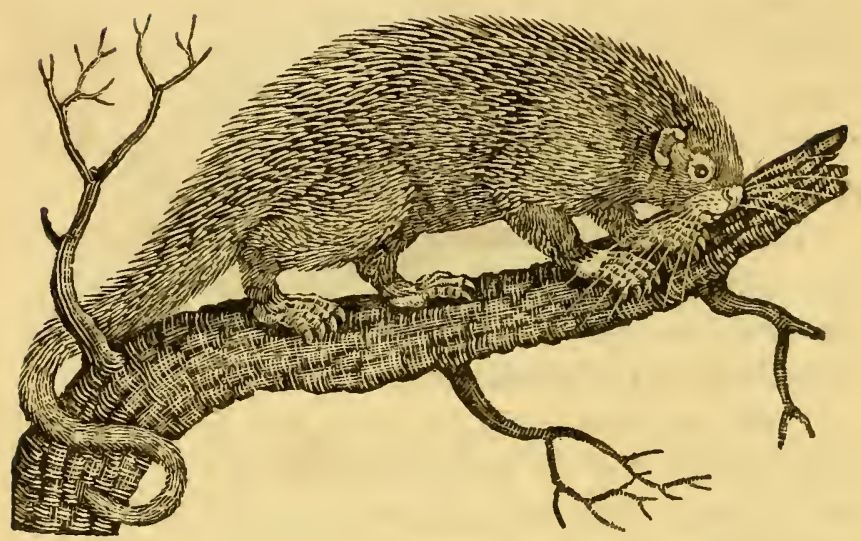

THE BRAZILIAN PORCUPINE,

(Hiftrix Prebenfilis, Lin.)

DIFFERs fo greatly from the laft, that it can fcarcely be faid to bear any relation to it, except in its being covered with fpines about three inches in length: They are white, very tharp, and have a bar of black near the points. The breaft, belly, and lower part of the legs, are covered with ftrong briftly hairs of a brown colour. Its tail is long and flender, and almoft naked at the end: The animal ufes it in defcending trees, by twifting it round the branches.

It inhabits Mexico and Brazil, lives in woods, and feeds on fruits and fmall birds. It preys by night, and neeps in the day. It makes a noife like the grunting of a Swine, and grows very fat.-Its fleth is white, and efteemed good to eat. 


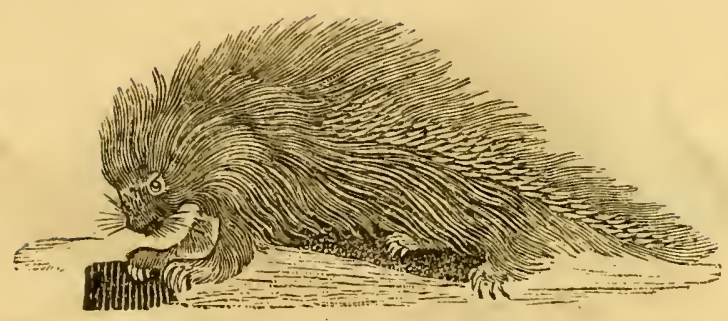

THE CANADA PORCUPINE.

(Hiftrix Dorfata, Lin.-L'Urfon, Buff.)

$I_{T}$ is found in Canada, and various parts of NorthAmerica, as high as Hudfon's Bay.

Its ears are fhort, and hid in the hair; its head, body, and upper part of its tail, are covered with long foft hair, in which are interfperfed a number of ftrong tharp fpines; its tail is thorter than that of the preceding fpecies, and it ufes it in the fame manner in defcending trees, frequently fufpending itfelf from the branches.

Many of the trading Indians, during their long excurfions, depend on this creature for a fupply of food, and efteem it both wholefome and pleafant: They alfo make ufe of the quills to trim the edges of their deer-Ikin habits, fo as to look like fringe; and ftick them in their nofes and ears to make holes for their rings. 


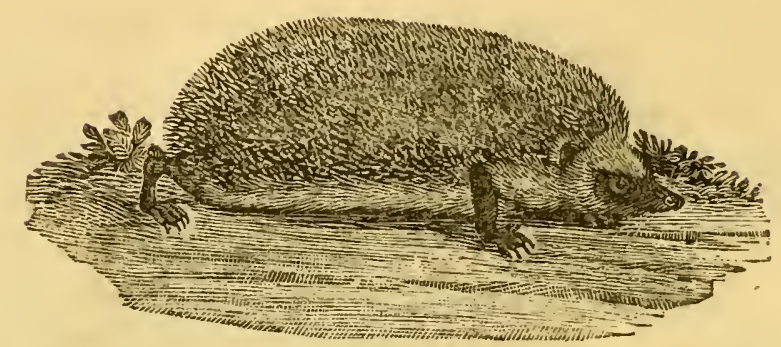

THE HEDGE-HOG, OR URCHIN.

(Erinaceus Europeus, Lin.-Le Heriffon, Buff.)

THrs animal, deftitute of every other means of defence, 1s provided by Nature with a fpinous armour, which fecures it from the attacks of all the fmaller beafts of prey; fuch as Weafels, Martins, Polecats, \&c.-When alarmed, it immediately collects itfelf into the form of a ball, and prefents on all fides a furface covered with fharp points, which few animals are hardy enough to engage. The more it is haraffed, the clofer it rolls itfelf; till its fears become an additional means of fafety, by caufing it to void its urine, which, running over its whole body, frequently obliges its enemy to defift, difgufted by the fmell.

There are few Dogs that will venture to attack the Hedge-hog, except fuch as are trained to the fport, merely to gratify the cruel pleafure of feeing a harmlefs animal endure, with aftonifhing patience, the moft wanton outrages; whilft the Dogs, becoming more enraged at the wounds they receive from its prickles, at laft oblige it to unfold itfelf, and it then foon falls a victim to their fury. This little animal has been fo far do- 
mefticated, as to learn to turn a fpit by means of a fmall wheel in which it was placed; it likewife anfwered to its name.

The Hedge-hog generally refides in fmall thickets and hedges; lives on fruits, worms, beetles, and all kinds of infects; conceals itfelf in the day, and feeds during the night.-It is eafily taken, for it neither flies nor attempts to defend itfelf; but, when touched, fhrinks into its circular form, which it will not eafily quit, unlefs thrown into water.

The Hedge-hog, in the winter, wraps itfelf up in a warm neft, made of mors, dried grafs, and leaves; and fleeps out the rigours of that feafon. It is frequently found fo completely enriched with herbage on all fides, that it refembles a ball of dried leaves. When taken out and placed before a fire, it foon recovers from its torpid ftate.

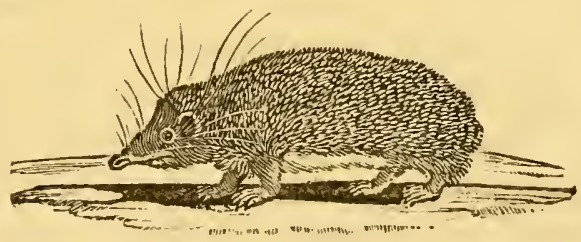

THE TENDRAC,

Is about the fize of a Rat. The upper part of its body is covered with fpines, thorter and fmaller than thofe of the Hedge-hog, which it fomewhat refembles, but does not roll itfelf up like that animal; the reft of the body is covered with a kind of fine hard hair, of a whitifh cop 
lour; about the head and nofe it has feveral long hairs, like whifkers.

An animal fimilar to this is mentioned by M. Buffon, under the name of the Tanrec.

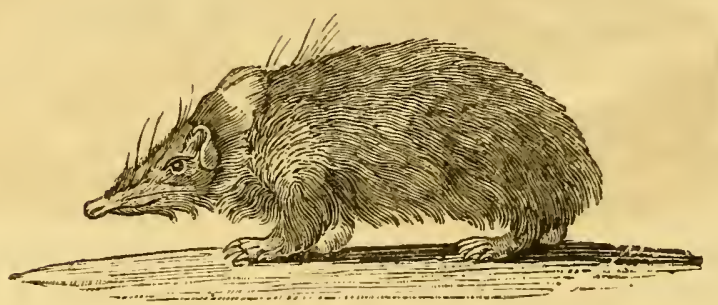

THE TANREC.

THrs animal is larger than the laft, and has fewer briftles: They only occupy the top of the head, and along the back, as far as the houlders: The reft of the body is covered with a brifty kind of hair, of a yellowifh colour, among which are intermixed fome black hairs, much longer than the other. Its nofe is long, and its ears more apparent than thofe of the Tendrac.

Both of them are natives of India._-Thefe make a grunting noife, and are fond of wallowing in mud, like Hogs: They frequent the banks of rivers, can live a long time in the water, and are frequently caught in fmall inlets of the fea: They dig holes in the ground, where they continue in a kind of torpid ftate for feveral months. - They are generally very fat; and the Indians eat their fiefh, though it is reckoned infipid and ftringy. 


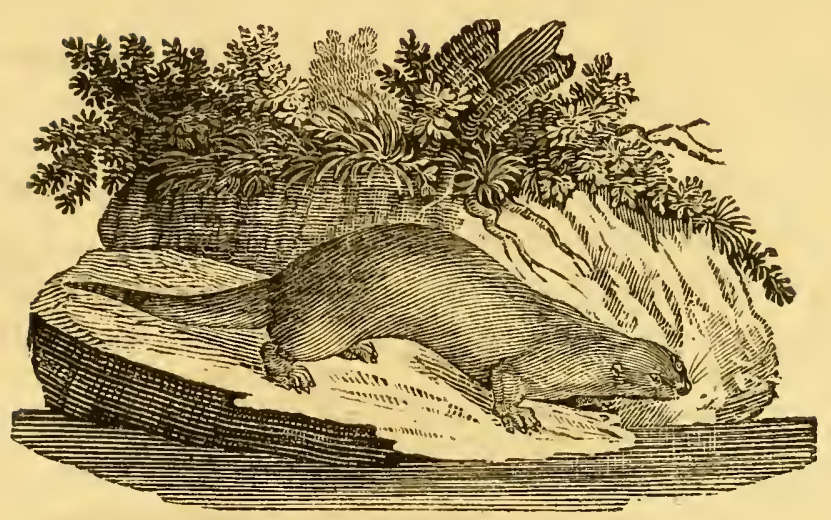

THE OTTER.

(Muftela Lutra, Lin.-Le Loutre, Buff.)

Although the Otter is not confidered by naturalifts as wholly amphibious, it is neverthelefs capable of remaining a confiderable time under water, and can purfue and take its prey in that element with great facility.

Its legs are very thort, but remarkably ftrong, broad, and mufcular; on each foot are five toes, connected by ftrong membranes, like thofe of water fowl; its head is broad, of an oval form, and flat on the upper part; the body is long and round, and the tail tapers to a point; the eyes are brilliant, and placed in fuch a manner, that the animal can fee every object that is above it, which gives it a fingular afpect, very much refembling an eel or an afp; the ears are fhort, and their orifice narrow.

The fur of the Otter is of a deep-brown colour, with 
two fmall light fpots on each fide of the nofe, and another under the chin.

This animal ,makes its neft in fome retired fpot by the fide of a lake or river, under a bank, where, it has an eafy and fecure accefs to the water, to which it immediately flies upon the leaft alarm; and, as it fwims with great rapidity, frequently efcapes from its purfuers.

It deftroys great quantities of fifl, and, in purfuit of its prey, has been obferved commonly to fwim againft the ftream.

- As foon as the Otter has caught a fifh, it immediately drags it to the fhore; devours a part, as far as the vent; and, unlefs preffed by extreme hunger, always leaves the remainder, and takes to the water in queft of more.

Otters are fometimes taken in traps placed near their landing places, where they are carefully concealed in the fand.-When hunted with Dogs, the old ones defend themfelves with great obfinacy: 'They bite feverely, and do not readily quit their hold where they have once faftened. An old Otter will never give up while it has life; nor make the leant complaint, though wounded ever fo much by the Dogs, nor even when transfixed with a fpear.

There are many inftances of Otters being tamed; but in thofe which have come to our knowledge, they were taken when young; accuftomed by degrees to obedience and reftraint, they became fo far domefticated, as to follow their mafter, anfwer to a name, and employ their excellent talents at fifhing in his fervice.

Otiers, when taken young, may be eafly reared and made tame.-We have feen two young ones fucking a 


\section{HISTORY OF QUADRUPEDS.}

Bitch, and treated by her with as much tendernefs as her own offspring.

William Collins, of Kinmerfon, near Wooler, had a tame Otter, which followed him wherever he went. He frequently carried it to filh in the river; and when fatiated, it never failed returning to its mafter. One day, in the abfence of Collins, being taken out by his fon to fifh, inftead of returning as ufual, it refufed to come at the accuftomed call, and was loft. The father tried every means to recover it; and after feveral days fearch, being near the place where his fon had loft it, and calling it by its name, to his inexpreffible joy, it came creeping to his feet, and fhewed many genuine marks of affection and firm attachment.-Its food, exclufive of finh, confifted chiefly of milk and hafty-pudding.

Some years ago, James Campbell, near Invernefs, had a young Otter, which he brought up and tamed. It would follow him wherever he chofe; and, if called on by its name, would immediately obey. When apprehenfive of danger from Dogs, it fought the protection of its mafter, and would endeavour to fly into his arms for greater fecurity. - It was frequently employed in catching fillh, and would fometimes take eight or tên falmon in a day. If not prevented, it always nade an attempt to break the fifh behind the fin next the tail: As foon as one was taken away, it immediately dived in purfuit of more. When tired, it would refufe to fin any longer; and was then rewarded with as much fifh as it could devour. Being fatisfied with eating, it curled itfelf round, and fell afleep; in which ftate it was generally carried home. - The fame Otter fifhed as well in the fea as in a river, and took great numbers of codlings and 
other fifh.-Its food was generally frefh fifh, and fometimes milk.

Another perfon, who kept a tame Otter, fuffered it to follow him with his Dogs. It was very ufeful to him in filhing, by going into the water, and driving trouts and other fin towards the net.-It was remarkable, that the Dogs, though accuftomed to the fport, were fo far from giving it the fmalleft moleftation, that they would not even hunt an Otter whilf it remained with them; on which account the owner was under the neceffity of difpofing of it.

Notwithftanding the Otter's avidity for fifh, it will not eat it, unlefs it be perfectly frefh. When that cannot be procured, it is fed with milk, or pudding made of oatmeal, \&c.

Otters are found in moft parts of the world, with no great variation.- They are common in Guiana, and frequent the rivers and marhes of that country. They are fometimes feen in great numbers together; and are fo fierce, that it is dangerous to come near them. They live in holes, which they make in the banks of the rivers.

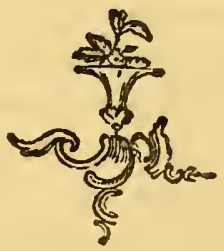




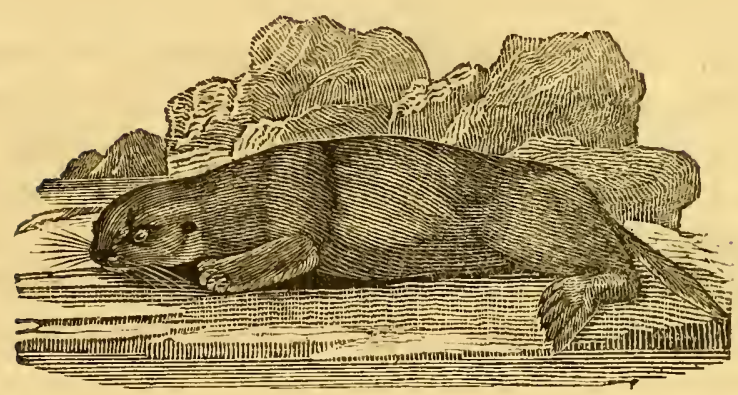

THE SEA-OTTER.

\section{(Muftela Lutris, Lin.)}

VAST numbers of thefe animals inhabit the coafts of Kamfchatka, and the numerous iflands contiguous to it; as well as the oppofite coafts of America: They are alfo found in fome of the larger rivers of South-America.

Their fkins are of great value, and have long formed a confiderable article of export from Ruflia. They difpofe of them to the Chinefe at the rate of feventy or a hundred rubles each, and receive in return fome of their moft valuable commodities.

The fur of the Sea-Otter is thick and long, of a beautiful fhining black colour, but fometimes of a filvery hue; the legs are thick and fhort; the toes joined by a

r web; the hind feet like thofe of a Seal; length, from nofe to tail, four feet two inches; tail thirteen, flat, and pointed at the end.- The largent of them weigh from feventy to eighty pounds.

The Sea-Otter is remarkably harmlefs, and moft affec- 


\section{HISTORY OF QUADRUPEDS.}

tionately fond of its young: It will pine to death for its lofs, and die on the very fpot where it has been taken away. Before its young can fwim, it will carry it in its paws, and fupport it in the water, lying upon its back. -It fwims in various pofitions, - on its back, fides, and even in a perpendicular pofture; and in the water is very fportive.-Two of them are fometimes feen embracing each other.-It frequents fhallow places, abounding with fea-weed; and feeds on lobfters, crabs, and other fhellfifh.

It breeds but once a year, and produces one young at a time, which it fuckles and carefully attends almoft a year.

The flen of a young Otter is reckoned delicate eating, and not eafily diftinguifhed from that of a lamb.

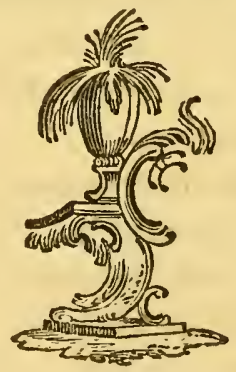




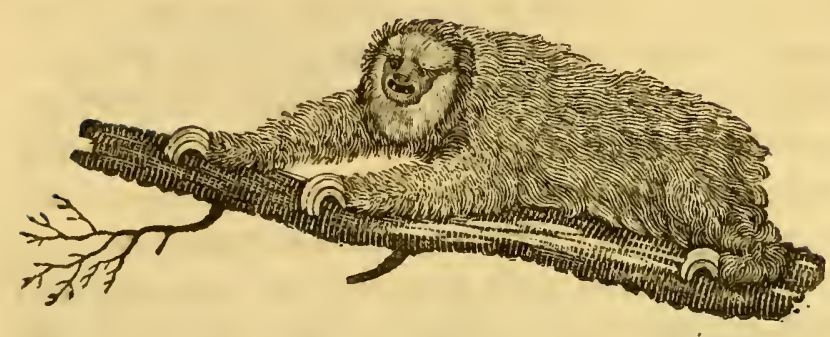

THE SLOTH,

(Bradypus Tridactylus, Lin.-L'Ai, Buff.)

Of all animals, is the moft fluggin and inactive; and, if we were to judge from outward appearance, would feem the moit helplefs and wretched. All its motions feem to be the effect of the moft painful exertion, which hunger alone is capable of exciting.

It lives chiefly in trees; and having afcended one with infinite labour and difficulty, it remains there till it has entirely ftripped it of all its verdure, fparing neither fruit, bloffom, nor leaf; after which it is faid to devour even the bark. Being unable to defcend, it throws itfelf on the ground, and continues at the bottom of the tree till hunger again compels it to renew its toils in fearch of fubfiftence.

Its motions are accompanied with a moft piteous and lamentable cry, which terrifies even beafts of prey, and proves its beft defence.

Though flow, aukward, and almoft incapable of motion, the Sloth is ftrong, remarkably tenacious of life, and capable of enduring a long abftinence from food. 
We are told of one that, having faftened itfelf by its feet to a pole, remained in that fituation forty days without the leaft fuftenance.-The ftrength of its legs and feet is fo great, that, having feized any thing, it is almoft impolfible to oblige it to quit its hold. The fame animal laid hold of a Dog that was let loofe upon it, and held him faft with its feet till he perifhed with hunger.

There are two kinds of Sloths, which are principally diftinguifhed by the number of their claws.-The one, called the Ar, is about the fize of a Fox, and has three long claws on each foot: Its legs are clumfy, and aukwardly placed; and the fore legs being longer than the hind, add greatly to the difficulty of its progreffive motion: Its whole body is covered with a rough coat of long hair, of a lightifh-brown colour, mixed with white, not unlike that of a Badger; and has a black line down the middle of the back: Its face is naked, and of a dirty white colour; tail thort; eyes fmall, black, and heavy. It is found only in South-America.

'The UNAU has only two claws on each foot: Its head is thort and round, fomewhat like that of a Monkey; its ears are fhort; and it has no tail. It is found in SouthAmerica, and alfo in the illand of Ceylon.

The flefh of both kinds is eaten.-They have feveral ftomachs, and are faid to belong to the tribe of ruminating animals.

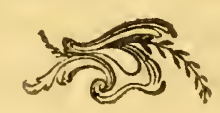




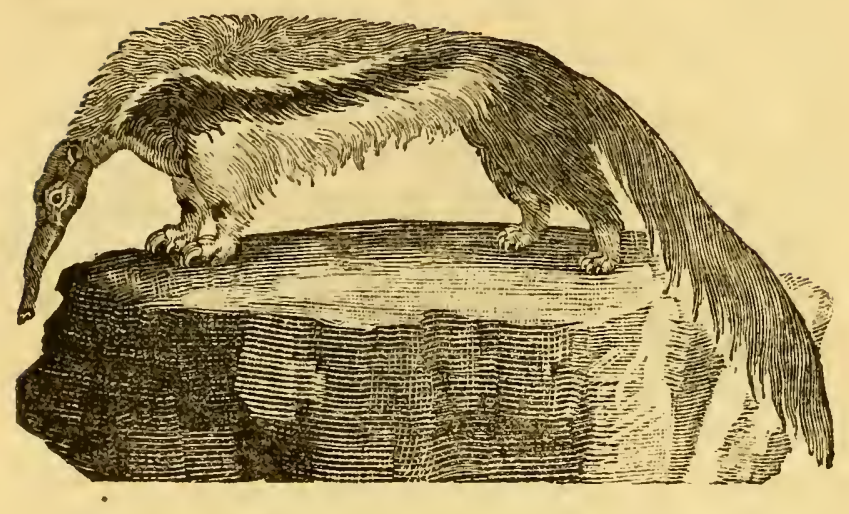

THE ANT-EATER.

(Myrmecopbaga Fubata, Lin.-La Tamanoir, Buff.)

There are feveral animals diftinguifhed by the common name of Ant-eaters, which differ greatly in form. - They are divided into three claffes; viz. the Great, the Middle, and the Leffer Ant-eater.

The Great ANT-Eater is nearly four feet in length, exclufive of its tail, which is two and a half. It is remarkable for the great length of its fnout, which is of a cylindrical form, and ferves as a theath to its long and flender tongue, which always lies folded double in its mouth, and is the chief inftrument by which it finds fubfiftence.

This creature is a native of Brazil and Guiana, runs flowly, frequently fwims over rivers, lives wholly on ants, which it collects by thrufting its tongue into their holes, and having penetrated every part of the neft, withdraws it into its mouth loaded with prey. 
Its legs are fo ftrong, that few animals can extricate themfelves from its gripe. It is faid to be formidable even to the Panthers of America; and fometimes fixes itfelf upon them in fuch a manner, that both of them fall and perifl together; for its obftinacy is fo great, that it will not extricate itfelf from its adverfary even after he is dead.

The flefh has a ftrong difagreeable tafte, but is eaten by the Indians.

The Midde Ant-Eater is one foot feven inches. from nofe to tail. It inhabits the fame countries, and procures its food in the fame manner, as the laft. Its tail is ten inches long, with which it fecures its hold in climbing trees by twifting it round the branches.

Both thefe animals have four ftrong claws on the fore feet, and five on the hind.

The Lesser ANT-eater has a fharp-pointed nofe, inclining a little downward: Its ears are fmall, and hid in the fur: It has two ftrong hooked claws on the fore feet, the outward one being much the largeft; and four on the hind feet: Its fur is long, foft, and filky, - of a yellowifh-brown colour: Its length, from nofe to tail, is feven inches and a half; tail above eight, thick at the bafe, and taper to the end.-It inhabits Guiana; climbs trees in queft of a fpecies of ants which build their nefts among the branches.

Animals of this kind are found in Ceylon and the Cape of Good Hope._Kolben defcribes the latter as having long heads and tongues; that they feed on ants; and are fo ftrong, that if they faften their claws in the ground, they cannot eafily be pulled away._- It is called in Ceylon the Ialgoi, or Ant-Bear. 


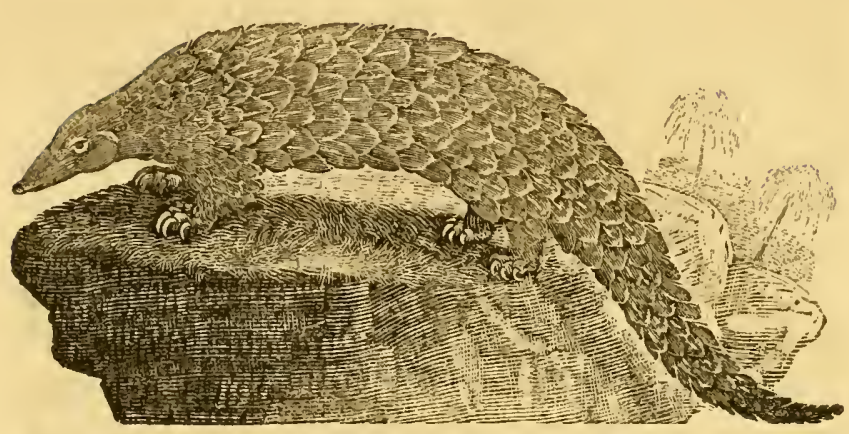

THE GREAT MANIS.

(Manis Pentadactyla, Lin.-Le Pangolin, Buff.)

THrs fingular animal is defended by a coat of mail, which protects it from the attacks of the moft powerful animals. All the upper parts of its body are clofely covered with fcales of different fizes, which it can exect at pleafure, oppofing to its adverfary a formidable row of offenfive weapons. The Tiger, the Panther, or the Leopard in vain attempt to force it. The moment it perceives the approach of an enemy, it rolls itfelf up like a Hedge-hog, and by that means fecures all the weaker parts of its body.

It is a native of the Indian ifles, and is likewife faid to be found in Guinea.

It is flow in its motions; grows to the length of eight feet, including its tail, which is four.

Its flefh is much efteemed.for its delicacy; but it is difficult to procure, as the animal avoids mankind, and lives in obfcure retreats, in woods, and marfly places. 


\section{THE LONG-TAILED MANIS, \\ (Manis Tetradacyla, Lin. - Le Phatagin, Buff.)}

Is lefs than the laft, being not more than a foot long from head to tail. Its body is covered with fharp-pointed fcales; its throat and belly with hair: Its legs are fhort; and each foot has four claws. It is remarkable. for the great length of its tail, which in fome is above a yard long.

It is a native of Guinea, has been fometimes called the SCAly Lizard, and may be faid to be the connecting link in the chain of being between quadrupeds and reptiles.

\section{THE ARMADILLO,}

Is found only in South-America, where there are feveral varieties of them.-They are all covered with a ftrong cruft or thell, and are diftinguifhed from each other by the number of the flexible bands of which it is compofed.

It is a harmlefs, inoffenfive animal; feeds on roots, fruits, and other vegetables; grows very.fat; and is greatly efteemed for the delicacy of its flefh.

The Indians hunt it with fmall Dogs, trained for that purpofe.-When furprifed, it runs to its hole, or attempts to make a new one, which it does with great expedition, having ftrong claws on its fore feet, with which it adheres fo firmly to the ground, that, if it fhould be caught by the tail whilft making its way into the earth, its refiftance is fo great, that it will fometimes leave it in the hands of its purfuers: To avoid this, the 


\section{HISTORY OF QUADRUPEDS.}

Iunter has recourfe to artifice; and, by tickling it with a ftick, it gives up its hold, and fuffers itfelf to be taken alive. If no other means of efcape be left, it rolls itfelf up within its covering by drawing in its head and legs, and bringing its tail round them as a band to connect them more forcibly together: Iu this fituation it fometimes efcapes by rolling itfelf over the edge of a precipice, and generally falls to the bottom unhurt.

The moft fuccefsful method of catching Armadillos is by fnares laid for them by the fides of rivers or other places where they frequent.-They all burrow very deep in the ground, and feldom ftir out, except during the night, whilf they are in fearch of food.

To give a minute defcription of the thells or coverings of the Armadillos would be extremely difficult, as they are all compofed of a number of parts, differing greatly from each other in the order and difpofition of the figures with which they are diftinguifhed: But it may be neceffary to obferve, that in general there are two large pieces that cover the houlders and the rump, between which lie the bands, which are more or lefs in number in different kinds. Thefe bands are not unlke thofe in the tail of a lobfter; and, being flexible, give way to the motions of the animal.-The firft we thall mention is

THE THREE-BANDED ARMADILLO.

(Da/ypus Tricinctus, Lin.-L'Apar, Buff.)

It's thell is about twelve inches long, with three bands in the middle: The cruft on the head, back, and rump, 
is divided into a number of elegant raifed figures, with five angles or fides: Its tail is not more than two inches long: It has neither cutting nor canine teeth; and has five toes on each foot.

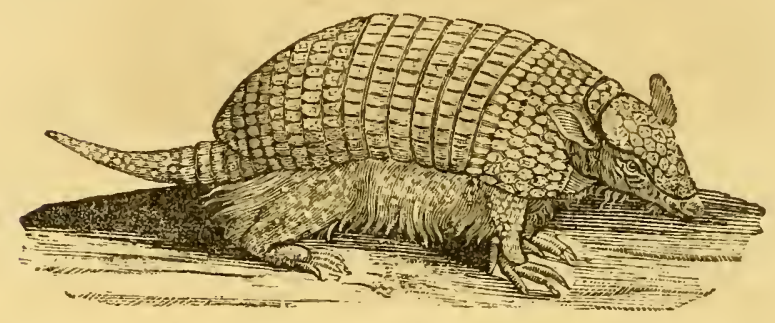

THE SIX-BANDED ARMADILLO,

(Dafypus Sexcinctus, Lin.-L'Encoubert, Buff.)

Is about the fize of a young Pig. Between the folds of the bands there are a few fcattered hairs: Its tail is long, thick at the bafe, and tapers to a point._- It is found in Brazil and Guiana.

\section{THE EIGHT-BANDED ARMADILLO,}

\section{(Le Tatuette, Buff.)}

Is furnifhed with eight bands. Its ears are long and upright; eyes fmall and black: It has four toes on the fore feet, and five on the hind: Its length, from nofe to tail, is about ten inches; the tail nine.-It inhabits Brazil, and is reckoned more delicious eating than the others. 


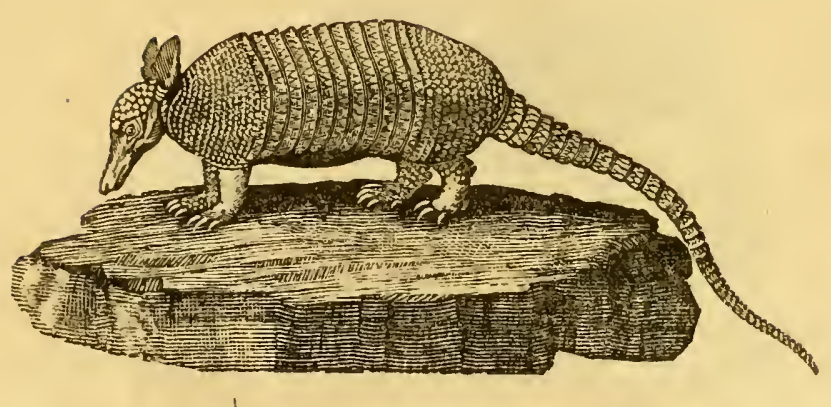

THE NINE-BANDED ARMADILIO,

(Dafypus Novemcinctus, Lin.-Le Cacbichame, Buff.)

HAS a tenth band, moveable half way up on each fide: The fhell on the fhoulders and rump is marked with hexangular figures; the breaft and belly are covered with long hairs; its tail is long and taper; and the whole animal three feet in length.

One of this kind was brought to England a few yearș ago from the Mufquito fhore, and lived fome time. It was fed with raw beef and milk, but refufed to eat our fruits and grain.

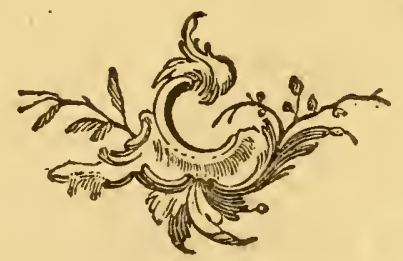

I i 3 


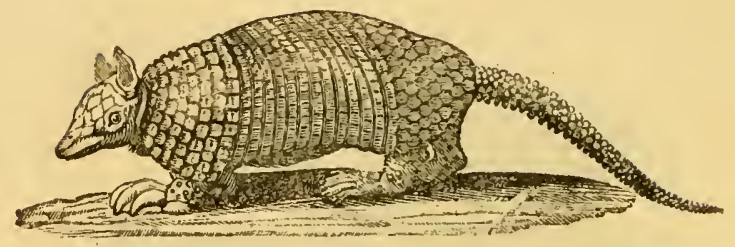

THE KABASSOU,

Is furnifhed with twelve bands, and is the larget of all the Armadillos, being almoft three feet long from nofe to tail: The figures on the fhoulders are of an oblong form; thofe on the rump hexangular. It is feldom eaten.

\section{THE WEASEL-HEADED - ARMADILLO, (Dafypus Unicinctus, Lin.-Le Cirqumçon, Buff.)}

So called from the form of its head, which is flender, has eighteen bands from its fhoulder to its tail: The fhell is marked with fquare figures on the fhoulders; thofe on the legs and thighs are roundin: The body is about fifteen inches long; tail five.

All thefe animals have the power of drawing themfelves up under their thells, either for the purpofe of repofe or fafety. They are furnifhed with ftrong lateral mufcles, confifting of numberlefs fibres, croffing each other in the form of an $X$, with which they contract themfelves fo powerfully, that the ftrongeft man is fircely able to force them open. The thells of the larger Armadillos are much ftronger than thofe of the fmaller kinds: Their flefl is likewife harler, and more infit for the table. 


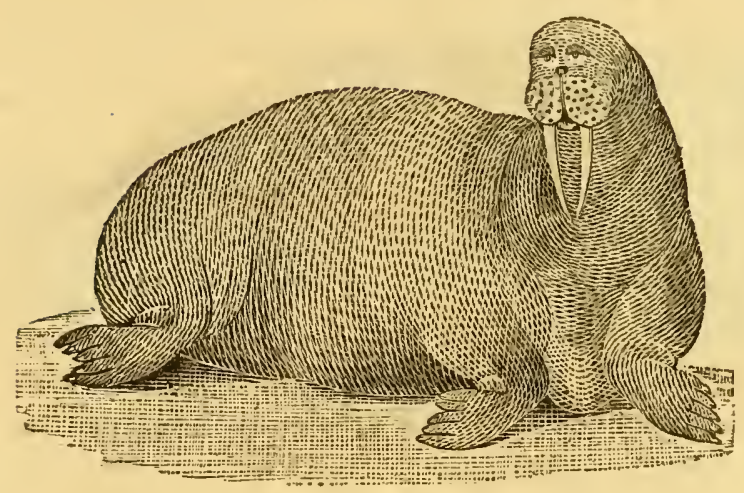

THE WALRUS, OR SEA-HORSE.

(Trichechus Rofinarus, Lin.-Le Morfe, Buff.)

THERE are feveral animals whofe refidence is almoft conftantly in the water, and which feem to partake greatly of the nature of fifhes, that are neverthelefs claffed by naturalifts under the denomination of quadrupeds; and being perfectly amphibious, living with equal eafe in the water as on land, may be confidered as the laft ftep in the fcale of Nature, by which we are conducted from one great divifion of the animal world to the other.-Of thefe the Walrus is the moft confiderable for its fize, being fometimes found eighteen feet in length, and twelve in circumference at the thickeft part: It is likewife remarkable for two large tufks in the upper jaw, which fometimes exceed two feet in length, and weigh from three to twenty pounds each.

The head of the Walrus is round; its lips very broad, and covered over with thick pellucid brifles; its eyes

$$
\text { I i } 4
$$


fmall and red; inftead of ears, it has two fmall orifices; and above the whifkers, femicircular noftrils, through . which it throws out water like the whale, but with much lefs noife : Its $\mathrm{fkin}$ is thick and wrinkled, and has a thin covering of fhort brownifh hair: Its legs are fhort: It has five toes on each foot, connected by membranes; and on each toe a fmall nail: The hind feet are very broad, and extended nearly on a line with the body.

The Walrus is chiefly found in the northern feas.Great herds of them are fometimes feen together on the fea fhore, or fleeping on an ifland of ice. When alarmed, they inftantly throw themfelves into the water with great precipitation. If wounded, they become bold and furious, and unite in the defence of each other: They will attack a boat, and endeavour to fink it by ftriking their great teeth into its fides, at the fame time bellowing in a moft hideous manner.

It is hunted' for its teeth, which are equal to thofe of the Elephant for durability and whiteners.

An ordinary Walrus is faid to yield half a ton of oil, equal in goodnefs to that of the whale.

The female produces one or two young at a time, which the fuckles upon land.

In climbirg upon the ice, the Walrus makes ufe of its teeth as hooks to fecure its hold, and draw its great unwieldy body after it.___ It feeds on fea-weeds and fhellfifh, which it is faid to difengage from the rocks to which they adhere with its tuks.

The White Bear is its greatert enemy.-In the combats between thefe animals, the Walrus it faid to be generally victorious, on account of the defperate wounds it inflicts with its teeth. 


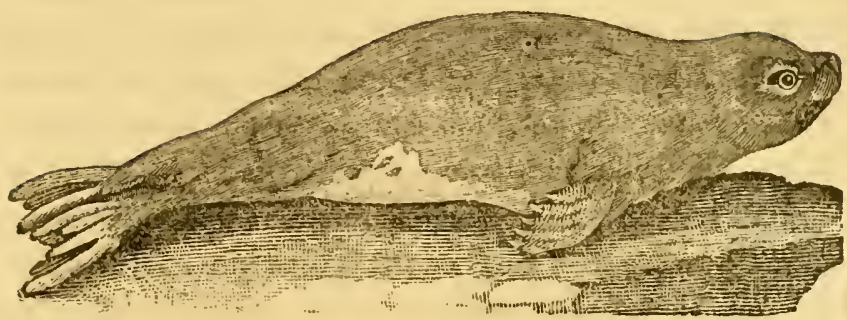

THE SEAL,

(Pboca Vitulina, Lin.-Le Phoque, Buff.)

Is found, with fome variety, in almoft every quarter of the globe: In the northern feas of Afia, Europe, and America; as well as the lefs frequented regions towards the fouth pole.

Its ufual length is from five to fix feet. The body is clofely covered with thort hair of various colours, fmooth and fhining; its tongue is forked at the end; it has two canine tceth in each jaw, fix cutting teeth in the upper, and four in the lower; it has five toes on each foot, furnifhed with ftrong fharp claws, which enable it to climb the rocks, on which it frequently bafks.

It fwims with great ftrength and fwiftnefs, is very playful, and fports without fear about thips and boats.It feeds on various kinds of fifh, and is frequently feen near the thore in purfuit of its prey.

Seals are found in great abundance on the coafts of Great-Britain; particularly in the deep receffes and caverns in the northern parts of the ifland, where they refort in the breeding time, and continue till the young ones are old enough to go to fea. 


\section{HISTORY OF QUADRUPEDS,}

The time for taking Seals is in the month of October, or the beginning of November. The hunters, provided with torches and bludgeons, enter the moutlss of the caverns about midnight, and row in as far as they can : They then land; and, being properly ftationed, begin by making a great noife, which alarms the Seals, and brings them down from all parts of the cavern in a confufed body, making frightful fhrieks and cries. In this hazardous employment, great care is neceffary on the part of the hunters to avoid the throng, which preffes down with great impetuofity, and bears away every thing that oppofes its progrefs; but when the firft crowd is paft, they kill great numbers of young ones, which generally ftraggle behind, by ftriking them on the nofe.

A young Seal yields above eight gallons of oil.-When full grown, their fkins are very valuable, and make a beautiful kind of leather, much ufed in making thoes, \&c.

The fleth of the Seal is fometimes eaten; and that it was formerly admitted to the tables of the great, may be feen in the bill-of-fare of a fumptuous entertainment given by archbifhop Nevil in the reign of Edward the Fourth.

The growth of Seals is fo amazingly rapid, that after nine tides from their birth they are as active as the old ones.

The female brings forth her young on the land, fits on her hind legs while the fuckles them, and as foon as they are able, carries them to fea, and learns them to fwim and fearch for food: When they become fatigued, fhe places them on her back.-The young ones know the voice of their mother, and attend to her call. 
The voice of the Seal has been compared to the hoarfe barking of a Dog; when young, it is clearer, and refembles the mewing of a Cat.

Seals are likewife found in the Mediterranean and $\mathrm{Caf}-$ pian feas, in the lake Baikal, and fome of the larger lakes. Thefe are fmaller than the falt-water Seals; but fo fat, that they feem almoft fhapelers.

\section{THE HOODED SEAL,}

Is found in the fouth of Greenland, and is diftinguifhed by a thick fold on its forehead, with which it can cover its eyes and nofe. Its hair is white, with a thick coat of black woolly hair underneath, which makes it appear of a fine gray colour.-The hunters fay that it is not eafily killed, till the covering on its head is removed.

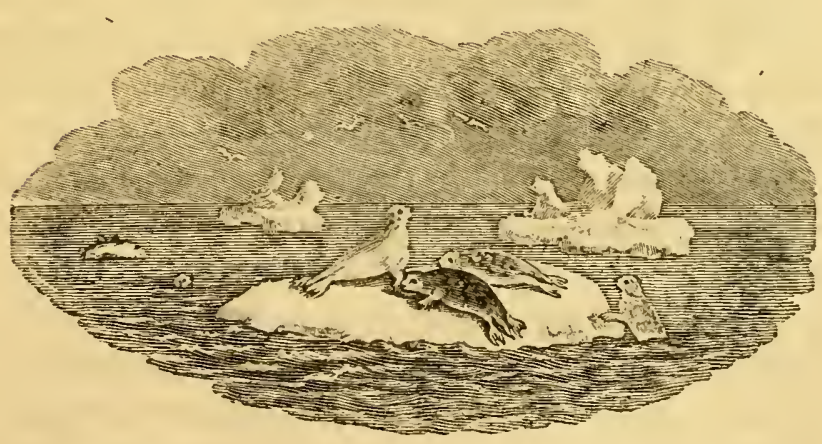




\section{HISTORY OF QUADRUPEDS.}

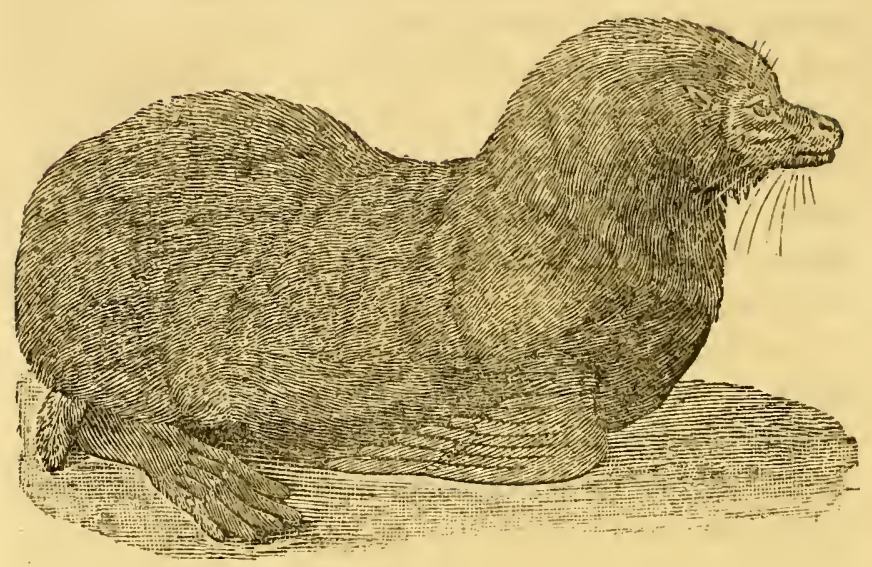

THE URSINE SEAL, OR SEA-BEAR,

(Ploca Urfma, Lin.-L'Ours Marin, Buff.)

Is much larger than the common Seal, being eight feet in length, and weighing eight hundred pounds.

Thefe animals are found among the iflands which lie between Kamfchatka and America; alfo on the coafts of New Zealand, Staten Inland, New Georgia, and Falkland's iflands.- They lie in thoufands on the fhore, in feparate families, each confinting of above an hundred. One male will fometimes have fifty females, which he guards with extreme jealoufy. They are exceffively fat and indolent, fometimes even fcarcely moving from the place where they lie for the fpace of three months; during which time the females breed and fuckle their young. If another approach their ftation, they are roufed from their fupinenefs: A battle enfues, which fre- 
quently becomes general, and fpreads confufion through the whole fhore. Thefe conflicts are extremely violent; and the wounds given are very deep, refembling a cut with a fabre.

The attachment of the male to the young is very ftrong: He defends them with great obftinacy, and frequently revenges their lofs upor the female, whom he beats moft cruelly; whilft the crawls to his feet, and feems to deprecate his wrath with the moft obfequious geftures.

The female generally brings forth one, feldom two, at a time.

They fwim with great eafe, at the rate of about feven miles in an hour.- When wounded, they will feize on a boat, carry it along with them, and fometimes fink it.They can continue a long time under water.-In climbing rocks, they faften their fore paws, and draw themfelves up.

Thefe, and all the Seal kind, will live a long time after receiving the moft dreadful wounds; but the moft trifling blow on the fnout or forehead inftantly kills them.

The general colour of thefe animals is black. They are covered with a coat of long rough hair, under which is a foft down of a bay colour. On the neck of the old ones, the hair is erect, and a little longer than the reft.

The fat and flefh of the old males are very naufeous; but thofe of the females and the young, when roafted, are faid to be as good as the flefh of a fucking Pig. 


\section{THE BAT.}

THIs fingular animal is diftinguifhed from every other quadruped by being furnifhed with wings, and feems to poffers a middle nature between four-footed animals and birds : It is allied to the one by the faculty of flying on$1 y$, to the other both by its external and internal ftructure : In each refpect it has the appearance of an imperfect animal. In walking, its feet feem to be entangled with its wings, and it drags its body on the ground with extreme aukwardnefs. Its motions in the air do not feem to be performed with eafe; it raifes itfelf from the ground with difficulty, and its flight is laboured and ill directed; from whence it has very fignificantly been called the FLITTER-Mouse._- There are feveral varieties of the Bat kind.

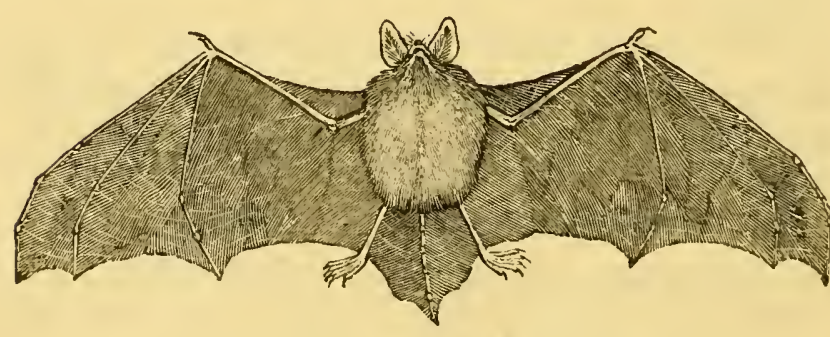

THE SHORT-EARED BAT,

(Vespertilio Murinus, Li1. - Le chauve Souris, Buff.)

Is found in almoft every part of Europe, and is moft commonly known in Great-Britain.-Its ufual length is about two inches and a halt; the extent of the wings nine inches. 


\section{HISTORY OF QUADRUPEDS.}

It makes its firft appearance early in the fummer. It neeps during the day, and begins its flight in the dufk of the evening. It frequents the fides of woods, glades, and hady walks; and is frequently obferved to fkim along the furface of the water in queft of gnats and other infects, which are its principal food.

Its membranes or wings are of a duky colour, and very thin; they extend from the fore feet to the tail: The hind feet are divided into five toes, furnithed with claws; the body is covered with a fhort foft fur, of a moufecolour, tinged with red; the eyes are very fmall; and the ears like thofe of a Moufe; it has four cutting teeth in the upper jaw, and fix in the under.

The female produces two young at a time, which the fuckles at her breaft; and is faid to carry them when flying.

Towards the end of fummer, the Bat retires into caves, old buildings, or hollow trees; where it remains in a ftate of inactivity. During winter, fome cover themfelves with their wings as with a mantle, and fufpend themfelves by the hind feet; others ftick faft to old walls; and fome retire into holes.

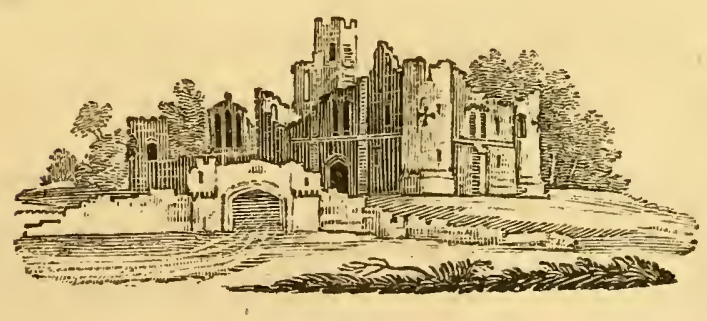




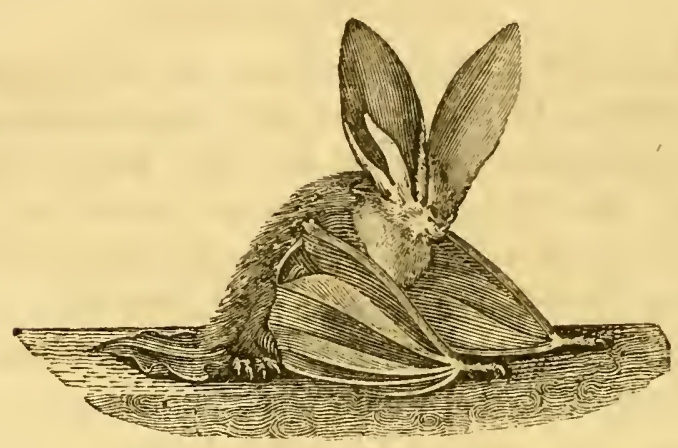

\section{THE LONG-EARED BAT,}

(Vejpertilio Auritus, Lin._L'Oreillar, Buff.)

Is only an inch and three quarters in length; the extent of its wings is feven inches; its ears are above an inch long, very thin, and almoft tranfparent; within each of them there is a membrane, refembling an ear, which may poffibly ferve as a valve to defend the organs of hearing during its inactive ftate.

\section{THE GREAT BAT, (La Noctule, Buff.)}

Is found in Great-Britain, but is not fo common as the two laft-mentioned: It is likewife found in France, and is common in various parts of Ruflia.

Its length is nearly three inches; that of the tail one and feven-tenths; the extent of the wings thirteen inches; the ears are thort, the hair of a reddinh-anh colour, and on the chin there is a very fmall wart. 


\section{HISTORY OF QUADRUPEDS.}

\section{THE PIPISTRELLE,}

Is the fimalleft, and its appearance the leaft difgufting, of all Bats. Its length is not quite one inch and a quarter; the extent of its wings fix and a talf; its nofe is fmall, ears broad, and its forehead covered with long hairs; the upper part of the body is of a yellowinh-brown colour, the lower part dufky, and the lips yellow.-It inhabits France, and is common in Ruflia and Siberia.

\section{THE BARBASTELLE,}

Is diftinguifhed by the thortnefs of its face, almoft concealed by its large broad ears, the bafes of which touch each other, and cover the forehead and eyes: Its cheeks are full, and its lips hairy; its nofe is very thort, and the end of it flat. Its length is about two inches; the extent of the wings ten and a half.-It is found in France.

\section{THE SEROTINE,}

Is about the fize of the common Bat; its nofe is fomewhat longer; its ears are fhort, and broad at the bafe; the hair on the upper part of the body is of a light brown or ruft colour, and the belly paler.-It is likewife found in France.

\section{THE HORSE-SHOE BAT,}

Is diftinguifhed by a membrane furrounding its nofe and upper lip fomewhat in the form of a horfe-fhoe; from whence it derives its name. Its ears are long, very broad. $\mathrm{Kk}$ 
at the bafe, and are not furnifhed with a fmaller or internal ear, common to almoft all the Bat kind: The upper part of the body is of an ant colour, the belly whitith.-They vary in fize; the largeft are above three inches and a half long from the nofe to the end of the tail; the extent of the wings is above fourteen.

This kind is very common in France, and is the laft of feven diftinct fpecies defcribed by M. Buffon as natives of that country.-Thefe are all equally harmlefs, diminutive, and obfcure; fhunning the light, and endeavouring to conceal themfelves in holes and caverns. They never come out, but during the night, in queft of food; and return at day-break to their dreary habitations. But under the influence of a warmer climate, the Bat affumes a very different character, and poffeffes powers which render it formidable to mankind, and a fcourge to thofe countries where it is found. Some of them are as large as a well-grown pullet; and fo numerous, that they frequently darken the air as they fly. They are fond of blood, and will attack men whom they find anleep; they are faid to introduce their fharp-pointed tongues into a vein, fucking the blood till they are fatiated, without awakening the fufferer.

The ancients had an imperfect knowledge of thefe animals; and from their aptnefs to convert every object of terror into an imaginary being, it is probable they had conceived the idea of Harpies, from the cruelty, voracity, and difgufting deformity of thefe creatures.

Thefe monfters inhabit Madagafcar, and all the iflands of the Indian Ocean: They have likewife been found in New Holland, the Friendly Ifles, the New Hebrides, and New Caledonia. 


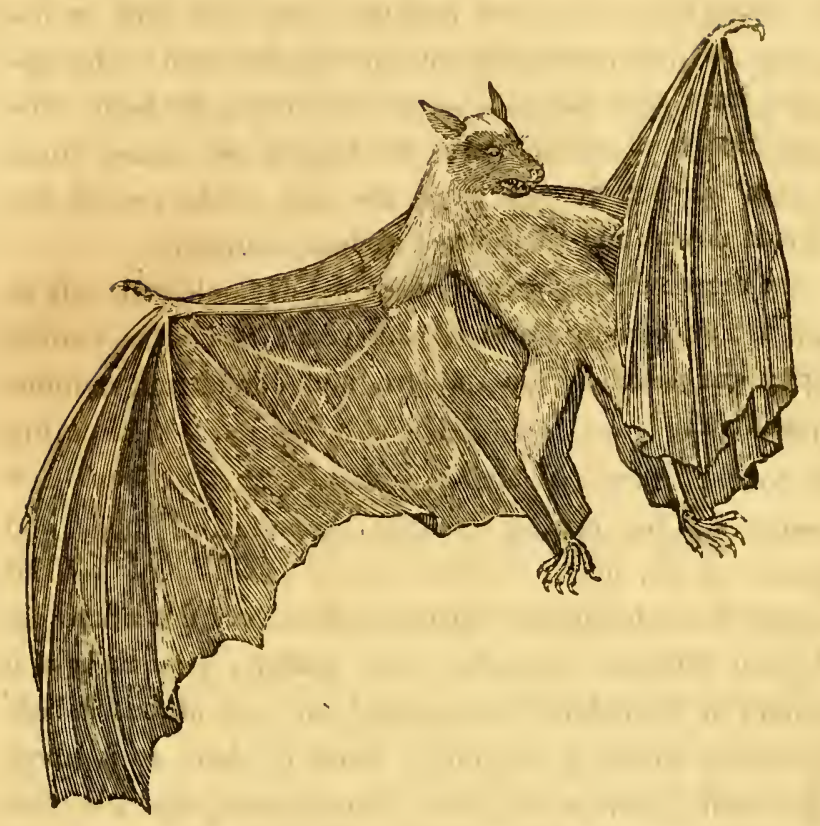

THE TERNATE BAT,

(Vefpertilio Vampyrus, Lin._La Roufette, Buff.)

Is above one foot in length, and the extent of its wings more than four: It has large canine teeth, four cutting teeth above, and the fame below; its tongue is pointed, and terminated with fharp-pointed papillæ, or prickles; its nofe is tharp, and its ears large and naked; it has five toes on the hind feet, furnifhed with ftrong hooked claws; it has no tail; the head is of a dark ruft colour; the back dufky; the neck, thoulders, and under fide, of a lightifh-brown, inclining to red; the membranes of the wings dufky.

IK k 2 


\section{HISTORY OF QUADRUPEDS.}

They feed on fruits, and are extremely fond of the juice of the palm-tree, with which they will frequently intoxicate themfelves, fo as to drop on the ground. One hundred and fifty or two hundred of them may fometimes be feen on the fame tree, all hanging with their heads down, and their wings folded; and in this manner they repofe during great part of the day.-They grow very fat at certain times of the year; and when young, they are eaten by the Indians, and confidered as excellent food.

\section{THE ROUGETTE, OR LESSER TERNATE BAT,}

INHABITS the fame countries, and is very fimilar to the laft in the fhape of its head and body: The hair is of a cinereous brown colour; and on the neck it has a halfcollar, of a lively red, mixed with orange. It is about five inches long; and the extent of its wings little more than two feet.

The Rougettes fly in flocks, and perfectly obfcure the air with their numbers. They fly from one ifland to another, and begin their flight about fun-fet. During the day, they lodge in the hollow trunks of trees. They live chiefly in trees; and when about to fly, they beat the air with their wings, before they can difengage themfelves from the branch to which they are attached.When thot or fuddenly furprifed, feveral, of them fall to the ground; and in that fituation are incapable of refuming their flight, till they climb upon fome elevated object. They move aukwardly on the ground, and ufe their utmolt efforts to quit it as foon as poffible.-Both thefe kinds bring only one young at a time once a year. 
THE SPECTRE BAT.

\section{(Vespertilio Spectrum, Lin.-Le Vampire, Buff.)}

ITs nofe is long; and at the end there is a membrane, of a conical form, fomewhat like a horn, but flexile, which gives it a hideous and difgufting afpect. It has no tail. Its body is covered with long hair, of an ath colour. - It is found in Surinam. Stedman, in his account of that colony, particularly defcribes it, and fays that it is fond of human blood.

\section{THE SENEGAL BAT,}

Has two cutting teeth in the upper, and fix in the under jaw; and two canine teeth, and eight grinders, in each jaw : Its head is long, ears thort and pointed, hend and body of a tawny-brown colour, belly lighter, length rather more than four inches, extent of the wings twenty one.-It is found in Senegal.

\section{THE BULL-DOG BAT.}

Irs nofe is thick; lips large, and fomewhat pendulous; its ears are broad and round, the edges touching each other in the front; the upper part of the body is of a deep afh colour, the lower paler; its tail long; length about two inches; extent of the wings nine and a half: It has twenty-fix teeth; two cutting and two canine in each jaw; eight grinders in the upper, and ten in the lower jaw.-It inhabits the Weft-Indies. 


\section{THE BEARDED BAT.}

THE noftrils of this animal are not feparated by a cartilage, as in moft animals, but are placed on the fide of a fmall gutter or furrow, which is open from one end to the other; the ears are long and narrow; the upper part of the head and body is of a reddifh-brown colour, the lower part whitifh, tinged with yellow; hair on the forehead and under the chin very long; length of the body about an inch and a half,-extent of the wings little more than feven.

\section{THE STRIPED BAT,}

(Vejpertilio Spafina, Lin.)

Has a fmall, fhort nofe; ears thort, broad, and pointing forward.-Thefe Bats vary in colour. The body is generally of a clear brown, the under part whitifh: Its wings are ftriped with black, and fometimes with yellow and brown.-Length of the body two inches. - It is a native of Ceylon, where it is called Kirizuoula.

To this we may add a very minute kind, mentioned by Mr Forfter, which was feen and heard in myriads on the illand of Tanna, one of the New Hebrides; but every attempt of our voyagers to obtain a nearer infpection of them failed of fuccefs.

Bats differ very much in the number and difpofition of their teeth, which has occafioned no fmall confufion in the arrangements of fyftematic writers; fome of them being furnifhed with two, others with more, cutting teeth in each jaw. 


\section{HISTORY OF QUADRUPEDS.}

We have now given the moft diftinguifhed varieties of this curious fpecies. It wrould be fruitlefs, if not imporfible, to point out all the peculiarities to be found in the various tribes which abound in every country in the world, and differ from each other more in their habits and difpolitions than in their exterior form and appearance, which in all of them feem to be equally deformed and difgufting.-But we fhould not from hence conclude that imperfection and deformity are always in uniform analogy with the notions we have preconceived of what is fair and beautiful.-Amidft the infinite productions of Creative Power, variety of form, difference of faculties, and degrees of utility, are eminently obfervable; compofing one general plan, in which wifdom, order, and fitnefs, are difplayed through all its parts.

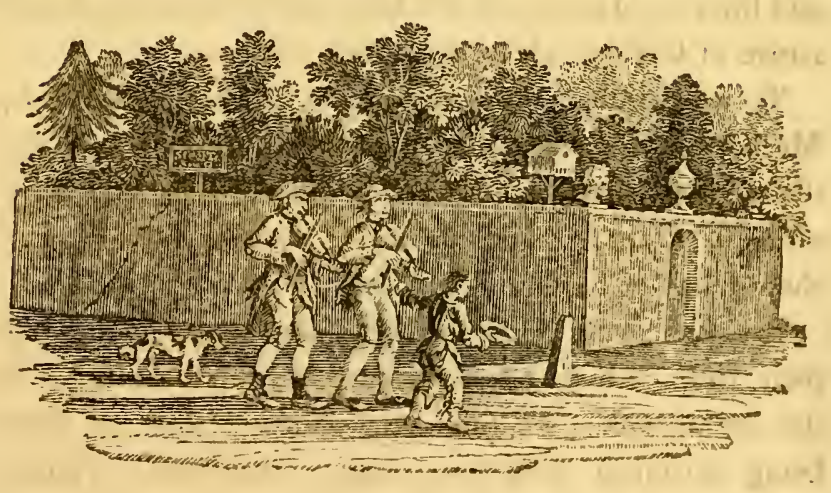





\section{$A D D E N D A$.}

WE are favoured, by the Literary and Philofophical Society of Newcaftle upon Tyne, with the figures and defcriptions of two very rare animals, fent to them from New South Wales, by James Hunter, Efq. Governor of that fettlement.

The one appears to be of the Opoffum genus, of which the mort unqueftionable proof is, that it has a falfe belly or pouch, for the reception of its young after their protrufion from the uterus; common to every animal of that kind.

The other feems to be an animal fuigeneris; it appears to poffers a threefold nature, that of a fifh, a bird, and a quadruped, and is related to nothing that we have hitherto feen: We fhall not attempt to arrange it in any of the ufual modes of claflification, but content ourfelves with giving the defcription of both thefe curious animals as they have been tranfmitted to.us. 


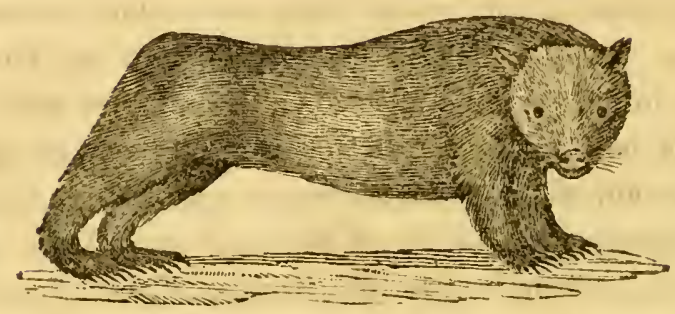

THE WOMBACH.

“ Sydney, New South Wales, Auguft 5, 1798.

"THIs animal was found upon an ifland on the coaft of New South Wales, in latitude $40^{\prime \prime} 3^{6}$ S. where confiderable numbers were caught by the company of a thip which had been wrecked there on her voyage from Bengal to Port Jackfon.

" I received this animal alive, by a veffel which $I$ had fent to the relief of the fufferers: It was exceedigly weak when it arrived, as it had, during its confinement on board, refufed every kind of fuftenance, except a fmall quantity of boiled rice, which was forced down its throat. I had it frequently taken out of the box in which it was kept, that it might receive the benefit of the warmth of the fun, which, however, it did not feen to enjoy; but whenever it could fhelter itfelf under a fhrub, there it would continue and neep. It refufed every kind of food on fhore as it had done on board, but we could fee it fometimes nibble a little of the roots of 


\section{HISTORY OF QUADRUPEDS.}

rufhes or grafs: It grew weaker every day, was exceedingly harmlefs, and would allow any perfon to carry it about. After having lived, with fearcely any kind of food, for fix weeks, it died; and its inteftines and brain having been taken out, I preferved the body in fpirits, for the infpection of the learned members of the Literary and Philofophical Society of Newcaftle upon Tyne.

"It is abbut the fize of a Badger, a fpecies of which we fuppofed it to be, from its dexterity in burrowing in the earth, by means of its fore paws; but on watching its general motions, it appeared to have much of the habits and manner of a Bear.

"Its head is large; the forehead, above the eyes, is particularly broad, from which it tapers to the nofe, which is a hard grifly fubftance, and feems well adapted for removing the earth when it burrows: It has two cutting teeth in each jaw, long and tharp like thofe of a Kanguroo, with a fpace of about an inch between them and the grinders, which are ftrong and well fet: From the ftructure of its teeth, it does not appear to be a carnivorous animal : Its eyes are fmall and black; its ears 1hort and pointed; its paws are fomething like thofe of a Beaver: Its weight appeared to be about forty pounds. It runs aukwardly, in the manner of a Bear, fo that 2 man could eafily overtake it. There is fomething uncommon in the form of its hinder parts; its pofteriors do not round off like thofe of moft other animals, but fall fuddenly down in a floping direction, commencing at the hip joint, and defcending to the knee joint of the hind $\operatorname{leg}_{3}$; from this joint to the toe it appears to tread flat upon the ground ; its tail is fo hort, as hardly to be difcovered: Its colour is that of a cream-coloured brown, 
internixed with black hairs. This animal has lately been difcovered to be an inhabitant of the interior of this country alfo. Its flefh is delicate meat.-This one is a female, and has the falfe belly* for the fecurity of its young. The mountain natives call it Wombach."

* It is a remarkable circumfance, that the few animals hitherto found in the newly-difcovered countries in the South Seas, thould all be diftinguifhed by the pouch or falfe belly, though in other refpects they differ from each other both in form and manners.

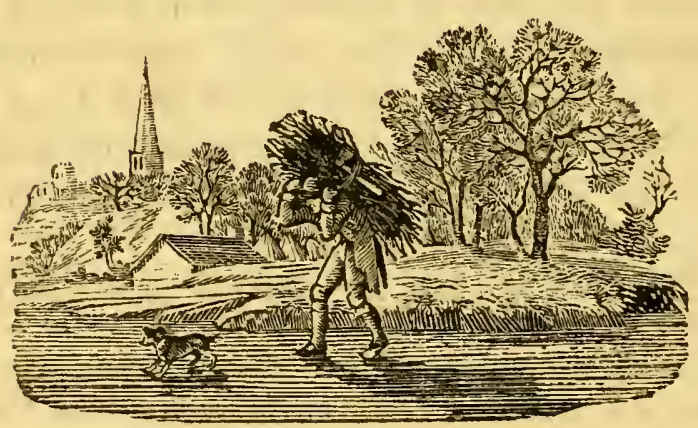




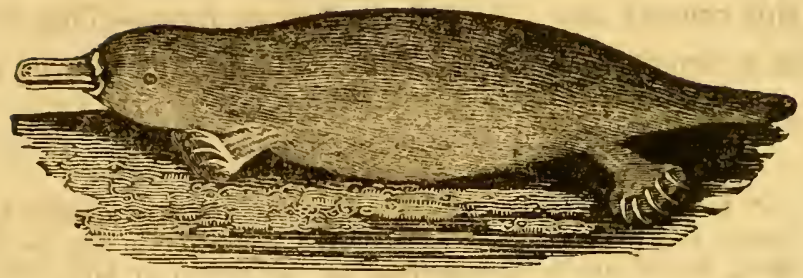

\section{AN AMPHIBIOUS ANIMAL,}

"Is found in the frefh water lakes, which is about the fize of a fmall Cat; it chiefty frequents the banks of the lakes; its bill is very fimilar to that of a duck, and it probably feeds in muddy places in the fame way; its eyes are very fmall; it has four fhort legs; the fore legs are fhorter than thofe of the hind, and their webs fpread confiderably beyond the claws, which enables it to fwim with great eafe; the hind legs are alfo webbed, and the claws are long and tharp. They are frequently feen on the furface of the water, where they blow like a turtle: Their tail is thick, fhort, and very fat.

"The natives fay they fometimes fee them of a very large fize."

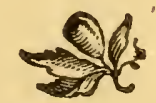




\section{ERRATA.}

Page 46, Line 2, for Grumiens read Grunniens.

- 8I, 12, for Sarrus read Sarris.

- 90, I7, for Leucopher read Leucophas.

- $90,-23$, dele with.

_ 96, 10, for Codous read Coudous.

- 107, - 18, for Corina read Corine.

256, 2, for Marte read Martes.

- 304, —, for Dox read Dog.

- 502, - 8, for Cirqumçon read Cirquinçon. 





\section{.}


